UNIVERSIDADE DE SÃO PAULO

FACULDADE DE FILOSOFIA, LETRAS E CIÊNCIAS HUMANAS

DEPARTAMENTO DE LETRAS CLÁSSICAS E VERNÁCULAS

PROGRAMA DE PÓS-GRADUAÇÃO EM FILOLOGIA E LÍNGUA PORTUGUESA

EVERTON ALTMAYER LEOPOLDINO

A fala dos tiroleses de piracicaba: um perfil linguístico dos bairros Santana e Santa Olímpia

SÃO PAULO

2009 


\author{
UNIVERSIDADE DE SÃO PAULO \\ FACULDADE DE FILOSOFIA, LETRAS E CIÊNCIAS HUMANAS \\ DEPARTAMENTO DE LETRAS CLÁSSICAS E VERNÁCULAS \\ PROGRAMA DE PÓS-GRADUAÇÃO EM FILOLOGIA E LÍNGUA PORTUGUESA
}

\title{
A fala dos tiroleses de Piracicaba: um perfil linguístico dos bairros Santana e Santa Olímpia
}

Everton Altmayer Leopoldino

Dissertação apresentada ao curso de PósGraduação em Filologia e Língua Portuguesa do Departamento de Letras Clássicas e Vernáculas da Faculdade de Filosofia, Letras e Ciências Humanas da Universidade de São Paulo, como requisito parcial para a obtenção do título de Mestre.

Área de Concentração: Filologia e Língua Portuguesa.

Orientador: Prof. Dr. Mário Eduardo Viaro.

São Paulo

2009 
Aos imigrantes tiroleses e seus descendentes no Brasil. 


\section{SUMÁRIO}

$\begin{array}{ll}\text { RESUMO } & 07\end{array}$

$\begin{array}{ll}\text { ABSTRACT } & 08\end{array}$

$\begin{array}{ll}\text { AGRADECIMENTOS } & 09\end{array}$

Abreviaturas 10

INTRODUÇÃO

PARTE I - DAdOS DA COMUNIDAdE TIROLESA DE PIRACICABA 17

1. A CIDAde DE PIRACICABa 18

1.0. Localização 18

1.1. Dados históricos $\quad 19$

1.1.1. As Bandeiras e as Monções $\quad 20$

1.1.2. O núcleo populacional de Piracicaba $\quad 21$

1.1.3. Formação da população caipira 23

$\begin{array}{ll}\text { 1.1.4. O século XIX } & 27\end{array}$

1.1.5. O século XX 29

1.2. Dados atuais do município 31

2. O TIROL HISTÓRICO 33

2.0. Introdução 33

2.1. Dados históricos da região tirolesa 34

2.1.1. Da pré-história à conquista romana 35

2.1.2. Invasões germânicas (Alta Idade Média) 39

2.1.3. O Principado Episcopal de Trento e o Condado do Tirol (Baixa Idade Média) 41

2.1.4. O Concílio de Trento, o período napoleônico e as disputas territoriais da I Guerra Mundial 46

2.1.5. O período fascista no Tirol italiano, a II Guerra Mundial

3. A IMigraÇão TiROleSA 62

3.0. A emigração no Tirol e suas causas 63 
3.1. A imigração tirolesa no Brasil

3.2. A imigração tirolesa em São Paulo $\quad 78$

$\begin{array}{ll}\text { 3.2.1. Os missionários capuchinhos de Trento } & 81\end{array}$

4. A COMUnidade tirolesa de Piracicaba 84

4.0. Introdução

4.1. A imigração e a Fazenda Sete Quedas $\quad 85$

4.2. As fazendas Santa Olímpia, Sant'Ana e Negri 93

4.3. Os parentes da Fazenda Traviú 95

4.4. Os bairros tiroleses $\quad 96$

4.4.1. Religiosidade $\quad 97$

4.4.2. Costumes e tradições 100

$\begin{array}{ll}\text { 4.4.2.1. Vestimenta } & 100\end{array}$

$\begin{array}{ll}\text { 4.4.2.2. Musicalidade, teatro e danças típicas } & 101\end{array}$

$\begin{array}{ll}\text { 4.4.2.3. Festas } & 103\end{array}$

$\begin{array}{ll}\text { 4.4.3. A escola } & 104\end{array}$

4.4.4. Aspectos sociais 106

$\begin{array}{ll}\text { 4.4.5. Demais origens nos bairros } & 107\end{array}$

$\begin{array}{ll}\text { 4.4.6. Projetos de resgate cultural } & 107\end{array}$

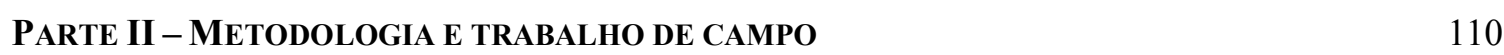

1. LEVANTAMENTO DE DADOS E ENTREVISTAS 111

1.0. Introdução 111

1.1. Perguntas iniciais $\quad 112$

1.2. Caracterização dos informantes e entrevistas $\quad 115$

1.3. Tópico conversacional 119

2. CONTEXTO Linguístico Da COMUNIDAdE 122

2.1. Perfil dos falantes e bilinguismo entre as gerações $\quad 128$

2.1.1. Grupo C: falantes do dialeto trentino 132

2.1.2. Grupo B: nem todos falantes bilíngues 133

2.1.3. Grupo A: busca pela identidade trentina 135

$\begin{array}{ll}\text { 2.2. Status linguístico da variante da comunidade } & 137\end{array}$

2.3. Usos do português e do dialeto trentino nas relações sociais 141 
2.4. Existem diferenças significativas, na variante do português, entre Santana e Santa Olímpia?

PARTE III - ANÁLISES Linguísticas

1. ASPeCtos gerais do dialeto trentino na Itália e eM Piracicaba

1.0. Introdução

1.1. O dialeto trentino na Itália

1.1.1. Classificação dos dialetos trentinos 153

1.2. O dialeto trentino de Piracicaba $\quad 155$

$\begin{array}{ll}\text { 1.2.1. Aspectos vocálicos } & 160\end{array}$

1.2.1.1. Queda das vogais finais 162

$\begin{array}{ll}\text { 1.2.2. Aspectos consonantais } & 164\end{array}$

$\begin{array}{ll}\text { 1.2.2.1. Fonemas consonantais } & 168\end{array}$

$\begin{array}{ll}\text { 1.2.3. Padrões silábicos e vocabulares } & 175\end{array}$

$\begin{array}{ll}\text { 1.2.3.1. Variações morfofonêmicas } & 177\end{array}$

$\begin{array}{lr}\text { 1.2.3.2. Demais variações fonológicas } & 180\end{array}$

$\begin{array}{ll}\text { 1.2.4. Formação do plural } & 183\end{array}$

1.2.5. Desinências e verbos 184

$\begin{array}{ll}\text { 1.2.6. Acento e intensidade } & 188\end{array}$

$\begin{array}{ll}\text { 1.2.7. Arcaísmos do trentino piracicabano } & 188\end{array}$

$\begin{array}{ll}\text { 1.2.8. Empréstimo e variação } & 190\end{array}$

$\begin{array}{ll}\text { 1.2.8.1. Empréstimos do alemão } & 191\end{array}$

1.2.8.2. Empréstimos do português 193

$\begin{array}{ll}\text { 1.2.8.3. Variação } & 201\end{array}$

1.2.8.4. Derivação 203

$\begin{array}{ll}\text { 1.2.8.5. Outros casos } & 204\end{array}$

2. O DIALETO CAIPIRA EM PIRACICABA: ASPECTOS GERAIS 206

2.0. Introdução 206

2.1. Origens do dialeto caipira $\quad 207$

2.2. O dialeto caipira em Piracicaba 210

2.2.1. Aspectos vocálicos $\quad 211$

$\begin{array}{ll}\text { 2.2.2. Aspectos consonantais } & 214\end{array}$ 
3.0. Introdução 221

3.1. Empréstimos lexicais do dialeto trentino na variante do português 223

3.1.1. Léxico trentino entre não-descendentes 229

3.2. Aspectos fonéticos e fonológicos da variante local 232

3.2.1. Aspectos vocálicos $\quad 232$

$\begin{array}{ll}\text { 3.2.2. Aspectos consonantais } & 237\end{array}$

3.3. Aspectos morfossintáticos 243

3.3.1. Formação do plural 243

3.3.2. Aspectos sintáticos 244

CONSIDERAÇõES FINAIS

GLOSSÁRIO 253

REFERÊNCIAS BIBLIOGRÁFICAS

$\begin{array}{ll}\text { ANEXos } & 268\end{array}$

1. DADOS PESSOAIS DOS INFORMANTES 269

2. TRANSCRIÇÕES 270

2.0. Critérios adotados na transcrição ortográfica das entrevistas 270

3. CONTEXTO LINGUíSTICO ALPINO 346

3.0. Introdução 346

3.1. Línguas e dialetos românicos da região trentina 347

3.1.1. O grupo galo-itálico 351

3.1.2. O vêneto 355

3.1.3. O grupo ladino (dolomítico) 358

3.1.4. Exemplos do dialeto trentino 363

3.1.4.1. Mapa dialetal trentino 365

3.2. O grupo germânico 366

3.2.1. O alemão bávaro $\quad 367$

3.2.1.1. O alemão tirolês 368

3.2.1.2. O moqueno $\quad 370$

$\begin{array}{ll}\text { 3.2.1.3. O cimbro } & 371\end{array}$ 


\section{RESUMO}

Leopoldino, Everton Altmayer. A fala dos tiroleses de Piracicaba: um perfil linguístico dos bairros Santana e Santa Olímpia. 2009. Dissertação (mestrado) - Faculdade de Filosofia, Letras e Ciências Humanas da Universidade de São Paulo, São Paulo, 2008.

São mais de cento e trinta anos de imigração tirolesa no Brasil. Ainda não sabemos exatamente qual o número real de imigrantes tiroleses que, saídos principalmente da região trentina no final do século XIX, desembarcaram em terras brasileiras com suas esperanças e o sonho de far l'América. Sabemos, entretanto, que sua influência cultural deixou contribuições importantes na sociedade brasileira, sobretudo nos estados do Sul e Sudeste.

O presente trabalho propõe analisar a fala da comunidade tirolesa (trentina) da cidade de Piracicaba, formada por dois bairros: Santana e Santa Olímpia. Juntos, os bairros rurais são a mais significativa colônia tirolesa do estado de São Paulo, cuja variante do português, marcadamente influenciada pelo dialeto trentino (ainda mantido na comunidade e ali chamado tirolés), destaca e diferencia seus moradores no contexto linguístico piracicabano.

As análises registram os aspectos principais dessa variante do português e acreditamos que servirão, alfim, para um melhor conhecimento sobre a comunidade tirolesa de Piracicaba, bem como para uma compreensão mais abrangente acerca da diversidade linguística das comunidades de imigração do Brasil.

Palavras-chave: Sociolinguistica, língua portuguesa, dialeto trentino, dialeto caipira, Piracicaba 


\begin{abstract}
Leopoldino, Everton Altmayer. The speech of the tyrolean community in the city of Piracicaba: a linguistic profile from Santana and Santa Olímpia. 2009. Dissertação (mestrado) - Faculdade de Filosofia, Letras e Ciências Humanas da Universidade de São Paulo, São Paulo, 2008.
\end{abstract}

More than one hundred and thirty years have passed since the tyrolean immigration in Brazil has began and we still do not know the exactly real number of tyrolean immigrants that landed in brazilian territories with their hopes and dreams of "far l'America", most of them coming from the Trentino region in the late nineteenth century. We know, however, that their cultural influence left important contributions in the brazilian society, especially in the states of the south and southeast.

This work proposes to analyze the speech of the tyrolean community (from Trentino) in the city of Piracicaba, comprised of two neighborhoods: Santana and Santa Olimpia. Together, the rural districts are the most significant tyrolean colony of São Paulo state, in which the portuguese language variant highlights and differentiates the people who lives there from the linguistic context of the city of Piracicaba, strongly influenced by the Trentinian dialect ( which remains in those neighborhoods)..

The analysis show the main aspects of this variant of the portuguese language and we believe that they will be useful to better understand the tyrolean community of Piracicaba as well to improve the knowledge about the linguistic diversity of communities of immigrants in Brazil.

Keyword: Sociolinguistic, portuguese language, trentinian dialect, caipira dialect, Piracicaba. 


\section{Agradecimentos}

Gostaria de agradecer, em primeiro lugar, ao orientador e amigo, professor Doutor Mário Eduardo Viaro, por sua paciência e incentivo. Seus conselhos não se limitaram aos rigores da orientação acadêmica, mas foram mostra de sua amizade, e seus comentários me ajudaram sobremaneira na realização deste trabalho.

Agradeço também aos professores do meu período de Graduação e Pós-graduação, e especialmente às Doutoras Valéria Gil Condé e Giliola Maggio, que formaram minha Banca de Qualificação e fizeram observações importantes sobre minhas pesquisas.

Agradeço à FAPESP (Fundação de Amparo à Pesquisa do Estado de São Paulo) pela bolsa de Mestrado, que viabilizou minhas pesquisas de campo e viagens.

A minha avó Sylvia (in memorian), a quem agradeço a paciência e o interesse por transmitir ao neto seu idioma trentino. Aos meus pais, Sinesio e Ruth, pelo incentivo e suporte, e por sua compreensão sobre a importância dessa pesquisa para mim.

A Alois Unterberger que, melhor do que ninguém, sempre soube de meus esforços e sempre me apoiou. Ao Grupo Folclórico Tirol, sem o qual eu não teria conhecido a comunidade tirolesa de Piracicaba. Agradeço também a diretoria do Circolo Trentino di São Paulo pelo suporte e incentivo em meus estudos sobre o dialeto trentino, e pelo significativo auxílio durante minhas pesquisas na Europa.

Gostaria de agradecer, alfim, a comunidade tirolesa de Piracicaba, os colaboradores e informantes dos Bairros Santana e Santa Olímpia, especialmente os amigos Ivan Correr e família; Leonardo Degasperi e seus avós, Jacob Degasperi (Cobi) e Clementina Christofoletti Degasperi (Mentina); Francisco Caetano Degasperi (zio Chico); Diogo Vitti, sua irmã Jacinta e seus pais (in memorian) Paulo Vitti (Paolin) e Amália Forti Vitti; Ana Cláudia Bomback; Lucas Mariano; Maria Cecília Stenico Correr (e família); José Edivaldo Stenico; Adalberto Stenico; Ivanete Degasperi; José Luis Negri; membros do Grupo Santa Olímpia de danças folclóricas, do Coro Stella Apina, do Grupo Cortesano de danças folclóricas e Padre Daniel Stenico. Agradeço Maria Carolina Vitti Stenico (la me ciócia) e família, pelo apoio e carinho. 


\section{ABREVIATURAS}

a.a.a. antigo alto alemão

al. alemão

bav. alemão bávaro

cimb. cimbro

Cfr. conferir

fem. feminino

fig. figurativo

got. gótico

interj. interjeição

it. italiano

lad. ladino dolomítico

lat. latim

lomb. lombardo

maa. médio alto alemão

moq. moqueno

pl. plural

port. português

S Bairro Santana

SO Bairro Santa Olímpia

tb. também

tir. alemão tirolês

trent. trentino europeu

trent. pir. trentino piracicabano 


\section{INTRODUÇÃO}

Todos os emigrantes europeus que desembarcaram no Brasil trouxeram consigo seus ideais, tradições e, naturalmente, seus sistemas linguísticos. Decorridos mais de cem anos desde a chegada dos primeiros imigrantes de língua italiana ao Brasil, o quadro linguístico dessas populações não é totalmente conhecido dos estudiosos brasileiros. Dialetos italianos de diferentes lugares foram trazidos com os imigrantes e colocados em contato nas áreas coloniais brasileiras e desses contatos surgiram variantes de língua falada que se tornaram "brasileiras". A maioria dos imigrantes italianos que desembarcaram no Brasil era oriunda das regiões setentrionais da Península: gente saída da Lombardia, do Piemonte, do Vêneto e da Friuli-Venezia Giulia ${ }^{l}$. Os dialetos de suas regiões de origem são ainda falados nas áreas coloniais brasileiras, com vários casos de conservação de formas arcaicas, diferenciando-os dos dialetos europeus; aqueles mantidos nas colônias do Rio Grande do $\mathrm{Sul}^{2}$ foram objeto de estudo de linguistas brasileiros (FrOSI \& MiORANZAI, 1983), que procuravam registrar o modo de falar dessas áreas coloniais e sua conservação, e italianos (FRANCESCHI \& CAMMELLI, 1977), que buscavam nas colônias brasileiras resquícios de antigos dialetos já extintos na Itália atual.

As comunidades mantêm em seus núcleos rurais ora formas dialetais arcaicas, ora variantes dialetais que foram suprimidas nas áreas originais por dialetos mais influentes ou, ainda, um koinai - variações de língua falada criadas nas colônias brasileiras a partir do contato estabelecido entre diferentes dialetos italianos. Um exemplo é o taliàn, língua corrente entre os descendentes italianos (inclusive trentinos) em várias localidades da Serra Gaúcha no Rio Grande do Sul. Trata-se de uma koiné de base vêneta (STAWINSKI, 1996; LuZZATO, 2000), acrescida de vocábulos advindos de outros dialetos e grupos linguísticos da Itália Setentrional (principalmente lombardo). Preserva arcaísmos de diversos tipos, tanto no campo semântico, como nos aspectos morfossintáticos e na fonologia. Do contato entre as línguas de imigração (italiano, alemão, japonês, polonês etc) e o português

\footnotetext{
${ }^{1}$ Por questões práticas e simplesmente para contextualização exata daquilo que se pretende apresentar, omitirse-ão maiores detalhes sobre os imigrantes de demais regiões e províncias italianas.

${ }^{2}$ Colônias fundadas, sobretudo, por vênetos, mas também por lombardos, trentinos, friulanos, piemonteses e toscanos.
} 
brasileiro, surgiram variantes que ainda são a língua corrente em várias áreas coloniais brasileiras. Conhecê-las e analisá-las ainda é, com certeza, um desafio para a sociolinguística brasileira.

Entre os imigrantes de língua italiana, que desembarcaram no Brasil entre o final do século XIX e início do século XX, estavam aqueles originários da parte meridional da austríaca Província do Tirol$^{3}$, então pertencente ao Império Austro-húngaro. Após a I Guerra Mundial (1918), a designação Tirol permaneceu à porção austríaca, enquanto a porção italiana foi subdividida em duas províncias: Província Autônoma de Bolzano (al. e lad. Südtirol; it. Alto Adige) e Província Autônoma de Trento (Trentino) ${ }^{4}$. A região tirolesa possui três grupos linguísticos distintos: o grupo majoritário, de língua alemã, existente no Tirol austríaco, Südtirol e alguns vilarejos do Trentino ${ }^{5}$; o grupo de língua italiana, concentrado historicamente na região trentina e em alguns vales do Südtirol, e o grupo

\footnotetext{
${ }^{3}$ Sobre a ortografia dos topônimos das regiões analisadas, nem todos possuem correspondentes em português. Optamos, na maioria dos casos, por respeitar os topônimos originais quando não encontramos equivalentes em português ou se são muito pouco conhecidos. No caso de aparecerem traduzidos, também indicaremos (na primeira vez em que aparecerem) sua forma original entre parênteses, pois isso facilita sua localização nos mapas apresentados. Todos os nomes estrangeiros (topônimos, etnias, dialetos) que não possuem equivalentes em português aparecerão em itálico. No que se refere aos topônimos da região tirolesa, a palavra Tirol não aparecerá em itálico, assim como Trentino, Bolzano e Trento, porque ocorrem desse modo em português e aparecem com certa freqüência nos trabalhos que tratam da região (BONATTI, 1974; VIARO, 2004; LEME, 2002; Boso, 2002). As cidades, vales e rios da região do Tirol aparecerão, sempre que houver, com os seus dois ou mais topônimos originais, dando-se preferência àquele de origem mais antiga, seguido dos demais entre parênteses, com o sinal indicativo $/=/$. Preferimos respeitar a grafia original dos nomes de cidades e regiões tirolesas, alemãs e italianas que aparecerão sempre em itálico. Não aparecerão em itálico os nomes Tirol (existente dessa forma no português) e Trentino, enquanto Südtirol virá em itálico; para designar o indivíduo originário do Südtirol utilizaremos o adjetivo sul-tirolês. Preferimos utilizar a nomenclatura Südtirol àquela italiana Alto Adige por dois motivos: o primeiro nome é histórico, ao passo que o segundo é um resquício do processo de italianização pela qual a região passou durante o período fascista, com mudanças na toponímia local; o segundo motivo é pelo fato de até hoje a designação Alto Adige não ser totalmente aceita pela população da região. Südtirol designa atualmente somente a Província Autônoma de Bolzano (Autonom Provinz Bozen; Provincia Autonoma di Bolzano), mas até 1918 indicava toda a região hoje composta pelas províncias autônomas de Trento e Bolzano. A região trentina, historicamente de língua italiana, era chamada em alemão Welschtirol (ou Welsch-Südtirol) e em italiano Tirolo Italiano ou Tirolo Meridionale - esta denominação se tornou oficial após 1813, sendo depois de 1918 abolida pelo governo italiano.

${ }^{4}$ Para facilitar a compreensão, ao se mencionar a emigração tirolesa até o ano de 1918, o termo Tirol será usado para designar toda a região que, até a mesma data, manteve-se com este nome unida ao Império Austrohúngaro e que hoje se encontra dividida entre a Áustria (Nordtirol e Osttirol formando o Estado do Tirol) e Itália (Südtirol e Trentino, formando a Região Autônoma Trentino-Alto Adige/Südtirol).

${ }^{5}$ Val dei Mòcheni (=Fersental), extremo norte de Val di Non (= Nonstal; Nonsberg) e na cidade de Luserna (=Lusern).
} 
ladino $^{6}$, existente em alguns vales entre o Trentino, o Südtirol e a região italiana do Vêneto (Belluno $)^{7}$.

Localizado no coração dos Alpes (Land im Gebirge ${ }^{8}$ ), com montanhas com mais de dois mil metros, o Tirol tem sua população concentrada nos vales, em médias e pequenas cidades ou nas várias aldeias (Dörfer; paesi). A geografia local faz com que o falar da população tirolesa não seja de forma alguma uniforme, inclusive entre os três grupos linguísticos ${ }^{9}$, havendo uma diversidade considerável de falares e dialetos.

Do antigo Welschtirol ou Tirolo Italiano (atual Província Autônoma de Trento) partiu a maioria absoluta dos emigrantes tiroleses ${ }^{10}$ (e austríacos) que desembarcaram no Brasil entre 1875 e 1919. No Brasil, os tiroleses seguiram principalmente para os estados do Sul e Sudeste e, em algumas áreas coloniais brasileiras (sobretudo de Santa Catarina e

\footnotetext{
${ }^{6} \mathrm{O}$ ladino dolomítico é um idioma que, juntamente com o reto-românico suíço e o friulano italiano, forma um grupo linguístico alpino que teve sua origem na latinização principalmente dos réticos e celtas, entre outros povos, da Récia e Gália Cisalpina (SCHMIED, 1998). O ladino dolomítico não deve ser confundido com o ladino espanhol, língua dos judeus sefarditas da Península Ibérica. Trata-se da designação histórica ladin, utilizada por seus falantes enquanto identificatória desse grupo linguístico, que se destaca no contexto germânico tirolês por ter mantido seu idioma latino desde a romanização daquela área rética. $\mathrm{O}$ termo ladin também é utilizado na Suíça, mas somente pelos engadinos (VIARO 2001), falantes do romanche puter (conhecido localmente como rumantsch, ladin, putèr ou em alemão Oberengadinisch) e valáder (conhecido localmente como rumantsch, ladin, vallader).

${ }^{7}$ Destacada do Südtirol durante o período fascista italiano

${ }^{8}$ Terra nas montanhas, termo usado para designar a região tirolesa desde o século XV.

${ }^{9}$ No que se refere à cultura tirolesa e seus costumes de modo geral, seria errôneo afirmar que o Trentino não participa de tal realidade pelo simples fato de a região ser italianófona. Sabe-se, contudo, que o fator linguístico foi um pretexto utilizado durante o período fascista, que procurou destacar o Trentino da realidade cultural tirolesa enquanto oprimia os falantes germanófonos do Südtirol (HOLZNER, 1991). O modus vivendi trentino reflete a identidade linguística (italiana) de sua região, inserida historicamente no contexto político e cultural tirolês e, portanto, de marcada influência germânica. Findado oficialmente o fascismo na Itália, não faltam ainda na região trentina saudosistas da política de preconceito aos germanófonos e, do mesmo modo, há também entre os habitantes do Südtirol aqueles que erroneamente consideram enquanto tirolesas somente as áreas de língua alemã do Tirol, ignorando a realidade histórica das populações trentina e ladina dolomítica, elos culturais entre os mundos latino e germânico na área alpina (RIENZNER, 2004).

${ }^{10}$ LEME (2001: 25) justifica o uso do termo tirolo-trentino, empregado em seu trabalho sobre a comunidade, como um adjetivo pátrio que, segundo a autora, satisfaria a identificação da comunidade enquanto austríaca (tirolesa) e italiana (trentina). No entanto, um termo não exclui o outro. Como se observa na Parte I (capítulo 3) deste trabalho, referente à história do Tirol, fica demonstrado que a região trentina, terra de origem dos emigrantes que fundaram os bairros Santana e Santa Olímpia, não deixou de ser considerada tirolese após ser anexada ao território italiano em 1918 (final da I Guerra Mundial). Do mesmo modo, a atual Província Autônoma de Trento não perdeu sua identidade cultural tirolesa, mesmo durante os anos da política de repressão do período fascista. Acreditamos que não seja adequado considerar a diversidade linguística da região tirolesa - que há séculos une, pela comum cultura, três grupos lingüísticos - como uma justificativa para destacar a região trentina do contexto histórico, político e social do Tirol, pois tal destacamento não condiz com a realidade trentina. Por outro lado, como se observa na Parte II (capítulo 2), essa diferenciação exclusiva entre tirolês e trentino atenuou-se há décadas na comunidade, gerando confusões de identidade, $\mathrm{e}$ deve-se, entre outros motivos, à uma política equivocada de alguns indivíduos do Circolo Trentino di Piracicaba, entidade cultural local.
} 
Rio Grande do Sul), o dialeto trentino ainda é mantido como língua corrente e faz parte do cotidiano de seus habitantes.

$\mathrm{O}$ presente trabalho investiga a fala da comunidade $^{11}$ tirolesa da cidade de Piracicaba, estado de São Paulo, que se concentra em dois bairros rurais, Santana e Santa Olímpia, afastados mais de vinte e cinco quilômetros do perímetro urbano piracicabano. A colonização desses bairros remonta ao final do século XIX, exatamente no período das grandes imigrações trentinas e italianas para o Brasil (GrosselLI, 1991). A variante falada do português da comunidade - que recorda, de chofre, o falar dos habitantes das áreas coloniais do Sul do Brasil - destaca-se no contexto piracicabano e diferencia o falar dos bairros tiroleses dos demais bairros piracicabanos. Essa variante apresenta diversos aspectos e traços linguísticos oriundos do dialeto trentino, que é ainda mantido pelos falantes mais velhos da comunidade em duas variantes distintas, próprias a cada bairro.

A metodologia empregada para a obtenção de dados sobre a variante falada do português baseou-se na gravação da elocução espontânea de quinze informantes, moradores de ambos os bairros, pertencentes às diferentes gerações de descendentes. Uma vantagem para as análises e entrevistas é que há anos mantemos contato com os moradores da comunidade e possuímos ali amigos e conhecidos, de modo que isso se converteu numa vantagem para as análises e entrevistas, que foram realizadas num ambiente de naturalidade e de descontração. Além das informações gravadas, recolhemos o léxico trentino ou trentinizado, característico da fala local, por meio de registros não-gravados e que só foram possíveis de se registrar por causa do convívio com os membros da comunidade. No que se refere às entrevistas, procuramos inicialmente dividir os informantes exatamente segundo as gerações, todavia descobrimos que desse modo não corresponderíamos à realidade local, pelo fato de as famílias serem grandes e a faixa etária de filhos serem bem diversas dentro de um mesmo núcleo familiar. Assim, notamos que a faixa etária é o principal fator para uma análise fidedigna da realidade linguística da comunidade ${ }^{12}$.

\footnotetext{
${ }^{11}$ Utilizamos o termo comunidade para designar a comunidade linguística existente nos bairros Santana e Santa Olímpia, e para identificar seus moradores enquanto pertencentes a um mesmo grupo de descendentes. O que nos interessa principalmente é o sentido linguístico do termo. Cfr. LEME (2001: 25).

${ }^{12}$ Trata-se, contudo, de uma realidade de outrora (comum até meados da década de 1970), pois atualmente as famílias da comunidade não têm mais um número grande de filhos. Entretanto, ainda é possível encontrar ali vários casos de casamentos entre indivíduos que possuem a mesma idade, mas pertencem a diferentes gerações de descendentes. Também existem casos (não raros) de tios que são mais jovens que seus sobrinhos.
} 
Dividimos os informantes em três faixas etárias: A, B e C. O grupo A abrange os informantes de até vinte e nove anos (pertencentes, sobretudo, às quinta e sexta gerações de descendentes). $\mathrm{O}$ grupo $\mathbf{B}$ de trinta a sessenta anos (maioria pertencentes às terceira $\mathrm{e}$ quarta gerações de descendentes). $\mathrm{O}$ grupo $\mathbf{C}$ os informantes com mais de sessenta anos (pertencentes às primeira, segunda e terceira gerações de falantes), que acreditamos ser formado por aqueles indivíduos que preservam os traços linguísticos mais antigos e característicos da comunidade. Não há mais imigrantes vivos nos bairros e poucos são os pertencentes à primeira geração de descendentes (filhos de imigrantes), sendo esses, atualmente, cinco indivíduos ${ }^{13}$. Há um considerável número de pessoas pertencentes à segunda geração de descendentes (netos de imigrantes), cujo dialeto trentino ainda é a primeira língua, utilizada no ambiente doméstico e no convívio social.

Após as gravações e o levantamento de informações no trabalho de campo, todos os dados foram analisados e comparados com o material bibliográfico existente sobre a comunidade (LEME, 2001). O tempo aparente apresentado pelas faixas etárias é capaz de retratar a fala dos descendentes de maneira sincrônica, mas também diacrônica, tornando possível apresentar quais os traços linguísticos que se perdem ou se fortalecem, e como a fala da comunidade se vem transformando com o decorrer do tempo. Um tema tratado durante as análises, relevante para a pesquisa, foi o da "ruptura" linguística ocorrida nas décadas de 1960 e 1970, quando o dialeto trentino perdeu sua posição principal de língua da comunidade e foi substituído pelo português, que gradativamente passou a ser mais utilizado pelos descendentes.

Outro fator importante é que, no que se refere ao dialeto trentino ainda mantido pelos descendentes, existem diferenças próprias a cada bairro, que identificamos como sendo duas variantes de um mesmo dialeto trentino, aquele de Val dell'Adige. Os imigrantes que fundaram cada bairro eram oriundos de diferentes distritos trentinos e, por conta disso, mantêm duas variantes dialetais trentinas, cuja influência na variante falada do português da comunidade analisamos neste trabalho. Enquanto descendente de tiroleses e falante do dialeto trentino, pudemos analisar as variantes de cada bairro e registrar suas principais características, tendo em vista que desenvolvemos na comunidade, em parceria

\footnotetext{
${ }^{13}$ Quatro irmãos pertencentes à família Degasperi do Bairro Santa Olímpia e uma senhora da família Forti do Bairro Santana, cujo pai nascera no Brasil e a mãe no Tirol.
} 
com moradores locais, um trabalho de resgate e ensino do dialeto para as gerações mais novas, com organização de um dicionário.

Do ponto de vista linguístico, os falares das comunidades de imigração carecem, de modo geral, de estudos e registros. Sobre as variedades do português dessas comunidades existem menos estudos ainda, pois estudar a língua falada é um desafio por si só. Algumas áreas coloniais mantêm há mais de um século seus idiomas e dialetos originais, conservando traços linguísticos extintos em seus locais de origem e apresentando diversos casos de arcaísmos lexicais. Escassas são as publicações que descrevem o falar das comunidades trentinas no Brasil. Existem algumas teses de mestrado e doutoramento e alguns artigos, mas publicações sobre o assunto são poucas e se referem, sobretudo, aos estudos de dialetologia (Frosi \& Mioranza, 1983; BonAtTi, 1968, 1974; Boso, 2002). Sobre os tiroleses de Piracicaba consultamos o estudo de LEME (2001), que trata da realidade linguística da variante falada do português na comunidade, mas não se aprofunda no dialeto trentino.

Uma vez que a fala é a expressão humana num contexto temporal, podemos através desses estudos compreender melhor a realidade do Português Brasileiro no seu rico e diferenciado aspecto histórico. Estudar os falares das comunidades de imigração é, sem dúvida, de grande importância para a sociolinguística brasileira. $\mathrm{O}$ presente trabalho pretende apresentar, por meio de dados colhidos em trabalho de campo, uma sistematização dos mais relevantes aspectos da fala da comunidade tirolesa de Piracicaba e seu contexto linguístico. 


\section{PARTE I:}

A Comunidade Tirolesa de Piracicaba 


\section{A Cidade de Piracicaba}

\subsection{LOCALIZAÇÃo}

Piracicaba (popularmente chamada "a noiva da colina" ou "Pira") se localiza praticamente no centro do estado de São Paulo, numa das regiões atualmente mais industrializadas e economicamente produtivas.

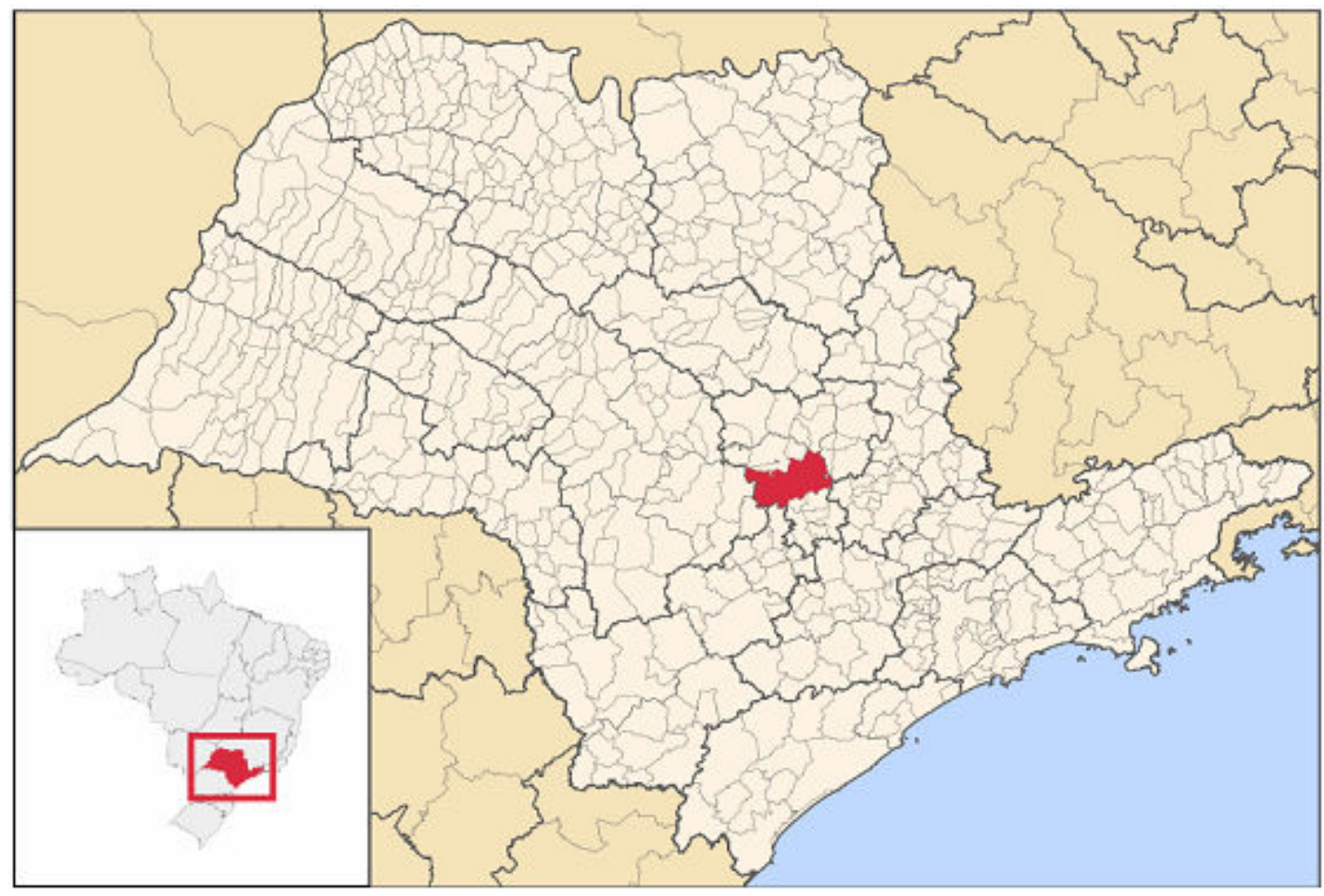

Mapa 1: Localização do município de Piracicaba no estado de São Paulo ${ }^{14}$

Densamente povoada, a região de Campinas, à qual pertence Piracicaba, concentra uma população superior a um milhão de habitantes. Piracicaba supera os 350 mil.

\footnotetext{
${ }^{14}$ Mapa: http://pt.wikipedia.org/wiki/Ficheiro:SaoPaulo_Municip_Piracicaba.svg
} 


\subsection{DADOS HISTÓRICOS}

O vale do Rio Piracicaba começou a ser ocupado durante o século XVII, quando alguns colonos adentraram a floresta e começam a ocupar as terras ao redor do rio. Durante o século XVII, a região paulista não apresentava um crescimento econômico significativo nas terras do interior. O cultivo da cana-de-açúcar - que movia a economia dos núcleos açucareiros nordestinos - não se desenvolvia nos povoados que eram mantidos em precárias condições. A população do interior se sustentava com a caça, a pesca e as pequenas plantações de subsistência e viviam, em muitos locais, de forma semelhante aos nativos.

Esse período marcou também o aprisionamento e tráfico de índios tupi, numa "tentativa" paulista de superação da precariedade econômica à qual estava imersa. Os conflitos entre índios e bandeirantes, a escravidão de aldeias inteiras e a propagação das doenças trazidas pelos portugueses fizeram com que o número de índios nas terras paulistas sofresse uma grande redução em meados de 1640. A redução da população indígena nas terras próximas do litoral fez com que os bandeirantes seguissem através dos sertões do interior da capitania (MEgale, 2000). Seguiam, sobretudo, em direção das prósperas missões jesuíticas do Paraguai, que foram por diversas vezes saqueadas, com seus índios levados como prisioneiros e escravizados pelos traficantes paulistas.

\subsubsection{As BANDEIRAS E AS MONÇõES}

Essas incursões em busca de índios proporcionaram aos bandeirantes a descoberta de jazidas de ouro no interior paulista, despertando o interesse dos europeus pela exploração mineradora. As bandeiras seguiam em direção a Cuiabá e, embora, mantinham a caça aos indígenas, cada vez mais o interesse pelo precioso minério as movia para o interior. A corrida do ouro que atraía cada vez mais paulistas em direção ao oeste fez com 
que o trajeto entre São Paulo e Cuiabá se tornasse intenso. É correto afirmar que foi a corrida do ouro que possibilitou a fundação de várias vilas e, dentre elas, aquela que se tornaria a cidade de Piracicaba.

A movimentação em direção a Cuiabá, feita principalmente através dos rios, ficou conhecida como Monções ${ }^{15}$, por sua dependência do período das cheias. A rota principal seguia através do Rio Tietê que, apesar da boa navegabilidade, em determinados trechos não permitiam a passagem das canoas por causa das cachoeiras Anhandava e Itapura; os bandeirantes eram obrigados a margear os rios por terra, carregando suas canoas.

Com o tempo, surgiu a necessidade de se criarem paradas (pousos) para descanso e auxílio dos viajantes nos trechos mais perigosos, bem como para garantia de suprimentos e socorros. Desses locais de pouso dos bandeirantes (chamados rancharias) nasceram os primeiros arraiais, vilas e cidades do interior, e que o processo migratório teve continuidade com os núcleos de mineração durante a corrida do ouro ${ }^{16}$.

Dos locais de paradas surgiam, gradativamente, núcleos de povoamento humano, criados para o suprimento dos que por ali passavam e, desse modo, mantidos pelos locais de exploração mineral e de expansão da Coroa Portuguesa.

Entretanto, o caminho para o oeste era difícil e cheio de dificuldades: doenças, inundações no período de chuvas, seguidas de grandes períodos de seca (prejudicando qualquer iniciativa de pequenas plantações de subsistência) e sucessivos ataques dos índios guaicurus e paiaguás. Por tais razões, entre 1721 e 1725, o bandeirante Luiz Pedroso de Barros, sob ordens do governador Rodrigo César de Menezes ${ }^{17}$, abriu um picadão cruzando os rios Capivari, Piracicaba e os Campos de Araraquara, aproveitando-se de uma antiga

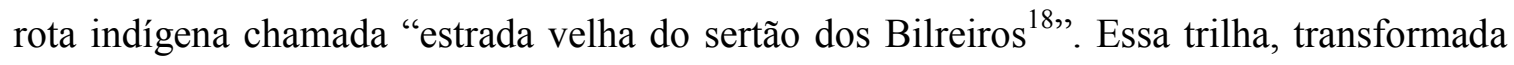
em rota de passagem dos brancos, serviu para o transporte de mulas e gado para Cuiabá (RIBEIRO, 1946; NEME, 1974; BACELLAR, 2006).

\footnotetext{
${ }^{15}$ Movimento para o interior do Brasil através dos rios, iniciado em 1718 quando Pascoal Moreira descobriu ouro nas barrancas do rio Coxipó-Mirim, na região onde atualmente se localiza a cidade de Cuiabá. A palavra portuguesa origina-se do termo árabe mausin, que significa estação do ano (TEYSSIER, 2001: 87) e fazia parte do linguajar dos navegadores portugueses para designar os ventos favoráveis para as viagens às Índias. Entre os bandeirantes, significou a estação das chuvas que propiciava a navegação fluvial em direção ao oeste.

${ }^{16}$ Cfr. Ribeiro (1946).

${ }^{17}$ Governador da Capitania de São Paulo, à qual as Minas dos Goyazes (Goiás) eram dependentes.

${ }^{18}$ Documentada entre os portugueses desde 1650. Bilreiros eram os índios caiapós que habitavam as regiões Norte e Nordeste de São Paulo (NEME, 1969).
} 


\subsubsection{O NÚCleO POPUlacional De Piracicaba}

Piracicaba significa em tupi-guarani "lugar onde o peixe para", e é uma referência às quedas do rio que bloqueiam a subida dos peixes na época da reprodução (piracema). $\mathrm{Na}$ parada que ficava à margem direita do Rio Piracicaba formava-se o primeiro povoamento ${ }^{19}$ por meio do sistema de posseiros e roceiros, que não possuíam concessão oficial de terras. No pedido de um título de sesmaria em Piracicaba, datado de 1726, Felipe Cardoso faz alusão à população que já habitava a região e cita o Porto de Piracicaba, indicando a navegação através do rio sua ligação com o povoado. Temendo o tráfico do ouro, em 1726, Rodrigo César de Menezes mandou fechar a antiga estrada dos Bilreiros e proibiu a abertura de novas estradas "indiretas".

Em 1748 uma carta régia extinguia o governo da Capitania de São Paulo, que foi subordinada aos governadores e capitães-gerais do Rio de Janeiro; em 1765, outra carta régia restabelecia a Capitania de São Paulo e seu governo, assumindo Luiz Antonio de Souza Botelho Mourão, chamado Morgado de Mateus. O novo governador recebeu em 1795 uma ordem expressa de Portugal para a criação de povoações nas áreas vazias do território paulista, expandindo, assim, as vilas para o sul e para o oeste. O Marquês de Pombal procurava proteger as terras portuguesas e incentivava o povoamento do interior por causa da crescente invasão espanhola. Foi, assim, reaberta a antiga estrada que ligava São Paulo a Cuiabá e que passava por Piracicaba e seguiu-se com a política de povoamento da colônia de Iguatemi (principalmente por famílias de negros e mulatos), na divisa com o futuro Paraguai, para estabelecer a posse definitiva da Coroa Portuguesa nas terras de Mato Grosso e Cuiabá (NEME, 1969, 1974).

Além da criação de novas vilas, o governo paulista tratou de fazer um levantamento dos habitantes da capitania e de ampliar o recrutamento militar da população pobre, no intuito de controlar o povoamento do interior de maneira objetiva. Era necessário, entre outras coisas, ampliar o poderio militar paulista para "barrar" a expansão espanhola do oeste e do sul. Contudo, o recrutamento não obtinha grandes êxitos por causa do modo de

\footnotetext{
${ }^{19}$ Em 1693, certo Pedro de Morais Cavalcanti requeria do governo paulista uma sesmaria em Piracicaba, para ali morar com toda sua família (NEME, 1974).
} 
vida itinerante da população do interior, formada principalmente por roceiros, que trabalhavam em pequenas lavouras de subsistência e viviam em sítios volantes ${ }^{20}$ (com o mesmo modo de plantio indígena), dificultando o recenseamento populacional e, conseqüentemente, o recrutamento militar.

Morgado de Mateus proibiu os sítios volantes e a deserção dos recrutas para os matos, com ameaças de punição. Formavam-se verdadeiros "quilombos de brancos" (Peregalli, 1986). Entretanto, o recrutamento não se limitava aos brancos pobres e sem expressão política, mas também aos negros, caboclos e mulatos. Os soldados eram, em sua maioria, pessoas pobres e no exército se lhes eram oferecidas premiações e até cargos de importância, no caso de auxiliarem o governo da capitania na captura de quilombolas. Desse período, existem os relatos dos quilombos paulistas e mineiros, formados principalmente por negros.

Em 1766 foi nomeado pelo governo da capitania o Capitão Antonio Corrêa Barbosa para o cargo de Diretor e Povoador de Piracicaba, que teve a responsabilidade de atender as famílias de posseiros já estabelecidas na região, bem como ampliar a população. A região era responsável por facilitar o abastecimento de víveres e munição às tropas que seguiam para Iguatemi, bem como auxílio e fornecimento de canoas para as frotas fluviais que seguiam para o oeste.

A povoação originalmente deveria ter sido fundada na foz do rio Piracicaba com o Tietê, nas proximidades da atual cidade de Santa Maria da Serra (NEME, 1969, 1974). Antonio Corrêa Barbosa, contrariando a decisão do governador (pela recusa das famílias de ocupar aquela área considerada pouco fértil e pestilenta), decidiu povoar um ponto localizado a setenta quilômetros da foz do Piracicaba, pois ali já habitavam os primeiros posseiros e havia melhor acesso a outras vilas da região, notadamente Itu. As famílias se estabeleceram na margem direita do rio, mantendo-se através da cultura de subsistência, da caça e da pesca e com um pequeno comércio que se limitava à produção de canoas e ao abastecimento de necessidades para os habitantes de Iguatemi. Para lá também foram enviados presos e homens sem ofício fixo, com os quais Antonio Corrêa Barbosa

\footnotetext{
${ }^{20}$ Modo de plantio semelhante às plantações de mandioca indígenas, com mudanças de roça depois de determinado tempo de uso do solo. Acreditava-se que a mudança para solos de mata virgem ajudaria no plantio; trata-se de um dos fatores responsáveis, já àquela época, pela derrubada da Mata Atlântica paulista que, como é sabido, extendia-se por boa parte do interior.
} 
posteriormente povoou as margens do Rio Tietê (Avanhandava, barra de Piracicaba e Itapura). Considera-se oficialmente a fundação de Piracicaba em $1^{\circ}$ de agosto de 1767.

Em 1775, Martim Lopes Lobo de Saldanha assume o governo da Capitania de São Paulo e em 1776 a povoação de Piracicaba é elevada a freguesia. O novo governador considerava Iguatemi como uma colônia inútil e responsável pela dispersão dos habitantes da capitania. Iguatemi perde sua importância e, enfraquecida, é atacada em 1777 pelos espanhóis sob o comando de D. Agostinho Fernando de Pinedo, governador espanhol da Província do Paraguai. Segundo Neme (1974: 40-48), com a destruição da colônia militar pelos espanhóis, a freguesia de Piracicaba começou a perder sua importância, pois era economicamente dependente de Iguatemi. Não havendo mais necessidade de permanecer na margem direita do rio para servir de barreira contra os espanhóis no caminho para Itu, nem a necessidade de se produzir canoas para Iguatemi, a população começou a diminuir e foi necessária uma transferência.

Diante da situação, Frei Tomé de Jesus e o Capitão Corrêa Barbosa fizeram um abaixo-assinado pedindo ao governador a transferência da povoação da margem direita para a margem esquerda do Rio Piracicaba, abaixo do salto. $\mathrm{O}$ então governador, Francisco da Cunha Menezes, tratou de enviar o capitão-mor de Itu, Vicente da Costa Taques, para participar em Piracicaba da transferência da população; este percorreu pelas novas terras e demarcou o pátio da nova igreja matriz, bem como a área das duas ruas direitas da nova freguesia.

\subsubsection{FORMAÇÃO DA POPULAÇÃO CAIPIRA}

O movimento das Monções também proporcionou condições de prosperidade para aqueles que se aventurassem na mineração. Permitiu a um grande número de mestiços (principalmente de brancos com índios) a sobrevivência através de pequenas propriedades rurais com lavouras de subsistência. 
O incentivo do governo para a povoação do interior e a decadência da atividade mineradora obrigou os mineradores já sem trabalho a buscarem seu sustento nas pequenas lavouras. Houve um aumento significativo no número de posseiros e roceiros que seguiram para as margens de vários rios. Contudo, a posse das terras ocasionou um povoamento dispersivo, com um considerável distanciamento entre famílias distribuídas em suas pequenas propriedades, mantendo ali o cultivo do milho, da mandioca, de algumas frutas e também utilizando a caça e a pesca como meios de sobrevivência (CANDIDO,1975). O povoamento dos posseiros nas margens dos rios, o estabelecimento de ex-mineradores em pequenas propriedades rurais e a fuga de homens pobres para o mato, desertando do recrutamento obrigatório do exército, são fatores importantes para a compreensão da realidade cultural daquela que se tornaria a população caipira paulista.

A região de Piracicaba, desde o início de seu povoamento, apresentava uma economia baseada na agricultura de subsistência, e que assim permaneceu até a metade do século XIX. As roças de mandioca, milho e feijão propiciavam a base da alimentação dos caipiras e dos sertanistas que seguiam para Cuiabá. Com o declínio da exploração do ouro, a população manteve a mesma base alimentar de subsistência mínima, e quase não havia giro de capital entre essas populações:

"O capital de que dispõe o roceiro é o mínimo, e o método que utiliza para ocupar novas terras, o mais primitivo. Reunidos em grupos, abatem as árvores maiores e, em seguida, usam o fogo como único instrumento para limpar o terreno. Aí, entre troncos abatidos e tocos não destruídos pelo fogo, plantam a roça. Para os fins de alimentação de uma familia, essa técnica agrícola é suficiente".

(FURTADO, 2000: 125-6)

A freguesia foi elevada à condição de vila em 1821 e recebeu o nome de Vila Nova Constituição, em homenagem à constituição portuguesa promulgada naquele ano. Seus habitantes viviam sobretudo de suas pequenas lavouras familiares e o modo de viver dos caipiras não havia se modificado significativamente, permanecendo bastante rudimentar e baseando-se em mínimos vitais (PIRES, 2008).

A partir do século XIX, na Vila Nova Constituição e nas demais localidades da região teve início a produção açucareira, que se desenvolveria nas décadas seguintes e 
modificaria toda a economia local. Entretanto, no início do cultivo da cana-de-açúcar, a vila não havia perdido suas antigas características:

"Com mais de meio século de existência, às vésperas de se tornar cidade, Piracicaba, de fato, não passava de uma vila, onde, apesar de sua ponderável produção açucareira, mantinha características de economia de subsistência".

(TORRES, 2003: 99)

E do mesmo modo seus habitantes. Eram os caipiras, descendentes dos primeiros posseiros e roceiros, mescla dos portugueses e indígenas, que haviam se transferido para "os matos" e criado as primeiras roças. Seu sistema de trabalho não era rígido e não havia uma cultura de acúmulo de riquezas; antes, era a cultura de subsistência (auxiliada pela caça e pela pesca) que o sustentava.

“(...) o caipira é de origem paulista. É produto da transformação do aventureiro seminômade em agricultor precário, na onda dos movimentos de penetração bandeirante que acabaram no século XVIII e definiram uma extensa área (...). Nessa linha de formação social e cultural, o caipira se define como um homem rústico de evolução muito lenta, tendo por forma de equilibrio a fusão intensa da cultura portuguesa com a aborigine e conservando a fala, os usos, as técnicas, os cantos, as lendas que a cultura da cidade ia destruindo, alterando essencialmente ou caricaturando".

(CANDIDO, 2004: 270-1)

Sobre as características do modo de vida caipira, CANDIDO (1975) atenta para o fato do isolamento, onde os agrupamentos humanos (bairros rurais) se constituíam como pequenas nações. As relações de vizinhança baseadas no assistencialismo e na participação mútua nos trabalhos das roças - permeados de crenças e costumes lúdico-religiosos, assim como de festejos arcaicos - desenvolviam o senso de solidariedade mútua do grupo e ditavam os costumes sociais da população caipira. Essa foi, durante praticamente dois séculos, a "ordem social” da sociedade rural da região piracicabana.

A pouca relação dos meios rurais com os centros urbanos permitia aos caipiras preservar seu antigo modo de vida, suas crenças e costumes (muitos dos quais remetem ao 
período colonial, preservados que foram nos hábitos simples). Esse modo de viver "à margem" preservou não somente os costumes, mas também o modo de falar dos caipiras; sua fala também ficou "marginalizada", no sentido de que não acompanhou as mudanças do falar das cidades, permitindo à sociedade caipira a permanência de um estado de língua mais conservador.

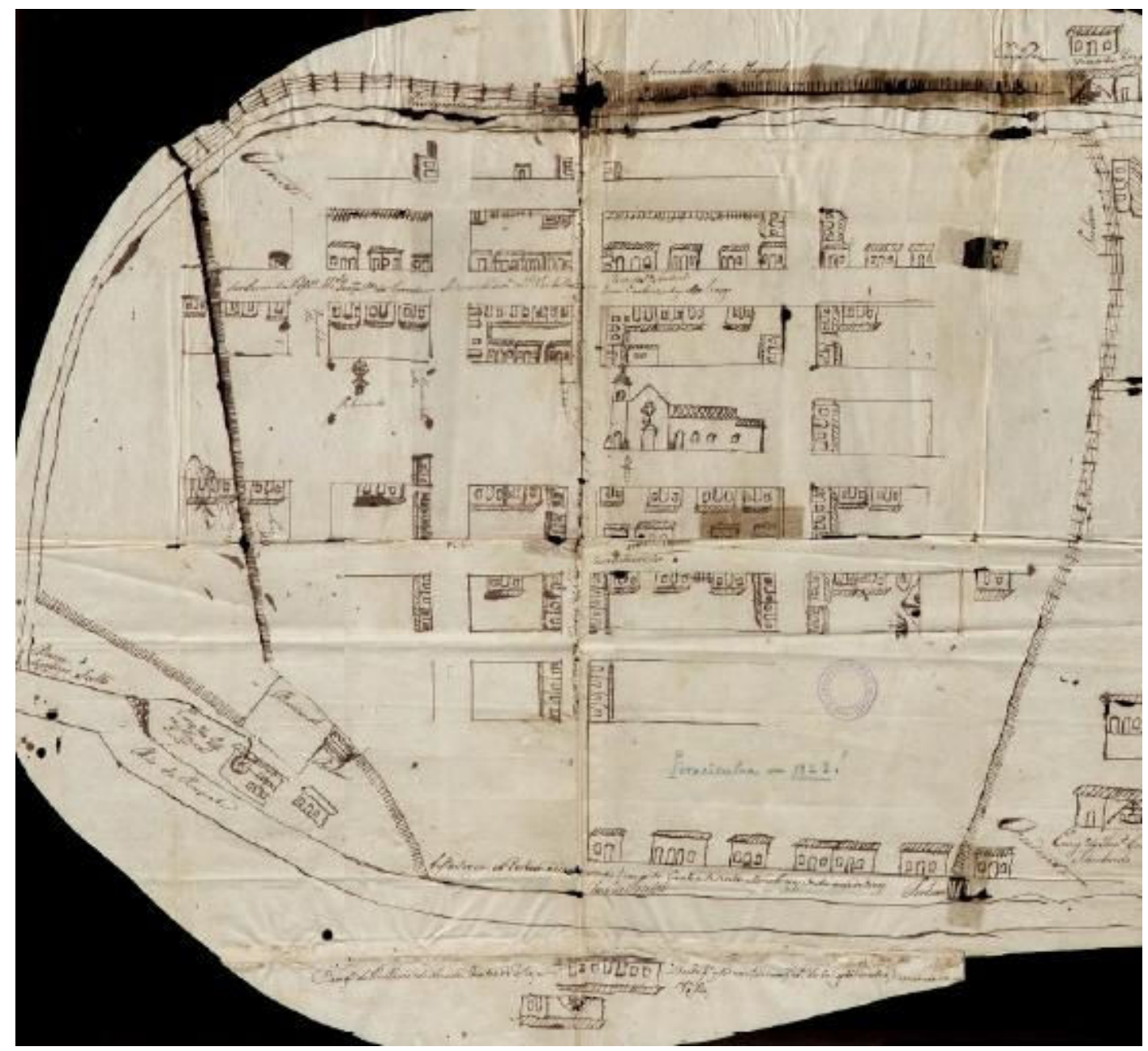

Mapa 2: A Vila Nova Constituição (atual Piracicaba) em um mapa de $1823^{21}$.

A região de Piracicaba ficou por muito tempo "isolada" por conta das precárias condições das estradas e pontes que a ligavam à capital e ao Mato Grosso. A pouca comunicação com os grandes centros foi um fator que preservou as antigas roças de

\footnotetext{
${ }^{21}$ Mapa: acervo do Arquivo Público do Estado de São Paulo.
} 
subsistência e os hábitos das pequenas comunidades rurais até a primeira metade do século XIX.

\subsubsection{O SÉCULO XIX}

É a partir do século XIX que ocorrem mudanças sociais mais significativas na região piracicabana. Em 1821 a freguesia fora elevada a vila e, no ano seguinte, reuniu-se aquela que seria a primeira câmara de vereadores de Vila Nova Constituição. Entretanto, durante a primeira metade do citado século, a policultura ainda dominava a paisagem rural e a estrutura econômica era agrícola, baseada no trabalho servil dos escravos negros.

A câmara, ligada ao governo provincial paulista, não conseguia desenvolver grandes obras de desenvolvimento, pois não lhe era permitida a cobrança de impostos. Sem grandes recursos, a produção açucareira que começava a se desenvolver nas terras piracicabanas não conseguia transportar o açúcar produzido para Santos e isso prejudicava sobremaneira sua economia.

Em 24 de abril de 1856 a vila foi elevada à categoria de cidade, mantendo o nome Nova Constituição. Somente em 1877, em sessão extraordinária da câmara municipal (e por indicação do então vereador Prudente de Moraes), restitui-se o nome Piracicaba para a cidade, uma vez que a região era popularmente conhecida por causa do rio. Enquanto cidade, Piracicaba passou por um momento de desenvolvimento e urbanização mais intenso, embora sua economia permanecesse essencialmente agrícola e sua urbanização fosse precária (ruas de terra, paisagem rural ainda mesclada àquela urbana).

Durante a segunda metade do século XIX, enquanto as regiões de Rio Claro, Capivari e Santa Bárbara d'Oeste viam suas áreas rurais serem tomadas pela cultura do café (que crescia gradativamente pelo interior paulista), Piracicaba permanecia o cultivo da cana-de-açúcar. Em 1836 foi inaugurada a estrada de ferro que ligava a cidade a Itu, permitindo o transporte da produção açucareira para o litoral. 
Em 1881 foi construído o Engenho Central às margens do Rio Piracicaba, e sua instalação garantiu um avanço significativo para a cidade: centralizou a fabricação do açúcar de forma organizada, utilizou equipamentos modernos (movidos principalmente pela força da água) e, pela primeira vez, houve contratação de mão-de-obra assalariada na cidade. A instalação do engenho fez de Piracicaba a maior produtora de açúcar da América Latina. O crescimento econômico trouxe a instalação de prestigiosas instituições de ensino, que ajudaram significativamente no desenvolvimento social da cidade. Em 1881 foi fundado o Colégio Piracicabano ${ }^{22}$ pela missionária metodista norte-americana Martha Watts. Em 1892 Luiz de Queirós doava ao governo paulista a Fazenda São João da Montanha para que ali fosse construída uma escola agrícola ${ }^{23}$ que, em 1901 teve seus primeiros alunos. A iluminação pública demonstrava o rápido desenvolvimento do município e a criação de jornais despertou na sociedade local uma adesão significativa ao movimento republicano (TORRES, 2003).

No final do século XIX o Brasil começava a receber os imigrantes vindos principalmente da Europa. Esses imigrantes substituiriam os escravos nas lavouras e trariam um avanço econômico para as fazendas através dos contratos de parceria. Contudo, se, por um lado, a imigração resolveria o problema da mão-de-obra das fazendas, muitos dos grandes fazendeiros se preocupavam com a criação de pequenos sítios dos imigrantes. Essa preocupação fez com que os fazendeiros propusessem uma legislação que proibisse os imigrantes de adquirirem suas pequenas propriedades, assim como os pequenos lavradores caboclos e os negros forros. Essa medida culminou com a Lei de Terras de 1850, que restringia o acesso à compra de terras e reforçava o poder dos latifundiários.

Já em 1846, o fazendeiro e senador Nicolau Pereira de Campos Vergueiro foi um dos pioneiros na contratação de imigrantes europeus. Desde 1840 procurou atrair imigrantes portugueses para sua fazenda de café, através de contratos de parceria. Sua propriedade, a Fazenda Ibicava, ficava na região de Limeira, distrito de Piracicaba (então Vila Nova). Posteriormente, com auxílio do governo, o Senador Vergueiro trouxe imigrantes alemães e suíços; em 1846 estabeleceu acordos com 364 famílias alemãs, na maioria prussianos, bávaros e do Holstein, que trabalhariam juntamente com os duzentos e

\footnotetext{
${ }^{22} \mathrm{O}$ colégio tornar-se-ia futuramente a Universidade Metodista de Piracicaba (UNIMEP).

${ }^{23}$ Atual Escola Superior Agrícola Luiz de Queiros (ESALQ), pertencente à Universidade de São Paulo (USP) e reconhecida internacionalmente por sua produção científica e atuação.
} 
quinze escravos da fazenda Ibicava (CosTA, 1985: 70). Posteriormente, Piracicaba receberia demais imigrantes vindos do Império Austro-húngaro, da Espanha e, principalmente, da Itália.

Em Piracicaba, o cultivo do café foi importante e, juntamente com a cana-de-açúcar (cuja produção era maior), formava a base econômica do município. As grandes levas de imigrantes que seguiam para o interior paulista trabalharam no cultivo do café, mas em Piracicaba muitos imigrantes também substituíram a mão-de-obra escrava na produção canavieira.

O desenvolvimento econômico e social marcou o declínio da cultura caipira nas áreas rurais. A partir da segunda metade do século XIX a maioria da população rural de Piracicaba estava de algum modo envolvida com a produção canavieira. Com a expansão dos canaviais e a modernização das usinas, a monocultura provocou grandes desmatamentos e a "expulsão" dos lavradores caipiras de suas pequenas propriedades. A presença estrangeira dos imigrantes trazia modos diferentes de lidar com a terra; esses camponeses europeus possuíam hábitos muito diferentes daqueles da cultura cabocla.

\subsubsection{O SÉCULO XX}

Piracicaba no início do século XX tornava-se gradativamente um complexo agroindustrial desenvolvido, e na década de 1950 era chamada "a capital do açúcar". Nesse período, teve início no Brasil e quase toda a América Latina uma política de substituição de importações. Intensificava-se em Piracicaba a atividade industrial ligada à produção açucareira e as fábricas eram ampliadas, além das novas que eram instaladas. Destaca-se o empenho do imigrante italiano Mário Dedini, nascido em Lendinara (Província de Rovigo), fundador do Grupo Dedini que se consolidava como o maior do país no setor açucareiro, com grande importância para a economia de Piracicaba. 
A partir da década de 1970, teve início um processo de diversificação econômica com a implantação de um complexo parque industrial. Tiveram destaque as indústrias mecânica e agrícola, metalúrgica e de papel. A instalação da produtora americana de máquinas rodoviárias e tratores Caterpillar marcou a chegada de modernas indústrias de capital estrangeiro e de novos segmentos industriais. A criação do Proálcool, em 1975, deu um grande impulso às usinas e destilarias piracicabanas, aumentando o desenvolvimento do parque industrial voltado para o setor canavieiro.

Com o desenvolvimento do setor açucareiro e industrial (voltado principalmente para a produção daquele), continuava o êxodo rural e as pequenas propriedades se tornavam cada vez mais raras. As décadas de 1960 e 1970 marcam o pior período de uma crise econômica estagnada na cana-de-açúcar e sem novos investimentos. Piracicaba perdia seu status de maior cidade da região para Campinas e Jundiaí e de principal polo regional da região, torna-se um centro local para as cidades ao redor e, como tais, torna-se uma dependente de Campinas. Nesse período, Piracicaba ganha o apelido de "fim de linha", referente ao estagnado posicionamento logístico da cidade; a ferrovia secundária dependia de linhas mais importantes e isso demonstrava sua decadência econômica e a diminuição de sua importância na região.

A partir da década de 1970 a prefeitura passou a tomar ações específicas no sentido de incentivar o crescimento da economia local: construi-se a Rodovia do Açúcar ligando Piracicaba à Rodovia Castello Branco e servindo como uma nova rota de escoamento da produção açucareira e industrial, bem como garantindo a influência piracicabana na microrregião de Capivari; duplicou-se a Rodovia Luiz de Queiróz até a Via Anhanguera, melhorando o acesso à cidade e ligando-a com a principal rodovia do interior paulista; criaram-se novos distritos industriais que atraíram novas empresas para a cidade. Paralelamente, o Proálcool modernizou o cultivo da cana-de-açúcar e ajudou a revigorar a produção canavieira piracicabana. Não atingindo o mesmo potencial do passado, as medidas tomadas permitiram que, nas décadas seguintes, Piracicaba se tornasse novamente uma das cidades mais promissoras do interior paulista ${ }^{24}$.

\footnotetext{
${ }^{24}$ Piracicaba é atualmente o $9^{\circ}$ Município do Estado de São Paulo em valor de produtos exportados.
} 
Sobre os efeitos do desenvolvimento econômico na cultura caipira, AMARAL (1920) já afirmava que até o final do século XIX a cultura caipira conseguira sobreviver entre boa parte da população paulista e que, a partir do século XX, desapareciam os antigos modos de viver e falar da população caipira paulista. Em Piracicaba não foi diferente. Além dos fatores citados, a monocultura da cana-de-açúcar ocasionou a transferência de muitos dos pequenos sitiantes para a cidade, provocando um êxodo rural que modificou sobremaneira a realidade da população local.

A campanha do Proálcool gerou um crescimento urbano descontrolado e fundaramse novos bairros, para onde os antigos sitiantes se transferiam. Durante as décadas de 1960 e 1970 , o crescimento urbano oscilava entre $70 \%$ e $80 \%$ e na década de 1980 era de $92,3 \%$, o que significou a transferência de mais de oito mil piracicabanos que migraram de suas áreas rurais para a cidade. A descontrolada urbanização gerou pobreza e miséria entre várias famílias. Muitos trabalhadores se tornaram "bóias-frias" no corte da cana e aqueles que seguiram para as usinas e fábricas, viviam em periferias semelhantes às favelas dos grandes centros urbanos; aqueles que preferiram manter suas pequenas propriedades, viram o asfalto se aproximar a ponto de suas terras "sobrarem" nas imediações do perímetro urbano.

\subsection{DADOS ATUAIS DO MUNICÍPIO}

O municício de Piracicaba é dividido em seis distritos (que se subdividem em bairros): centro, Artemis, Ibituruna, Tupi, Guamium e Santa Teresinha (ao qual pertencem os bairros rurais de Santana e Santa Olímpia, objetos de estudo desse trabalho).

Atualmente, estima-se que a população piracicabana seja de aproximadamente 366 mil habitantes, dos quais cerca de 355 mil vivem na área urbana. Segundo os dados do 
IBGE de $2000^{25}, 79,1 \%$ da população é de etnia branca, $6,3 \%$ negra, $14,1 \%$ parda, $0,3 \%$ amarela e $0,2 \%$ indígena.

Representante significativa da força econômica do interior paulista, Piracicaba é a $52^{\mathrm{a}}$ mais rica do Brasil e exibe um Produto Interno Bruto (PIB) de R\$ 5,7 bilhões. O complexo industrial regional é formado por mais de cinco mil indústrias, destacando-se aquelas dos setores metalúrgico, mecânico, têxtil, alimentício e de combustíveis (petroquímicos e álcool). No setor agrícola, a cultura de cana-de-açúcar (10 milhões de toneladas/ano) ainda domina a paisagem piracicabana. Entretanto, destacam-se também as culturas do café, laranja e milho. A pecuária é representativa (rebanho de 150 mil cabeças de gado), além da avicultura (mais de sete milhões de aves) ${ }^{26}$, que abastecem a demanda local.

\footnotetext{
${ }^{25}$ Fonte: http://pt.wikipedia.org/wiki/Piracicaba (dados recolhidos em 14 de janeiro de 2009 à 17h00).

${ }^{26}$ Dados do município: www.piracicaba.sp.gov.br (recolhidos em 14 de janeiro de 2009 às 17h10).
} 


\section{O TIROL HISTÓRICO}

\subsection{INTRODUÇÃO}

Procuraremos apresentar nesse capítulo introdutório sobre o Tirol, os principais aspectos de sua história e cultura, desde suas origens na Antiguidade até os dias atuais. Por ser uma terra de encontros de diferentes etnias e falares, a região tirolesa possui características muito peculiares, próprias de seu contexto geográfico e político, relevantes para uma compreensão mais abrangente acerca da realidade da imigração tirolesa para o Brasil e dos motivos que a ocasionaram.

O termo Tirol histórico (al. Historisches Tirol; it. Tirolo storico) é utilizado para identificar toda a extensão territorial do antigo condado tirolês, que permaneceu sob o domínio da Casa Imperial da Áustria do século XV até o final do Império Austro-húngaro, ou seja, após a Primeira Guerra Mundial (1918). Enquanto histórica, a região não se limita ao atual estado (Bundesland) austríaco do Tirol, mas também abrange a porção anexada ao território italiano após 1918. Trata-se, portanto, de um território que se localiza entre dois paises, numa área montanhosa entre os Alpes centrais, ao norte, e as montanhas Dolomitas, ao sul. Atualmente, o território tirolês divide-se em três províncias politicamente distintas, cujas denominações oficiais demonstram a complexidade linguística e étnica da região. Linguisticamente, o Tirol localiza-se numa área de divisão natural dos falares latinos dos germânicos, onde ocorre o encontro das culturas italiana e alemã. Pertence à Áustria, o estado do Tirol (Bundesland Tirol) é a porção setentrional do antigo Tirol, subdividido em Tirol Setentrional (Nordtirol) e Tirol do Leste (Osttirol). A porção meridional, anexada pela Itália em 1918, forma uma região administrativamente autônoma, com três denominações oficiais: em italiano, Regione Autonoma Trentino-Alto Adige; em alemão, Autonom Region Trentino-Südtirol; em ladino, Region Autonoma Trentin-Südtirol. Essa região subdividide-se em duas província autônomas: Província Autônoma de Trento (Trentino) e Província Autônoma de Bolzano (Südtirol / Alto Adige). 
A geografia tirolesa é marcada pelas montanhas acima de dois mil metros, e quase dois terços de sua área total é coberta por florestas e bosques. A maior montanha tirolesa é o Großglockner, localizado no Tirol do Leste (Áustria), com 3.797 metros; ao sul, na porção italiana, a região é dominada pelas montanhas Dolomitas, com destaque para o Maciço do Sella. Seus principais rios são: o Inn, com 510 quilômetros de comprimento, que nasce na Suíça (Engadina ${ }^{27}$ ), atravessa toda a região do Tirol Setentrional, entra na Alemanha (Baviera) e desemboca no Danúbio; o Isarco (=Eisack), que nasce no Südtirol e desemboca no principal rio da parte meridional, o Adige (=Etsch), que atravessa todo o território Trentino e segue para o sudoeste, em direção a Verona. As cidades tirolesas e as diversas aldeias se espalham pelos diversos vales da região, e algumas se localizam acima dos mil e quinhentos metros.

Os Alpes cobrem uma área que abrange partes da Alemanha, Áustria, França, Suíça, Liechtenstein, Itália e Eslovênia, países localizados na região culturalmente denominada pelos falantes de alemão Mitteleuropa <Europa Central>, por causa de características peculiares do modo de vida montanhês, comum a diversos países. Ao se estudar algum aspecto histórico, étnico ou linguístico de uma região como o Tirol, torna-se necessário regredir cronologicamente até as suas origens e entender a sua formação enquanto região histórica, pois essas origens estão intrinsecamente ligadas às realidades linguísticas, culturais e políticas.

\subsection{DADOS HISTÓRICOS DA REGIÃO TIROLESA}

A arqueologia dispõe, até certo ponto, de limitadas informações sobre as civilizações e culturas que habitaram a região alpina, de modo que dependem dos vestígios históricos desses povos (muitos dos quais não conheciam a escrita) para poderem tecer qualquer tipo de comentário. Muitas vezes somos obrigados a supor muito mais do que comprovamos, de modo que aquilo que sabemos sobre algumas populações se resume a

\footnotetext{
${ }^{27} \mathrm{O}$ radical Enn refere-se ao rio.
} 
poucos fragmentos de objetos. Pela precariedade de vestígios, a arqueologia procura, também, complementar suas informações sobre tais civilizações baseando-se nos relatos de outros povos (como os gregos), o que torna seus estudos ainda mais difíceis, pois freqüentemente esses comentários estão cheios argumentos fantasiosos. Comparando vestígios mortuários ou arquitetônicos dessas antigas civilizações, podemos, de modo geral, saber sobre culturas de origem semelhante, mas isso nem sempre significa mesma etnia ou, ainda mais difícil, falantes de uma mesma língua. Sabe-se que entre alguns povos da Antiguidade, era comum a adoção dos costumes e do idioma de outros povos, causados pelos mais diversos motivos: mescla étnica, adoção voluntária (prestígio social) ou dominação estrangeira.

Do mesmo modo ocorre com a filologia, em sua tentativa de reconstrução de idiomas extintos, como o indo-europeu ou o latim vulgar (BASSETTO, 2001). A descoberta de algum novo fragmento escrito pode influenciar todas as informações até então levantadas, de forma que muito do que se conhece (e se toma por princípio) é também suposição. Isso não significa, contudo, que a filologia se baseia somente em suposições ou que se sustenta sobre informações infundadas. O método histórico-comparativo de DIEZ (1794 - 1876) para o estudo das línguas românicas, baseando-se nos dados obtidos a partir de idiomas de origem latina, pode determinar os fenômenos linguísticos ocorridos nas diferentes línguas oriundas do latim vulgar e do latim clássico, os contextos fonéticos e morfológicos que ocasionaram as mudanças e o distanciamento de uma língua perante outra.

\subsubsection{DA PRÉ-HISTÓRIA À CONQUISTA ROMANA}

A região dos Alpes centrais foi inicialmente povoada pelos ilírios, cujas origens remontam à Idade do Bronze (aproximadamente 2000 a.C.). Os gregos identificavam os

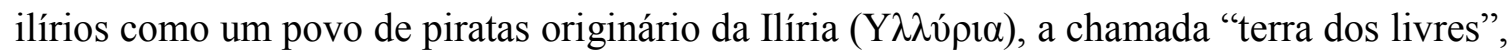
região que hoje compreende os países surgidos da ex-Iugoslávia: Sérvia, Montenegro, norte 
da Albânia, Bósnia-Herzegovina e Croácia. Segundo BASSETTO (2005: 170), os ilírios eram falantes de uma língua indo-européia pertencente ao grupo Centum, e pouquíssimo conhecimento existe sobre seu idioma. A partir de 1500 a.C. os ilírios começaram a migrar em direção aos Alpes orientais, ampliando sua área de domínio e se estabelecendo nas atuais regiões da Eslovênia, Ístria e sul da Áustria (Kärnten - antiga Carintia romana). Illyricum designava o interior da região; a área costeira era chamada Dalmácia (Dalmatia), mas era habitada por povos ilírios (dálmatas, libúrnios, iápiges e dárdanos).

Em 229 a.C. a política expansiva romana passou a considerar o Mar Adriático como parte da sua esfera de influência e Roma declarou guerra à Ilíria, também como resposta à prática de pirataria dos ilírios que incomodava o comércio marítimo romano. A região costeira foi conquistada por César, estendendo-se posteriormente com Otávio Augusto e Tibério até às planícies da Panónia (Pannonia), por onde corre o rio Danúbio.

Alguns povos de origem proto-ilírica já se haviam estabelecido em boa parte dos Alpes Orientais em aproximadamente 1000 a.C., nas atuais regiões italianas do Vêneto, Friúlia e sul do Tirol. Essas tribos (arusnatos, histros, iápodos e liburnos) substituíram a antiga cultura dos euganeus, resultando no povo venético ou paleovêneto (VIARO, 2001), que desenvolveu naquela área alpina seus núcleos coloniais. Além da própria designação italiana Veneto (terra dos vênetos), alguns topônimos tiroleses, segundo BATTISTI (1931), remetem à dominação paleovêneta naquela área alpina, como a denominação de Val Venosta (=Vinschgau; Vintschgau), no Südtirol, que teria origem no mesmo étimo do termo vêneto.

O paleovêneto é um idioma pouco conhecido, com pouquíssimos vestígios de sua escrita. Nem mesmo as afirmações sobre suas origens são totalmente seguras enquanto oriundas da cultura Este, que se desenvolveu na Idade do Ferro. Sabe-se que a cultura paleovêneta tem relação com os povos centro-danubianos dos Campos das Urnas e com os grupos ilírios dos Bálcãs. Para Devoto (1991), o idioma dos venéticos é de origem indoeuropéia e formado a partir de uma cristalização de uma série de elementos linguísticos indo-europeus. Pelo contato com a população céltica a oeste, o paleovêneto adotou muitos termos da língua celta, e a população paleovêneta também adotou os caracteres da escrita etrusca (CONWAY, 1933). 
Acima da Pannonia viviam os celtas (também chamados gauleses), cujos registros históricos remetem à Idade do Bronze e que entre 1200 a.C. - 1000 a.C. iniciaram um processo de individualização cultural que desenvolveu durante a Idade do Ferro a civilização da cultura de Hallstatt (nome que provém da cidade austríaca homônima, na região de Salzburg). O termo celta é de origem grega (K $\square \lambda \tau$ oí), pois os helenos mantinham relações comerciais com os celtas em suas excursões através dos Alpes, adquirindo destes o sal de sua região. A expansão céltica ocorreu durante o período da cultura de Hallstatt (século VI a.C. até 450 a.C.) atingindo praticamente toda a área alpina e, a partir dos Alpes ocidentais, seguiu para várias direções. Durante esse período, os celtas já haviam seguido para a Península Ibérica, onde se mesclaram em muitas áreas com os iberos ${ }^{28}$ (BASSETTO, 2005).

Durante essa fase da Idade do Ferro, que vai de 800 a.C. a 450 a.C., os celtas trabalhavam na confecção de armas de bronze e grande armas de ferro. A segunda fase da Idade de Ferro marca o desenvolvimento da cultura de La Tène (em alusão à cidade onde foram encontrados tais vestígios arqueológicos, localizada no norte da Suíça), que marcou o desenvolvimento cultural e a expansão dos celtas, mobilizada pelo crescimento demográfico e pela pressão de outros povos vizinhos. Os celtas se estabeleceram na Gália Cisalpina (Gallia Cisalpina), que compreendia boa parte da planície padana até o rio Reno (Rhein) ao norte; para o oeste pela Gallia (região da atual França) e península ibérica. Foi neste período que, após diversas excursões, seguindo do norte da França (Bretanha), os celtas concluíram a ocupação das Ilhas Britânicas, onde encontraram outros povos, como os pictos. Os ataques ao mundo Greco-Romano foram freqüentes no final da expansão céltica: em 390 a.C., Roma foi saqueada pelos gauleses e, em 272 a.C., o santuário de Apolo na cidade grega de Delfos foi também alvo de seus ataques. Através do rio Danúbio, os celtas atingiram em 276 a.C. a Ásia Menor, onde se estabeleceram na região da Galácia (Galatia), atual Turquia.

A região dos Alpes centrais e ocidentais fora ocupada pelos réticos (Rcetii), cujas origens enquanto falantes de uma língua indo-européia são incertas; existem hipóteses (sem

\footnotetext{
${ }^{28}$ Estudos indicam que o povo ibero não era indo-europeu e se encontrava na península ibérica desde tempos imemoriais. O historiador clássico Flávio Josefo afirmava os chamava tubalinos, descendentes de um certo Tubal; os gregos os classificavam em dois povos, os tartessos e os bastetanos. A escrita ibérica consistia num sistema de vinte e oito sílabas e caracteres alfabéticos, alguns derivados do fenício e do grego, mas de origem desconhecida, que se conservou até a conquista romana. Cfr. COUTINHAS (2006).
} 
comprovação) de que os réticos teriam parentesco com os etruscos (CONWAY, 1933). Este povo se estabeleceu entre 800 a.C. e 500 a.C. em toda a área montanhosa da Récia (Rhaetia ou Raetia), nas atuais regiões oeste e central da Suíça, sul da Alemanha (sul da Baviera e parte da Suábia), Áustria (Vorarlberg e boa parte do Tirol) e norte da Itália (Lombardia); a principal cidade dos réticos foi posteriormente chamada pelos romanos Augusta (atual Augsburg, na Alemanha). Na atual área tirolesa, a Récia compreendia as regiões de Val Venosta (=Vinschgau) e parte de Val d'Isarco (= Eisacktal).

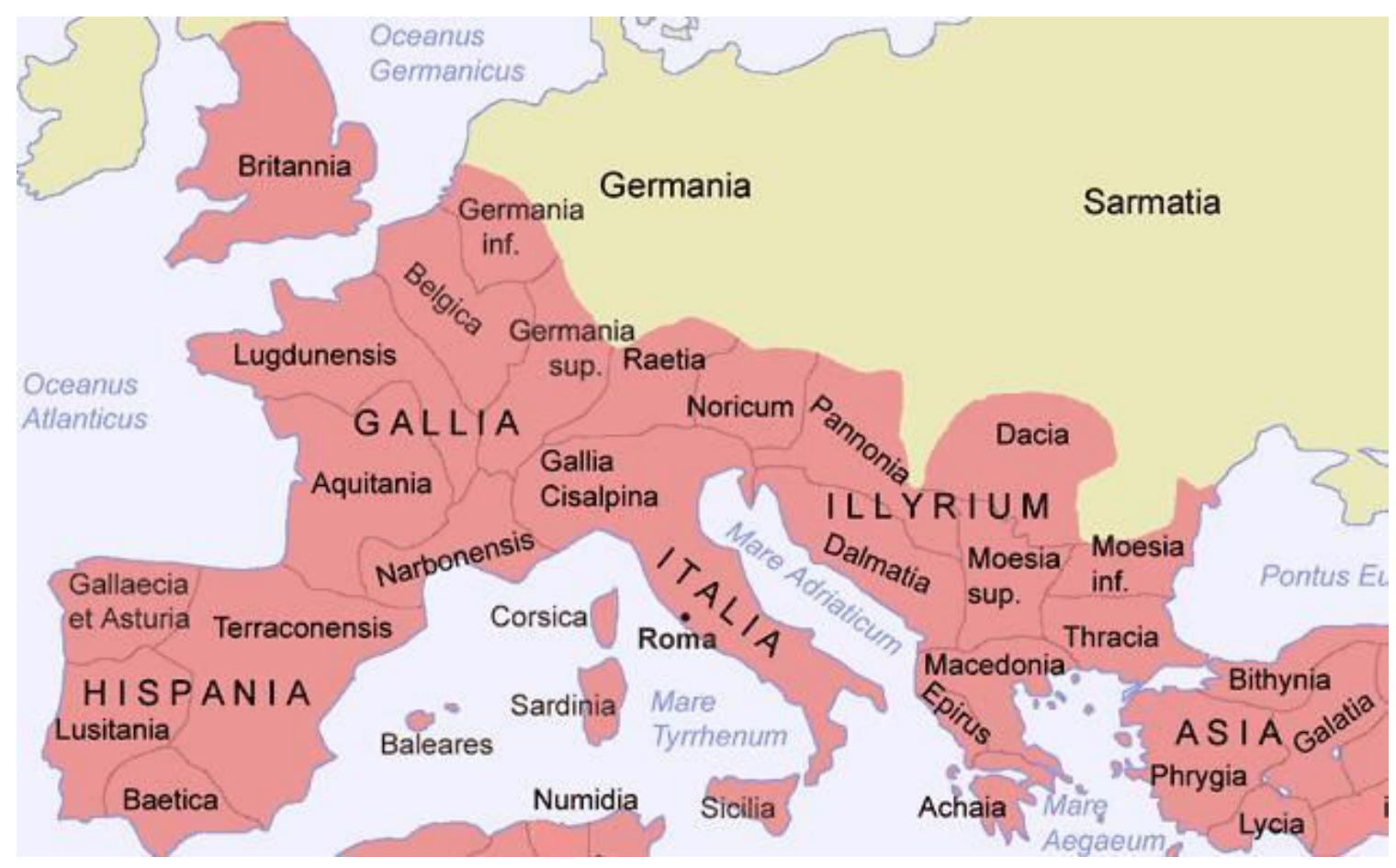

Mapa 3: A posição da Récia, da Gália Cisalpina e do Noricum no Império Romano ${ }^{29}$

Desde 225 a.C. Roma buscava dominar toda a planície do rio Pó e as terras réticas, por conta dos saques dos gauleses, mas a dominou totalmente somente em 15 d.C., tendo posteriormente dividido a região em duas províncias: Récia nos Alpes Ocidentais e Gália Cisalpina entre os Apeninos e os Alpes Centrais, na planície do Rio Pó. À época de Augusto, as populações célticas, ilíricas e réticas da área alpina foram totalmente romanizadas, adotando o latim como seu idioma e em meados de 89 a.C. a cidadania

\footnotetext{
${ }^{29}$ MAPA: www.territorioscuola.com
} 
romana chegou à Gália Cisalpina. A região do Noricum, ao norte da Gália Cisalpina, fazendo divisa com a Récia, formava uma província aliada do Império Romano e compreendia a atual área tirolesa de Val Pusteria (= Pustertal) e parte de Val d'Isarco (= Eisacktal).

Assim, o território do atual Trentino e parte do Südtirol foram incluídos na Regio Decima, denominada Venetia et Histria; da região de Venosta em direção ao norte iniciava a Récia e a região de Pusteria foi incorporada ao Noricum. O período romano marcou a fundação da cidade de Trento (Tridentum) enquanto cidade latina na área montanhosa, uma vez que as demais regiões ao norte, ainda que latinizadas, mantiveram durante muito tempo seus falares célticos e réticos. O edito de Cles (Tabula Clesiana), que deu a cidadania romana aos habitantes do hodierno Val di Non (= Nonsberg), no atual Trentino, demonstra a preocupação romana de então de latinizar toda aquela área rética que, posteriormente, manteve-se sob a influência cultural e política dos conquistadores.

\subsubsection{INVASÕES GERMÂNICAS (ALTA IDADE MÉdiA)}

A partir do século III os povos germânicos começaram a migrar de suas regiões originais no norte da Europa em direção às terras imperiais romanas. No final do século IV, com o crescimento das migrações germânicas e suas contínuas invasões ao Império Romano, a região alpina foi sucessivamente ocupada por diversas tribos ou servia de rota para aquelas que atravessaram os Alpes em direção à planície padana e à Península Itálica: longobardos, ostrogodos, alamanos, francos e principalmente os baiuvares ${ }^{30}$ (Bajuwaren, Baiuwaren), que povoaram os vales desde o centro da atual Alemanha até a parte alta do rio Adige (=Etsch). Assim, da faixa territorial norte, desde a Baviera (Bayern) até a parte sul

\footnotetext{
${ }^{30} \mathrm{O}$ termo baiuvar teria origem no antigo germânico * baio-warioz < povo da Boêmia>, indicando a origem da tribo que ocuparia toda a região meridional da atual Alemanha, quase toda a Áustria e Tirol Meridional. Das denominações germânicas (todas?) baiwaren, baioaren, bajoras surgiram os termos latinizados baioarii e bavarii. Enquanto baiuvares classificava-se a tribo germânica que se estabeleceu na área acima indicada; o termo bávaro (portanto, derivado da forma latina) já era utilizado na Idade Média e na literatura em latim (MENGHin, 1990; STÖRMER, 2002).
} 
da cidade de Bolzano (Balsanum / Bozen), predominaram os falares germânicos, enquanto que na parte baixa do rio, na região ao redor da cidade de Trento (Tridentum / Trient), predominaram os falares latinos.

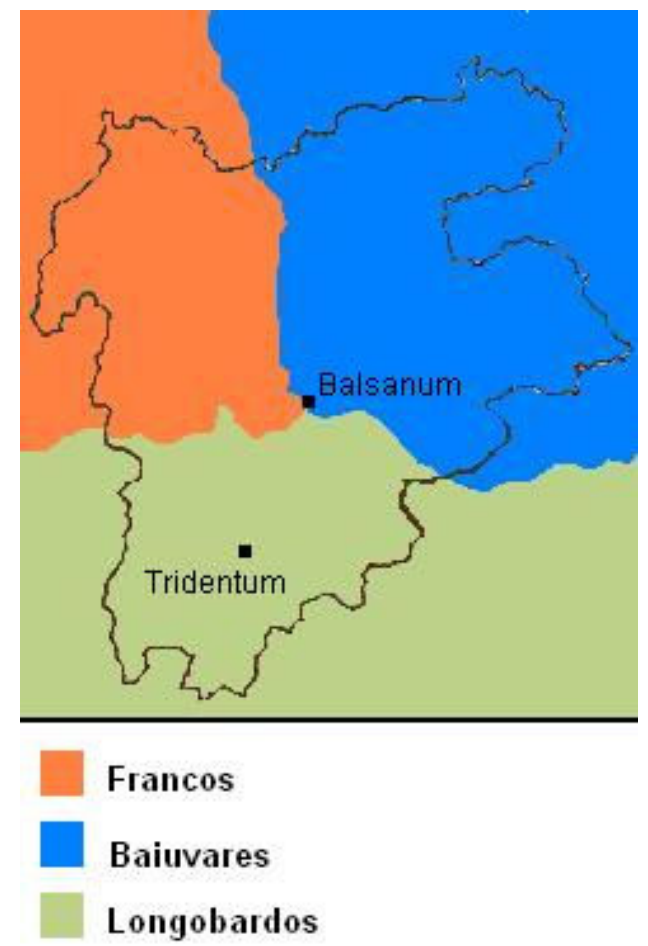

Mapa 4: A ocupação germânica na atual região tirolesa - séculos VII e VIII ${ }^{31}$

Os Longobardos administraram boa parte da área alpina entre as atuais regiões da Lombardia e do Veneto e influenciaram o falar de várias localidades alpinas. Em 569, por decreto de Alboino (526 - 572) rei dos Longobardos, o antigo município romano de Trento (Tridentum) teve sua área estendida (ocupando partes dos municípios de Feltre, Verona e Brescia), tornando-se um ducado que firmou uma aliança com os baiuvares na tentativa de defender a região dos assaltos francos. Através de casamentos com nobres baiuvares, o condado de Tridentum continuou sob o controle longobardo. Em meados do ano 600, a rainha Teodolinda (535? - 591), por influência do monge e historiador longobardo Secondo (Secundus) de Trento $(?-612)^{32}$, converteu-se a si e todos os seus súditos ao Cristianismo.

\footnotetext{
${ }^{31}$ MAPA: nosso.

${ }^{32}$ Cfr. JARNUT (2002), sobre o domínio longobardo na península itálica.
} 
Os Francos substituíram os Longobardos. Em 773, Carlos Magno (747 - 814) transformou o ducado tridentino em uma "marca" (condado de fronteira), com vários condados dependentes e, entre eles, o de Bolzano, que seu filho Pepino (580 - 640) havia reconquistado dos baiuvares. No ano 800 Carlos Magno foi coroado imperador pelo Papa Leão III e deu início ao Sacro Império Romano-germânico, que fora por mais de um século disputado pelas divisões de seus sucessores.

\subsubsection{O PRincipado Episcopal de Trento e o Condado do TIROL (BAIXA IDADE MÉDIA)}

Antes mesmo da formação do condado tirolês, foram instituídos em 1027 pelo Imperador Conrado II (990 - 1039) os Principados Episcopais de Trento (Trientner Fürstbistum; Principato vescovile di Trento) e Bressanone (Brixner Fürstbistum; Principato vescovile di Bressanone). Tratavam-se de títulos que elevaram as dioceses a principados importantes e que concediam aos bispos locais uma soberania regional comparada aos demais principados do Sacro Império Romano-germânico ${ }^{33}$.

O dúplice caráter do império - político e religioso - garantia não somente à nobreza secular o domínio das terras, mas também à Igreja. Assim, além da administração dos duques e condes, existiam feudos pertencentes às administrações episcopais.

As terras pertencentes ao príncipe-bispo (Fürstbischof, Principe Vescovo) eram administradas juntamente com a diocese, havendo controle sobre as paróquias e mosteiros. Além do controle eclesiástico, cabia ao bispo o governo secular de tais áreas, contudo o domínio não era pessoal, mas episcopal, ou seja, ligado à Igreja. O bispo de Trento, assim como o bispo de Bressanone (= Brixen), o arcebispo de Salzburg e o patriarca de Aquiléia

\footnotetext{
${ }^{33}$ Muitos principados episcopais que tiveram relevante importância no Sacro Império Romano-germânico perduraram nas terras então austríacas, suíças e alemãs até o século XIX, quando foram laicizados nos governos estaduais e provinciais após o período napoleônico. Destacavam-se os principados episcopais de Salzburg, Basel, Coira, Konstanz, Augsburg, Worms, Speyer, Straßburg, Freising, Regensburg, Münster, Lüttich e Lübeck.
} 
eram feudatários diretos, ou seja, de direta nomeação imperial (príncipes terrae), não sendo reconhecida nenhuma autoridade temporal senão o imperador do Sacro Império e nenhuma eclesial senão o papa ${ }^{34}$.

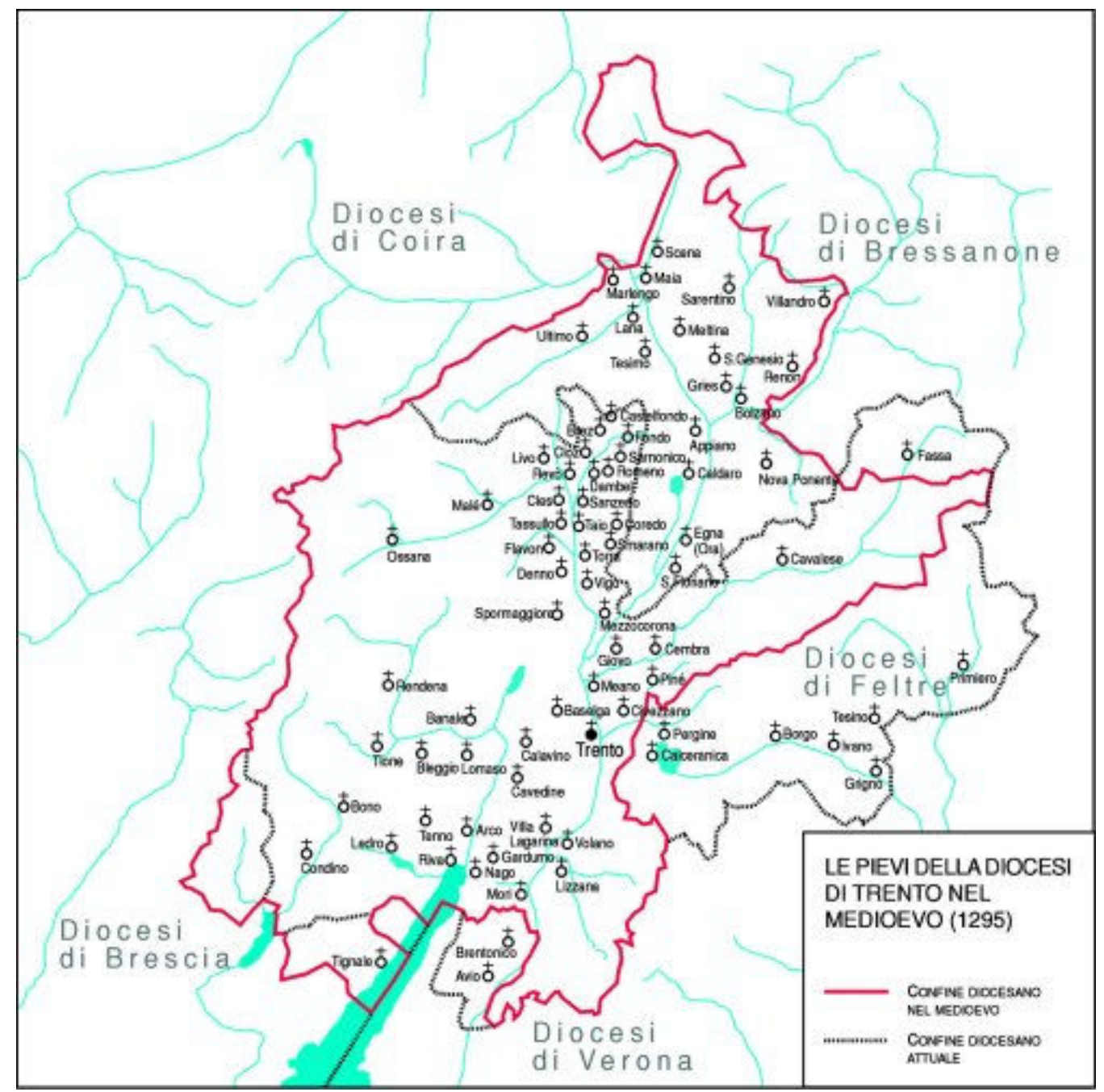

Mapa 5: Limite histórico do Principado Episcopal de Trento ${ }^{35}$

Os principados episcopais de Trento e Bressanone administravam boa parte do atual Tirol, seguidos do principado episcopal de Salzburg (que abrangia a região tirolesa de

\footnotetext{
${ }^{34} \mathrm{O}$ que não ocorria com as demais dioceses. Os bispos de Praga, de Gurk (Klagenfurt) e de Bratislava eram príncipes indiretos, nomeados pelo arcebispo de Salzburg e pelo duque da Boêmia. Do mesmo modo os bispos de Viena, de Gorizia, de Lavant (Maribor) que receberam a condecoração principesca somente como título honorífico.

${ }^{35}$ MAPA: http://www.trentinocultura.net/doc/radici/storia/44a h.asp
} 
Zillertal). A diocese de Coira administrava uma parte do atual Südtirol e boa parte da atual Suíça (Grisões); a diocese de Innsbruck administrava a maioria das igrejas da área setentrional e central; a diocese de Feltre administrava as regiões tirolesas de Primiero (= Primör) e Valsugana (= Suganertal); a diocese de Verona administrava parte da região de Vallagarina (= Lagertal).

Era extremamente estratégica a instituição dos principados episcopais, de forma que seus regentes fossem ligados diretamente ao imperador e ao papa. Com maior razão isso aconteceu nos principados de Trento e Bressanone, nos territórios alpinos que os imperadores deveriam atravessar para chegarem a Roma e se fazerem coroar pelo Papa, assim como para chegarem a Pavia e obterem a coroa da Itália. O vale do Rio Adige (= Etschtal) sempre foi o melhor local de passagem pelos Alpes Centrais, unindo Roma às terras alemãs. O principado episcopal de Trento administrava boa parte desse vale de rápida e fácil travessia e, por isso, sempre despertou o interesse de vários ducados. Das oitenta vezes que os imperadores precisaram atravessar os Alpes, quarenta e cinco vezes o foram através dos vales dos rios Adige e Isarco (= Eisacktal).

Uma vez que não era permitido à administração eclesial aplicar penas capitais (ecclesia non sitit sanguinem $^{36}$ ) e organizar-se militarmente (der Pfaffe ist nicht wehrhaft $^{37}$ ), os príncipes-bispos deviam recorrer a outros feudos e chamar (advocare) um feudatário ou aliado político de sua confiança. Para tanto, a diocese nomeou como advogados $^{38}$ das terras episcopais os senhores do Castelo Tirol, um condado fundado no início do século XIII na região de Merano (= Meran) por nobres de origem bávara. Esses condes eram feudatários do príncipe-bispo de Trento e assumiram militarmente a responsabilidade pela defesa da região e das dioceses.

Desse modo, o Tirol enquanto região histórica se iniciou no século XII, posteriormente à instituição do Principado-episcopal de Trento. $O$ nome Tirol (originalmente Tyrol) designou toda a região por ser o topônimo da área dominada pelo Castelo Tirol (Schloß Tyrol, Castel Tirolo), morada dos condes (senhores feudais).

\footnotetext{
36 "A Igreja não tem sede de sangue".

37 "O Pastor não é munido de arma".

${ }^{38} \mathrm{O}$ termo advogado (it. avvocato) era utilizado na diocese tridentina para designar a função dos condes tiroleses, protetores das dioceses de Trento e Bressanone.
} 


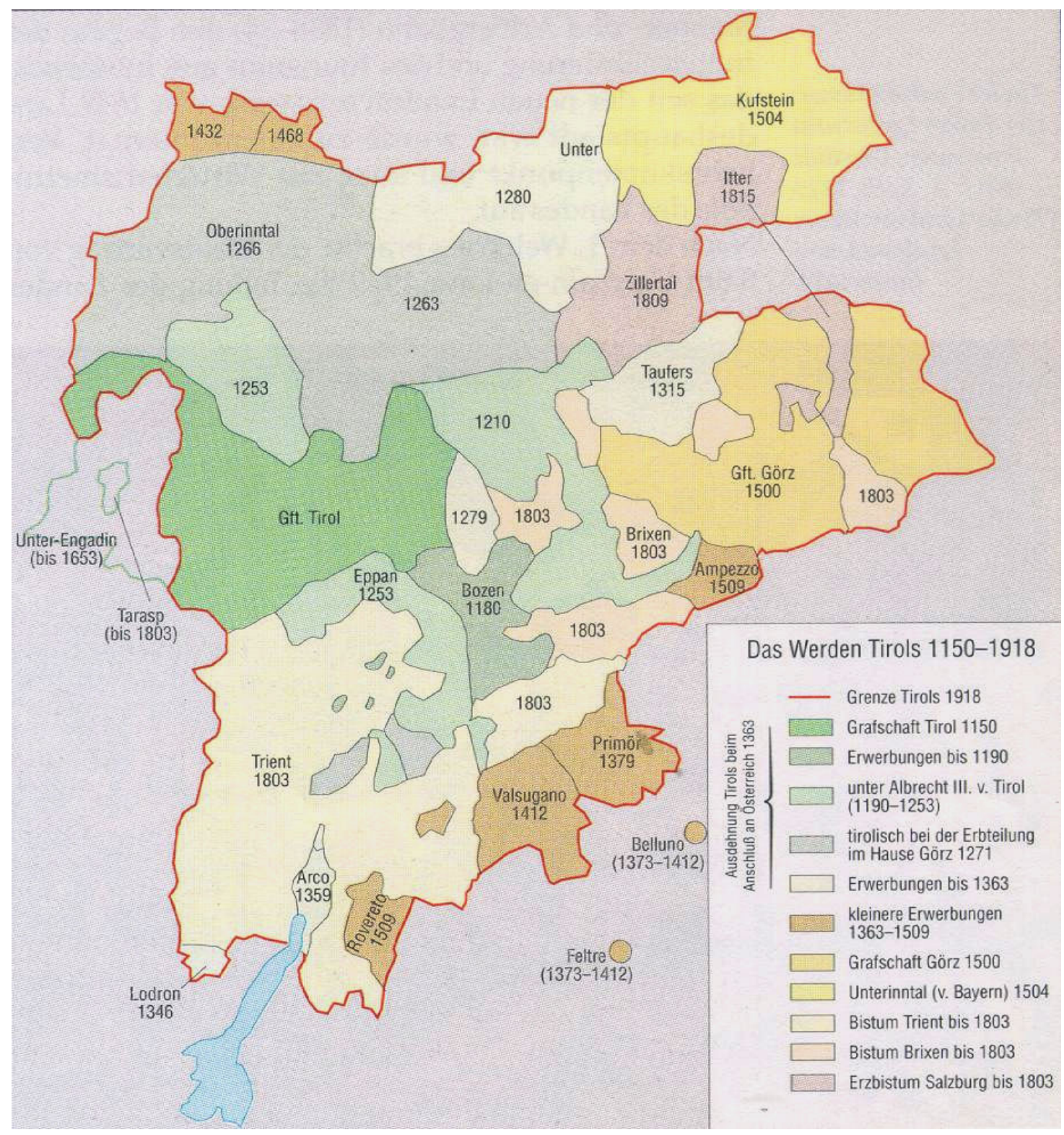

Mapa 6: Formação do Tirol histórico ${ }^{39}$

Os territórios eclesiais foram assumidos militarmente pelos condes em 1140, e imediatamente a administração das terras da diocese passaram a ser disputadas com os bispos (sobretudo a partir de 1200), com a política do conde tirolês Meinhard II (12371295), feudatário do bispo de Trento. O Tirol expansionista se "iniciou” em 1248. De 1258 a 1298, o conde Meinhard trabalhou pela unificação do Tirol, desafiando o poder episcopal.

${ }^{39}$ MAPA: www.grupotirol.com 
Em 1282, com o apoio do rei Rodolfo de Habsburg, Meinhard II tornou o Tirol um condado autônomo e unificado com os principados episcopais de Trento e Bressanone e dividiu este último em senhorios.

O condado tirolês ganhou maior importância a partir de 1314, com as estratégias políticas da condessa Margarethe (chamada Maultasch), que aumentou a importância do condado no contexto da nobreza de origem bávara e ampliou seu controle militar junto das dioceses de Trento e Bressanone. Dentre a ampliação das concessões cedidas pela diocese tridentina aos condes tiroleses estavam o direito hereditário do controle regional (inclusive com sucessão por via feminina), a nomeação de um capitão para a cidade de Trento e uma série de direitos governativos que permitiram aos condes ampliar suas terras e ter seus próprios feudatários.

Em setembro de 1363 faleceu o conde Meinhard III, filho de Margarethe e Ludwig. Margherita decidiu ceder os condados no Tirol e em Gorízia, a terra e região do Ádige e o Vale do Inn aos seus parentes paternos, os duques de Habsburg da Áustria. Os bispos de Trento e Bressanone investiram Rodofo IV von Habsburg, conde do Tirol. O condado confirmou as terras da diocese tridentina e permitiu a residência do bispo no Castelo de Buonconsiglio (Trento) e a diocese prometeu fidelidade aos condes tiroleses. Por meio da política de boas relações com a casa imperial austríaca, os condes tiroleses adquiriram poderes contratuais e benfeitorias que culminaram - mediante casamentos - com o domínio completo dos Habsburg ${ }^{40}$ sobre o condado tirolês.

\footnotetext{
${ }^{40}$ Os Habsburg exerciam uma considerável influência na região tirolesa com um ramo secundário da família. Os condes de Habichtsburg (posteriormente Habsburg), originários da família residente no homônimo castelo suíço, ampliou gradativamente seus domínios no território austríaco a partir do século XII; em 1273 o fundador da dinastia no trono imperial, Rodolfo I (1218 - 1240?), foi coroado imperador do Sacro Império Romano-germânico, pondo fim a um intervalo de mais de duas décadas de trono vacante. Em 1278, com a derrota e morte do Rei da Boêmia Otokar II (1230 - 1278) na batalha de Dürnkrut, o Imperador Rodolfo recebeu os ducados da Áustria e da Estiria (= Steiermark; lat. Styria), que cedeu em feudo a seus filhos. Contudo, após sua morte e a sucessão pelo seu filho Alberto I (1255 - 1308) em 1298, houve grande instabilidade no império. Alberto I foi assassinado e os Habsburg foram afastados da sucessão imperial pelos nobres da Casa de Luxemburg, que com eles disputavam. Quando da Bula de Ouro (constituição selada a ouro, dada pelo soberano no Sacro Império e que fixava os sete príncipes que elegiam o imperador) em 1356, os Habsburg sequer participavam do grupo de eleitores e, no mesmo período, a Confederação Helvética (iniciada em 1291) ameaçava suas antigas terras originais na Suíça. Através de acordos, os Habsburg adquiriram a Carníola (Krein) em 1335, o Tirol em 1363, parte da Ístria em 1374 e Trieste (1382), consolidando o ducado da Áustria, base territorial de seu futuro poder imperial. Com a extinção da Casa de Luxemburg, os Habsburg recuperaram a coroa imperial com Alberto II (1397 - 1439) e, a partir desta época em diante, praticamente todos os imperadores do Sacro Império eram membros da Casa de Habsburg.
} 
A partir de 1490 o Imperador do Sacro Império era também o Conde do Tirol e, embora o poder tirolês fosse muito maior, o imperador não havia abolido a administração regional dos principados episcopais de Bressanone (mais antiga cidade tirolesa) e Trento (de maior importância), que se mantinham sob a proteção do condado tirolês. Desse modo, as dioceses de Trento e Bressanone formavam, com as terras do conde tirolês, o Condado Episcopal do Tirol $^{41}$ e a guarda do principado episcopal mantinha-se sob o comando do conde do Tirol, ou seja, do próprio imperador. Merano (lat. Mairanium), fundada em 857, foi a capital administrativa do Tirol de 1317 a 1420, por se tratar da sede familiar dos condes de Castelo Tirol. Em 1421, a capital tirolesa foi transferida para a cidade de Innsbruck (atual capital do Tirol austríaco), que teve grande importância durante o reinado de Maximiliano I de Habsburg (1459 - 1519), coroado imperador na Catedral de São Vergílio, em Trento. Maximiliano fez de Innsbruck sua morada e uma das sedes imperiais do Sacro Império (GIRARDI, 2008) e, desde então, passou a ser a capital administrativa do condado tirolês $^{42}$, então Condado Episcopal do Tirol.

\subsubsection{O CONCÍlio de TRENTO, O PERÍOdo NAPOLEÔNICO E AS DISPUTAS TERRITORIAIS DA I GUERRA MUNDIAL}

A região tirolesa teve relevante destaque no século XVI quando do movimento da Contra-Reforma, que culminou com o Concílio de Trento (1545 - 1563), o mais longo concílio da história da Igreja e uma resposta do Vaticano à Reforma protestante na Europa.

\footnotetext{
${ }^{41} \mathrm{E}$ as terras foram também designadas como Federação Tirolesa (Foederatio Tyrolensis).

${ }^{42}$ Durante algum tempo fez parte da administração tirolesa o atual estado austríaco de Vorarlberg, cuja população tem origem na tribo germânica dos Alamanos, que se fixou a Suíça e parte da Alemanha. Também fez parte do território tirolês a atual região suíça da Baixa Engadina (até 1653), banhada pelo Rio Inn. Na região vêneta de Belluno (Itália) mantêm-se, até os dias atuais, os grupos linguísticos ladino (Livinalongo del Col di Lana, Fodom e Cortina d'Ampezzo), bávaro tirolês (Sappada = Plodn) e cimbro (Cansiglio). A região de língua ladina de Belluno pertenceu ao Tirol até o final da Primeira Guerra Mundial e permaneceu unida ao Südtirol até 1927, quando Mussolini, numa tentativa de assimilação (leia-se supressão) linguística, segundo os modos fascistas, anexou a região ao Vêneto. Num referendo popular realizado em 2007, a população ladina belunesa pediu o retorno de suas cidades para o Südtirol; até o momento, apesar da maioria de votos e seu reconhecimento em Roma, o governo vêneto ainda não aprovou tal decisão.
} 
A missa tridentina, que padronizou o ritual da missa romana e aboliu as variações regionais existentes, é uma alusão à cidade de Trento, que abrigou o concílio católico. A introdução da Contra-reforma determinou na região trentina uma inversão da tendência do passado, com a definitiva difusão da língua italiana no território episcopal, que gerou uma significativa diminuição da língua alemã nos vales, que outrora era difundida principalmente entre os religiosos.

O Sacro Império tornou-se, após o concílio tridentino, um defensor da fé católica e seus dirigentes, a Casa de Habsburg, defensores da Igreja. Essa imagem se manteve durante os séculos seguintes, propagada pelo clero e incentivada pela regência imperial. Os Habsburg mantinham em seu governo uma política de culto da família, estreitamente ligada à sua "missão" histórica, ou seja, a indivisibilidade de seu domínio, a defesa da fé católica e a hereditariedade sempre garantida. A política de casamentos ${ }^{43}$ e descendências evitou divisões e permitiu a chamada Pragmática Sanção, que estabelecia que, na falta de sucessores homens, seria permitida a herança monárquica às mulheres (uma lei que ia muito além dos padrões medievais). Dessa estratégia resultou o reinado de Maria Teresa (1717 - 1780), que se destacou, na Europa, pela modernidade das suas reformas institucionais ${ }^{44}$, bem como pela influência de seus costumes palacianos.

Quando das invasões francesas iniciadas em 1796 e comandadas por Napoleão Bonaparte (1769 - 1821), a Áustria formou uma coligação com a Prússia, a Inglaterra e a Rússia, no intuito de frear o avanço francês para o leste. Havia a preocupação dos monarcas em manterem seus governos absolutistas, por conta da Revolução Francesa que antecedeu o período napoleônico e que poderia causar demais revoluções por toda a Europa. Firmandose no poderio naval britânico e nos exércitos austríacos, prussianos e russos, a coligação não conseguiu impedir o avanço francês. A Áustria sucumbiu em 1805, durante a Batalha de Austerlitz; a Prússia foi vencida em 1806 e a Rússia em 1807.

\footnotetext{
${ }^{43}$ Bella gerant alii - tu felix Austria nube <que guerreiem os outros - tu, feliz Áustria, conclui casamento>, uma característica dos Habsburg, que ampliaram seus domínios graças a diversos casamentos com famílias de nobres estirpes de praticamente toda a Europa.

${ }^{44}$ Entre as medidas governamentais do reinado de Maria Teresa, destaca-se o ensino básico dos camponeses. Essa política se refletiu, inclusive, durante a imigração, pois os imigrantes tiroleses de língua italiana (então austríacos) eram alfabetizados, diferentemente da maioria dos imigrantes italianos.
} 
A Áustria fora então dominada pela França com o apoio do Reino da Baviera ${ }^{45}$. Franz II (a partir de 1804, Imperador Franz I da Áustria), abdicou da coroa do SacroImpério Romano-Germânico e o dissolveu em 1806, durante as guerras napoleônicas. Em Viena, Napoleão procurou estrategicamente se unir à princesa Maria Luisa, querendo, assim, instituir a paz entre a França e a Áustria e ampliar seus domínios com a união da casa de Habsrburg. Contudo, Bonaparte já era casado com Josephine e encontrou resistência do Papa para o novo casamento. O cardeal Fesch, tio de Napoleão - cuja política consistia, mutuamente, em subserviência ao império e obediência ao papa -, concedeu uma bênção ao casamento, mas não uma anulação do antigo matrimônio. Em 1809, Napoleão ordenou a prisão do Papa Pio VII, que o excomungou ${ }^{46}$.

Depois da Paz de Preßburg (1805), havia grande descontentamento no Tirol por conta da ameaça bávara. Sabendo do interesse do Reino da Baviera pelo Tirol, Napoleão pôde manter seu domínio em Viena enquanto a região tirolesa passou para a administração bávara $^{47}$, que logo tratou de introduzir ali as idéias francesas de inspiração iluminista (MatTeI, 1990; EGG, 2000). O príncipe-bispo de Trento, Peter Vigil Thun (1724 - 1800), fugiu para o exílio antes da chegada das tropas franco-bávaras e Innsbruck foi dominada pelo exército bávaro rapidamente. A população tirolesa, fortemente apegada ao clero e à coroa austríaca, reagiu ao domínio bávaro por meio de uma rebelião que marcou a queda do domínio napoleônico na Áustria e na Europa.

A resistência contra a ameaça francesa era animada pela forte influência do clero, pois a população tirolesa era extremamente apegada ao catolicismo. Os missionários jesuítas haviam trabalhado durante muitos anos do século XVIII na região tirolesa, tendo influenciado profundamente os hábitos locais, difundindo a devoção ao Sagrado Coração de Jesus e consagrando a terra tirolesa em Terra Santa (Heiliges Land Tirol). Esse aspecto é

\footnotetext{
${ }^{45}$ O Reino da Baviera pertencia ao Sacro Império, mas era totalmente autônomo. A paz de Vestfália, em 1648, que acabou com a guerra dos 30 anos, deu aos territórios uma autonomia quase completa. Com a paz, a Confederação Suíça (cuja quase-independência fora conquistada em 1499) e a Holanda Setentrional abandonaram o império. A Casa de Habsburg, mantendo apenas o título imperial do Sacro Império, focava sua política nas terras de seu domínio direto, e aos estados constituintes havia apenas a restrição de não formarem alianças contra o imperador.

${ }^{46}$ A excomunhão do imperador francês gerou na população tirolesa um ferrenho ódio à ocupação francesa. Vale lembrar que o clero austríaco sempre propagara que a nação austríaca, enquanto herdeira e defensora do legado histórico do Sacro Império Romano-Germânico, o era também da fé católica.

${ }^{47}$ A Baviera sempre procurou para si o controle da região tirolesa, desde o período medieval. Foram as estratégias políticas dos Habsburg que conseguiram unir as terras do condado àquelas do ducado austríaco.
} 
extremamente relevante para se compreender a aversão tirolesa frente as idéias iluministas advindas da França (também através da Baviera) e a forte oposição do clero tirolês contra as novas administrações eclesiásticas dos séculos XVIII e XIX (HORMAYR, 1817).

Os grupos armados de proteção ${ }^{48}$ (al. Schützen; it. Sìzzeri; lad. Scìzer), formados por atiradores voluntários das mais diversas origens (nobres, artesãos, comerciantes e camponeses) e existentes por quase todo o território tirolês; trataram de se organizar frente às notícias da expansão francesa. Entre os atiradores que formavam companhia da cidade de Merano e arredores, estava um taberneiro nascido em Sankt Leonhardt in Passeiertal (San Leonardo nella Val Passiria), comerciante de cavalos e carismático personagem: Andreas Nikolaus Hofer (1767 - 1810), fervoroso católico e carismático líder popular.

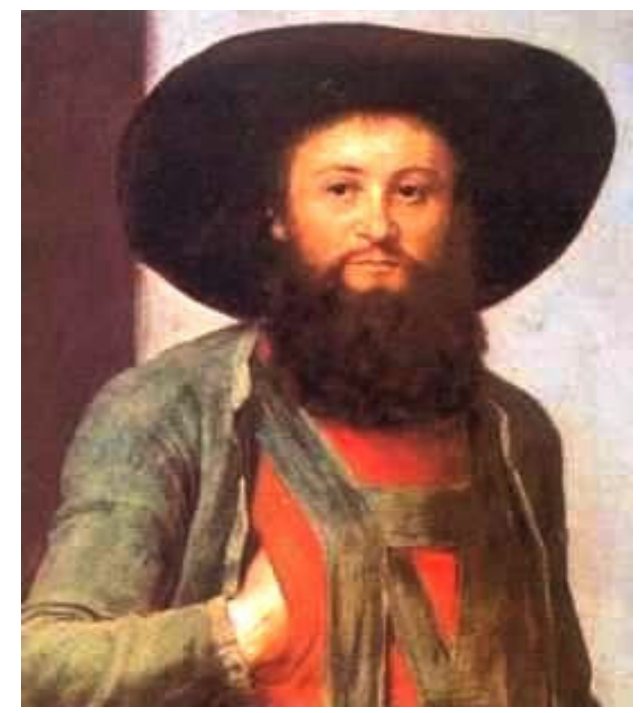

Figura 1: Andreas Hofer ${ }^{49}$

O mais novo numa família de seis filhos (e o único homem), Hofer perdeu sua mãe Maria Aigentler quando tinha apenas três anos, sendo criado praticamente por suas irmãs, pois seu pai Josef Hofer morreu três anos depois de ter contraído seu segundo matrimônio com Anna Frick em 1772. Na sua educação e formação, tiveram papel relevante sua irmã

\footnotetext{
${ }^{48}$ Esses grupos armados têm sua origem no século XIV, recrutados pelos Condes do Tirol e pelas dioceses para a defesa do condado tirolês. Já o conde Meinhard II havia concedido a alguns camponeses parte de suas terras a título de feudos hereditários em troca de seu alistamento entre os cavaleiros que formavam a guarda tirolesa.

49 IMAGEM: detalhe da obra Andreas Hofer, do pintor tirolês Franz von Deffregger (1835 - 1921); Kaiserjäger Museum - Innsbruck Áustria (foto tirada em 2007).
} 
mais velha Anna Hofer e seu marido Joser Grüner. Concluídos os estudos primários ${ }^{50}$ e religiosos, Andreas foi enviado pela irmã ao Tirol Italiano (região trentina), para ali aprender o ofício de taberneiro e camponês (Oberbauer); permaneceu alguns anos em Val di Non (= Nonsberg), tendo trabalhado em vários ofícios e numa hospedaria. Ali, o jovem também aprendeu o dialeto tirolês ${ }^{51}$ (HORMAYR, 1817), ou seja, o dialeto trentino, importante para seu ofício de comerciante. Terminados sua experiência fora de casa, Hofer retornou para ocupar em sua casa o mesmo ofício de seu pai e de seu avô; alguns anos depois se alistou no corpo voluntário de atiradores, tendo chegado em poucos anos a comandante. Seu período à frente do grupo lhe garantiu algumas idas e vindas pelos vales tiroleses e coincidiu com o período das invasões francesas. Por ser conhecido em várias regiões tirolesas, Hofer conseguiu regimentar um considerável número de combatentes para enfrentar os exércitos napoleônicos (RICCADONNA, 2009).

Após um ato religioso com a bênção da bandeira tirolesa (abril de 1809), os rebeldes tiroleses se organizaram em grupos que atuavam em várias regiões. Hofer teve grande apoio do frade capuchinho Joachim Haspinger, que com ele participou ativamente da resistência $^{52}$. Com apoio de boa parte do clero e auxílio do príncipe e Arquiduque da Áustria Johann von Habsburg (1782 - 1859), irmão do imperador austríaco, os rebeldes venceram várias batalhas locais durante os meses de abril e maio de 1809 e, com as vitória alcançada em Bergisel em 29 de maio de 1809 (data que passou a ser comemorada no Tirol sob a designação $A N N O$ 9), a resistência retomou a capital Innsbruck do domínio bávaro, expulsando as tropas napoleônicas e instaurando um governo provisório que durou quase dois anos. Este período reforçou profundamente o sentimento de unificação política e administrativa do Tirol. Vitorioso e aclamado, o comandante ficou conhecido entre os tiroleses de língua alemã como Vater Hofer < pai Hofer> e como Capitàn Barbón <capitão barbudo> entre os tiroleses italianos (RICCADONNA, 2009: 23). Em demonstração pública pelos seus atos patrióticos em defesa do território nacional, o comandante tirolês fora

\footnotetext{
${ }^{50}$ Em 1774 a Imperatriz Maria Teresa havia introduzido o estudo obrigatório para todos.

${ }^{51}$ Muito interessante é que, à época de Andreas Hofer e durante o século XIX, entendia-se também por "dialeto tirolês" os falares trentinos e ladinos e não somente o alemão (Tirolerisch), que muitas vezes era chamado simplesmente "alemão" ou "bávaro" (Bairisch). Sobre o assunto, SUlzER (1855), HoRMAYR (1817), WEBER (1852), RICCADONNA (2009).

${ }^{52} \mathrm{Na}$ região trentina, nomes destaque são o da jovem Giuseppina Negrelli $(1790-1842)$ de Primiero (= Primör), combatente aos dezoito anos e irmã do renomado engenheiro Luigi Negrelli (1799 - 1858), idealizador e projetista do Canal de Suez, além de Bernardino Dal Ponte das montanhas Giudicarie (= Judikarien) e Michael Giacomelli de Val di Fiemme (=Fleimstal).
} 
condecorado pela Igreja e pelo governo de Viena com o colar de honra (Ehrenkette) de três mil ducados. Contudo, Napoleão mantinha forte influência no governo vienense, que procurou não intervir na situação política tirolesa com medo das represálias francesas contra sua nobreza. Esse período foi marcado pela política ambígua do governo austríaco, que apoiava extra-oficialmente as iniciativas populares dos tiroleses, mas não afrontava diretamente as lideranças franco-bávaras.

Após algumas batalhas contra as tropas bávaras que procuravam recuperar o poder de Innsbruck, o governo provisório tirolês ficou cada vez mais isolado politicamente. Seguiu-se um curto período de trégua, seguido de batalhas localizadas contra as forças franco-bávaras. Com as sucessivas baixas, Hofer havia se refugiado em sua terra natal. As derrotas sucessivas dos rebeldes permitiram o avanço das tropas bávaras, francesas e italianas (pois o Reino Italiano estava sob o domínio napoleônico). A dificultosa situação "pressionou" as tropas tirolesas e a derrota culminou com a traição de um dos excombatentes tiroleses, Josef Raffl, que entregou Hofer em troca de uma quantia em dinheiro recebida do exército italiano. O líder tirolês foi capturado em sua terra natal, preso e levado para Mântua (Mantova), onde foi fuzilado em 22 de fevereiro de 1810.

Com a morte de Hofer, a porção setentrional do Tirol passou para o domínio bávaro e a porção meridional para o Reino da Itália, que tratou de substituir rapidamente os cargos públicos e adequá-los ao modo administrativo das cidades italianas - esse período marcou o início da disputa italiana pela região tirolesa (sobretudo pela área italianófona e ladina).

Após o ano de 1812, com as baixas napoleônicas na frente russa e as duas abdicações de Napoleão (a segunda após a derrota de Waterloo), a Áustria reorganizou rapidamente seu governo e tratou de expulsar as tropas franco-bávaras de seu território. $\mathrm{O}$ Tirol retornou, assim, ao domínio austríaco. Viena tratou imediatamente de mudar a política administrativa do Tirol, laicizando, em 1813, as administrações dos Principados Episcopais de Trento e Bressanone e anexando-os ao controle único do Estado do Tirol. Embora muitas vezes omisso durante a revolta tirolesa, o governo vienense adotou a figura de Andreas Hofer a partir de então como símbolo de defesa da pátria tirolesa (Tiroler Heimat) e como modelo austríaco de patriotismo (MATTEI, 1994; RiCCADONNA, 2009).

O domínio napoleônico findou o Sacro Império Romano-Germânico e boa parte de seu território foi herdado pelo Império Austríaco que, através de articulações políticas, 
anexou para si outras regiões. Aa influência austríaca se estendeu por praticamente toda a Europa e o império chegou a abranger boa parte do continente quando da união com o Reino Húngaro no século XIX e a instituição do Império Austro-húngaro (1867).

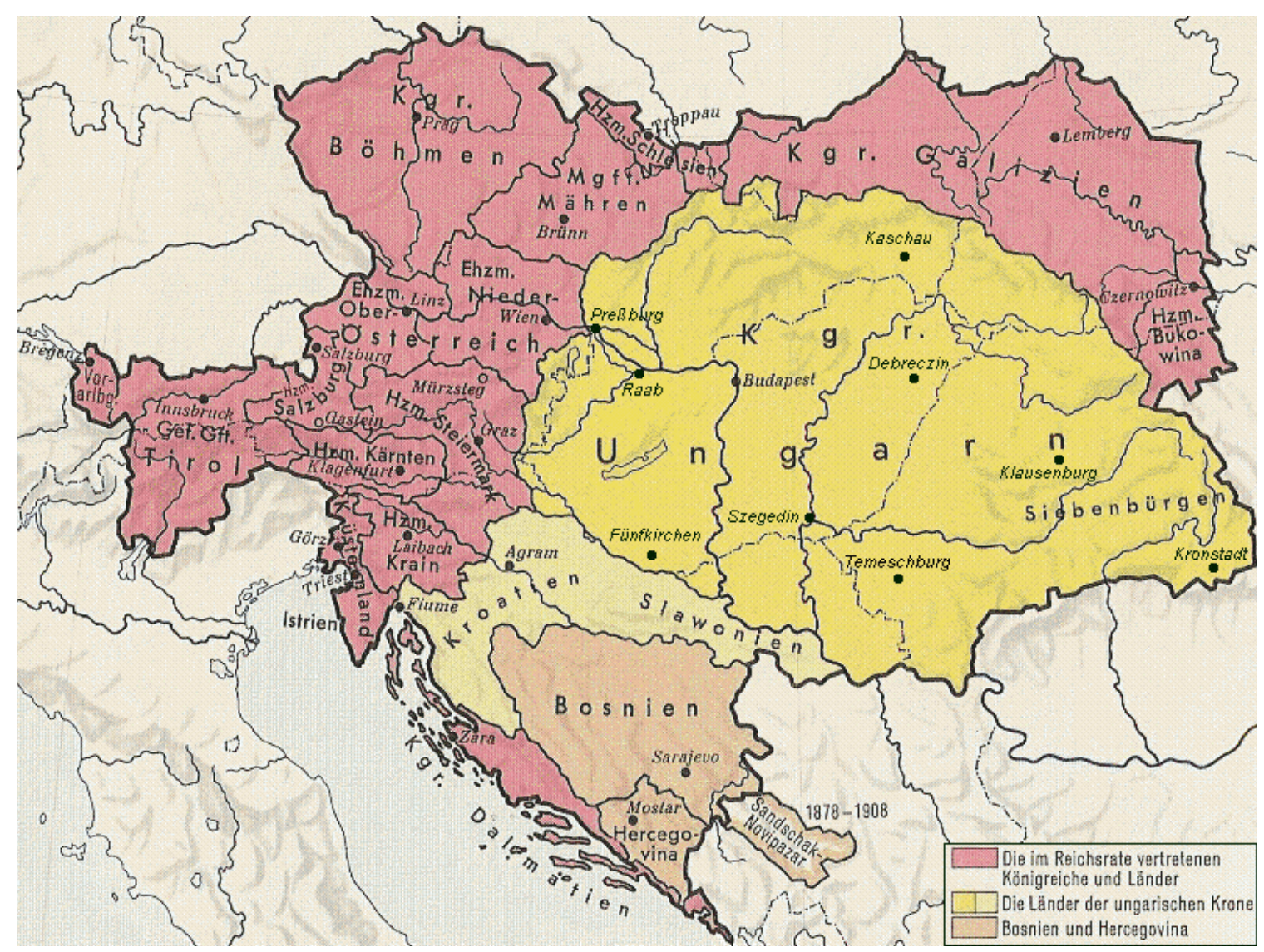

Mapa 7: Os limites do Império Austro-húngaro em $1908^{53}$

O século XIX marcou profundamente a Europa com as lutas separatistas seguidas de uniões nacionalistas que começaram a surgir em várias regiões; tiveram início nesse período os processos de unificação alemã e italiana. Durante as incursões de Giuseppe Garibaldi (1807 - 1882), o Reino Italiano procurou anexar novamente a porção italiana do Tirol ao seu território; alguns tiroleses italianos haviam se alistado em suas fileiras, mas a grande maioria da população permanecia fiel à coroa austríaca, principalmente os camponeses sob a influência do clero (BARATTER, 2009).

\footnotetext{
${ }^{53}$ MAPA: http://images.encarta.msn.com/xrefmedia/iencmed/targets/maps/mhi/T028717A.gif
} 
Entre os meios políticos e intelectuais havia mais simpatizantes pela unificação do Tirol italiano ao Reino da Itália, mas em muitos lugares a memória de Andreas Hofer ainda mantinha o senso de união tirolesa com a Áustria. Sociedades secretas italianas como os carbonários participavam ativamente do processo de unificação italiana e no Tirol atuavam pela substituição do nome Tirol italiano para Trentino ${ }^{54}$, reforçando, assim, sua diferença frente o Tirol germanófono. Além disso, atuavam num movimento que ficou conhecido como irredentismo, que buscava a unificação ao reino italiano pela vontade popular (MATTEI, 1992).

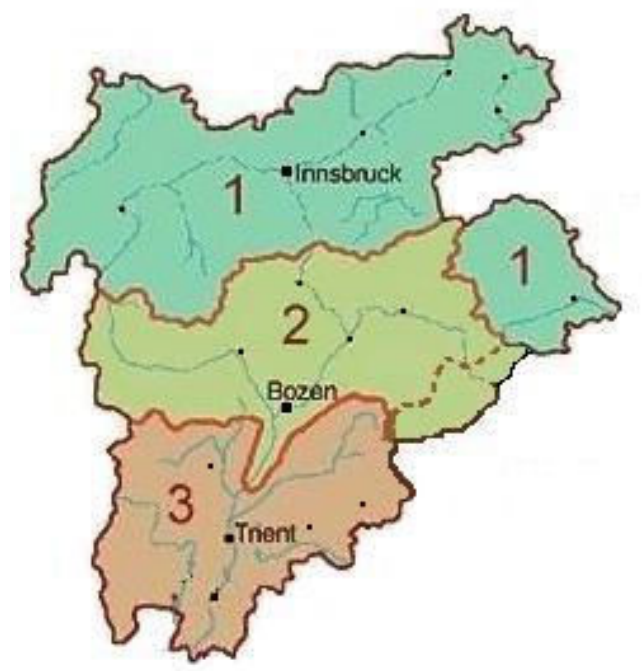

1 - Nordtirol e Osttirol - hoje na Áustria.

2-Südtirol (outrora também chamado Mitteltirol) - hoje na Itália (parte na província de Belluno). 3 - Trentino (até 1818, chamado Welschtirol / Tirolo Italiano) - hoje na Itália.

Mapa 8: As três partes que compunham até 1918 o austríaco Estado do Tirol ${ }^{55}$

O imperador austríaco se tornou o grande inimigo da unificação italiana, pois mantinha sob seu domínio várias regiões da península italiana, como as regiões da Lombardia e Vêneto (Reino Lombardo-vêneto, herdado em 1815, no Congresso de Viena)

\footnotetext{
${ }^{54} \mathrm{O}$ nome Trentino é histórico, ainda que fosse utilizado somente para designar a região administrada pelo príncipe-bispo, com referência à cidade de Trento (= área trentina). A administração eclesial tridentina já nomeava no século XVI as terras do principado-episcopal como Trentino, na porção meridional do Tirol Meridional (Südtirol).

${ }^{55}$ MAPA: http://www.grupotirol.com
} 
e parte do Friuli-Venezia-Giulia. A Áustria controlava a administração de várias cidades italianas como Milão e Veneza, e a marinha austríaca se situava, sobretudo, na cidade de Trieste. A Casa de Savóia, reinante na Itália, unificava os estados italianos por meio das guerras comandadas por Garibaldi e, em 1866, a Áustria perdeu o controle sobre o Reino Lombardo-vêneto. O Tirol se tornava, então, uma região de fronteira e arcaria com tais consequências (GrosSELLI, 1991). Em 1867, com a coroação de Franz Joseph I como Rei da Hungria, iniciava-se o Império Austro-húngaro, cuja administração era (e necessitava ser) extremamente centralizadora na pessoa do imperador.

A situação política italiana influenciava os meios intelectuais da sociedade tridentina, gerando divergências ideológicas no Tirol. O termo Trentino passava a ser usado para designar a porção italianófona tirolesa, outrora pertencente ao Principado Episcopal de Trento - tratava-se de uma maneira de desvincular a região da órbita tirolesa (alemã) e aproximá-la da vizinha Itália. Entre os meios políticos (inclusive socialistas), propagavamse as idéias de unificação do Trentino ao Reino da Itália, inclusive com manifestações públicas (mesmo se tímidas). Os irredentistas trentinos acusavam o governo tirolês de não respeitarem a população italianófona da área trentina, por conta do baixo número de seus representantes na Dieta Tirolesa (espécie de Câmara Estadual).

Em 1889 foi inaugurado em Bolzano o monumento a Walter von der Vogelweide, o poeta-símbolo da cultura alemã, na praça ao lado da catedral de Bolzano (que assumiu o nome de Walterplatz), demonstrando, assim, a defesa da fronteira linguística alemã do Tirol. Em outubro de 1896 foi inaugurado na cidade de Trento o monumento a Dante Alighieri ${ }^{56}$ na praça da estação ferroviária, em demonstração da italianidade linguística da região trentina (MATTEI, 1992). O governo austríaco não demonstrou nenhuma hostilidade, pois era consciente de que qualquer ação de impedimento contra a imagem do grande poeta Dante seria desaprovada também pela população de língua alemã do Tirol. A epígrafe colocada aos pés do monumento de Dante afirmava a italianidade da terra, sem, contudo, desrespeitar os demais grupos linguísticos: Inchiniamoci italiani, Inchinatevi stranieri, deh rialziamoci affratellati nella giustizia ${ }^{57}$. Tratava-se, também, de uma epígrafe de notório

\footnotetext{
${ }^{56}$ Em Trento, como pudemos observar, diz-se que a posição da imagem de Dante, com o braço erguido e palma estendida, como que num gesto de impedimento, significaria uma demonstração da italianidade trentina frente o avanço da língua alemão em direção ao sul.

${ }^{57}$ Inclinemos-nos italianos, inclinai-vos estrangeiros, enfim levantemo-nos fraternizados na justiça.
} 
cunho positivista e irredentista, de autoria de Giuseppe Mazzini (1805 - 1872), revolucionário do Risorgimento italiano, isto é, do movimento da unificação italiana.

O maior expoente do irredentismo trentino foi Cesare Battisti (1875 - 1916), geógrafo e deputado na Dieta Tirolesa. Reivindicava veementemente uma universidade italiana em Innsbruck e foi um dos mais ativos deputados dispostos a unir a região trentina ao reino italiano. Nascido em Trento, aderiu ao movimento socialista durante seus estudos em Florença, onde também conheceu sua futura esposa Ernesta Bitanti (italiana e militante socialista, a quem se atribui a composição do hino trentino ${ }^{58}$ ). Battisti retornou ao Tirol em 1899, assumindo a direção do partido comunista e fundou, em 1900, o jornal socialista $\mathrm{Il}$ Popolo. Fundou também a revista de estudos históricos e geográficos Tridentum, que constituía, ainda que de forma tendenciosa, um instrumento de divulgação das tradições históricas da região trentina, bem como de seus topônimos históricos. Em 1902, Battisti se elegeu conselheiro do município de Trento, reivindicando o ensino da língua italiana nas áreas germanófonas do Tirol setentrional e a criação de uma universidade italiana na capital tirolesa Innsbruck. Ali, organizou um curso livre de italiano, com apoio de vários professores, que terminou por causa da hostilidade das autoridades municipais e dos estudantes de língua alemã. Tais acontecimentos acentuaram em Battisti seu caráter irredentista e, em 1911, quando foi eleito deputado no parlamento de Viena (com apoio do partido liberal), reivindicava uma autonomia política para o Tirol Italiano, que deveria ser designado oficialmente como Trentino. Com o início da guerra austríaca na Sérvia, Battisti transferiu-se para a Itália com sua esposa, atuando ativamente nos meios políticos antiaustríacos (MATTEI, 1992).

Em 1914, com o início da I Guerra Mundial, o Reino Italiano mantinha-se aliado ao Reino Alemão e ao Império Austro-húngaro, formando com estes a Tríplice Aliança. Entretanto, o movimento nacionalista que ganhava força na sociedade italiana reivindicava as terras "irredentas" sob o domínio austríaco, ou seja, o Friuli-Venezia-Giulia, a porção italianófona do Tirol (Trentino) e a Ístria. Em 1915, por causa das promessas inglesas da

\footnotetext{
58 Autoria contestada atualmente com a publicação dos manuscritos do padre tirolês Livio Rosa (1884 1928), escritos em 1915, onde consta o Inno al Tirolo, cujas primeiras estrofes são exatamente aquelas do hino apresentado por Ernesta Bittanti. O hino consta no Arquivo histórico da biblioteca municipal de Trento como sendo de autoria (embora com um ponto de interrogação) de Gugliemo Bussoli. Nos manuscritos de dom Livio Rosa aparecem riscadas as menções ao Tirol e à Áustria, tendo sido substituídas pelas palavras e versos que atualmente se encontram no Inno al Trentino. O hino dos manuscritos contém mais estrofes e um ritornello, inexistentes na versão de Ernesta Bittanti. Sobre o tema, cfr. TONINA (2006).
} 
divisão de colônias na África e domínio sobre as regiões italianófonas do Império Austrohúngaro, a Itália declarou guerra contra a Áustria e Alemanha. Os Estados Unidos, oficialmente neutros, financiavam, contudo, as campanhas inglesas e italianas. $\mathrm{O}$ exército italiano partiu, então, em direção aos Alpes e a batalha ocorreu brutalmente nas montanhas. Muitos soldados tiroleses da região trentina (Kaiserjäger, Standschützen) haviam seguido para as frentes no Leste e as tropas italianas foram avançando progressivamente.

Com a entrada da Itália na guerra, o irredentista Cesare Battisti, alistou-se como voluntário no exército italiano e, em 1916, durante os combates em Monte Corno, foi reconhecido por um soldado austríaco, trentino de Rovereto (BARATTER, 2009). Preso e acusado de alta traição ao governo imperial, Battisti foi condenado à forca. No mesmo ano, faleceu o imperador austríaco Franz Joseph $\mathrm{I}^{59}$. Até o final de guerra, em 1918, o Império Austro-húngaro foi governado pelo Imperador Karl I (1887 - 1922), sobrinho do imperador.

A autonomia do Tirol Italiano não era um desejo apenas dos irredentistas, mas de outros setores da sociedade trentina. Um exemplo foi o jornalista e deputado na antiga Dieta Tirolesa Alcide De Gasperi (1881 - 1954) que, ainda que de forma menos radical, trabalhava pela autonomia administrativa da região trentina. Ao contrário de Battisti, De Gasperi jamais negou sua identidade enquanto "tirolês", embora apoiasse e propagasse a designação Trentino para sua região, numa política de defesa e valorização da italianidade local sem, contudo, confrontar o Império Austro-húngaro e a região tirolesa. Nas décadas de 1870 e 1880 havia por parte do Tirol germanófono e do Tiroler Volksbund <Federação popular tirolesa> uma política de germanização no Trentino que, sob o pretexto de lutar contra o irredentismo, fundava escolas alemãs nos vales trentinos e procurava substituir o idioma local pelo alemão ${ }^{60}$. De Gasperi participou, em sua vida pública, das atividades políticas do Império Austro-húngaro; freqüentou a universidade em Viena e Innsbruck,

\footnotetext{
59 Anos antes, sua esposa Elisabeth (von Wittelsbach) von Habsburg, conhecida como Sissi, havia sido assassinada na Suíça (1898), pelo anarquista italiano Luigi Luccheni.

${ }^{60}$ Do mesmo modo que o irredentismo procurava justificar a latinidade do Südtirol, o Tiroler Volksbund procurava, sob a bandeira tirolesa, criar uma identidade alemã para os tiroleses da região trentina. Trata-se do reflexo dessa época européia, em que os nacionalismos territoriais se encontravam profundamente ligados à identidade linguística dos povos. As regiões limítrofes e de encontros linguísticos como o Trentino dividiam a opinião popular entre "identidade nacional" e "identidade linguístico-cultural" que àquela época se confundiam. VIARO (2001: 122) afirma que durante o século XIX havia um status linguístico do idioma alemão nas áreas de falares românicos do Tirol e da Suíça e que era comum no Tirol Italiano os pais enviarem seus filhos para as áreas alemãs da Áustria ou para a Alemanha para lá trabalharem e dominarem o idioma.
} 
onde defendeu, ao lado de Cesare Battisti, a criação da Faculdade Italiana de Direito ${ }^{61}$. Em 1905 entrou na redação do jornal Il Trentino ("o Trentino"), que defendia a italianidade regional sem defender abertamente o irredentismo; passado algum tempo, assumiu a redação do jornal. Eleito deputado em 1911, teve seu trabalho interrompido com o início da I Guerra Mundial (1914); a redação de Il Trentino foi fechada sob a acusação de irredentista pelo governo tirolês. Durante a I Guerra Mundial, De Gasperi se dedicou aos feridos, tendo sido nomeado delegado na Alta Áustria (Oberösterreich) e Boêmia Ocidental (Westböhmen). Em 1918 assinou, juntamente com os demais representantes das nações que compunham o Império Austro-húngaro, um documento que deliberava a auto-determinação das etnias imperiais. Em 1919, quando o Trentino passara a pertencer ao Reino Italiano, De Gasperi participou do Partido Popular Italiano, tendo sido eleito deputado em Roma e não em sua terra, pois a região trentina era ainda administrada pelo regime italiano do pósguerra.

\subsubsection{O Período fascista no Tirol italiano, a Segunda GUERRA MUNDiAl E A AUTONOMIA REgIONAL SUL-TIROLESA}

A anexação da porção meridional do Tirol não causou contentamento para a grande maioria da população (sobretudo camponesa), que permanecia fiel à coroa austríaca. Logo que anexada pela Itália, a região passou por um processo de italianização que não se enquadrava na realidade sócio-cultural dos tiroleses (BARATTER, 2009). Esse processo tomou maiores proporções com o advento do período fascista, que procurou italianizar a região por meio da proibição de tudo o que lembrasse o Tirol ou a Áustria.

O fascismo italiano origina-se em 1919, inspirado nas ideias nacionalistas que circulavam pelos meios trabalhistas da Europa (sobretudo França). Seu maior expoente na

\footnotetext{
${ }^{61}$ A manifestação estudantil dos trentinos em prol da Faculdade Italiana em Innsbruck, ocorrida em 04 de outubro de 1904, gerou uma reação imediata na cidade. Muitos estudantes e populares consideraram uma provocação a manifestação estudantil e os alvoroços tomaram conta das ruas; Battisti e De Gasperi foram presos pela polícia imperial e, posteriormente, libertos.
} 
Itália foi Benito Mussolini (1883 - 1945), líder do movimento, que iniciou sua vida política junto dos meios socialistas, tendo trabalhado em Trento juntamente com Cesare Battisti. Após a Grande Guerra de 1918, Mussolini organizou o partido fascista, propagando suas idéias nacionais e alcançando rapidamente um considerável número de adeptos.

$\mathrm{O}$ descontentamento causado pelo pós-guerra gerou fome, violência e crises por toda a Itália, permitindo ao movimento fascista juntar às suas fileiras milhares de pessoas que não aceitavam a realidade política italiana, com um discruso que pregava a salvação para os italianos. O partido conseguiu chamar a atenção popular com demonstrações públicas que visavam intimidar o governo, como a marcha sobre Roma, ocorrida em 1922, da qual participaram milhares de pessoas. A marcha culminou, dois dias depois, com o chamado do Rei Vittorio Emmanuele III (1869 - 1947), que encarregou Mussolini de formar um novo governo. Um mês depois, sob a forte pressão política do movimento fascista, o parlamento italiano concedeu plenos poderes a Mussolini.

Quando da Anexação (Anschluß) da Áustria à Alemanha, Mussolini se mostrou inicialmente contrário e tratou de enviar tropas até o Passo do Brenner (Brennerpaß / Passo Brennero), vale entre o Tirol austríaco e o Tirol italiano, com receio de que as tropas alemãs procurassem anexar o Tirol meridional ao Reich (com apoio da população local). Na região sul-tirolesa o governo fascista implantou uma perseguição étnica, linguística e cultural que tomou proporções exageradas. $\mathrm{O}$ uso do alemão foi proibido publicamente com as escolas de língua alemã fechadas e seus professores substituídos por professores italianos vindos de outras regiões; os topônimos alemães foram substituídos por correspondentes italianos e os sobrenomes de origem germânica foram italianizados ou traduzidos para o italiano $^{62}$. A denominação Alto Adige (em referência ao rio que corta as províncias meridionais) foi imposta à região germanófona do Südtirol e a denominação Trentino foi oficializada para o antigo Tirol Italiano (= Welschtirol).

A política do trentino Ettore Tolomei (1865 - 1952), foi extremamente significativa para a italianização das terras tirolesas que passaram para o domínio da Casa de Savóia.

\footnotetext{
${ }^{62}$ Chegou-se a ponto de se substituir nos cemitérios as lápides com nomes alemães por aquelas onde se liam os nomes traduzidos ou italianizados. A política de italianização não se limitou somente ao Südtirol (alemães e ladinos), mas tratou de "resolver" a problemática de outras áreas lingüísticas: alemão (minorias moquena e cimbra) do Trentino; franco-provençal e alemão (minoria Walser) de Val d'Aosta; grego da Sicília e Puglia; alemão, esloveno e croata da Friulia-Venezia-Giulia; francês e provençal do Piemonte; sardo da Sardenha e o albanês do sul da Itália. Além das línguas de minoria, a política de italianização também procurou acabar com os dialetos italianos que, segundo o ideal fascista, "ameaçavam" a unidade linguística nacional.
} 
Austríaco de nascimento, Tolomei era filho de uma família de imigrantes italianos de Rovereto; sua formação acadêmica se deu em terras italianas: primeiro em Florença e, posteriormente, em Roma, onde fundou a revista irredentista La Nazione Italiana, em 1890. Em 1906, estabeleceu-se em Montagna (= Montan), no atual Südtirol, onde fundou a revista Archivo per l'Alto Adige, de inspiração irredentista, que contou com a colaboração de ilustres estudiosos, como Graziadio Isaia Ascoli, Carlo Battisti e Giosuè Carducci. No mesmo ano, Tolomei iniciava seu Prontuario dei nomi locali dell'Alto Adige, um manual de toponomástica que propunha a substituição dos topônimos alemães do Tirol Meridional por correspondentes italianos (muitos dos quais sem tradição histórica). A publicação do prontuário, em 1916, ficou a encargo da Real Sociedade Italiana de Geografia. Durante a I Guerra Mundial, Tolomei se alistou no exército italiano e adotou o nome Eugenio Treponti de Verona, pois temia as consequências sofridas pelo irredentista Cesare Battisti (BARATTER, 2005).

Durante o fascismo, Tolomei foi o "idealizador" do Alto Adige. Em 1923, em Bolzano, publicou o seu programa de italianização da população alemã local, assim como de propagação do ideal fascista em toda a região. As cidades de língua alemã do Südtirol tiveram seus nomes trocados por correspondentes italianos ${ }^{63}$, principalmente. Toda a região que até 1918 formava o Tirol Meridional foi designada Venezia Tridentina, numa tentativa de apagar qualquer alusão ao "passado tirolês". A italianização implantada pelo governo fascista teve graves conseqüências para a população, sobretudo nas áreas germanófonas: o uso do idioma alemão foi proibido e para a região foram trazidos colonos vindos, sobretudo do Sul da Itália, pois Mussolini acreditava que com a mescla étnica na região, em algumas gerações o problema patriótico austríaco estaria resolvido. O governo italiano também tratou de desagregar a população de língua ladina da região montanhosa do Maciço do Sella, separando da região as cidades de Cortina d'Ampezzo, Colle e Livinalongo, que foram anexadas ao território Vêneto. Culturalmente, a política de italianização (que até os

\footnotetext{
${ }^{63}$ Alguns dos topônimos italianos eram históricos e utilizados juntamente com os correspondentes alemães durante o governo austríaco, inclusive pela população italianófona: Bozen / Bolzano; Brizen / Bressanone; Brozoll / Bronzollo; Meran / Merano. Outros, de origem latina, haviam caído em desuso durante a Idade Média, sendo, então retomados ou adequados à língua italiana: Aldein / Aldino (lat. Aldinus); Toblach / Dobbiaco (lat. Duplago); Stilfis / Stelvo (lat. Stilvis); Schnalls / Senales (lat. Snalles). Vários foram italianizados a partir da toponomástica ladina dolomítica (pois o fascismo não considerava o ladino uma língua autônoma, mas um dialeto italiano): Vintl / Vandoies; Ritten / Renon; Pfalzen / Falzes. Há aqueles topônimos, entretanto, chamados ex novus, criados durante o período fascista, por meio de adaptações, sem qualquer tradição histórica: Rodeneck / Rodengo; Taisten / Tesido; Vöran / Verano.
} 
dias de hoje mantém suas influências) proibia as organizações dos Schützen ${ }^{64}$ (it. Sizzeri; lad. Scizer) e controlava todas as manifestações culturais, que deveriam ser adaptadas segundo o "modelo italiano". Até os trajes típicos foram substituídos por novos modelos, elaborados para substituir a tradicional vestimenta dos grupos folclóricos tiroleses ${ }^{65}$.

$\mathrm{Na}$ região trentina, ainda que o movimento fascista tivesse conseguido regimentar milhares de seguidores, não havia contentamento por parte da maioria da população (sobretudo nas áreas rurais). A italianização na região trentina se aplicou de forma mais sutil que na vizinha província sul-tirolesa, de língua alemã, Nem por isso foi menos taxativa. Movimentos que pudessem despertar a desconfiança do governo fascista eram perseguidos e seus líderes presos ou assassinados. Alcide De Gasperi, por ser ligado ao movimento católico, foi preso em 1927 e solto dezesseis meses depois porque seu caso chegou aos ouvidos do Papa, que solicitou sua soltura.

Entre 1928 e 1930 já havia se formado no Südtirol um grupo de resistência que clandestinamente mantinha o ensino do alemão ${ }^{66}$ e contava com o apoio (não-oficial) do clero. Um dos períodos mais dolorosos da região se deu com o pacto entre a Itália e Alemanha conhecido como Opção (Option / Opzione), que tentou pôr fim ao problema do descontentamento da população de língua alemã do Alto Adige. Este pacto, que funcionou de 1939 a 1943, permitia o repatriamento na Alemanha dos sul-tiroleses que abandonassem suas terras na Itália. O governo fascista promoveu esse pacto com propagandas, no intuito de esvaziar as áreas germanófonas e substituir sua população original por colonos italianos. Famílias inteiras abandonaram suas terras e seguiram para o Reich na esperança de poder manter seu idioma e costumes no Tirol Setentrional, o que não ocorreu, pois Hitler se utilizou dessas famílias nos assentamentos alemães nas regiões tcheca e ucraniana ${ }^{67}$.

\footnotetext{
${ }^{64}$ As companhias dos Schützen ("atiradores") têm sua origem em meados do século XIV (sobretudo após o Landlibell do Imperador Maximiliano I), mas assumiram uma padronização de organização e de trabalhos sociais após a revolta tirolesa de 1809.

${ }^{65}$ Cfr. GRI \& GIUSEPPE (1994).

${ }^{66}$ As chamadas escolas das catacumbas (al. Katakomben-schulle), por seu caráter clandestino. As aulas de língua alemã contavam com o auxílio de tiroleses austríacos que enviavam livros escolares em língua alemã; várias professoras, quando descobertas pela fiscalização fascista, eram exiladas em outras regiões italianas. Também os estudantes o eram, mesmo se crianças - eram deportados com toda a família. Cfr. BARATTER (2005).

${ }^{67}$ Com o final da II Guerra, algumas famílias conseguiram retornar para sua terra natal ou se estabeleceram na Áustria; outras foram obrigadas a seguir para campos de concentração soviéticos (BARATTER, 2005).
} 
Nos anos finais da guerra, a região foi ocupada pelas tropas alemãs que anexaram a região ao Reich sob a designação Alpenvorland (“área pré-alpina”), juntamente com a província de Belluno. Com as perdas do Eixo e o final da Segunda Guerra Mundial, a recuperação da região foi marcada pela busca da identidade, que gerou pequenos conflitos e manifestações durante toda a década de 1950. Muitas famílias saídas durante e Opção conseguiram retornar, mas encontraram dificuldades com a posse de terras e documentação italiana. Atentados terroristas ocorreram durante a década de 1960 no Alto Adige, cuja população exigia a anexação de suas terras pela Áustria, que apoiava internacionalmente a causa sul-tirolesa. O problema foi encaminhado até a representação das Nações Unidas e, para garantir seu domínio na região, o governo italiano reconheceu o idioma alemão como oficial, quando à população alemã do Alto Adige recuperou, por meio de manifestações ${ }^{68}$, a designação Südtirol para a província (embora Alto Adige se mantém como designação oficial em italiano). Além da recuperação do idioma, foi concedida à região uma autonomia administrativa especial (a maior conhecida na Europa), que foi estendida também ao Trentino.

Após a guerra, Alcide De Gasperi fundou o partido da Democracia Cristã na Itália e de 1945 a 1953 ocupou o cargo de primeiro-ministro italiano, assumindo um trabalho de reconstrução do pós-guerra com iniciativas de reforma agrária e aproximação com os países vizinhos. De Gasperi tinha um importante papel na sua conturbada região que se dividia entre a Áustria e a Itália. As manifestações se tornaram cada vez mais freqüentes, sobretudo no Alto Adige. A população sul-tirolesa havia obtido maioria de votos para um retorno à Áustria, com apoio de parte da população trentina (embora a maioria desta tivesse em 1848 votado pela autonomia administrativa do Tirol Italiano na Dieta Tirolesa).

As potências aliadas confirmaram toda a região com a Itália, que manteve sutilmente o processo de italianização na região ${ }^{69}$. O partido único Südtiroler Volkspartei ("partido popular sul-tirolês") adotou a política de defesa da autonomia administrativa da região com grandes manifestações organizadas em Bolzano e demais cidades.

\footnotetext{
${ }^{68}$ Principalmente após a manifestação pública do Los von Trient (“deixar Trento”), organizada pelo político sul-tirolês Silvius Magnago, que propunha a separação do Südtirol da província trentina, visando, assim, sensibilizar a política trentina para a situação sul-tirolesa (MATTEI, 1996).

${ }^{69} \mathrm{E}$, até hoje, o mantém, haja vista o número de monumentos e relíquias históricas do período fascista, ainda existentes em locais públicos trentinos e sul-tiroleses.
} 
Em setembro de 1946, De Gasperi assinou em Paris, juntamente com Karl Gruber (1909 - 1995), primeiro-ministro da Áustria (nascido em Innsbruck), o Tratado de SaintGermain, que reconhecia à população germanófona do Südtirol e do Trentino o direito à língua, cultura e uma autonomia administrativa regional ${ }^{70}$. O estatuto também previa a defesa da minoria ladina, bem como o restabelecimento dos topônimos alemães e ladinos substituídos pela italianização fascista. Em 1948 foi aprovado o estatuto de autonomia, que foi repartido entre as duas províncias e comandado pela administração da região autônoma. O estatuto de autonomia atual foi elaborado na década de 1960, sendo o maior já concedido na Europa até hoje. Foi, entretanto, totalmente aplicado apenas na década de 1990.

Atualmente, o Tirol austríaco e as Províncias Autônomas de Trento e Bolzano possuem um escritório comum nas Nações Unidas, chamado Departamento da Região Européia do Tirol (it. Euregio Tirolo; al. Europaregion Tirol). Trata-se de um projeto de colaboração mútua entre as históricas regiões tirolesas, onde os governadores das três regiões trabalham em conjunto. Desde ano de 2007 existe uma representação das três cidades tirolesas da Província de Belluno (Região Vêneto) que, nos anos de 2007 e 2008, organizaram um referendo popular que optava por sua anexação à Região TrentinoSüdtirol. O referendo obteve a maioria dos votos necessários e as cidades ladinas, até o momento, aguardam aprovação do governo italiano.

\footnotetext{
${ }^{70}$ Tal autonomia já havia sido prometida pelo Reino da Itália, quando da anexação do Tirol Meridional em 1918, mas não cumprida. Ao contrário, procurou-se apagar a memória austríaca da região.
} 


\section{A IMigRaÇão TIROLESA}

\subsection{A EMIGRAÇÃo do TIROL E SUAS CAUSAS}

Para compreendermos a emigração tirolesa, no contexto da emigração de europeus do final do século XIX, torna-se necessário conhecer os principais motivos que a desencadearam. As crises políticas, econômicas e sociais que atingiram a Europa entre os séculos XIX e XX prejudicaram principalmente os camponeses, que não encontravam alternativas perante as grandes baixas na agricultura e na pecuária.

Com os governos enfraquecidos financeiramente e recuperando-se dos problemas enfrentados durante a dominação napoleônica, a população camponesa - a menos favorecida - não recebia auxílios significativos e era a primeira a sofrer com os resultados das crises. O Império Austro-húngaro, “em certos aspectos moderno e em algumas localidades com desenvolvimento veloz de industrialização" (GROSSELLI, 2008: 94), sofreu significativas crises econômicas e sociais no final do século XIX. Por conta disso, houve um grande contingente humano que procurou, em outras terras, melhores condições de vida, mesmo se o governo imperial austríaco não prestasse muita atenção e assistência ao fenômeno emigratório de seus súditos.

As crises iniciadas logo após o período napoleônico se agravaram em meados de 1850, gerando uma situação extremamente dificultosa para os camponeses. No Tirol, cuja grande maioria da população era camponesa, os problemas surgidos na agricultura baseada no sistema familiar, assolaram regiões inteiras. Pragas nas plantações, falta de tecnologia adequada, divisão de terras baseada em sistemas $\operatorname{arcaicos}^{71}$ e queda dos rebanhos, vítimas de várias doenças, foram os motivos para uma verdadeira crise camponesa. Em alguns vales a pobreza gerou miséria e aumento de mortalidade, sobretudo entre os idosos e crianças.

\footnotetext{
${ }^{71}$ Em muitos vales, predominava o sistema de herança das terras somente para o filho primogênito. Cfr. GROSSELLI, 1990; 2001.
} 
O historiador trentino Renzo Maria Grosselli (2008: 37), que dedicou vários estudos historiográficos sobre a imigração tirolesa (sobretudo trentina) e italiana para o Brasil, afirma que no início do século XIX os camponeses eram $90 \%$ da população trentina e que esse número caiu para 66\% no início do século XX. GRANDI (1978: 41) afirma que em 1890, na região meridional do Tirol (atual Trentino), os agricultores representavam $71,10 \%$ da população do e os artesãos $10 \%$ da população.

Em 1865, na região trentina, o deslocamento do Rio Adige - por causa da ferrovia prejudicou a agricultura de alguns vales e zonas de montanha; em outras regiões, seu deslocamento provocou enchentes que devastaram a agricultura já debilitada pelas pragas da época. A pebrina causou enormes baixas nas criações do bicho-da-seda, que foram introduzidas na região trentina pelos padres missionários que haviam trazido os primeiros casulos da China. Nos vales trentinos, assim como nas regiões do Vêneto e Lombardia, a pobre alimentação à base de polenta sem quase nenhuma presença proteica (a carne estava cada vez mais rara e, principalmente, cara) desencadeou naqueles anos a pelagra ${ }^{72}$, uma doença causada pelo baixo número de nutrientes, e que gerou milhares de mortes na população camponesa.

As mudanças nos confins meridionais do Império Austro-húngaro (vide mapa 7), devido às guerras da unificação italiana, nas quais o império perdeu a Lombardia (1859) e o Vêneto (1866), fizeram do Tirol novamente (e bruscamente) um território de fronteira (BARATTER, 2009). A criação de barreiras alfandegárias prejudicou a indústria têxtil e nos campos atingiu os produtores de uvas e vinhos do vale do Adige, que não puderam mais contar com os tradicionais mercados das vizinhas regiões lombarda e vêneta, nem com o mercado italiano. Para conter a crise do sistema agrário, a Igreja Católica, com apoio do Conselho Provincial de Agricultura do Tirol (Tiroler Provinzrat für Agrikultur / Consiglio Provinciale dell'Agricoltura del Tirolo), iniciou uma campanha que organizou as primeiras cooperativas populares. A difusão da encíclica Rerum Novarum em 1891, lançada pelo

\footnotetext{
${ }^{72}$ A pelagra (it. pellagra) não foi apenas uma doença de época; tratou-se de um problema social de toda a zona setentrional italiana (da qual a região trentina se inclui). Quando da redução da produção de trigo no início do século XVIII, o consumo da farinha de milho substitui a farinha de trigo, mas o milho não possui a vitamina PP (cujo nome se origina do termo "preventivo à pelagra"). Por causa da alimentação baseada no consumo quase exclusivo de polenta e vinho (inclusive entre as crianças), alimentos pobres de nutrientes (principalmente vitamina B e PP e aminoácidos como o triptofano), a doença se alastrou em larga escala entre os camponeses famintos. A pelagra causa dermatite, seguida de diarréias e alterações mentais (demência); sua afecção é também ligada ao alcoolismo.
} 
Papa Leão XIII, foi também muito significativa para o crescimento das cooperativas e dos movimentos sociais e, apesar das dificuldades iniciais, as cooperativas contribuíram de maneira fundamental para o ressurgimento econômico e social tirolês no século XX.

A primeira cooperativa, fundada em 1890, foi posteriormente denominada Famiglia Cooperativa ("Cooperativa Família"), indicando a ausência de fins especulativos na obra. Em 1892 fundou-se a primeira Caixa de Crédito rural, uma solução menos burocrática para os camponeses. Em 1895, as cooperativas eram mais de cinqüenta só na região trentina. A cooperação não era apenas uma resposta às condições de fome e pobreza, mas um resultado natural das mudanças mercadológicas do velho sistema econômico. Contudo, não foi suficiente para impedir a saída de milhares de camponeses, desesperançosos em sua terra natal. As promessas de fortuna e promissão no continente americano, divulgadas pelas companhias de imigração, criavam expectativas e esperanças entre as famílias. Em meados 1860, muitos tiroleses emigraram para outras regiões europeias em busca de trabalho e, a partir de 1875, levas ainda maiores seguiram para a América (MATTEI, 1986).

A emigração era, portanto, uma fuga. Não apenas da pobreza e das baixas no campo, mas do sistema agrário arcaico baseado no trabalho praticamente servil de pequenos proprietários para os Senhores do Tirol, ou seja, as famílias de maior prestígio da região, remanescentes de tradicionais famílias outrora feudatárias do condado tirolês e dos principados-episcopais de Trento e Bressanone, às quais muitos camponeses estavam submetidos:

$\begin{array}{ll}\begin{array}{l}\text { Quàndo sarémo en Mèrica } \\ \text { la tèra ritrovàta }\end{array} & \begin{array}{l}\text { Quando estivermos na América } \\ \text { a terra encontrada (prometida) } \\ \text { nòi ghe darém la zàpa } \\ \text { nòi ghe darém la zàpa }\end{array} \\ \begin{array}{l}\text { nuàndo sarémo en Mèrica } \\ \text { nós lhes daremos a enxada }\end{array} \\ \begin{array}{l}\text { la tèra ritrovàta } \\ \text { nòi ghe darém la zàpa } \\ \text { ai sióri del Tirol }\end{array} & \begin{array}{l}\text { a terra encontrada (prometida) } \\ \text { nós lhes daremos a enxada }\end{array} \\ \end{array}$

\footnotetext{
${ }^{73}$ Canto de emigração, ainda mantido entre os descendentes tiroleses das cidades catarinenses de Rio dos Cedros e Rodeio. Cfr. LEDRA (1945); GROSSELLI (1991).
} 
A emigração ocasionou uma histórica saída dos camponeses, tornando algumas aldeias praticamente desertas. A cooperação fora, portanto, uma alternativa para aqueles que não pretendessem partir e para evitar que mais famílias camponesas se lançassem à mercê da sorte na emigração.

Um dos maiores nomes da cooperação foi o padre Lorenzo Guetti (1847 - 1898), natural de Vigo Lomaso, na região das montanhas Giudicarie (= Judikarien). Técnico agrário, foi também presidente do Consórcio Agrário de Santa Cruz (Consorcio Agrario di Santa Croce) em Bleggio e membro na Sessão de Trento do Conselho Regional de Agricultura. Colaborador do Jornal La Voce Cattolica (“A Voz Católica”), registrava em seus artigos a emigração trentina e foi um dos pioneiros nesse sentido.

Em 25 de junho de 1888, Padre Guetti publicava uma estatística sua com o número de famílias inteiras que haviam emigrado do Trentino para a América ${ }^{74}$ :

\begin{tabular}{|c|c|}
\hline \multicolumn{2}{|c|}{ Familias trentinas emigradas entre 1870 e 1888 } \\
\hline Região & Número de famílias \\
\hline Levico & 344 \\
\hline $\begin{array}{c}\text { Trento e arredores } \\
\text { Romagnano e Sardagna) }\end{array}$ & 317 \\
\hline Rovereto & 223 \\
\hline Vallagarina & 216 \\
\hline Primiero & 185 \\
\hline Borgo & 181 \\
\hline Cles & 165 \\
\hline Cembra & 119 \\
\hline Pèrgine & 116 \\
\hline Civezzano & 114 \\
\hline Cavalino & 102 \\
\hline Mezzolombardo & 96 \\
\hline Ala & 93 \\
\hline Tajo & 78 \\
\hline
\end{tabular}

\footnotetext{
${ }^{74}$ Estatística publicada em Grosselli (1986: 160), que afirma que Padre Lorenzo Guetti utilizava em seus artigos jornalísticos o pseudônimo Correspondente da margem direita do Silla.
} 


\begin{tabular}{|c|c|}
\hline Strigno & 77 \\
\hline Lomaso & 61 \\
\hline Mori & 51 \\
\hline Cavalese & 46 \\
\hline Fondo & 41 \\
\hline Condino & 28 \\
\hline Arco & 26 \\
\hline Male & 22 \\
\hline Riva & 19 \\
\hline Tione & 18 \\
\hline Fassa & 1 \\
\hline
\end{tabular}

Trata-se de estimativas baseadas nos poucos e precários registros. O número de indivíduos não é possível saber, mas se levarmos em conta que àquela época eram comuns as famílias numerosas (geralmente com mais de cinco filhos), o número de emigrantes desse período é bastante considerável.

"Segundo a estatística da imigração americana de Lorenzo Guetti, nos anos de 1886 a 1870, quase vinte e quatro mil trentinos imigraram para o continente americano. Representava cerca de 7\% da população total, mas a porcentagem aumenta se levarmos em conta os imigrantes da Oceania e aqueles que peregrinavam por toda a Europa, em busca de uma nova residência definitiva. Em poucos anos, $20 \%$ a 30\% da população emigrou em busca de emprego e alimento".

(GROSSELLI, 1987: 63) $)^{75}$

Ainda que a grande maioria dos emigrantes optou - a partir de 1875 - pela América, ocorreram consideráveis migrações para outras regiões européias, tanto para aquelas sob o domínio do Império (Vorarlberg, Krain ${ }^{76}$, Boêmia, Tirol Setentrional), como para demais países como Alemanha (Baviera), França (Alsácia, Nice) e Itália (Lombardia e Vêneto).

O Império Austro-húngaro conseguiu unir sob sua regência diferentes povos. Era um Estado singular que agregava diferentes culturas, etnias e religiões. Não possuía

\footnotetext{
${ }^{75}$ Tradução nossa.

${ }^{76}$ Atual Eslovênia.
} 
unidade étnica, linguística, confessional e nem mesmo nacional. No último censo de 1910 sobre os povos da parte ocidental do Império, na Cislethania (parte ocidental), dum total de 27.936 .872 habitantes, $35,58 \%$ eram alemães, $23,02 \%$ tchecos, $17,77 \%$ poloneses, $12,58 \%$ rutenos, $4,48 \%$ eslovenos, $2,80 \%$ servo-croatas, $2,75 \%$ italianos (incluindo os tiroleses da região trentina), $0,98 \%$ romenos, $0,04 \%$ húngaro-armênios. Do outro lado, na Transleithania, só os húngaros representavam $48,1 \%$ da população e somavam mais de dez milhões de pessoas ${ }^{77}$.

Ainda que a figura do imperador conseguisse - de forma singular - manter tão elevado número de nações e povos sob uma mesma regência, que se que sustentou de forma ordenada e consensual até o final do Império (1918), deve-se registrar que os ideais nacionalistas floresciam no continente europeu e muitas etnias pertencentes aos domínios imperiais reivindicaram para si autonomias nacionais e regionais, através de manifestações e movimentos separatistas. A situação política no Tirol era instável desde 1859 por conta das disputas territoriais entre o Império Austríaco e o Reino Italiano, pois este - depois de conquistar a Lombardia e o Vêneto - também revogava para si o controle da área de língua italiana do Tirol Meridional. A unificação era uma realidade que fazia surgir uma verdadeira nação italiana, antes dividida em pequenos reinos e condados (muitas vezes inimigos). Entretanto, da parte do Tirol Italiano não havia nenhum movimento popular que buscasse a união com a Itália, além do pequeno e clandestino movimento irredentista, que se propagava entre os carbonários e entre alguns meios intelectuais de inspiração socialista. Os tiroleses de língua italiana que lutaram voluntariamente nas tropas garibaldinas foram muito poucos e o próprio Garibaldi, quando de suas incursões nas terras trentinas, recebera ordens do Rei Vittorio Emmanuele para que se retirasse do Tirol.

O camponês do Tirol (de língua alemã, ladina ou italiana) não participava da realidade política da Itália, ou seja, do movimento de unificação - isso era discussão dos meios intelectuais e políticos. A grande maioria da população camponesa permanecia ligada às suas tradições, ao clero e ao imperador.

\footnotetext{
${ }^{77}$ Segundo BenVEnUtTI (1994), poucos anos antes da I Guerra Mundial ocorreu um juramento de recrutas em Viena que se realizou em dez línguas diferentes e com a participação de capelães militares de sete comunidades religiosas, a saber: católica romana, greco-católica, greco-ortodoxa, ortodoxa armênia, luterana, hebraica e islâmica (para os muçulmanos da Bósnia que se encontravam em Viena).
} 
Por causa de seus ideais liberais e ocupação das terras da Igreja, a unificação italiana era considerada pelo clero como inimiga da fé cristã e sua política vinha duramente criticada entre os austríacos. O clero tirolês criticava o movimento irredentista, que propunha a união da região trentina ao Reino da Itália, e a administração austríaca procurava sufocar os grupos irredentistas e carbonários com prisões e penas de morte. Entre os camponeses tiroleses, que temiam as represálias do clero e do governo imperial, o movimento irredentista trentino era rejeitado e com poucos adeptos (MATTEI, 1996; GrosSELLI, 1991; BARATTER, 2009).

Um aspecto bastante relevante era a influência da Igreja na população tirolesa desde a consagração do Tirol como Terra Santa pelos jesuítas, que se reforçou com o apoio do clero na resistência antinapoleônica de Andreas Hofer. A mentalidade camponesa na região trentina não via na anexação do Trentino a solução de seus problemas, mas uma ameaça aos seus costumes religiosos e culturais. Vale lembrar que o Império Austro-húngaro, enquanto inimigo da Itália, era também considerado o maior defensor da fé católica. A figura do imperador austríaco inspirava no clero e na população rural profundo respeito; e mantinha sua posição de defesa do papado e das terras da Igreja, e condenando o reino unificado da Itália que havia usurpado as terras eclesiásticas de Roma. A figura de Garibaldi, que entre diversos colonos italianos era aquela do "herói da pátria italiana", não encontrava entre os trentinos tamanha admiração. Ao contrário, representava a tentativa italiana de invasão ao Tirol e uma ameaça ao papa. As invasões às terras da Igreja e as incursões garibaldinas contra o papa, em 1848, provocaram um verdadeiro sentimento anti-italiano no Tirol:

"Assim sendo, havia simpatia natural pelo Império Austríaco, cuja orientação política se afinava melhor com as diretrizes marcadamente conservadoras da Santa Sé”.

(AZZI, 1990: 65)

Os tiroleses de língua italiana que chegavam na América ou em outras regiões européias não eram italianos, mas "austríacos que falavam italiano" e, portanto, podem ser considerados somente até certo ponto dentro da mesma realidade sócio-cultural dos imigrantes da Itália setentrional, pois ressalvas precisam ser feitas quanto à sua identidade, ainda que muito próxima do contexto imigratório vêneto ou lombardo. 
"Os trentinos mantiveram sempre a máxima união entre eles e um grande apego e saudade de sua cara Áustria, demonstrando sempre uma certa aversão à Itália e aos italianos. E não podia ser diferente se pensarmos no ambiente do qual haviam chegado e a educação que haviam recebido em sua pátria”.

Isso se deve ao fato dos tiroleses de língua italiana estarem culturalmente ligados aos tiroleses de língua alemã, serem fiéis ao clero e - principalmente - ao governo imperial austríaco. Enquanto a Itália se unificava, esses italianos permaneciam fiéis ao imperador austríaco Franz Josef von Habsburg (1830 - 1916) - chamado pelos trentinos Francesco Giuseppe (ou Cecco Beppe) -, pois sua imagem de era muito respeitada pelos tiroleses ${ }^{78}$.

O século XIX foi marcado pelas lutas nacionalistas que geraram as unificações alemã e italiana, mas que também provocaram a I Guerra Mundial (e as divisões no Império Austro-húngaro). De um lado, grupos separatistas e, de outro, a repressão imperial com punições, prisões e penas de morte. Os meios políticos europeus estavam agitados: questões nacionais mal resolvidas em várias regiões dos impérios russo e austro-húngaro, revoltas populares nos reinos alemão e italiano, disputas pelas colônias africanas; a ameaça de uma guerra estava eminente. O assassinato do sucessor ao trono austríaco, Arquiduque Franz Ferdinand $(1863$ - 1914) e de sua esposa Sofia von Hohenberg (1868 - 1914), pelo terrorista sérvio Gravilo Princip (? - 1918), em Sarajevo, foi o estopim da I Guerra Mundial (1914-1918).

Entretanto, a grande maioria dos tiroleses emigrou no final do século XIX e, portanto, anos antes da I Guerra Mundial e da anexação do Tirol Meridional pelo Reino da Itália. Enquanto austríacos, os trentinos participavam da realidade cultural e administrativa austríaca e não daquela que se seguiu na Itália após a unificação. Tais aspectos são importantes para compreendermos a realidade trentina que, apesar de sua identidade linguística, diferencia-se das demais regiões setentrionais da Itália por causa de sua estreita ligação histórica com a população germanófona do Tirol.

\footnotetext{
${ }^{78}$ Em muitos meios tiroleses, a figura do imperador era tão ou mais respeitosa que a própria nação austríaca, como se pode observar nas fotos antigas da época da imigração, bem como na memória dos descendentes mais velhos. Em muitas comunidades trentinas do Brasil, a pessoa de Francisco José é ainda recordada e admirada, mesmo sem muitas referências à antiga nação austríaca. Sobre o assunto, conferir LORENZONI (1975), GROSSELLI (1990; 2001).
} 


\subsection{A IMIGRAÇÃO TIROLESA NO BRASIL}

A crise econômica e a difícil situação política no Reino Alemão no final do século XIX dificultaram a vinda de seus emigrantes para a América. Segundo Roche (1969), algumas famílias alemãs esperavam até dois meses no porto de Hamburgo para poderem emigrar, em situações precárias. Outros fatores que ocasionaram a proibição da emigração por parte do governo alemão foram o alto número de mortalidade entre os colonos no Brasil (por conta de doenças tropicais e miséria), a precária viagem até a América em navios superlotados e a propaganda enganosa do governo brasileiro, que não garantia aos colonos condições básicas de adaptação.

Não podendo mais contar com a mão-de-obra alemã, os agentes brasileiros na Europa procuraram incentivar, em outras nações, a emigração para a América, como no Império Austro-húngaro, no Reino da Itália e no Reino Espanha. Como o Império Austrohúngaro também não permitia a emigração, por causa da rápida repercussão das péssimas condições enfrentadas pelos colonos alemães, seus súditos partiam para a América em navios de outros países (italianos, alemães, ingleses e norte-americanos).

A crise econômica que atingia os camponeses italianos e austríacos ${ }^{79}$ no final do século XIX favoreceu sua emigração para o Brasil. Do lado austríaco, a maioria do contingente humano era representada pelos tiroleses de língua italiana, ou seja, trentinos. As agências de imigração e as representações imperiais brasileiras desenvolviam uma propaganda de incentivo à emigração, com destaque para a Empresa Joaquim Caetano Pinto Junior \& C.

As grandes levas de emigrantes tiroleses que seguiram para o Brasil vieram a partir de 1875, do mesmo modo que os friulanos (então austríacos), vênetos, lombardos e demais italianos. Em 1876, a campanha brasileira de incentivo à imigração era intensa no Tirol, sobretudo na área trentina. A crise social tirolesa e a grave situação das entidades administrativas, aliadas às pestes e baixas do setor agrário, criavam um ambiente propício

\footnotetext{
${ }^{79}$ Entenda-se como "austríacos" os diversos povos que compunham a população do Império Austro-húngaro, ou seja, falantes de alemão, italiano, tcheco, eslovaco, esloveno, croata, húngaro, romeno, polonês etc.
} 
para a propaganda imigratória de Caetano Pinto. Milhares de pessoas partiram naquele ano, cuja grande maioria seguiu para as colônias públicas do Espírito Santo e Santa Catarina.

Entretanto, alguns anos antes, um pequeno grupo de imigrantes havia se estabelecido no Espírito Santo. WAGEMANN ${ }^{5}$ (1949) afirma que em 1860, na Colônia Santa Leopoldina no Espírito Santo, havia 82 tiroleses que se estabeleceram ali com demais colonos alemães, suíços e holandeses. O autor indica que eram falantes do alemão e supõese que fossem do Tirol Setentrional (Nordtirol), embora não haja confirmação disso. Numa outra localidade colonial não muito longe de Santa Leopoldina, foi posteriormente fundada a colônia Tyrol, fundada por tiroleses de língua italiana, isto é, trentinos (GROSSELLI, 2001).

A imigração trentina para o Brasil se iniciou aproximadamente na década de 1860 e durante as décadas de 1870 e 1880 teve seus mais altos índices; decresceu gradativamente nos primeiros anos do século XX e foi logo interrompida no início da I Guerra Mundial (1914). O maior número de emigrantes austríacos que seguiu para o Brasil era composto por trentinos:

"Entre 1872 e 1914 entraram no Brasil 78.358 austríacos e destes 27.463 seguiram para São Paulo. Segundo os dados de Sobral estes últimos foram 1.562 a mais. Baseando-nos sempre sobre estas estatísticas e considerando a falta de dados para os anos de 1876 e 1881, podemos tranquilamente supor que cerca de 30.000 cidadãos pertencentes ao Império Austro-húngaro tenham emigrado para São Paulo durante o periodo considerado. Mas (...) os erros existentes nessas fontes estatísticas nos sugerem pensar em um número maior de austríacos emigrados, seja em São Paulo como em todo o Brasil. Podemos, pois, verossimilmente colocar entre 35.000 e 40.000 os austríacos que entraram em São Paulo no período por nós considerado".

(GROSSELLI, 1991: 154) ${ }^{80}$

Os emigrantes austríacos não eram todos tiroleses, mas de todas as etnias pertencentes ao Império Austro-húngaro: alemães das terras historicamente austríacas, alemães da Romênia e da Hungria, poloneses, húngaros, romenos, eslovenos, croatas, italianos (friulanos e trentinos), tchecos, eslovacos, entre outros; católicos romanos,

\footnotetext{
${ }^{5}$ Cfr. WAGEMANN (1949).

${ }^{80}$ Tradução nossa.
} 
católicos ortodoxos, protestantes e judeus. Entretanto, a maioria dos imigrantes austríacos era composta indubitavelmente pelos tiroleses de língua italiana (GROSSELLI, 1991).

Os jornais de circulação no Tirol publicavam artigos cheios de promessas de vida fácil e comida abundante na América, auxiliando, desse modo, a propagar as esperanças de se procurar na emigração as soluções para as crises econômicas e sociais. Também no meio católico, o jornal La Voce Cattolica publicava artigos e poemas que incentivavam a emigração. Desse modo, é possível observar que o clima de incertezas e divergências de opinião sobre a emigração existia também entre o clero da época que, se por um lado auxiliava a permanência das famílias através das cooperativas, por outro incentiva a emigração em seus meios de comunicação. Na edição de 23 de janeiro de 1877, foi publicado o seguinte poema ${ }^{81}$ (acentuadamente sarcástico), de autoria anônima:

Al Brasile, al Brasile, o buone genti,

Al Brasile, al Brasile presti correti;

Orsù che fato? in questi steppe nigenti

D'inedia e povertà tutti morrete!

Celà di latte e miel scorren torrenti,

Fruttar salami i larici vedrete,

E sei stagioni all'anno in quei tepenti

Climi! A bigonci el vin raccoglierete.

E questo è ancor un nulla: ogni campagna

(Son galantuomo, amici, e dico il vero)

Di gemme è piena e d'oro ogni montagna.

Chi assevera il contrario, no sa un zero;

È il paese il Brasil della cuccagna:

Lo vidi io stesso... stando qui in Primiero.
Ao Brasil, ao Brasil, ó boas gentes,

Ao Brasil, ao Brasil rápido correis;

Vamos, que fizestes? nestas gélidas estepes

De inanição e pobreza todos morrereis!

Cobertas de leite e mel correm torrentes,

Produzir salames os pinheiros vereis,

E seis estações no ano naqueles tépidos

Climas! Em cântaros o vinho recolhereis.

E isto é ainda nada: cada campo

(Sou homem sério, amigos, e falo a verdade)

É cheio de gemas e de ouro cada montanha.

Quem afirma o contrário, de nada sabe;

É o país, o Brasil, da cocanha ${ }^{82}$

Eu mesmo o vi... estando aqui no Primiero.

\footnotetext{
${ }^{81}$ Poema publicado em SANTOS (1995).

${ }^{82}$ Lenda surgida na França medieval, a "terra da cocanha" (Terre de la cocagne) seria um país mitológico onde o alimento é abundante e não há trabalho (considerado uma prática abominável). Terra mágica onde todos são gratificados sem esforço, é formada por rios de leite e vinho, montes de queijo e todos os tipos de delícias; leitões assados que circulam com facas cravadas no lombo para melhor serem servidos e frangos assados que voam livremente e se oferecem para serem devorados. Uma verdadeira antítese do sistema servil feudal, a lenda possui diferentes versões em vários países europeus e também no imaginário folclórico do Nordeste do Brasil, de acentuada influência medieval. Na comunidade tirolesa de Piracicaba, trata-se dos festejos da terça-feira de carnaval, como se pode observar no capítulo seguinte (4.4.2.2.). Sobre o assunto, cfr. FRANCO JR (1998, 2007).
} 
A imprensa incentivava a emigração como uma solução para a desagregação do modelo familiar tradicional que o militarismo obrigatório austríaco causava na região tirolesa, tirando os jovens rapazes de suas casas e os enviando para outras terras. Para compensar a renda familiar, as moças eram obrigadas a procurar emprego nas cidades e a morar sozinhas ou em pensões. Além do aspecto econômico, a emigração para a América seria uma alternativa eficaz e segura para resguardar a integridade da família patriarcal camponesa, tirando os rapazes do serviço militar obrigatório e preservando a integridade das moças (Possamai, 2004).

No mesmo ano de 1877, foi publicado no jornal La Valsugana, datado de 15 de março, o seguinte poema ${ }^{83}$ (sem título) de Carlo Gruft, trentino de Besenello:

O Brasile di vastità grandissima,

Tu sei dei poverelli il gran conforto,

Come il faciulo de fedeli sposi,

Che lo carezzan, e sostegon in ogni porto,

La terra tua eccelente e fruttuosa,

Di frutti e di granaglia in abbondanza,

Più volte all'anno si munge e si tosa...

E ben si può mangiare a crepa panza.

L'acqua che gira dolce e cristallina,

Che in ogni parte si fa ben trovare,

Che bevere si può sera e mattina,

Che non fa male e si può rinfrescare.

Ai monti, al piano, spira l'aria sana,

Da rinfrescare il corpo calorito,

Come che la natura assai lo brama,

Credete in verità quanto vi dico.

Il caldo è moderato a perfezione,

Che la natura il può sopportare,

\footnotetext{
${ }^{83}$ Poema publicado em SANTOS (1995: 75).
}

Oh Brasil de vastidão grandíssima,

Tu és dos pobres o grande conforto

Como filhinho de fiéis esposos,

que o acariciam e o amparam em cada porto.

A tua terra excelente e frutuosa,

De frutos e grãos em abundância,

Mais vezes ao ano se ordenha e se tosa...

E bem se pode comer de estourar a pança.

A água que corre doce e cristalina,

Que em toda parte se pode encontrar,

Que beber se pode de noite e de manhã,

Que não faz mal e só nos faz refrescar.

Nos montes, nas planícies, sopra o ar puro,

Para refrescar o corpo calorento,

Como que a natureza muito o cobiça,

Creiais que é verdade o que vos digo.

O calor é moderado à perfeição,

Que a natureza o pode suportar, 
Assai propizio alla maturazione;

La piaggia mai non manca di bagnare.

A voi cacciatori, parlerò di caccia,

Selvatici vi sono d'ogni sorte,

Basta solo seguire la lor traccia,

Poi si prendono e si mettono in basiccia.

Se il colpo ben diretto fu per sorte;

Chi brama di passare il proprio effetto,

Venga al Brasile e prenda il suo schioppetto.

I Brasiliani poi son buona gente,

Formiti di umiltà e di prudenza,

E si può ben girare liberamente,

Che non vi usan pubblica violenza;

Anzi vi porge la mano e vi saluda

Adoperando moltissima prudenza,

E quindi vi dirò liberamente,

Che nel Brasile esiste buona gente.

Ho ben intenso che certi fuggitivi turubetti

Han detto e dicon male del Brasile.

E questi, esser da Nomi e Delaiti,

Che in ogni modo male voglion dire;

Non date ascolto a tali persone

Poichè il vizio loro vogliono seguire;

Se andassero in Paradiso questa sera,

Ancor domani moverian la guerra.

Ed ora per dar fine alla poesia

Io sto meglio quà che non là via.

Evviva il Brasile, evviva il suo Governo

E col Sovrano suo viva in eterno.

Il segno di riconoscenza,

Carlo Gruft, trentino di Besenello.
Muito propício à maturação;

A chuva nunca falta para molhar.

A vós caçadores, falarei de caça,

Animais existem de toda a sorte,

Basta somente seguir seus rastros,

Depois se pegam e se metem no saco.

Se o golpe por sorte foi bem direto;

Quem deseja passar por tal experiência,

Venha ao Brasil e apanhe sua arma.

Os brasileiros são boa gente,

Cheios de humildade e prudência

E se pode andar ali livremente

Que não vos mostram pública violência;

Antes vos levantam a mão e vos saúdam

Usando muitíssima prudência,

Portanto vos direi livremente,

Que no Brasil existe boa gente.

Entendo que certos fugitivos turbulentos

Falaram e falam mal do Brasil.

E estes, de Nomi e de Delaiti,

Que de qualquer modo querem mal falar;

Não deis ouvidos a tais pessoas

Porque seus defeitos querem seguir;

Se chegassem ao Paraíso esta noite,

Já amanhã iniciariam uma guerra.

E agora para terminar a poesia,

Eu estou melhor aqui que lá longe.

E viva o Brasil, e viva seu Governo

E com seu Soberano viva eternamente.

Em sinal de reconhecimento,

Carlo Gruft, trentino de Besenello. 
A emigração contava com o apoio de uma significativa parte do clero, que via na saída dos camponeses a solução para a desagregação familiar que o serviço militar obrigatório austríaco proporcionava; a Igreja considerava que o exército, arregimentando os rapazes, obrigava as mulheres ao trabalho nas fábricas e as retirava dos lares. Era, segundo a visão da época, uma prática imoral (GROSSELLI, 1991, 2001).

No período entre 1870 e 1889 o número de emigrantes trentinos que seguiram para a América foi o de 23.846, quase 7\% da população atual da Província Autônoma de Trento. Além desses, $8 \%$ da população emigrava temporariamente em outras áreas do Império Austro-húngaro e da Europa. No período entre 1874 e 1884, estima-se que os tiroleses de língua italiana que seguiram para as colônias imperiais brasileiras eram aproximadamente 10.000 pessoas (GrosselLI, 1987; 1990; 2001).

Os tiroleses que desembarcaram no Brasil estabeleceram-se principalmente nos estados de Santa Catarina, Rio Grande do Sul e São Paulo. Em menor número nos estados de Espírito Santo, Paraná, Rio de Janeiro, Minas Gerais e Bahia. Segundo Grosselli (1986), o estado de Santa Catarina é aquele que mais recebeu imigrantes tiroleses.

Nos estados do Sul, os tiroleses fundaram colônias rurais e até mesmo cidades; em São Paulo e Minas Gerais, seguiram principalmente para as grandes fazendas de café (substituindo com os demais imigrantes a antiga mão-de-obra escrava) e um menor número para os centros urbanos do interior e cidades do grande ABC (à época, pouco expressivas); no Rio de Janeiro e Espírito Santo fundaram pequenos núcleos rurais; na Bahia, os poucos emigrantes trentinos se estabeleceram em Salvador, trabalhando em pequenos ofícios.

A imigração tirolesa mais recente é aquela da cidade catarinense de Treze Tílias, fundada por tiroleses de língua alemã vindos do Tirol Setentrional (Tirol austríaco) e Meridional (Südtirol). Trata-se de uma colonização relativamente recente, ocorrida no ano de 1933 e chamada de "epopéia de Andreas Thaler (1852 - 1928)", então ministro da agricultura da Áustria e fundador da colônia. Em 1933 Thaler criou a Sociedade Austríaca de Colonização no Exterior, com sede em Innsbruck. No mesmo ano, visitou várias localidades no Sul do Brasil e na Argentina, procurando um lugar "ideal” para a emigração (era sabido que uma segunda guerra viria e os tiroleses ainda sentiam os abalos que a primeira lhes causara). O ministro, após sua pesquisa, escolheu a região montanhosa de Joaçaba (município de Água Doce), no oeste catarinense, para a fundação de um núcleo 
colonial e, no mesmo ano, instalou ali o primeiro grupo de 84 tiroleses na colônia que chamou Dreizehnlinden ${ }^{84}$. Antes da fundação da colônia, algumas famílias tirolesas emigraram por conta própria e se instalaram na região de Caçador e algumas delas se transferiram posteriormente para a nova colônia.

A partir de 1937 chegaram outros grupos e os habitantes somavam cerca de 800 colonos. Durante a II Guerra Mundial, com a perseguição do governo getulista, obrigou-se a mudança do nome da colônia para Papuan (antigo nome indígena da localidade). Em 1963 a colônia tornou-se um município com o nome de Treze Tílias ${ }^{85}$. Algumas famílias trentinas da região se transferiram para Treze Tílias, embora haja um maior número de descendentes trentinos na cidade vizinha de Luzerna.

Os nomes das localidades coloniais no Brasil demonstram a ligação histórica que uniu os dois grupos linguísticos tiroleses: com o nome Tirol ou Tyrol existem várias localidades brasileiras fundadas por emigrantes de língua alemã ou italiana. Já em 1859 foi fundada no Espírito Santo, a setenta quilômetros da capital Vitória, a colônia Dorf Tirol (“Aldeia Tirol”) por tiroleses de língua alemã; na cidade catarinense de Nova Trento (fundada por tiroleses de língua italiana), a localidade outrora denominada Ronzenari se chama hoje Tirol; na cidade catarinense de Rio dos Cedros, fundada por tiroleses de língua italiana, a uma estrada colonial para Blumenau é chamada Estrada dos Tiroleses; no Paraná, na cidade de Piraquara (próxima a Curitiba), está a localidade Santa Maria do Novo Tyrol, fundada por tiroleses de língua italiana saídos da região de Primiero (GROSSELli, 1987); uma das principais avenidas da cidade de Treze Tílias, fundada por tiroleses de língua alemã, chama-se Avenida Tirol - além dela, a leiteria da cidade também se chama Tirol e a própria cidade é conhecida turisticamente como Tirol brasileiro.

\footnotetext{
${ }^{84}$ Referência ao poema "Die dreizehn Linden" do poeta alemão Wilhelm Weber.

${ }^{85} \mathrm{O}$ significado em português é Treze Tílias. Tília é uma árvore européia, cujo nome em alemão é Linde. Houve, portanto, um decalque do nome original alemão da colônia.
} 


\subsection{A IMIGRAÇÃo TIROLESA EM SÃo PAUlO}

Segundo GrosSELli (1991: 162), as fontes austríacas que indicam quantos tiroleses (sobretudo trentinos) emigraram para trabalhar nas fazendas de café paulistas são praticamente nulas; as trentinas também o são. As estatísticas existentes (cujos dados não são precisos) são aquelas de Padre Lorenzo Guetti.

Os tiroleses que vieram para o Sudeste (principalmente para São Paulo) saíram, sobretudo, das regiões trentinas: Valle dell'Adige (Vale do Rio Adige, incluindo Trento e cidades vizinhas), Vallagarina (Rovereto e cidades vizinhas), Valsugana (Borgo e cidades vizinhas) e Primiero (Fiera e cidades vizinhas).

Imigração trentina para São Paulo entre 1875 e $1914^{86}$

\begin{tabular}{|c|c|c|}
\hline \multirow{2}{*}{ Período } & \multicolumn{2}{|c|}{ Número de imigrantes } \\
\cline { 2 - 3 } & Mínimo & Máximo \\
\hline $1875-1882$ & 600 & 1.200 \\
$1883-1890$ & 3.000 & 4.000 \\
$1891-1897$ & 1.200 & 1.600 \\
$1898-1910$ & 350 & 700 \\
$1911-1914$ & 400 & 500 \\
\hline Total: & 5.500 & 8.000 \\
\hline
\end{tabular}

Muitos tiroleses e italianos eram informados pelas companhias de imigração e representações do governo brasileiro que, assim que chegassem ao Brasil, poderiam escolher seu destino, isto é, ou as fazendas paulistas ou as áreas coloniais do Sul. Entretanto, logo que desembarcavam no Rio de Janeiro, os imigrantes eram encaminhados para Santos e, dali, para as fazendas paulistas sem qualquer opção de escolha de seu destino

\footnotetext{
${ }^{86}$ Estatística publicada em GROSSELli (1991: 168), também baseada em dados do Memorial do Imigrante (antiga hospedaria dos imigrantes) da cidade de São Paulo.
} 
(GROSSELLI, 1990: 319) ${ }^{87}$. No período entre 1875 e 1914, o número de imigrantes trentinos que seguiram para o interior paulista foi relativamente grande, mas os dados não são precisos pela precariedade de registros e controle da época.

"Uma minoria dos austríacos que imigraram para o Brasil na década de 1840 escolheu (ou foi obrigada a escolher) o Estado de São Paulo. Um número significativo provinha do Império Austro-húngaro, como os austríacos eram de língua italiana e de língua alemã, foram classificados em sua chegada como sendo de origem italiana ou alemã, ultrapassando oitenta mil imigrantes".

(GROSSELLI, 1991: 154-155)

É difícil saber exatamente o número de imigrantes tiroleses (trentinos) no estado de São Paulo. Muitas pesquisas basearam-se nos sobrenomes e, assim, era mais fácil deduzir a origem trentina dos descendentes "italianos" que possuíssem sobrenomes germânicos, uma vez que os nomes de origem alemã na região trentina são numerosos; dificultoso era, entretanto, determinar por dedução a origem trentina nos casos de sobrenomes que também ocorrem em demais áreas italianas limítrofes, como o Vêneto e a Lombardia. GROSSELLI afirma que ultrapassa seguramente a casa dos 27.000 o número de emigrados trentinos que entraram no Brasil nas áreas coloniais (principalmente do Sul) ou nas fazendas de café paulistas.

"Entre o ano de 1872 e 1914 entraram no Brasil setenta e oito mil, trezentos e cinqüenta e oito austríacos. Destes, vinte e sete mil e quatrocentos foram para São Paulo. Conforme os dados de Sobral estes últimos foram um mil e quinhentos e sessenta e dois a mais. Baseando-nos sempre nestas estatísticas e considerando a falta de dados para o ano de 1876 e 1881, poderíamos tranqüilamente supor que cerca de trinta mil cidadãos pertencentes ao Império Austro-húngaro tinham emigrado para São Paulo durante o periodo considerado. Constituem 38\% daqueles austríacos que foram ao interior de São Paulo”.

(GROSSELLI, 1991: 154)

\footnotetext{
${ }^{87}$ Alguns dos mais velhos moradores da comunidade tirolesa de Piracicaba afirmam que seus avós preferiam ter seguido para o Sul, onde criariam ovelhas e cultivariam vinhedos, mas foram obrigados a permanecer em São Paulo e seguirem para a fazenda do Visconde de Indaiatuba.
} 
Além dos trentinos, há também - ainda que em menor número - os emigrantes tiroleses de língua alemã. As imprecisões e a precariedade de registros (tanto austríacos como brasileiros) da época, os registros paroquiais, as emigrações ocorridas antes, durante e depois das duas grandes guerras, estima-se que o número total de imigrantes tiroleses seja ainda maior.

A partir de 1852, o Visconde de Indaiatuba iniciava em sua Fazenda Sete Quedas um sistema de colonização organizada (com contrato de quatro anos), com a introdução de colonos alemães que trabalharam nas lavouras juntamente com escravos negros. Com a forte propaganda anti-imigratória que se propagou pelos reinos alemães, o visconde procurou nas terras austríacas a mão-de-obra necessária para seu projeto de colonização. É durante esse período, que se inicia em 1875, que a imigração tirolesa faria parte da realidade social brasileira e paulista.

MuNiCíPIOS DE MÁXIMA PRESENÇA TRENTINA ENTRE 1881 E $1914^{88}$

\begin{tabular}{|l|c|c|}
\hline \multicolumn{1}{|c|}{ Cidade } & Região & Número de famílias \\
\hline Campinas & Central & 114 \\
Pirassununga & Paulista & 86 \\
Amparo & Mogiana & 81 \\
Ribeirão Preto & Mogiana & 46 \\
Itu & Central & 43 \\
Descalvado & Paulista & 25 \\
Brotas & Araraquarense & 24 \\
Piracicaba & Central & 23 \\
Araras & Paulista & 22 \\
São Carlos & Paulista & 22 \\
Jaú & Araraquarense & 21 \\
Rio das Pedras & Central & 20 \\
Rio Claro & Paulista & 19 \\
Botucatu & Sorocabana & 14 \\
Casa Branca & Mogiana & 12 \\
\hline
\end{tabular}

\footnotetext{
${ }^{88}$ Estatística publicada em Grosselli (1991: 182).
} 
A tabela apresentada por GROSSELLI não contempla as cidades do ABC Paulista. Mas é sabido também que algumas famílias não seguiram para as fazendas. Ainda que a grande maioria dos colonos trabalhasse nas fazendas de café do interior, um número pequeno se estabeleceu nas (então) pequenas cidades do chamado $\mathrm{ABC}$ Paulista, principalmente Santo André, São Bernardo do Campo e Mauá.

Sabe-se que nessa época o número de indivíduos de uma família era muito diverso dos padrões atuais. Era comum que os casais tivessem muitos filhos e isso faz supor que o número de imigrantes era bastante significativo. O número de colonos tiroleses cresce se pensamos nos descendentes da primeira geração, cujos casamentos mistos (com brasileiros ou demais imigrantes) era raro.

\subsubsection{OS MISSIONARIOS CAPUCHINHOS DE TRENTO}

Além da imigração de camponeses, merece atenção a missão capuchinha trentina que se desenvolveu no Brasil, sobretudo em São Paulo. Ela representa uma imigração de indivíduos letrados e - é possível afirmar - intelectuais, que influenciaram em várias localidades a sociedade paulista da época.

A entrada dos frades capuchinhos (franciscanos), cuja ordem religiosa era popular no Tirol ${ }^{89}$, não foi um resultado da imigração trentina para o Brasil, mas um pedido do próprio Imperador Dom Pedro II, que procurou, enquanto monarca católico, introduzir em suas terras missionários europeus (visto o baixo número de clérigos no país) para a catequização do povo de "fé oscilante" (sincretista); do outro lado, da parte da Santa Sé romana, o envio de missionários reforçava seu controle sobre a Igreja brasileira (GROSSELLI, 1991: 213).

Os missionários capuchinhos já trabalhavam no Brasil colonial desde o século XVII e eram capuchinhos franceses que primeiramente seguiram para o Maranhão e, posteriormente, para a Bahia; por contrato com o rei de Portugal, vieram os capuchinhos

\footnotetext{
${ }^{89}$ Destacou-se a participação de Padre Joachin Haspinger no levante tirolês de 1809.
} 
italianos (e tiroleses) de todas as províncias, formando no Brasil um Comissariato que mantinha conventos em Recife, Salvador e Rio de Janeiro. Sob as ordens do governo, percorriam todo o país em suas missões, mas não podiam abrir noviciados.

Os capuchinhos italianos e tiroleses já haviam percorrido toda a província colonial e imperial de São Paulo quando Dom Pedro II, em sua última viagem política à Europa (1887-1888), pediu que viessem mais missionários capuchinhos para evangelizarem os índios. Houve essa escolha, porque o imperador considerava a ordem bastante severa e acreditava que, assim, haveria mais rápida moralização da população cabocla e indígena. Era então o Ministro Geral dos Capuchinhos o suíço Bernardo de Andermatt, que pediu, por meio de seu secretário o Frei Antonino de Reschio, à província capuchinha de Trento que se encarregasse da missão com os índios, com a permissão imperial de se abrir um noviciado para acolher vocações brasileiras.

Aos 29 de julho de 1889, partiram para a América os primeiros capuchinhos tiroleses e tiveram algumas dificuldades na viagem, inclusive com a morte de do Frei Vigilio de Trento. Chegaram em 1890, estabelecendo sua sede missionária na cidade de Piracicaba e, além de se dedicarem às missões entre os índios, abriram diversos conventos e mantinham um grande trabalho de auxílio aos pobres e doentes. Em 1892 os capuchinhos abriram o primeiro noviciado e se destacaram pela aceitação de jovens índios, negros e caboclos para a ordem; em 1896 abriram o primeiro seminário brasileiro.

Entre os colonos trentinos, os capuchinhos eram comumente chamados fràti de la barba (frades barbados) por causa do seu uso de longas barbas e representaram um importante papel na integração dos emigrantes na sociedade brasileira. Entretanto, os capuchinhos não perderam completamente seu elo com a terra de origem, nem com a mentalidade política de sua pátria: faziam uma "propaganda aberta" de defesa da imagem do imperador austríaco e da unidade territorial tirolesa, com críticas ferrenhas contra a unificação italiana que se desenrolava à época e cuja forte ligação com os ideais maçônicos (contrários àqueles da Igreja) se dava através dos carbonários ${ }^{90}$.

\footnotetext{
90 É sabido que a Igreja era bastante crítica à unificação italiana, sobretudo por causa da perda de terras eclesiásticas pelas incursões garibaldinas. A posição austríaca era ferrenha contra o reino italiano por dois motivos já mencionados: a perda de terras nas regiões lombarda, vêneta e triestina, e a imagem de "defensor" da fé cristã que o imperador austríaco sustentava. A grande maioria da população tirolesa, fortemente apegada ao clero e à sua fé, mantinha a posição ideológica incentivada pelo clero.
} 
Segundo Grosselli (1991: 386), foram 71 os missionários capuchinhos que trabalharam no Brasil, e que a ordem aumentou consideravelmente com os "filhos de trentinos emigrados em São Paulo que se fizeram capuchinhos, entrando nos noviciados abertos pelos frades". A influência capuchinha no campo auxiliou o grande movimento de expansão agrícola do oeste paulista e sua ação missionária trouxe para imigrantes e brasileiros algumas noções de cidadania e de trabalho consciente com a terra. Os frades foram participantes e até mesmo pioneiros no processo de melhoria de técnicas agrícolas em várias localidades paulistas.

Em Piracicaba, a missão capuchinha desempenhou um papel muito relevante na comunidades de Santana e Santa Olímpia, que estudamos, inclusive porque a fundação dos bairros se liga ao trabalho que os frades mantinham entre os colonos da Fazenda Sete Quedas. O contato existente entre os colonos e os capuchinhos (que circulavam pelas fazendas) mantinha os imigrantes informados e, de certa forma, unidos. 


\section{A COMUnidade Tirolesa de Piracicaba}

\subsection{INTRODUÇÃO}

Os imigrantes tiroleses que fundaram os bairros Santana e Santa Olímpia são oriundos de diferentes distritos localizados no vale do Rio Adige, na atual Província Autônoma de Trento (Trentino) - Itália.

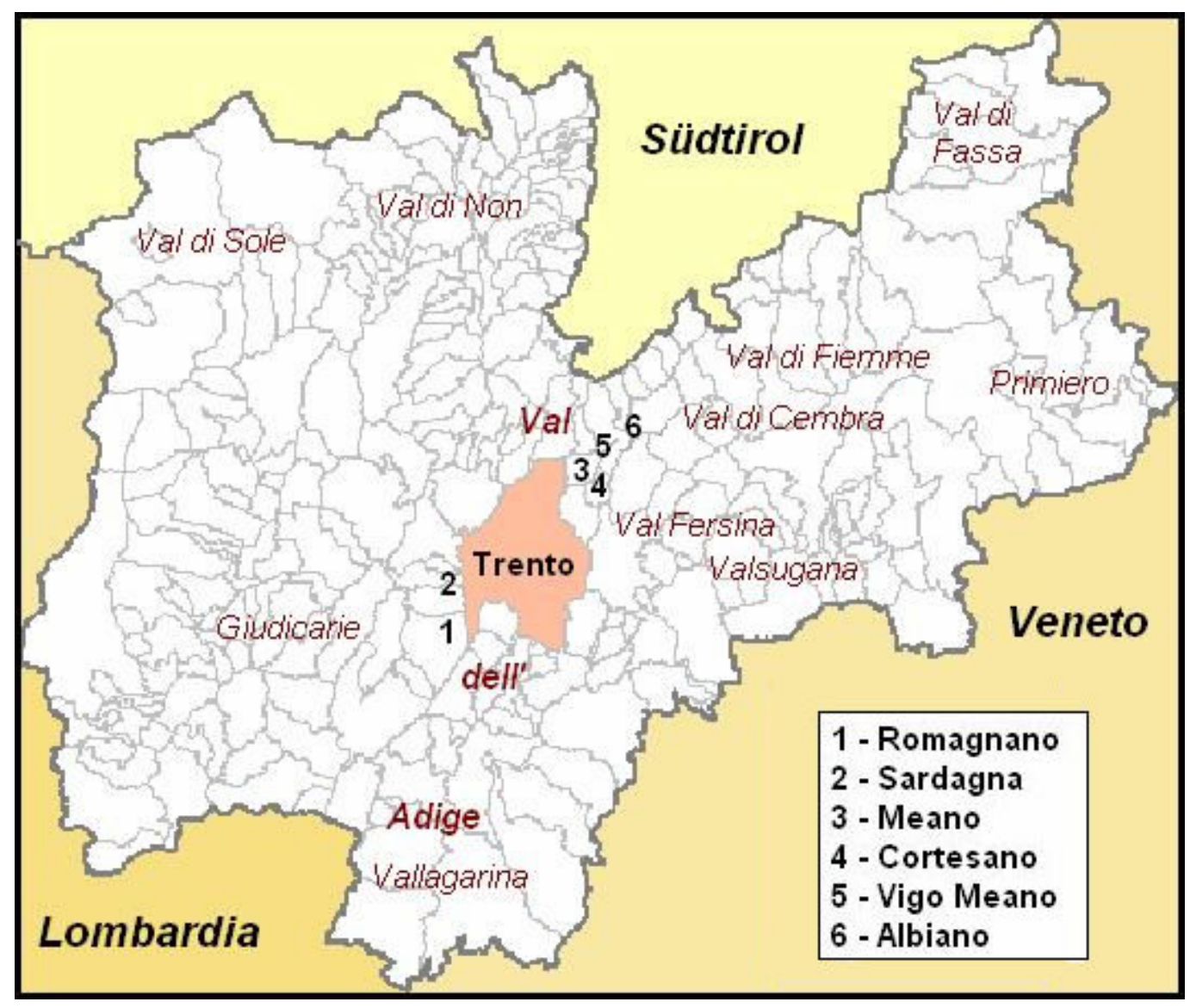

Mapa 9: Localização dos distritos originários dos imigrantes de Santana e Santa Olímpia ${ }^{91}$.

\footnotetext{
${ }^{91}$ MAPA: nosso.
} 
Os bairros somam juntos pouco mais de mil moradores, divididos entre os principais núcleos familiares, a saber: Brunelli, Correr, Degasperi, Forti, Mosna, Negri, Pompermayer, Stenico e Vitti. Outra família de tiroleses, os Negri, comprou uma antiga fazenda vizinha às demais e ali surgiu um "terceiro núcleo tirolês" da região, a Fazenda Negri, que foi posteriormente incorporada ao Bairro Santa Olímpia. Juntos, os bairros formam a principal comunidade tirolesa da região de Piracicaba e do estado de São Paulo.

\subsection{A IMIGRaÇão e a FaZenda Sete Quedas}

No ano de 1852 teve início a contratação de colonos europeus para a Fazenda Sete Quedas, de propriedade de Joaquim Bonifácio do Amaral (1815 - 1884), Visconde de Indaiatuba. A grande fazenda, herdada do pai José Rodrigo Ferraz do Amaral, fazendeiro e latifundiário do oeste paulista, localizava-se na região de Campinas.

Abolicionista, homem enérgico e de espírito liberal (foi fundador em 1869 da Loja Maçônica Independência, a qual presidiu), Joaquim Bonifácio do Amaral foi condecorado barão em 1876 e recebeu o título de Visconde de Indaiatuba em 1879. Foi membro do Partido Liberal, vereador e vice-governador da então Província de São Paulo e um dos fundadores da Companhia Paulista de Estradas de Ferro e da Companhia Mogiana de Estradas de Ferro, em 1875. Poderoso e influente personagem do império, o visconde hospedou por duas vezes o Imperador D. Pedro II em seu solar à Rua Barão de Jaguará (ainda existente em Campinas), tendo sido a primeira vez quando da inauguração da Companhia Mogiana. Por seus ideais políticos, o visconde foi um dos primeiros fazendeiros paulistas a contratar colonos europeus para a sua Fazenda Sete Quedas. As primeiras famílias eram alemãs, saídas de Holstein, que mantiveram um contrato de parceria com duração de quatro anos. Durante os primeiros anos, os colonos trabalharam no cultivo da cana-de-açúcar juntamente com escravos negros e, posteriormente, nas lavouras de café (GROSSELLI, 1991: 304). 
No final de 1873, o visconde comprou uma nova fazenda em Amparo, denominada Salto Grande, e quis introduzir ali colonos alemães. A partir de 1859, por causa do processo de unificação da Alemanha, a situação se tornou bastante delicada e as autoridades alemãs não permitiam a emigração de seus habitantes ${ }^{92}$ (GIRALDELLI, 1992: 24). Impedido de trazer novos colonos, o visconde comprou alguns escravos para sua nova fazenda, mas não deixou de procurar trabalhadores europeus. Ainda que fosse um ferrenho crítico das agências de imigração, o visconde buscou a Empresa Joaquim Caetano Pinto Junior \& C. para a contratação de colonos austríacos, sobretudo tiroleses de língua italiana, ou seja, trentinos.

No Tirol, assim como no Império Austro-húngaro e no Reino Alemão, a propaganda anti-imigração se propagava, desencorajando várias famílias que seriam escravizadas em solo americano. Indaiatuba encontrava dificuldades para trazer austríacos para suas fazendas, tendo que, através de cartas, convencer os receosos tiroleses de que, no Brasil, não seriam escravizados ou submetidos a uma situação financeira mais precária que aquela na qual já se encontravam. Uma outra estratégia de Amaral foi estabelecer os contratos já na Europa e, assim, “obrigar" os colonos tiroleses - mas também italianos da lombardia e vêneto - a seguirem para suas fazendas logo que desembarcassem em solo brasileiro. Em 1876, o próprio visconde esteve no Tirol, auxiliado pelos agenciadores da emigração, a fim de contratar já na Áustria os primeiros colonos tiroleses para a sua fazenda.

Em 1876, a propaganda de Caetano Pinto se espalhara pelo Tirol e muitas famílias decidiram seguir para o Brasil, algumas com o dinheiro da venda de seus poucos bens. A maioria dos tiroleses almejava seguir para as colônias públicas do Sul e do Espírito Santo, mas muitos imigrantes, assim que desembarcavam, eram obrigados a seguir para as fazendas do interior paulista. Sua precária situação financeira não lhes permitia opções. Essa situação fez com que algumas cidades tirolesas tomassem providências, no sentido de informar seus habitantes sobre os riscos da emigração desinformada; assim o fizeram as

\footnotetext{
92 "Verificada a guerra violenta da Alemanha contra a emigração de seus habitantes para o Brasil, esta fonte não poderia ter sido melhor substituida senão pelos habitantes das terras do Tirol. As familias são autenticamente patriarcais, seja pela dimensão, seja pela moralidade, união e amor ao trabalho. Sendo certo que a colonização não deve ser afrontada unicamente como elemento de evolução material, isto é, braços, mas decididamente valorizada como elemento de evolução social, que retempera o sangue e a virilidade brasileira, e coopera proficuamente para a nossa civilidade, parece que a esse desejo, melhor correspondem os emigrantes tiroleses" (Visconde de Indaiatuba, 1879) in GIRALDELLI (1992: 22).
} 
comuni $^{93}$ de Romagnano e de Meano, nos arredores de Trento, terra de origem da maioria das famílias dos bairros tiroleses de Piracicaba.

Por conta do desejo de várias famílias de seguir para o Brasil, a administração de Meano requisitara à Junta Provincial Tirolesa, sediada na capital Innsbruck, um auxílio financeiro para as famílias que resolvessem emigrar. A Junta aprovou a iniciativa, mas o governo austríaco não, para que não viesse incentivada a emigração; Meano então conseguiu auxílio da administração de Trento (GROSSELLI, 1991: 321). Essas medidas, porém, mostraram-se praticamente impossíveis nos anos seguintes, por conta do grande número de emigrantes.

Em 1877, emigrou um grupo de famílias tirolesas que seguiu para Campinas e Amparo, indo trabalhar nas fazendas Sete Quedas e Salto Grande; um ano antes, alguns parentes desses mesmos emigrantes haviam seguido para as colônias do Sul. A promessa de Caetano Pinto era de que também a leva de 1877 pudesse escolher seu destino, mas não foi o que ocorreu. Entre as dezenas de famílias tirolesas que seguiram para as fazendas do visconde, estavam aquelas que nas décadas seguintes se transferiram para Piracicaba. Em 31 de julho de 1877 partiram, do porto italiano de Gênova, no navio Nord América as famílias Stenico e Pompermayer, de Romagnano; Vitti, de Cortesano e Cristofoletti, de Vigo Meano. ViTTi (1993) afirma que a viagem foi dificultosa e que as condições do velho navio eram precárias, tendo sido necessárias várias paradas para reparos, mas aportaram na cidade do Rio de Janeiro em 23 de agosto do mesmo ano e o navio, durante seu retorno, naufragou na costa da África, carregado de café brasileiro.

"No ano de 1877, o Visconde de Indaiatuba recebeu mais ou menos cinqüenta lombardos e trezentos e cinqüenta tiroleses. Segundo o visconde, essas famílias apresentavam grande moralidade, união e amor ao trabalho. Reconhecia, dessa forma, as maiores vantagens para si, porque a solidariedade de todos trazia a certeza do pagamento integral do débito que, além de acelerar a emancipação do colono, proporcionaria maior garantia ao lavrador".

(GIRALDELLI, 1992: 26)

\footnotetext{
93 A administração austríaca da época, assim como a atual administração italiana, possui diferenças significativas se comparada ao vigente sistema municipal de prefeituras do Brasil. Comune, grosso modo, pode ser comparada a uma pequena cidade, cuja administração encontra-se ligada hierarquicamente a uma cidade de maior relevância que, no caso de Meano, Romagnano e Sardagna, é a cidade de Trento.
} 
GIRALDELLI apresenta o número de 350 tiroleses nessa embarcação de 1877, enquanto GROSSELLI (1991: 156) apresenta o número de 162 emigrantes, mas afirma que outras fontes contam 266 pessoas, divididas em trinta e duas famílias.

Outra leva de emigrantes chegaria em 1881 para trabalhar na Fazenda Sete Quedas, incentivados pela propaganda brasileira no Tirol e pelos frades capuchinhos de Trento ${ }^{94}$. Entre as dezenas de famílias emigradas, estavam também aquelas pela família Stenico que havia chegado em 1877: famílias Brunelli, Correr, Forti e Pompermayer, de Romagnano; Degasperi, de Sardagna e Cristofoletti, de Vigo Meano e Cortesano. Partiram do porto de Genova em 1881 com dezenas de outras famílias tirolesas, no navio Frankfurt (de bandeira alemã) e desembarcaram no Brasil no dia 24 de dezembro do mesmo ano e seguindo para a fazenda de Campinas.Em 1883 emigraram da região trentina cerca de 430 tiroleses e somente da pequena Romagnano partiram cerca de 21 famílias e, entre elas, os Mosna.

Os tiroleses eram considerados pelo visconde ordeiros e bons trabalhadores. Eram católicos fervorosos, fiéis à Áustria e ao seu imperador, e mantinham um temperamento difícil e teimoso com sua visão política marcadamente monarquista, o que muitas vezes lhes causava conflitos com os imigrantes italianos (LoRENZONI, 1975; POSSAMAI, 2004). A mentalidade antiliberal dos colonos tiroleses era refletia o sentimento nacional da resistência tirolesa de $1809^{95}$, que se manteve durante todo o século XIX e, no Novo Mundo, "transferiu" o respeito pela pessoa do imperador austríaco para a pessoa do imperador brasileiro (LORENZONI, 1975; GROSSELLI, 1990; 1999; 2008) ${ }^{96}$.

\footnotetext{
94 Cfr. VitTi (1977). Como afirmado, os religiosos tiroleses incentivavam a imigração dos camponeses, considerada pelo clero uma solução para a crise social e moral vigente. Cfr. entrevista 8B.SO - J.E.S.

${ }^{95}$ Segundo os informantes mais velhos da família Correr, do Bairro Santa Olímpia, seus avós imigrantes contavam que os ascendentes haviam participado de uma "revolução" contra os italianos, em defesa do Tirol; pelas datas, idade de seus ascendentes e pelo período a que se referem, conclui-se que essa luta armada provavelmente não seria aquela do exército austríaco contra as tropas italianas de Garibaldi, mas a revolta tirolesa de 1809. Alguns filhos de Bortolo Vitti, "patriarca" fundador do Bairro Santana, tinham a parte inferior de uma das orelhas cortada. Mutiladas na época pelos irredentistas trentinos numa ocasião em que os jovens, ainda no Tirol, tendo sido surpreendidos na estrada pelos revolucionários, haviam se negado a bradar “abaixo à Áustria!”. Já no Brasil, Maximiliano Correr, de Santa Olímpia, teria sido assassinado por colonos italianos já quando residia em Piracicaba, por causa de seu patriotismo austríaco e posicionamento abertamente anti-italiano.

${ }^{96}$ Grosselli (1999: 184) afirma que, quando a monarquia brasileira caiu em 1889, os jornais do Tirol, principalmente aqueles católicos da região trentina, manifestaram sinais de luto. POSSAMAI (2004: 21) afirma que na localidade gaúcha de Muçum, quando da morte do Imperador Franz Joseph da Áustria, os tiroleses (trentinos) mandaram rezar uma missa fúnebre, que não teve o badalar do sino, pois os italianos haviam roubado o badalo para impedir os dobres.
} 
Entre as canções ainda mantidas pela comunidade tirolesa de Piracicaba, merece destaque Colp de Canón ("golpe de canhão"), que é admirável por seu conteúdo e pelo fato de vir cantada em um dialeto italiano, demonstrando, assim, a realidade cultural dos trentinos e friulanos, então austríacos:

\begin{tabular}{|c|c|}
\hline Föra, föra talianòti & Fora, fora "italianinhos" \\
\hline paùra non abiàmo & medo nós não temos \\
\hline co la fórza del cortèlo & com a força da faca \\
\hline la pàce nói faciàmo. & A paz nós fazemos \\
\hline Bim, bom, bom & Bim, bom bom \\
\hline el colp de canón! & O golpe do canhão! (Refrão) \\
\hline Garibaldi $^{97}$ 'l ga na rógna & Garibaldi tem coceira \\
\hline Vitorio $^{98}$ 'l ga la gràta & Vitório tem a sarna \\
\hline Francesco ${ }^{99}$ co la zàpa & Francisco com a enxada \\
\hline ghe le rùa da gratàr. & Os termina de coçar \\
\hline Vitorio Emanuele & Vitório Emanuel \\
\hline viagiàva d'aeroplàne & viajava de aeroplano \\
\hline mancàva de benzìna & faltava-lhe gasolina \\
\hline pizàva ntél motóre! & Mijava no motor! \\
\hline Garibaldi l'èi n'infèrno & Garibaldi está no inferno \\
\hline Vitorio ancór pù fóndo & Vitório ainda mais fundo \\
\hline Francesco per el móndo & Francisco pelo mundo \\
\hline el farémo encoronár! & faremo-lo coroado! \\
\hline A le ùndeze de óre & Às onze horas \\
\hline passàva l'aeroplàno & passava o aeroplano \\
\hline ghe sóto gh'èra scrito: & abaixo vinha escrito: \\
\hline Trièste l'èi taliàno! & Trieste é italiano! \\
\hline
\end{tabular}

\footnotetext{
${ }^{97}$ Giuseppe Garibaldi, comandante da unificação italiana.

${ }^{98}$ Vittorio Emmanuele, rei da Itália

${ }^{99}$ Francisco José (Franz Josef ou Francesco Giuseppe, como era chamado pelos trentinos), imperador da Áustria-Hungria.
} 
A le ùndece e tre quàrti

passàva en girigibile

ghe sóto gh'èra scrito:

Trièste impossibile!

Vitorio Emanuele

sul pónte de Orizóna

co ei binòchili ntéi òci

guardàva i taliàni.

El generàl Cadorna ${ }^{100}$

ga scrito a la marina

se vuòl vedér Trièste

guardàlo en cartolìna!

La nóstra è giàla e néra ${ }^{101}$

Austriaca bandiéra

Austrìaca bandiéra

farémo ventolàre!

La se séssa dei massóni

al cólpo dei canóni

al cólpo dei canóni

le pòrte fonderémo.

El generàl Cadorna

ga fàto na de grósse

a quéle signorìne

de la cróce róssa.
Às onze e um quarto

passava um dirigível

abaixo vinha escrito:

Trieste impossível!

Vitório Emanuel

Sobre a ponte de Orizona

com binóculo nos olhos

Olhava os italianos

O general Cadorna

escreveu à marinha:

se quereis ver Trieste

olhai-no cartão postal!

A nossa é amarela e preta

austríaca bandeira

austríaca bandeira

faremos tremular!

La se cessam os maçons

ao golpe dos canhões

ao golpe dos canhões

as portas afundaremos

O general Cadorna

fez uma de grosseiro

àquelas senhoritas

da cruz vermelha

\footnotetext{
${ }^{100}$ General do exército italiano, comandante das incursões alpinas contra as tropas imperiais austríacas.

${ }^{101}$ Amarelo e negro são as cores da Casa de Habsburg e, portanto, da monarquia austríaca. Vinham utilizadas em detalhes dos uniformes militares austro-húngaros. Originalmente o amarelo é a cor da Casa de Habsburgo. Segundo estudos historiográficos, o amarelo da bandeira imperial brasileira, idealizada pela Imperatriz Maria Leopoldina e executada pelo pintor francês Jean Baptiste Debret, remetia à casa austríaca, enquanto o verde era uma referência à Casa de Bragança. Cfr. SILVEIRA (1972).
} 
La nóstra è giàla e néra

Austriaca bandiéra

Austriaca bandiéra

farémo ventolàre!
A nossa é amarela e preta

austríaca bandeira

austríaca bandeira

faremos tremular!

Entretanto, parece que a unificação italiana despertava um sentimento antiliberal não somente entre os austríacos, mas também entre brasileiros, como se pode observar nessas trovas populares do século XIX:

Viva Garibaldi,

Victorio Emmanuel,

Comendo macarroni

Embrulhado no papel.

Viva Maria Pia,

Rainha de Portugal,

$O$ vestido que ella usa

Não se póde uzar igual.

Garibaldi foi a missa

No seu cavallo lasão,

O cavallo entrupicou,

Garibaldi foi ao chão.

Garibaldi foi a missa,

Foi fallar ao sachristão

O sachristão metteu-lhe as mãos:

Garibaldi foi ao chão.

Garibaldi já morreu,

Já foi dar contas a Deus

Da farinha que comeu,

Da cachaça que bebeu. 
Garibaldi já morreu,

Enterrou-se no chafariz;

Quem quizer ver Garibaldi,

Metta o dedo no nariz.

COSTA (1908: 463-464)

A ligação com o clero se pode demonstrar através do grande número de cartas enviadas pelos colonos aos párocos de sua terra natal, bem como aos missionários capuchinhos. Sobre a migração, Padre Daniele Rossi, pároco de Romagnano, escrevia em uma nota para o Jornal La Voce Cattolica:

"Na última década, cerca de 250 pessoas partiram de Romagnano para a América para procurarem meios de subsistência. A maioria se estabeleceu em Campinas, província de São Paulo no Brasil, na qualidade de colonos, ocupando-se do cultivo do café. Quase todos passam bem, pelo menos ninguém passa fome, não tem dividas, muitos, ao contrario conseguiram juntar algum dinheiro. Mas o que mais importa, como parece da carta que escrevo, conservam naquele lugar vivo o amor à religiosidade e a Pátria.Dos seus patrões, pediram e obtiveram um grande local para uso de uma Igreja, onde ergueram um altar, todos os dias rezam em comum a terça parte do terço e outras preces e, aos domingos cantam musicas sacras que aprenderam em sua Pátria. Só lamentam a falta de sacerdotes. Mas, então Deus, em parte ouviu os seus desejos, pois não muito longe deles, se encontravam aqueles nossos beneméritos capuchinhos, que se estabeleceram na região em numero de 7, para conservar entre os nossos caros, a religiosidade cristã católica e com a religiosidade, a cidadania e instrução verdadeira, também com escola para as crianças. Uma outra prova de fé viva e amos a Pátria desses nossos irmãos imigrados, se deu há alguns dias passados: se recordaram que a Igreja de Romagnano, a sua antiga Pátria, não tinha enfeites e precisava de reparos. Por isso, o líder deles, um certo Romano Forti fez uma coleta da qual arrecadou 532 florins que mandou diretamente a mim para a Igreja".

(La Voce CATtolica, 09/12/1890) $)^{102}$

${ }^{102}$ Publicada em Rivista Trentini nel Mondo. Numero 9. Trento: ATNM, 2003. 


\subsection{As FAZENDAS SANTA OLÍMPIA, SANT’AnA E NEGRI}

Na Fazenda Sete Quedas, os colonos tiroleses trabalhavam nas lavouras de café, num sistema de parceria, com contrato de nove anos:

"O contrato para trabalharem na fazenda Sete Quedas foi feito nas seguintes bases: prazo de nove anos; trato de cafezais sem ganho, recebendo $500 \$ 000$ (quinhentos réis) por alqueire de café colhido; não havendo serviço de capinação, o fazendeiro era obrigado a dar-lhes outras obrigações ou ocupações, pagas por diárias, ou conseguir-lhes trabalhos avulsos em fazendas vizinhas. Os imigrantes tinham, além disso, direito ao uso das terras para o plantio de cereais, sem limites e condições, obrigando-se o contratante a fornecer os víveres (gêneros alimentícios) para o sustento das familias, para posterior desconto depois das colheitas de café".

(VITTI, 1988: 4)

Depois de findados os contratos na fazenda, as famílias procuraram comprar seus próprios lotes de terra nos arredores de Campinas, como Amparo e Capivari. As famílias Brunelli, Correr, Cristofoletti, Degasperi, Pompermayer e Stenico seguiram para a Fazenda Monte Alegre, na região de Piracicaba, propriedade de Joaquim Rodrigues do Amaral; ali permaneceram por cinco anos, trabalhando como colonos no cultivo da cana-de-açúcar. Em 1892, após quatro anos de trabalhos na fazenda, as famílias se transferiram para Piracicaba e compraram em conjunto a Fazenda Santa Olímpia, cujos "patriarcas" foram Jacob Correr e sua esposa Rosa Pompermayer.

A compra da fazenda Santa Olímpia foi dificultosa. Após pagarem em conjunto pela compra da fazenda, as famílias não estabeleceram um contrato de compra; como não possuíam a soma suficiente, hipotecaram a fazenda e deveriam pagar sua dívida com a produção de café. A compra da fazenda foi feita em janeiro de 1893, cujo contrato firmado com João Baptista Pinto de Almeida (proprietário) e Firmino Bueno de Oliveira não se encontra. Quando da morte do antigo proprietário, seus herdeiros reivindicaram um segundo pagamento e, em novembro de 1895, foi paga uma nova quantia que quitava a hipoteca. Para tanto, as famílias fizeram um empréstimo com Cícero Bastos, cuja quantia (mais juros semestrais) deveria ser paga de uma vez um ano após o empréstimo, e as 
garantias eram: uma nova hipoteca sobre a fazenda e toda a colheita de café de 1896 . O contrato era abusivo e a fazenda continuava hipotecada. Isso obrigou os colonos a venderem provisoriamente a fazenda em 1909 para o tirolês Luigi Negri de Albiano, que adquiriu, em meados de 1900, uma grande fazenda vizinha às fazendas Santa Olímpia e Sant'Ana, então chamada Fazenda Negri.

No mesmo dia que comprou a fazenda Santa Olímpia, Negri emprestou 90 mil réis de Cícero Bastos, utilizados para as despesas de sua fazenda, para adquirir parte da vizinha Fazenda Glória, de propriedade de seu irmão Carlo Negri, e para a compra da Fazenda Santa Olímpia. Como garantia de pagamento, os Negri hipotecaram toda a Fazenda Glória, isto é, a parte de Carlo e toda a fazenda Santa Olímpia, então anexada; tratava-se de 477 alqueires ou 1.154 hectares. Essa não foi, contudo, uma venda definitiva da Fazenda Santa Olímpia, mas um "auxílio", pois em 1912 Luigi Negri assinou um novo contrato com as famílias em que previa o pagamento das dívidas da fazenda anos depois, como realmente ocorreu (com aquisição definitiva da fazenda pelas famílias). Esses acontecimentos renderam à fazenda Santa Olímpia o apelido de $\mathrm{Banco}^{103}$, referente à dívida da hipoteca que se pagava no banco (GROSSELLI, 1991: 376-379).

Contudo, findada a dívida, a fazenda já não contava com os 580 hectares iniciais, mas com 310 que foram divididos entre os núcleos familiares; parte das terras foi anexada à Fazenda Negri, enquanto outras partes foram "tomadas" pelas demais propriedades confinantes. Nas fazendas Negri e Glória, Luigi Negri contratou colonos tiroleses, que ali se estabeleceram. Entre eles, estavam os Stolf, os Zotelli e os Rover.

As famílias Vitti e Forti renovaram seu contrato na Fazenda Sete Quedas por mais um ano, até 1887 e um ano após seguiram para o pequeno Sítio do Rio Cabeça, em Rio Claro, onde permaneceram por pouco tempo, pois os frades capuchinhos os informaram da compra da Fazenda Santa Olímpia pelo grupo de colonos tiroleses da Fazenda Sete Quedas.

Em 1893, Bortolo Vitti, com sua esposa Maria Sartori e filhos, e Francesco Forti, compraram a Fazenda Sant'Ana, vizinha à Fazenda Santa Olímpia, e que à época contava com 300 alqueires de terra, ou 726 hectares. Os Vitti entraram no negócio com

\footnotetext{
${ }^{103} \mathrm{O}$ apelido se mantém até os dias de hoje entre todos os moradores e é bastante comum ouvir frases do tipo "vou lá no Banco" ou "ele é do Banco"; quando em conversas com pessoas de fora da comunidade, vem utilizada a designação "Santa Olímpia". Como banquista ou banchestèl (em dialeto trentino) são chamados os moradores de Santa Olímpia, principalmente pelos moradores de Santana. Estes, por sua vez, são chamados santanèri (em dialeto trentino) ou santaneiro(a) pelos moradores de Santa Olímpia.
} 
porcentagem maior de pagamento que Forti, mas haviam recebido empréstimos de outras famílias trentinas (Fontana e outros Vitti que haviam trabalhado em Sete Quedas e depois em Rio Claro). Por conta da alta no preço do café, parte da dívida foi quitada em um ano, mas a fazenda foi totalmente paga somente em 1909, através de um empréstimo feito com Cícero Bastos, quitado em 1913 e cujos juros obrigaram os colonos a pagar muito mais do que o valor da fazenda (Grosselli, 1991: 375). Até meados de 1907 trabalhavam na fazenda Sant'Ana, demais colonos, sobretudo de origem vêneta, que se retirariam gradativamente.

\subsection{OS PARENTES DA FAZENDA TRAVIÚ}

Outro grupo de trentinos oriundos de Romagnano e que haviam trabalhado na Fazenda Sete Quedas, adquiriram em outubro de 1893, juntamente com algumas famílias vênetas, uma fazenda nas imediações da cidade de Jundiaí. Tratava-se da Fazenda Traviú, propriedade de Francisco Augusto de Morais Campos, e que foi vendida por 25 mil réis, tendo 10 mil réis sido pagos no ato e o restante em cinco parcelas anuais com juros de $6 \%$; a garantia foi, como era hábito à época, a hipoteca sobre a propriedade. Tratava-se de 190 hectares, onde se estabeleceram inicialmente 45 pessoas.

Entre os primeiros trentinos, estavam as famílias Brunelli, Carbonari e Steck de Romagnano, aos quais se juntaram posteriormente os Condini e os Pompermayer, oriundos do mesmo distrito e que desembarcaram no Brasil entre 1881 e 1883. Segundo informantes da comunidade tirolesa piracicabana ${ }^{104}$, durante as primeiras décadas da compra das fazendas, alguns casamentos foram contraídos entre moradores das fazendas Santa Olímpia e Fazenda Traviú (Pompermayer).

\footnotetext{
${ }^{104}$ Cfr. entrevista 8B.SO - J.E.S.
} 


\subsection{OS BAIRROS TIROLESES}

Os bairros Santana e Santa Olímpia, doravante assinalados como S e SO respectivamente, somam pouco mais de mil habitantes, com aproximadamente 720 pessoas em SO, 590 em S e dez famílias na Fazenda Negri (atualmente pertencente ao bairro SO). A Fazenda Glória praticamente se destacou do contexto dos bairros, embora ainda faça divisa com a Fazenda Negri e possua alguns núcleos familiares de origem tirolesa (famílias Stolf e Zotelli).

As primeiras décadas marcam a organização dos bairros e a adaptação dos colonos em sua nova pátria. Vale lembrar que dos anos da chegada das famílias ao Brasil até a compra definitiva das fazendas, passaram-se quase três décadas, de modo que a fundação da comunidade já contava com filhos de imigrantes, bastante inseridos na realidade cultural de seus pais. O contato com os indivíduos de outras áreas foi, durante muito tempo, limitado e ligado, sobretudo, ao que se referisse ao mundo fora dos bairros, sobretudo o comércio. Casamentos com não-tiroleses eram extremamente raros e eram, inclusive, proibidos pelos mais velhos. Outro fator de considerável importância era a fervorosa religiosidade, que ditava muitas regras na comunidade e era mantida pela presença dos frades capuchinhos de Trento. A abertura da comunidade era, contudo, inevitável.

A economia manteve-se agrária durante décadas e se modificou gradativamente com o passar dos anos. Inicialmente, havia o cultivo do café, já existente nas fazendas antes de sua compra pelos tiroleses. O café foi o principal meio de sobrevivência das famílias durante os primeiros anos, juntamente com as roças de subsistência, com cultivo as hortaliças e criação de alguns animais, que proporcionavam para o consumo interno da comunidade carnes e uma modesta produção de linguiças e defumados. Tentou-se a criação do bicho-da-seda, incentivada pelos frades capuchinhos ${ }^{105}$, que se manteve durante alguns anos, mas não prosperou.

A partir da década de 1950, os canaviais dominavam a paisagem piracicabana, com o incentivo dos engenhos que se instalavam na cidade. Nas fazendas dos tiroleses, que

\footnotetext{
${ }^{105} \mathrm{Na}$ região trentina, os frades foram os pioneiros na produção da seda, pois haviam trazido da China os primeiros casulos do bicho-da-seda.
} 
gradativamente viam chegar a luz elétrica (meados de 1950), o cultivo da cana-de-açúcar para o Engenho Central era a principal fonte de renda das famílias. Uma década depois, o êxodo rural, ocasionado pela monocultura da cana, ocasionou a abertura da comunidade tirolesa, que até então vivia praticamente isolada em si própria. As pessoas saíam dos bairros em busca de melhores empregos, pois o cultivo da cana ${ }^{106}$ já não atendia as necessidades de todas as famílias. Atualmente, a cana é mantida de forma bastante reduzida por alguns núcleos familiares, de ambos os bairros.

A uva foi introduzida pelos tiroleses desde a fundação dos bairros, mas não constituía uma atividade econômica, proporcionando a fabricação artesanal de vinho. Entre os anos de 2008 e 2009, foi estabelecida uma cooperativa vinícola, com sede em S, e membros moradores de ambos os bairros. A cooperativa é a primeira na comunidade e o primeiro projeto de divulgação de um produto comunitário (Vinho Trentino Tirolês). Existe, há alguns anos, o Alambique Stenico, cuja cachaça orgânica é vendida em Piracicaba e algumas cidades do interior paulista.

Cada bairro possui sua própria associação de moradores, fundadas em meados de 1995 com o intuito de conseguir melhorias para a comunidade. Por meio de seu esforço, a comunidade conquistou alguns benefícios, como o posto de saúde, o posto de correio, a construção dos salões de festas (paroquiais) e banheiros públicos.

\subsubsection{RELIGIOSIDADE}

Desde a fundação dos bairros, a religiosidade católica esteve sempre presente no cotidiano da comunidade. Os frades capuchinhos tiroleses, primeiros religiosos a trabalhar na comunidade, influenciaram a vida social dos fiéis colonos segundo o rígido modelo de seus seminários, com horários fixos de orações, recitações diárias do terço (três vezes ao dia) e do rosário. Além da rigidez moral e obediência, os frades implantaram na comunidade um senso de solidariedade e assistencialismo, que foi - em muitos momentos -

${ }^{106}$ Ainda mantido por alguns núcleos familiares das famílias Stenico (Santa Olímpia) e Vitti (Santana). 
extremamente importante nos momentos de crise. O isolamento dos bairros em relação ao centro urbano piracicabano é um aspecto relevante para a compreensão do sentimento de união de seus moradores. Além disso, o temor existente na comunidade, de perda de seus costumes, favoreceu a obediência e confiança nos frades capuchinhos, considerados defensores da moral dos colonos. Sobre a religiosidade dos tiroleses, GIRALDELLI (1992:44) afirma que havia um temor constante no contato com o povo brasileiro, considerado imoral. Talvez o principal motivo desse isolamento fosse a perda da identidade, que a imigração, em si, ocasiona. Os frades capuchinhos se relacionavam com a comunidade somente em dialeto trentino, tratavam dos assuntos políticos do Tirol e representavam a religiosidade segundo os modelos culturais tiroleses. O contato com os brasileiros representava, aos olhos do colono, um rompimento com todo esse amparo que a presença capuchinha lhe proporcionava. Por outro lado, segundo alguns informantes, e como atesta LEME (2001: 60 ), a rigidez moral dos frades capuchinhos impunha um sentimento constante de pecado entre os colonos, que lhe gerou verdadeiros tabus: era visto com muitas ressalvas o contato físico de meninos com meninas, de modo que se lhes era proibido brincarem juntos; os namoros dos mais jovens eram controlados e, entre os casados, não ter um filho por ano era considerado um pecado grave ${ }^{107}$.

A religiosidade da comunidade se observa pelo elevado número de religiosos que gerou: são mais de setenta, entre padres, frades, freiras e até mesmo bispos. Uma considerável parte dos homens da comunidade, com mais de quarenta anos, estudou em seminários. Aqueles que não seguiram na vida religiosa retornaram para suas casas, mas seu sentimento de veneração pela vida sacerdotal, quando indagados sobre o assunto, é notório, demonstrando a importância e o respeito que a comunidade mantém pelos religiosos. Entre as mulheres, o respeito pela vida religiosa é bastante perceptível.

Essa mentalidade teve seu expoente máximo em Maria Correr Stenico, filha dos patriarcas de SO, Jacob Correr e Rosa Pompermayer. Casada com Simone (Simão) Stenico, zia $<$ tia $>$ Maria, como era conhecida, era catequista e conselheira da comunidade, sobretudo de SO, com atuação que não se limitou ao âmbito religioso. De moralidade forte e obediência fiel aos conselhos do papa, zia Maria atuava diretamente na vida social dos

\footnotetext{
${ }^{107}$ GiRALDELLi (1992: 47) e LEME (2001: 63-64) também atestam a insistência de outrora dos capuchinhos, para que os casais da comunidade tivessem filhos.
} 
moradores, determinando até quem deveria seguir para os seminários. Participou ativamente na fundação da escola local, além de organizar direta ou indiretamente todas os festejos e ações comunitárias de seu tempo. A matriarca e líder comunitária era também chamada comandaréssa $<$ comandante $>$ por alguns membros da comunidade, sobretudo por aqueles que, de algum modo, não se contentavam com sua postura severa. Entre os moradores de SO, sua imagem inspira veneração (principalmente entre os mais velhos) ou descontentamento (entra alguns jovens) ${ }^{108}$. Seu zelo e dedicação pela vida religiosa era tal que após encaminhar praticamente todas as mulheres de SO para os conventos, gerou-se ali um problema de escassez de moças para se casar com os rapazes do bairro. A partir desse momento, a maioria dos rapazes de SO se casou com moças da família Vitti, do vizinho bairro $\mathbf{S}^{109}$, proporcionando, assim, o parentesco entre boa parte dos moradores. Antes de falecer, zia Maria deixou para a comunidade seu testamento espiritual, repleto de conselhos aos mais jovens.

Cada bairro possui sua própria igreja. A capela de Santa Olímpia foi inaugurada em 1913 e, em 1945, foi inaugurado o calvário com muitos degraus, ao lado esquerdo da igreja, utilizado nas novenas. A capela de Santana, inaugurada em 1927, durante os festejos do cinquentenário da chegada de Bortolo Vitti ao Brasil, foi substituída por uma igreja em 1929. A igreja de $\mathbf{S}$ apresenta, acima da porta principal, uma grande pintura em azulejos, inaugurada durante as comemorações do centenário da fundação dos bairros, mostrando a partida de seus fundadores de Cortesano, no Trentino, e sua chegada ao Brasil ${ }^{110}$. Atualmente, existem missas diárias em ambos os bairros, além de procissões (nos dias festivos) e novenas. As missas são, na comunidade tirolesa, um momento de encontro. Em frente a cada igreja existe uma praça, onde, após as missas, os moradores se reúnem e discutem sobre os mais variados assuntos. O sentimento de união que a Igreja incentiva entre os moradores se mantém com a atuação voluntária de membros da comunidade nas chamadas pequenas comunidades, diversos grupos de pessoas que prestam serviços sociais

\footnotetext{
${ }^{108}$ Entre muitos moradores mais velhos da comunidade, o termo comandaréssa, referindo-se à zia Maria, é considerado desrespeitoso. Para muitos jovens, ela representava o fanatismo religioso e a opressão.

${ }^{109}$ Cfr.entrevista do informante 3B.SO - J.E.S.

${ }^{110} \mathrm{Na}$ pintura aparece a bandeira italiana que, à época, gerou descontentamento por parte de alguns moradores. Do ponto de vista histórico, constitui um erro, uma vez que Bortolo Vitti e família eram cidadãos austríacos.
} 
a moradores doentes ou necessitados. Além desses grupos, as pastorais, existentes em ambos os bairros, se encarregam de atender as necessidades da comunidade.

\subsubsection{COSTUMES E TRADIÇÕES}

Passados mais de cento e dez anos desde a chegada dos primeiros emigrantes, a comunidade preserva diversas tradições e hábitos tiroleses, como o dialeto trentino, cantos e danças típicas. Outros costumes, como aqueles referentes às festividades do carnaval, se adaptaram à realidade brasileira com o passar dos anos. Esses hábitos, como pudemos observar, garantem aos moradores da comunidade sua identificação enquanto tiroleses ou moradores dos bairros tiroleses.

\subsubsection{VESTIMENTA}

No que se refere ao vestuário, destaca-se o traje feminino outrora utilizado pelas mulheres casadas, que caiu em desuso, mas é ainda lembrado pelos mais velhos da comunidade. Durante muitas décadas, as mulheres casadas se identificavam por meio de seu vestuário, seguindo o costume tirolês da região trentina: no dia seguinte ao casamento, a mulher casada usava um vestido comprido (àbit), cuja saia (vèsta em SO; sotàna em $\mathbf{S}$ ) ficava na altura do tornozelo; um avental (gorgnàl) amarrado na cintura (sinal de boa cozinheira); os cabelos eram presos em um coque (crich; cricol) e, no inverno, era usado um casaco feminino (gonèla). As fotos mais velhas mostram as senhoras usando um longo lenço (fasöl) por cima dos ombros e preso no avental, como ainda é costume no Tirol.

Para o trabalho, as mulheres usavam uma saia velha (sgàlda; sgàida; gàida) por cima do vestido, um pequeno lenço em torno do pescoço ou por sobre a cabeça, que podia 
ser substituído por um chapéu (capèl) de palha. Os homens usavam uma camisa com mangas compridas (camiza), uma calça comprida (bràghe), que poderia ser presa a um suspensório (spalàz), cingida com um cinto (centüra) ou mesmo com uma corda (córda); sobre a cabeça usavam um lenço ou um chapéu (capèl), que poderia ser de palha ou bem simples, feito à mão (celéta), usado para proteger a cabeça e o rosto de queimaduras do sol.

\subsubsection{MUSICALIDADE, TEATRO E DANÇAS TÍPICAS}

A música religiosa era mantida na comunidade através de corais, que interpretavam cantos polifônicos em língua latina e portuguesa ${ }^{111}$. O canto coral esteve sempre presente na vida da comunidade; além de se reunirem nas missas para o canto religioso, os tiroleses também cantavam em festas familiares e encontros festivos. Atualmente, existem dois coros, com sede em SO, com integrantes de ambos os bairros e pessoas de fora da comunidade: Coro Stella Alpina, composto por vozes mistas e Coro Càneva, composto por vozes masculinas. Além deles, os corais infantis Và Pensiero de SO e Nostalgia deompostos por crianças dos respectivos bairros.

Em 1925, foi fundada em $\mathbf{S}$ uma banda de metais, composta por membros da família Vitti, cujo primeiro maestro foi o brasileiro Domingos de Moraes. A Banda de Santana ficou bastante conhecida em Piracicaba, animando procissões, festas religiosas e bailes em diversos bairros. Posteriormente, em meados de 1930, foi seu maestro o imigrante italiano Genaro Donadio $^{112}$, seguido de um maestro alemão, de sobrenome Petermann, recordado apenas por alguns dos informantes mais velhos da comunidade. A banda foi extinta no

\footnotetext{
${ }^{111}$ Os cantos religiosos em língua italiana ou em dialeto trentino que, como se sabe, faziam parte da realidade religiosa do Tirol Italiano, não se mantiveram na comunidade. Mesmo as músicas em latim trazidas pelos emigrantes não se preservaram, sendo substituídas pelas músicas latinas que faziam parte do repertório religioso brasileiro. Cfr. informante

112 A Banda de Santana, de certo modo, divulgava a comunidade, mas não representava um instrumento de emancipação social daquela, ou seja, não promovia, com sua popularidade no município, uma integração entre os moradores dos bairros tiroleses e demais habitantes de Piracicaba.
} 
início da década de 1950, quando muitos de seus integrantes, pela falta de terras suficientes para o trabalho em $\mathbf{S}$, tiveram que procurar empregos na zona urbana.

Atualmente, existe a Banda Nostalgia, composta por integrantes de ambos os bairros (com maioria de $\mathbf{S}$ ) e alguns da cidade de Charqueada (metais), que executa um repertório diverso, com músicas do folclore tirolês, italiano, alemão, austríaco e brasileiro. Não é uma banda de metais, mas conta com vários instrumentos, como acordeão, violão, guitarra, teclado e baixo. A banda anima as festas da comunidade e se apresenta em festas típicas do interior e até mesmo em São Paulo.

O teatro sempre esteve presente na comunidade, sendo até os dias atuais muito apreciado nos bairros. As peças de outrora eram todas de cunho religioso e encenadas em palcos improvisados nas praças ou nos antigos salões das igrejas. Atualmente, a comunidade tem procurado apresentar peças infantis com uso do dialeto trentino, no intuito de resgatar o idioma dos mais velhos entre as crianças.

Os grupos folclóricos estão presentes em ambos os bairros. A única dança típica trazida pelos imigrantes, que se mantém na comunidade, é a chamada quàtro-pàssi <quatro passos $>^{113}$; as demais foram sendo trazidas posteriormente e são aquelas dos folclores tirolês, austríaco, alemão e italiano. Como é possível observar, a confusão no que se refere à identidade da comunidade (tirolesa ou trentina? austríaca ou italiana?) se reflete em suas manifestações culturais. Em SO há o Grupo Santa Olímpia de danças folclóricas, com mais de cem integrantes divididos em três modalidades (adulto, juvenil e infantil); seu traje típico é aquele de Trento (o mesmo de Romagnano e Sardagna) e seu repertório musical apresenta danças dos países acima citados. Em S há dois grupos: o Grupo Nostalgia, composto apenas por mulheres, com traje e repertório napolitanos (tarantelas) ${ }^{114}$, e o Grupo Cortesàn, dividido nas modalidades adulto, juvenil e infantil, cujo traje é inspirado no traje tirolês e o repertório musical é de inspiração semelhante ao do Grupo Santa Olímpia.

\footnotetext{
${ }^{113}$ A única dança folclórica que se preservou na comunidade. As demais que hoje fazem parte do repertório dos grupos folclóricos foram introduzidas posteriormente, através de intercâmbios com demais grupos folclóricos, como aquele no qual integramos (Volkstanzgruppe Tirol - Schuhplattler).

${ }^{114}$ Trata-se, sem dúvida, de um exemplo da crise de identidade da comunidade, que foi proibida pela política do Circolo Trentino di Piracicaba (com sede em $\mathbf{S}$ ) de se considerar austríaca ou, no mínimo, tirolesa. Essa crise fez com que muitos moradores buscassem sua identidade no modelo italiano de cultura, repleto de estereótipos. Atualmente, o Circolo e a comunidade procuram reverter esse quadro, buscando no contexto trentino seus modelos culturais.
} 


\subsubsection{FESTAS}

As festas religiosas estão presentes na comunidade praticamente desde a fundação dos bairros. No que se refere às festas típicas, apenas uma foi trazida do Tirol, que é a festa da cucàgna; as demais surgiram a partir de iniciativas da própria comunidade.

A festa da cucàgna (festa de la cucàgna), cujas origens remontam aos fundadores dos bairros, tem origens nas tradições carnavalescas do Tirol. A terça-feira de carnaval é a data para a comemoração da festa que, segundo os informantes, sempre existiu nos bairros e foi se modificando com o passar dos anos. Antigamente, os homens pintavam seus rostos com carvão e saiam pelas casas brincando com os moradores, contando anedotas e fazendo chacotas; ao final da brincadeira era servida a cucàgna, o prato típico do carnaval. Desse modo os festejos de carnaval são ainda mantidos em alguns vales tiroleses ${ }^{115}$. Em SO, a cucàgna é preparada com os seguintes ingredientes: ovo (öf), cebola (zigola), toucinho (làrt; làrdo), tomate (pomidóro), queijo (formai) e linguíça (lugànega) misturados e servidos juntamente com polenta mole (polénta). Em S, os ingredientes são: ovo (öf), cebola (cìgola), toucinho (làrt; làrdo), tomate (pomidóro), queijo (formai) e bacalhau (bacalà), misturados à polenta (polénta) ainda mole e servidos depois que toda a massa fique rígida.

Cada bairro desenvolveu a sua festa própria, com suas particularidades: em SO, as pessoas reúnem-se pela manhã na praça em frente à igreja, onde dão início à festa, caminhando pelo bairro e cantando marchinhas de carnaval (brasileiras) e algumas canções trentinas, acompanhadas por uma banda de tocadores de lata; todos os que entram no festejo, devem ser molhados com água e barro, pois não se pode festejar limpo. Ao cair da tarde, após atravessarem terrenos e até um riacho (onde acontece um grande banho de lama) e circularem por quase todas as ruas do bairro (onde fazem paradas nas casas para comerem bolos, biscoitos e beberem vinho, refrescos e água), reúnem-se novamente em torno da igreja, onde entoam a música Và Pensiero, de Giuseppe Verdi, em homenagem ao falecido Padre Jacob Stenico, ali chamado Pacó. Com todos reunidos na praça, são então

\footnotetext{
115 Em algumas localidades tirolesas há ainda pessoas vestidas em trajes exóticos e com máscaras, representando alguns seres mitológicos (matòci; marascóns; Klousn). Cfr. BARBIERI (2005).
} 
eleitos o rei e a rainha da Cucàgna, que são os indivíduos que não pararam de pular e cantar durante o cortejo; após a eleição, seguem todos para o salão paroquial, onde a cucàgna (preparada por moradores do bairro, principalmente as senhoras) é servida a todos os participantes. A festa segue com um baile realizado na praça, que para exatamente à meianoite, quando então se inicia a Quaresma. Em $\mathbf{S}$, a festa da cucàgna se inicia já no sábado de carnaval, quando os jovens do bairro saem pelas casas brincando, cantando e pedindo os ingredientes da cucàgna que será preparada na terça-feira. Na terça-feira de manhã, as senhoras do bairro preparam o prato típico que fica guardado pronto, em grandes bandejas, dentro da igreja, enquanto na praça em frente à igreja a festa tem início com os homens fantasiados com roupas femininas, que dançam e divertem os moradores. A festa se concentra na praça, onde algumas crianças também festejam fantasiadas ao som de marchinhas (brasileiras). São eleitos os mais bem fantasiados entre os participantes e, após a eleição, ao cair da tarde, a cucàgna é retirada de dentro da igreja e servida a todos os participantes da festa.

Em SO é realizada há mais de dez anos, no último final de semana de julho, a Festa da Polenta (Fèsta de la polénta), que reúne, nos três dias, cerca de dez mil pessoas. A festa comemora a imigração tirolesa e segue com apresentações folclóricas e musicais (inclusive de grupos convidados), gastronomia típica trentina e venda de produtos artesanais. Em $\mathbf{S}$, teve início em 2008 a Festa do Vinho, realizada no mês de junho, promovida em parceria com a cooperativa do Vinho Trentino Tirolês, com apresentações folclóricas, musicais e culinária trentina.

\subsubsection{A ESCOLA}

Os colonos tiroleses tiveram, desde a fundação dos bairros, uma preocupação com a alfabetização $^{116}$ de suas crianças. Após 1900, contrataram o professor italiano Antonio

\footnotetext{
${ }^{116}$ É válido lembrar que, diferentemente da maioria dos imigrantes italianos, os tiroleses (trentinos) eram, em sua maioria, alfabetizados e preocupados com a alfabetização de seus filhos. Essa mentalidade se deve,
} 
Michelon para ensinar aos mais jovens a escrita da língua italiana. Segundo os informantes mais velhos, e como atesta LEME (2001: 65), o salário do professor, de quarenta mil réis, exigia um esforço de toda a comunidade, pois o salário mensal dos colonos era de aproximadamente quinze mil réis.

Durante a década de 1920, a comunidade reivindicou do governo piracicabano algumas melhorias para seus bairros, como saneamento básico, esgoto, água encanada, implantação de uma rede elétrica e um posto de saúde. Os tiroleses estabeleceram contato com Samuel de Castro Neves, deputado pelo Partido Republicano; médico de profissão, auxiliava os colonos gratuitamente, visitando as fazendas e cuidando dos doentes da comunidade. Em 1922, o doutor Castro Neves procurou conceder aos tiroleses o direito ao voto, mas isso não foi possível porque a grande maioria dos homens da comunidade mal conseguia se comunicar em português. Em 1923, a comunidade mantinha em um dos núcleos da família Vitti uma escola informal, com professores da própria comunidade, que ensinavam o português e davam noções básicas de língua italiana. Castro Neves conseguiu, no mesmo ano, uma autorização para a implantação de uma escola em Santana, e contou com o auxílio de zia Maria e José Vitti, líderes da comunidade. Em 18 de março de 1924, foi fundada a escola da comunidade, com duas classes iniciais. O grupo escolar foi fundado na mesma casa em que funcionava a escola informal e recebeu o nome de Escolas Reunidas de Santana. Com a fundação da escola também foi conquistado o direito de voto aos tiroleses, que tinham Samuel de Castro Neves como seu candidato e representante político.

A escola manteve, a partir da década de 1960, uma política de proibição do dialeto trentino entre os mais jovens. LEME (2001: 66-67) confirma que durante esse período, a escola passou a influenciar sobremaneira o linguajar da comunidade. Segundo os informantes mais velhos, as professoras primárias pediam aos pais para que não se comunicassem com as crianças em tirolés, porque elas apresentavam dificuldades de aprendizado. Tratava-se, sem dúvida, de um problema pedagógico da escola local, que gerou um tabu, cujos resultados, entre outros motivos, se observam na perda gradativa do uso do dialeto trentino entre as gerações mais novas. Sobre o papel da escola e sua influência no linguajar da comunidade, conferir Parte II (capítulo 2.0).

sobretudo à política austríaca do século XVIII, quando a Imperatriz Maria Theresia instituiu a obrigatoriedade do ensino básico nas terras imperiais. 


\subsubsection{ASPECTOS SOCIAIS}

Cada bairro possui sua própria associação de moradores, fundadas em meados de 1995 com o intuito de conseguir melhorias para a comunidade. Por meio de seu esforço, a comunidade conquistou alguns benefícios, como o posto de saúde, o posto de correio, a construção dos salões de festas (paroquiais) e banheiros públicos.

A vida nos bairros começou a se transformar a partir da década de 1950, com a aquisição dos primeiros tratores e caminhões. LEME (2001: 71), afirma que esse foi um motivo relevante no contato da comunidade com demais áreas piracicabanas. Os mais velhos $\mathrm{d}$ comunidade afirmam que, antes desse período, todo o trabalho era feito manualmente, com uso de tração animal ou força humana no arado (plainé; aregàgn), enxada (zàpa), foices (falz em SO; falc em S) e foices manuais (zèrla em SO; cèrla em S).

O crecimento demográfico transformou seu antigo aspecto de fazenda e lhes deu aspecto de bairros. A rede elétrica chegou inicialmente a $\mathbf{S}$, em 1950, por iniciativa do professor Guilherme Vitti, eleito vereador e primeiro-secretário da Câmara Municipal de Piracicaba; no entanto, a eletricidade chegou a SO somente em 1962. As estradas da comunidade eram todas de terra durante décadas. Somente em 1996, após diversas reivindicações dos moradores, foi asfaltada a estrada que une Piracicaba a $\mathbf{S}$ e esta a $\mathbf{S O}$, enquanto a estrada que une Piracicaba a SO, através da Fazenda Negri, ainda é de terra.

Em 1972, membros da família Stenico de SO compraram dois ônibus, que se transformaram no primeiro transporte público que ligava a comunidade ao centro urbano piracicabano. A partir de então, os jovens da comunidade começaram a trabalhar em outros bairros piracicabanos e no centro. Os jovens interessados pelos estudos começaram a frequentar cursos técnicos e o ensino médio; alguns ingressaram na faculdade e, desse modo, o número de jovens que estudava nos seminários era cada vez menor. O convívio com pessoas de fora diminuía os casamentos entre descendentes, de modo que, a partir da década de 1970, casamentos entre descendentes e não-descendentes começaram a ser uma realidade na comunidade. Essas transformações sociais marcam o declínio do uso do dialeto trentino no cotidiano da comunidade, assim como a perda de algumas tradições tirolesas (GIRALDELLI, 1992; LEME, 2001). 


\subsubsection{DEMAIS ORIGENS NOS BAIRROS}

Após a fundação dos bairros, colonos de outras origens estabeleceram-se, sobretudo, em $\mathbf{S}$, ao passo que, durante muito tempo, SO permaneceu mais isolada. Em $\mathbf{S}$, entre os mais antigos colonos de outras origens, há os Bomback (originalmente Bombach), oriundos da região alemã do Rio Reno (Rheinland); os espanhóis Goya (ou Goia) que às vezes afirmam serem italianos (os mais velhos se consideram espanhóis na origem) e os descendentes italianos, oriundos de diferentes regiões: os Geraldini e os Vendemiatti do Vêneto (alguns não têm certeza sobre a região de origem); os Vasca, da Campania (Nápoles); os Gobetti (ou Gobeth), que ora afirmam ter origem italiana, ora francesa ${ }^{117}$. No bairro não encontramos traço algum de presença de língua alemã, de outro dialeto italiano ou do espanhol. Por meio de casamentos, as famílias foram assimiladas (praticamente todas as famílias de $\mathbf{S}$ possuem ascendência dos Vitti).

É mais comum, entre os mais velhos descendentes de outras nacionalidades, o uso do português como língua corrente, ainda que alguns compreendam (e até falem) muito bem o dialeto trentino. Contudo, entre os descendentes tiroleses de $\mathbf{S}$, não se encontram traços da presença de vocábulos de origem distinta do dialeto trentino ou do português. Entre as demais gerações ocorrem influências do italiano padrão em diferentes níveis, de acordo com o grau de contato desses falantes com o idioma, que começou a ser ensinado em aulas particulares e divulgado principalmente depois da década de 1970.

\subsubsection{Projetos De Resgate Cultural}

Preocupados com a perda rápida de suas tradições, um grupo de descendentes resolveu, a partir de 1985, iniciar um projeto de resgate cultural. Com o apoio do professor

\footnotetext{
${ }^{117}$ Talvez oriundos das regiões italianas do Piemonte e Val d'Aosta, fronteiriças com a França e com a Suíça francófona.
} 
Guilherme Vitti, considerado o historiador da comunidade, os tiroleses procuraram manter contatos com a terra de origem. Durante as décadas de 1980 e 1990, foram criados, em ambos os bairros, grupos folclóricos de dança e canto, com roupas inspiradas nos trajes típicos tiroleses $^{118}$.

Por meio de contatos realizados com a Associazione Trentini nel Mondo ${ }^{119}$, com sede em Trento, e com o já existente Circolo Trentino di São Paulo, alguns membros da comunidade organizaram uma diretoria e fundaram, em 1987, o Circolo Trentino di Piracicaba. O intuito era de preservar os costumes e tradições mantidas na comunidade, além de manter os vínculos com a terra de origem em sua atualidade, isto é, dentro da realidade italiana. Esse contato com a realidade atual da terra de origem causou decepções entre alguns membros da comunidade; sua terra original já não era austríaca, mas italiana, e não se chamava mais oficialmente Tirol, mas Trentino ${ }^{120}$. Por outro lado, foram recebidos materiais informativos sobre a realidade trentina, como livros sobre os mais diversos assuntos relacionados à terra natal ${ }^{121}$.

Em 1992, SO comemorou o centenário da compra da Fazenda Santa Olímpia com a inauguração de um monumento na praça do bairro, homenageando os pioneiros do bairro. Durante os festejos, foi adotado como símbolo do bairro uma borboleta, cujas cores das asas se referem às cores das nações que fazem parte da história do bairro: vermelho e branco, recordando a Áustria (passado da terra de origem); vermelho, verde e branco, recordando a Itália (presente da terra de origem); verde, amarelo e azul (cores da nova pátria brasileira). Trata-se de uma adaptação de um dos símbolos oficiais da atual Província Autônoma de Trento, pois o mapa de seu território recorda uma borboleta de asas abertas. Em 1993, foi a vez de $\mathbf{S}$ comemorar o centenário da compra da fazenda Sant'Ana, com festejos e a adoção do símbolo do bairro, um ramalhete de flores amarrado com uma fita de com as cores vermelha e branca (lembrando a bandeira austríaca), simbolizando uma das canções mais populares da comunidade, quel mazolin de fiori <aquele ramalhetinho de flores>. Após a comemoração do centenário de ambos os bairros, em agosto de 1993, foi

\footnotetext{
118 Durante alguns anos, um casal austríaco auxiliou o grupo folclórico de SO, com instruções sobre a confecção de trajes típicos.

${ }^{119}$ Entidade italiana, fundada na década de 1950, cujo objetivo é manter vínculos entre os descendentes de emigrados trentinos (na Europa, América e Oceania) e a terra de origem.

${ }^{120}$ Sobre essa ruptura na identidade, conferir Parte II (capítulo 2.0).

${ }^{121}$ Além de possibilitar intercâmbios culturais e de estudo na Província Autônoma de Trento.
} 
inaugurado na bifurcação da estrada que dá acesso aos bairros, um monumento que representa a fundação da comunidade por meio seus patriarcas Jacob Correr (SO) e Bortolo Vitti (S), onde constam os símbolos de ambos os bairros e a águia da bandeira da Província Autônoma de Trento. Para quem chega na comunidade, é possível ler no monumento a seguinte frase em língua italiana: benvenuti alle comunità trentine < bem-vindos às comunidades trentinas>; para quem parte, lê-se em português: obrigado pela visita - boa viagem.

A partir de 2007, a comunidade de SO iniciou um curso de dialeto trentino na sede de sua associação de moradores. Inicialmente, as aulas contavam com alunos de todas as idades, de ambos os bairros; atualmente freqüentam as aulas somente moradores de SO. As aulas contaram, no primeiro ano, com um auxílio da prefeitura piraicabana, que pagava um salário ao professor, morador do bairro $\mathbf{S O}^{\mathbf{1 2 2}}$.

Desde janeiro 2007, mantemos na comunidade pesquisas do dialeto trentino, que se desenvolvem num dicionário que pretende recolher o maior número possível de verbetes referentes às duas variantes dialetais respectivas a cada bairro. Esse projeto, de cunho pessoal, contou com o auxílio de moradores de ambos os bairros e tem se desenvolvido até os dias atuais com coleta de dados referentes à linguagem, aos costumes e com registros gravados em áudio e vídeo de entrevistas e conversas em dialeto trentino.

\footnotetext{
${ }^{122}$ Cfr. entrevistado 2B.SO - E.P.
} 


\section{PARTE II:}

METODOLOGIA E TRABALHO DE CAMPO 


\section{LEVANTAMENTO DE DADOS E ENTREVISTAS}

\subsection{INTRODUÇÃO}

Quando uma pesquisa se desenvolve, alguns dos pressupostos iniciais, referentes ao objeto de estudo, podem perder sua importância; em determinados momentos da pesquisa aquilo que parecia ser "primordial" pode tornar-se um assunto secundário. As questões que surgem ao longo do recolhimento do corpus a ser analisado, assim como aquelas que surgem durante sua análise, podem redirecionar o foco da pesquisa para outros sentidos, contemplando características e problemáticas que não faziam parte da proposta inicial de estudo. Temas principais transformam-se em partes ou detalhes de temas ainda mais complexos e que só puderam ser compreendidos com o desenvolver da análise dos dados obtidos.

A proposta principal deste estudo, ou seja, traçar um perfil lingüístico da comunidade tirolesa da cidade de Piracicaba, se iniciou com o intuito de analisar as principais características da variante falada do português da comunidade. Além disso, entendendo que serviriam para uma melhor contextualização das análises, propusemo-nos a analisar as duas variantes dialetais trentinas mantidas pelos moradores dos dois bairros, principalmente pelos falantes mais velhos.

Separando os estudos sociolingüísticos daqueles históricos, no intuito de emancipar a sociolingüística dos aspectos puramente historiográficos, pode-se correr o risco de se perder informações relevantes. Se pensarmos na formação das variantes brasileiras, com atenção aos fenômenos geolingüísticos, torna-se necessário vinculá-los aos aspectos históricos de nossa formação social. Tal relação entre história e língua é muito visível quando analisamos as variantes dialetais européias da área alpina, como o dialeto trentino ou os grupos lingüísticos como o ladino dolomítico ou o romanche. Todos os momentos históricos são importantes para se compreender o grande número de línguas, dialetos e 
variantes existentes naqueles pequenos vales de montanha. Foram, inclusive, tais momentos históricos e políticos, que permitiram (e garantiram) um número tão variado de falares.

Para um estudo sobre o dialeto trentino, tornou-se necessário o estudo sobre a história da região tirolesa, desde suas origens até os dias atuais. Como se sabe, em se tratando de comunidades de imigração européia e seus sistemas lingüísticos, o Brasil possui um escasso material publicado e que, na maioria das vezes, trata apenas das áreas coloniais da Região Sul. Sobre os falares das áreas de imigração européia no Estado de São Paulo, os trabalhos são escassos, de forma que foi preciso fazer um levantamento inicial do material existente sobre o assunto para, a partir dele, prosseguirmos com as pesquisas.

\subsection{Perguntas iniciais}

Para uma análise linguistica da comunidade tirolesa de Piracicaba, levantaram-se algumas questões primárias e, a partir delas, foi possível desenvolver este estudo. Algumas perguntas foram bastante importantes como, por exemplo, se a fala da comunidade tirolesa de Piracicaba e a situação de bilingüismo sofreram mudanças com o passar dos anos.

Uma das perguntas iniciais foi descartada, pois desviaria o foco da pesquisa: indagar-se-ia sobre as diferenças lingüísticas entre um morador da comunidade tirolesa e um morador de outra área de colonização italiana da região piracicabana. Não foi possível, infelizmente, aprofundarmos as análises nessas situações porque nos limitamos a recolher e analisar os dados referentes ao uso da variante do português dentro da comunidade tirolesa, assim como nas relações internas da própria comunidade. Um fator relevante é que, ainda que haja um grande número de descendentes italianos em Piracicaba (sobretudo de origem vêneta, cujo dialeto é semelhante ao dialeto trentino), não existe ali outra colônia nos moldes dos bairros Santana e Santa Olímpia. Desse modo, não obtendo material para essa análise, descartamos essa possibilidade de análise e, pelo grande número de informações a serem recolhidas na comunidade, limitamo-nos a tratar somente da fala dos descendentes tiroleses. 
Assim, algumas questões iniciais da proposta de estudo não entraram nas análises. Entretanto, das questões que pretendíamos analisar, conseguimos trabalhar com a maioria durante o trabalho. Eram elas:

a) A variante falada do português da comunidade mudou historicamente (com mais ou menos influências do dialeto trentino)? Como?

b) Como se dá a situação de bilingüismo? Em que níveis?

c) Como ocorre o dialeto trentino na comunidade? Quais suas características principais?

d) Existe alguma espécie de koiné dialetal entre as duas variantes trentinas da comunidade?

e) O dialeto trentino de Piracicaba mudou historicamente?

f) Existem diferenças significativas entre a fala dos bairros?

g) Quais as diferenças lingüísticas entre um morador descendente de tiroleses e um não descendente?

É possível afirmar que este trabalho conseguiu esclarecer detalhes concernentes a todas essas sete perguntas, com levantamento de dados. Não foi possível realizar uma análise completa sobre as diferenças lingüísticas entre moradores dos bairros estudados e moradores de alguma área rural vizinha. Limitamo-nos a registrar os fenômenos comuns da variante caipira e as diferenças existentes em situações de fala do português.

Os dados referentes ao dialeto caipira em Piracicaba foram coletados principalmente nas obras que o retratavam, sobretudo, na região piracicabana (AMARAL, 1920; NATAL, 1974; CANDido, 1975; NetTO, 1988; Leme, 2001; Pires, 2008). Não procuramos, contudo, levantar um grande número de informações sobre o dialeto caipira em Piracicaba. Antes, procuramos apontar as suas principais características sem, contudo, esgotar o assunto. Uma vez que não fizemos nenhum registro gravado em outros bairros que não fossem Santana e Santa Olímpia, limitamo-nos a registrar e comentar as características do dialeto caipira presentes na comunidade tirolesa. 
A obtenção dos dados do dialeto trentino e da variante do português da comunidade se deu através de entrevistas e do convívio com a comunidade. Não seria possível levantar tão significativo número de informações se não tivéssemos participado ativamente do dia-adia da comunidade. Foi, portanto, necessário que fizéssemos várias viagens e participássemos de algumas atividades da comunidade, o que não se mostrou dificultoso por causa do grau de intimidade que temos com vários moradores. Esta proximidade proporcionou uma interação bastante positiva no que se refere à naturalidade dos informantes durante as entrevistas.

A proposta inicial previa a gravação de vinte e cinco informantes, pertencentes às gerações de descendentes tiroleses (trentinos) de ambos os bairros. A realização dessas gravações, como afirmado, foi feita sem grandes problemas. Entre os idosos, o fato de ser gravado parecia incomodar inicialmente, mas o direcionamento dos assuntos, auxiliados pelo nosso conhecimento do dialeto trentino, permitiu uma interação positiva e resultados satisfatórios. Feitas as gravações, passamos a analisá-las mesmo antes de transcrevê-las e, a partir disso, não sentimos a necessidade de utilizar todas as entrevistas para as análises. Pensando nas características da variante do português da comunidade e nas diferenças existentes na fala das faixas etárias, concluímos que não seria necessário utilizarmos todas as entrevistas. A divisão dos informantes em três grupos (que abrangiam mais de uma geração de descendentes) permitiu a diminuição de entrevistas a serem transcritas, pois as informações levantadas durante as conversas e o convívio com os moradores ${ }^{123}$ se mostravam abundantes e supriam qualquer dúvida acerca dos aspectos fonéticos, morfossintáticos e lexicais que poderiam se perder na diminuição ${ }^{124}$ das gravações. Desse modo, tendo dividido em três os grupos de falantes a serem analisados (de acordo com a

\footnotetext{
${ }^{123}$ Participamos, desde 2006, dum projeto de resgate dialetal por nós ali organizado. Foram realizadas entrevistas, filmagens e fotos, que compõe o material de estudo e ilustrativo do projeto. Desenvolvemos atualmente um dicionário trentino - português que contemplará as duas variedades dialetais referentes a cada bairro, além de registrar os provérbios, canções, orações, trava-línguas e demais tradições orais da comunidade. Conta, até o momento, com mais de cinco mil verbetes escritos.

124 Ainda que a probabilidade de resultados mais fidedignos seja proporcional ao tamanho da amostra recolhida (OLIVEIRA E SILVA, 2003), a redução do número de entrevistados não comprometeu, ao nosso ver, a quantidade de resultados a serem obtidos. Isso foi possível, como afirmado, por causa do convívio bastante amigável com os moradores da comunidade. Além disso, ainda que um grande número de entrevistados possa garantir um maior número de dados, se as entrevistas não ocorrerem de forma adequada, a análise pode ser comprometida (HOFER, 1997).
} 
faixa etária), optamos por diminuir o número de entrevistas a quinze informantes, cinco para cada grupo.

As informações levantadas garantiram à pesquisa analisar contextos sociolingüísticos bastante peculiares. Muitas vezes, durante a análise dos dados, o caráter indutivo pôde auxiliar o direcionamento da pesquisa, ainda que este trabalho não tenha excluído em momento alguns modelos típicos a priori. Essa posição, entretanto, mostrou-se muito mais útil nas análises acerca da história social da comunidade (e das características comportamentais dos informantes) do que nos dados lingüísticos coletados. Neste sentido, os conhecimentos que possuímos do dialeto trentino e do alemão tirolês auxiliaram-nos sobremaneira na descrição de certos fenômenos lingüísticos referentes ao dialeto trentino.

\subsection{CARACTERIZAÇÃO DOS INFORMANTES E ENTREVISTAS}

A metodologia utilizada para a coleta dos dados nos dois bairros que compõem a comunidade tirolesa de Piracicaba foi a mesma, com equivalência entre o número de informantes gravados.

Dos quinze informantes, oito foram do Bairro Santa Olímpia e sete do Bairro Santana, selecionados a partir dos seguintes parâmetros: faixa etária, local de nascimento (somente indivíduos nascidos na comunidade) e a residência nos bairros (sem terem jamais morado em outra localidade). Os fatores sexo e escolaridade foram registrados, mas não foram considerados para a seleção. Foram coletados os nomes completos dos entrevistados e seus bairros, mas utilizamos apenas as iniciais dos nomes nas transcrições.

A organização identificatória dos informantes dos bairros é a seguinte: grupo ao qual pertence (A, B ou $\mathbf{C}$, com cinco indivíduos para cada grupo), bairro (S significando Santana e SO significando Santa Olímpia), nome, idade, escolaridade e sexo.

Os entrevistados foram identificados através das iniciais de seus nomes, divididos em três grupos, segundo a faixa etária $(\mathbf{A}, \mathbf{B}$ e $\mathbf{C})$, e elencados numericamente nos três grupos, segundo a idade. O grupo A abrange os informantes de zero a vinte e nove anos 
(pertencentes, principalmente, às quinta e sexta gerações de descendentes). $\mathrm{O}$ grupo $\mathbf{B}$ de trinta a cinqüenta e nove (maioria pertencentes às terceira e quarta gerações de descendentes). $\mathrm{O}$ grupo $\mathbf{C}$ os informantes com mais de sessenta anos (pertencentes à primeira, segunda e terceira gerações de falantes); acreditamos ser formado pelos indivíduos que preservam os traços lingüísticos mais característicos da comunidade.

As identificações dos bairros (S e SO) aparecem nas transcrições após a sigla que assinala a faixa etária dos informantes.

Apresentamos o quadro com os dados dos informantes entrevistados neste trabalho:

\begin{tabular}{|c|c|c|c|c|c|}
\hline Grupo & Bairro & $\begin{array}{c}\text { Iniciais do } \\
\text { nome }\end{array}$ & Idade & Escolaridade & Sexo \\
\hline 1A & S & G.V.B. & 11 & fundamental & F \\
\hline 2A & S & F.V.C. & 15 & ensino médio & M \\
\hline 3A & SO & L.D. & 17 & ensino médio & M \\
\hline 4A & SO & E.S. & 24 & superior & F \\
\hline 5A & S & A.C.B. & 30 & superior & F \\
\hline 1B & SO & O.P. & 41 & superior & F \\
\hline 2B & SO & E.P. & 47 & ensino médio & M \\
\hline 3B & SO & J.E.S. & 50 & superior & $\mathrm{M}$ \\
\hline 4B & SO & R.C.C. & 58 & ensino médio & F \\
\hline 5B & S & J.B. & 59 & ensino médio & M \\
\hline 1C & SO & M.C.S.T. & 71 & fundamental & F \\
\hline 2C & S & A.F.V. & 83 & fundamental & F \\
\hline 3C & S & J.V. & 83 & fundamental & $\mathrm{M}$ \\
\hline 4C & SO & J.D. & 87 & fundamental & $\mathrm{M}$ \\
\hline 5C & SO & F.C.D. & 98 & fundamental & $\mathrm{M}$ \\
\hline
\end{tabular}


Uma vez que a geração de descendência não garante uma análise fidedigna da realidade linguística, mas a idade do falante é o fator que a define, separamos os falantes segundo sua idade. Separando os falantes segundo as gerações de descendentes às quais pertencem, temos o seguinte quadro:

- $\mathbf{1}^{\text {a }}$ geração. Filhos de tiroleses: são os mais velhos da comunidade e hoje em dia são menos que sete indivíduos. São todos falantes do dialeto trentino (primeira língua) e falam o português com certa dificuldade (sobretudo variante caipira); pertencentes ao grupo $\mathbf{C}$.

- $2^{\mathrm{a}}$ geração. Netos de tiroleses: maioria dos mais velhos da comunidade. São todos falantes do dialeto trentino (primeira língua) e alguns falam o português com certa dificuldade (sobretudo variante caipira); pertencentes ao grupo $\mathbf{C}$.

- $3^{\text {a }}$ geração. Bisnetos de tiroleses: ocorrem menos casos de falantes bilíngues, mas na maioria dos casos ainda conseguem se comunicar em dialeto trentino (para alguns foi ainda a primeira língua) e a norma culta do português exerce mais influências no falar, principalmente em SO. É a geração que mais participou do processo de abertura da comunidade; ocorrem casos de descendentes de casamentos entre tiroleses e pessoas de fora da comunidade; pertencentes ao grupo $\mathbf{B}$ (grande maioria) e alguns ao grupo $\mathbf{A}$.

- $4^{\text {a }}$ geração. Tataranetos de tiroleses: o bilinguismo é raro nessa geração, mas existe em casos isolados, e a norma culta do português exerce grande influência por causa da escolaridade. São alfabetizadas segundo a norma culta do português e o bilinguismo não existe, mas em compensação há uma intensa busca pela identidade. Geração formada por adolescentes e crianças, alguns conhecem um razoável vocabulário trentino pelo convívio com os avós, mas não são falantes do dialeto. A geração com maior número de descendentes de casamentos mistos entre descendentes e pessoas de fora dos bairros; pertencentes ao grupo $\mathbf{A}$.

- $5^{\text {a }}$ geração. Pentanetos de tiroleses: a geração mais nova, composta de grande número de crianças (maioria pequenas e bebês). Pelo convívio com os avós, utilizam o vocabulário típico da comunidade, mas não são capazes de se comunicar em dialeto trentino; pertencentes ao grupo $\mathbf{A}$.

A maioria dos indivíduos entrevistados é descendente de tiroleses por linha paterna e materna; alguns, entretanto, são descendentes de tiroleses e de outras nacionalidades que compõem a população local, como italianos e alemães. Todos os entrevistados, entretanto, 
são nascidos nos bairros e ali sempre moraram, conviveram em diferentes níveis com o dialeto trentino e seu modo de falar é aquele característico da comunidade.

Durante a maioria das entrevistas estiveram presentes somente o entrevistador e o entrevistado. Procurou-se, na medida do possível, realizar as entrevistas em locais silenciosos e fora da presença de demais familiares e amigos, para evitarmos quaisquer interferências de terceiros nas gravações.

Como as entrevistas eram feitas nas salas, cozinhas, varandas e quintais das casas, algumas vezes ocorriam na presença de parentes dos entrevistados (que queriam, curiosos, ver como se realizavam as entrevistas). Ainda que comentássemos antes das gravações que se evitassem as interferências e as conversas paralelas durante as entrevistas, aparecem em alguns diálogos casos de interferências de terceiros, que tratamos de identificar nas transcrições informando apenas de quem se trata (esposa, marido, filha, filho, irmão, irmã etc), sem qualquer identificação por iniciais de nome.

Apenas em um caso (5B.S) permitimos a participação da tia do entrevistado, que se manteve em silêncio durante boa parte da entrevista, mas conversou com o sobrinho e conosco em alguns momentos (principalmente em dialeto trentino). Em três gravações (3B.SO, 5B.S e 3C.S) aparecem ruídos externos, como cantos de um joão-de-barro (bem altos) e barulho de carros e motos, pois tais gravações foram realizadas nos quintais dos entrevistados.

Procuramos, sempre que possível, realizar gravações de fala espontânea dos informantes, em situações descontraídas de fala, o que se mostrou perfeitamente possível. Os resultados obtidos foram positivos e no final das entrevistas as fichas de identificação eram preenchidas.

As entrevistas foram realizadas durante os meses de março, abril e maio de 2008. Optamos por não as realizar num único momento, pois, antes disso, preferimos analisar entre os moradores da comunidade quais possuíam as características da comunidade e que fossem, desse modo, os mais adequados à proposta de estudo deste trabalho, segundo os critérios acima mencionados.

Não pretendíamos, contudo, analisar apenas indivíduos que possuíssem idioletos por nós considerados "ideais" ou, ainda, que pudessem satisfazer qualquer interesse em demonstrar determinados fenômenos da fala da comunidade, excluindo outros que 
pudessem comprometer seu falar característico. Ao contrário, procuramos entre as pessoas da comunidade aquelas que se enquadrassem naqueles requisitos mínimos que consideramos necessários para uma análise fidedigna da realidade lingüística dos bairros. Por conta disso, alguns fenômenos que acreditávamos não encontrar na fala da comunidade foram registrados, como o a ocorrência das africadas [t]] e [dz] como realização de /t/ e /d/, ou, que pensávamos ocorrer apenas entre alguns indivíduos de um determinado grupo, como o uso da retroflexa [^] entre falantes do grupo B.

Utilizamos como modelo para os tópicos propostos, assim como para a coleta de informações acerca do dialeto trentino, os assuntos apresentados no Atlas Lingüístico do Brasil (ALiB, 2001), embora não tenhamos feito uso de nenhum questionário lingüístico.

\subsection{TÓPICO CONVERSACIONAL}

O tópico é uma atividade construída de forma interativa, por meio de uma correspondência (mesmo que parcial) de objetivos comuns entre os interlocutores. $\mathrm{O}$ sentido de "tópico discursivo" está muitas vezes associado a "sobre o que se fala" mas, buscando ampliar este sentido, pensamos estudá-lo sob o aspecto de um conceito maior, aquele da topicalidade, segundo os critérios de PRETI (1999: 78-79), que define "as várias formas como os interlocutores se entrosam na organização" dos tópicos, através de seu desenvolvimento e seleção, e como interagem "para manter a unidade de conversação".

Existem tópicos que se mostram mais produtivos do ponto de vista narrativo, como aquele das experiências pessoais do informante. Quando indagado sobre os temas que mais lhe interessam, o entrevistado discorre com mais facilidade, fazendo com que a entrevista flua mais livremente. LABOV (1972) define a língua vernácula, objeto da pesquisa sociolinguística, como a língua do cotidiano, da conversa informal, das relações familiares e comunitárias. O informante, ao ser indagado sobre os temas tratados na vida quotidiana, discorre com mais naturalidade na entrevista, sem a preocupação de como enunciar suas idéias e prestando mínima atenção ao modo como fala (TARALLO, 1985: 19). O pesquisador 
não precisará, desse modo, intervir com frequência na conversa, pois quanto mais envolvente for a narrativa para o entrevistado, mais produtiva será a entrevista. Outro fator lingüisticamente relevante é que o pesquisador deve, sempre que possível, assimilar as marcas do dialeto local, para facilitar a interação com os informantes. A familiaridade com o vocabulário local é extremamente útil e diminui a distância entre o entrevistador e o entrevistado.

Uma preocupação constante durante as entrevistas foi o ajuste dos tópicos mais interessantes ao informante, para garantir à entrevista e ao entrevistado maior naturalidade e interação. Nas entrevistas realizadas com os informantes do grupo A, geralmente mais concisos em suas respostas (principalmente as crianças), foi necessário o uso freqüente de marcadores conversacionais que os instigassem a interagir com mais entusiasmo: procuramos tratar dos assuntos ligados à sua realidade cotidiana (escola, festas, jogos, brincadeiras), deixando-os o mais à vontade possível. Entre os indivíduos dos grupos $\mathbf{B}$ e C, procuramos abordar os temas ligados à infância e às experiências do passado, de modo que as entrevistas se realizaram mais facilmente que no grupo $\mathbf{A}$, sobretudo entre os falantes do grupo $\mathbf{C}$, que gostavam de contar experiências antigas e histórias pessoais e da comunidade.

As possibilidades de tópicos são, contudo, as mais diversas, de modo que não é possível dizer que existam tópicos ruins; antes, o que importa é a interação e o entrosamento da conversação. Essa interação só é possível com a adaptação do tópico segundo a idade e a realidade cultural do informante, de modo que trabalhando com o tempo aparente é possível interagir mais apropriadamente com cada faixa etária e com os diferentes níveis culturais e sociais. Nesse sentido, o mínimo de conhecimentos comuns que os interlocutores devem partilhar durante uma conversação, como o domínio das situações sociais e o envolvimento cultural (TARALLO, 1985; MARCUSCHI, 1986), são importantes para o entrosamento com os informantes, levando em conta, sempre que possível, o contexto social de cada entrevistado.

TARALLO (1985: 20) afirma que "uma primeira alternativa seria a de procurar fazer o papel do pesquisador-observador", isto é, o pesquisador que não participa da situação de comunicação. Porém, logo adiante, o mesmo autor atenta para o fato de que, em se tratando da sociolingüística, o pesquisador "sentirá a necessidade de controlar tópicos de conversa e 
de eliciar realizações da variável lingüística em que esteja interessado" - isto significa que, no que se refere à sociolingüística, não é possível uma coleta de dados significativos sem a interação do pesquisador. Trata-se do que LABOV (1972) chamou de o paradoxo do Observador.

HOFER (1997), em seus estudos sobre a mudança dos padrões lingüísticos de uma área dialetal suíça, a saber, a região do alemão suíço de Basel (Baseldytsch), atenta para a necessidade de se conhecer o mínimo sobre a realidade local dos falantes. Ainda que Hofer não tenha - infelizmente - descrito o dialeto de Basel, remetendo o assunto aos trabalhos de Suter (1992) e de BAumgartner \& HOtZENKÖCHERLE (1996), trata, entre outros assuntos, da variação lingüística entre as diferentes faixas etárias, do status lingüístico da variante dialetal entre as mesmas e sobre a relação entre língua e idioleto, dados possíveis de se analisar somente através da coleta de dados em situações de interação com os falantes (KAHMANN, 1987).

O pesquisador precisará conhecer ao máximo a comunidade que pretende analisar e, se possível, deverá inserir-se na realidade local de modo que, assim, compreenda a comunidade em suas particularidades. Também deverá permanecer atento no curso da interação com os entrevistados, evitando informar-lhes sobre sua real intenção (registrar a variante em que se expressam), evitando, assim, que os informantes se intimidem e percam a naturalidade.

Com base nesses pressupostos, julgamos que o material recolhido nas entrevistas se mostrou satisfatório para as análises. Uma vez que mantemos, há anos, um grau de relativa intimidade com vários indivíduos da comunidade, houve uma interação positiva durante as entrevistas. Os informantes, na grande maioria das vezes, respondiam de forma espontânea. Várias expressões do dialeto trentino, presentes na fala da comunidade, foram registrados nas conversas e no convívio com os moradores dos bairros; não foram gravados, mas recolhidos em situações de naturalidade, de interação com a comunidade. 


\subsection{CONTEXTO LiNGUíSTICO DA COMUNIDADE}

No que se refere aos aspectos sociais e linguísticos que moldaram o falar característico dos descendentes tiroleses de Piracicaba, sabe-se que a linguagem da comunidade foi formada em dois casos de contato linguístico: o primeiro contato ocorreu entre as variantes dialetais trentinas trazidas pelos primeiros imigrantes que fundaram os bairros Santa Olímpia e Santana (doravante indicados como SO e S respectivamente); o segundo contato se deu entre o dialeto trentino e o português.

O contato entre o trentino e o português, por sua vez, pode ser subdividido em duas situações:

a) contato com a variante caipira (ocorrida principalmente nas primeiras sete décadas das fundações dos bairros, mas que subsiste ainda hoje no contato dos moradores com habitantes das áreas rurais vizinhas);

b) contato com a variante culta do português (português padrão), referente principalmente às novas gerações que saem da comunidade (ou passam boa parte do dia fora dela) por causa da escola, da faculdade e do trabalho.

A fala da comunidade, no que se refere ao português, apresenta características próprias - principalmente fonológicas - que a diferenciam e fazem recordar, de chofre, o falar da região Sul do Brasil.

O grande número de vocábulos de origem trentina de algumas gerações de falantes chama a atenção e pudemos presenciar casos de pessoas de fora da comunidade que se surpreendiam com o falar dos tiroleses que, mesmo falando o português, "pareciam falar outra língua"; também LEME (2002) afirma que a primeira impressão de uma pessoa de fora dos bairros que escuta o falar de alguns indivíduos é que se está diante de uma língua estrangeira.

O uso do português na comunidade, durante as primeiras décadas, limitava-se ao externo, ou seja, ao mundo fora dos bairros; falava-se português com os não-tiroleses, nos bairros vizinhos, na cidade de Piracicaba, nos negócios fora da comunidade. Um dado 
importante para a compreensão dessa realidade está no fato de, desde o início da comunidade, haver ali um sentimento de isolamento que, segundo a maioria dos informantes, baseava-se no medo de que ali se perdessem as características da comunidade. Vale lembrar que o emigrante, na maioria das vezes, procura retornar à sua terra e, por isso, entende que sua situação fora da pátria é temporária. Desse modo, perder sua identidade significaria a assimilação total e o não retorno à terra de origem.

Havia entre os primeiros colonos um sentimento de medo de serem, de algum modo, hostilizados pela comunidade local brasileira. Mesmo a realidade social das pequenas comunidades alpinas é baseada no isolamento que a própria geografia local os condiciona; o ambiente extremamente montanhoso e os difíceis acessos por pequenas estradas alpinas $^{125}$ dificultavam o contato entre as cidades e aldeias e, de certa forma, isolavam a população em pequenos grupos. Não fosse assim, não haveria tantas variedades dialetais e costumes próprios a cada vale ou, mesmo, a cada aldeia ${ }^{126}$.

Alguns sobrenomes são endêmicos de determinadas regiões tirolesas e, desse modo, até os dias de hoje, é possível que se identifique a origem familiar como sendo oriunda deste ou daquele vale. Assim, é possível identificar os hábitos e costumes específicos de cada vale ou aldeia e - segundo o costume popular - o temperamento de seus habitantes ${ }^{127}$.

Outro fator de relevante importância foi a presença de religiosos tiroleses na comunidade, desde a fundação dos bairros. Os frades capuchinhos vindos da região trentina

\footnotetext{
${ }^{125}$ Realidade comum da região tirolesa até o final do século XIX, ou seja, antes da implantação das vias ferroviárias alpinas.

${ }^{126}$ Cfr. Parte III, Capítulo 1, sobre o uso da palavra stofis < bacalhau> (al. Stockfisch) somente entre os membros da família Degasperi (ou Degaspari) de SO.

${ }^{127}$ Essa é uma interessante realidade que pudemos constatar na região tirolesa. O sobrenome, o modo de falar e de agir ainda pode ser identificado como sendo de determinado vale ou, ainda, de uma cidade ou aldeia. Desse modo, os habitantes do Zillertal são considerados os grandes músicos e artistas do Tirol austríaco, pois a centenária tradição hoteleira e turística do vale lhes garantiu fama mundial. Até certo ponto, as comunidades de imigração conseguiram manter um pouco dessa realidade em suas colônias e na comunidade de Piracicaba não é diferente. Ali, até os modos de agir são identificados como sendo próprios deste ou aquele bairro. Pudemos constatar que no Bairro Santa Olímpia, composto por diversas famílias (diferentemente de Santana composta principalmente pela família Vitti), a divisão do território ainda se baseia em núcleos familiares, lembrando o Trentino do século XIX. Na comunidade, cada família identifica a outra por certos modos de agir e pensar - ainda que isso seja bastante relativo - e os próprios moradores contribuem para a propagação desses estereótipos: os Stenico são expansivos, assumem lideranças e também são considerados exibicionistas; os Cristofoletti (ou Christofoletti) são sinceros, mas considerados briguentos; os Forti costumam se isolar entre os membros de sua família; os Correr são ordeiros e tolerantes; os Degasperi (ou Degaspari) são cultos e pacatos; os Pompermayer são decididos e preferem assumir lideranças; os Negri (por sua antiga posição social) são cultos e exibicionistas; os Vitti são alegres, desbocados e expansivos. Trata-se de identificações recolhidas nas diversas conversas com membros da comunidade (não gravadas) e limitamonos aqui apenas a registrá-las.
} 
assistiam espiritualmente os colonos e, segundo os moradores ${ }^{128}$, utilizavam o dialeto trentino e o italiano em sua comunicação com a comunidade, inclusive nos atos de culto ${ }^{129}$. Segundo alguns moradores, os primeiros emigrantes mantinham contato com os capuchinhos no Tirol e muitos religiosos atenderam a comunidade porque vinham trabalhar no Brasil como missionários. Alguns deles, inclusive, incentivaram a emigração para a América.

A escola, introduzida em 1923 por iniciativa dos moradores, contou com o apoio de voluntários; foi ali que ocorreu o contato mais efetivo com a língua portuguesa e boa parte das crianças logo freqüentou o curso primário (oferecido até hoje, além do ensino médio). Os moradores até a terceira geração dizem que foi na escola que tiveram o primeiro contato com o português, pois o trentino continuava a ser a língua do uso doméstico e do dia-a-dia da comunidade. O português subsistia nas relações dos adultos com pessoas de fora dos bairros; já as crianças mantinham pouquíssimo contato com crianças que falassem o português. Os informantes mais velhos afirmam como era difícil em sua infância estabelecer uma conversa com as professoras. Diferentemente das escolas coloniais do Sul do Brasil, onde as aulas eram ministradas muitas vezes em italiano (ou mesmo em dialeto), na comunidade piracicabana sempre o foram em português.

Quando da entrada do Brasil na Segunda Guerra Mundial, a demonstração pública de qualquer ligação com a Alemanha (e Áustria), a Itália e o Japão era considerada criminosa; o uso público dessas línguas foi proibido e a maioria das escolas foi fechada ou obrigada a implantar o português (GROSSELLI, 1986, 2001; DilleNBURG, 1995). No caso da comunidade tirolesa de Piracicaba, os informantes mais velhos afirmam que a proibição do dialeto trentino ocorreu gradativamente, desde o início da escola.

\footnotetext{
${ }^{128}$ Cfr. Informante 3B.SO - J.E.S.

${ }^{129}$ O italiano era no século XIX, juntamente com o latim, a língua utilizada pela Igreja na maioria das paróquias da região trentina. No Tirol é o contexto lingüístico regional que determina o uso deste ou daquele idioma nos atos de culto. Interessante caso ocorria na área trentina (ou de língua ladina): o idioma alemão era mais usado nas cidades e servia também para as relações de trabalho e comércio, no exército e para as relações com órgãos públicos (e, assim, limitava-se sobretudo aos homens); o dialeto trentino ou o ladino era utilizado para as relações domésticas e familiares e as mulheres, geralmente, falavam apenas o idioma de uso doméstico. É interessante que, na organização da Igreja, as divisões diocesanas locais podiam mostrar exatamente as divisas territoriais dos grupos lingüísticos; ainda que a língua ritual fosse o latim, a língua do sermão era sempre no idioma local (língua padrão ou variante dialetal). Desse modo, o alemão era a língua dos sermões nas áreas germanófonas tirolesas, o italiano nas áreas trentinas e o ladino (mas também o italiano ou o alemão) nas áreas ladinas.
} 
Tratava-se de uma iniciativa das professoras, vindas de fora, que simplesmente não compreendiam seus alunos. Houve, conforme afirmam os mais velhos, casos de professoras preocupadas em se integrar com a comunidade, mas, segundo a maioria dos informantes, a proibição do dialeto trentino gerou inúmeros problemas no desempenho escolar dos alunos. Algumas crianças tinham medo de falar o trentino com os pais por conta das repressões de algumas professoras - por outro lado, essas crianças não compreendiam tão bem o português e naturalmente tinham dificuldades de comunicação na escola. Durante as pausas nos estudos as crianças ainda utilizavam entre si o trentino, que se mantinha nas relações sociais da comunidade e nas brincadeiras infantis. O português das crianças das primeiras gerações trazia fortes influências do trentino (no léxico, na fonologia e na morfologia); por outro lado, o dialeto recebia gradativamente maiores influências lexicais e fonológicas do português que entrava na comunidade, como afirmado, principalmente pela escola.

Segundo a população dos bairros, o dialeto trentino era a língua usual da comunidade até meados da década de 1970. Foi já na década anterior que os professores da escola local "obrigavam" os alunos a falar apenas o português também fora da escola, no intuito de eliminar as interferências que o dialeto trentino exercia na fala das crianças. Tratavam-se dos indivíduos hoje pertencentes às gerações mais velhas.

Já a partir da década de 1960, as gerações mais novas passaram a utilizar menos o trentino e mais o português em suas relações sociais na comunidade. O papel da escola foi desde cedo muito respeitado na comunidade tirolesa; o que era dito pelos professores era considerado (principalmente pelas gerações mais velhas) como regra incontestável a ser seguida (KREUTZ, 2000), principalmente pelo caráter simples daquela gente, formada em sua maioria por camponeses semi-analfabetos. A rotatividade de professores que trabalhavam na escola local também contribuiu para a não existência de um trabalho focado na realidade da comunidade.

LEME (2001; 2002), que lecionou na comunidade no final da década de 1980, confirma essas atitudes de caráter antididático, ocorridas principalmente na década anterior ao seu trabalho, atitudes essas que geraram um preconceito linguístico nas gerações mais novas que vivenciaram essa realidade escolar na comunidade: 
"Esta foi uma atitude preconceituosa desses professores, que não sabiam ensinar uma língua sem destruir outra. Além disso, trouxe o complexo de culpa, fazendo os alunos se sentirem piores porque falavam uma variedade estigmatizada pela sociedade. A autoridade da escola foi muito forte e mudou, de certa forma, a vida da comunidade".

A atitude da escola começou a mudar no final da década de 1970, quando da criação do Circolo Trentino di Piracicaba ${ }^{130}$, mas não sem ter influenciado a comunidade. Constatamos que, nos dias de hoje, alguns educadores da escola local ainda buscam mudar o modo de falar dos descendentes tiroleses, gerando alguns problemas de caráter extremamente preconceituoso, sobretudo com os alunos que utilizam o modo de falar local, considerado por alguns professores "errado"131, procurando apontar - e eliminar - os aspectos fonológicos típicos da comunidade, como a neutralização da oposição entre a vibrante simples [r] e a vibrante múltipla [r] do português ${ }^{132}$.

Segundo os moradores, a ruptura com os antigos modos de viver e falar da comunidade ocorreu na década de 1970, período que significou mudanças na realidade dos moradores com a busca de empregos em outros locais, maior contato com os meios de comunicação e aumento significativo no número de casamentos entre membros da comunidade e não-descendentes de tiroleses.

Essa ruptura provocou um declínio da antiga organização social da comunidade e gerou, num segundo momento, uma busca pela identidade da comunidade, incentivada pelo Circolo Trentino di Piracicaba. Ainda assim, não é correto afirmar que o resgate da memória, das tradições e da cultura teve início com a criação do Circolo Trentino. Sua

\footnotetext{
${ }^{130}$ Agremiação cultural que se propõe a manter permanentes vínculos entre os descendentes trentinos e a terra de origem (Província Autônoma de Trento). Ligados à Associazione Trentini nel Mondo, com sede em Trento, na Itália, os círculos existem em várias localidades brasileiras e desempenham atualmente um importante papel no que se refere à busca de cidadania européia (italiana) entre os descendentes no Brasil, a partir de uma lei italiana (379/2000) que permitiu a cidadania para os descendentes de "italianos" oriundos das áreas outrora pertencentes ao Império Austro-húngaro e que, após 1918, passaram a pertencer à Itália: Trentino, Südtirol, Verona e parte do Friuli-Venezia-Giulia (Udine, Gorizia e Trieste).

${ }^{131}$ Conversamos com alguns adolescentes que reclamaram do modo rude de certos professores (inclusive de uma professora nascida na própria comunidade), que tratavam com ofensas pessoais os alunos que falam "errado" (LEME, 2002).

${ }^{132}$ Atualmente é bastante difuso o uso da fricativa velar surda $[\mathrm{x}]$ entre os mais jovens da comunidade.
} 
fundação contribuiu para que os descendentes conhecessem ${ }^{133}$ a realidade atual da região de seus antepassados, o que gerou surpresa para boa parte da comunidade, que mantinha na memória o antigo Tirol austríaco, e não uma Província Autônoma de Trento, pertencente à Itália, considerada pelos descendentes tiroleses como uma "nação inimiga" "134.

O próprio Circolo Trentino não conseguiu (e ainda hoje não consegue de forma adequada) tratar da questão da identidade local, pois adotou (por desconhecimento de seus dirigentes) uma política que proibia tudo o que se referisse à Áustria e ao Tirol. Uma vez que a porção meridional do Tirol passou à Itália, foi considerado e incentivado ali que seria "incorreto" um morador do bairro ser designado tirolês ou se dizer descendente de $\operatorname{austríacos}^{135}$.

Essa política do Circolo contribuiu sobremaneira para o declínio do uso do dialeto trentino na comunidade, que passou a ser encarado como uma língua "proibida" e em desuso, uma vez que a sua própria designação se referia ao "passado": até então os falantes não se consideravam falantes de um dialeto, mas de uma língua; falavam o tirolés considerado ali um idioma próprio e "austríaco".

Incentiva-se através do Circolo o ensino do italiano, mas sem um projeto que preserve o idioma dos mais velhos e, desse modo, o trentino perde cada vez mais espaço no que se refere à identidade linguística da comunidade ${ }^{136}$. Houve, consequentemente, uma perda da identidade cultural entre as gerações mais novas ${ }^{137}$.

Durante os anos que antecederam a criação do Circolo Trentino di Piracicaba e alguns mais tarde à sua fundação, frequentava a comunidade o próprio cônsul austríaco,

\footnotetext{
${ }^{133}$ É bastante contestável, do ponto de vista ideológico, a posição do Circolo Trentino no que se refere à identidade trentina. Muito do material divulgado entre os descendentes fazia referências a um Trentino liberto do jugo austríaco (MATTEI, 1997), o que gerou, entre vários descendentes, confusões acerca da identidade da comunidade. Pudemos observar que há pessoas que acreditam que o Tirol, enquanto região, não existe mais e que seria incorreto identificar-se enquanto tirolês (desconhecendo, assim, a atual realidade política da região tirolesa). Há aqueles que acreditam que é proibido o uso do termo tirolês para designar os trentinos (lembrando as influências ideológicas do período fascista no Trentino); trata-se de uma política adotada, inclusive, por membros do Circolo Trentino, como pudemos observar. Cfr. Informante 3ASO - L.D.

${ }^{134}$ Isso se deve pelo fato de, à época da emigração trentina, o Reino da Itália procurar anexar a porção sul do Tirol ao seu território, durante as guerras de unificação italiana lideradas por Garibaldi. Ocorreram no Tirol Italiano (Trentino) diversas incursões garibaldinas que geraram batalhas nos vales trentinos e um sentimento anti-italiano entre os camponeses (incentivado pelo governo austríaco e pelo clero).

${ }^{135}$ Nada mais errôneo, uma vez que a província de Trento, juntamente com a província de Bolzano, forma uma Região Autônoma exatamente para garantir e preservar sua particular identidade tirolesa.

${ }^{136}$ Essa situação começou a mudar há relativamente pouco tempo, por conta das iniciativas e projetos de preservação e resgate do dialeto trentino (iniciadas em Santa Olímpia e que ganham cada vez mais espaço em Santana).

${ }^{137}$ Cfr. Informante 3A.SO - L.D.
} 
que mantinha ali boas relações com os moradores (sobretudo no Bairro $\mathbf{S}$ ). Após a fundação do Circolo, quando das buscas dos moradores pela cidadania européia, descobriu-se que não seria possível obter a cidadania austríaca (primeira opção da comunidade), mas que a Província Autônoma de Trento obteve junto ao governo italiano a permissão para os descendentes das regiões do antigo Império Austro-húngaro encaminharem a Roma seus processos para obtenção de cidadania italiana. Se quisessem possuir dupla cidadania, os moradores deveriam ser italianos. A partir de então, as relações de amizade da comunidade com o consulado austríaco cessaram ${ }^{138}$.

Contudo, muitos aspectos positivos tiveram início nesse período, principalmente por conta do auxílio que a Associação Trentini nel Mondo enviava ao círculo e à comunidade. Foram enviados para Piracicaba livros, fitas-cassete e demais materiais que pudessem informar os descendentes sobre a província trentina atualmente; livros didáticos de italiano e informações sobre as possibilidades de descendentes estudarem e trabalharem no Trentino. Se, por um lado, ocorreu a diminuição do uso do trentino, que deixou de ser a língua de comunicação do grupo e se limitou ao uso doméstico dos falantes mais velhos, é possível notar que o modo de falar da comunidade (com todas as suas peculiaridades) é considerado como aspecto da identidade dos bairros e, de certo modo, também faz parte da bagagem cultural que se pretende preservar na comunidade. O termo "tirolês", apesar da insistência do Circolo Trentino, não caiu em desuso e se mantém entre todas as gerações de descendentes, tanto para se identificaram como para se referirem ao dialeto trentino.

\subsection{PERFIL DOS FALANTES E BILINGUISMO ENTRE AS GERAÇÕES}

Na comunidade, o total de gerações de descendentes é o de seis, mas a faixa etária não é o principal fator de diferença linguística entre as gerações. Isso se deve pelo grande

\footnotetext{
${ }^{138}$ Seja por conta da política extremista do Circolo Trentino di Piracicaba (que "afastou" os representantes austríacos), seja pelo próprio desenrolar dos fatos, ambos, consulado austríaco e comunidade, mantinham nesses contatos os laços culturais de um Tirol que não existe mais. A comunidade, por desconhecimento, não considerou o fato de as regiões européias do Tirol histórico, ou seja, aquelas pertencentes à Áustria e Itália, mantêm laços de união política e social, exatamente para que seja preservada sua identidade cultural.
} 
número de filhos nas famílias, comumente acima de cinco, o que gerou em algumas famílias casos de irmãos com grande diferença de idade. Por conta disso, existem casamentos de pessoas pertencentes a diferentes gerações, mas que possuem a mesma idade: encontram-se ali casos de indivíduos pertencentes à primeira geração casados com indivíduos pertencentes à segunda geração, e da segunda geração com aqueles da terceira.

Os indivíduos da primeira geração (filhos de imigrantes) são hoje a minoria da comunidade e, juntamente com os da segunda e terceira gerações, possuem o dialeto trentino como primeira língua e apresentam na variante do português falado (com forte influência da variante caipira) maiores traços fonéticos, lexicais e morfossintáticos do trentino. A partir da terceira geração de descendentes, formada por bisnetos de imigrantes, o português ocorre como primeira língua, tanto no uso doméstico como com indivíduos de fora dos bairros; com maior influência da variante caipira entre os falantes mais velhos e da norma padrão entre os mais jovens (embora com as características do falar piracicabano).

O bilinguismo era uma realidade inicial do grupo B até a década de 1970, quando foi gradativamente cedendo espaço para o uso do português, principalmente da variante local (substrato português com léxico e expressões do trentino), que já vinha se formando desde a primeira geração. A grande maioria dos indivíduos do grupo $\mathbf{B}$ teve o trentino como primeira língua. Entre as gerações de descendentes pertencentes ao grupo A o português é a primeira língua, sendo o dialeto trentino uma realidade da fala dos mais velhos.

Alguns dos fenômenos mais característicos, próprios da comunidade tirolesa, são comuns a todas as gerações de falantes. As três gerações mais velhas se diferem das demais pela maior influência trentina em sua fala, com fenômenos linguísticos exclusivos; as gerações mais novas se diferem das gerações mais velhas pela maior influência da norma culta do português e, por sua vez, também trazem em sua fala características próprias da fala de sua geração. Entretanto, o "pano de fundo" da linguagem da comunidade é "tirolês", e é por isso que as interferências lexicais e fonéticas do dialeto trentino não ocorrem somente para determinadas gerações de descendentes, mas (ainda que em diferentes níveis) ocorre em todas.

Sobre os aspectos morfossintáticos, pode-se dizer que as interferências e empréstimos do trentino ocorrem entre os falantes do dialeto e, por isso, não é um aspecto característico de todas as gerações. Diferentemente dos fenômenos fonéticos e do léxico, 
pudemos observar que as influências morfossintáticas estão mais ligadas ao uso particular do trentino que cada núcleo familiar mantém, e não a um aspecto linguístico comum a todas gerações de descendentes na comunidade.

Em seus estudos acerca da variante falada do português dos bairros, LEME (2002: 121-122) afirma existir "diferentes variedades linguísticas na comunidade", que dependem diretamente à geração de descendência. A autora afirma que para as duas primeiras gerações de descendentes ocorre situação de bilinguismo (dialeto trentino e português caipira); nas terceira e quarta gerações a variante caipira prevalece sobre o trentino, com forte influência lexical deste; e a quinta geração, convivendo com ambas as realidades, adquiriu uma terceira variante, típica de sua geração, que LEME (2001) classificou como variedade misturada.

Entretanto, pudemos constatar que o fator principal para o uso ou não do dialeto trentino (ou mesmo da variante caipira) não é exatamente a geração à qual pertence o indivíduo, mas a sua idade. Como afirmado, é relativamente comum, nos bairros, casamentos entre indivíduos da primeira geração com aqueles da segunda, e da segunda com a terceira.

Tratemos, por exemplo, da terceira geração de descendentes, cuja maioria incluímos no grupo C. Em muito dos casos, os mais velhos desta geração são todos falantes bilíngues, e utilizam o dialeto trentino principalmente nas conversas com os mais velhos e, em alguns casos, entre familiares de mesma idade, ou mesmo com filhos. É possível encontrar indivíduos da terceira geração com mais de sessenta anos de idade e indivíduos da mesma geração com vinte e sete anos. Há um grande número de sobrinhos que são mais velhos que seus tios. Isso, como afirmado, ocorre por causa do grande número de filhos nas famílias. Existem várias famílias na comunidade, cujo irmão mais velho tem idade acima de cinqüenta anos e o irmão mais novo com faixa etária entre vinte cinco e trinta anos. $\mathrm{Na}$ grande maioria desses casos, os irmãos mais velhos são falantes bilíngues, os mais novos não o são. Ainda que estes compreendam razoavelmente, poucos são capazes de manter uma conversa razoável em dialeto trentino.

Assim, acreditamos que a "substituição" do dialeto trentino pelo português, enquanto língua principal da comunidade, é um aspecto mais ligado à faixa etária e à própria questão cronológica que às gerações de descendência. 
LEME afirma que essa variante misturada, própria da fala dos mais jovens (que classificamos no grupo A), é a variante caipira acrescida de regras e fenômenos linguísticos próprios da comunidade. Nem sempre. Pudemos constatar que a interferência da norma culta é bastante visível e tende a ser cada vez maior entre os mais jovens, ainda que estes mantenham um considerável número de palavras da variante caipira e realizem (sobretudo em $\mathbf{S}^{139}$ ) aspectos próprios da fala piracicabana, como o uso da retroflexa: [sina'le^o]; ['kaцa]; ['tıato].

Além do contato estabelecido durante as gravações e conversas, mantemos contato direto com muitos jovens da comunidade, pelo fato de ali participarmos das atividades ligadas ao folclore tirolês. A participação dos jovens nessas atividades culturais é relativamente intensa, principalmente no Bairro SO (onde o número de crianças também é bem maior se comparado ao Bairro $\mathbf{S}$ ); o grupo folclórico de $\mathbf{S O}$ conta hoje com mais de cem indivíduos entre cinco e cinqüenta anos de idade, subdividido em categorias: adulto, juvenil, infanto-juvenil e infantil. Em $\mathbf{S}$ existem dois grupos, um de folclore italiano e um de folclore tirolês ${ }^{140}$. Com esses jovens conversamos, conhecemos as suas famílias, participamos em festas e eventos. Essa convivência nos permitiu interagir com os jovens de ambos os bairros, sempre em situações de fala espontânea. Como afirmado, durante as pesquisas fazíamos anotações escritas, além das gravações, buscando registrar palavras, expressões e dados importantes para a pesquisa. Baseando-nos nessas situações, pudemos recolher um material significativo.

Entre os mais jovens não existe uma fala uniforme, de modo que alguns apresentam um falar muito parecido com o falar piracicabano; outros mantêm uma fala mais conservadora, própria da comunidade; há, ainda, aqueles que assumem na fala os modelos da norma culta propostos pela mídia, que não apresenta as características da fala piracicabana.

\footnotetext{
${ }^{139}$ Cfr. Informantes 2A.S - F.V.C. e 5A.S - A.C.B.

${ }^{140} \mathrm{O}$ grupo de folclore tirolês Cortesàn (Gruppo folcloristico Cortesàn), relembrando a forma dialetal do distrito de Cortesano, pátria de Bortolo Vitti, patriarca e fundador do Bairro Santana, foi por nós iniciado no ano de 2007 em parceria com alguns moradores do bairro.
} 


\subsubsection{GRUPO C: FALANTES DO DIALETO TRENTINO}

Os indivíduos do grupo $\mathbf{C}$ (falantes com faixa etária próxima aos sessenta anos de idade), são aqueles que mantêm os traços fonéticos mais originais do dialeto trentino. Ainda que brasileiros (filhos, netos e até bisnetos de imigrantes), adquiriram como primeira língua o dialeto trentino, mantido em suas relações domésticas e sociais (nos bares, jogos de bocha e baralho, nas festas e nas igrejas dos bairros), principalmente com os indivíduos de mesma idade.

A grande maioria dos falantes do grupo $\mathbf{C}$ não é formada, segundo os critérios de WEINREICH (1953), por bilíngues ideais: falantes capazes de mudar apropriadamente o idioma em uma situação linguística variante que oscila entre o uso de um ou de outro idioma. Os falantes deste grupo quase não são capazes de manter o uso perfeito de apenas um idioma em uma situação linguística não oscilante; são indivíduos que se utilizam espontaneamente de expressões da outra língua (geralmente a dominante e, no caso, o trentino) e que, encontrando dificuldades para se expressar somente em um idioma, introduzem na frase léxicos do outro idioma, que aparecem como "citações" ou interjeições. Estes falantes se comunicam entre si somente em dialeto trentino e nas situações de fala com seus filhos e familiares mais jovens (que não são todos falantes do trentino), utilizam ora o dialeto trentino, ora uma variante misturada (LEME, 2002), cujo substrato morfossintático e mesmo lexical é, sobretudo, português, acrescido com palavras e expressões do dialeto trentino.

Ainda que todos os indivíduos do grupo possam se comunicar em português, isso ocorre em diferentes graus, de acordo com as situações de fala, com a necessidade de utilizar o português e com a vivência pessoal de cada indivíduo. Existem ali casos de senhores que estudaram durante a juventude em seminários católicos e que não chegaram a se tornar religiosos, retornando para a comunidade e ali se casando. Embora tenham estudado nos colégios religiosos, não encontramos nenhum traço fonético em sua fala que os diferenciasse dos demais indivíduos pertencentes ao grupo $\mathbf{C}$.

HAUGEN (1953:6), numa definição descritiva sobre o bilinguismo, classifica como indivíduo bilíngue o falante de uma língua "que é capaz de produzir empregos completos e 
com significado em outra língua”. Contudo, é possível perceber que, mesmo entre os mais velhos da comunidade, as interferências lexicais e morfossintáticas do trentino variam de um indivíduo para outro. Não foi possível, contudo, identificar detalhadamente quando e em que níveis ocorrem essas interferências; limitamo-nos a identificá-las e apresentar, na medida do possível, aspectos relevantes à proposta de nossa pesquisa:

"Aquilo que importa é somente saber, por qualquer exemplo de interferência, qual língua é a origem ou o modelo e qual é a receptora ou a réplica, e também se em uma dada situação de contato uma língua possa ser tanto a origem como a receptora da interferência".

(WEINREICH, 1953:108-109) ${ }^{141}$

Em algumas gravações nos foi possível registrar a passagem espontânea do português para o trentino e vice-versa ${ }^{142}$, que nos remetem às características descritas por WEINREICH (1953) acerca da capacidade dos falantes bilíngues.

\subsubsection{GRUPO B: NEM TODOS FALANTES BILÍNGUES}

Entre os indivíduos pertencentes ao grupo $\mathbf{B}$ - aqueles que mais vivenciaram a substituição gradativa do dialeto trentino pelo português no uso doméstico - é possível notar que, segundo a situação de fala, ocorre uma distinção (inclusive fonológica) para os usos do português e do dialeto trentino ${ }^{143}$. A maioria desses indivíduos, pertencentes principalmente à terceira geração de descendentes, ainda se comunica com os mais velhos em dialeto e, não poucos, também entre si.

\footnotetext{
${ }^{141}$ Tradução nossa.

${ }^{142}$ Cfr. Informantes 5C.SO - F.C.D. e 3C.S - J.V.

${ }^{143}$ Pudemos constatar que, na fala de algumas pessoas da comunidade que se utilizam da retroflexa [^], a mesma ocorre somente quando em situações de fala do português, substituída pela vibrante simples [r] numa situação de fala do dialeto trentino. Poucos falantes dos grupos B e A utilizam a retroflexa em alguma palavra do trentino.
} 
Pode-se dizer que os falantes do grupo B ainda utiliza o dialeto trentino em determinados locais públicos dos bairros, como nos bares, nas praças e nas igrejas. É comum ouvir os indivíduos deste grupo alternarem o uso do português e do dialeto nos jogos de bocha e baralho, e nas conversas nas praças e quintais das casas.

Boa parte desses indivíduos freqüentou somente o curso primário oferecido pela escola local. E a escola sempre privilegiou o uso do português, de forma que muitos afirmam que seus pais eram chamados pelas professoras para comparecerem em reuniões onde eram instruídos a falar com seus filhos somente em português. Houve casos extremos (mesmo se raros) de pais que aboliram o uso do tirolés na vida privada da família, por conta das instruções da escola, que estigmatizava o modo de falar das crianças que atualmente formam o grupo B - um falar carregado de empréstimos e interferências do trentino. Do mesmo modo que algumas famílias aceitaram tais "propostas", outras não abandonaram seus hábitos e podemos afirmar que essas atitudes também são importantes para uma caracterização do perfil linguístico dos indivíduos do grupo $\mathbf{B}$, formado tanto por verdadeiros falantes do trentino como por indivíduos que são capazes de compreender, mas não conseguem se comunicar em trentino.

Durante a década de 1970 houve um êxodo dos mais jovens em busca de melhores condições de vida e de trabalho. Na maioria dos casos, os moradores trabalhavam na cidade de Piracicaba ou em bairros vizinhos e voltavam ao final do dia para a comunidade (situação ainda comum). Mas há casos de moradores que fixaram residência na cidade de Piracicaba, em bairros vizinhos, em bairros afastados da comunidade e até em outras cidades. Mesmo os religiosos da comunidade, alguns velhos capuchinhos que ali viviam, incentivavam a saída dos mais jovens por ser o êxodo a única forma de combater a escassez de trabalho provocada pela monocultura da cana, que limitava o crescimento econômico dos moradores dos bairros. A partir de então (meados da década de 1970), alguns jovens moradores começaram a estudar fora em cursos técnicos e superiores, no intuito de melhorarem suas condições financeiras. A maioria desses jovens, porém, não pretendia abandonar definitivamente os bairros.

Aqueles que saíam da comunidade para estudar não perderam contato com seus pais e com os mais velhos da comunidade e, por isso, não encontramos em seu modo de falar grandes mudanças fonéticas vindas da variedade piracicabana ou dos meios de 
comunicação. Trata-se da primeira geração de falantes que consegue alternar, conforme a situação, o uso do português padrão ou da variedade local, além de haver casos de pessoas que ainda podem se comunicar em dialeto trentino com os mais velhos ${ }^{144}$. Isso é possível notar em algumas gravações, feitas com pessoas que trabalham fora da comunidade há anos, mas que não perderam as principais características fonéticas da comunidade ${ }^{145}$. $\mathrm{O}$ contato regular com a família não permitiu, nesses casos, a perda total do falar característico da comunidade.

Fora dos bairros, em oportunidades que tivemos de acompanhar os descendentes em outras localidades ou mesmo no centro de Piracicaba, observamos que as mulheres mantêm um discurso mais característico da comunidade, chamando a atenção das outras pessoas pelo léxico que utilizam, assim como pelo modo de falar e $\operatorname{agir}^{146}$. Já os homens diminuem consideravelmente o número de palavras e expressões trentinas em seu falar, substituindo o seu uso por palavras do português. Para ambos os casos, tratamos apenas do léxico, pois os fenômenos fonéticos não se alternam nessas situações para os indivíduos do grupo $\mathbf{B}$, diferentemente do que ocorre no grupo $\mathbf{A}$.

Como afirmado anteriormente, não procuramos analisar essas situações de fala fora da comunidade, mas somente nos bairros, onde a variante do português se manifesta espontaneamente entre os moradores. Dessa forma, limitamo-nos aqui a somente registrar o que presenciamos algumas poucas vezes ${ }^{147}$.

\subsubsection{GRUPO A: BUSCA PELA IDENTIDADE TRENTINA}

Entre as gerações mais novas o idioma doméstico é o português, ainda que haja um considerável contato com o trentino nas relações com os avós e com os demais indivíduos

\footnotetext{
${ }^{144}$ Cfr. Informantes 4B.SO - R.C.C., 2BSO - E. P. e 3B.SO - J.E.S.

${ }^{145}$ Cfr. Informantes 4B.SO - R.C.C. e 1B.SO - O.P.

${ }^{146}$ Essa constatação condiz em vários aspectos com as afirmações de SILVA NETO (1970) sobre o falar mais conservador das mulheres, assim como com a orientação da conversação feminina e sua postura.

147 Situações sempre caracterizadas pelas risadas e bom humor dos próprios descendentes tiroleses ao perceberem a admiração das outras pessoas que não compreendiam muito bem seu modo de falar e agir.
} 
das gerações mais velhas. Entre os jovens de faixa etária entre dezoito e trinta anos, a presença de vocábulos de origem trentina é muito menor do que entre os falantes com mais de trinta anos e - dado importante - do que entre algumas crianças.

Algumas crianças da comunidade (principalmente as de SO), fruto dos casamentos desses indivíduos com faixa etária entre trinta e quarenta anos, convivem muito com os avós (pois em muitos casos os pais trabalham fora da comunidade) e, assim, fazem parte do dia-a-dia dos mais velhos, presenciando constantemente situações de fala em dialeto trentino. Ainda que as crianças não falem o dialeto, trazem em sua fala vários vocábulos e expressões de origem trentina, geralmente substituídas pelo português na fala dos indivíduos entre dezoito e trinta anos, por causa do contato escolar e profissional com falantes de norma culta (ainda que com as características fonológicas da variante de Piracicaba).

Diferentemente do que acreditávamos no início da pesquisa, pudemos constatar que não existe bilinguismo entre as gerações mais novas, somente casos isolados de jovens que podem comunicar-se em dialeto trentino porque aprenderam por interesse próprio, não por terem sido criados falando dialeto. Ainda assim, há (principalmente na comunidade de SO) um interesse muito grande pelo resgate da cultura dos avós, que eles observam diminuir gradativamente do mesmo modo como observam diminuir os indivíduos das gerações mais velhas, que levam consigo a língua, as histórias e modos de ser dos tiroleses ${ }^{148}$.

Entre os jovens é possível observar que sua fala é por eles considerada um aspecto positivo, que os caracteriza como tiroleses $^{149}$, como moradores da comunidade. Mas, também é considerada uma maneira errada de falar (talvez pela pressão escolar). Entendem, desse modo, que falam errado, mas que esse modo de falar é o modo do grupo e, portanto, não deveria ser mudado, pois poria em risco a identidade local. Esse interessante aspecto do status linguístico dos mais jovens parece refletir as duas pressões exercidas pela sociedade piracicabana e pela escola (que estigmatizam o falar local) e pela comunidade (que procura cada vez mais preservar sua identidade).

LEME (2002: 107) chama a atenção para a fala das gerações mais novas que apresentam fenômenos linguísticos típicos da comunidade juntamente com aqueles do

\footnotetext{
${ }^{148}$ Cfr. Informante 3 ASO - L.D. (aprendeu, por interesse pessoal, o dialeto trentino com seus pais e avós, com comunicando-se com estes geralmente em dialeto).

${ }^{149}$ Cfr. Informante 3ASO - L.D. sobre o "conflito" nas designaçôes tirolês e trentino.
} 
contexto piracicabano, numa variante que ela chamou misturada. Algumas características, como o uso da retroflexa alveolar sonora [ $]$ ] é muito mais comum no grupo $\mathbf{A}$ que no grupo $\mathbf{B}$, principalmente entre os jovens de $\mathbf{S}^{150}$. Do mesmo modo, ainda que com bem menos frequência, ocorrem as africadas alveopalatais $[t]]$ e $[d z]^{151}$ como realizações de $[t]$ e $[d]$, que praticamente inexistem nos indivíduos do grupo $\mathbf{B}$.

Há um considerável número de casamentos entre descendentes de tiroleses e nãodescendentes. Os filhos desses casamentos estão, principalmente, entre os indivíduos pertencentes ao grupo $\mathbf{A}$, havendo alguns casos no grupo $\mathbf{B}$ e poucos no grupo $\mathbf{C}$. Os filhos de casamentos mistos pertencentes ao grupo $\mathbf{C}$ são quase todos falantes do trentino, que, durante sua infância, era a principal língua das relações sociais da comunidade. Entre os indivíduos do grupo $\mathbf{B}$, há aqueles que compreendem razoavelmente o dialeto trentino e, ainda, falantes do dialeto; entre os mais jovens, pertencentes ao grupo $\mathbf{A}$, não há falantes do dialeto e o léxico trentino que ocorre em sua fala é aquele do uso cotidiano da comunidade, presente também na fala dos filhos de casamentos entre descendentes.

\subsection{STATUS LINGUÍSTICO DA VARIANTE DA COMUNIDADE}

O status linguístico da variante do português da comunidade é encarado pelos moradores locais de diferentes maneiras. Para alguns, o modo de falar dos bairros é tão importante quanto o próprio dialeto trentino (principalmente entre as gerações mais novas); para outros, principalmente entre os indivíduos do grupo $\mathbf{B}$, trata-se de um modo de falar "errado".

A maioria dos jovens, não falantes de trentino, utiliza a variante do português da comunidade e a consideram como aspecto relevante de sua identidade enquanto moradores dos bairros. Os jovens não falam o trentino, mas consideram o modo de falar dos bairros como um "dialeto" próprio, ainda que esse "dialeto" seja a variante caipira de Piracicaba,

\footnotetext{
${ }^{150}$ Cfr. Informantes 1 AS - G.V.B., 2AS - F.V.C. e 5AS - A.C.B.

${ }^{151} \mathrm{C}$ fr. Informante 1B.SO - O.P. quando comenta sobre a fala das crianças de SO.
} 
sobre a qual ocorrem modificações de influência trentina ${ }^{152}$. Esse status da variante entre os jovens é compreensível, pois o modo de falar dos bairros realmente os diferencia no contexto piracicabano porque traz em si os fenômenos linguísticos herdados do dialeto trentino, sobretudo no que se refere ao léxico e à fonologia.

Um dos aspectos fonológicos mais relevantes da variante do português da comunidade (segundo os próprios moradores) é a baixa ocorrência da consoante retroflexa [^], típica do falar piracicabano. A retroflexa entre alguns indivíduos das gerações mais velhas, relativamente pouco nos indivíduos pertencentes ao grupo $\mathbf{B}$ e aparece, principalmente, na fala dos mais jovens, pertencentes ao grupo A (sobretudo entre aqueles de $\left.\mathbf{S}^{153}\right)$.

Pudemos constatar que para os indivíduos dos grupos $\mathbf{C}$ e $\mathbf{B}$, essa diferenciação da fala da comunidade é positiva e ligada à herança cultural dos antepassados, trata-se da identidade local. Durante muito tempo, os contatos com falantes do português padrão se limitavam a alguns políticos de Piracicaba e religiosos não-tiroleses que os visitavam raramente; o português dos mais velhos era aquele formado do contato deles com a variante caipira adquirida no trabalho com demais camponeses de outras áreas rurais das redondezas, ou casamentos (raros) com não-descendentes.

Acreditamos que o pouco contato dos falantes do grupo $\mathbf{C}$ com a variante culta do português possibilitou às gerações mais velhas o desconhecimento de variantes de prestígio e, por isso, os falantes deste grupo consideram sua variante (com todas suas características fonéticas e seu léxico característico) uma realidade positiva em si, porque não há para eles parâmetros comparativos entre o seu modo de falar e os outros existentes em Piracicaba.

Vários são os fatores que reforçam essa informação:

- o isolamento social dos bairros;

- a proibição de casamentos com não-tiroleses até meados de 1970;

- a carência de meios de comunicação de massa como rádio e televisão (a luz elétrica chegou em meados da década de 1950);

- a presença de religiosos tiroleses que usavam o idioma original na comunidade.

\footnotetext{
${ }^{152}$ Cfr. Informante 3ASO - L.D.

${ }^{153}$ Cfr. Informantes 1 AS - G.V.B., 2AS - F.V.C. e 5AS - A.C.B., 4ASO - E.S., 5BS - J.B. e 3B.SO - J.E.S.
} 
Ainda que a escola estivesse presente, os primeiros professores eram voluntários dos próprios bairros e, assim, não é possível afirmar quais eram os parâmetros didáticos para o ensino da língua portuguesa. Segundo informantes, a precariedade do ensino durante os primeiros anos da escola local era característica do próprio isolamento geográfico dos bairros (distantes vinte e cinco quilômetros do perímetro urbano) e a própria dificuldade de compreensão dos alunos (que aprendiam o português na escola) fez o ritmo do aprendizado do idioma ser diferente daquele de uma escola rural de outra localidade, com alunos falantes nativos do português.

Para alguns os indivíduos dos grupos B e A o léxico de origem trentina "dificulta" o falar com pessoas de outras localidades e, por isso, a fala da comunidade não representa um status linguístico positivo - não é a opinião da maioria, mas pudemos constatar durante as conversas com pessoas dos bairros. Acreditamos que essa mentalidade seja resultado do contato com outras variantes linguísticas de prestígio. Entre aqueles do grupo B, seria um resultado da imposição escolar das décadas de 1960-70, que procurou mudar a fala da comunidade, acrescido das influências exercidas pelo contato com pessoas da cidade de Piracicaba e com os meios de comunicação. Entre os indivíduos do grupo A, a influência da norma culta do português da escola, dos cursos técnicos e do trabalho, além da forte presença dos meios de comunicação no seu dia-a-dia.

Para outros, a fala característica remete à fala dos velhos (grupo A $)^{154}$. Várias vezes, quando procuramos utilizar ou o dialeto trentino ou o léxico trentino (da comunidade) em conversas informais com indivíduos com faixa etária entre vinte e cinco e trinta anos (para sabermos de sua reação) ouvíamos que, mesmo sendo da cidade de São Paulo, às vezes falávamos como os "nonos" ("avós"), ou seja, como os mais velhos da comunidade. Os mais jovens, que não são falantes de trentino, percebem a diferença entre seu modo de falar e o de seus avós ${ }^{155}$, além do uso de expressões em dialeto.

\footnotetext{
${ }^{154}$ Cfr. Informante 1B.SO - O.P. quando comenta sobre o comportamente de algumas crianças de SO quando utilizam expressões em dialeto trentino.

${ }^{155}$ Em outros casos isso foi naturalmente aceito e percebemos situações de satisfação de jovens em ver alguém de outra localidade que "era como os moradores" do bairro. Ou ainda, em situações que falávamos em dialeto trentino com mais velhos na presença de alguns mais jovens, percebíamos a satisfação de alguns destes em poder compreender e interagir conosco em dialeto trentino ou utilizando palavras do dialeto; não poucas vezes nos foi pedido para que ensinássemos o modo correto de se escrever em tirolés, porque tais jovens desejavam conhecer a escrita correta das palavras em dialeto trentino.
} 
Para muitos indivíduos em todas as faixas etárias e, no que se refere aos jovens (principalmente em SO), o não-uso da retroflexa [^], substituída, em posição de ataque silábico, pela vibrante múltipla $[r]$, pela fricativa velar surda $[x]$ ou mesmo pela vibrante simples [r], é considerado um diferencial de prestígio, por não caracterizar a do termo, indicando uma pessoa sem estudos, de hábitos retrógrados). A fricativa velar surda $[x]$, na posição de ataque silábico, ocorre principalmente entre os falantes com maior grau de escolaridade.

A retroflexa é um dos traços fonológicos mais característicos da região piracicabana e, por esse motivo, muitos indivíduos da comunidade afirmam que são imediatamente identificados pela população piracicabana como tiroleses, ou, ainda, são indagados sobre sua origem, se são de outra cidade ou até mesmo do Sul do Brasil. Essa diferenciação se deve, sobretudo, ao uso frequente da vibrante [r], além do pouco uso da retroflexa na fala da comunidade.

Pudemos constatar que entre indivíduos do grupo B e A é possível encontrar o uso da retroflexa, traço característico do falar piracicabano. Perguntando aos indivíduos do grupo A sobre os porquês de não falarem exatamente como os demais jovens de Piracicaba, ouvíamos frequentemente que "as pessoas de Piracicaba falam muito feio" ou "falam de maneira igual ao caipira" (referindo-se à retroflexa).

Para um retrato exato e detalhado sobre a linguagem da comunidade entre as diferentes faixas etárias, seria necessário uma pesquisa quantitativa em larga escala, o que não foi possível neste trabalho. Ainda assim, os anos de contato com os moradores dos bairros, as conversas espontâneas, os dados recolhidos, acrescidos das pesquisas realizadas nos projetos de resgate dialetal e histórico, permitem-nos admitir que, no que se refere ao português falado na comunidade, temos duas situações distintas, mas nem por isso desligadas: maior influência da variante caipira entre as gerações mais velhas (grupos $\mathbf{C}$ e B) e maior influência da variante culta e da fala urbana de Piracicaba entre as gerações mais novas (grupo A). 


\subsection{USOS DO PORTUGUÊS E DO DIALETO TRENTINO NAS RELAÇÕES SOCIAIS}

Como afirmado acima, a idade dos indivíduos e a sua geração de descendência (ainda que esta não seja a característica determinante) podem indicar se os falantes utilizam com maior ou menor frequência o português ou o dialeto trentino nas relações sociais da comunidade.

Além disso, mesmo entre indivíduos bilíngues dos grupos $\mathbf{C}$ e $\mathbf{B}$, não existem regras sociais da comunidade que determinem o uso do português e do trentino, mas as alternâncias ocorrem de acordo com as situações, ou seja, em uma situação onde a maioria é composta por falantes de dialeto trentino, opta-se pelo uso do trentino. Quando numa situação de fala com maioria de falantes de português, opta-se pelo português, ainda que, entre os mais velhos, ocorra com bastantes interferências do trentino.

Os falantes do grupo $\mathbf{C}$ podem ser considerados os bilíngues da comunidade; são falantes do trentino e o léxico de seu português é muito próximo da variante caipira, ainda que quase não apareça a retroflexa [^], típica do falar piracicabano. Podemos afirmar que entre os falantes do grupo $\mathbf{C}$ a variante caipira agiu no dialeto trentino principalmente no que se refere aos empréstimos lexicais (e em raros casos fonéticos), ocasionados pelo contato linguístico dos dois idiomas. Assim, utilizam o dialeto trentino frequentemente na comunidade: no ambiente doméstico (entre casais e parentes), na igreja e nas relações sociais com membros da comunidade (festas, jogos, bares).

Não é raro vermos em uma conversa a mudança de código dos interlocutores, que oscila entre o trentino e o português ou, no caso das gerações mais novas, entre a variante da comunidade e a norma culta. A mudança de código é geralmente espontânea e ocorre sem grandes modificações especiais como pausas e dificuldades no falar.

No que se refere à entonação e à prosódia, podemos afirmar que entre os indivíduos mais velhos quase não há mudança, uma vez o próprio português deles é carregado de interferências trentinas; entre os mais jovens, entretanto, parece que ao procurarem utilizarse de expressões trentinas, também procuram adequar a sua fala ao modo de falar dos mais 
velhos. Sobre o assunto, limitamo-nos a registrar aqui sobre essas características, uma vez que não nos foi possível desenvolver uma análise da prosódia ${ }^{156}$, nem do dialeto trentino, nem da variante do português da comunidade.

Já entre os indivíduos do grupo B não existe um perfil homogêneo de falantes, pois existem falantes bilíngues e não-falantes de dialeto. A grande maioria compreende bem o trentino, mas não é possível afirmar que sejam capazes de se comunicar em dialeto sem trazerem um razoável número de interferências (sobretudo lexicais e morfossintáticas) do português (principalmente da variante caipira de Piracicaba). Como afirmado anteriormente, a idade do indivíduo do grupo B é o principal fator para caracterizá-lo como bilíngue, uma vez que os mais velhos do grupo presenciaram e participaram mais ativamente da realidade da comunidade tirolesa em seu período mais isolado, quando o dialeto trentino predominava na fala local. Os mais novos do grupo participaram do processo de abertura da comunidade e vivenciaram a proibição do dialeto pela imposição escolar local, que privilegiava o uso do português.

Como afirma LEME (2002: 127), que lecionou na comunidade, "a escola privilegia o português". Assim, os indivíduos do grupo B não criaram seus filhos falantes de trentino, mas, por conta das necessidades de estudo e trabalho, fizeram com que os falantes do grupo A soubessem apenas o português. Muitos dos falantes do grupo A (principalmente em SO) procuram evitar a variante caipira, optando pela variante do português local com bastantes influências da norma culta.

Vários são os motivos que levam os falantes do grupo A a utilizarem a norma culta, os quais destacamos:

- a fonologia trentina, que desconhece a retroflexa alveolar típica de Piracicaba;

\footnotetext{
156 A realização da prosódia é ainda um desafio para a lingüística, uma vez que sua análise se mostra extremamente dificultosa. Seu papel dentro de um sistema lingüístico é, contudo, essencial, pois garante à lingua não somente a sua caracterização em si, como participa de seu processo evolutivo e nele atua. Um aspecto muito interessante da prosódia da comunidade é que, em situações de fala do português, ela parece se assemelhar com o português de outras áreas de imigração tirolesa, como Nova Trento (SC), fundada também por trentinos e mesmo Treze Tílias (SC), fundada por tiroleses de língua alemã. Enquanto falante do dialeto trentino e do alemão tirolês (Tirolerisch), pudemos notar que existem algumas semelhanças na entonação das duas línguas tirolesas, mas não analisamos essas possíveis semelhanças entre Piracicaba e as demais áreas catarinenses porque não podemos comprová-las fidedignamente. Ainda que muito interessantes para o estudo da prosódia, não fazem parte da proposta principal deste estudo.
} 
- a variante do português local que estigmatiza, entre outros aspectos, a retroflexa piracicabana e o léxico caipira, e dá à variante da comunidade um status de variante de estrangeiros;

- os meios de comunicação que privilegiam a norma culta que, como se sabe, exclui a retroflexa.

Houve uma tentativa frustrada de se ensinar o italiano na escola, por incentivo do Circolo Trentino di Piracicaba, que não frutificou porque o italiano padrão representa uma realidade totalmente diferente daquela do dialeto trentino. Além disso, o sentimento antiitaliano de vários moradores (principalmente em SO) identificava no idioma uma "imposição", que procurava apagar a memória tirolesa. Existe por parte de indivíduos do grupo A um interesse pelo resgate do idioma e da tradição dos mais velhos, mas sem abdicar dos valores atuais de suas gerações.

Ainda que os mais jovens privilegiem a norma culta do português, é possível encontrar na fala de muitos indivíduos do grupo $\mathbf{A}$, principalmente em $\mathbf{S}$, o uso da retroflexa. Isso se deve pelo fato de a comunidade tirolesa se localizar numa área rural onde a variante caipira ocorre. Além disso, há um grande número de indivíduos (principalmente do grupo A, mas também muitos do grupo B) que estudam ou trabalham em outras localidades de Piracicaba. A maioria dos moradores da comunidade tirolesa trabalha em bairros vizinhos (principalmente em Santa Teresinha) ou no centro, e grande parte dos mais jovens estuda nas escolas e faculdades da área central de Piracicaba, mantendo, diariamente, contato com falantes da variante caipira ou da variante culta piracicabana (com todas suas peculiares características ${ }^{157}$ ). Há, também, pessoas que trabalham e estudam em outras cidades. No caso dos jovens que estudam em faculdades em outras cidades da região, como Sorocaba e Campinas, a maioria retorna aos finais de semana para suas casas. Muitos desses indivíduos, que passam boa parte de seu tempo fora da comunidade, trazem em sua fala as características próprias da região e não se diferenciam

\footnotetext{
157 Utilizamos aqui este termo para indicar a norma culta que, na cidade de Piracicaba, apresenta
} características próprias do falar local, como o uso da retroflexa e o léxico regional. 
dos demais piracicabanos a não ser pelo uso do léxico trentino da variante da comunidade, e que utilizam, sobretudo, dentro da própria comunidade ${ }^{158}$.

Em muitos casos, a comunidade se serve do fato de dominar duas línguas ou de possuir uma variedade do português com carregada influência trentina, com palavras e expressões desconhecidas para demais pessoas (léxico trentino e neologismos), como estratégia comunicativa, no intuito de isolar da interação linguística as pessoas de fora da comunidade. Isso ocorre tanto dentro da comunidade (nas festas locais muito visitadas por pessoas de outras localidades) ou mesmo fora dela (quando estão em grupo numa excursão, por exemplo). Essa estratégia fora utilizada já pelas primeiras gerações que buscavam no uso restrito do trentino um isolamento cultural e nos dias de hoje ocorre de forma um pouco diversa, que se não se serve do dialeto trentino ou da variante do português local para se “isolarem”, mas para isolar uma pessoa da interação linguística ou impressioná-la ${ }^{159}$. Também pudemos observar entre os mais velhos o uso do trentino em certos casos para isolar da conversa alguns indivíduos mais novos, que não o compreendem.

\subsection{EXISTEM DIFERENÇAS SIGNIFICATIVAS, NA VARIANTE DO PORTUGuÊS, ENTRE SANTANA E SANTA OLÍMPIA?}

A comunidade tirolesa de Piracicaba não foi formada apenas por uma leva de emigrantes, mas teve seu desenvolvimento de forma gradativa, a partir da compra da Fazenda Santa Olímpia por um grupo de imigrantes, seguida da compra da Fazenda

\footnotetext{
${ }^{158}$ Perguntando a alguns jovens de ambos os bairros sobre utilizarem o léxico trentino no convívio com pessoas de fora da comunidade, a maioria dos jovens afirmou que o utiliza normalmente, sendo identificados como tiroleses entre os colegas. Entre os indivíduos do grupo B, muitos afirmam que, outrora, era vergonhoso ser identificado como tirolês, que era o equivalente a ser chamado de caipira (num sentido pejorativo do termo). Observa-se, pois, uma valorização cada vez maior da identidade cultural da comunidade; isso se nota também nos projetos culturais de resgate da cultura tirolesa, que se desenvolvem nos dois bairros.

${ }^{159}$ Pudemos constatar diversas vezes esse objetivo entre as gerações mais novas. Em casos onde não éramos ainda conhecidos por alguns membros da comunidade, muitas vezes ouvíamos comentários a nosso respeito em dialeto trentino ou em expressões típicas da comunidade. Ao demonstrarmos entender o dialeto e o modo de falar dos moradores, percebíamos espanto ou admiração por podermos compreender o que de nós se falava.
} 
Santana por outro grupo (família Vitti principalmente) e da Fazenda Negri pela família Negri. Seria possível, com base nessas informações, afirmar que a variante do português da comunidade apresenta possíveis diferenças que remetessem às origens dos imigrantes fundadores, uma vez que a maioria das famílias de SO (incluindo a Fazenda Negri) não é originária dos mesmos distritos trentinos das famílias de $\mathbf{S}$.

Assim como LEME (2001: 135), buscamos encontrar possíveis diferenças na fala dos bairros que pudessem remeter às diferentes origens de seus fundadores. Em comunidades pequenas e durante muito tempo isoladas como os bairros tiroleses, o sentimento de ligação com a família e com as origens é muito forte e pode servir para destacar as diferenças existentes no grupo, como forma de definição da própria identidade. Isso é possível notar no dialeto trentino, que ambos os bairros preservam em duas variantes, cada uma respectiva à região da qual partiram os emigrantes ancestrais de cada bairro. Desse modo, em SO, prevalece a variante dialetal trentina de Romagnano e Sardagna, enquanto, em S, prevalece a variante dialetal de Cortesano (que é a mesma de seus distritos vizinhos, Gazzadina, Vigo Meano e Meano) ${ }^{160}$.

Existem, como pudemos observar, o uso de diferentes palavras trentinas na variante do português, próprias a cada bairro e que refletem as influências das duas variantes dialetais trentinas existentes na comunidade. Assim, é possível encontrar algumas palavras trentinas na variante do português de $\mathbf{S}$ (por exemplo roseghìn [roze'gin] <coceira na garganta>) que não ocorrem em SO, e vice-versa. Do mesmo modo, é possível encontrar uma mesma palavra trentina que ocorre segundo a fonologia do dialeto de cada bairro: em $\mathbf{S}$ cigola ['t $f$ igola] < cebola $>$, que ocorre em SO como zigola ['sigola].

Mas seriam as diferentes origens trentinas dos moradores relevantes a ponto de formarem duas variantes distintas do português, respectivas a cada bairro? Ou, ainda, as diferentes palavras de origem trentina, correspondentes às variantes dialetais de cada bairro, onde algumas ocorrem somente em SO e, outras, somente em $\mathbf{S}$, seriam suficientes para diferenciar a fala dos bairros em duas variantes distintas do português? A resposta é não. E isso se deve ao principal fato de que, desde o início, os bairros sempre mantiveram estreitos contatos entre si e trabalharem juntos; houve casamentos entre pessoas das duas

\footnotetext{
${ }^{160}$ Cfr. Parte III, Capítulo I, sobre as duas variantes dialetais trentinas existentes na comunidade tirolesa de Piracicaba.
} 
localidades. Ainda que lhes foi possível preservar por mais de um século as características dialetais trentinas correspondentes às suas regiões de origem, no que se refere ao português, não existem duas variedades correspondentes a cada bairro.

No que se refere ao uso da variante culta, existem maiores diferenças entre os bairros, sobretudo nos indivíduos do grupo A. Os moradores de SO interagem há mais tempo com comunidades vizinhas, sobretudo com indivíduos da área urbana, e seus jovens apresentam graus mais elevados de escolaridade. O bairro $\mathbf{S}$ procurou durante muito tempo ficar mais isolado, de forma que seus moradores se dedicaram mais à vida agrícola. Numa proporção considerável, há menos jovens com nível superior em $\mathbf{S}$ do que em SO. Contudo, um fator relevante é que, em SO, o número de jovens (principalmente crianças) é maior do que em $\mathbf{S}$, onde há mais pessoas solteiras e sem filhos. A escolaridade demonstra maiores diferenças na fala dos jovens dos bairros, com uso mais frequente da norma culta entre os falantes de $\mathbf{S O}$ e da variante caipira entre os falantes de $\mathbf{S}$, inclusive no uso da retroflexa, mais comum em $\mathbf{S}$.

Contudo, no que se refere à variante do português própria da comunidade, não encontramos diferenças que pudessem dividi-la em duas variantes distintas, referentes a cada bairro. Ainda que o uso da retroflexa ocorra com mais frequencia em $\mathbf{S}$, sobretudo entre os indivíduos dos grupos A e B, também ocorre entre alguns falantes de SO. No que se refere ao léxico de origem trentina presente na variante do português, não encontramos diferenças significativas que justifiquem a existência de duas variantes distintas, mesmo se haja diferenças no uso de algumas palavras que ocorrem somente em $\mathbf{S}$ ou somente em $\mathbf{S O}^{161}$. Além disso, o sotaque peculiar da comunidade, que a caracteriza no contexto piracicabano enquanto tirolesa, é o mesmo, em ambos os bairros.

\footnotetext{
${ }^{161}$ São aquelas palavras próprias das variantes dialetais correspondentes a cada bairro. Sobre essa diferença, conferir Parte III, Capítulos I (sobre dialeto trentino) e II (sobre o léxico trentino no português da comunidade).
} 


\section{PARTE III:}

\section{ANÁLISES LINGUÍSTICAS}




\section{ASPECTOS GERAis do Dialeto TRENTINO NA ITÁlia E EM PIRACICABA}

\subsection{INTRODUÇÃO}

Os dialetos existentes nas regiões de fronteira política, histórica, ou, ainda, nas fronteiras linguísticas naturais, como os vales trentinos, podem conservar traços outrora comuns a toda uma região e que se reduziram com o passar do tempo a comunidades que nem sempre se encontram geograficamente próximas (SCHMID, 1998).

Existe uma preocupação de se classificar os falares como língua ou dialeto. Trata-se de uma classificação limitada, do ponto de vista linguístico, pois pressupõe um modelo de árvore genealógica no qual uma língua gera outras, transmitindo, assim, as características da "língua-mãe" para a "língua-fillha" (VIARO, 2001: 61). Essa metáfora exclui a idéia da interferência entre a língua-mãe e língua-filha ${ }^{162}$ e entre duas línguas-filhas ${ }^{163}$. Por outro lado, admitir "cruzamentos" entre línguas pode gerar uma idéia errônea de que, para haver falares "híbridos", houvesse no passado falares "puros".

Ambas as concepções são exemplos de uma visão limitada sobre os fenômenos linguísticos que, como se sabe, são muito mais complexos. PELLEGRINI (1972: 238-243), ao classificar as línguas românicas, afirma que elas podem ser:

a. Uma língua nacional unitária, com tradição literária fundada sobre uma koiné (italiano, romeno, francês, português, espanhol).

b. Uma língua literária não-nacional, reconhecida e oficial apenas na região em que se fala e com tradição literária (friulano, provençal, catalão, galego).

\footnotetext{
${ }^{162}$ Por exemplo, as interferências lexicais do latim no português a partir do século XVI, por causa das obras dos gramáticos lusitanos da época.

${ }^{163}$ Como entre o galego e o português ou, ainda, entre o galego e o mirandês. Do mesmo modo entre os falares ladinos no Tirol histórico e no Vêneto.
} 
c. Uma língua nacional não-oficial, com certa produção literária, com muita variação dialetal e sem uma koiné (romanche) ${ }^{164}$.

d. Uma língua extinta, sem grande tradição escrita (dalmático).

e. Grupos com características comuns e com bastante variação dialetal, sem literatura e sem koiné (ladino dolomítico, franco-provençal, sardo).

f. Grupos isolados, destacados do tronco, sem produção literária ${ }^{165}$ (istro-romeno, meglenoromeno, macedo-romeno)

g. Línguas formadas por questões políticas, praticamente idênticas a outras a não ser por peculiaridades, como a escrita (moldavo, istriota).

Por questões de nomenclatura e para facilitar a descrição de determinadas variantes lingüísticas ou grupos dialetais, utilizamos em alguns momentos os termos língua e dialeto. Contudo, evitando uma classificação estreita, preferimos usar o termo "falares", também utilizado por VIARO (2001: 60) em seu trabalho sobre o romanche. Essa definição evita a tentativa de distinção taxativa entre língua e dialeto, mas - como afirma o autor - não resolve o problema, apenas evita discussões. VIARO se baseia na hipótese poligenética de oposição múltipla e negativa defendida por TAGLIAVINI (1972), que admite que o romanche que não se confunde nem com o lombardo, nem possui uma relação "monogenética" com o ladino dolomítico ou com o friulano. Por outro lado, os falares ladino-vênetos e vênetoladinos identificados por ASCOLI (1873) revelam algo de falares ladinos extintos, ou na condição de substrato que garantiu semelhanças na estrutura morfológica ladina (ladinovêneto), ou na difusão de formas (sobretudo lexicais) ladinas no substrato vêneto (vênetoladino).

Desse modo, parece exagerado afirmar que o lombardo ou vêneto sejam considerados dialetos de uma mesma língua italiana. O conceito língua se torna uma

\footnotetext{
${ }^{164}$ Cfr. SCHMID (1998).

${ }^{165}$ PELLEGRINI inclui nesse grupo o ladino sefardita. Entretanto, sabe-se que há uma considerável produção literária sefardita na Península Ibérica, que durante o período da dominação muçulmana (de 711 a 1492) era muito rica. O desenvolvimento do Califado de Córdoba, propiciado pelo intercâmbio com o norte da África e com o Oriente, coincidiu com o período áureo dos judeus sefarditas, refletindo-se nas artes e na literatura, com destaque, entre outros, para os gramáticos, lexicógrafos e poetas Menachen Ben Saruc, Dunas Ben Labrat e Semuel Ibn Nagrella, este último que chegou a condição de vizir no mundo islâmico ibérico. Destaca-se, ainda, a figura de Maimônides (rabino Moshe ben Maimon), cujo pensamento filosófico gerou divergências entre os religiosos judaicos da época. No século XI, a população sefardita representava $96 \%$ do mundo judeu (SCLIAR-CABRAL, 1990).
} 
entidade abstrata, pancrônica, formada a partir de discursos contínuos falados e/ou escritos, que se distingue dos falares vizinhos por interesses políticos ${ }^{166}$.

\subsection{O DIALETO TRENTINO NA ITÁLIA}

A região tirolesa foi durante séculos a principal passagem pelos Alpes ligando a Itália à Alemanha. A diocese tridentina dominava, portanto, quase toda a região italianófona do Condado Episcopal do Tirol e sua capital sempre fora no contexto regional tirolês a principal cidade de língua italiana, seguida de Rovereto mais ao sul (atualmente a segunda mais importante cidade da província). O dialeto trentino traz em si as características dessa realidade de região limítrofe, situada no encontro dos idiomas germânicos e latinos.

$\mathrm{O}$ atual Trentino, no que se refere à sua latinidade, sempre manteve seu status de Tirol Italiano $(=\text { Welschtirol })^{167}$. Mas o é também uma terra de encontros entre os dois principais falares da Itália setentrional: o lombardo e o vêneto. E os subdialetos trentinos são exemplo disso. O rio Adige (= Etsch) "divide" os falares trentinos de influência lombarda (galo-itálica) a oeste daqueles de influência vêneta a leste e, por isso, o vale é considerado uma fronteira linguística natural entre os falares lombardos e o vênetos (mezzogiorno), e ponto de partida para a classificação dialetal da região. Ainda que alguns dialetólogos (ROHLFS, 1949) contestem a existência de uma antiga koiné lombardo-vêneta, enquanto língua própria da região trentina, os falares trentinos apresentam características desses dois grupos linguísticos, que ali se encontraram.

Além destes dois dialetos, a pressão alemã vinda do norte, conforme atesta ŠEBESTA (1984: 15), estacionou há pouco mais de cinquenta quilômetros de Trento. A partir do

\footnotetext{
166 Essa mentalidade influenciou sobremaneira a unificação do estado italiano e as consequências desse conceito negativo geraram inúmeros conflitos armados em várias italianas, inclusive no Tirol. Cfr. HoLZNER (1991).

${ }^{167}$ Cfr. HORMAYR (1817); EGG (2000); RiCCADONNA (2009).
} 
século XII, colonos de língua alemã vindos do condado tirolês ${ }^{168}$, isto é, da região de Meran (= Merano), se estabeleceram em alguns vales pertencentes ao principado episcopal tridentino, de modo que o alemão tirolês se tornou a língua corrente dessas áreas.

Somente nas regiões setentrionais do atual Trentino sobreviveram os falares ladinos, que na região de Val di Fassa, no Maciço do Sella, são os mais conservadores. Nas regiões de Val di Fiemme, Val di Non e Val di Sole o superstrato italiano (trentino) influenciou sobremaneira seus falares originais, ainda que estes preservem características que lhe garantam uma identidade ladina-italiana ${ }^{169}$.

Segundo BAtTisti (1931) e Rohlfs (1949; 1954), o galo-itálico avançou em meados do século $\mathrm{X}$ pela planície padana, atravessando o atual território trentino e seguindo para a margem esquerda do Adige, pelas regiões de falares ladinos. Não seguindo mais para o oeste, pois encontrou a resistência do falar vêneto, o galo-itálico recuou até a margem direita do Adige, pois o vêneto reocupou a região até a margem esquerda do rio, influenciando os falares ladinos daqueles vales e, sobretudo, o falar da cidade de Trento.O lombardo oriental, que influenciou sobremaneira o dialeto trentino ${ }^{170}$, constitui uma transição entre os falares galo-itálicos da área alpina italiana e as línguas galo-romanas. O vêneto influenciou sobremaneira os falares trentinos, pelo contato dos dialetos de Belluno (incluindo Feltre), Vicenza e Verona, que em alguns vales trentinos são encontrados de forma idêntica, como na região de Primiero, cujo dialeto é semelhante ao feltrino, apesar do razoável número de vocábulos de origem germânica ${ }^{171}$, ou na região de Valsugana, cujo dialeto se assemelhança com o vicentino.

Alguns estudiosos do dialeto trentino (GROFF 1955; GORFER 1986; FoX 1997), ainda que não admitam um dialeto separado do lombardo e do vêneto, assumem o termo dialeto trentino para classificar o falar da província, que possui uma série de fenômenos linguísticos comuns a praticamente toda sua extensão territorial. $\mathrm{Na}$ região de Bolzano

\footnotetext{
${ }^{168}$ Não se sabe, ao certo, se somente da região do condado tirolês. Acredita-se que colonos saídos da Baviera também tenham se estabelcido na região trentina (MATTEI, 1994, 1997; RICCADONNA, 2009).

${ }^{169}$ No mesmo sentido de AsCOLI (1873).

${ }^{170} \mathrm{O}$ dialeto lombardo é mantido em algumas localidades de Val di Sole, vale trentino fronteiriço com a Lombardia.

${ }^{171}$ Cfr. OsTi (2001); LONGO (2006).
} 
(Bozner Unterland), no Südtirol, mantém-se há séculos o dialeto trentino, que influenciou sobremaneira o léxico do alemão tirolês daquela área.

Considera-se, portanto, razoável a utilização de dialeto trentino, sobretudo pelos fatores históricos que o compuseram. Os motivos são os seguintes:

a) Nessa região existem falares típicos que, apesar das semelhanças, não são nem lombardos, nem vênetos. O substrato ladino e o superstrato germânico são próprios da área trentina, por conta de seus peculiares aspectos históricos e, ainda que em demais áreas setentrionais italianas haja realidades parecidas (Província de Belluno, na região vêneta), essas características garantiram ao longo dos séculos o desenvolvimento de variantes próprias da região trentina.

b) Mesmo que em os falares trentinos ora compartilhem dos fenômenos lombardos e, ora compartilhem dos fenômenos vênetos, a relação genética não exclui a existência de um dialeto particular formado, como acima afirmado, a partir do substrato ladino e com as contribuições do superstrato germânico ${ }^{172}$.

c) Muito provavelmente, o antigo galo-itálico suplantou o antigo ladino da região e teve posteriormente um forte superstrato do lombardo e do vêneto, formando - ainda que proporcionalmente diferente das áreas de perservação das características ladinas - uma anfizona (ASCOLI, 1873), geradora de um grupo particular, o trentino ${ }^{173}$.

Entre as características comuns à maioria dos subdialetos trentinos, temos: tendência a destacar com intensidade e clareza a sílaba tônica, atenuando as átonas; tendência à terminação em consoante surda, com queda das vogais exceto $-a$; distinção entre fricativas alveolares surda [s] e sonora [z] com caráter fonêmico; tendência à manutenção das vogais anteriores arredondadas [y] e [ø]. No que se refere ao léxico, as diferenças se devem, sobretudo, à heterogeneidade dos elementos étnicos e à diversidade de culturas agrícolas.

\footnotetext{
${ }^{172} \mathrm{O}$ mesmo ocorre com o mirandês de Portugal: não é português, não é galego, não é castelhano, embora participe de fenômenos comuns a todos os anteriores; conjectura-se que se trata de uma conservação do lionês que se desenvolveu naquela região de Miranda.

${ }_{173}$ Trata-se de uma realidade muito comum entre dialetos de tradição ágrafa, sobretudo em regiões geograficamente isoladas como na área alpina.
} 


\subsubsection{ClassifiCAÇÃO DOS DIALETOS TRENTINOS}

Como afirmado acima, várias influências determinaram na região trentina a difusão de dialetos e línguas com características próprias. Segundo BATTISTI (1960), os dialetos trentinos são substancialmente divididos em quatro grupos principais:

a) Grupo central, formado pelos falares de Trento e das regiões de Val dell'Adige, Valle dei Laghi, Giudicarie Esteriori, Altopiano di Pinè e Altopiano di Pergine. Com bastante influência do dialeto de Trento, se divide entre os falares da área urbana tridentina (dialeto urbano) e regiões vizinhas (dialeto rural).

b) Grupo ocidental, com falares de acentuada influência lombarda (bresciano), nas regiões de Giudicarie Interiori e Val di Ledro (ledro-giudicario).

c) Grupo oriental, com falares de acentuada influência vêneta, que se subdivide em três áreas:

- área feltrina, na região de Primiero (primieroto).

- área vicentina, na região de Valsugana (valsuganoto).

- área veronesa, na região de Vallagarina (valagarino), com a cidade de Rovereto.

d) Grupo de substrato ladino, de falares semelhantes ao ladino (ladino trentinizado), que se subdivide em duas áreas distintas, separadas pelo Vale do Adige:

- área ocidental, nas regiões de Val di Non (nonês) e Val di Sole (solandro).

- área oriental, nas regiões de Val di Fiemme (fiamazzo) e Val di Cembra (cembrano). 


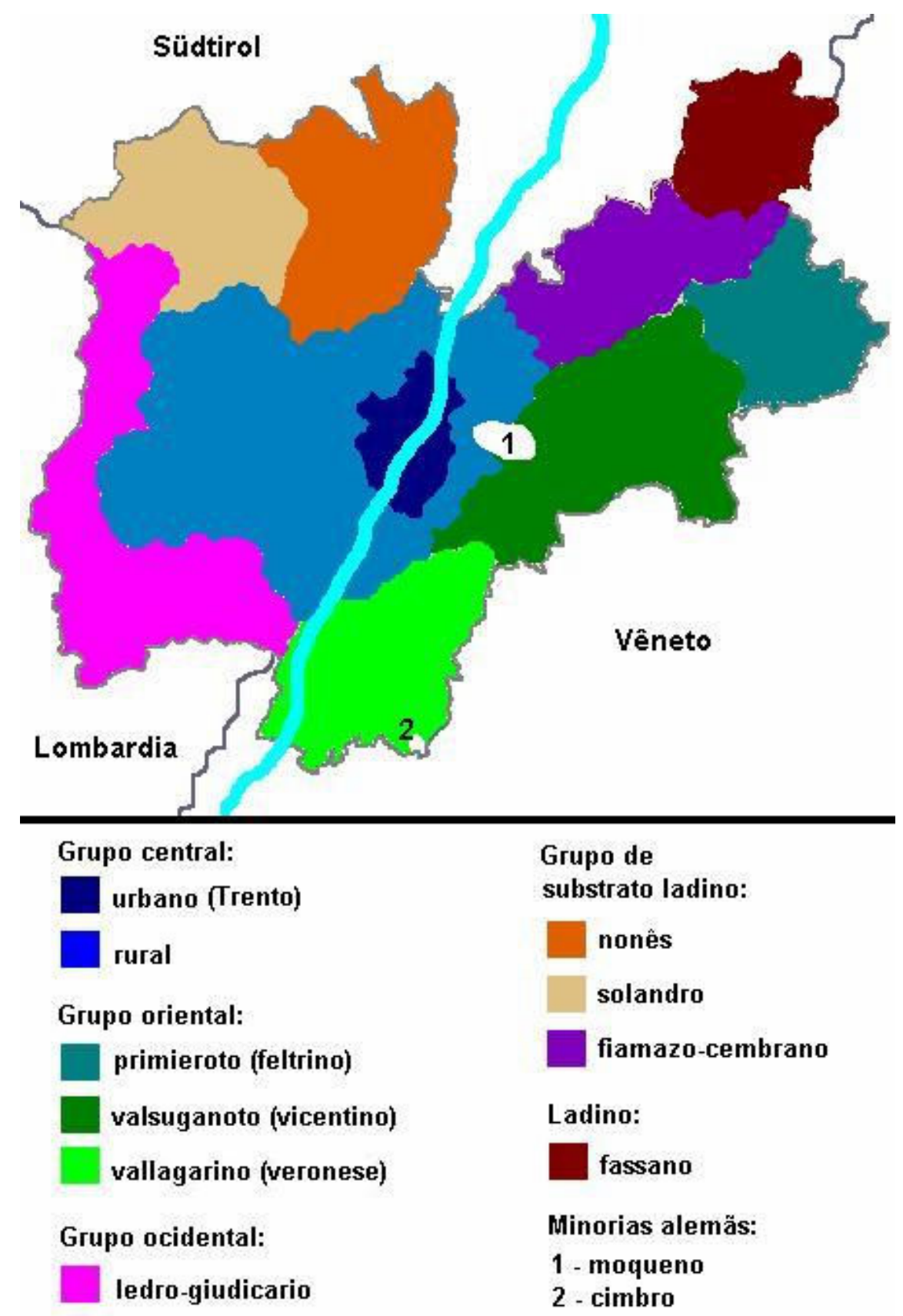

Mapa 10: A subdivisão dos dialetos trentinos ${ }^{174}$.

${ }^{174}$ MAPA: nosso. 


\subsection{O dialeto Trentino de Piracicaba}

O dialeto trentino na comunidade tirolesa de Piracicaba (que doravante chamaremos de trentino piracicabano) mantém-se em duas variantes próprias a cada bairro. LEME (2001) atestou essa diferença, mas não informou, em seus estudos, sobre se tratarem de dois dialetos distintos ou duas variantes de um mesmo dialeto.

Como pudemos observar, existem duas variantes de um mesmo dialeto: uma correspondente a $\mathbf{S}$ e outra a SO. As diferenças entre as variantes dialetais dos bairros são encontradas no plano fonético (principalmente) e lexical, e não no plano morfológico. Desse modo, não é possível afirmar que ali existam dois dialetos distintos; tratam-se de duas variantes de um mesmo subdialeto trentino, dos arredores da cidade de Trento, no Vale do Adige. TOMASINI (1960), em sua classificação dos dialetos trentinos, identificou os falares dessa região como pertencentes ao dialeto rural dos arredores de Trento (Dialetto rurale); BATTISTI (1936) identificou-os como pertencentes ao grupo linguístico do Trentino centro-ocidental, por sua posição entre duas áreas linguísticas definidas: ao sul com a variedade da cidade de Trento, com a qual divide várias características; ao norte com o falar semiladino de Val di Fiemme em direção à região ladina de Val di Fassa.

Ascoli(1873) em em seus Saggi Ladini, tratou brevemente das características dialetais daquela área trentina. O renomado lingüista goriziano, pesquisador atento dos "fenômenos" ladinos, não identificou na região de Fiemme e Cembra fenômenos linguísticos relevantes que demonstrassem ali grande proximidade do dialeto trentino com o ladino. Hoje, contudo, afirma-se que os fenômenos presentes nos dialetos daquela região e nos dialetos ladinos "são resultado de uma comum conservação de fases linguísticas amplamente difusas, em tempos antigos, na planície padana” (RIzzOLATTI, 1984: 19). As características "ladinas" reconhecidas por ASCOLI nos falares trentinos não iam muito além de alguns poucos fenômenos fonéticos, os quais são também observados no trentino piracicabano: as vogais anterior $\ddot{\boldsymbol{u}}[\mathrm{y}]$ e posterior $\ddot{\boldsymbol{\theta}}[\varnothing]$ e os fonemas alveopalatais [t]] e $[\mathrm{d} 3]^{175}$.

\footnotetext{
${ }^{175}$ Os fonemas ocorrem, sobretudo, na variante trentina de Santana.
} 
A variante de SO possui mais semelhanças com os falares dos arredores de Trento (região de origem de seus habitantes), ao passo que a variante de $\mathbf{S}$ compartilha várias características do dialeto de Val di Cembra ${ }^{176}$ (vale próximo da região de origem de seus habitantes). Ambas as variantes trazem, contudo, características das influências linguísticas daquela região: dos falares lombardo e vêneto e do dialeto da cidade de Trento (de maior prestígio). Por conta dos séculos de convivência com os tiroleses de língua alemã ${ }^{177}$ e com a administração austríaca, o dialeto trentino da comunidade apresenta um considerável número de vocábulos de origem germânica.

As famílias de origem tirolesa ${ }^{178}$ de $\mathbf{S}$ são oriundas dos distritos trentinos de Cortesano, Meano e Vigo Meano. Os três paesi são pequenas cidades vizinhas, localizadas na margem direita do rio Adige, área dominada pelo monte Gazzadina, no encontro dos

${ }^{176}$ Val di Cembra é historicamente um local de resistência do falar trentino frente à pressão exercida pelo alemão bávaro, pois se localiza na fronteira linguística natural entre o Tirol alemão e o Tirol italiano, que já no ano 1000 fora estabelecida com o assentamento de colonos baiuvares na parte alta do rio Adige (=Etsch). A presença germânica na região de Cembra é antiga. Embora a região fosse administrada pelo principado episcopal de Trento, a influência dos Condes do Tirol se propagou com os colonos de língua alemã por toda aquela área alpina. No início do século XIII o controle do condado tirolês seguiu pelas terras que circundavam a parte alta do rio Adige e chegou à entrada do Vale de Cembra, nos arredores da cidade de Lavis, limitandose exatamente na região dos distritos de Cortesano (que em mapas antigos aparece também como Cortegiano), Meano e Vigo Meano (=Vigo). Ainda que influenciado pelos arredores "germânicos", o interior do Vale de Cembra - sob o controle do convento dos Agostinianos de São Miguel - permaneceu italianófono mesmo depois do final do século XIII, quando todo o vale fora concedido pelo príncipe-bispo de Trento ao Conde Meinhard II do Tirol. Essa linha natural se manteve praticamente intacta durante os séculos seguintes e foi confirmada em 1438 pelo domenicano Felix Faber de Ulm que, ao passar pela ponte de San Lazaro em direção à cidade de Lavis (início do Vale de Cembra), afirmou que aquela região "dividit Italos ab Alemannos" (FABER, 1960). Seguindo pelo Cembra para o nordeste da região, na direção de Val di Fassa, o idioma histórico é o ladino. Um antigo ladino (VIDESOTT, 2006) teria se expandido por quase todo o norte do Trentino na Alta Idade Média, e influenciado o falar de toda a região do atual Trentino e região sul (dolomítica) do atual Südtirol, antes da descida germânica pelo Adige, que fixou o idioma alemão até o sul de Bolzano (também Bolgiano em alguns documentos antigos). A área germanófona limitou-se, assim, ao norte de Val di Cembra. Ainda que, desde a Antiguidade, toda a região do vale do Adige fora uma região de passagem (ligando as terras "italianas" àquelas "alemãs"), a porção meridional do vale, atravessando as terras do principado episcopal - e administrada pela diocese tridentina -, manteve-se italianófona. Outra leva de colonos de língua alemã começou a se estabelecer naquelas terras após a peste do século XVII, e isso se comprova pelo considerável número de sobrenomes de origem alemã na região (RICCADONNA, 2009). Contudo, sua total assimilação linguística permitiu a continuação dos falares trentinos em toda a extensão meridional do vale do Adige. Difícil é afirmar qual o distanciamento dos falares trentinos daqueles ladinos durante a Idade Média, haja vista a carência de documentos históricos em dialeto trentino.

${ }^{177}$ Esse contato linguístico ocorria não somente nas áreas trentinas colonizadas por tiroleses de língua alemã na Idade Média. Vale lembrar que as relações comerciais entre os diversos grupos linguísticos do Tirol era uma prática comum e os tiroleses da região trentina costumavam migrar periodicamente para trabalhar em outras áreas da região setentrional ou nas vizinhas províncias italianas, exercendo ofícios como artesãos, vendedores ambulantes, taberneiros, pastores e agricultores provisórios. Em Val dei Mòcheni, até o início de século XX, sobrevivia o ofício dos Krùmern, vendedores ambulantes que circulavam por todas a área tirolesa e parte da área alpina vêneta.

${ }^{178}$ Com o passar do tempo, descendentes de outras nacionalidades e de origem brasileira (cabocla) se estabeleceram nos bairros. 
vales do Adige e do Cembra. As famílias de origem tirolesa de SO são oriundas dos distritos trentinos de Romagnano, Sardagna, Cortesano e Albiano. Os três primeiros paesi são originalmente aqueles dos fundadores do bairro; do último distrito são oriundos os membros da família Negri, estabelecidos na homônima fazenda vizinha alguns anos depois da compra da Fazenda Santa Olímpia.

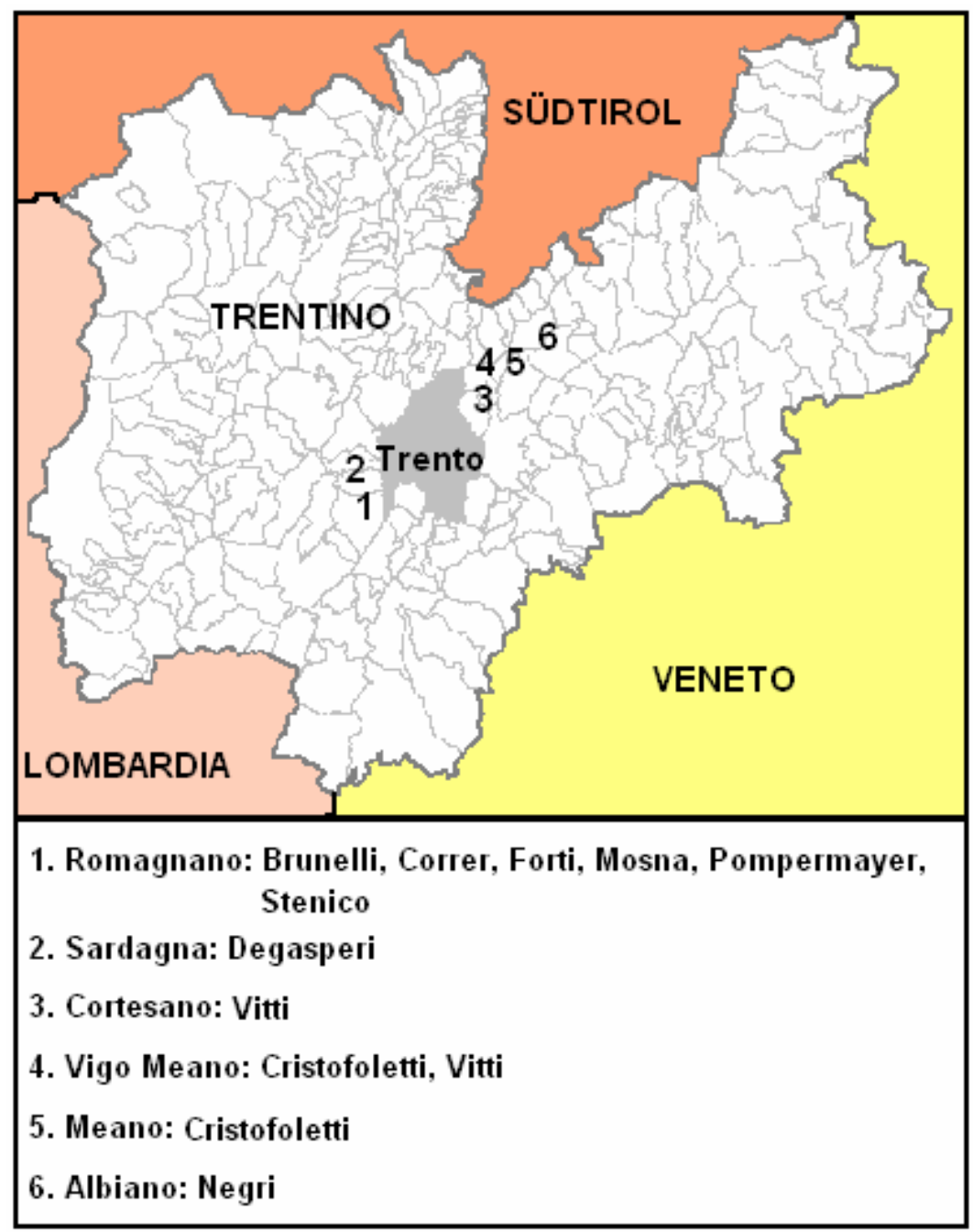

Mapa 11: Localização dos distritos originais dos imigrantes de Santana e Santa Olímpia ${ }^{179}$.

Romagnano e Sardagna são pequenos distritos que próximos à capital Trento, localizados na margem esquerda do rio Adige. Cortesano, principal distrito de origem dos

${ }^{179}$ Mapa: nosso. 
moradores de $\mathbf{S}$, localiza-se mais ao norte, próximo ao monte Gazzadina. Albiano é um dos primeiros distritos da região de Val di Cembra.

Observa-se na comunidade piracicabana um caso de uso restrito de vocábulos entre membros de um mesmo núcleo famíliar, como a palavra stofis <bacalhau> (al. Stockfisch) que é utilizada entre os falantes do trentino da família Degasperi (ou Degaspari) de SO. Somente entre os membros dessa família, originária do distrito trentino de Sardagna, é utilizado o termo stofis; entre os demais falantes do dialeto, de ambos os bairros, é utilizada a forma bacalà.

Portanto, é possível afirmar que, em SO, prevalece a variante dialetal trentina de Romagnano e Sardagna, enquanto, em S, prevalece a variante dialetal de Cortesano (que é a mesma de seus distritos vizinhos, Vigo Meano e Meano).

Para exemplificação do dialeto da comunidade piracicabana, apresentamos dois exemplos nas duas variantes existentes nos bairros. O texto foi por nós elaborado e lido aos mais velhos da comunidade, de modo que o traduzissem livremente conforme o líamos. Eis o texto em português e as versões traduzidas nas variantes dialetais de cada bairro ${ }^{180}$ :

\section{Português:}

Quando os nossos avós decidiram partir do Tirol, precisaram organizar tudo. Os parentes e toda a gente perguntavam muitas coisas, se lá havia igrejas e se antes de partir os noivos precisavam se casar. Quando partiram, as mulheres choravam e as crianças não entendiam que a viagem era longa. Mas aqui no Brasil eles trabalharam e não perderam sua língua e seus costumes, nem a religião.

\footnotetext{
${ }^{180}$ Para a ortografia do dialeto trentino da comunidade piracicabana, baseamo-nos na grafia utilizada pelos dicionários do dialeto trentino (Vittore, 1904; GrofF, 1955; Azzolini, 1974; ANeGGi, 1984; Prati, 1960; QuARESIMA, 1964; ZoRZI, 1977; BONISEGNA, 1980; FranChINI, 1984; GuAdAGNINI, 1985; Tissot, 1996). Como modelo ortográfico para a acentuação, utilizamos, principalmente, o trabalho de ANEGGI (1984), que acentua todas as sílabas tônicas: vàca $<$ vaca $>$; tégola $<$ telha $>$; perméter $<$ permitir $>$; tamburèl $<$ tamborzinho>; pericolós $<$ perigoso $>$. Nos casos monossilábicos, a vogal anterior semi-aberta $\dot{e}[\varepsilon]$ e a vogal posterior semiaberta $\dot{o}[$ [] são acentuadas, como em bèch $<$ bico $>$ e $\grave{o m}<$ homem $>$, sendo que a vogal anterior semifechada [e] e a vogal posterior semifechada [o] não o são, como em bech $<$ bode $>$ e $o r<$ ouro $>$. Uma vez que a palavra $p \grave{u}<$ mais $>$ aparece acentuada na maioria dos trabalhos sobre o dialeto trentino, respeitamos essa tendência gráfica para o dialeto da comunidade piracicabana. Ainda respeitando os modelos europeus, optamos por utilizar $e i<\mathrm{os}>$ sem acentuação, pois a pronúncia varia entre [ej] e [i]; no caso do verbo èi $<$ é $>$ aparece sempre dessa forma, pois a pronúncia varia entre $[\varepsilon]$ e $[\varepsilon j]$. A grafia do dialeto trentino utiliza $z$ para representar a fricativas alveolares surda [s] e sonora [z], pois ambas se alternam em algumas variantes do trentino europeu (e na variante de SO); esse padrão não se aplica ao vêneto, como se pode observar em STAWINSKI (1995) e LUZZATO (2000).
} 


\section{Santana:}

Quan che ei nóssi nóni ei ha resolvést nar vìa dal Tirol, le bisognàva comedàr tüt. Ei parénti e la gent ei domandàva tànte ròbe per savér còssa far, se la via gh'èra ciése e se ei morósi ei dovéva maridàrse prìma de viagiàr. Lóri ei no avéva pac! Quàndo ei èi nàdi vìa, le dòne le piangéva e ei matelòti ei no entendéva che el viag 'l sarìa lónch. Ma chì en Brasil lóri ei ha laorà e no ha pèrs la so léngua, gnànca la religión.

['kwanke i'nəsi 'noni i'a rezot'vest nar 'via dat ti'rot le bizo'nava kome'dar tyt / Ej pa'renti e la dzent i doman'dava 'tante 'robe per sa'ver 'kəsa far se la via 'gera 't $\int$ eze e se i mo'rozi ej do'veva mari'darse 'prima de vja'dzar / 'Iori i no a'veva pats / 'kwando i'z 'nadi 'via le 'dəne le pjan'dzeva e i mate'loti i no nten'deva ket vjadz + sa'ria lonk / Ma ki en bra'zit 'lori i'a lao'ra e no'a pers la so 'lengwa 'nanka la reli'dzon]

\section{Santa Olímpia:}

Quan che ei nóssi nóni ei ga (ha) resolvést nar vìa dal Tirol, le bisognàva comedàr tüt. Ei parénti e la zent ei domandàva tànte ròbe per savér còssa far, se la via gh'èra ciése e se ei morósi ei dovéva maridàrse prìma de viazàr. Lóri ei no gavéva (avéva) paz! Quànde ei è nàdi vìa, le dòne le pianzéva e ei matelòti ei no entendéva che el viaz 'l sarìa lónch. Ma chì en Brasil lóri ei ha laorà e no ha pers la so léngua, gnànca la religión.

['kwanke i'nəsi 'noni i'a rezot'vest nar 'via dat ti'rot le bizo'nava kome'dar tyt / Ej pa'renti e la zent i doman'dava 'tante 'robe per sa'ver 'kəsa far se la via 'gera 'tfeze e se i mo'rozi ej do'veva mari'darse 'prima de vja'zar / 'lori i no a'veva pas / kwande i'z 'nadi 'via le 'dəne le pjan'zeva e i mate'loti i no nten'deva ket vjas + sa'ria lonk / Ma ki en bra'zit 'lori i'a lao'ra e no'a pers la so 'lengwa 'nanka la reli'dzon]

Como é possível observar, não se trata de dois dialetos diferentes, mas de duas variantes de um mesmo dialeto, cujas diferenças se encontram principalmente no plano fonológico, embora existam diferenças lexicais entre as variantes. 


\subsubsection{ASPECTOS VOCÁLICOS}

SÍMBOLOS FONÉTICOS VOCÁLICOS DO TRENTINO PIRACICABANO

\begin{tabular}{|c|c|c|c|c|}
\hline Símbolo & $\begin{array}{c}\text { Correspondente } \\
\text { ortográfica }\end{array}$ & $\begin{array}{c}\text { Exemplo } \\
\text { ortográfico }\end{array}$ & $\begin{array}{c}\text { Transcrição } \\
\text { fonética }\end{array}$ & Significado \\
\hline [i] & $\mathrm{i}$ & $\begin{array}{c}m i \\
\text { sénti }\end{array}$ & $\begin{array}{c}\text { ['mi] } \\
\text { ['senti] }\end{array}$ & $\begin{array}{c}\text { eu } \\
\text { escute }\end{array}$ \\
\hline [y] & $\ddot{\mathrm{u}}$ & $\begin{array}{c}\text { tüt } \\
\text { capütèl }\end{array}$ & $\begin{array}{c}\text { ['tyt] } \\
\text { [kapy'tcł] }\end{array}$ & $\begin{array}{c}\text { tudo } \\
\text { capitelo }\end{array}$ \\
\hline [e] & $\begin{array}{l}\text { e } \\
\text { é }\end{array}$ & $\begin{array}{l}\text { éla } \\
\text { pel }\end{array}$ & $\begin{array}{l}\text { ['ela] } \\
\text { ['peł] }\end{array}$ & $\begin{array}{l}\text { ela } \\
\text { pelo }\end{array}$ \\
\hline$[\varnothing]$ & $\ddot{o}$ & $\begin{array}{c}\text { föch } \\
\text { ànzöl (SO) } \\
\text { àngiöl (S) }\end{array}$ & $\begin{array}{c}\text { ['føk] } \\
\text { ['anzøł] } \\
\text { ['andzøł] }\end{array}$ & $\begin{array}{l}\text { fogo } \\
\text { anjo }\end{array}$ \\
\hline$[\varepsilon]$ & è & $\begin{array}{l}\text { pèl } \\
\text { lorèl }\end{array}$ & $\begin{array}{c}\text { ['pet] } \\
\text { [lo'rct] }\end{array}$ & $\begin{array}{l}\text { pele } \\
\text { funil }\end{array}$ \\
\hline [a] & $\begin{array}{l}\mathrm{a} \\
\text { à }\end{array}$ & $\begin{array}{c}c a \\
m a ̀ m a\end{array}$ & $\begin{array}{c}\text { ['ka] } \\
\text { ['mama] }\end{array}$ & $\begin{array}{c}\text { casa } \\
\text { mamãe }\end{array}$ \\
\hline [כ] & ò & loròi & [lo'rวj] & relógio \\
\hline [o] & $\begin{array}{l}\text { o } \\
\text { ó }\end{array}$ & $\begin{array}{l}\text { porét } \\
\text { órbo }\end{array}$ & $\begin{array}{l}\text { [po'ret] } \\
\text { ['orbo] }\end{array}$ & $\begin{array}{c}\text { pobrezinho } \\
\text { cego }\end{array}$ \\
\hline [u] & $\begin{array}{l}\mathrm{u} \\
\text { ù }\end{array}$ & $\begin{array}{c}\text { nut } \\
\text { paùra }\end{array}$ & $\begin{array}{c}\text { ['nut] } \\
\text { [pa'ura] }\end{array}$ & $\begin{array}{c}\text { nu } \\
\text { medo }\end{array}$ \\
\hline
\end{tabular}


O sistema fonológico vocálico do trentino piracicabano é o mesmo nas duas variantes da comunidade. Dentre suas características, encontramos a presença da vogal anterior meio-fechada $\ddot{\boldsymbol{o}}[\varnothing]$, em consonância com a vogal anterior fechada $\ddot{\boldsymbol{u}}[\mathrm{y}]$, características dos falares do vale do Adige (Tomasini, 1960) e que, na cidade de Trento, são realizadas respectivamente como [o] ou [ग] e [u]. No trentino europeu, ambas vêm sendo substituídas respectivamente pelas vogais posteriores meio-fechada $\boldsymbol{o}$ [o] (ou meio-aberta $\boldsymbol{o}$ [ว] em alguns casos) e posterior fechada $\boldsymbol{u}[u]$.

À vogal $\ddot{\boldsymbol{o}}$ sucedeu outrora um antigo ditongo $\boldsymbol{u \boldsymbol { o }}$, desenvolvimento de $\breve{\mathbf{o}}$ latino em sílaba aberta $($ fŏcum $>$ föch $<$ fogo $>$; jŏcum $>$ giöch $<$ jogo $>$; cŏrem $>$ cör $<$ coração $>$; nŏram $>$ nöra $<$ nora $>$ ). Diferente desenvolvimento ocorreu no ladino dolomítico, que em alguns de seus dialetos mantém a presença do antigo ditongo surgido no latim vulgar da área alpina (fŏcum > ladino gardenês fuech; ladino fassano fech).

O desenvolvimento de $\overline{\mathbf{u}}$ latino em $\ddot{\boldsymbol{u}}$ ocorre em qualquer posição, (matūrum > madür <maduro $>$; frūctum $>$ früt $<$ fruto $>$; cūnam $>$ cüna $<$ berço $>$; plümam $>$ piüma $<$ pluma $>$; sūdorem $>$ südór $<$ suor $>$ ). Em ambos os casos, notamos que entre os falantes de SO as vogais [ø] e [y] são mais utilizadas; em $\mathbf{S}$ as vogais ocorrem sobretudo na fala dos mais velhos e muito pouco entre os falantes das gerações mais novas, que geralmente as realizam como [o] e [u] (foch; cor; nóra; piùma; cùna). Em em alguns casos, aparecem também como vogal posterior meio-aberta [ग] (nöra - nòra; ciuciöl - ciuciòl <chupeta>), característica da variante de $\mathbf{S}^{181}$.

Os êxitos de $\breve{~(a b e r t o ~ n o ~ l a t i m ~ v u l g a r) ~ o c o r r e r a m ~ n o s ~ f a l a r e s ~ t r e n t i n o s ~}$ prevalentemente na vogal posterior meio-fechada $\grave{o}$ [0], antes de nasal (hŏmo $>$ òm $<$ homem $>$; sŏnat $>$ sòna $<$ soa $>$ ), em sílaba fechada (mŏrtum $>$ mòrt $<$ morto $>$; dŏrmit $>$ dòrm < dorme>). Assim como o desenvolvimento de $\breve{\mathbf{~}}$ temos o desenvolvimento de $\breve{\mathbf{e}}$ (aberto do latim vulgar) em $\grave{\boldsymbol{e}}[\varepsilon]$, evolução de um antigo ditongo ie que havia se fechado em $\boldsymbol{e}$ [e] por influência da semivogal [j] - traço deste antigo ditongo permanece em algumas palavras (sĕgat $>$ séga $<$ serra $>$; mĕle $>$ mel $<$ mel $>$ ); em outro contexto a vogal aberta se mantém inalterada (vitěllum $>$ vedèl $<$ bezerro $>$; fĕrrum $>$ fèr $<$ ferro $>$ ). BATTISTI (1906)

\footnotetext{
${ }^{181} \mathrm{Na}$ variante de $\mathbf{S}$ é comum o uso de [つ] para os casos que em SO ocorrem como [o] ou mesmo [ø].
} 
afirma que a redução dos ditongos $\boldsymbol{i} \boldsymbol{e}>\boldsymbol{\boldsymbol { e }}$ e $\boldsymbol{u} \boldsymbol{\boldsymbol { o }}>\boldsymbol{\boldsymbol { o }}$ é muito antiga, provavelmente anterior ao século XII.

As vogais $\boldsymbol{e}$ [e] e $\boldsymbol{o}$ [o] (fechadas do latim vulgar) ocorrem no trentino piracicabano como nos demais subdialetos do trentino europeu; trata-se de uma característica dialetal trentina em que é (desenvolvimento de $\breve{\mathbf{~}}, \overline{\mathbf{e}}$ do latim clássico) e $\boldsymbol{o}$ (desenvolvimento de $\breve{\mathbf{u}}, \overline{\mathbf{o}}$ do latim clássico) permancem inalteradas em qualquer posição (p̌scem > pes <peixe>; pŭlum > pel <pêlo>; têlam > téla <tecido; membrana; nata $>$; fêmĭnam $>$ fémena $<$ mulher $>$; spōsum $>$ spos $<$ esposo $>$; vŭlpem $>$ bolp $<$ raposa $>$ ). RIZZOLATTI (1984) afirma que a sua presença dos fonemas não pode ser considerada um fato de direta continuação do sistema fonético do latim vulgar; isso vale para as formas em que a vocal ocorria em sílaba fechada, enquanto os êxitos em sílaba aberta presupõem a redução dos antigos ditongos $\boldsymbol{e i}$ e ou, que são características no ladino e no friulano ${ }^{182}$.

\subsubsection{QUEDA DAS VOGAIS FINAIS}

Nos dialetos do grupo lombardo a forma morfológica das palavras apresenta a queda de todas as vogais finais exceto - $\boldsymbol{a}$ (D’OVIDIO, 1932; RoHLFs, 1954; DEvoto, 1991), característica presente no dialeto trentino (RIzzolATTI, 1984) e em algumas variantes dialetais vênetas (sobretudos das regiões limítrofes com a Lombardia e Trentino).

"A característica geral da maior parte dos dialetos galo-itálicos (menos o Ligure) é a queda das vogais finais, as quais se extinguem todas com exceção da vogal /a/. Numa abordagem

\footnotetext{
${ }^{182}$ Válido é lembrar que existem poucas evidências de tais ditongos nas variantes dialetais trentinas centroocidentais, enquanto até algum tempo algumas atestações se baseavam no desenvolvimento medieval do sufixo -ētum em -ait, como nos mapas alemães da área trentina em que a cidade de Rovereto (Robūretum) aparece com o nome alemão Rofrait (Rofreit e Rovereit no período imperial austríaco). Folgaria tem, entretanto, sua correspondente alemã como Vielgereuth. Esse ditongo permanece nos dialetos trentinos de Val di Non (que preserva os traços mais antigos do trentino) e Val di Ledro, no ladino, no romanche, em alguns dialetos de Brescia (Malcesine e Lumezzane), indicando, desse modo, que a área do ditongo seria outrora mais extensa que a região alpina tirolesa.
} 
sobre as características dos dialetos lombardos, G. Devoto e G. Giacomelli afirmam que, normalmente, estes dialetos perdem as vogais finais, exceto - $a$ ".

(FROSI \& MIORANZA, 1983: 99)

O trentino piracicabano preservou uma característica própria do trentino europeu, onde as vogais finais $\boldsymbol{e}, \boldsymbol{i}, \boldsymbol{o}$ e $\boldsymbol{u}$ praticamente não são realizadas (vŭlpem > bolp <raposa>; hŏmo $>$ òm $<$ homem $>$; fŏcum $>$ föch $<$ fogo $>$; fĕrru $>$ fèr $<$ ferro $>$ ), com algumas exceções (ghèto <confusão>; ghìrlo < tufão de vento>; obligo < obrigação >; passàgio < passagem>); já as palavras terminadas em $\boldsymbol{a}$ mantêm a vogal final (capra $>$ càora $<$ cabra $>$; femĭna $>$ fémena $<$ mulher>). Há casos, entretanto, em que a conservação da vogal final é aparente, sendo, na verdade, uma consequência da vocalização da consoante labial posvocálica no final da palavra, como no exemplo neó $<$ nepos $<$ neto $>$. Do mesmo modo, não se considera etimologicamente o morfema -o encontrado na primeira pessoa do singular do presente do indicativo na grande maioria dos verbos (mi laóro <eu trabalho $>$; mi màgno $<$ eu como $>$; mi digo $<$ eu digo $>$ ), característica trentina.

No trentino piracicabano, assim como no trentino europeu, todas as vogais exceto -a “caíram" na maioria das palavras masculinas, nos verbos no infinitivo e, nos verbos no presente do indicativo, na terceira pessoa do singular e plural:

$\begin{array}{lll}\text { ['an] } & \text { an } & <\text { ano }> \\ \text { ['føk] } & \text { föch } & <\text { fogo }> \\ \text { [ga'ver] } & \text { gavér } & <\text { ter }> \\ \text { ['mat] } & \text { mat } & <\text { louco }> \\ \text { ['əm] } & \text { òm } & <\text { homem }> \\ \text { ['pøł] } & \text { pöl } & <\text { pode; podem }> \\ \text { [ser'nir] } & \text { sernìr } & <\text { escolher }> \\ \text { ['svøjd] } & \text { svöid } & <\text { vazio }> \\ \text { [var'dar] } & \text { vardàr } & <\text { olhar }>\end{array}$


Em algumas palavras femininas:

$\begin{array}{lll}\text { ['fam] } & \text { fam } & <\text { fome }> \\ \text { ['lym] } & \text { lüm } & <\text { luz; lanterna }>\end{array}$

Contudo, a regra não se aplica a todas palavras masculinas, havendo exceções:

$\begin{array}{lll}\text { ['tSotSo] } & \text { ciócio } & <\text { boneco }> \\ \text { ['gcto] } & \text { ghèto } & <\text { bagunça; confusão; sujeira }> \\ \text { [luni] } & \text { lùni } & <\text { segunda-feira }> \\ \text { [ne'o] } & \text { neó } & <\text { neto; sobrinho }> \\ \text { ['JtSo] } & \text { òcio } & <\text { olho }> \\ \text { ['pare] } & \text { pàre } & <\text { pai }> \\ \text { ['sJtSo] } & \text { sòcio } & <\text { sócio }>\end{array}$

\subsubsection{ASPECTOS CONSONANTAIS}

SÍMBOLOS FONÉTICOS CONSONANTAIS DO TRENTINO PIRACICABANO

\begin{tabular}{|c|c|c|c|c|}
\hline Símbolo & $\begin{array}{c}\text { Correspondente } \\
\text { ortográfica }\end{array}$ & $\begin{array}{c}\text { Exemplo } \\
\text { ortográfico }\end{array}$ & $\begin{array}{c}\text { Transcrição } \\
\text { fonética }\end{array}$ & Significado \\
\hline $\mathrm{p}$ & $\mathrm{p}$ & $p e l$ & ['pet] & pelo \\
\hline $\mathrm{b}$ & $\mathrm{b}$ & $b e ̀ l$ & ['beł] & belo; bom \\
\hline $\mathrm{t}$ & $\mathrm{t}$ & $t e$ & {$[\mathrm{te}]$} & te \\
\hline $\mathrm{d}$ & $\mathrm{d}$ & $d e$ & ['de] & dedo \\
\hline
\end{tabular}




\begin{tabular}{|c|c|c|c|c|}
\hline k & $\begin{array}{c}\mathrm{c} \\
\mathrm{ch} \\
\mathrm{ch}+\mathrm{e} \\
\mathrm{ch}+\mathrm{i}\end{array}$ & $\begin{array}{c}\text { compàr } \\
\text { bech } \\
\text { che } \\
\text { chi }\end{array}$ & $\begin{array}{c}\text { [kom'par] } \\
\text { ['bek] } \\
\text { ['ke] } \\
\text { ['ki] }\end{array}$ & $\begin{array}{c}\text { compadre } \\
\text { bode } \\
\text { que } \\
\text { quem }\end{array}$ \\
\hline $\mathrm{g}$ & $\mathrm{g}$ & gómbet & ['gombet] & cotovelo \\
\hline $\mathrm{t} \int$ & $\begin{array}{l}c+e \\
c+i\end{array}$ & $\begin{array}{c}\text { célega }(\mathbf{S}) \\
\text { ciuciöl }\end{array}$ & $\begin{array}{l}\text { ['t } \mathrm{telega}] \\
\left.\text { [t } \int \mathrm{u}^{\prime} \mathrm{t} \int \varnothing \mathrm{t}\right]\end{array}$ & $\begin{array}{c}\text { sobrancelha } \\
\text { chupeta }\end{array}$ \\
\hline d3 & $\begin{array}{l}g+e \\
g+i\end{array}$ & $\begin{array}{c}\text { gelà } \\
\text { giùgno }\end{array}$ & $\begin{array}{l}\text { [dze'la] } \\
\text { ['dzuno] }\end{array}$ & $\begin{array}{l}\text { gelado } \\
\text { junho }\end{array}$ \\
\hline$f$ & $\mathrm{f}$ & folt & ['fott] & denso; espesso \\
\hline $\mathrm{v}$ & $\mathrm{V}$ & völ & ['vøt] & quer \\
\hline S & $\mathrm{S}$ & salt & ['sałt] & salto \\
\hline z & $\mathrm{z}$ & zalt & ['załt] & amarelo \\
\hline $\int$ & $\begin{array}{c}\mathrm{s}+\mathrm{gn} \\
\mathrm{s}+\mathrm{c}(\mathbf{S})\end{array}$ & $\begin{array}{l}\text { sgnàpa } \\
\text { vàsca }\end{array}$ & $\begin{array}{l}\text { ['Snapa] } \\
\text { ['vaSka] }\end{array}$ & $\begin{array}{l}\text { aguardente } \\
\text { tanque; tina }\end{array}$ \\
\hline 3 & $\mathrm{~s}+1^{183}$ & slipegàr & [3lipe'gar] & escorregar \\
\hline $\mathrm{m}$ & $\mathrm{m}$ & marénda & [ma'renda] & merenda \\
\hline $\mathrm{n}$ & $\mathrm{n}$ & narànz & [na'rans] & laranja \\
\hline $\mathrm{n}$ & gn & gnorànt & [no'rayt] & ignorante \\
\hline$\eta$ & $\mathrm{n}$ & banch & ['bayk] & banco \\
\hline$r$ & $r$ & radór & [ra'dor] & navalha \\
\hline$r$ & $r$ & raf! & ['raf] & $\begin{array}{l}\text { onomatopéia: } \\
\text { corte do capim } \\
\text { com a foice }\end{array}$ \\
\hline I & 1 & lóri & ['lori] & eles \\
\hline$t$ & 1 & el & ['eł] & ele \\
\hline
\end{tabular}

\footnotetext{
${ }^{183}$ Somente nesse caso, cuja palavra deriva-se do verbo alemão tirolês schlimpfn (“escorregar”; “deslizar”).
} 


\begin{tabular}{|c|c|c|c|c|}
\hline$\wedge$ & $1^{184}$ & canéderli & [ka'neder $\mathrm{i}]$ & $\begin{array}{c}\text { nhoque típico } \\
\text { feito de pão } \\
\text { (al. Knödel; tir. } \\
\text { Knöderl })\end{array}$ \\
\hline
\end{tabular}

O sistema fonológico do trentino piracicabano é o mesmo nos dois bairros, não havendo diferenças entre as duas variantes dialetais ali existentes, que correspondem ao sistema fonológico trentino das regiões originárias (Val dell'Adige). A única diferença fonética se encontra na "inclusão" fonema consonantal [ $[$ ], que não ocorre no trentino europeu.

Dentre as características consonantais do trentino piracicabano, conservam-se os exemplos do desenvolvimento de - $\boldsymbol{c l}$ - intervocálico em [d3] (após uma fase precedente em $\boldsymbol{g l}$-), característica outrora comum também ao vêneto antigo (PELLEGRINI, 1977: 51-60), mas sucessivamente eliminado pela forte influência dos resultados de palatalização de *[lj] $>[j]>[d 3]$. A presença da africada alveopalatal sonora [d3] (spěcŭlum $>$ spégio <espelho $>$ ) é muito menos freqüente do que a da africada alveopalatal surda [t $\mathrm{t}$ ] (auř̌cŭlam > récia $<$ orelha>; ŏcŭlum > òcio <olho>). O único caso por nós registrado no trentino piracicabano de não-ocorrência da palatalização existe na variante dialetal de $\mathbf{S}$ : ciócla $<$ boneca>, que coexiste com a forma palatalizada ciócia, esta também existente em $\mathbf{S O}^{185}$.

A marcante diferença entre as variantes do trentino piracicabano se encontra, como afirmado, no plano fonético. Para os casos em que a variante de $\mathbf{S}$ apresenta as africadas alveopalatal sonora (àngiöl <anjo $>$ ) e surda (cigola $<$ cebola $>$ ), a variante de SO apresenta as fricativas alveolar sonora [z] (ànzöl) e surda [s] (zìgola) ${ }^{186}$.

A variante de $\mathbf{S}$ conserva os fonemas de $\boldsymbol{c i}$-, $\boldsymbol{c} \boldsymbol{e}$-, $\boldsymbol{g} \boldsymbol{i}$-, $\boldsymbol{g} \boldsymbol{e}$ - e $\boldsymbol{j}$ - do latim (cěrěbellum $>$ cervèl <cérebro>; cĕntum $>$ cénto $<$ cem>; quīnque $>$ cinque $<$ cinco $>$ ). $\mathrm{O}$ uso destes

\footnotetext{
${ }^{184}$ No trentino europeu não ocorre a lateral palagtal sonora, que existe no italiano e é grafada como $g l(+\mathrm{i})$. Contudo, o trentino piracicabano a realiza no caso apresentado na tabela, cuja palavra origina-se do alemão Knödel (variante Knöderl).

${ }^{185}$ Acreditamos tratar-se de um arcaísmo na articulação.

${ }^{186}$ A grafia do dialeto trentino utiliza em alguns casos $z$ tanto para representar a fricativa alveolar sonora [z] como para a fricativa alveolar surda [s], uma vez que ambas se alternam em algumas variantes.Seguimos, portanto, este "padrão" gráfico do trentino europeu e que não se aplica à grafia do vêneto, como se pode observar em LUZZATO (2000) e STAWINSKI (1995).
} 
fonemas vêm sendo substituídos no trentino europeu cada vez mais pela variante da cidade de Trento (de maior prestígio), que os realiza com a fricativa alveolar surda [s] da mesma forma que a variante dialetal de SO (zervèl; zénto; zìnque), característica dos falares vênetos.

Não há traços no trentino piracicabano dos "fenômenos ladinos" de palatalização de $\boldsymbol{c a}$ e $\boldsymbol{g a}$, o que nos faz descartar uma hipótese de preservação de possíveis arcaísmos desses traços fonéticos no Brasil. De fato, a variante dialetal da região trentina de Val dell'Adige não realiza a palatalização de $\boldsymbol{c a}$ e $\boldsymbol{g a}$, que ocorre somente no dialeto de Val di Non (ciavàl $<$ cavalo $>$; giàt $<$ gato $>$ ) e no ladino de Val di Fassa (ciasa $<$ casa>).

$\mathrm{Na}$ variante de $\mathbf{S}$, os sons palatais ocorrem em posição posconsonantal interna (mólger <ordenhar>; sorgiàt <camundongo $>$ ) e final (dolc < doce $>$; falc < $<$ foice $>$; sorg $<$ rato>; marc < podre>), assim como em posição posvocálica interna (abraciàr <abraçar>; baciàr <beijar>; sbruciàr <queimar >; bategiàr <batizar $>$ ) e final (abràc <abraço>; bac $<$ beijo $>$; brac $<$ braço $>$; lac $<$ laço $>$ ). A variante de SO apresenta bem menos casos de sons palatais e para os casos acima descritos os apresenta com a fricativa alveolar sonora [z] e surda [s] (mólzer; sorzàt; dolz; falz; sorz; marz; abrazàr; bazàr; sbruzàr; batezàr; laz) ${ }^{187}$.

Nas variantes dialetais centro-ocidentais do trentino europeu, o desenvolvimento de -ti- e - $\boldsymbol{d i}$ - latinos, quando em posição interna pós-consonantal e final, ocorreu como [z] e [3], inclusive no dialeto de Val di Cembra, que compartilha totalmente dessa característica presente nas demais variantes trentinas centro-ocidentais.

Ao passo que a variante de SO compartilha dessa característica (gŭttiam > góza $<$ gota $>$; mandiam > mànza <espiga $>$ ), a variante de $\mathbf{S}$ não participa totalmente desse fenômeno, havendo casos de africadas alveopalatais surda e sonora em posição interna (gócia; mància). Apesar dessa diferenciação, aparece essa característica trentina na variante de $\mathbf{S}$ principalmente em posição final (mĕdium > mez <meio>; pŭteum > poz <poço>; nĕptiam $>$ nèza $<$ neta $>$ ).

\footnotetext{
${ }^{187}$ Relembrando que a alternância do uso de [s] e [z] é relativamente comum na fala de SO, como no caso de vanéza $<$ canteiro $>$ que se realiza como [va'neza] (que prevalesce) e [va'nesa]. Entretanto, o uso de [z] parece ser mais frequente em posição prevocálica, sobretudo antes de $-a$ e $-e$ (batezàr <batizar >; mólzer $<$ ordenhar $>$ ).
} 


\subsubsection{FONEMAS CONSONANTAIS}

\section{A) OCLusivas}

Os fonemas oclusivos / $\mathrm{p}, \mathrm{b}, \mathrm{t}, \mathrm{d}, \mathrm{k}, \mathrm{g} /$ realizam-se da seguinte maneira:

$\begin{array}{lll}\text { ['pci] } & \text { pèi } & <\text { pés }> \\ \text { ['bci] } & \text { bèi } & <\text { belos }> \\ \text { ['tør] } & \text { tör } & <\text { pegar }> \\ \text { ['dor] } & \text { d'or } & <\text { de ouro }> \\ \text { ['kola] } & \text { co la } & <\text { com a }> \\ \text { ['gola] } & \text { góla } & <\text { gola }>\end{array}$

No trentino piracicabano encontramos cinco casos de alofonia que envolvem a realização do fonema / $\mathrm{t}$ / como africada alveopalatal surda [t] nas palavras derivadas de òstia <hóstia>. Ocorre também um caso da realização do fonema /d/ como africada alveopalatal sonora $/ \mathrm{d} 3 /$ apenas no caso diàol $<$ diabo $>$ :

\begin{tabular}{|c|c|c|}
\hline ['ost $\left.\int \mathrm{a}\right]$ & òs-cia! (òstia) & $<$ interjeição de maravilha ou desaprovação $>$ \\
\hline [ost $\left.\int^{\prime} \tilde{o}\right]$ & os-ción! (ostión) & <interjeição de maravilha ou desaprovação> \\
\hline 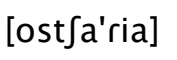 & os-ciarìa! (ostiarìa) & <interjeição de maravilha ou desaprovação> \\
\hline ['ost $\left.\int e t a\right]$ & òs-ceta! (ostiéta) & <interjeição de maravilha ou desaprovação> \\
\hline ['ostSete] & òs-cete! (ostiéte) & <interjeição de maravilha ou desaprovação> \\
\hline \multirow[t]{2}{*}{ ['dzaoł] } & giàol! (diàol) & $<$ interjeição de maravilha ou desaprovação $>$ \\
\hline & odór da giàol! (diaol) & $<$ odor fétido; suor $>$ \\
\hline
\end{tabular}




\section{B) NASAIS}

Há três fonemas nasais no dialeto trentino de Piracicaba / m, n, n /, que se realizam da seguinte maneira:

$\begin{array}{ll}\text { ['mar] } & \text { mar } \quad<\text { mar }> \\ \text { ['nar] } & \text { nar } \quad<\text { ir }> \\ \text { [ma'nar] } & \text { magnàr }<\text { comer }>\end{array}$

Antes de / $/$ e /g/, ocorre / $\mathrm{g} /$ como alomorfe do fonema /n/:

['bank] banch $<$ banco $>$

O glide palatal nasalizado [j] pode ocorrer no trentino piracicabano no lugar da consoante nasal palatal em casos onde a nasal é precedida de um som de $\boldsymbol{i}$ :

[kan] / [kayj] cagn <cão> (também ocorre como càign na grafia dialetal trentina)

[ko'd’n] / [ko'də̌̌] $\quad$ codògn $<$ marmelo $>^{188}$

Ocorre também em palavras cujas formas plurais que podem omitir a desinência plural $-\boldsymbol{i}$ :

\begin{tabular}{|c|c|c|}
\hline ['kaǰ] & $\operatorname{cagn}(i)$ & <cães> \\
\hline ['raȳ] & $\operatorname{ragn}(i)$ & <aranhas> \\
\hline o'doǰ] & codògn(i) & $<$ marmelo \\
\hline
\end{tabular}

${ }^{188}$ Também ocorre como codòign na grafia dialetal trentina (ANEGGI, 1984). 


\section{C) FRICATIVAS E AFRICADAS}

Os fonemas fricativos / f, v, s, z, $\int, 3$ / ocorrem da seguinte maneira:

$\begin{array}{lll}\text { [fa'ra] } & \text { farà } & <\text { fará> } \\ \text { [va'rar] } & \text { varàr } & <\text { ver }> \\ \text { ['sorz] } & \text { sorz } & <\text { rato }>(\text { SO }) \\ \text { ['zorz] } & \text { Zorz } & <\text { Jorge }>\end{array}$

No trentino piracicabano, a oposição entre [] e [s] não ocorre nas palavras originais do dialeto trentino, ocorrendo apenas com palavras advindas do português:

$\begin{array}{lll}\text { ['sapa] } & \text { zàpa } & <\text { enxada }> \\ \text { ['Sapa] } & \text { chapa }\end{array}$

Entretanto, ocorre no dialeto trentino:

['tJapa] ciàpa <pega>

Não é uma característica trentina o uso da fricativa alveopalatal surda [], que existe no italiano; para esses casos do italiano, o dialeto trentino geralmente as realiza com a fricativa alveolar surda $[\mathrm{s}]^{189}$ :

\footnotetext{
${ }^{189}$ Também não existe no dialeto trentino a forma $\boldsymbol{s} \boldsymbol{c}$ enquanto representante gráfica da fricativa alveopalatal surda [], existente no italiano. Contudo, assim como no vêneto, uma consoante sibilante semelhante a [] aparece para os casos de [s] entre alguns dialetos do trentino europeu e também no dialeto trentino da cidade catarinense de Rio dos Cedros (CURI, 1984).
} 


\begin{tabular}{|c|c|c|c|}
\hline $\begin{array}{c}\text { Trentino } \\
\text { piracicabano }\end{array}$ & Ortografia & Italiano & Significado \\
\hline ['pes] & pes & 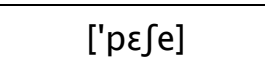 & peixe \\
\hline ['syt] & süt & ['Suto] (dialetal) & enxuto \\
\hline [suga'man] & sugamàn & [aSugamano] & toalha de mão \\
\hline ['bas] & bas & ['baso] & baixo \\
\hline
\end{tabular}

É característica de alguns subdialetos trentinos (Val di Cembra, Valsugana) o uso da fricativa dental sonora (sobretudo no início da palavra) antes de vogais, de consoantes sonoras e de $l, r, n$ e $m$. Trata-se de uma característica comum também ao vêneto. Entre alguns falantes de $\mathbf{S}$, o uso da fricativa dental sonora ocorre antes de $\boldsymbol{r}$ (desrudolàr $<$ desenrolar $>$ ), antes de gn (sgnàpa <aguardente; embriaguês $>$ ) e antes de $\boldsymbol{t}$ (Costa $<$ sobrenome $>)^{190}$.

A palavra sgnàpa <aguardente; embriaguês $>$ ocorre no trentino piracicabano de três maneiras: ora utilizando a fricativa alveopalatal surda [], ora a fricativa alveopalatal sonora [3] e ora a fricativa alveolar surda [s]. No primeiro caso, trata-se da preservação do som original da palavra alemã Schnaps <aguardente>. O uso de [s] seria a perda dessa conservação do som original alemão e [3] seria, portanto, um fenômeno trentino (que tende a sonorizar as fricativas antes de nasais). Também ocorre a forma gnàpa, provavelmente uma influência fonológica setentrional italiana, que tende a eliminar as fricativas de palavras de origem germânica ${ }^{191}$.

Entretanto, as palavras slipegàr <escorregar; deslizar> e slipegón <escorregão; deslize> ocorrem no trentino piracicabano somente com a fricativa alveopalatal sonora [3], ainda que também se origine a partir de um vocábulo germânico: tir. schlimpfn <escorregar; deslizar>. Do mesmo modo, ocorre com sgnèch <mole>, que tem sua provável correspondente no alemão moderno em Schnecke <caracol>.

\footnotetext{
${ }^{190}$ Cfr. informante 3C.S - J.V.

${ }^{191}$ Pudemos observar, em viagem nossa ao Trentino, que no dialeto da cidade de Trento e na região de Val di Cembra também ocorre a palavra sgnàpa com uso da fricativa alveolar sonora.
} 
A oposição [] e [3] pode ocorrer, entre alguns falantes, em palavras oriundas do português, ou palavras do trentino com significado ou sonoridade semelhantes ao português:

$\begin{array}{ll}\text { [Sa] } & <\text { chá }> \\ {[3 a]} & <\text { já }>\end{array}$

Contudo, as variantes do trentino piracicabano apresentam os seguintes casos:

$\begin{array}{lll}\text { [dza] } & \text { già } & <\text { já> (S) } \\ \text { [za] } & \text { zà } & <\text { já }>(\mathbf{S O})\end{array}$

As africadas ocorrem no trentino de piracicabano em ambas as variantes. Contudo, como afirmado, há um maior uso das africadas alveopalatais sonora [d3] e surda [t] na variante de $\mathbf{S}$, em palavras que na variante de $\mathbf{S O}$ ocorrem com a fricativa alveolar sonora [z] e surda [s].

\begin{tabular}{|c|c|c|}
\hline ['ot $\left.\int e\right]$ & óce & $<\mathrm{vOZ}>(\mathbf{S}$ e $\mathbf{S O})$ \\
\hline ['dzest] & gèst & $<$ gesto $>(\mathbf{S}$ e $\mathbf{S O})$ \\
\hline ['teigola] & cigola & $<$ cebola $>(\mathbf{S})$ \\
\hline ['sigola] & zigola & $<$ cebola $>$ (SO) \\
\hline ['dzo] & gió & $<$ embaixo $>(\mathbf{S})$ \\
\hline ['zo] & $z o$ & $<$ embaixo $>$ (SO) \\
\hline [vane'dza] & vanégia & $<$ canteiro $>(\mathbf{S})$ \\
\hline [vane'za] [vane'sa] & vanéza & $<$ canteiro $>(\mathbf{S O})$ \\
\hline
\end{tabular}




\section{D) VibRANTES}

A vibrante múltipla $[r]$ praticamente não ocorre no trentino piracicabano e trata-se de uma característica não só deste dialeto, como de praticamente todos do sententrional italiano, que realizam somente a vibrante simples [r].

A geminada $* / \mathrm{rr} /$ - que provavelmente ocorria no latim - simplificou-se em /r/ no desenvolvimento fonético da Itália Setentrional (Rohlfs 1954; Frosi \& MiORAnZA 1983). Trata-se de uma característica comum a todas as variantes dialetais trentinas e também ao vêneto:

"No que diz respeito, enfim, a /r/, tem-se, em geral, uma vibrante simples dental, ao passo que o standard possui uma vibrante múltipla".

A vibrante múltipla ocorre no dialeto trentino piracicabano em algumas situações, como ênfase da palavra que se está pronunciando. Em algumas expressões onomatopaicas, também pode ocorrer o uso da vibrante alveolar:

\begin{tabular}{|c|c|c|c|}
\hline ['raf] & raf & & $<$ som da foice cortando o capim $>$ \\
\hline ['ros] & früt ros! & fruto vermelho! & $<$ uma fruta madura e bela $>$ \\
\hline
\end{tabular}

No que se refere ao uso das vibrantes múltipla e simples na variante falada do português da comunidade, percebe-se que existe, entre algumas gerações de descendentes, uma confusão ocasionada pela neutralização da oposição entre as vibrantes múltipla e simples. Essa neutralização apresenta, na fala de alguns indivíduos da comunidade, casos como [ka'rısa] < carroça $>$; ['baro] $<$ barro $>$; ['barãko] $<$ barranco $>$ e [a'rame] $<$ arame $>^{192}$.

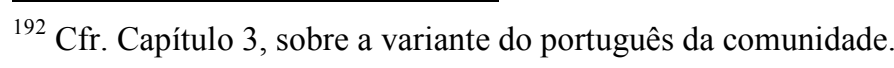




\section{E) LATERAIS}

$\mathrm{O}$ trentino piracicabano apresenta os fonemas laterais $/ \mathrm{I}, \downarrow, \Lambda /$ da seguinte maneira:

['øøf]

löf $\quad<$ lobo $>$

[lu'ganega] lugànega <lingüiça>

O som [t] ocorre em posição posvocálica preconsonantal ou posvocálica em final absoluto de palavra:

['załt] zalt $\quad<$ amarelo $>(\mathrm{SO})$

[pa'røł] paröl <tacho; caldeirão da polenta $>$

No trentino piracicabano ocorre um fenômeno de vocalização da lateral palatal, com um segmento com as características articulatórias de uma vogal do tipo /i/, que ocorre como [y]:

['Iuljo] ou [lu'lyo] $\quad$ lùlio $\quad<$ julho $>$

O dialeto trentino não faz a oposição $/ \mathrm{lj}: \Lambda /$, ocorrendo somente como $/ \mathrm{lj} / . \mathrm{Em}$ Piracicaba, a tendência é manter essa característica trentina, mas no caso das palavras milio $<$ milho> e canéderli <nhoques típicos feitos de pão>, observamos várias vezes na comunidade a realização de $[\Lambda]$ em casos aleatórios (sobretudo entre os falantes mais jovens).

[ka'nederli] / [ka'nederᄉi] canéderli <nhoque de pão>

['miljo] / ['mi^o] milio $\quad<$ milho $>$ 


\subsubsection{PADRÕES SILÁBICOS E VOCABULARES}

As duas variantes do trentino piracicabano parecem manter o mesmo esquema de padrões silábicos dos demais subdialetos do trentino europeu:

\begin{tabular}{|c|c|c|c|}
\hline V & [o] & ho & $<$ tenho $>$ \\
\hline $\mathrm{CV}$ & {$[\mathrm{mi}]$} & $m i$ & $<\mathrm{eu}>$ \\
\hline $\mathrm{CCV}$ & ['ste] & sté & $<$ estais $>$ \\
\hline $\mathrm{CCCV}$ & ['spla] & $\operatorname{spla}(t)$ & $<$ plaino $>$ \\
\hline $\mathrm{VC}$ & [as] & as & $<$ tábua $>$ \\
\hline $\mathrm{CVC}$ & ['vøt] & vöt? & $<$ queres?> \\
\hline CCVC & ['pret] & prèt & $<$ padre $>$ \\
\hline CCCVC & ['strak] & strach & $<$ cansado $>$ \\
\hline VCC & ['ałt] & alt & $<$ alto $>$ \\
\hline CVCC & ['fort] & fòrt & $<$ forte $>$ \\
\hline CCVCC & ['stort] & stòrt & $<$ torto $>$ \\
\hline CCCVCC & ['strons] & stronz & $<$ escremento $>$ \\
\hline
\end{tabular}

O trentino piracicabano apresenta vocábulos de uma, duas, três e quatro sílabas. Os padrões monossilábicos correspondem aos padrões silábicos do trentino europeu, onde não se encontra registro do padrão $\mathrm{CCCV}$, que só ocorre em vocábulos polissilábicos ${ }^{193}$. Os padrões polissilábicos ocorrem em posição inicial, medial e final nos vocábulos.

193 Característica comum ao dialeto trentino (valsuganoto) da comunidade de Pomeranos, na cidade catarinense de Rio dos Cedros (BONATTI, 1974). 


\section{A) Posição inicial}

$\begin{array}{llll}\text { V } & \text { [a'verzer] } & \text { avèrzer } & <\text { abrir }> \\ \mathrm{CV} & \text { ['pødo] } & \text { pödo } & <\text { posso }> \\ \mathrm{CCV} & \text { ['tretfa] } & \text { trécia } & <\text { trança }>(\mathbf{S}) \\ \mathrm{CCCV} & \text { ['strisa] } & \text { strìza } & <\text { risca; linha }>(\mathbf{S O}) \\ \mathrm{VC} & \text { ['orbo] } & \text { órbo } & <\text { cego }> \\ \mathrm{CVC} & \text { [tor'ment] } & \text { tormént } & <\text { tormento }> \\ \mathrm{CCVC} & \text { [skarme'nar] } & \text { scarmenàr } & <\text { derrubar; derramar }>\end{array}$

\section{B) PosiÇão MEdial}

$\begin{array}{llll}\mathrm{CV} & \text { [a'mori] } & \text { amóri } & <\text { amores> } \\ \mathrm{CCV} & \text { [engra'sar] } & \text { engrassàr } & <\text { engordar }> \\ \mathrm{CVC} & \text { [nas'kJrzer] } & \text { nascòrzer } & <\text { perceber> (SO) } \\ \mathrm{CCVC} & \text { [pa'tron] } & \text { patrón } & <\text { patrão }>\end{array}$

\section{C) Posição final}

$\begin{array}{llll}\mathrm{V} & \text { [ne'o] } & \text { neó } & <\text { neto; sobrinho> } \\ \mathrm{CV} & \text { [ga've] } & \text { gavé } & <\text { tendes }> \\ \mathrm{CCV} & \text { ['graspa] } & \text { gràspa } & <\text { grapa }> \\ \mathrm{CCCV} & \text { [fe'nestra] } & \text { fenèstra } & <\text { janela }> \\ \mathrm{VC} & \text { [sga'us] } & \text { sgaìs } & <\text { oco }> \\ \mathrm{CVC} & \text { [mate'lst] } & \text { matelòt } & <\text { menino }> \\ \mathrm{CCVC} & \text { ['fret] } & \text { fret } & <\text { frio }>\end{array}$


CVCC [lao'rant] laorànt <trabalhador $>$

\subsubsection{VARIAÇÕES MORFOFONÊMICAS}

No ato da fala espontânea, o som pode se modificar devido a vários contextos e, assim, pode ocorrer de maneira diferente do que se fosse registrado isoladamente. Isso só se percebe quando analisamos o som por meio de registros da fala, ou seja, em gravações de um falante. Assim, no contexto discursivo, cada fonema tende a adaptar-se, em sua articulação, aos fonemas que lhe são contíguos. As variações fonéticas podem, por sua constante repetição, assumir uma forma regular e entrar no sistema dos sons de uma língua, de modo que possam ser descritas (e até previstas).

Um exemplo no dialeto trentino são as palavras advindas do alemão, onde a fricativa alveopalatal surda [] ocorre, em início de palavra, somente antes de uma consoante surda, como em stùa ['Stua] <taberna $>$ (al. Stube) ${ }^{194}$. Antes de uma consoante sonora e, sobretudo, antes de nasal, ocorre geralmente a fricativa alveopalatal sonora [3], como em ['znapa] <aguardente; embriaguês> (do al. Schnaps). Contudo, no caso slipegàr <escorregar; deslizar> (tir. schlimpfn), que tende a ocorrer como [3lipe'gar] (e assim ocorre na maioria das vezes), aparece também [Jlipe'gar], dependendo da situação de fala. Em Piracicaba pudemos observar a ocorrência das duas formas.

As variações existem do mesmo modo com os morfemas, que assumem forma sonora dentro da cadeia da fala. Essas variações ocorrem no interior do próprio vocábulo ou na relação de um vocábulo perante outro, de forma externa. No que se refere ao trentino piracicabano, registramos os seguintes casos dessa relação entre morfemas e fonemas na fala do dialeto:

\section{A) VARIAÇÃo CVC PARA CVCV}

\footnotetext{
${ }^{194}$ Ilustramos apenas como exemplo, uma vez que stùa não ocorre no trentino piracicabano.
} 
Como afirmado, é característica trentina a queda das vogais finais exceto $\boldsymbol{- a}$. Contudo, no caso piracicabano, para algumas palavras do dialeto que também ocorrem no português (inclusive com realização fonética muito semelhante), aparecem variações que seguindo os padrões vocálicos do português - acrescentam uma vogal à consoante surda final, que passa a ser sonora.

\begin{tabular}{|c|c|c|c|}
\hline $\begin{array}{c}\text { Trentino europeu / } \\
\text { trentino piracicabano }\end{array}$ & $\begin{array}{c}\text { Variação } \\
\text { do trentino } \\
\text { piracicabano }\end{array}$ & Ortografia & Significado \\
\hline$[\mathrm{fret}]$ & {$[$ 'fredo] } & fret & frio \\
\hline$[\mathrm{ka}$ 'tif] & {$[$ ka'tivo] } & catif & nervoso \\
\hline$[$ 'nef] & {$[$ 'neve] } & nef & novo \\
\hline$[$ 'nøf] & {$[$ 'nøvo] ['novo] } & nöf & \\
\hline
\end{tabular}

As formas surgidas na variação ocorrem sobretudo entre os falantes mais novos do dialeto trentino que, apesar disso, não deixam de utilizar a forma própria do dialeto, com palavras terminadas em consoante surda. Mas não se trata de uma característica puramente brasileira. Os adjetivos terminados em consoante surda também podem ocorrer com a consoante sonora final no trentino europeu, como, por exemplo, no dialeto de influência vêneta da região de Valsugana, onde esta característica é muito comum ${ }^{195}$.

Observa-se no trentino piracicabano casos de palavras utilizadas ou com consoante final surda ou sonora. Ambas as formas convivem no falar da comunidade, que não faz distinção alguma para o uso de uma ou de outra forma:

$\begin{array}{lll}\text { ['dzałt] ou ['dzałd] } & \text { giàlt / giàld } & <\text { amarelo }>(\text { S }) \\ \text { ['załt] ou [załd] } & \text { zalt / zald } & <\text { amarelo }>(\text { SO }) \\ \text { ['lark] ou ['larg] } & \text { larch /largh } & <\text { largo }>\end{array}$

${ }^{195}$ Em seus estudos sobre o dialeto de Pomeranos, BONATTI (1974) observa a ocorrência dessa característica. A grande maioria dos imigrantes trentinos que fundaram a cidade de Rio dos Cedros era oriunda da região de Valsugana. 


$\begin{array}{lll}\text { ['lonk] ou ['long] } & \text { lonch /longh } & <\text { longo }> \\ \text { ['nerf] ou ['nerv] } & \text { nerf / nerv } & <\text { nervo }> \\ \text { ['nut] ou ['nud] } & n u t / \text { nud } & <\text { nu }> \\ \text { ['pis] ou ['piz] } & \text { piz } & <\text { urina }>\end{array}$

Também ocorrem no trentino piracicabano (assim como no trentino europeu) formas acrescidas de uma vogal final, que convivem com a forma terminada em consoante surda ou sonora:

$\begin{array}{lll}\text { ['før] ou ['føra] } & \text { för / föra } & <\text { fora }> \\ \text { ['lart] ou ['lardo] } & \text { lart / làrdo } & <\text { toucinho }> \\ \text { ['pom] ou ['pomo] } & \text { pom / pómo } & <\text { maçã }> \\ \text { [po'ret] ou [po'reto] } & \text { porét / poréto } & <\text { pobrezinho }> \\ \text { [s'dzonf] ou [s'dzonfo] } & \text { sgiónf / sgiónfo } & <\text { farto }>\end{array}$

\section{B) SEQUÊNCIA ARTIGO INDEFINIDO+NOME}

A seqüência do artigo indefinido + nome apresenta variações no dialeto trentino de um modo geral, em distribuição complementar:

[m] diante de consoante labial

[n] diante de consoante palatal

[n] para os demais casos

Trata-se de uma característica comum a alguns idiomas latinos e no dialeto trentino ocorre exatamente como no ladino de Val di Fassa (Rossi, 1999). As duas variantes trentino piracicabano apresentam essa característica, comum a demais comunidades trentinas no Brasil (BonATTI, 1974; Boso, 2002). 


$\begin{array}{lll}\text { [m'mat] } & \text { en mat } & <\text { um louco }> \\ \text { [m'pos] } & \text { en poz } & <\text { um poço }> \\ \text { [n'naro] } & \text { en gnàro } & <\text { um tolo }> \\ \text { [n'nom] } & \text { en nom } & <\text { um nome }> \\ \text { [nna'rans] } & \text { en naranz } & <\text { uma laranja }> \\ \text { [n'lart] } & \text { en lart } & <\text { um toucinho }> \\ \text { [n'sałt] } & \text { en salt } & <\text { um salto }>\end{array}$

Em alguns casos, podem ocorrer casos similares de geminação resultantes de uma prótese, em palavras normalmente iniciadas por vogal:

$\begin{array}{lll}\text { [n'nom] } & \text { n'om } & <\text { um homem }> \\ \text { [n'nora] } & \text { n'òra } & <\text { uma hora }> \\ \text { [n'narboł] } & \text { n'àrbol } & <\text { uma árvore }> \\ \text { [nna'mik] } & \text { n'amich } & <\text { um amigo }> \\ \text { [nn'an] } & n ' a n & <\text { um ano }>\end{array}$

\subsubsection{DEMAIS VARIAÇÕES FONOLÓGICAS}

Além das variações morfofonêmicas, ocorrem aquelas do trentino (comuns ao vêneto e ao lombardo), com diferenças fonéticas para as formas masculinas e femininas. As características a seguir são encontradas no trentino piracicabano, comuns ao trentino 
europeu (sobretudo nas regiões de influência vêneta, como Valsugana e Primiero, neste último com acentuada influência do dialeto de Feltre $)^{196}$.

\section{A) VARIAÇõeS ENTRE PALAVRAS MASCULINAS E FEMININAS}

É característica trentina o acréscimo de $\mathbf{- a}$ em posição final para as palavras femininas cujas correspondentes masculinas ocorrem com consoante final surda ou sonora. O trentino piracicabano mantém essa característica, sonorizando ou não a consoante prévocálica, como nos exemplos:

\begin{tabular}{|c|c|c|c|c|}
\hline Masculino & Ortografia & Feminino & Ortografia & Significado \\
\hline ['ałt] & alt & ['atta] & àlta & alto / alta \\
\hline ['mat] & mat & ['mata] & máta & louco / louca \\
\hline ['nut] ['nud] & nut / nud & ['nuda] & nùda & nu / nua \\
\hline ['Іøf] & löf & ['lova] ou ['loba] & lóva / lóba & lobo / loba \\
\hline ['nøf] & $n \ddot{o f}$ & ['nøva] & nóva & novo / nova \\
\hline ['fjøl] & fiöl & [fi'øla] & fióla & filho / filha \\
\hline ['pør] & $p \ddot{o r}$ & ['pora] & póra & pobre \\
\hline [pre'sis] & prezis & [pre'siza] & prezisa & $\begin{array}{c}\text { exato / exata } \\
\text { (SO) }\end{array}$ \\
\hline ['kan] & $\operatorname{cagn}$ & ['kana] ['kana] & càgna / càna & cão / cadela \\
\hline [kan'tor] & cantór & [kan'tora] & cantóra & cantor / cantora \\
\hline ['ntrek] & entréch & ['ntrega] & entréga & inteiro / inteira \\
\hline [ka'zot] & casòt & [ka'zวta] & casòta & casebre / casinha \\
\hline ['fat] & fat & ['fata] & fàta & pronto / pronta \\
\hline ['fjak] & fiàch & [fi'aka] & fiàca & fraco / fraca \\
\hline
\end{tabular}

\footnotetext{
${ }^{196}$ Cfr. pp. 140-141, sobre a classificação dos dialetos trentinos.
} 
O caso de $n u t<$ nu> é explicável diacronicamente: a sonora latina /d/ em nudum $<$ nu $>$ se torna $/ \mathrm{t} /$ em posição final (nudum $>n u t)$, mas a característica trentina de não-queda de -a na forma feminina garantiu a preservação da sonora latina de nudam <nua>, ocorrendo no dialeto a forma nùda $<$ nua $>$.

Observa-sem, ainda, um caso com sonorização por conta do acréscimo de $\boldsymbol{- a}$ enquanto desinência da do verbo no pretérito perfeito:

$\begin{array}{lll}\left.\text { [t } \int \text { ołt }\right] & \text { ciólt } & <\text { prego }> \\ {\left[\mathrm{t} \int \mathrm{ioł'da}\right]} & \text { cioldà } & <\text { pregado }> \\ {[\mathrm{kałt}]} & \text { calt } & <\text { quente }> \\ {[\text { skał'da }]} & \text { scaldà } & <\text { aquecido }>\end{array}$

No caso de calt e scaldà, a sonora latina presente em calidum $<$ frio $>$ se tornou surda - segundo a tendência trentina - após a queda da terminação ${ }^{197}$, mantendo a sonoridade em scaldà $<*$ ex-calid-are - neste caso, a característica trentina de queda vocálica ocorreu com a vogal $\boldsymbol{e}$, fenômeno comum nos verbos trentinos ${ }^{198}$ terminados em -are, -ere, -ire.

\section{B) VARIAÇÃO CV PARA CVCV EM PALAVRAS FEMININAS}

$\mathrm{O}$ acréscimo de -àda ocorre para adjetivos masculinos terminados em vogal tônica (-à) e também enquanto desinência feminina no particípio passado que, em alguns verbos trentinos - assim como no italiano -, concorda com o sujeito.

Trata-se do desenvolvimento do sufixo latino -atum $>*_{-}$ado $>*_{-}$at $>-a ̀$ na forma masculina, que na feminina ocorreu -atam $>-a ̀ d a$. Na forma feminina, a vogal tônica passa da última à penùltima sílaba.

\begin{tabular}{|l|l|l|l|l|}
\hline Masculino & Ortografia & Feminino & Ortografia & Significado \\
\hline
\end{tabular}

\footnotetext{
${ }^{197}$ No dialeto vêneto, as palavras ocorrem respectivamente como cióldo e càldo; no italiano ocorrem como chiodo e caldo.

${ }^{198}$ Característica comum ao vêneto e ao taliàn, como se pode observar em LUZZATTO (2000).
} 


\begin{tabular}{|c|c|c|c|c|}
\hline [ma'la] & malà & [ma'lada] & malàda & doente \\
\hline [roj'na] & roinà & [roj'nada] & roinàda & arruninado(a) \\
\hline [au'ta] & autà & [au'tada] & autàda & ajudado(a) \\
\hline [sku'sa] & scusà & [sku'sada] & scusàda & desculpado(a) \\
\hline [sepo'li] & sepolì & [sepo'lida] & sepolida & sepultado(a) \\
\hline [tfa'pa] & ciapà & [tfa'pada] & ciapàda & pego(a) \\
\hline 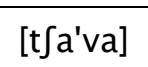 & ciavà & [tfa'vada] & ciavàda & roubado(a) \\
\hline [ris't $\left.\int a\right]$ & ris-cià & [ris'tfada] & ris-ciàda & arriscado(a) \\
\hline [sbu'na] & sbugnà & [sbu'nada] & sbugnàda & amassado(a) \\
\hline
\end{tabular}

\subsubsection{FORMAÇÃO DO PLURAL}

No que se refere à formação do plural, ambas as variantes do trentino piracicabano, seguindo os padrões trentinos, apresentam-na de modo semelhante ao italiano. Nas palavras femininas geralmente terminadas em - $\boldsymbol{a}$ (saídas da primeira declinação latina) o plural ocorre com a desinência -e (cà <casa> pl. càse; dòna <senhora; mulher> p. dòne; càora <cabra> pl. càore; caréga <cadeira> pl. caréghe); no caso de palavras femininas terminadas em $\boldsymbol{e} \boldsymbol{e}$ a variante de Santana realiza a forma plural com a desinência $\boldsymbol{- i}$ (como no italiano) ou não a realiza (ciàve <chave> pl. ciàvi ou ciàve). As palavras masculinas (saídas sobretudo da segunda e terceira declinações latinas) realizam o plural em $-\boldsymbol{i}$ (brac $<$ braço $>$ pl. bràci; dent < dente> pl. dénti; madür <maduro> pl. madüri; matelòt <garoto> pl. matelòti; parón < patrão> paróni); a palatalização da consoante final por influência de da desinência plural $-\boldsymbol{i}$ ocorre nos casos de $l+i$ (cavàl <cavalo> pl. cavài; gal <galo> pl. gài; matèl <moço> pl. matèi; salvanèl <topete de cabelo> pl. salvanèi; ciuciöl <chupeta> pl. ciuciöi). 
Ocorrem alguns fenômenos comuns ao dialeto cembrano (e mesmo a demais dialetos trentinos), como a ausência da forma plural em algumas palavras, resultado da perda do plural sigmático que HEILMANN (1955) observou em seu trabalho sobre o ladino de Val di Fassa ${ }^{199}$. A pressão linguística exercida pelo vêneto no leste e pelo lombardo no oeste (que não possuem plurais sigmáticos) influenciou o falar trentino de forma a praticamente eliminar as antigas formas plurais que se mantiveram no ladino e no friulano.

Ainda que o uso de $-\boldsymbol{i}$ seja, de fato, a marca de plural das palavras oriundas da segunda e terceira declinações latinas, tal regra, nas palavras femininas oriundas da terceira declinação, resultou na não-variação de algumas formas no plural que se mantivram idênticas à forma singular, o que poderia demonstrar o substrato ladino do dialeto, por causa da perda do antigo plural em $-s$ que não resultou na substituição completa pela desinência plural trentina em $\boldsymbol{- i} / \boldsymbol{e}$ (fam <fome> pl. fam; sòrt<sorte> pl. sòrt; ciàve $<$ chave $>$ pl. ciàve), resultando em formas plurais idênticas no trentino e no ladino (bòlp $<$ raposa $>$ pl. bòlp).

Entretanto, em Piracicaba encontramos a desinência plural $\boldsymbol{- i}$ em palavras que na região do vale de Cembra, por exemplo, ocorre não-variação nas formas singular e plural (trentino piracicabano: cagn <cão> pl. càgni; an <ano> pl. àni; Val di Cembra: cagn pl. cagn; an pl. an). No caso da variante de $\mathbf{S}$, a desinência ocorre, demonstrando a influência dos falares do vale do Adige nos distritos de Cortesano, Meano e Vigo Meano ${ }^{200}$.

\subsubsection{DESINÊNCIAS E VERBOS}

\footnotetext{
${ }^{199}$ Ainda que a desinência plural em -s (que outrora se estendia por toda a região "ladina" de Val di Cembra e Val di Fiemme) seja mantida na parte norte do vale de Fassa, vem perdendo terreno nos distritos ao sul do vale para a influência trentina vinda de Val di Cembra e Val di Fiemme, que a realiza no tipo - $\boldsymbol{i} / \boldsymbol{- e}$, demonstrando, assim, a continuidade do fenômeno em direção ao norte.

${ }^{200}$ Tais fenômenos apresentam os resultados linguísticos trentinos das áreas de transição: o primeiro, do falar ladino de Fassa com o trentino (substituição da desinência plural -s por $\boldsymbol{- i}$ ou ausência de desinência, como em alguns casos do dialeto de Val di Cembra); o segundo, de dos falares trentinos da região de Cortesano (ocorrência da desinência -i para os casos cembranos de ausência de desinência).
} 
A influência verbal vêneta se expandiu por boa parte da região trentina e muitos verbos aparecem idênticos nos dialetos trentinos das com a região do Vêneto. Contudo, algumas características não são exclusivas do falares vênetos, ocorrendo também no lombardo, no friulano e em praticamente toda a área setentrional italiana.

Uma característica comum encontrada no vêneto e no trentino europeu é a manutenção da vogal final -o na desinência da primeira pessoa do singular de alguns tempos verbais. Não representa, contudo, uma continuação da desinência latina, uma vez que é característica trentina a queda das vogais finais exceto $-\boldsymbol{a}$. Trata-se, na verdade, de uma influência ocorrida na região trentina a partir do século XVIII, surgida do prestígio falar da cidade que influenciou o falar camponês, que outrora apresentava a desinência $-\boldsymbol{i}$ (vàgi $<$ eu vou>; digi $<$ eu digo $>$ ), utilizada nos verbos de primeira conjugação do friulano (ió lavóri <eu trabalho>; ió clàmi <eu chamo>). A desinência $-i$ ocorre em alguns alguns verbos - em todas as conjugações - dos dialetos trentinos considerados mais conservadores, como Val di Cembra, Val di Fiemme e Val di Non. Em variedades lombardas, a desinência - $\boldsymbol{i}$ também ocorre na primeira pessoa do presente do indicativo (làvi $<$ lavo $>$; regòrdi $<$ recordo $>$; védi $<$ vejo $>$ ), por ênclise do pronome pessoal latino (ego $>$ i) que se une à vogal final do verbo (ROHLFs, 1954).

$\mathrm{O}$ morfema -o (mi laóro <eu trabalho>; mi digo <eu digo>; mi vàgo <eu vou>) ocorre em todas as conjugações do trentino piracicabano, nas quatro conjugações regulares. Não aparece nenhum traço dessa antiga desinência $\boldsymbol{- i}$, talvez pela forte influência que o falar da cidade de Trento exercia (e ainda exerce) nas variantes dialetais do Vale do Adige. O taliàn - falado sobretudo no Rio Grande do Sul - apresenta a forma béo < bǐbo <eu bebo $>$, ao passo que o trentino piracicabano conserva a forma bévo, que sofreu a influência do infinitivo béver (assim como scrìver $<$ escrever $>$ mi scrìvo; vìver $<$ viver $>$ mi vìvo).

Como afirmado, é próprio dos falares trentinos a ausência das vogais finais com exceção de $\boldsymbol{- a}$. Tal permanência nas formas verbais se deve aos êxitos da primeira conjugação latina (cuja vogal final em dependência de -as, -at se conservou), ao passo que

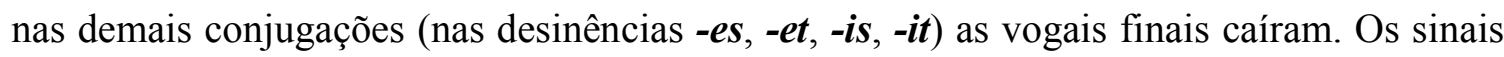
das vogais finais no trentino piracicabano se manifestam sobretudo nos verbos monossilábicos $($ dīcit $>$ diz $<$ diz $>$; tŏllet $>$ töl $<$ pega $>$; *vŏlet $>$ völ $<$ quer $>-$ e por analogia 
pöl $<$ pode $>$ ) e naqueles oriundos da quarta conjugação latina (dŏrmit $>$ dorm $<$ dorme $>$; vĕnit $>$ ven $<\mathrm{vem}>$ ).

A queda da vogal final nos verbos de terceira pessoa do singular não ocorre em todas as conjugações do dialeto trentino por conta da influência vêneta, que realiza a desinência - $\boldsymbol{e}$ nos verbos de primeira e terceira declinações latinas (RIzzOLATTI, 1984). No trentino piracicabano, a desinência $\boldsymbol{e}$ aparece em verbos de terceira pessoa do singular como créde $<$ crê $>($ de créder $<$ crer $>$ ); rìde $<\mathrm{ri}>($ de rìder $<$ rir $>$ ); béve $<$ bebe $>$ (de béver $<$ beber $>$ ); enténde <entende $>$ (de enténder $<$ entender $>$ ), porém apresenta também a forma tègn $<$ segura $>$ (de tègner $<$ segurar $>$ ).

No ladino a desinência verbal latina -umus se desenvolveu em -ón, que se generalizou para as demais conjugações; no trentino, ainda que seja uma tendência a generalização da desinência -emus em -én (do mesmo modo que no vêneto e no lombardo), apresentam-se também os êxitos das demais desinências: -amus em -àn e -imus em -ìn. No trentino piracicabano as desinências da primeira pessoa do plural refletem essas desinências latinas: distinção para os verbos da primeira conjugação (-an em cantāmus > cantàn $<$ cantamos $>$ ), da segunda e terceira conjugações (-én em vidèmus > vedén < <emos>; ridèmus $>$ ridén <rimos $>$ ) e da quarta conjugação (-ìn em dormìmus $>$ dormìn $<$ dormimos $>$ ).

A redução de $\boldsymbol{m}>\boldsymbol{n}$ ocorreu no desenvolvimento da nasal labial em posição final, do mesmo modo que em outras línguas românicas. Mas encontramos algumas poucas exceções como na palavra fam < fome>, ou no exemplo dos pares com < como> (ocorre também a forma come) em oposição a con $<$ com>, mantidos para preservar os diferentes significados.

A terceira pessoa plural ocorre no dialeto trentino de forma idêntica à terceira singular. Essa característica comum ao ladino, ao friulano, ao vêneto e a alguns dialetos lombardos, aparece também no trentino piraciabano (el 'l laóra <ele trabalha> lóri ei laóra $<$ eles trabalham>), em todos os tempos verbais:

éla la ga <ela tem> lóre le ga <elas têm>

el 'l gavéva $<$ ele tinha $>$ lóri ei gavéva $<$ eles tinham>

éla la gaveria $<$ ela teria $>$ lóre le gaverìa $<$ elas teriam> 
el 'l ga abù <ele teve> lóri ei ga abù <eles tiveram>

éla la gaverà <ela terá>; lóre le gaverà <elas terão>

se el 'l gavés $<$ se ele tivesse $>$ se lóri ei gavés $<$ se eles tivessem $>$

che 'l gábia élo <que ele tenha> che ei gàbia lóri <que eles tenham>

Os pronomes enclíticos que se fundem com os verbos ocorrem nas formas interrogativas, assim como no vêneto. Ocorrem também nos verbos de terceira pessoa (singular el? <é ele?>; plural ei? <são eles?>) e remetem, segundo diversos autores (BATTISTI 1906; Rohlfs 1954; RizzOLATTI 1984), respectivamente aos demonstrativos latinos ille e illi.

Não encontramos no trentino piracicabano nenhum traço do antigo passado bicomposto, uma interessante e arcaica forma verbal da área alpina registrada por ASCOLI (1873) e já não mais encontrada em praticamente nenhum dos dialetos alpinos e padanos. O passado bicomposto corresponde ao passé surcomposé do francês, formado com o pretérito perfeito (passato prossimo) do verbo avér (gavér) < ter> unido ao particípio passado de um verbo transitivo (ex: ài abù dit < tinha tido dito>, cujo significado oscilava entre os correspondentes italianos do trapassato prossimo (pretérito imperfeito do indicativo) e trapassato remoto (que exprime uma ação do passado ocorrida pouco antes de outra, também do passado), mas se distiguia deste pela idéia de independência da ação. No português não há uma correspondente para o trapassato remoto, cada vez mais em desuso no italiano, que o substitui pelo passato remoto (corresponde ao pretérito perfeito do indicativo).

O passado bicomposto se difundia por quase toda a região da Galorromânia e - ainda no século passado - fora registrado por ROHLFS (1954) em alguns dialetos da área padana. Hoje substituído principalmente pelo passato prossimo (que também corresponde ao pretérito perfeito do indicativo ${ }^{201}$ ), o passado bicomposto ainda aparece no dialeto

\footnotetext{
201 A distinção entre o passato remoto e o passato prossimo se assemelha semanticamente à distinção aspectual que havia no grego clássico entre o Aoristo e o Perfeito. O Aoristo indicava um evento totalmente concluído que ocorreu no passado, sem nenhuma relação com o momento da enunciação; o Perfeito também indicava um evento concluído ocorrido no passado, mas que mantinha uma relevância no momento da enunciação. Os dois paradigmas confluíram no Perfectum latino.
} 
trentino da comunidade germanófona de Val dei Mòcheni ${ }^{202}$ (=Fersental) e também pode ser observado no friulano, onde ocorre com freqüência, indicando um aspecto ocasional ou de pré-intenção de uma ação.

\subsubsection{ACENTO E INTENSIDADE}

O dialeto trentino apresenta sílabas tônicas e átonas, pré- ou postônicas, podendo ocorrer o acento no final da sílaba, na penúltima sílaba, na antepenúltima e em sílabas de vocábulos fonológicos formados por mais de uma palavra por ênclise, em sílaba que precede a antepenúltima, como ['gela] em táche ghe éla (táche gh 'éla) <amarre-a nele>.

"No dialeto trentino, a intensidade se apresenta como a maior ou menor força com que a emissão de uma sílaba se opõe às duas outras que lhe são próximas. $O$ acento do trentino apresenta, às vezes, caráter fonêmico".

(BONATTI, 1974:48)

BonatTi (1974), em seus estudos sobre o dialeto trentino de Pomeranos (município de Rio dos Cedros - SC), afirma que o dialeto trentino apresenta maior incidência de vocábulos paroxítonos, numa freqüência superior a 63 por cento, enquanto o percentual de palavras oxítonas em torno de 30 por cento e os proparoxítonos entre 3 e 8 por cento.

\subsubsection{ARCAÍSMOS DO TRENTINO PIRACICABANO}

\footnotetext{
${ }^{202}$ Um interessante caso de preservação de traços arcaicos do dialeto trentino na histórica e mais expressiva comunidade de língua alemã do atual Trentino. Outrora, o dialeto trentino falado pelos habitantes de Val dei Mòcheni era principalmente utilizado nas relações comerciais de seus vendedores ambulantes (Krùmern) com as vizinhas áreas italianófonas da região trentina.
} 
Além da substituição de palavras do trentino por palavras do português, há também casos de palavras trentinas que praticamente caíram em desuso, aparecendo raramente na fala dos mais velhos da comunidade e desconhecidas da maioria dos falantes mais jovens.

Algumas palavras são consideradas - mesmo entre os mais velhos - como "pouco usadas" ou pertencente ao vocabulário de outrora, "dos antigos". Contudo, essas palavras possuem equivalentes no próprio dialeto local, conhecidas e utilizadas pela maioria dos falantes do trentino piracicabano. Acreditamos que a preservação das próprias variantes tenha proporcionado a sobrevivência e a manutenção de vocábulos hoje raros ou inexistentes no trentino europeu. Alguns casos são considerados raros no trentino europeu atual, como pàita <preguiça>; outros caíram em desuso na terra de origem, como làica <preguiça>. Há ainda as palavras scaravànzi (SO) e scaravànci $(\mathbf{S})<$ ervilha $>$, que não aparecem em nenhum dicionário do trentino europeu ou do vêneto por nós consultado ${ }^{203}$. Desse modo, é possível afirmar que os arcaísmos do trentino piracicabano se devem a dois fatores:

a) À preservação de palavras que se tornaram raras ou caíram em desuso no trentino europeu.

b) À preservação de palavras outrora usadas pelos primeiros imigrantes e que, atualmente, limitaram-se a alguns poucos falantes. Essas palavras, à época da imigração, possuiam equivalentes de "prestígio" que se tornaram mais usadas e conhecidas da maioria da comunidade.

\begin{tabular}{|c|c|c|c|c|}
\hline $\begin{array}{c}\text { Trentino } \\
\text { piracicabano } \\
\text { (arcaísmo) }\end{array}$ & Grafia & $\begin{array}{c}\text { Trentino } \\
\text { piracicabano } \\
\text { (correspondente) }\end{array}$ & Grafia & Significado \\
\hline $\begin{array}{c}\text { [skara'vanzi] } \\
\text { [skara'vansi] }\end{array}$ & scaravànzi & ['bisi] & bisi & ervilha (SO) \\
\hline [skara'vant $\mathrm{Si}]$ & scaravànci & ['bisi] & bisi & ervilha (S) \\
\hline
\end{tabular}

${ }^{203}$ Os dicionários trentinos consultados foram os seguintes: Trento e Pinè (VITTORE, 1904; GROFF, 1955); Vallagarina (AzZolini, 1974); Cembra (ANEGgi, 1984); Valsugana (PrATI, 1960); Val di Non e Val di Sole (QuARESIMA, 1964); Val di Fiemme (ZORZI, 1977; BONISEGNA, 1980); Val Rendena e Giudicarie (Franchini, 1984; GuAdagnini, 1985); Primiero (Tissot, 1996). Os dicionários vênetos consultados foram aqueles de STAWINSKI (1995) e LUZZATO (2000). 


\begin{tabular}{|c|c|c|c|c|}
\hline [ver'got] & vergót & [kwat'kəs] & qualcòs & alguma coisa \\
\hline ['lajka] & làica & ['pajta] & pàita & preguiça \\
\hline
\end{tabular}

A palavra vergót ocorre raramente na comunidade, que se utiliza na maioria das vezes da correspondente qualcòs. Essa palavra ocorre no trentino europeu e no lombardo, que também conhecem a forma feminina vergóta [ver'gota] (RIZzolatTI, 1984).

As palavras làica e pàita são muito usadas na comunidade e làica ocorre frequentemente entre os mais jovens ${ }^{204}$. No trentino europeu, a palavra pàita ocorre raramente, e, segundo GROSSELLI (1990: 417), o termo làica caiu em desuso.

\subsubsection{EMPRÉSTIMOS E VARIAÇÃO}

Apresentamos aqui os casos de contato linguístico, onde tratamos dos temas ligados aos empréstimos lexicais e morfológicos, bem como àqueles ligados à variação semântica e aos neologismos.

No caso do trentino piracicabano, destacam-se as seguintes características, importantes para que se possa compreender sua formação:

Na Europa:

- A conservação de formas arcaicas, comuns ao ladino dolomítico.

- O contato entre o alemão e o dialeto trentino, que proporcionou empréstimos lexicais de origem germânica nas duas variantes dialetais existententes na comunidade.

No Brasil:

\footnotetext{
${ }^{204}$ A maioria dos moradores não usa a palavra portuguesa "preguiça". A forma làica é usada, inclusive, em situações de fala com pessoas de fora da comunidade, como pudemos observar. As formas laicão <preguiçoso> e laicôna <preguiçosa>, de radical trentino e sufixo português, é muito utilizada por todas as pessoas da comunidade, independente da idade. O termo pàita é utilizado principalmente pelos falantes mais velhos, embora a forma spaitàr < <star a tôa $>$ e espaitando <espreguiçando-se; vadiando $>$ é bastante utilizada pelo mais jovens.
} 
- O contato entre diferentes variantes dialetais trentinas, ocorrido na comunidade.

- O contato entre o português e o dialeto trentino, ocorrido desde a chegada dos pioneiros, mas, sobretudo, ocorrido na formação da comunidade piracicabana.

Não foi possível analisar quais os níveis de interferência entre si das duas variantes dialetais dos bairros, uma vez que ambas participam do mesmo subdialeto trentino da região de Val dell'Adige. Limitamo-nos, assim, a documentar as características próprias de cada variante e como ocorrem em seus respectivos bairros.

\subsubsection{EMPRÉSTIMOS DO ALEMÃO}

GROFF (1955), em seu dicionário do dialeto trentino, recolhe cerca de quatrocentos vocábulos de origem germânica. Estudos sobre a presença de vocábulos "alemães" no trentino europeu demonstram que alguns desses termos têm caído em desuso pelas gerações mais novas, como no caso do dialeto primieroto (NICOLAO, 1948; TiSSOT, 1976; LONGO, 2006); seu desuso reflete também as ações da política do estado fascista, que durante as décadas de 1920 e 1930 proibia qualquer ligação cultural com o Tirol austríaco, gerando tabus linguísticos ${ }^{205}$ para o uso de certos termos germânicos, assim como para hábitos da cultura tirolesa outrora comuns na população trentina.

\footnotetext{
${ }^{205}$ Esse tabu persiste atualmente no Trentino, como pudemos presenciar pessoalmente. Sobretudo entre as pessoas mais velhas, que vivenciaram o período da dominação fascista. A política de "italianização" de Mussolini atingiu principalmente o Südtirol de maioria germanófona, mas também procurou enquadrar o Trentino no modelo de Italia fascista, suprimindo suas tradiões locais (em língua italiana, mas de origem tirolesa). Como se pôde observar com o final da II Guerra Mundial e a reconstrução italiana, os ideais fascistas não perduraram, mas deixaram sequelas. Por conta disso, surgiram já na década de 1950 movimentos populares em busca da autonomia administrativa da região, bem como dos direitos dos grupos linguísticos alemão e ladino. Essa mobilização (ocorrida principalmente no Südtirol) culminou com o estatuto de autonomia que se estendeu ao Trentino e garantiu o respeito do governo de Roma pela identidade "tirolesa" local. Ainda hoje, entretanto, não faltam movimentos nacionalistas que, de maneira muito ingênua, procuram ofuscar a identidade linguística do Südtirol ou destacar a região trentina do contexto cultural tirolês. Sobre o assunto, cfr. HOLZNER (1991) e TONINA (2006). Opus cit.
} 
Algumas palavras de origem germânica não refletem apenas um período histórico da região tirolesa ou ao período do Império Austro-húngaro. Existem palavras cujas origens remetem às invasões germânicas durante os tempos da dominação romana, como o léxico de origem longobarda, que ocorre também no lombardo e mesmo no vêneto (veronês). Outras foram incorporadas durante as ondas migratórias dos tiroleses de língua alemã no período medieval, quando das colonizações de alguns vales trentinos. E, por fim, existem aquelas mais recentes, oriundas do período da administração austríaca entre os séculos XIX e XX (incorporadas pela forte influência política e cultural do Tirol setentrional), onde o uso do alemão, na região trentina, era comum nos serviços públicos e no exército ${ }^{206}$.

No caso da comunidade tirolesa de Piracicaba, o léxico de origem germânica é exatamente aquele trazido pelos emigrantes europeus, não havendo no caso piracicabano incorporação de vocábulos alemães em terras brasileiras, como ocorreu em algumas áreas de colonização trentina de Santa Catarina (BONATTI, 1974).

Apresentamos alguns exemplos recolhidos para nossos estudos junto da comunidade, no projeto local de resgate do dialeto trentino. Não pudemos fazer um levantamento apurado do número real de vocábulos de origem germânica do dialeto trentino em Piracicaba e limitamo-nos, aqui, a registrar alguns exemplos:

\begin{tabular}{|c|c|c|c|}
\hline Trentino piracicabano & Ortografia & Etimologia & Significado \\
\hline ['sat] & sat & al. satt & farto; satisfeito (S) \\
\hline [ka'nederli] & canéderle & $\begin{array}{c}\text { al. / bav. Knödel } \\
\text { tirolês: Knöderl } \\
\text { (diminutivo) }\end{array}$ & $\begin{array}{c}\text { nhoques grandes, } \\
\text { feitos de pão, leite, } \\
\text { ovos e especiarias }\end{array}$ \\
\hline ['fransele] & Frànzele & $\begin{array}{c}\text { al. Franz } \\
\text { tirolês: Franzel(e) } \\
\text { (apocorístico e } \\
\text { diminutivo) }\end{array}$ & Francisco \\
& & $\begin{array}{c}\text { bav. Madel } \\
\text { alamano: Maitli }\end{array}$ & moça \\
\hline [ma'tzla] & matèla & al. müssen $<$ precisar> & (eu) devo; preciso; \\
\hline ['mus] & mus! & &
\end{tabular}

${ }^{206} \mathrm{O}$ alemão vinha comumente utilizado pelo exército austríaco na região tirolesa. 


\begin{tabular}{|c|c|c|c|}
\hline & & ich muss $<$ eu preciso $>$ & não tenho outro jeito \\
\hline ['sgit] & sghit & $\begin{array}{l}\text { al. Scheisse } \\
\text { b.a. Schit }\end{array}$ & excremento de galinha \\
\hline ['Snapa] ['znapa] & sgnàpa & al. Schnaps & $\begin{array}{l}\text { aguardente; } \\
\text { embriaguêz }\end{array}$ \\
\hline [3lipe'gar] & slipegàr & tir. schlimpfn & escorregar; deslizar \\
\hline [trin'kar] & trincàr & al. trinken $<$ beber $>$ & embriagar-se \\
\hline ['topk] & tonch & bav. Tunke & molho \\
\hline [ton'kar] & toncàr & bav. tunken & $\begin{array}{c}\text { molhar o pão } \\
\text { no molho }\end{array}$ \\
\hline ['snck] ['znck] & sgnèch & $\begin{array}{c}\text { al. Schnecke } \\
\text { (caracol) }\end{array}$ & mole \\
\hline ['bjət] & biòt & $\begin{array}{c}\text { al. blo } \beta \\
\text { b.a. blot } \\
\text { got. blauths } \\
<\text { nu; mero> }\end{array}$ & puro; sozinho \\
\hline
\end{tabular}

Durante as entrevistas e conversas, soubemos que alguns dos primeiros emigrantes (alguns homens) falavam o alemão, mas, como se sabe, o alemão era no Trentino o idioma das relações com o governo e ofícios a ele ligados (exército, ferrovias etc), sendo o dialeto trentino o idioma doméstico ${ }^{207}$.

\footnotetext{
${ }^{207}$ Sobre o uso da língua alemã entre os falantes do ladino do século XIX, VIDESOTT (2002) afirma que somente os homens dominavam o idioma alemão, por causa de suas obrigações com o exército e por ser a língua dos ofícios públicos; as mulheres, limitadas ao ambiente doméstico, falavam somente o ladino. O idioma na escola dependia da área de influência: em alguns vales era o alemão, em outros o italiano. Pellegrini (1972) afirma de forma crítica que o ladino era incentivado no Südtirol por se tratar de uma presença latina na região, ao passo que em Val di Fassa, no Trentino (onde não há a presença linguística alemã), o ladino perdia espaço para o italiano em prol da unidade nacional. O ladino enquanto língua obrigatória nas escolas do Südtirol é uma realidade desde 1948; no Trentino, fortificou-se a identidade ladina com o estatuto de autonomia e no Vêneto, uma lei regional de 1983 obrigou o governo a contribuir economicamente com a cultura ladina de Ampezzo e Fodom. É válido lembrar que, durante a administração austríaca, não havia no Tirol do século XIX nenhum incentivo governamental para o ensino escolar do ladino, mas não havia, por outro lado, políticas de integração como aquela italianizante e opressora do período fascista, que permanece entre alguns movimentos políticos italianos e entre alguns institutos.
} 


\subsubsection{EMPRÉSTIMOS DO PORTUGUÊS}

Num ambiente de colonização, os empréstimos se devem, sobretudo, à presença de novos conceitos e objetos culturais do novo ambiente. Com a comunidade tirolesa de Piracicaba não é diferente. A adoção de traços linguísticos que não pertencem ao sistema que os recebe caracteriza o empréstimo, que pode ser o resultado de um condicionamento social ou geográfico, ou efeito do contato linguístico. São nesses casos que a língua, sempre em transformação, se adapta às novas situações e procura automaticamente dar maior expressividade e dinamismo à comunicação entre os falantes.

Os empréstimos lexicais do português no trentino piracicabano ocorrem em diversos campos semânticos e são oriundos principalmente da variante caipira do português, comum na área rural piracicabana e principal variante de contato dos primeiros emigrantes tiroleses com o português, assim como das gerações mais velhas de falantes da comunidade. Em boa parte do léxico brasileiro incorporado ao dialeto trentino local, ocorreu algum fenômeno de adequação fonética, segundo os padrões do trentino. BONATTI (1974: 78) registra a palavra cavaòci [kava'st $\left.\int \mathrm{i}\right]<$ libélula $>$ no dialeto trentino de Pomeranos (Rio dos Cedros) e afirma se tratar de um empréstimo do português. No entanto, a palavra também ocorre no trentino piracicabano e ANEGGI (1984: 55), em seu dicionário do dialeto trentino de Val di Cembra, registra a mesma palavra indicando libélula.

\section{A) EMPRÉSTIMOS FONÉTICOS}

Analisando o dialeto trentino da comunidade, preservado em sua forma mais conservadora pelas duas gerações mais velhas de descendentes, a mais notória influência fonética do português é, sem dúvida, a realização de [ $\Lambda$ que inexiste no trentino europeu e, segundo ROHLFs (1954), nos dialetos setentrionais italianos daquela área alpina. A lateral palatal sonora ocorre em posição intervocálica como no português, sobretudo nas palavras brasileiras incorporadas ao dialeto trentino. Os casos registrados em palavras trentinas são os seguintes, acima identificados e descritos: 
$\begin{array}{lll}\text { [ka'nederli] / [ka'nederᄉi] } & \text { canéderli } & <\text { nhoque de pão }> \\ {[\text { 'miljo] / ['mißo] }} & \text { milio } & <\text { milho }>\end{array}$

A retroflexa alveolar [ $\iota]$, típica do falar piracicabano, inexiste entre os falantes bilíngues do dialeto trentino e não foi registrado nenhum caso de seu uso entre os falantes mais velhos do trentino piracicabano. Trata-se de uma característica encontrada no português das gerações mais novas, principalmente das pessoas que mantém maior contato com pessoas de fora da comunidade ${ }^{208}$.

\section{B) EMPRÉSTIMOS GRAMATICAIS}

Os empréstimos são, de modo geral, de palavras simples, compostas ou de locuções. Temos casos de empréstimos de palavras simples:

[Sa] <chá>

['Sapa] <chapa $>$

Para os casos de empréstimos de palavras compostas existem dois casos. Ou com os dois elementos do português:

['para 'rajo] <para-raios $>$

Ou com um elemento do português e outro do trentino:

$\begin{array}{ll}\text { ['benja 'fjor] } & <\text { beija-flor }> \\ \text { ['nar 'mbora] } & <\text { ir embora }>\end{array}$

${ }^{208}$ Cfr. nas gravações a ocorrência da retroflexa na fala de uma informante do Grupo C (1CSO - M.C.S.T), cuja atuação ativa nos eventos da comunidade lhe garante bastante contato com pessoas de outros bairros e da área urbana de Piracicaba. 
['dio 'pia] < < > > lins pia!> (interjeição de admiração ou reprovação)

['dio mos'kito] < < > Deus mosquito!> (interjeição de admiração ou reprovação)

['dio 'tanke] > > Deus tanque!> (interjeição de admiração ou reprovação)

['dio kas'tzlo] < > Deus castelo!> (interjeição de admiração ou reprovação)

['dio 'bəja] $\quad<$ Deus bóia $>^{209}$ (interjeição de admiração ou reprovação)

O caso ['nar 'mbəra] apresenta uma variação lexical com uso do verbo trentino nar $<$ ir> juntamente com embora do português. O mesmo uso foi registrado por BonATTI (1974: 75) no dialeto trentino de Pomeranos (município de Rio dos Cedros), em Santa Catarina.

\section{C) EMPRÉSTIMOS LEXICAIS}

Para o uso do léxico trentino na comunidade piracicabana, existem três situações:

a) Preservação das formas originais do trentino europeu.

b) Variação lexical por ampliação, com uso das formas originais do trentino europeu juntamente com aquelas advindas do português (variante caipira e norma culta).

c) Substituição total das formas do trentino europeu por aquelas advindas do português.

Interessa-nos aqui a variação lexical por ampliação que ocorrem na comunidade, onde os empréstimos do português são utilizados pelos falantes juntamente com o as palavras originalmente trentinas:

\begin{tabular}{|c|c|c|c|c|}
\hline Português & $\begin{array}{l}\text { Trentino } \\
\text { europeu }\end{array}$ & Grafia & \multicolumn{2}{|c|}{ Trentino piracicabano } \\
\hline tijolo & [ma'ton] & matón & [ma'ton] & $\begin{array}{r}\text { [ti'dzoł] } \\
{\left[\mathrm{ti}^{\prime} \mathrm{d} 3 \mathrm{O}^{\mathrm{j}}\right]}\end{array}$ \\
\hline
\end{tabular}

${ }^{209}$ bóia $=$ comida 


\begin{tabular}{|c|c|c|c|c|}
\hline lugar & [posti'øł] & postiöl & [posti'øł] & [luga'rot] \\
\hline tesoura & ['forbes] & fòrbes & ['fJrbes] & [te'zora] \\
\hline estaca & [s'tela] & stèla & ['stela] & ['staka] \\
\hline capeta & [di'aoł] & diàol & [di'aoł] & [ka'peta] \\
\hline empilhar & [nmu't\}ar] & enmuciàr & [nmu't $\left.\int a r\right]$ & [mp'iar] \\
\hline telha & ['tegola] & tégola & ['tegola] & ['teja] \\
\hline encaixar & [s'meter] & sméter & ['smeter] & [nka'sar] \\
\hline cerveja & ['bira] & bira & ['bira] & $\begin{array}{l}\text { [ser'veza] (SO) } \\
\text { [ser'vedza] (S) }\end{array}$ \\
\hline tostão & ['sołdi] & sòldi & ['sołdi] & [tos'tõ] \\
\hline veado & ['t $\left.\int e r v o\right]$ & cérvo & ['t tervo] & [via'dst] \\
\hline terreiro & [te'ren] & terén & [te'ren] & [te'rero] \\
\hline apressado & $\begin{array}{c}\text { [spese'ga] } \\
\text { [pese'ga] }\end{array}$ & $\begin{array}{l}\text { spessegà } \\
\text { pessegà }\end{array}$ & $\begin{array}{c}\text { [spese'ga] } \\
\text { [pese'ga] }\end{array}$ & [apre'sa] \\
\hline alemã & $\begin{array}{l}\text { [to'deska] } \\
\text { [te'deska] } \\
\text { [ale'mana] }\end{array}$ & $\begin{array}{l}\text { todésca } \\
\text { tedésca } \\
\text { alemàna }\end{array}$ & $\begin{array}{l}\text { [to'deska] } \\
\text { [te'deska] } \\
\text { [ale'mana] }\end{array}$ & [ale'moa] \\
\hline barro & 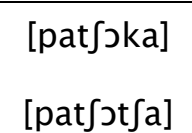 & $\begin{array}{l}\text { paciòca } \\
\text { paciòcia }\end{array}$ & $\begin{array}{l}\left.\text { [pa't } \int \partial k a\right] \\
{\left[p a^{\prime} t \int \partial t \int a\right]}\end{array}$ & ['baro] \\
\hline bagaço & [gran] & gran & ['gran] & [ba'gas] \\
\hline azul & [gris] & gris & ['gris] & [a'zuł] \\
\hline barranco & [mont] & mont & ['mont] & [ba'rayk] \\
\hline brejo & ['pałta] & pàlta & ['pałta] & ['bredzo] \\
\hline foice & [fałs] & falz & ['fałs] & ['fołs] ['fojs] \\
\hline neta & $\begin{array}{l}\text { ['nesa] } \\
\text { [ne'ola] } \\
\text { [ne'ola] }\end{array}$ & $\begin{array}{c}\text { nèza } \\
\text { neóla } \\
\text { neóda }\end{array}$ & $\begin{array}{c}\text { ['nesa] } \\
\text { [ne'ola] } \\
\text { [ne'oda] }\end{array}$ & ['ncta] \\
\hline
\end{tabular}




\begin{tabular}{|c|c|c|c|c|}
\hline sogro & [mi'ser] & misér & [mi'ser] & ['sogro] \\
\hline cenoura & ['rava 'załda] & ràva zàlda $(\mathrm{SO})$ & ['rava 'załda] & [se'nora] \\
\hline cenoura & ['rava 'dzałda] & ràva giàlda $(\mathrm{S})$ & ['rava 'dzałda] & [se'nora] \\
\hline
\end{tabular}

\section{D) EMPRÉSTIMOS DA VARIANTE CAIPIRA}

Alguns empréstimos de origem indígena ocorrem no trentino piracicabano, por conta do contato deste com a variante caipira (que preserva um considerável número de palavras de origem indígena).

Algumas palavras da variante caipira ocorrem no trentino piracicabano exatamente como em Piracicaba, sem nenhuma adequação fonética.. Na maioria dos casos, entretanto, o dialeto tende a adequar as palavras às características foneticais do trentino, inclusive com casos de mudança de entonação de uma sílaba para outra.

\begin{tabular}{|c|c|c|}
\hline $\begin{array}{c}\text { Dialeto caipira } \\
\text { Piracicaba }\end{array}$ & Trentino piracicabano & Significado \\
\hline [taцa'iła] [taцa'ira] [tra'ira] & [tara'ira] & traíra (espécie de peixe) \\
\hline [baso'ła] & [baso'ra] & espécie de arbusto \\
\hline [bo'dske] & [bo'dəka] & estilingue \\
\hline [buti'kaba] [boti'kaba] & [boti'kaba] [boti'kava] & jaboticaba \\
\hline [ka'jera] [koa'jera] & [ka'jera] [koa'jera] & $\begin{array}{c}\text { coalheira; peça de couro que se } \\
\text { coloca sobre o arreio }\end{array}$ \\
\hline [ka'lipju] & [ka'lipjo] & eucalípto \\
\hline [kalipi'a] & [kalipi'a] & bosque de eucalíptos \\
\hline \multirow[t]{2}{*}{ [ka'pz̃w] } & [ka'pon] & capão; moita \\
\hline & & rubim \\
\hline
\end{tabular}




\begin{tabular}{|c|c|c|}
\hline [xu'bĩ] & [ru'bin] & $\begin{array}{c}\text { (planta medicinal contra } \\
\text { bicheira em animais) }\end{array}$ \\
\hline ['3cka] & ['dzzka] & Jeca \\
\hline [mo'rz̃w] & [mo'ron] & mourão \\
\hline [3agwati'rika] [zagwatfi'rika] & [dzagata'rika] & jaguatirica \\
\hline [3aka're] & [dzaka're] & jacaré \\
\hline [mз̃du'i] & [mandu'i] & amendoim \\
\hline [zata'i] & [zata'i] [dza'taj] & $\begin{array}{c}\text { jataí; jatobá (espécie de } \\
\text { árvore) }\end{array}$ \\
\hline [lai'gatu] & [lar'gat] [lar'gata] & lagarto \\
\hline ['õsa] & ['onsa] & onça \\
\hline [o'גisu] & [o'riso] & ouriço \\
\hline [pĩta'siwgv] [pĩta'siwva] & [pinta'setva] & pintassilgo \\
\hline [xo'ż̃พ] & [ro'dzon] & rojão \\
\hline [u^u'bu] & [ru'bu] & urubu \\
\hline [ga'java] & [ga'java] [sga'java] & goiaba \\
\hline [is'teła] & ['stera] & esteira para grãos \\
\hline [tra'tol] & [stra'tor] & trator \\
\hline [goja'beła] [gaja'beıa] & $\begin{array}{c}\text { [goja'vare] [gaja'vare] } \\
\text { [sgaja'vare] [sgaja'vara] }\end{array}$ & goiabeira \\
\hline ['tz̃̂ke] & ['tanke] & tanque; açude \\
\hline ['tafv] & ['tas] & tacho \\
\hline [a'vẽka] & ['venke] & avenca \\
\hline [vin'tẽ] & [vin'tin] & vintém \\
\hline 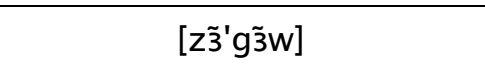 & [zan'gon] & zangão \\
\hline ['Sapa] & ['tfapa] & chapa \\
\hline [be'zoxu] & [be'zoro] & besouro \\
\hline [bol'da] & [bor'dar] & bordar \\
\hline
\end{tabular}




\begin{tabular}{|c|c|c|}
\hline [kaxa'patu] & [kara'pat] & carrapato \\
\hline [ka'^ũfu] & [ka'rut $\left.\int o\right]$ & caruncho \\
\hline [kĩ'taw] [kî'ta] & [kin'tał] & quintal; pátio \\
\hline [Su'xaskv] & [su'rasko] [Su'rasko] & churrasco \\
\hline [ko'keıv] & [ko'ker] & coqueiro \\
\hline [ko'kĩnu] & [ko'kin] & coquinho \\
\hline [ĩkos'ta] & [nkos'tar] & enconstar \\
\hline [ĩfexu'za] & [nferu'dzar] & enferrujar \\
\hline ['zaka] & ['dzaka] & jaca \\
\hline
\end{tabular}

Dois casos registrados no dialeto trentino de Piracicaba merecem especial atenção: as palavras ['bruza] e ['bułger]. A palavra bùlgher ['bułger] ou bùlghero ['bułgero] para designar bugre (índio) não é um caso apenas da comunidade piracicabana ${ }^{210}$. Também BonATTI (1974) registra bùlgher no dialeto trentino de Rio dos Cedros - SC, o que torna curiosa sua etimologia no Brasil, uma vez que a palavra ocorre de forma idêntica em duas colônias trentinas distintas ${ }^{211}$.

\footnotetext{
${ }^{210}$ Segundo o dicionário HoUAISS, a palavra bugre se originou do francês bougre < búlgaro > que, por sua vez, se originou da forma latina medieval bulgarus <búlgaro>, registrada pela primeira vez em $1172 \mathrm{com}$ significando de "herege" ou "sodomita". A palavra possuía na Idade Média um acentuado valor pejorativo, associado à heresia que se desenvolveu na Bulgária no século IX, a seita dos bogomilitas, cujo nome se origina em seu fundador, o padre Bogomil. O bogomilismo era associado entre os bizantinos ao maniqueísmo, por ser muito semelhante à heresia maniqueísta que no século VII havia se desenvolvido na Ásia Menor. Os seguidores do bogomilismo negavam o mundo material, considerado por eles uma obra do demônio que, enquanto artífice da natureza, estaria presente na natureza humana; também negavam os ensinamentos da Igreja, a liturgia, os sacramentos, o casamento, a veneração da Cruz, autoridade eclesiástica e tudo o que consideravam perecível (também não comiam carne,). Na Europa Ocidental, a denominação "búlgaro" foi associada à heresia e, no decorrer dos séculos, aos atos "heréticos" como a sodomia, a devassidão, a pederastia, o incesto etc. Aqueles que representavam a porção mais baixa da sociedade européia, como infiéis ou praticantes da sodomia, eram chamados "búlgaros". BRUNELLO (1996: 21) afirma que na península itálica do século XIX, as palavras bulgaro ou bulghero preservavam o significado herético, não indicando somente os sodomitas, mas também as pessoas de hábitos brutos e incivilizados. Em Portugal, a palavra chegou através da França, sob a forma de bougre, significando herege ou sodomita. FREYRE (1963: 178) afirma que o herege era imediatamente associado ao sodomita, de forma que uma condenação gerava a outra. Quando da colonização lusitana no Brasil, os portugueses chamaram os índios "bugres" por causa de seus hábitos selvagens (nudez, antropofagia) e de sua moral vacilante (poligamia, sodomia).

${ }^{211}$ Pudemos registrar na cidade de São Bento do Sul, em Santa Catarina, a palavra Buger $<$ bugre $>$ que ocorre como ['buger] ou ['bugar]. Na cidade, colonizada sobretudo por emigrantes bávaros e suábios, registramos Bugersbach [bugers'bax] / [bugas'bax] <rio dos bugres $>$.
} 
No caso correspondente à palavra blusa do português, existem no dialeto trentino as formas blùsa ['blusa] ['bluza], plus(a) ['plus] e ['plusa] ${ }^{212}$. A mudança da lateral alveolar sonora [I] para a vibrante simples [r] é um fenômeno de evolução normal dos grupos de $\boldsymbol{l}$ do latim vulgar para o português (lat. blandus port. brando; lat. clavus port. cravo; lat. duplus port. dobro). São relativamente comuns no trentino e no vêneto os casos de metátese: dormì / dromìr <dormir>; endormenzàr / endromenzàr <adormecer>; compràr / crompàr <comprar>. Contudo, não nos é possível afirmar se neste caso ocorre um fenômeno do dialeto trentino ou uma interferência da variante caipira do português que também apresenta a palavra ['bruza] e, assim, limitamo-nos a registrá-lo ${ }^{213}$.

\subsubsection{VARIAÇÃO}

\section{A) DIFERENÇA NA FORMA LEXICAL}

Algumas palavras trentinas foram completamente substituídas pelas palavras advindas do português (variante caipira) e foram adaptadas à fonologia trentina:

\begin{tabular}{|c|c|c|c|}
\hline Português & Trentino Europeu & Grafia & Trentino Piracicaba \\
\hline abacaxi & [ana'nas] & ananàs & [baka'si] \\
\hline padeiro & [pis'tor] & pistór & [pa'der] [pa'dero] \\
\hline rolo & {$[$ 'dzom] } & gióm & ['rolo] \\
\hline chá & ['tz] & tè & ['Sa] ou ['sa] \\
\hline violão & [vi'วla] & viòla & [vio'lõ] \\
\hline
\end{tabular}

${ }^{212}$ No alemão ocorre Bluse <blusa>, que também ocorre alemão tirolês (tirolerisch). Não encontramos, entretanto, nenhum dado comprobatório de empréstimo advindo do alemão e limitamo-nos a registrar a palavra.

${ }^{213}$ OSTI (2001) registra o caso bródegh < sujo>, que ocorre no trentino piracicabano, como uma adequação trentina do termo pluetig $<$ sujo de sangue $>$ do alemão tirolês. 


\begin{tabular}{|c|c|c|c|}
\hline chiqueiro & [sta'lıt] & stalòt & [si'kero] \\
\hline firma & {$[$ 'dita] } & dita & ['firma] \\
\hline $\begin{array}{c}\text { arreio } \\
\text { port. caipira } \text { zarreio }^{214}\end{array}$ & ['dzof] & gióf/gióch & [za'rejo] \\
\hline
\end{tabular}

\section{B) DIFERENÇA DE SIGNIFICADO POR SUBSTITUIÇÃO DE OBJETO}

Em alguns casos, ocorreu a preservação de palavras trentinas que no Brasil tiveram seus significados transferidos para outros objetos, por causa da mudança de ambiente.

\begin{tabular}{|c|c|c|c|c|}
\hline $\begin{array}{l}\text { Trentino } \\
\text { europeu }\end{array}$ & Grafia & Significado & $\begin{array}{c}\text { Trentino } \\
\text { piracicabano }\end{array}$ & Significado \\
\hline [stropa'kuł] & stropacùl & $\begin{array}{l}\text { fruto de planta } \\
\text { (Rosa canina) }\end{array}$ & [stropa'kuł] & $\begin{array}{l}\text { fruto silvestre local } \\
\text { (não identificado) }\end{array}$ \\
\hline ['kJrf] & còrf & $\begin{array}{c}\text { corvo europeu } \\
\text { (Corvus corone } \\
\text { corone) }\end{array}$ & ['kJrf] & $\begin{array}{c}\text { urubu } \\
\text { (Sarcorhampus papa) }\end{array}$ \\
\hline ['bołp] & bolp & $\begin{array}{c}\text { raposa } \\
\text { (Vulpes vulpes) }\end{array}$ & ['bołp] & $\begin{array}{c}\text { gambá } \\
\text { (Didelphis } \\
\text { marsupialis) }\end{array}$ \\
\hline ['pasera] & pàssera & $\begin{array}{c}\text { pardal } \\
\text { (Passer domesticus) }\end{array}$ & ['pasera] & $\begin{array}{c}\text { tico-tico } \\
\text { (Zonotrichia capensis) }\end{array}$ \\
\hline ['merlo] & mèrlo & $\begin{array}{c}\text { melro } \\
\text { (Turdus merula) }\end{array}$ & ['merlo] & $\begin{array}{c}\text { sabiá } \\
\text { (Turdus rufiventris) }\end{array}$ \\
\hline $\begin{array}{l}\text { [ga'lina } \\
\text { 'dakwa] }\end{array}$ & galìna d'àqua & $\begin{array}{c}\text { galinha d'água } \\
\text { (Gallina chloropus) }\end{array}$ & $\begin{array}{c}\text { [ga'lina } \\
\text { det'mato] }\end{array}$ & $\begin{array}{c}\text { galinha d’água } \\
\text { (Gallina chloropus } \\
\text { galeata); } \\
\text { saracura } \\
\text { (Aramides cajanea) }\end{array}$ \\
\hline [fjo'rin] & fiorin & florim & [fjo'rin] & unidade monetária \\
\hline
\end{tabular}

${ }^{214}$ Criado por metanálise, como ['żjo]. 


\begin{tabular}{|c|c|c|c|c|}
\hline & $\begin{array}{c}\text { (antiga unidade } \\
\text { monetária } \\
\text { austríaca) }\end{array}$ & & $\begin{array}{c}\text { brasileira } \\
\text { (réis, cruzeiro, } \\
\text { cruzado, real, etc) }\end{array}$ \\
\hline
\end{tabular}

\subsubsection{DERIVAÇÃO}

Por derivação entende-se a criação de novas palavras dentro da língua, por meio de sufixação. O domínio semântico da flora e da fauna é geralmente aquele onde mais se encontram esses casos - com base em empréstimos do português - mas há ainda casos em outros domínios, como adjetivos e ofícios.

A derivação no trentino piracicabano seguiu, na grande maioria dos casos, a partir do modelo gramatical e fonológico do trentino, com aparecimento das variantes alomórficas -àr, -àra, -àre, -àve, -èl, -èi, -èr, -èri, -ér, em variação livre:

$\begin{array}{lll}\text { [goja'var] } & \text { goiavàr } & <\text { goiabeira }> \\ \text { [gaja'vara] } & \text { gaiavàra } & <\text { goiabeira }> \\ \text { [sgaja'vara] } & \text { sgaiavàra } & <\text { goiabeira }> \\ \text { [gaja'vare] } & \text { gaiavàre } & <\text { goiabeira }> \\ \text { [goja'vare] } & \text { goiavàre } & <\text { goiabeira }> \\ \text { [sgaja'vare] } & \text { sgaiavàre } & <\text { goiabeira }> \\ \text { [sgaja've] } & \text { sgaiàve } & <\text { goiabeira }> \\ \text { [pa'tcł] } & \text { patèl } & <\text { pato }> \\ \text { [bankes'tzł] } & \text { banchestèl } & <\text { morador do Bairro Santa Olímpia }>\end{array}$




\begin{tabular}{|c|c|c|}
\hline [bankes'tej] & banchestèi & $<$ morador(es) do Bairro Santa Olímpia $>^{215}$ \\
\hline [santa'ner] & santanèr & $<$ morador do Bairro Santana $>$ \\
\hline [sayta'neri] & santanèri & $<$ morador(es) do Bairro Santana $>$ \\
\hline [brazi'ljer] & brasiliér & $<$ brasileiro $>$ \\
\hline [pa'der] & padér & $<$ padeiro $>$ \\
\hline [pi'ner] & pignér & $<$ pinheiro $>$ \\
\hline
\end{tabular}

\subsubsection{OUTROS CASOS}

Algumas palavras da fala da comunidade têm significado muito particular e ocorrem tanto no trentino piracicabano como na variante do português. Não foram encontradas nem no trentino europeu, nem no dialeto caipira em Piracicaba e parecem ser construções neológicas do trentino piracicabano.

\begin{tabular}{|c|c|c|}
\hline Português & Trentino piracicabano & Significado \\
\hline caneco & {$[$ kane'kət] [kane'kəta] } & criança pequena \\
\hline caneco & {$[$ kane'karo] [kane'kara] } & $\begin{array}{c}\text { pessoa que recolhe latinhas de } \\
\text { alumínio }\end{array}$ \\
\hline novela & [nove'laro] [nove'lara] & $\begin{array}{c}\text { pessoa que assiste muitas } \\
\text { novelas televisivas }\end{array}$ \\
\hline goiaba & [gaia'von] [sgaia'von] & desdentado \\
\hline
\end{tabular}

Nenhum dos informantes por nós consultados (das entrevistas ou demais membros da comunidade) soube explicar a origem dos termos canecòt [kane'kət] e canecòta

\footnotetext{
${ }^{215}$ É uma característica relativamente comum no dialeto trentino a ocorrência das desinências plurais $\boldsymbol{- i}$ e $\boldsymbol{- e}$ em palavras no singular. No caso de palavras masculinas, ocorre, sobretudo, em casos de -o precedidos de $-\boldsymbol{i}$ : el fastìdi ou el fastidio <0 desmaio $>$, el sòli ou el sòlo <0 solo; as propriedades $>$, el sòci ou el sócio <0 sócio $>$.
} 
[kane'kıta] para indicar crianças pequenas, embora sejam palavras frequentes na fala da comunidade. No caso de gaiavón [gaia'von] ou sgaiavón [sgaia'von], trata-se de uma alusão à goiaba partida ao meio, que lembra uma gengiva com poucos dentes.

Os casos novelàro [nove'laro] e novelàra [nove'lara], lembrando os adjetivos noveleiro e noveleira existentes no português, são frequentemente usados, inclusive na variante do português da comunidade. Ambos os sufixos seguem o modelo trentino, a partir do masculino -àr (que se tornou -àro) e do feminino -àra.

Encontramos, ainda, os seguintes exemplos, nomeando algumas aves:

\begin{tabular}{|c|c|c|}
\hline Português & Trentino piracicabano & Significado \\
\hline $\begin{array}{c}\text { anu-branco } \\
\text { (Guira guira })\end{array}$ & ['koa 'longa] & rabo comprido; cauda longa \\
\hline $\begin{array}{c}\text { anu preto } \\
(\text { Chrotophaga ani })\end{array}$ & ['koa 'longa] & rabo comprido; cauda longa \\
\hline $\begin{array}{c}\text { saracura } \\
\text { (Aramides cajanea })\end{array}$ & [ga'lina deł'mato] & galinha do mato \\
\hline
\end{tabular}

O termo cóa lónga ['koa 'longa] faz alusão ao rabo comprido dessas aves brasileiras e sua construção apresenta duas palavras existentes no dialeto trentino. Caso diferente é o de galina del màto [ga'lina dદt'mato], referindo-se à saracura, onde ocorre uma diferença de significado por substituição de objeto (saracura do português por galina do trentino) e um empréstimo da palavra mato do português, cujo termo trentino correspondente seria bosch. 


\section{O DiALETO CAIPIRA EM PIRACICABA: ASPECTOS GERAIS}

\subsection{INTRODUÇão}

O principal objetivo desse trabalho é traçar um perfil linguístico da variante do português falado da comunidade tirolesa de Piracicaba, apresentando suas peculiaridades e influências do dialeto trentino. Trata-se, assim, de uma descrição dos aspectos presentes na fala dos bairros Santana e Santa Olímpia, cuja maioria de moradores é descendente de tiroleses. Entretanto - como se pode observar no próximo capítulo - o léxico de origem trentina presente na variante do português da comunidade não se limita à fala dos descendentes, mas aparece na fala de não-descendentes que moram nos bairros.

Durante a coleta de dados sobre a variante falada da comunidade tirolesa, tivemos oportunidade de registrar alguns aspectos do dialeto caipira em Piracicaba. Haja vista que a variante da comunidade diferencia-se do falar dos demais bairros piracicabanos por causa das influências do dialeto trentino, acreditamos que uma apresentação introdutória sobre alguns aspectos do dialeto caipira em Piracicaba sirva para uma melhor contextualização do ojeto de estudo deste trabalho. 
A intenção desse capítulo não é, portanto, descrever exaustivamente o dialeto caipira como ocorre na cidade de Piracicaba. Como afirmado, trata-se de uma descrição introdutória, a partir de observações nossas e de estudos sobre o dialeto caipira (AMARAL, 1920; NATAL, 1974; LEME, 2001), visando facilitar a identificação das diferenças existentes na variante falada do português da comunidade tirolesa.

Nos exemplos apresentados abaixo, há alguns que são comentados nas notas de rodapé com informações referentes às entrevistas gravadas na comunidade tirolesa.

\subsection{ORIGENS DO DIALETO CAIPIRA}

Da antiga língua utilizada pelos jesuítas e bandeirantes, chamada língua geral, que na capitania paulista recebia gradativamente as influências do português que se expandia pelo interior brasileiro, originou-se o dialeto caipira ${ }^{216}$. Pode-se afirmar que a língua Geral (cuja forma moderna, ainda em uso na região amazônica é chamada nheengatu) era o tupi mais ou menos regulado pela gramática da língua portuguesa ${ }^{217}$. Os portugueses que chegavam ao Brasil durante o período colonial eram oriundos de diferentes regiões de Portugal e pertenciam a classes sociais distintas; possuíam um falar heterogêneo e diversificado, de acordo com seus dialetos regionais. Segundo MatTos E SiLVA (2004), as sucessivas ondas de colonizadores portugueses (que atingiam momentos de pico, como na corrida do ouro) não foram suficientes para a implantação do português como língua de comunicação da costa e do interior. Minoria perante os tupinambás, a população lusa adotou a língua indígena para estabelecer comunicação com os nativos; outro fator

\footnotetext{
${ }^{216}$ RiBeiro (1946) e Melo (1975) utilizam o termo "dialeto dos bandeirantes" em vez de "língua geral".

217 Os jesuítas utilizaram o tupi (na sua variante conhecida como tupinambá) como referência para a elaboração da língua geral porque foi este o idioma do primeiro contato com as tribos indígenas da costa brasileira. Acrescido de vocábulos do guarani, do português e do espanhol (uma vez que seu desenvolvimento se deu na época da unificação das coroas portuguesa e espanhola, entre 1580 e 1640), o nheengatu teve sua disseminação pelo Brasil durante o trabalho missionário jesuítico. Era utilizado, inclusive, para o contato com índios de outros troncos linguísticos, como o jê.
} 
relevante para a adoção do tupi era o sistema de cunhadismo ${ }^{218}$, que garantiu o aprendizado da língua indígena aos descendentes de casamentos mistos. Do contato entre os falares tupis e os falares portugueses, foi criada uma língua franca para que a comunicação efetiva fosse estabelecida entre portugueses e índios e mesmo entre as diversas tribos:

"Admitindo a afinidade troncal tupi-guarani, cada individuo de cada tribo continuava com sua lingua para fins intratribais. Mas, para fins extratribais e intertribais - poderosamente estimulados pela subversão trazida pelo colonizador-, recorria à língua geral, que lhe era afim, com o que se fazia bilíngue na mesma, digamos, estrutura linguageira”.

(HouAISS, 1992: 80)

Do século XVII até o início do século XVIII a língua geral foi o idioma corrente em boa parte do Brasil e se expandiu por São Paulo no século XVII com o movimento das Monções que seguia para Mato Grosso e Goiás. O idioma servia como instrumento pacificador e unificador entre as tribos que falavam variações da língua tupi. O padre José de Anchieta deixou uma gramática e várias orações traduzidas para o nheengatu; do século XVII há o dicionário de Pero de Castilho.

A partir de 1757, quando de sua ampla difusão através do trabalho catequético dos jesuítas, a língua geral começou gradativamente em desuso. Por determinação coroa lusitana, com a criação da Lei do Diretório dos Índios implantada à época de Sebastião de Carvalho e Melo (1699 - 1792), Marquês de Pombal, que, entre outras coisas, estabelecia a proibição da escravidão indígena, impunha o uso obrigatório do português e proibia o uso da popular língua geral. A estratégia política da metrópole de impor o português (para manter seus vínculos com a colônia) fez com que a língua geral fosse abolida na região litorânea e se preservasse apenas no interior (principalmente na Capitania de São Paulo). Preservada entre os habitantes do interior, foi sendo transmitida através da oralidade e sem o controle da escolarização sistemática.

O dialeto caipira é uma variante histórica do Português Brasileiro, que se estende pelos estados de São Paulo, Goiás, sul de Minas Gerais, parte do Mato Grosso do Sul, do Rio de Janeiro, do Paraná, de Santa Catarina e do Rio Grande do Sul. Formada

\footnotetext{
${ }^{218}$ Antigo costume entre algumas populações indígenas de incorporar estranhos à sua comunidade. Homens portugueses que chegavam sozinhos ao Brasil contraiam casamento com mulheres indígenas, estabelecendo, assim, laços de amizade e de parentesco. Cfr. SAnTiAgO-AlmeidA \& Cox (2005).
} 
principalmente do contato entre o português da época colonial (séculos XVI a XVII) e as línguas indígenas, foi enriquecido posteriormente com os vocábulos de origem africana trazidos pela mão-de-obra escrava que Portugal introduziu no Brasil. Pode ser considerado um resultado da interação entre a língua Geral e o português e apresenta vários fenômenos lingüísticos arcaicos (sobretudo fonéticos e lexicais) comuns ao período colonial brasileiro. Esse dialeto vem sofrendo profundas mudanças, por causa da influência de outras normas.

Na década de 1920, AMARAL afirmava que na então província de São Paulo havia um "dialeto ${ }^{219}$ bem pronunciado", que até o final do século XIX era a fala dominante da maioria da população paulista, inclusive entre a minoria culta. Naquela década, AMARAL já comentava a diminuição do antigo modo de falar caipira, por conta da educação das gerações mais novas e das mudanças sociais brasileiras:

"Ao tempo em que o célebre falar paulista reinava sem contraste sensivel, o caipirismo não existia apenas na linguagem, mas em todas as manifestações da nossa vida provinciana. De algumas décadas para cá tudo entrou a transformar-se. A substituição do braço escravo pelo assalariado afastou da convivência cotidiana dos brancos grande parte da população negra, modificando assim um dos fatores da nossa diferenciação dialetal. Os genuínos caipiras, os roceiros ignorantes e atrasados, começaram também a ser postos de banda, a ser atirados à margem da vida coletiva, a ter uma interferência cada vez menor nos costumes e na organização da nova ordem de coisas. A população cresceu e mesclou-se de novos elementos. Construíram-se vias de comunicação por toda a parte, intensificou-se o comércio, os pequenos centros populosos que viviam isolados passaram a trocar entre si relações de toda a espécie, e a província entrou por sua vez em contato permanente com a civilização exterior. A instrução, limitadíssima, tomou extraordinário incremento. Era impossível que o dialeto caipira deixasse de sofrer com tão grandes alterações do meio social”.

${ }^{219}$ Como afirmado, a definição entre língua e dialeto se baseia, muitas vezes, em diferenças muito tênues. Dialeto é um termo originário do grego $\delta$ iá $\lambda \varepsilon \kappa \tau o \varsigma$ (“conversação, maneira de falar"), que vem entendido como o modo particular de se falar de uma determinada região ou comunidade linguística. ELIA (2000: 15), afirma que as características diferenciadoras entre a língua e o dialeto nem sempre se excluem. Segundo o autor, o que define o conceito de língua é o falar estruturado de uma comunidade, seu prestígio histórico e seu reconhecimento oficial do Estado; o dialeto, em contraposição, é definido como o falar de uma comunidade menor, cuja língua é geralmente praticada sob a forma oral e sem reconhecimento oficial do Estado para as relações internas e externas. Sabe-se, contudo, que o conceito de dialeto não se limita apenas ao que se refere ao "extra-oficial", uma vez que as questões políticas e sociais são fundamentais para o êxito de um dialeto perante outros; do resultado desse êxito, oficializa-se um dialeto de prestígio e de tradição cultural que passsa a ser considerado a língua oficial de uma nação - um exemplo é o idioma italiano que se solidificou na península itálica meio século depois da unificação italiana, com auxílio dos meios de comunicação de massa. 
Além disso, o dialeto caipira apresenta traços comuns a outras variantes regionais brasileiras e lusitanas, como o enfraquecimento da lateral palatal $[\Lambda]$, que se transforma em um alofone do tipo glide ou vogal anterior alta, formando um hiato com a vogal anterior: ['paᄉa] > ['paja] <palha> (NATAL, 1974; LEME, 2001). Conforme as observações de AMARAL (1920: 30-47), são encontradas estruturas linguísticas que eram empregadas em textos escritos arcaicos do português medieval e seiscentista, de modo que eram consideradas formas adequadas à norma padrão daquela época.

O dialeto caipira é, portanto, o falar da população interiorana que manteve durante muito tempo pouco ou praticamente nenhum contato com os centros urbanos. Por ser falado pela população (principalmente cabocla) de nenhuma ou pouca escolaridade, foi amplamente estigmatizado pela sociedade hierarquizada (RODRIGUES, 2006) e perdeu espaço rapidamente com a crescente constituição da norma culta padrão.

\subsection{O DiAleto CAIPIRA EM PiraCiCABA}

$\mathrm{Na}$ região piracicabana, o dialeto caipira é a variedade de português em uso nas áreas rurais e, até mesmo, urbanas. Ainda que tenha perdido muitas de suas características mais arcaicas, a variante caipira é ainda uma característica marcante do falar piracicabano, sobretudo pelo uso da retroflexa [^], que não tem seu uso limitado às áreas rurais.

Entre os descendentes tiroleses dos bairros Santana e Santa Olímpia, a variante caipira é considerada natural, conforme também constatou LEME (2001). O convívio com moradores de outros bairros (sobretudo Santa Teresinha) - onde o uso do dialeto caipira é comum -, por causa do trabalho, permitiu a influência da variante caipira na fala da comunidade tirolesa. Ainda que a variante caipira não ocorra entre os descendentes tiroleses da mesma forma que nos demais bairros rurais de Piracicaba, trata-se de uma variante linguística presente nos bairros (principalmente entre os mais jovens), por conta do 
contato da comunidade com moradores de demais bairros, além do grande número de descendentes que trabalham ou estudam fora da comunidade ${ }^{220}$.

\subsubsection{ASPECTOS VOCÁLICOS}

SÍMbOLOS FONÉTICOS VOCÁLICOS DO DIALETO CAIPIRA EM PIRACICABA

\begin{tabular}{|c|c|c|}
\hline Símbolo & Transcrição fonética & Significado \\
\hline [i] & [tıa'iła] & traíra \\
\hline [e] & ['feła] & feira \\
\hline$[\varepsilon]$ & ['pc] & pé \\
\hline [3] & ['tz̃ta] & tanta \\
\hline [e] & ['mate] & mata \\
\hline [a] & ['mato] ['matu] & mato \\
\hline [כ] & ['دłta] & horta \\
\hline [o] & ['połto] ['połtu] & porto \\
\hline$[v]$ & ['komv] ['komo] & como \\
\hline [u] & ['fumo] ['fumv] & $\begin{array}{c}\text { fumo; } \\
\text { verbo: fomos }\end{array}$ \\
\hline
\end{tabular}

\section{A) Fonemas vocálicos}

${ }^{220}$ Cfr. Parte II, capítulo 2.0. 
O sistema vocálico do dialeto caipira de Piracicaba é praticamente o mesmo se comparado às demais áreas de ocorrência do dialeto. Os fonemas vocálicos apresentam restrições de ocorrência segundo a tonicidade das sílabas, assim como demais variantes do Português Brasileiro (CÂMARA JR, 1975). A vogal central [e] parece ter pouca ocorrência em Piracicaba, que a substitui por [a]. Característica comum da fala brasileira (inclusive da norma culta falada), a variação das vogais meio-fechadas [e] e [o] para fechadas [i] e [u] em posição átona, sobretudo postônica, também ocorre em Piracicaba. Contudo, há uma convivência de formas, uma vez que, entre os piracicabanos, é frequente o uso das vogais meio-fechadas.

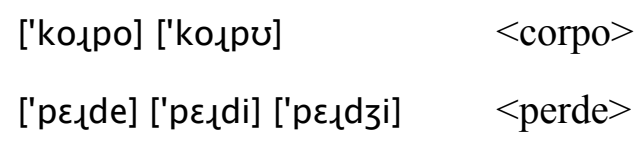

A modificação dos ditongos e tritongos é uma característica comum entre as variantes faladas do Português Brasileiro, com acréscimo ou queda da semivogal. As variações entre [a] e [aj] e entre [e] e [ej] ocorrem diante de $/ \mathrm{r} /, / \mathrm{s} /, / \mathrm{S} / \mathrm{e} / 3 /$, enquanto a variação entre [o] e [ow] parece ocorrer sem previsão do contexto sonoro que a precede ou sucede. Estes fenômenos ocorrem no dialeto caipira de Piracicaba e, nos contextos mencionados, as formas monotongadas são mais comuns que as ditongadas, que aparecem com maior frequência nos casos de sílaba tônica em posição final, seguida de /S/.

$\begin{array}{ll}\text { ['kafa] } & <\text { caixa }> \\ \text { [ka'deła] } & <\text { cadeira }> \\ \text { ['so] } & <\text { sou }>;<\text { senhor }> \\ \text { ['poko] ['pokv] } & <\text { pouco }> \\ \text { ['majs] ['maj] } & <\text { mas }>^{221} \\ \text { ['nэjs] ['nэj] } & <\text { nós }>^{222}\end{array}$
${ }^{221}$ Cfr. uso de ['maj] entre os informantes 1AS - G.V.B., 3ASO - L. D., 5AS - A.C.B., 1B.SO - O.P., 2BSO -
E.P., 4B.SO - R.C.C., 5BS - J.B., 1C.SO - M.C.S.C., 3CS - J.V., 5C.SO - F.C.D. 


$\begin{array}{ll}\text { [xa'pajs] [ıа'pajs] [ıа'paj] } & <\text { rapaz> } \\ \text { ['mejs] } & <\text { mês }> \\ \text { ['peSe] ['pe } \text { i] } & <\text { peixe> } \\ \text { ['lujs] } & <\text { luz }>\end{array}$

No dialeto caipira, é mais rara a formação de ditongos nasais oriundos de sequências fonológicas compostas por vogal oral mais arquifonema nasal; prevalece a ocorrência de uma vogal nasalizada, sem ditongo e sem consoante e, no caso de sílaba tônica em posição medial e final, realiza-se geralmente uma vogal oral.

$\begin{array}{ll}\text { [a'lẽj] } & <\text { além }> \\ \text { ['mẽte] ['mẽti] } & <\text { mente> } \\ \text { [vi'aze] } & <\text { viagem }> \\ \text { ['pase] } & <\text { passem }>\end{array}$

Nas formas verbais do dialeto caipira, em sílabas átonas em posição final, ocorrem as vogais posteriores [o] e [ひ] em lugar do ditongo nasal [ãw].

\begin{tabular}{|c|c|}
\hline [аı'maıo] [аı'maıv] & $<$ armaram $>$ \\
\hline 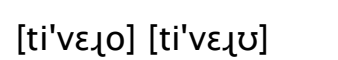 & $<$ tiveram $>$ \\
\hline [vol'taro] & $<$ voltaram $>^{223}$ \\
\hline
\end{tabular}

Naquelas cuja sequência fonológica é /oN/, onde o alofone é o ditongo nasal [õw], o dialeto caipira as realiza comumente como [з̃w].

$\begin{array}{ll}\text { ['sร̃w] } & <\text { som }> \\ \text { ['b3̃w] } & <\text { bom }>\end{array}$

${ }^{222}$ A forma ['njj] ocorre frequentemente na fala de todos os entrevistados da comunidade tirolesa. Também observamos seu uso na fala de pessoas de fora dos bairros, inclusive da área urbana de Piracicaba.

${ }^{223}$ Cfr. entrevista 5BS - J.B. 
Entretanto:

[kõ] $\quad<\mathrm{com}>$

\subsubsection{ASPECTOS CONSONANTAIS}

SíMbolos Fonéticos CONSONANTAIS do DIALETo CAIPIRA EM PIRACICABA

\begin{tabular}{|c|c|c|}
\hline Símbolo & Transcrição fonética & Significado \\
\hline p & ['pata] & pata \\
\hline b & ['bata] & tão \\
\hline t & ['tz̃w] & dão \\
\hline d & ['dz̃w] & cata (pega) \\
\hline k & ['kata] & gata \\
\hline g & ['gata] & tia \\
\hline t & ['tsia] & dia \\
\hline$d 3$ & ['dzia] & faca \\
\hline f & ['faka] & vaca \\
\hline$v$ & ['vaka] & sumido \\
\hline s & [su'mido] [su'midv] & zunido \\
\hline z & [zu'nido] [zu'nidu] & chama \\
\hline s & & \\
\hline
\end{tabular}




\begin{tabular}{|c|c|c|}
\hline 3 & ['зวja] & jóia \\
\hline$x$ & ['maxa] & marra \\
\hline $\mathrm{m}$ & ['mata] & mata \\
\hline $\mathrm{n}$ & ['nata] & nata \\
\hline $\mathrm{n}$ & ['vena] & venha \\
\hline$r$ & ['frz̃go] & frango \\
\hline$r$ & ['fara] & farra \\
\hline I & ['laygo] ['laıgv] & largo \\
\hline$\Lambda$ & ['gaᄉo] ['ga人u] & galho \\
\hline lj & $\begin{array}{c}\text { ['galjo] ['galju] } \\
\text { também: ['gajo] ['gajv] }\end{array}$ & galho \\
\hline
\end{tabular}

A) OCLusivas:

Os fonemas oclusivos / p, b, t, d, k, g / realizam-se da seguinte maneira:

\begin{tabular}{|c|c|}
\hline ['pz̃w] & $<$ pão $>$ \\
\hline ['bz̃w] & $<$ bom $>$ \\
\hline ['tz̃w] & $<$ tão $>$; <estão $>$ \\
\hline ['dz̃w] & $<$ dão $>$; $<$ dom $>$ \\
\hline ['kaza] & $<$ casa $>$ \\
\hline ['gota] & $<$ gota $>$ \\
\hline
\end{tabular}

No dialeto caipira em Piracicaba é possível encontrar (principalmente no meio urbano) casos de alofonia que envolvem a realização da oclusiva alveolar surda [t] como africada alveopalatal surda [t $]$, aparecendo frequentemente nos meios de comunicação (rádio principalmente). Ocorre também, no mesmo contexto, casos de realização da oclusiva alveolar sonora [d] como africada alveopalatal sonora [dz]. 


$\begin{array}{ll}\text { ['tia] ['t } f \text { ia] } & <\text { tia }>^{224} \\ \text { ['dia] ['dzia] } & <\text { dia }>\end{array}$

\section{B) NASAIS:}

Os fonemas nasais no dialeto caipira são / m, n, n / e se realizam da seguinte maneira:

$\begin{array}{ll}\text { ['mal] } & <\text { mar }>;<\text { mal }> \\ \text { ['nada] } & <\text { nada }> \\ \text { [lena'dol] } & <\text { lenhador }>\end{array}$

A oposição fonológica ocorre em contexto inicial de sílaba; em posição final, o arquifonema nasal /N/ pode ocorrer como uma consoante nasal ou como uma marca de nasalização da vogal precedente (mais comum no dialeto caipira):

$\begin{array}{ll}\text { ['kz̃mpo] ['kz̃mpv] ou ['kz̃po] ['kz̃pv] } & <\text { campo> } \\ \text { [kz̃n'tal] [kz̃n'ta] ou [kz̃'tal] [kz̃'ta] } & <\text { cantar }>\end{array}$

\section{C) Fricativas E AFRICADAS:}

Os fonemas fricativos / f, v, s, z, $\int, 3, \mathrm{x} /$ ocorrem da seguinte maneira:

$\begin{array}{ll}\text { ['faka] } & <\text { faca }> \\ \text { ['vaka] } & <\text { vaca }> \\ \text { ['sako] ['sakv] } & <\text { saco }> \\ \text { ['meza] } & <\text { mesa }> \\ \text { ['mufa] } & <\text { murcha }>\end{array}$

${ }^{224}$ Cfr. informante 1B S - O.P. sobre a fala das crianças da comunidade tirolesa. 
['suza] $\quad<$ suja $>$

Como afirmado acima, os casos de alofonia que realizam a oclusiva alveolar surda [t] como africada alveopalatal surda [t $]$ e a oclusiva alveolar sonora [d] como africada alveopalatal sonora [d3] ocorrem entre alguns falantes da área urbana e na fala dos meios de comunicação.

['lejt ii] ['lejte] $\quad<$ leite>

['dzia] ['dia] $\quad<$ dia $>$

LEME (2001: 104) apresenta os casos [tfa'pew] e [dza'ncla] como variantes de [ $\left.a^{\prime} p \varepsilon w\right]$ e [za'ncla] existentes no dialeto caipira de Piracicaba. Não registramos, em nenhum momento, o uso de africadas em posição inicial na variante caipira da comunidade tirolesa. É sabido, porém, que essa forma arcaica fora relativamente comum no dialeto caipira (AMARAL, 1976: 8), mas também não registramos nenhum caso em conversa com moradores de outras áreas de Piracicaba, como, por exemplo, do distrito de Santa Teresinha.

Uma característica da variante caipira, presente em Piracicaba, é a queda da fricativa alveolar surda [s] na forma plural dos nomes, uma vez que o morfema plural marca apenas o primeiro elemento mais à esquerda da frase e os demais ficam sem a marca de plural $\mathbf{s}$.

$\begin{array}{ll}\text { [us tłabaja'do] } & <\text { os trabalhadores }> \\ \text { [nos 'p plato] } & <\text { nos pratos }>^{225}\end{array}$

Por analogia, o $-\boldsymbol{s}$ final tende a cair em outros contextos, como no encontro das fricativas alveolares surda e sonora e diante de pausa. A nasalidade dos verbos na terceira pessoa do plural não ocorre no dialeto caipira.

${ }^{225}$ Cfr. entrevista 5BS - J.B. 
[u'zomi tła'baja] <os homens trabalham>

A fricativa velar aparece principalmente entre os falantes da área urbana piracicabana e nos meios de comunicação.

$\begin{array}{ll}\text { ['maxa] } & <\text { marra }> \\ \text { ['xej] } & <\text { rei }> \\ \text { ['kaxo] ['kaxv] } & <\text { carro }> \\ \text { ['saxo] ['saxu] } & <\text { sarro }>\end{array}$

\section{D) ViBRANTES}

A vibrante múltipla [r] ocorre no dialeto caipira, mas em Piracicaba pode ser substituída ora retroflexa $[\iota]$, ora pela fricativa $[x]$ (principalmente entre os moradores da área urbana).

$\begin{array}{ll}\text { ['rio] ['xio] } & <\text { rio }> \\ \text { ['mara] ['maxa] } & <\text { marra }> \\ \text { ['karo] ['kaxo] ['kaxv] } & <\text { carro }>\end{array}$

A vibrante simples [r] raramente se dá no ataque silábico, ocorrendo principalmente nos casos em que é precedida pelos fonemas oclusivos, onde também pode ser substituída pela retroflexa típica do falar piracicabano.

['prata] ['płata] <prata>

['kara] ['kaцa] <cara $>$ 
A retroflexa vem utilizada em Piracicaba em outros contextos, como segundo segmento de grupos consonantais em que, na norma culta (e em algumas variantes brasileiras), apresentariam a lateral alveodental (NATAL, 1974; NETTO, 1988) ${ }^{226}$.

\begin{tabular}{|c|c|}
\hline Norma culta & Piracicaba \\
\hline ['plĩta] & [p $\left.p_{\ell} \tilde{t} t a\right]$ \\
\hline ['klaro] ['klarv] & 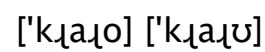 \\
\hline
\end{tabular}

Outra característica do dialeto caipira que ocorre comumente na região piracicabana (NATAL, 1974; LEME, 2001) é a realização da retroflexa em final de palavras que, na em vários dialetos do Português Europeu e em algumas variantes do Sul do Brasil (onde não ocorre o dialeto caipira), viria usada a lateral alveodental ou um glide velar arredondado.

\begin{tabular}{|c|c|c|c|}
\hline Piracicaba & Sul do Brasil & $\begin{array}{l}\text { Outras variantes do } \\
\text { Português Brasileiro }\end{array}$ & Ortografia \\
\hline [mal] & [mat] & [maw] & mal \\
\hline [a'nع] & [a'nct] & [a'ncw] & anel \\
\hline ['baıde] & ['batde] & $\begin{array}{c}\text { ['bawde] } \\
\text { ['bawdi] ['bawdzi] }\end{array}$ & balde \\
\hline ['alto] ['alto] & ['atto] & ['awto] ['awtu] & alto \\
\hline
\end{tabular}

Na posição de coda silábica final, principalmente nas formas verbais do infinitivo, o dialeto caipira não apresenta nem a retroflexa nem a vibrante múltipla (assim como outras variantes brasileiras, inclusive no registro informal de falantes cultos).

\footnotetext{
${ }^{226}$ Os informantes da comunidade tirolesa, ao comentar sobre as diferenças no seu modo de falar, afirmam (muitas vezes com ironia) que o uso da retroflexa é bastante comum em Piracicaba. Em determinada situação de conversa com os descendentes, sobre o modo de falar dos demais piracicabanos, apareceu ['£io], com uso da retroflexa em posição de ataque silábico (onset), no exemplo ['^io de Piłasi'kaba]. Não fizemos nenhum registro gravado que pudesse confirmar essa informação enquanto característica do falar piracicabano.
} 


$\begin{array}{ll}\text { [ma'ta] } & <\text { matar }> \\ {[\text { fa'ze] }} & <\text { fazer }> \\ {[\text { sen'ti] }} & <\text { sentir }> \\ {[\text { kuj'z] }} & <\text { colher }>\end{array}$

\section{E) LATERAIS}

Os fonemas laterais do dialeto caipira são / I, $\Lambda$ e ocorrem da seguinte maneira:

\begin{tabular}{|c|c|}
\hline [fa'la] & $<$ falar $>$ \\
\hline ['galo] ['galv] & $<$ galo $>$ \\
\hline 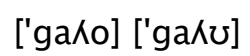 & $<$ galho \\
\hline
\end{tabular}

O uso da lateral alveolar dental varia na fala dos indivíduos e parece ser pouco usada em Piracicaba (NATAL, 1974; NetTo, 1988; LeME, 2001). É comum o uso da lateral palatal $[\Lambda]$ como lateral alveolar dental seguida da semivogal $[j]$, em qualquer contexto fônico:

$\begin{array}{ll}\text { ['galjo] ['gajo] ['galjv] ['gajv] } & <\text { galho }> \\ \text { [a'gulja] [a'guja] } & <\text { agulha }> \\ \text { ['velja] ['veja] } & <\text { velha }> \\ \text { ['maljo] ['maljv] ['majv] } & <\text { malho }> \\ \text { ['malja] ['maja] } & <\text { malha }> \\ \text { ['palja] ['paja] } & <\text { palha }> \\ \text { [mu'je] } & <\text { mulher }>^{227}\end{array}$

${ }^{227}$ Cfr. informante 8B.SO - J.E.S. Trata-se de uma característica relativamente presente no português da comunidade tirolesa. 


\section{A VARIANTE DO PORTUGUÊS DA COMUNIDADE TIROLESA DE Piracicaba}

\subsection{INTRODUÇão}

Dentre as peculiaridades culturais e sociais da comunidade tirolesa de Piracicaba, destaca-se sua variante falada do português, um diferencial que distingue o falar dos bairros $\mathbf{S}$ e SO no contexto linguístico piracicabano. Com características fonológicas e lexicais muito próprias, essa variante, enquanto sistema linguistico de uma comunidade de descendentes de imigrantes, faz recordar, de chofre, os falares das comunidades de imigração do Sul do Brasil ${ }^{228}$.

\footnotetext{
${ }^{228}$ Pudemos observar, em determinada ocasião, quando turistas catarinenses visitavam a comunidade tirolesa piracicabana, alguns moradores dos bairros dizendo que os turistas falavam de modo semelhante ao seu, identificando semelhanças de pronúncia e até mesmo da prosódia.
} 
Ainda que o dialeto trentino seja a língua principal apenas dos falantes mais velhos, sendo raramente utilizada entre os descendentes mais jovens (poucos a dominam), a variante do português, por sua vez, é compreendida e utilizada por indivíduos de todas as idades. O considerável número de vocábulos de origem trentina da variante do português estabelece, de certo modo, um elo entre o falar das gerações mais velhas com aquele das gerações mais novas (onde o português é, apesar das influências do trentino, a língua do cotidiano e das relações sociais). Podemos dizer que, no plano lexical, a variante do português está "segmentada" na comunidade, haja vista a adoção de palavras e expressões trentinas por moradores não-descendentes; trata-se de uma linguagem que, como afirmado, insere o indivíduo no grupo (PRETI, 1984).

Apesar disso, o trentino continua a ser, nos dias atuais, a língua do cotidiano dos falantes mais velhos da comunidade (grupo C), compreendida pelos indivíduos com idade acima dos quarenta anos (grupo B) e raramente compreendida entre os mais jovens (grupo A), cuja grande maioria, composta por não-falantes do trentino, mantém na variante do português diversas influências do idioma de seus avós.

Durante décadas o português limitava-se às relações da comunidade com o mundo fora dos bairros. O sentimento de isolamento que, como pudemos perceber, permanece em determinados aspectos até os dias atuais ${ }^{229}$, gerava nas gerações mais velhas um sentimento de temor de perda da identidade local, além do medo de sofrerem algum tipo de hostilidade pela comunidade brasileira. Com a introdução da escola, em 1923, o português começou gradativamente a fazer parte da vida da comunidade. Mas a adoção do português enquanto idioma principal das relações sociais ocorreu deu anos mais tarde, durante a década de 1970, quando a escola obrigou o uso do português para além de seus muros, pedindo aos pais que deixassem de se comunicar com seus filhos em tirolés, isto é, em dialeto trentino. A partir de então, a realidade da comunidade passa por transformações: aumentam consideravelmente os casamentos de descendentes com não-descendentes; o êxodo rural ocasiona a saída de vários moradores para outros bairros piracicabanos, para a área urbana da cidade e para outras cidades. Esses fatores contribuíram sobremaneira para o maior uso do português entre os tiroleses.

${ }^{229} \mathrm{O}$ bairrismo (às vezes exagerado na rivalidade entre $\mathbf{S}$ e SO) é um exemplo dessa realidade. 
O falar característico da comunidade foi formado em dois casos de contato linguístico, das diferentes variantes dialetais trentinas entre si e do dialeto trentino com o português. O resultado disso é a variante típica dos moradores, que LEME (2001) chamou de misturada. De modo geral, enquanto a influência do português no trentino foi sobretudo de caráter lexical, com casos raros de influência fonológica (como o uso da lateral palatal sonora $[\Lambda]$ ]) e morfossintática (em casos de empréstimo, como ['nar 'mbsra] <ir embora>), a atuação do trentino na fonologia do português é muito maior, além da influência morfossintática presente, sobretudo, na fala das gerações mais velhas.

No que se refere à maior ou menor influência lexical do dialeto trentino na variante do português, torna-se necessário reconhecer que a idade dos falantes é um fator de relevância. Com a abertura da comunidade, a partir da década 1970, as gerações mais novas perderam o forte contato com a língua dos mais velhos, mas mantém, por outro lado, um considerável número de palavras trentinas largamente utilizadas na comunidade, aceitas e compreendidas por todos os falantes das diferentes gerações de descendentes. Como pudemos observar, as variáveis do tipo sócio-econômica e escolar não excluem essa influência lexical trentina da fala, mas fazem com que os falantes utilizem com maior ou menor frequência, de acordo com o contexto linguístico, o vocabulário de origem trentina.

É característica a pronúncia "italianizada", onde se notam alguns aspectos da adequação fonêmica do trentino no português, que caracteriza o sotaque dos mais velhos e influencia a variante do português dos mais novos. No que se refere ao léxico, ainda que na fala dos mais velhos exista um número muito maior de palavras trentinas (utilizadas nos mais diversos domínios semânticos), a fala dos mais jovens ainda preserva diversos termos trentinos, largamente utilizado, tanto na comunidade como em situações de fala fora $\operatorname{dela}^{230}$.

\footnotetext{
${ }^{230}$ Em conversas com jovens da comunidade, geralmente ouvimos comentários (bem humorados) sobre as impressões de seus colegas - da área urbana ou de outros bairros - ao escutarem as palavras trentinas de sua fala.
} 


\subsection{OS EMPRÉSTIMOS LEXICAIS DO DIALETO TRENTINO NA VARIANTE DO PORTUGUÊS}

Algumas palavras são encontradas em todas as gerações de falantes da comunidade, inclusive com as diferenças lexicais ou fonéticas referentes às duas variantes dialetais trentinas de cada bairro. Algumas palavras ocorrem exatamente como no dialeto trentino:

\begin{tabular}{|c|c|c|c|}
\hline $\begin{array}{l}\text { Trentino europeu } \\
\text { (Valle dell'Adige) }\end{array}$ & Grafia & $\begin{array}{c}\text { Trentino } \\
\text { piracicabano }\end{array}$ & Significado \\
\hline ['bat $f i]$ & bàci! & ['batsi] & interj. de asco, nojo \\
\hline ['fistola] & fistola & ['fistola] & afta bucal \\
\hline ['gcto] & ghèto & ['geto] ['getu] & bagunça; confusão \\
\hline ['dio] & Dio! & ['dio] & interj. meи Deus! \\
\hline ['dio mad'כna] & Dìo Madòna! & ['dio mad'sna] & $\begin{array}{c}\text { interj. meu Deus (e } \\
\text { Nossa Senhora)! }\end{array}$ \\
\hline ['dio 'porko] & Dìo pòrco! & ['dio 'porko] & $\begin{array}{c}\text { interj. de maravilha ou } \\
\text { desaprovação }\end{array}$ \\
\hline ['porko 'dio] & pòrco Dìo! & ['porko 'dio] & $\begin{array}{c}\text { interj. de maravilha ou } \\
\text { desaprovação }\end{array}$ \\
\hline ['lajka] & làica & ['lajka] & preguiça \\
\hline ['pajta] & pàita & ['pajta] & preguiça \\
\hline ['brut] & brut & ['brut] & $\begin{array}{c}\text { coisa feia; ruim; } \\
\text { desagradável }\end{array}$ \\
\hline ['kwela 'su] & quèla su! & ['kwela 'su] & interj. minha nossa! \\
\hline [ba'rca] & barèa! & [ba'rca] & interj. de asco, nojo \\
\hline ['mus] & mus! & ['mus] & $\begin{array}{c}\text { interj. não tem outro } \\
\text { jeito; preciso }\end{array}$ \\
\hline ['mus maske'rin] & mus mascherìn! & ['mus maske'rin] & $\begin{array}{c}\text { interj. não tem outro } \\
\text { jeito; preciso }\end{array}$ \\
\hline
\end{tabular}




\begin{tabular}{|c|c|c|c|}
\hline [ma'gari] & magàri & [ma'gari] & talvez \\
\hline [po'reta] & poréta & [po'reta] & pobre; coitada \\
\hline [po'ret] [po'reto] & poréto & [po'reto] & pobre; coitado \\
\hline ['rantega] & ràntega & ['rantega] & $\begin{array}{c}\text { peito congestionado; } \\
\text { asma }\end{array}$ \\
\hline [skoma'rar] & scomaràr & [skoma'rar] & $\begin{array}{c}\text { falar muito } \\
\text { (como comadres) }\end{array}$ \\
\hline [skoma'ron] & scomarón & [skoma'ron] & conversador \\
\hline [ma'si] & ma si! & [ma'si] & interj. até parece! \\
\hline ['spusa] & spùsa & ['spusa] & odor fétido \\
\hline ['ruga] & rùga & ['ruga] & lagarta; taturana \\
\hline ['t $\int$ elega] & célega & ['t $\int$ elega] & sobrancelha (S) \\
\hline ['selega] & zélega & ['selega] & sobrancelha $(\mathrm{SO})$ \\
\hline ['skifo] & schifo & ['skifo] & nojo \\
\hline [slargi'tfon] & slarghiciòn & [slargi'tfon] & largo; comprido \\
\hline [slargi'tfona] & slarghicióna & [slargi'tsona] & $\begin{array}{c}\text { roupa comprida; } \\
\text { larga }\end{array}$ \\
\hline [ma'd’na] & Madòna! & [ma'dəna] & $\begin{array}{c}\text { interj. } \\
\text { Nossa Senhora! }\end{array}$ \\
\hline [ma'd’ne] & Madòne(ga)! & [ma'dəne] [ma'dəni] & $\begin{array}{c}\text { interj. } \\
\text { Nossa Senhora! (SO) }\end{array}$ \\
\hline [ma'dənega] & Madònega & [ma'dənega] & $\begin{array}{c}\text { interj. } \\
\text { Nossa Senhora! }\end{array}$ \\
\hline [ma'dəska] & Madòsca! & [ma'dəska] & $\begin{array}{c}\text { interj. } \\
\text { Nossa Senhora! }\end{array}$ \\
\hline 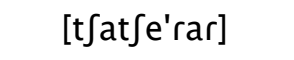 & ciaceràr & [t $\left.\int a t \int e^{\prime} r a r\right]$ & conversar \\
\hline [t $\left.\int a t \int e ' r o n\right]$ & ciacerón & 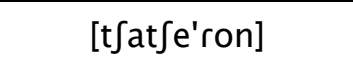 & conversador \\
\hline [t fat $\int e^{\prime}$ rona] & ciaceróna & 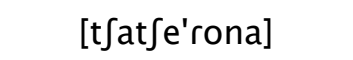 & conversadora \\
\hline [faj ma'loni] & fài malóni & $\begin{array}{l}\text { ['faj ma'loni] } \\
\text { ['faj ma'lon] }\end{array}$ & $\begin{array}{l}\text { criança; jovem } \\
\text { desobediente }\end{array}$ \\
\hline
\end{tabular}




\begin{tabular}{|c|c|c|c|}
\hline [ost $\left.\int a ' r i a\right]$ & osciarìa! & [ost $\left.\int a ' r i a\right]$ & $\begin{array}{c}\text { interj. de maravilha ou } \\
\text { desaprovação }\end{array}$ \\
\hline [ba'lote] & balòte! & [ba'lote] & interj. até parece! \\
\hline [pa'vela] & pavèla & [pa'vela] & $\begin{array}{c}\text { borboleta; } \\
\text { orelha grande }\end{array}$ \\
\hline [pa't $\left.\int \partial t \int a\right]$ & paciòcia & [pa't $\left.\int \partial t \int a\right]$ & $\begin{array}{c}\text { barro; lama; } \\
\text { material pegajoso }\end{array}$ \\
\hline 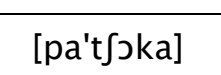 & paciòca & 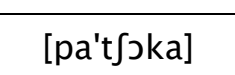 & barro; lama \\
\hline ['bjot] & biòt & ['bjjt] & $\begin{array}{l}\text { algo sozinho; sem } \\
\text { acompanhamento }\end{array}$ \\
\hline ['nona] & nóna & ['nona] & avó \\
\hline ['nono] & nóno & ['nono] & avô \\
\hline ['bet] & bèl & ['bet] & belo; bom \\
\hline ['skuzi] & scùsi & [s'kuzi] & desculpa; pretexto \\
\hline [sbege'lar] & sbeghelàr & [sbege'lar] & gritar \\
\hline [sbege'lon] & sbeghelón & [sbege'lon] & gritalhão \\
\hline [sbege'lona] & sbeghelóna & [sbege'lona] & gritalhona \\
\hline [be'u 'rana] & beù ràna? & [be'u 'rana] & $\begin{array}{c}\text { aprendeu? } \\
\text { (forma repreensiva) }\end{array}$ \\
\hline [t $\left.\int a^{\prime} p a r\right]$ & ciapàr & [tfa'par] & pegar; roubar \\
\hline [sfru'nar] & sfrugnàr & [sfru'nar] & fazer sexo; remexer \\
\hline [par 'vera] & par véra! & [par 'vera] & interj. até parece! \\
\hline [t $\left.\int a ' p a d a\right]$ & ciapàda? & [t $\left.\int a ' p a d a\right]$ & $\begin{array}{c}\text { aprendeu? } \\
\text { (forma repreensiva) }\end{array}$ \\
\hline $\begin{array}{l}\text { ['dzus] } \\
\text { ['dzust] }\end{array}$ & giust! & $\begin{array}{l}\text { [dzus] } \\
\text { ['dzust] }\end{array}$ & $\begin{array}{c}\text { justo! isso mesmo! } \\
\text { (interj de aprovação ou } \\
\text { desaprovação) }\end{array}$ \\
\hline ['st]ao] & s-ciào! & [s't $\left.\int \mathrm{aoo}\right]$ & $\begin{array}{l}\text { de uma vez! logo! } \\
\text { (interjeição) }\end{array}$ \\
\hline
\end{tabular}


Outras palavras trentinas comumente usadas na comunidade sofrem algum tipo de alteração fonética por influência do português, com casos de adequações fonéticas nos prefixos e sufixos. Esses casos ocorrem, sobretudo, entre os falantes mais jovens da comunidade (não-falantes do trentino), ou mesmo entre os falantes de dialeto, em situações de fala do português:

\begin{tabular}{|c|c|c|c|}
\hline $\begin{array}{c}\text { Trentino europeu } \\
\text { (Val dell'Adige); } \\
\text { Trentino piracicabano }\end{array}$ & Grafia & $\begin{array}{c}\text { Variante do } \\
\text { Português da } \\
\text { Comunidade }\end{array}$ & Significado \\
\hline [brut] & brut & ['brute] & $\begin{array}{c}\text { coisa feia; ruim; } \\
\text { desagradável }\end{array}$ \\
\hline ['beł] & bèl & ['bcł] ['bcw] & $\begin{array}{l}\text { alegria; beleza; } \\
\text { coisa agradável }\end{array}$ \\
\hline ['dio] & Dìo! & ['dio] ['dzio] & interj. meu Deus! \\
\hline [slargi't\}on] & slarghiciòn & [islargi'tsõ] & largo; comprido \\
\hline [slargi'tsona] & slarghicióna & [islargi't õna] & roupa larga \\
\hline [t $\left.\int a t \int e ' r a r\right]$ & ciaceràr & [t $\left.\int a t \int e^{\prime} r a\right]$ & conversar \\
\hline 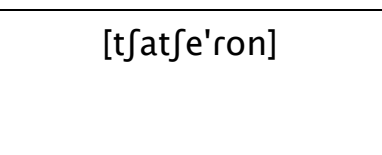 & ciacerón & $\begin{array}{l}\left.\text { [t } \int a t \int e^{\prime} r o ̃\right] \\
{\left[t \int a t \int e^{\prime} r \tilde{z} w\right]}\end{array}$ & conversador \\
\hline ['spusa] & spùsa & [is'pusa] & odor fétido \\
\hline ['ruga] & rùga & $\begin{array}{l}\text { ['ruga] } \\
\text { ['xuga] }\end{array}$ & lagarta; taturana \\
\hline [skoma'rar] & scomaràr & [iskoma'ra] & $\begin{array}{c}\text { falar muito } \\
\text { (como comadres) }\end{array}$ \\
\hline [skoma'ron] & scomarón & $\begin{array}{l}\text { [iskoma'rõ] } \\
\text { [iskoma'rz̃w] } \\
\text { [iskoma'‘z̃̋] }\end{array}$ & conversador \\
\hline ['st fao] & s-ciào! & ['st Jaw] & de uma vez! logo! \\
\hline
\end{tabular}




\begin{tabular}{|c|c|c|c|}
\hline [barbus'tet] & barbustèl & [barbus'tzw] & morcego \\
\hline [t $\left.\int a^{\prime} p a d a\right]$ & ciapàda? & [Sa'pada] & $\begin{array}{c}\text { aprendeu? } \\
\text { (forma repreensiva) }\end{array}$ \\
\hline [sbege'lar] & sbeghelàr & [isbege'la] & gritar \\
\hline [be'u 'rana] & beù ràna? & $\begin{array}{l}\text { [be'u 'rãna] } \\
\text { [be'u 'xz̃na] }\end{array}$ & $\begin{array}{c}\text { aprendeu? } \\
\text { (forma repreensiva) }\end{array}$ \\
\hline [sfru'nar] & sfrugnàr & [isfru'na] & fazer sexo; remexer \\
\hline ['dio ma'dona] & Dio Madòna! & $\begin{array}{l}\text { ['dio ma'dona] } \\
\text { ['dzio ma'dəna] } \\
\text { ['dzio ma'dona] }\end{array}$ & $\begin{array}{c}\text { interj. } \\
\text { Nossa Senhora! }\end{array}$ \\
\hline ['skifo] & schifo & [is'kifo] & nojo \\
\hline ['rantega] & ràntega & $\begin{array}{c}\text { ['rãtega] ['rz̃tega] } \\
\text { ['xz̃tega] }\end{array}$ & $\begin{array}{c}\text { peito congestionado; } \\
\text { asma }\end{array}$ \\
\hline ['spajtar] & spaitàr & [ispa'jta] & espreguiçar-se \\
\hline [endormen'sa] & endormensà & $\begin{array}{l}\text { [endormen'sado] } \\
\text { [endołmen'sado] }\end{array}$ & sonolento \\
\hline [endormen'sada] & endormensàda & [endołmen'sada] & sonolenta \\
\hline
\end{tabular}

O dialeto trentino não conhece verbos na forma do gerúndio. Alguns verbos trentinos ocorrem adequados segundo a fonética e a morfologia do português:

\begin{tabular}{|c|c|c|c|}
\hline $\begin{array}{c}\text { Trentino europeu } \\
\text { (Val dell'Adige); } \\
\text { Trentino piracicabano }\end{array}$ & Grafia & $\begin{array}{c}\text { Variante do } \\
\text { Português da } \\
\text { Comunidade }\end{array}$ & Significado \\
\hline 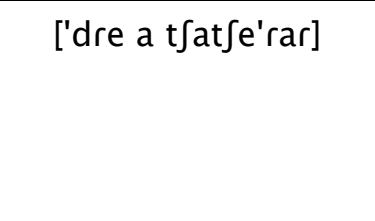 & ndré a ciaceràr & 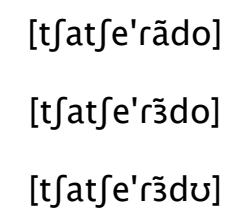 & conversando \\
\hline ['dre a skoma'rar] & ndré a scomaràr & $\begin{array}{l}\text { [iskoma'rãdo] } \\
\text { [iskoma'rz̃do] }\end{array}$ & conversando \\
\hline
\end{tabular}




\begin{tabular}{|c|c|c|c|}
\hline & & [iskoma'rz̃ dv] & \\
\hline ['dre a var'dar] & ndré a vardàr & $\begin{array}{c}\text { [var'dãdo] [var'dz̃do] } \\
\text { [var'dz̃dv] }\end{array}$ & olhando \\
\hline ['dre a sbege'lar] & ndré a sbeghelàr & $\begin{array}{l}\text { [isbege'lãdo] } \\
\text { [isbege'lz̃do] } \\
\text { [isbege'lz̃dv] }\end{array}$ & gritando \\
\hline ['dre a sfru'nar] & ndré a sfrugnàr & $\begin{array}{l}\text { [sfru'nãdo] } \\
\text { [sfru'nz̃do] } \\
\text { [sfru'fz̃do] }\end{array}$ & $\begin{array}{l}\text { remexendo; } \\
\text { fazendo sexo }\end{array}$ \\
\hline ['dre a spaj'tar] & ndré a spaitàr & $\begin{array}{l}\text { [ispaj'tãdo] } \\
\text { [ispaj'tz̃̃do] } \\
\text { [ispaj'tz̃do] }\end{array}$ & vadiando \\
\hline
\end{tabular}

O uso de formas de xingamento ocorre em contextos de atitude hostil, de admiração e até mesmo alegria. Trata-se de uma característica típica da cultura setentrional italiana, inclusive com o uso de blasfêmias do tipo Dio pòrco (ou pòrco Dìo) e os-ciarìa.

No que se refere às blasfêmias, os frades capuchinhos proibiam outrora essas expressões enfáticas, comuns na fala da comunidade (extremamente religiosa), por meio de tabuísmo que originaram os seguintes casos:

\begin{tabular}{|c|c|c|}
\hline [วspja'ria] & derivado de [Jst $\int a^{\prime}$ ria] & $<$ ospiarìa $>$ invés de $<$ os-ciarìa $>$ \\
\hline ['zio 'kane] & derivado de ['dio 'kane] & $<$ zìo càne $>$ invés de $<D$ \\
\hline
\end{tabular}

\subsubsection{LÉXICO TRENTINO ENTRE NÃO-DESCENDENTES}


Vale lembrar que a abertura da comunidade ocorreu somente em meados da década de 1970 quando, levados pela falta de emprego no campo, alguns indivíduos seguiram para trabalhar e estudar em outras localidades, de Piracicaba ou de cidades vizinhas. A partir desse período, o português (que era o idioma das reações externas) foi gradativamente tornando-se a língua principal da comunidade e substitui o trentino, que sobrevive hoje no falar dos mais velhos e nas relações deles com seus familiares.

Pudemos constatar em conversas com moradores oriundos de outras localidades que muitos deles também se utilizam das expressões e palavras mais comuns da comunidade. Esses moradores, que se casaram com descendentes tiroleses ou se transferiram para os bairros, também adotaram as palavras e expressões de origem trentina de uso cotidiano nos bairros (ainda que em alguns casos as falem ao seu modo) e adotaram também um pouco do temperamento dos moradores originais ${ }^{231}$.

Destacamos aqui expressões registradas em conversas (não gravadas) durante nossa pesquisa de campo, onde apareceram palavras e expressões próprias dos descendentes tiroleses, mas utilizadas por moradores não-descendentes. São as gírias próprias do falar dos bairros. Alguns verbos ocorrem com a transposição da desinência verbal do português, que adapta o verbo trentino. O significado de todas essas palavras é o mesmo, no trentino ou na variante falada do português de Piracicaba.

PALAVRAS DE ORIGEM TRENTINA UTILIZADAS POR MORADORES NÃO-DESCENDENTES ${ }^{232}$

\begin{tabular}{|c|c|c|c|}
\hline $\begin{array}{c}\text { Como ocorre na } \\
\text { comunidade }\end{array}$ & Exemplos registrados & $\begin{array}{c}\text { Forma dialetal } \\
\text { trentina original }\end{array}$ & Significado \\
\hline $\begin{array}{c}\text { adjetivo } \\
\text { [es'tomega] }\end{array}$ & Ele é um estômega & stómega & $\begin{array}{c}\text { pessoa incoveniente; } \\
\text { petulante; irritante }\end{array}$ \\
\hline
\end{tabular}

\footnotetext{
${ }^{231}$ Trata-se de uma característica interessante da realidade social da comunidade. Tanto para os descendentes, como para os de fora (como são chamados os moradores oriundos de outras localidades), alguém não descendente que participa da comunidade e adota seus hábitos e vocabulário é, até certo ponto, também tirolês. Criou-se ali um locus tirolês, onde determinadas regras sociais de seus moradores (ainda que estereotipadas até certo modo) influenciam o seu modo de agir e de pensar, e aqueles que buscam ser aceitos pela comunidade devem adotá-las. Sobre o assunto LEME (2001).

${ }^{232}$ Termos registrados durante a pesquisa de campo, em situações de fala espontânea nas conversas entre moradores da comunidade.
} 


\begin{tabular}{|c|c|c|c|}
\hline ['stomega] & & & \\
\hline $\begin{array}{c}\text { substantivo } \\
\text { ['gcto] ['gعto] }\end{array}$ & $\begin{array}{l}\text { Aqui está um gueto / } \\
\text { Comprei uns gueto }\end{array}$ & ghèto & $\begin{array}{l}\text { bagunça, confusão; } \\
\text { quinquilharia; objeto } \\
\text { de pouco valor }\end{array}$ \\
\hline $\begin{array}{l}\text { substantivo (pl) } \\
\left.\text { [ge'tวti] [ge'tวt } \int \mathrm{i}\right]\end{array}$ & $\begin{array}{l}\text { Comprei uns guetote } \\
\text { Comprei uns guetotes }\end{array}$ & ghetòti & quinquilharias \\
\hline $\begin{array}{c}\text { substantivo / adjetivo } \\
\text { ['petola] ['petola] }\end{array}$ & $\begin{array}{c}\text { Esse menino é um } \\
\text { pêtola }\end{array}$ & pétola & $\begin{array}{l}\text { carrapicho; puxa-saco; } \\
\text { pessoa inconveniente }\end{array}$ \\
\hline $\begin{array}{c}\text { adjetivo } \\
\text { [brut] ['brute] }\end{array}$ & $\begin{array}{l}\text { Ai que brute! } \\
\text { Ai que brut! }\end{array}$ & brut & $\begin{array}{l}\text { angústia; desânimo; } \\
\text { coisa feia }\end{array}$ \\
\hline $\begin{array}{c}\text { adjetivo } \\
\text { ['bcł] ['bsw] }\end{array}$ & Ai que bel ir na festa & bel & $\begin{array}{l}\text { alegria; beleza; } \\
\text { coisa agradável }\end{array}$ \\
\hline $\begin{array}{l}\text { interjeição } \\
\left.\text { [t } \int a^{\prime} p a d a\right]\end{array}$ & tchapáda? & ciapà / ciapàda & $\begin{array}{l}\text { modo repreensivo de } \\
\text { perguntar: aprendeu? }\end{array}$ \\
\hline $\begin{array}{c}\text { interjeição } \\
\left.\text { [ost } \int a ' r i a\right] \text { [ost } \int a^{\prime} \_ \text {Łia] }\end{array}$ & ostiaría! & ostiaria! & $\begin{array}{l}\text { interjeição de espanto } \\
\text { ou admiração }\end{array}$ \\
\hline $\begin{array}{c}\text { substantivo } \\
\text { ['ruga] ['xuga] }\end{array}$ & $\begin{array}{l}\text { O coqueiro estava } \\
\text { cheio de rúga. }\end{array}$ & rùga & lagarta; taturana \\
\hline $\begin{array}{c}\text { interjeição } \\
\text { [ma'dəna] (S e SO) } \\
\text { [ma'dəni] [ma'dəne] } \\
\text { (SO) }\end{array}$ & $\begin{array}{c}\text { Madòna que susto! } \\
\text { Madòne! }\end{array}$ & Madòna / Madòsca & $\begin{array}{c}\text { Nossa Senhora! } \\
\text { (interjeição de espanto } \\
\text { ou admiração) }\end{array}$ \\
\hline $\begin{array}{l}\text { interjeição } \\
\text { ['dio] ['dzio] }\end{array}$ & Dio! & Dio! & $\begin{array}{c}\text { Meu Deus! } \\
\text { (interjeição de espanto } \\
\text { ou admiração) }\end{array}$ \\
\hline $\begin{array}{c}\text { interjeição } \\
\text { ['pərko 'dio] } \\
\text { ['pərko 'dzio] }\end{array}$ & Porco Dio! & Porco Dio! & $\begin{array}{c}\text { (interjeição de espanto } \\
\text { ou admiração) }\end{array}$ \\
\hline verbo & $\begin{array}{c}\text { Ele estomegou de } \\
\text { fazer festa }\end{array}$ & stomegàr & enjoar; fatigar \\
\hline
\end{tabular}




\begin{tabular}{|c|c|c|c|}
\hline [estome'gar] & $\begin{array}{c}\text { Eles estomegaram de } \\
\text { comer cuscuz/ } \\
\text { [estome'gau] }\end{array}$ & $\begin{array}{c} \\
\text { Ele vive me } \\
\text { estomegando }\end{array}$ & \\
\hline adjetivo & $\begin{array}{c}\text { Ele é um estomeguês } \\
\text { Ela está hoje uma } \\
\text { estomeguessa }\end{array}$ & stomeghés / & pessoa incoveniente; \\
[estome'ges] & & irritante; petulante \\
[estome'ge $\left.{ }^{\mathrm{j}} \mathrm{s}\right]$ & & \\
\hline
\end{tabular}

Também os casamentos com pessoas de fora dos bairros (existentes principalmente no Bairro SO) são um dado bastante relevante para uma análise sobre o uso do dialeto trentino e sobre a variante falada do português na comunidade. Os casamentos com nãodescendentes de tiroleses "obrigam" uma comunicação somente em português; os filhos desses casamentos (ao que pudemos constatar) não falam o dialeto e possuem menos influências lexicais do trentino em sua fala que os filhos de descendentes tiroleses. $\mathrm{O}$ mesmo se diz do uso da consoante retroflexa, típica do falar piracicabano.

\subsection{ASPECTOS FONÉTICOS E FONOLÓGICOS DA VARIANTE LOCAL}

\subsubsection{ASPECTOS VOCÁLICOS}

\section{SíMBOLOS FONÉTICOS VOCÁLICOS ORAIS TÔNICOS DA VARIANTE DO PORTUGUÊS DA COMUNIDADE}

\begin{tabular}{|c|c|c|}
\hline Símbolo & Transcrição fonética & Significado \\
\hline$[\mathrm{i}]$ & {$[$ sen'ti] } & senti \\
\hline$[y]$ & {$[$ 'tydo] } & tudo \\
\hline
\end{tabular}




\begin{tabular}{|c|c|c|}
\hline [e] & ['ele] & ele \\
\hline [ø] & ['bruzakør] & $\begin{array}{c}\text { bruzacör } \\
\text { (dor de estômago) }\end{array}$ \\
\hline$[\varepsilon]$ & ['scw] & céu \\
\hline [a] & ['kaza] & casa \\
\hline [ว] & ['porta] & porta \\
\hline [o] & [po'so] & poço \\
\hline$[\mathrm{u}]$ & ['cura] & cura \\
\hline
\end{tabular}

O sistema vocálico da variante da comunidade é o mesmo do português falado de piracicaba, com o acréscimo das vogais anteriores $[\mathrm{y}] \mathrm{e}[\varnothing]$, advindas do dialeto trentino e que ocorrem na variante do português dos mais velhos da comunidade ${ }^{233}$. Pudemos observar que o uso das vogais anteriores é uma característica das duas variedades dialetais trentinas de $\mathbf{S O}$ e $\mathbf{S}$ e ocorre mais no dialeto de $\mathbf{S O}$, onde são substituídas entre os falantes mais novos pelas vogais posteriores $[\mathrm{u}]$ e [o] respectivamente; a variante trentina de $\mathbf{S}$ também substitui em alguns casos a vogal anterior [ø] por [つ]. Entre os falantes mais jovens do dialeto (principalmente aqueles do Grupo B), as vogais anteriores aparecem raramente na fala e são substituídas por [u] e [o]. Na comunidade, ocorre raramente o alçamento vocálico das vogais meio-fechadas [e] e [o] para fechadas [i] / [I] e [u] / [v] em posição átona, sobretudo postônica, fazendo a variante da comunidade lembrar os falares do Sul do Brasil.

As vogais fechadas são utilizadas principalmente pelos falantes com maior nível escolar; também aparecem na fala de crianças filhas de casamentos mistos entre descendentes e não-descendentes ou, ainda, na fala das crianças que estudam ou realizam alguma atividade fora da comunidade.

$\begin{array}{ll}\text { ['vidro] } & <\text { vidro }> \\ \text { [me'nino] } & <\text { menino }>\end{array}$

${ }^{233}$ Cfr. informantes 3CS - J.V. e 4C.S0 - J. D. 
['lejte] <leite>

['mõte] <monte $>$

$[\mathrm{te}]\left[\mathrm{t} \mathrm{i} \mathrm{i} \quad<\mathrm{te}>^{234}\right.$

As variações entre [a] e [aj] e entre [e] e [ej] ocorrem diante de $/ \mathrm{r} /, / \mathrm{s} /, / \mathrm{s} / \mathrm{e} / 3 /$, enquanto a variação entre [o] e [ow] parece ocorrer sem previsão do contexto sonoro que a precede ou sucede.

$\begin{array}{ll}\text { ['faJa] } & <\text { faixa }> \\ \text { ['fera] } & <\text { feira }> \\ \text { ['pefe] } & <\text { peixe }> \\ \text { ['so] } & <\text { sou }> \\ \text { ['roko] } & <\text { rouco }> \\ \text { ['lujs] } & <\text { luz }> \\ \text { ['mejs] ['mej] } & <\text { mês }> \\ \text { [ra'pajs] [ra'paj] [xa'pajs] [ła'paj] } & <\text { rapaz }>\end{array}$

Nas variações entre [a] e [aj]; [e] e [ej] diante de /s / final, a sílaba final tende a cair:

$\begin{array}{ll}\text { ['maj] } & <\text { mais }>^{235} \\ \text { ['faj] } & <\text { faz }> \\ \text { [ra'paj] } & <\text { rapaz }> \\ \text { [tiro'lej] } & <\text { tirolês }>\text {; }<\text { tiroleses }>^{236} \\ \text { ['fej] } & <\text { fez }>\text {; }<\text { fiz }> \\ \text { ['mej] } & <\text { mês }>\end{array}$

\footnotetext{
${ }^{234} \mathrm{Cfr}$. Informante 6B.S - O.P.

${ }^{235}$ Cfr. ocorrência de ['maj] nas entrevistas dos informantes 1A.S - G.V.B., 3A.SO - L. D., 5A.S - A.C.B., 1B.SO - O.P., 2B.SO - E.P., 4B.SO - R.C.C., 5B.S - J.B., 1C.SO - M.C.S.C., 3CS - J.V., 5C.SO - F.C.D. ${ }^{236}$ Pudemos observar a palavra tirolei escrita desse modo em um dos muros da escola local.
} 
Ocorre também:

['nวj] <nós $>$

No caso do ditongo nasal [ẽj], prevalece a ocorrência de uma vogal nasalizada, sem ditongo e sem consoante e, no caso de sílaba tônica em posição medial e final, realiza-se geralmente uma vogal oral, do mesmo modo como na variante caipira piracicabana.

$\begin{array}{ll}\text { [a'lẽj] } & <\text { além }> \\ \text { ['mẽte] } & <\text { mente }> \\ \text { ['vaze] } & <\text { vagem }>\end{array}$

Nas formas verbais do dialeto caipira, em sílabas átonas em posição final, ocorrem

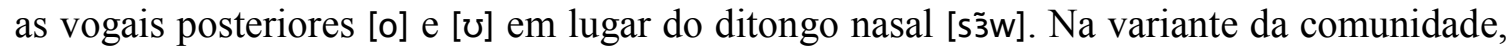
o ditongo nasal [ãw] convive com a vogal [o]; na fala dos mais velhos ocorre uma nasalização da vogal, que ocorre como [õ].

$\begin{array}{ll}\text { [ar'maro] [ar'marõ] } & <\text { armaram> } \\ \text { [ti'vero] [ti'verõ] } & <\text { tiveram> } \\ \text { [ka'iro] [[ka'irõ] } & <\text { caíram> }\end{array}$

Em alguns casos em que o português culto tem [õ] as influências da variante caipira (principalmente entre os falantes do Grupo B) resultam na ocorrência de [з̃w]:

$\begin{array}{ll}\text { ['sõn] ['sร̃w] } & <\text { som> } \\ \text { ['bõn] ['b3̃w] } & <\text { bom }>\end{array}$

As regras alofônicas atuantes na variedade local atingem um razoável número de palavras do português que apresentam um contexto favorável ao surgimento dessas regras. Um caso é a presença de alofones diferentes para a ocorrência da vogal baixa nasalizada e 
para o ditongo -ão, também confirmados por LEME (2001), com uso do monotongo nasalizado [õ] como alofone de /awN/ em substituição de [ãw] ou [3̃w], mesmo em sílaba tônica. Trata-se de uma característica encontrada no falar de todas as gerações de descendentes (inclusive entre crianças ${ }^{237}$ ), mas aparece com mais frequência entre os indivíduos com mais de trinta anos de idade.

$\begin{array}{ll}\text { ['nõ] ['ñ̃w] } & <\text { não> } \\ \text { ['põ] ['pz̃w] } & <\text { pão> } \\ \text { [kora'sõ] [kora'sz̃w] } & <\text { coração> }\end{array}$

Uma característica do Português Brasilero e do dialeto caipira é a substituição da qualidade vocálica de [a], quando acrescida de timbre nasal, para [3]. Esse fenômeno de centralização praticamente paraticamente não ocorre no Português Europeu e entre as comunidades de origem européia do Sul.

$\mathrm{Na}$ comunidade tirolesa piracicabana, a regra de centralização não se aplica entre os falantes do Grupo C, aparecendo na fala dos falantes mais jovens. Entretanto, é comum entre os jovens da comunidade o uso de [a] na palavra não, cuja vogal praticamente não apresenta nasalidade e ocorre como [naw] ou [nãw] 238 .

$\begin{array}{ll}\text { [san'tana] } & <\text { Santana }> \\ \text { [san'tãna] [san'tz̃na] } & <\text { Banco }>\text { (= Santa Olímpia) } \\ \text { ['banko] } & \\ \text { ['bãnko] ['bзyko] } & \\ \text { ['manga] } & \end{array}$

\footnotetext{
${ }^{237}$ Em quase três anos de convívio direto com a comunidade e observando o modo de falar das crianças com idade inferior a seis anos, pudemos observar que as crianças que passam boa parte do dia em contato com os avós, tendem a adquirir várias características de sua fala e que se estas tendem a desaparecer no convívio escolar. Ainda que a maioria das crianças na escola sejam da comunidade, há também crianças de outros bairros. LEME (2001: 134) também comenta que as crianças apresentam várias características da fala dos mais velhos por causa convívio doméstico com os avós. Pudemos presenciar várias vezes a conversa de pais e avós em dialeto trentino na presença das crianças; mesmo se respondessem em português, pareciam compreender várias partes das conversas e interferiam no discurso, porém falando em português.

${ }^{238}$ Cfr. informante 3A.SO - L. D.
} 
['mãnga] ['mz̃nga] <manga>

['planta]

['plãnta] ['plz̃nta] > <lanta>

\subsubsection{ASPECTOS CONSONANTAIS}

SÍMBOLOS FONÉTICOS CONSONANTAIS DA VARIANTE DO PORTUGUÊS DA COMUNIDADE

\begin{tabular}{|c|c|c|}
\hline Símbolo & Transcrição fonética & Significado \\
\hline $\mathrm{p}$ & ['pelo] & pelo \\
\hline b & ['bclo] & belo \\
\hline $\mathrm{t}$ & ['tia] & tia \\
\hline$d$ & ['dia] & dia \\
\hline k & ['kara] & cara \\
\hline $\mathrm{g}$ & ['gara] ['gaxa] & garra \\
\hline ts & ['t $\mathrm{t}$ ia] & tia \\
\hline$d_{3}$ & ['dzia] & dia \\
\hline$f$ & ['fejo] & feio \\
\hline v & ['vejo] & velho \\
\hline s & ['suko] & suco \\
\hline$z$ & [za'rejo] & arreio \\
\hline $\int$ & ['`з̆ma] & chama \\
\hline
\end{tabular}




\begin{tabular}{|c|c|c|}
\hline & ['Jama] & juro \\
\hline 3 & ['zuro] & rato \\
\hline $\mathrm{x}$ & ['xato] & moita \\
\hline $\mathrm{m}$ & ['mojta] & noite \\
\hline $\mathrm{n}$ & ['nojte] & venha \\
\hline $\mathrm{r}$ & ['vena] & barranco \\
\hline $\mathrm{r}$ & [barãn'ko] & marra \\
\hline $\mathrm{I}$ & [barã'ko] & galho \\
\hline$\wedge$ & ['mara] & ['luto] \\
\hline $\mathrm{lj}$ & ['gaᄉo] & galho \\
\hline
\end{tabular}

\section{A) OcLusivas:}

Os fonemas oclusivos / p, b, t, d, k, g / na variante da comunidade se realizam da seguinte maneira:

$\begin{array}{ll}\text { ['pera] } & <\text { pêra }> \\ \text { ['bera] } & <\text { beira }> \\ \text { [tew] } & <\text { teu }> \\ {[\text { 'dew] }} & <\text { deu }> \\ \text { ['koro] } & <\text { corro }> \\ \text { ['goro] } & <\text { gorro }>\end{array}$


Em Piracicaba, é possível encontrar (principalmente entre os falantes da área urbana) casos de alofonia que envolvem a realização da oclusiva alveolar surda [t] como africada alveopalatal surda [t $\int$ ] e casos de realização da oclusiva alveolar sonora [d] como africada alveopalatal sonora [dz]. Na comunidade tirolesa, prevalece o uso das oclusivas [t] e [d] e as africadas ocorrem nesses casos apenas na fala dos indivíduos com maior nível escolar (que, inclusive, alternam seu uso com o das oclusivas).

$\begin{array}{ll}\left.\text { ['tia] ['t } \int \mathrm{ia}\right] & <\text { tia }> \\ \text { ['dia] ['dzia] } & <\text { dia }>\end{array}$

B) NASAIS:

Os fonemas nasais na variante da comunidade são / $m, n, n /$ e se realizam da seguinte maneira:

$$
\begin{array}{ll}
\text { [mar] } & <\text { mar }>;<\text { mal }> \\
\text { ['nada] } & <\text { nada }> \\
\text { [esfru'nar] } & <\text { remexer }>\text {; }<\text { fazer sexo }>
\end{array}
$$

A realização do arquifonema $/ \mathrm{N} /$ enquanto / $\mathrm{\eta} /$ ocorre antes de / k/, /g/:

$$
\begin{array}{ll}
\text { ['tonko] } & <\text { molho }> \\
\text { ['manga] } & <\text { manga }>
\end{array}
$$

\section{C) FRICATIVAS E AFRICADAS:}

Os fonemas fricativos / f, v, s, z, $\int, 3, \mathrm{x} /$ ocorrem da seguinte maneira: 


\begin{tabular}{|c|c|}
\hline ['foto] & $<$ foto $>$ \\
\hline ['voto] & $<$ voto $>$ \\
\hline ['sako] & $<$ saco $>$ \\
\hline ['Sato] & $<$ chato $>$ \\
\hline [ka'zako] & $<$ casaco $>$ \\
\hline ['zaka] & $<$ jaca $>$ \\
\hline [ost $\left.\int a ' r i a\right]$ & <interjeição de espanto ou desaprovação> \\
\hline ['dzus] & <interjeição de aprovação ou desaprovação> \\
\hline [ĩpes't $\left.\int a d o\right]$ & $<$ empesteado $>$ \\
\hline
\end{tabular}

A característica caipira de queda da fricativa [s] na forma plural dos nomes, também aparece na variante da comunidade tirolesa:

$\begin{array}{ll}\text { [doz meni'no] } & <\text { dos meninos }> \\ \text { [az meni'na] } & <\text { as meninas }> \\ \text { [os tiro'lej] } & <\text { os tiroleses }>\end{array}$

$\mathrm{O}$ [s] final também cai em outros contextos, como no encontro das fricativas alveolares surda e sonora, diante de pausa e em posição inicial de algumas palavras.

$\begin{array}{ll}\text { [o'żjo 'dele] } & <\text { os olhos dele }> \\ \text { [tor'va] } & <\text { estorvar }>\end{array}$

A fricativa velar surda $[x]$ não ocorre com frequência na variante da comunidade, que a reliza como $[r]$, [r] ou (muito raro entre os falantes do Grupo $\mathbf{C}^{239}$ ) com retroflexa [^]. A fricativa velar surda aparece principalmente entre os falantes com maior nível de escolaridade e que mantém mais contato com falantes de fora da comunidade.

${ }^{239}$ Dos entrevistados, a única informante que realiza a retrfloexa no Grupo C é 1CSO - M.C.S.C. 
['maxa]

['mara] ['mara] ['maja] $\quad<$ marra $>$

['xej] ['rej] ['rej] $\quad<$ rei>

\section{D) VIBRANTES}

A vibrante múltipla [r] ocorre frequentemente na fala da comunidade, sendo uma das características que destaca seu modo de falar em Piracicaba. Nas demais áreas piracicabana, ocorre a retroflexa $[\iota]$ ou a fricativa $[x]$ (sobretudo em posição de ataque silábico).

['rio] $\quad<$ rio $>$

['roba] <coisa $>$

['rapido] < <rápido $>$

A vibrante simples [r] é característica do dialeto trentino, que não realiza a vibrante múltipla. Essa característica foi transportada para o português da comunidade tirolesa, que neutralizou a oposição entre a vibrante simples e múltipla, do mesmo modo como o trentino e demais dialetos setentrionais italianos.

"É bom lembrar que a variedade de português em uso na comunidade é o dialeto caipira da região (além do conhecimento da norma culta - o dialeto paulista - por intermédio da escola). No dialeto caipira também ocorre frequentemente a neutralização do $[r]$, mas em favor de um alofone retroflexo. Portanto, a comunidade tinha dois motivos para usar a neutralização do [r]. A escolha do alofone, porém, veio diferenciar a fala da comunidade da fala da região".

(LEME, 2001: 120) 
Outrora, o uso da vibrante simples era uma das principais características da fala da comunidade, que se preserva na fala dos mais velhos. A partir da década de 1970, com a abertura da comunidade e o êxodo rural, o modo de falar dos moradores foi estigmatizado, inclusive por causa da neutralização entre a vibrante simples e a vibrante múltipla, que caracterizava a fala do colono. Segundo informantes do grupo B, os mais jovens de então começaram a substituir o uso da vibrante simples pela vibrante múltipla [r], pela fricativa $[x]$ ou pela retroflexa $[\curlywedge]$.

A vibrante simples aparece na fala de todas as gerações, com maior ocorrência na fala dos mais velhos e menor ocorrência entre os mais novos.

$\begin{array}{ll}\text { ['kara] } & <\text { cara }> \\ \text { ['baro] } & <\text { barro }> \\ \text { ['barãnko] } & <\text { barranco }> \\ \text { [ka'rosa] } & <\text { carroça }> \\ \text { ['karo] } & <\text { caro }>\text {; }<\text { carro }> \\ \text { ['karino] } & <\text { carinho }>\text {; }<\text { carrinho }> \\ \text { [a'roj] } & <\text { arroz }> \\ \text { ['prata] } & <\text { prata }>\end{array}$

Por causa da neutralização entre a vibrante múltipla e a vibrante simples, ocorre, na fala da comunidade (principalmente do Grupo B), casos como:

$\begin{array}{ll}\text { [a'rame] } & <\text { arame }> \\ \text { [a'rado] } & <\text { arado }> \\ \text { ['prato] } & <\text { prato }>\end{array}$

A retroflexa vem utilizada nos seguintes contextos, entre alguns falantes dos grupos B e A:

['kaцa] <cara $>$ 


$\begin{array}{ll}\text { ['kaıo] } & <\text { caro }> \\ \text { ['kaıino] } & <\text { carinho }> \\ \text { ['plata] } & <\text { prata }>\end{array}$

\section{E) LATERAIS}

Os fonemas laterais na variante da comunidade são $/ I, N /$ e ocorrem da seguinte maneira:

$\begin{array}{ll}\text { ['galo] } & <\text { galo }> \\ \text { ['gaᄉo] } & <\text { galho }>\end{array}$

É comum a realização da lateral palatal [ $\Lambda$ ] como lateral alveolar seguida de semnivogal [lj] em qualquer contexto fônico. No dialeto trentino, que não utiliza a lateral palatal $[\Lambda]$, ocorre a sequência $[\mathrm{lj}]$ e a lateral alveolar palatalizada $\left[{ }^{j}\right]$. Na variante da comunidade, prevalesce o uso de [lj]:

\begin{tabular}{|c|c|}
\hline ['ga^o] ['galjo] & $<$ galho $>$ \\
\hline [a'gu^a] [a'gulja] & $<$ agulha $>$ \\
\hline 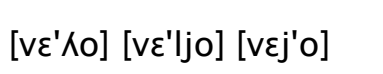 & $<$ velho $>^{240}$ \\
\hline [ma'Na] [ma'lja] [maj'a] & $<$ malhar $>$ \\
\hline
\end{tabular}

\subsection{ASPECTOS MORFOSSINTÁtiCOS}

${ }^{240} \mathrm{Cfr}$. informante 10BS - J.B. 


\subsubsection{FORMAÇÃO DE PLURAL}

A marcação do plural no dialeto trentino é caracterizado pela substituição morfemática: quando masculinas, terminam com o morfema -i (trentino; pl. trentini) e quando femininas com o morfema -e (trentina; pl. trentine); há aquelas, entretanto, que não apresentam diferenças nas formas singular e plural (an<ano>; pl. an).

$\mathrm{Na}$ comunidade tirolesa piracicabana, alguns indivíduos aplicam ao português uma regra semelhante ao trentino para indicar o plural, com a substrituição do morfema $-\boldsymbol{s}$ do português pelo $-\boldsymbol{i}$, que designa tanto o plural masculino quanto o feminino das palavras terminadas no singular em [e] e [es]. Dessa forma, as vogais temáticas nominais se convertem em verdadeiros morfemas. São exemplos:

$\begin{array}{lll}\text { ['mej] } & \text { em vez de } & \text { meses } \\ \text { ['pej] } & \text { em vez de } & \text { pés } \\ \text { [كa'prj] } & \text { em vez de } & \text { chapéus }\end{array}$

Ocorrem também formas mistas do português com o trentino:
[os mate'loti]
$<$ as crianças $>$
[os po'reti]
$<$ os coitados $>$
[os fajma'loni] [os fajma'Iz̃w] <os bagunceiros>
[os t $\left.\int a t \int e ' r o n i\right]$
$<$ os conversadores $>$

\subsubsection{ASPECTOS SINTÁTICOS}


Encontram-se alguns casos de interferência da regência do dialeto trentino na variante do português da comunidade. Principalmente entre os falantes do grupo $\mathbf{C}$ (mas também entre alguns indivíduos dos grupos B e A não-bilíngues) aparace o seguinte caso:

\begin{tabular}{|c|c|c|}
\hline Dialeto trentino & Português & Variante da comunidade \\
\hline son nà $(d a)$ dal mèdico & fui ao médico & fui $d o$ médico \\
& [fui no médico] & \\
\hline vàgo dal convént & vou ao seminário & vou $d o$ seminário \\
& [vou no seminário] & \\
\hline
\end{tabular}

Entre os mais jovens da comunidade é bastante comum o seguinte caso:

\begin{tabular}{|c|c|c|}
\hline Dialeto trentino & Português & Variante da comunidade \\
\hline el 'l se l'hà pensà & ele pensou & ele se pensou \\
\hline
\end{tabular}

Também é bastante comum entre todas as gerações de falantes:

eu me pensei ao invés de eu pensei

Entre os falantes do grupo $\mathbf{C}$ e alguns falantes do grupo $\mathbf{B}$ (principalmente em $\mathbf{S}$ ) é comum uma alternância entre a primeira e a terceira pessoas do singular do verbo fazer no pretérito perfeito:

$\begin{array}{ll}\text { ['ew fej] } & <\text { eu fiz }>^{241} \\ \text { ['ele fej] } & <\text { ele fez> } \\ \text { ['ew 'fis] } & <\text { eu fiz }> \\ \text { ['ele 'fis] } & <\text { ele fez }>\end{array}$

\footnotetext{
${ }^{241} \mathrm{O}$ português arcaico conhecia a forma $e u f e z$ (lat. feci).
} 
A alternância também ocorre entre a segunda e terceira pessoas:

['se fej] $\quad<$ você fez $>$

['se fis] <você fez $>$

E, assim como no dialeto caipira e em várias variantes brasileiras, aparece a forma verbal da terceira pessoa do singular utilizada na primeira pessoa do plural:

[nวj 'faj] <nós fazemos $>$

[nวj 'tẽj] <nós temos>

[nวj ' $\varepsilon$ ] < $\quad<$ nós somos>

[nวj 'fej] <nós fizemos>

[njj 'teve] <nós tivemos $>$

['noj 'foj] <nós fomos $>$ 


\section{CONSIDERAÇÕES FINAIS}

Este trabalho é o resultado de análises acerca da realidade linguística da comunidade tirolesa da cidade de Piracicaba, formada por dois bairros rurais, Santana e Santa Olímpia, fundados há mais de um século por imigrantes oriundos da região de Trento.

A variante falada do português da comunidade se diferencia no contexto linguístico piracicabano por sua acentuada influência do dialeto trentino, que lhe garante características fonológicas e lexicais próprias, e que ocorrem na fala de todas as gerações de descendentes. Por suas atividades culturais, a comunidade tirolesa se destaca na região e foi, inclusive, objeto de estudo de algumas pesquisas linguísticas e sociológicas (GiRALDELLI, 1992; LeME, 2001).

Para uma análise que abrangesse a realidade da comunidade, tornou-se necessário recolher informações que, em determinados tópicos deste trabalho, se desenvolveram em pesquisas de caráter sociolinguístico e - mesmo se para contextualização - histórico. Contudo, o que interessou a este trabalho foram os aspectos linguísticos presentes na fala dos moradores dos bairros: os graus de conservação de influências do dialeto trentino e do dialeto caipira, as variações e os neologismos. Ou seja, os aspectos principais da variante local e sua possível diferenciação entre as gerações de descendentes. 
Há poucos trabalhos que tratem dos falares das comunidades de imigração; sobre a comunidade em questão existem os estudos de LEME (2001), afirmando que, no que se refere à fala dos descendentes, é possível caracterizá-la, isto é, separá-la segundo as gerações de descendência:

"Depois de muito investigar, descobrimos que a situação linguística era bastante complexa. A pesquisa mostrou que era preciso caracterizar a fala das pessoas em função da geração (idade) a que pertenciam. Assim, ficamos sabendo que a primeira e a segunda gerações (dos nascidos no Brasil) são constituídas por pessoas realmente bilíngues, falantes do dialeto trentino (italiano) e do dialeto caipira (português). Na terceira e quarta gerações, a língua italiana começou a ficar de fora da vida das pessoas que, agora, já não viviam 'fechadas' nas fazendas, ou seja, nos bairros, mas tinham muitos contatos e até emprego na cidade. A quinta geração vive um momento especial de resgate das tradições e costumes da comunidade, até mesmo do ponto de vista linguístico, causado pelas comemorações do centenário da imigração e da fundação dos bairros".

(LEME, 2001: 149-150)

Entretanto, observou-se que não é exatamente a geração de descendência o principal fator de diferenciação na fala da comunidade. Dois fatores são relevantes para uma análise como esta, baseada no tempo aparente: a idade do falante e o seu grau de contato com o mundo fora dos bairros. LEME não deixou de levar em consideração a idade e o contato com a norma culta do português como fatores de diferenciação de fala, mas procurou “agregar” a diferença de fala das idades às gerações de descendência.

Sobre a idade, essa divisão de gerações se mostrou dificultosa, uma vez que, pelo fato das famílias serem grandes e possuírem filhos com idades bem diferentes, existem casamentos entre indivíduos da primeira geração com aqueles da segunda, da segunda com da terceira e da terceira com da quarta; é possível encontrar pessoas com mais de cinquenta anos que são descendentes da terceira geração no Brasil e pessoas com menos pouco mais de vinte e também pertencentes à terceira geração.

Quanto aos acontecimentos históricos, merece destaque um que significou muito na realidade social da comunidade, que foi o êxodo rural das décadas de 1960 e 1970 (causado pelo esgotamento que a monocultura de cana causou na comunidade), gerador da "abertura" da comunidade, até então resistente a tudo que se referisse ao externo. A partir 
de então, o nível escolar sobe entre aqueles que saem dos bairros para estudarem fora e cursar faculdades e os casamentos entre descendentes tiroleses e não-descendentes passou a ser uma realidade, que nas duas últimas décadas vem se mostrando bastante comum. Esses dois fatores trouxeram influências linguísticas até então desconhecidas entre os falantes e distanciaram o falar das gerações mais velhas daquelas mais novas, principalmente no que se refere ao uso do dialeto trentino.

Foi por isso que se dividiram os falantes segundo sua faixa etária e não por sua geração de descendência. Desse modo, dividindo os falantes entre os grupos A, B e C, foi possível realizar as análises pensando nesses dois aspectos principais que diferenciam os falantes da comunidade. Contudo, a diferenciação da fala entre as gerações, assim como a perda do dialeto trentino entre os falantes mais novos não significaram um nivelamento do falar dos bairros perante os demais bairros rurais piracicabanos; antes, permanece na comunidade seu modo particular de falar, repleto de influências (sobretudo lexicais) trentinas e que é utilizado por todas as gerações de falantes, aceito por todos os membros da comunidade e utilizado, inclusive, por não-descendentes que o utilizam como instrumento de aceitação no grupo.

LEME (2001) afirma que o dialeto caipira é uma realidade linguística das duas primeiras gerações de falantes da comunidade tirolesa. Sabe-se que em Piracicaba o dialeto caipira é uma variante difusa nas áreas rurais e influencia o modo de falar da área urbana. Entretanto, ressalvas precisam ser feitas no que se refere aos aspectos fonológicos da fala dessas primeiras gerações, ou melhor, dos falantes mais velhos, que desconhecem o uso da retroflexa [.], típica do falar de Piracicaba, mas considerada na comunidade tirolesa como uma característica atípica de sua fala e desprestigiada. Ela ocorre, entretanto, entre os falantes mais jovens, sobretudo de S. Se, por um lado, a retroflexa é vista entre os descendentes como uma característica do falar "caipira" e não do "imigrante", por outro lado, o dialeto caipira é aceito como uma variante conhecida da comunidade; resulta-se disso que há indivíduos entre todas as gerações que quase não apresentam em sua fala o uso da retroflexa, enquanto há outros cujo falar se diferencia daquele piracicabano apenas pelo uso do léxico trentino. 
"Os avós falam o dialeto trentino, os pais, o dialeto caipira, e os filhos misturam as duas variedades linguísticas. Há ainda quem saiba o italiano padrão e use a norma culta do português da região".

A variedade do português da comunidade, que LEME (2001) chama de variedade misturada por apresentar um considerável léxico trentino e regras particulares de realização alofônicas (descritas na Parte III deste trabalho), é o grande diferencial dos moradores em situações de contato com falantes de outras áreas de Piracicaba. A fala da comunidade foi muito estigmatizada, seja pelo seu léxico trentino (que muitas vezes torna incompreensível ao piracicabano o sentido do discurso), seja por suas regras alofônicas que lembram os falares do Sul, como o alçamento vocálico de [e] e [o] e o uso da vibrante simples [r] em contextos de uso da vibrante múltipla [r], que em Piracicaba vem utilizada com a retroflexa [^]. Outro aspecto significativo para o surgimento desse tabu linguístico foi a proibição do uso do dialeto trentino na escola local, que entre as gerações de crianças das décadas de 1950, 1960 e início de 1970 fez com que houvesse um rompimento com o antigo modo de falar da comunidade, cujo idioma das relações sociais do dial-a-dia era o dialeto trentino.

Sobre o léxico de origem trentina presente na variante local, nota-se que existem palavras que só ocorrem na fala dos mais velhos, enquanto há aquelas que ocorrem na fala de todas as idades e outras que aparecem principalmente na fala dos mais novos, que aplicam regras alofônicas e morfossintáticas do português. Nesse contexto, surgiram variações e ampliações de sentido, derivações e, até mesmo, alguns neologismos.

É sabido que os fundadores de $\mathbf{S}$ e $\mathbf{S O}$ eram oriundos de diferentes cidades tirolesas, de modo que são mantidas há mais de um século duas variantes dialetais trentinas próprias a cada bairro. Como demonstrado, não se trata de dois dialetos, mas de duas variantes de um mesmo, aquele que BATTISTI (1960) classificou como trentino rural ou dos arredores de Trento e que preserva em si aspectos arcaicos. O trentino piracicabano mantém-se, portanto, em duas variantes que diferenciam o falar dos mais velhos (bilíngues), e influenciou o português das gerações mais novas, proporcionando casos de palavras que ocorrem na variante do português de um bairro e não em outro. Ainda assim, não seria correto afirmar que essas diferenças lexicais são suficientes para a existência de duas 
variantes do português falado de cada bairro. Atenta-se para a ocorrência de arcaísmos do trentino europeu que são mantidos no trentino piracicabano, como, por exemplo, scaravànzi (SO) ou scaravànci (S) <ervilha>, que não encontramos em nenhum dicionário dialetal trentino ou vêneto por nós consultado, ou, ainda, làica <preguiça>, que segundo GROSSELLI (1991: 417) não ocorre mais na Europa, sendo uma palavra comumente usada na comunidade tirolesa de Piracicaba, inclusive na variante falada do português.

São raros os trabalhos que tratam das comunidades trentinas brasileiras, destacandose os estudos de BONATTI (1974) sobre a comunidade de Pomeranos, na cidade catarinense de Rio dos Cedros. Encontraram-se no trentino piracicabano palavras e construções como bùlgher significando "bugre" e nar "mbora <ir embora>, que ocorrem do mesmo modo no dialeto trentino da comunidade riocedrense.

A escola na comunidade procurou por muito tempo impor a norma culta do português sem levar em consideração a bagagem cultural e a realidade linguística dos alunos. Estigmatizava-se a variante caipira e proibia-se o uso do dialeto trentino entre os alunos; não se pensava que os pais das crianças mal sabiam se comunicar em português, pois utilizavam o dialeto trentino nas relações sociais da comunidade. A escola lhes pedia que deixassem de usar o dialeto em casa e os pais, que não dominavam o português, começaram a se comunicar com seus filhos em língua portuguesa. Não é por menos que uma variedade misturada, isto é, uma interlíngua, começou a ser o idioma de uso da comunidade. Porém, junto da proibição do dialeto, estava o conceito de certo e errado que não respeitava o modo de falar da comunidade e lhes impunha uma realidade linguística totalmente descontextualizada. Somente após as comemorações do centenário é que houve um despertar da comunidade para a valorização de seus costumes, por causa da valorização da própria história local. Isso se reflete atualmente na escola local, que procura valorizar a cultura tirolesa (trentina) e a variante falada da comunidade, embora não mantenha nenhum projeto temático nesse sentido.

Mas a fala se modifica não só pela pressão escolar, mas pela necessidade financeira e suas consequências. Aqueles falantes que estudam e trabalham fora da comunidade, já apresentam em sua fala diferenças, mesmo se ainda utilizem o léxico da comunidade. Entre os falantes com menor nível escolar, predominam as características do dialeto caipira de Piracicaba e o uso da retroflexa é mais perceptível; entre aqueles com maior nível escolar, a 
norma culta prevalece e, ao invés da retroflexa, vem utilizada tanto a vibrante múltipla como a fricativa velar surda que, como é sabido, prestigia-se nos meios de comunicação.

O grau de intimidade com a comunidade (por conta de ações culturais lá desenvolvidas em anos de convívio) permitiu um recolhimento de informações sem situações de tensão; ao contrário, as gravações das entrevistas foram feitas com espontaneidade e descontração. A análise dos corpora, baseada no conceito de tempo aparente, objetivou analisar a fala da comunidade de modo geral, sob os aspectos sincrônico e diacrônico, procurando identificar se a fala da comunidade mudou historicamente. Nesse sentido, a partir dos aspectos fonéticos, morfossintáticos e principalmente lexicais, percebe-se que a fala das gerações mais novas distanciam-se gradativamente da fala das mais velhas. Porém, ao mesmo tempo em que essa distância cresce com a diminuição dos falantes bilíngues da comunidade (mais velhos), é notória a vontade das gerações mais novas de não perder vínculos com seu passado e com sua identidade, procurando aprender o dialeto trentino (e o italiano padrão). Desse ínterim, surgem iniciativas como o curso de dialeto trentino para os jovens (em SO) e o status linguístico valorativo da variante do português local que os jovens fazem questão de manter. Se outrora era o próprio dialeto trentino que diferenciava a fala da comunidade dos demais piracicabanos, hoje é a variedade do português, trentinizada, que garante a identidade dos falantes mais jovens.

Outro fator que talvez influenciará a fala da comunidade no futuro é sua atual preocupação com o investimento turístico, tanto cultural como religioso. Trata-se, aos olhos dos moradores, uma "solução" para a preservação da identidade local, unindo a valorização de tudo o que é próprio aos bairros com um meio sustentável de sustento das famílias.

Embora predominem na fala dos mais velhos dos grupos $\mathbf{C}$ (principalmente) e $\mathbf{B}$ as influências morfossintáticas trentinas, observam-se também alguns casos no grupo A. São comuns na fala da comunidade várias formas verbais reflexivas, como na expressão eu me pensei, utilizada por praticamente todos os jovens da comunidade. Encontram-se, ainda, na fala da comunidade, formas verbais portadoras de pronomes pleonásticos, um uso não contemplado pelo Português brasileiro. 


\section{GLOSSÁRIO}

Neste glossário, apresentamos as palavras que apareceram durante as gravações e que são típicas do falar da comunidade. No caso das palavras oriundas do dialeto trentino, a ortografia adotada respeita os padrões tradicionalmente utilizados pelas línguas neolatinas do norte italiano e aparecem grifadas quando inseridas num discurso em português. Constarão aquelas que são mais utilizadas na variante do português da comunidade, que ocorrem na fala da maioria dos moradores.

As definições dos significados das palavras foram dadas pelo próprio pesquisador e as siglas e números que aparecem entre parênteses logo após são aquelas identificatórias dos informantes, utilizadas nas transcrições. Há casos de as palavras que apareceram em mais de uma entrevista, mas no glossário constarão as siglas de apenas um dos entrevistados que as utilizaram. Por último, aparecem pequenos trechos em que as palavras aparecem empregadas pelos entrevistados. 
atrai $=$ atrás (5BS - J.B.): lá atrai né?

$\operatorname{armoço~}=$ almoço (5BS - J.B.): patrão fei o armoço

avacaiou = avacalhou (3B.SO - J.E.S.): já avacaiou tudo já

Banco = Santa Olímpia (3ASO - L.D.): de um lado sentava só os do $\underline{\text { Banco }}$

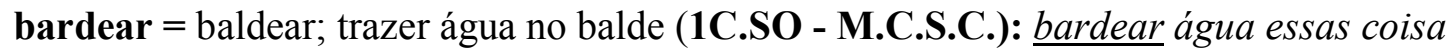
bèl = (trent.) belo; bonito, bom; agradável; que bèl! que bom!, que bonito! ter um bèl gostar de algo ou alguém; afeiçoar-se a alguém, apaixonar-se (4B.SO - R.C.C.): ai que bèl bèstia $=$ monstro imaginário (2BSO - E.P.): talvez seja o da bèstia

bisnóna $=($ trent.) bisavó (3B.SO - J.E.S.): aliás a minha bisnóna ela conheceu os frades bóna séra $=($ trent.) boa tarde (4B.SO - R.C.C.): $\underline{\text { bóna séra }}$ bóna nòte $=($ trent.) boa noite (4B.SO - R.C.C.): bóna nòte calipiá = eucaliptal (3CS - J.V.): desse calipiá... pegava cortava canéderli $=($ trent.) prato típico tirolês (tir. Knödel), nhoque de pão e linguíça (3ASO L.D.): stràngola prèti... canéderli... gróstoi cartola $=$ barril (5BS - J.B.): então tinha as cartola de vinho colazión $=($ trent.) café da manhã (3B.SO - J.E.S.): lá pa seis hora era a colazión comandaréssa $=$ (trent.) matriarca; mulher controladora (1C.SO - M.C.S.C.): comandaréssa entõ... entõ ela ia pa São Paulo così = (trent.) assim; tb. cossì (3B.SO - J.E.S.): ela sabia bem così cràuti $=($ trent.) chucrute (al. Sauerkraut) (3ASO - L.D.): de cràuti não gosto muito demai = demais (3ASO - L.D.): que era demai bagunceira depoi = depois (3ASO - L.D.): depoi ele veio

Dìo $=($ trent.) Deus; interj. de espanto, admiração ou desaprovação (1B.SO - O.P.): $\underline{D I: \because O}$ pare de falar igual nóna

doi = dois (3ASO - L.D.): dos doi bairro acho

far l'amór = (trent.) namorar (3B.SO - J.E.S.): se voléva far l'amór co móre ... poréti

fai = faz (3ASO - L.D.): a turma da minha geração é a mai que fai

$\mathbf{f e i}=$ fez (5BS - J.B.): patrão fei o armoço

gàmba = perna (4B.SO - R.C.C.): ah bèle gàmbe né?

gnent $=($ trent.) nada (5BS - J.B.): ma gnent que falava

gràspa $=($ trent.) aguardente da casca da uva (5BS - J.B.): gràspa ée::: é um outro 
gróstoi $=$ (trent.) prato típico tirolês, pastel doce (3ASO - L.D.): stràngola prèti... canéderli... gróstoi

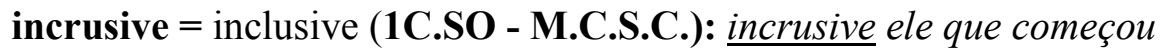

laicón = (trent.) preguiçoso (3B.SO - J.E.S.): não é porque é laicóni

lugànega $=($ trent.) linguiça de porco (5BS - J.B.): lugànega é

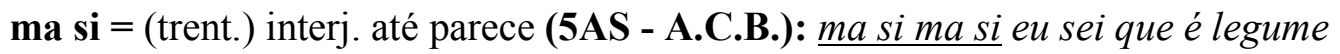

madòna $=($ trent.) Nossa Senhora; interj. de espanto ou admiração (3B.SO - J.E.S.): só um

foi esperto e foi embora ((risos))... madòna

mai = mas (3ASO - L. D.): eu to mai na dança

magnàr $=($ trent. $)$ comer (3B.SO - J.E.S.): magnàva magnàva

maledéta $=($ trent.) maldita (3B.SO - J.E.S.): é:: maledéta monocultura de cana

massàr $=($ trent.) matar (3B.SO - J.E.S.): ela massàva

massolìn = (trent.) ramalhet de flores (1B.SO - O.P.): né? massolìn né?

maridàrse $=($ trent.) casar-se (3B.SO - J.E.S.): ei èi se maridà coi coi móri coi zàldi

matèla $=($ trent.) garota; moça (4B.SO - R.C.C.): essa matèla bonita né?

matelòt = (trent.) garoto; menino (3B.SO - J.E.S.): matelòt che l'èra pién da vèrmi

me dìgo = (trent.) eu acho (5C.SO - F.C.D.): na ròba que gnànca ocoréva me dìgo

mèio $=$ (trent.) melhor (5BS - J.B.): l'èi mèio dòrmir

meió = melhor (2AS - F.V.C.): no controle é meió

merenda $=$ merenda (trent. marénda); café da tarde (3B.SO - J.E.S.): ao meio dia faziam a merenda

móro $=($ trent) homem negro (3B.SO - J.E.S.): se voléva far l'amór co móre... poréti

muié = mulher (3B.SO - J.E.S.): não tinha nenhuma muié aqui na: na fazenda

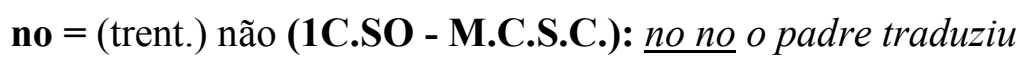

noi = nós (3CS - J.V.): naqueles tempo noi ia

nóna $=($ trent.) avó (1B.SO - O.P.): pare de falar igual nóna

nóno $=($ trent. $)$ avô (1C.SO - M.C.S.C.): por causa do nóno Simão

òcio $=($ trent.) olho $($ océt $<$ olhinho $>$; oción $<$ olhão $>)$ (3B.SO - J.E.S.): de océti de oción

((risos))

paia = palha (trent. pàia) (3CS - J.V.): tinha paia também 
pèrgola $=($ trent. $)$ pérgula para pendurar linguíças e demais defumados (5BS - J.B.): as linguiça da pèrgola

pis $=($ trent.) urina (5BS - J.B.): e pis quer dizer urinar aqui né?

ponhava = punham; colocavam (3CS - J.V.): no meio dia tirava e ponhava lá

pòrco bòia $=($ trent. pir.) interj. de espanto ou admiração (5BS - J.B.): aí o V. falou "pòrco bòia" lá

poréto $=($ trent. $)$ coitado (3B.SO - J.E.S.): entrou agiota no meio OH::: poréti

rósco $=($ trent.) sapo (5BS - J.B.): falou "é um rósco"

sacraménta $=$ (trent.) interj. de espanto ou admiração (3B.SO - J.E.S.): sacraménta

$(($ risos $))$... mai de de tanta criança que eles tinham salvava quem era teimoso

sgnàpa $=$ (trent.) aguardente; estado alcóolico (5BS - J.B.): sgnàpa é quando fica de fogo

stomeghés $=($ trent.) enfadonho; desagradável; demorado (3ASO - L.D.): um dia eu falei "ah que stomeghés"

stràngola prèti $=($ trent. $)$ prato típico tirolês, nhoque de pão, linguíça e espinafre (3ASO L.D.): stràngola prèti... canéderli... gróstoi

véio $=$ velho (10BS - J.B.): também acompanhava a turminha lá os véio

vortava $=$ voltava; voltavam (10BS - J.B.): eles num vortava

zàld com en codógn $=($ trent.) "amarelo como um marmelo", significando estar doente ou de cor pálida (15C.SO - F.C.D.): perguntaram còssa che l'èi zàld com en codógn? zìa $=($ trent.) tia (11C.SO - M.C.S.C.): a zìa Maria

Apresentamos, aqui, algumas palavras típicas do falar da comunidade, da variante do português ou oriundas do dialeto trentino. Tratam-se de palavras que não aparecem nas gravações, mas ocorrem com frequência na fala dos moradores:

abóbra = besteira; bobagem: como eles falam abóbra!

calor $=$ vergonha que uma pessoa pode causar com uma atitude embaraçosa; termo muito usado pelas meninas referindo-se a rapazes de atitudes infantis: $E$ um calor aquele menino! da sénza $=$ (trent. pir.) atitude ou pessoa sem noção; atitude impulsiva: aquele ali é um $\underline{d a}$ sénza 
paixão = pena; dó; tristeza: que paixão! [pa'کз̃w]

suspensól $=$ suspensório

tedéo $=($ lat. Te Deum $)$ significando bagunça ou confusão: depois da briga foi um tedéo

zucón (trent.) = “abóbora grande”; fig. cabeça dura; teimoso; tb. zucão; fem. zucóna. Mas você é um zucón!

\section{REFERÊNCIAS BIBLIOGRÁFICAS}

AMARAL, Amadeu. O dialeto caipira: gramática - vocabulário. São Paulo: Hucitec, 1982 (1 $1^{\text {a }}$ edição: 1920).

ANEGGI, Aldo. Dizionario cembrano. Trento: Artigianelli, 1984.

ASCOLI, Grazieadio. I. Saggi ladini in Archivo glottologico italiano 1, 316 - 533. Firenze: Archivio storico italiano, 1873.

AZZI, Riolando. Fé e italianidade: a atuação dos escalabrinianos e dos salesianos junto aos imigrantes. In: DE BONI, Luis Alberto (org). A presença italiana no Brasil. Porto Alegre: EST, 1990.

AZZOLINI, Giambattista. Vocabolario vernacolo - italiano pei distretti Roveretano e Trentino. Trento: Calliano, 1976.

BACELLAR, Carlos de A. P. O processo de povoamento do território paulista, séculos XVI a XX. In: OLIVEIRA, Marilza (org). Lingua portuguesa em São Paulo: 450 anos. São Paulo: Humanitas, 2006. 
BARATTER, Lorenzo. Le Dolomiti del Terzo Reich. Milano: Ugo Mursia, 2005.

. Dalla vendetta al ricordo - $i$ soldati trentini nell'esercito austro-ungarico durante la prima guerra mondiale (1914-1918). In. COMPAGNIA SCHÜTZEN DI ROVERETO. La memoria negata: l'oblio dei caduti austro-ungarici roveretani. Trento: Regione Autonoma Trentino-Alto Adige/Südtirol, 2009.

BARBIERI, Giuseppe (org). Die vier Elemente in Trentino, Südtirol und Tirol: Feuer. Vicenza: Terra Ferma / Bank für Trient und Bozen, 2005.

BASSETTO, Bruno Fregni. Elementos de filologia românica. São Paulo: Edusp, 2001.

BATTISTI, Carlo. Die Nonsberger Mundart. Wien: Alfred Hölder, 1908. . Sulla pretesa unità ladina. Archivo glottologico italiano, Firenze: Archivio storico italiano1920. . Popoli e lingue nell'Alto Adige: studi sulla latinità altoatesina. Firenze: R. Bemporad \& Figlio, 1931. . La classificazione dei dialetti trentini. Firenze: Sansoni, 1970.

BEC, Pierre. Manuel pratique de philologie. Paris: A \& J. Picard, 1971, v. 2.

BENVENISTE, Emile. Problemas de lingüistica geral I. Campinas, SP: Universidade Estadual de Campinas, 1995.

BERNARDI, Rut. Curs de gherdëina. San Martin de Tor: Institut Ladin “Micurà de Rü”, 1999.

BONATTI, Mário. Aculturação lingüistica numa colônia de imigrantes italianos de Santa Catarina. Lorena: Faculdade Salesiana da FCL / Instituto de Estudos Históricos do Vale do Itajaí, 1974. . O dialeto trentino de Pomeranos - um estudo de antropologia lingüística. Tese de doutoramento. Lorena: Faculdade Salesiana da FCL / Instituto de Estudos Históricos do Vale do Itajaí, 1968.

BONISEGNA, Arturo. Dialetto e mestieri a Predazzo. San Michelle all'Adige: Museo degli Usi e Costumi della Gente Trentina, 1980.

BUNSE, Heinrich. Estudos de dialetologia no Rio Grande do Sul. Porto Alegre: UFRGS, 1969.

BOSO, Ivete Maria. "Noialtri chi parlen tuti en talian" - Dialetti trentini in Brasile. Trento: Museo storico di Trento, 2002. 
CÂMARA Jr., Joaquim Mattoso. História e estrutura da língua portuguesa. Rio de Janeiro: Padrão, 1975.

. Estrutura da lingua portuguesa. Petrópolis: Vozes, 1988.

CANDIDO, Antonio. O caipira e sua cultura. In: FERNANDES, Florestan (org). Comunidade e sociedade no Brasil. São Paulo: Companhia Editora Nacional, 1975. . Os parceiros do Rio Bonito. São Paulo: Duas Cidades, 1977. . Piracicaba no alvorescer do século XIX-memórias da rua do Porto e de uma chaminé solitária. Piracicaba: Revista IHGP, vol 11, ano XI, 2004.

CAPRARA, Loredana. O Italiano dos Italianos em São Paulo. Introdução. Revista de Italianística 5. 1997. p. 9-15. FFLCH-USP, São Paulo.

CASTILHO, Ataliba.T. Estudo do português culto falado no Brasil. História do Projeto NURC. In: PRETI, D. e URBANO, H. (orgs). São Paulo, T.A. Queiroz / FAPESP, 1989. . (org.) - Gramática do Português Falado. Vol. I: A Ordem. Campinas, Editora da UNICAMP / FAPESP, 1990.

CASTRO, Giliola Maggio. Pedrinhas Paulista: o isolamento no espaço e na língua. In: Anais do X Congresso Nacional de Professores de Italiano e do IV Encontro Internacional de Italianística. Florianópolis, 2005. p. 118-128 (não publicado).

. Esempi di esitazione nella riformulazione del discorso interlinguistico degli immigrati "pedrinhenses". Revista de Italianística, São Paulo, 2004. p. 113 - 128 (não publicado).

COL, Gemo da. L'idioma ladino a Cibiana di Cadore. Pieve d'Alpago: Nuove edizioni Dolomiti, 1991.

COLLE, Liotta et alii. Vocabolario italiano-ampezzano. Cortina d'Ampezzo: Cassa Rurale ed Artigiana, 1997.

COMPAGNIA SCHÜTZEN DI ROVERETO. La memoria negata: l'oblio dei caduti austro-ungarici roveretani. Trento: Regione Autonoma Trentino-Alto Adige/Südtirol, 2009.

CONWAY, Robert S. The prae-Italic dialects of Italy. Cambridge: Harward University, 1933.

CORTELAZZO, Manilo \& MARCATO, Carla. Dizionario etimologico dei dialetti italiani. Torino: UTET, 1992. 
COUTINHAS, João M. Callaeci Bracari - aproximação à identidade etno-cultural. Porto: TM, 2006.

COVERI, Lorenzo \& BENUCCI, Antonella \& DIADORI, Pierangela. La varietà dell'Italiano - Manuale di sociolinguistica italiana. Siena: Bonacci, 1998.

CROATO, Enzo. Vocabolario ampezzano. Cortina d'Ampezzo: Cassa Rurale ed Artigiana, 1986.

CURI, José. Il dialeto de Rio Cedro - estudo fonético, morfológico, sintático, lexical e semântico. Florianópolis: UFSC, 1972.

. Raconti di Rio Cedro. Florianópolis: UFSC, 1984.

DAL BOSCO, Giorgio. Trento 1969 - 1988. Lavis: Alcione, 2007.

DELLA MONICA, Walter. I dialetti e l'Italia: inchiesta fra scritori, poeti, sociologi, specialisti. Milano: Pan, 1981.

DEVOTO, Giacomo \& GIACOMELLI, Gabriella. I dialetti delle regioni d'Italia. Firenze: Sansón, 1991.

DILLENBURG, Sérgio R.. Tempos de incerteza. Porto Alegre: Edições Est, 1995.

D’OVIDIO, Francesco. Grammatica storica della lingua italiana e dei dialetti italiani. Milano: Hoepli, 1932.

EGG, Erich. La tradizione degli Schützen nel Tirolo di lingua italiana. Matarello: Futura, 2000.

EICHENHOFER, Wolfgang. Diachronie des betonten Vokalismus im Bündnerromanischen seit dem Vulgärlatein. Zürich: Juris, 1989.

ENGLER, Günther. Oberitalien. Bern: Hallwag, 1980.

FABER, F. Evagatorium in terrae sanctae peregrinationem in PATLINGER, Josef. Beschwerdenschriften der Deutschen zu Trient. Folge III. Zeitschrift des Ferdinandeums für Tirol und Vorarlberg. Innsbruck: Ferdinandeums Museum, 1970.

FERREIRA, Carlota. A dialetologia no Brasil. São Paulo: Contexto, 1994.3v.

FERREIRA, Carlota et allii. Diversidade do português do Brasil-estudos de dialetologia rural e outros. Salvador: Proed, 1992.

FOX, Elio. I dialetti tretnini in Trentino Oggi, VII - Collana di monografie "La Patria di origine”. Trento: Panorama, 1997. 
FRANCESCHI, Temistocle \& Cammelli, Antonio. Dialetti italiani dell'ottocento nel Brasile d'Oggi. Firenze: Cultura, 1977.

FRANCHINI, Angelino. Taron: gergo di immigranti in Val Rendena. San Michele all'Adige: Museo degli Usi e Costumi della Gente Trentina, 1980.

FRANCO, Hilário. Cocanha: a história de um país imaginário. São Paulo: Companhia das Letras, 1998.

. Cocanha - várias faces de uma utopia. São Paulo: Ateliê Editorial, 2007.

FROSI, Vitalina \& MIORANZA, Ciro. Dialetos italianos: um perfil lingüístico dos italobrasileiros no Nordeste do Rio Grande do Sul. Caxias do Sul: EDUCS, 1983.

FURTADO, Celso. Formação econômica do Brasil. São Paulo: Publifolha, 2000.

GARTNER, Theodor. Die Grödner Mundart. Wien: Selbstverlag, 1879. . Rätoromanische Grammatik. Heilbronn. Henningen, 1883. . Ladinische Wörter aus den Dolomitentälern. Halle: Max Niemeyer, 1923.

GIRALDELLI, Sandra Regina. Santa Olímpia e Santana: trajetória social e memória. Dissertação de mestrado em História. Campinas: Unicamp, 1992.

GIRARDI, Silvio. L'avventura dell'ultimo cavaliere: biografia dell'Imperatore Massimiliano, uomo dell'Europa. Trento: Centro Stampa, 2008.

GIUSTINIANI, B. Storia Veneta. Roma: S\&L, 1969.

GRANDI, Casimira. "La popolazione rurale trentina nella prima metà dell'Ottocento, primi resultati di un indagine" in Popolazione, assistenza e strutura agraria nell'Ottocento trentino. Trento: Provincia Autonoma di Trento, 1978.

GRASSI, Conrado. Dialettologia italiana. Torino: Tirrenia, 1980.

GRI Paolo \& SAN GIUSEPPE Chiara. I costumi popolari del Trentino. Trento: Museo degli Usi e Costumi della Gente Trentina / Cassa Rurale Trentina, 1994.

GROFF, L. Dizionario trentino-italiano. Trento: Monauni, 1955.

GROSSELLI, Renzo M. Vincere o morire - Contadini trentini (veneti e Lombardi) nelle foreste brasiliane. Parte I - Santa Catarina 1875-1900. Trento: Provincia Autonoma di Trento, 1986. . Colonie imperiali nella terra del caffè - Contadini trentini (veneti e Lombardi) nelle foreste brasiliane. Parte II - Espírito Santo 1874-1900. Trento: Provincia Autonoma di Trento, 1987. 
. Dove cresce l'Araucaria - Dal Primiero a Novo Tyrol - Contadini trentini (veneti e Lombardi) nelle foreste brasiliane. Parte III - Paraná 1874-1940. Trento: Provincia Autonoma di Trento, 1987.

. Da schiavi bianchi a coloni. Um progetto per le fazendas - Contadini trentini (veneti e lombardi) nelle foreste brasiliane. Parte IV - São Paulo 1875-1914. Trento: Provincia Autonoma di Trento, 1990.

. Trentamilla tirolesi in Brasile - storia, cultura, cooperazione allo sviluppo. Trento: Provincia Autonoma di Trento, 2001.

. Noi tirolesi, suditi felici di Dom Pedro II. Trento: Provincia Autonoma di Trento, 2008.

. Il tirolese. Trento: Provincia Autonoma di Trento, 2009.

GUADAGNINI, Angelo. Dizionario del dialetto di Predazzo. Rovereto: Longo, 1985.

HAUGEN, Einar. The norwegian language in America. A study in biligual behavior. Philadelphia: University of Pensylvania, 1953.

HOFER, Lorenz. Sprachwandel im städtischen Dialekterepertoire: eine variationslinguistische Untersuchung am Beispiel des Baseldeutschen. Tübingen/Basel: Francke, 1997.

HOLZNER, Birgit. Tirol auf den Spuren der Kultur. Innsbruck: AMAG, 1999.

HOLTUS, Günter. Lexicon der romanistischen Linguistik. Tübingen: Max Niemayer,1994.

HOLZNER, Johann. Adler ohne Kopf: andere Erzählungen aus Tirol. Innsbruck: Haymon, 1991.

HORMAYR, Josef von. Geschichte Andreas Hofer's, Sandwirths aus Passeyr, Oberanführers der Tyroler im Kriege von 1809. Leipzig / Altenburg: Stern, 1817.

HOUAISS, Antonio. O português no Brasil. Rio de Janeiro: Revan, 1992.

HUTTER, Lucy Maffei. Imigração italiana em São Paulo (1880-1889); os primeiros contatos do imigrante com o Brasil. São Paulo: IEB - USP, 1972.

IVE, Antonio. I dialetti ladino-veneti dell'Istria. Bologna: Arnaldo Forni, 1975.

JARNUT, Jörg. Storia dei Longobardi. Torino: Einaudi, 2002.

KAHMANN, Christa I. Interferência entre a lingua portuguesa e um dialeto alemão.

Dissertação de Mestrado em Letras. Santa Cruz do Sul: CEPEIL, 19987. 
KREUTZ, Lúcio. A educação de imigrantes no Brasil. In: LOPES et alii (orgs.). 500 anos de educação no Brasil. Belo Horizonte: Autêntica, 2000.

LABOV, Willian. Sociolinguistic patterns. Philadelphia: University of Pennsylvania Press, 1972.

LE GOFF, Jacques. História e Memória. Campinas:Unicamp, 1992.

LEDRA, Vitório. Cancioneiro do imigrante italiano - Coletânea de canções populares italianas da época da emigração. Brusque: Mercúrio, 1945.

LEME, Maria Luisa de A. Dio, che brut estuda... um estudo lingüístico da comunidade tirolo-trentina da cidade de Piracicaba. Campinas: Unicamp, 2001.

. Educação, cultura e linguagem: a comunidade tirolo-trentina da cidade de

Piracicaba. Tese de doutoramento em Eduação. Campinas: Unicamp, 2001.

LENARD, Andrietta. Lealdade lingüística em Rodeio - SC. Dissertação de mestrado em Letras. Florianópolis: UFSC, 1976.

LEONARD, C. Proto-Raeto-Romance and French. In: Language 40: 32ss, 1962.

LONGO, Jessica. Germanismi nel dialetto primierotto. Trabalho de conclusão de curso em Letras e Tradução. Trieste: Scuola Superiore di Lingue Moderne, 2006.

LORENZONI, Júlio. Memórias de um imigrante italiano. Porto Alegre: Sulina / PUC RS, 1975.

LUCCHESI, Dante. Variação e norma: elementos para uma caracterização sociolingüistica do português do Brasil. In: Revista Internacional de Língua Portuguesa, n. 12, 1994 (Associação das Universidades de Língua Portuguesa).

LUZZATTO, Darcy L. Dissionàrio talian veneto brasilian - portoghese. Porto Alegre: Sagra Luzzatto, 2000.

MARCUSCHI, Luis A. Análise da conversação. São Paulo: Ática, 1986.

MATTEI, Luigino (org). La Patria di Origine. Vol I: Il bel Trentino. Trento: Panorama, 1986.

. La Patria di Origine. Vol II: Tesori d'arte nel Trentino. Trento: Panorama, 1987.

. La Patria di Origine. Vol III: Voci di poesia del Trentino. Trento: Panorama, 1988. . La Patria di Origine. Vol IV: Prodotti e piatti tipici. Trento: Panorama, 1989. 
. La Patria di Origine. Vol V: Gli 800 anni del Principato di Trento. Trento:

Panorama, 1990.

. La Patria di Origine. Vol VI: Canti e racconti (espressioni popolari del Trentino). Trento: Panorama, 1992.

. La Patria di Origine. Vol VII: Gli ultimi duecento anni. Trento: Panorama, 1994.

. La Patria di Origine. Vol VIII: Il Trentino oggi. Trento: Panorama, 1997.

MATTOS E SILVA, Rosa V. (org.). Para a história do Português Brasileiro. Primeiros estudos. v. II, tomos I e II. São Paulo: EDUSP, 2001.

. Ensaios para uma sócio-história do português brasileiro. São Paulo: Parábola, 2004.

MEYER-LÜBKE, Wilhelm. Grammaire des langues romanes. Paris: H. Welter, 1906. . Introdução ao estudo da glotologia românica. Antonio Guerra Judice (trad).

Lisboa: Clássica, 1916. . Romanisches Etymologisches Wörterbuch. Heidelberg: Carl Winter, 1992.

MAZZEL, Massimiliano. Dizionario Ladino fassano (cazet) - Italiano. Vigo di Fassa: Institut Cultural Ladin, 1996.

MEGALE, Heitor (org). Filologia Bandeirante. São Paulo: Humanitas, 2000.

MENGHIN, Wilfried. Frühgeschichte Bayerns. Stuttgart: Theiss, 1990.

MONDADORI, Oscar. Motti e proverbi dialettali delle regioni italiane. Milano: A. Mondadori, 1977.

NATAL, Ada. O dialeto caipira da região de Piracicaba. São Paulo: Ática, 1974.

NAZARI, Oreste. I dialetti italici: grammatica, escrizioni, versione, lessico. Milano: Hoepli, 1900.

NEME, Mário. Dois antigos caminhos de sertanistas de São Paulo. São Paulo: s/ed., 1969. . História da fundação de Piracicaba. Piracicaba: IHGP, 1974.

NETTO, Cecílio Elias. Arco, tarco, verva - as delícias do refinado dialeto piracicabano. Piracicaba: Shekinah, 1988.

OLIVEIRA E SILVA, G M. Coleta de dados. In: Introdução à sociolinguística - $O$ tratamento da variação. MOLLICA \& BRAGA (org). São Paulo: Contexto, 2003.

OSTI, Giuseppe. Tracce tedesche nei dialetti trentini. Rovereto: 2001. 
PELLEGRINI, Giovan Battista. Saggi sul ladino dolomitico e sul friulano. Bari: Adriatica, 1972.

PIRES, Cornélio. Conversas ao pé do fogo. São Paulo: Imprensa Nacional, $1987\left(1^{\mathrm{a}} \mathrm{ed}\right.$. 1921).

PIRES, Cibélia R. da Silva. A formação e expansão da cultura e dialeto caipira na região de Piracicaba. Dissertação de mestrado em Letras. São Paulo: USP, 2008.

POMPERMAYER, Malori José \& MIRANDA, Glaura Vasques de. Os Pompermayer na Itália, Brasil e Argentina. Uma história de sete séculos. Belo Horizonte: Mazza, 2005.

PRATI, Angelico. Dizionario valsuganotto. Veneza: ICC, 1960.

PRETI, Dino. A gíria e outros temas. São Paulo: USP, 1984. . Análise de textos orais. São Paulo: USP, 1999.

QUARESIMA, Enrico. Vocabolario anaunico e solandro raffrontato col trentino. Venezia/Roma: Olschk, 1964.

RAFAELLI, Umberto. Proverbi del Trentino. Firenze: Sansoni, 1981.

Revista Italianística (Universidade de São Paulo).

REDFERN, James. A lexical study of Raeto-Romance and contiguous Italian dialect areas. Paris: Mouton, 1971.

RIBEIRO, Joaquim. Folklore dos Bandeirantes. Rio de Janeiro: José Olympio, 1946.

RICCADONNA, Graziano. Andreas Hofer "trentino” nel secondo centenario dell'Anno Nove. Trento: Provincia Autonoma di Trento, 2009.

RIENZNER, Claudia. Volks- und Soldatenlieder in Trentino. Innsbruck: Institut für Geschichte / Universität Innsbruck, 2004.

RODRIGUES, Ângela C. S. A concordância verbal no português popular em São Paulo. Tese de doutoramento. São Paulo: USP, 1987.

. O português popular em São Paulo. In: OLIVEIRA, Marilza (org). Língua portuguesa em São Paulo: 450 anos. São Paulo: Humanitas, 2006.

ROHLFS, Gerhard. Historische Grammatik der italienischen Sprache und ihrer Mundarten. Berna: A. Francke, 1949-1954. 3v. . Lengua y cultura; estudios linguisticos y folkloricos. Madrid: Alcalá, 1966. . Studi e ricerche su lingua e dialetti d'Italia. Firenze: Sansoni, 1990. 
ROSSI, Hugo von. Ladinisches Wörtebuch - Vocabolario ladino (brach) - tedesco. Innsbruck / Vich: Universität Innsbruck / Institut Cultural Ladin, 1999.

SALVIONI, Carlo. Ladinia e Italia. Rediconti dell'Istituto Lombardo, 1917.

SANTIAGO-ALMEIDA \& COX (orgs). Vozes cuiabanas: estudos linguísticos em Mato Grosso. Cuiabá: Cathedral, 2005 (pp. 21 -28).

SANTOS, Roselys Izabel Correa dos. A Terra Prometida - Tese e antitese. Os Jornais do norte da Itália e a imigração para o Brasil (1875-1899). Tese de doutoramento em História. São Paulo: USP, 1995.

SCHMID, Heinrich. Wegleitung für den Aufbau einer gemeinsamen Schriftsprache der Dolomitenladiner. San Martin de Tor/Visch: Micurá de Rü/Majon de Fascegn, 1998.

SCLIAR-CABRAL, Leonor. Romances e canções sefarditas (Séc. XV ao XX). São Paulo: Massao Ohno, 1990.

ŠEBESTA, Giuseppe. Considerazione storiche sulla Val di Cembra. In: ANEGGI, Aldo. Dizionario cembrano. Trento: Artigianelli, 1984.

SEVERINO, José Roberto. Noi oriundi: cultura, identidade e representações da imigração italiana em Santa Catarina. Tese de doutoramento. São Paulo: USP, 2004.

SILVA NETO, Serafim da. A língua portuguesa no Brasil. Problemas. Rio de Janeiro: Acadêmica, 1960.

. História da língua portuguesa in Coleção Brasileira de Filologia Portuguesa. Rio de Janeiro: Presença, 1970. . Introdução ao estudo da língua portuguesa no Brasil. Rio de Janeiro: Presença, 1986.

SILVEIRA, Enzo. Breviário heráldico medalhístico e nobiliário. São Paulo: Ensil, 1972. SOLÈR, Clau. Sprachgebrauch und Sprachwandel: eine theoretische Faktoranalyse und die pragmatik der Sprachbehandlung bei den Rätoromanen von Lumbrein mit einem Vergleich der Germanisierung in Präz und Sarn. Zürich: Zentralstelle der Studentenschaft, 1983.

STAWINSKI, Alberto V. Dicionário Vêneto - Português - Italiano. Treviso: Cornuda, 1995.

STÖRMER, Wilhelm. Die Bajuwaren. München: C. H. Beck, 2002. 
SULZER, Giuseppe Giorgio. Dell'origine della natura dei dialetti comumente chiamati romanci messi a confronto coi dialetti consimili esistenti nel Tirolo. Trento: Perini, 1855.

TAGLIAVINI, Carlo. Studi linguistici ladino-veneti I. Nuovi contributi alla conoscenza del dialetto di Comèlico. Veneza: Carlo Ferrari, 1944.

. Le origini delle lingue neolatine. Bologna: Pàtron, 1982.

TAJINA, Alessandra D. Dizioner talian-fascian-talian. Pilat: Artigianelli, 1998.

TARALLO, Fernando. A pesquisa sociolingüística. São Paulo: Ática, 1985.

TEYSSIER, Paul. História da língua portuguesa. São Paulo: Martins Fontes, 1977.

TISSOT, Livio. Dizionario primierotto. Trento: Vallagarina, Museo degli Usi e Costumi della gente Trentina / Compresorio di Primiero, 1996.

TONINA, Osvaldo. Dall'Antologia di Don Livio Rosa. Tra gli scritti rimasti: l'Inno al Tirolo. Trento: Nuove Arti, 2006.

TORRES, Maria C. T. M. Piracicaba no século XIX. Piracicaba: Degaspari, 2003.

TRENTINI NEL MONDO - Mensile dell'Associazione Trentini nel Mondo a cura di Rino Zandonai. Provincia Autonoma di Trento (edições dos anos 2005-2008).

VIARO, Mario Eduardo. Comparaziun tranter varsaquantas construcziuns verb+adverb em rumantsch ed em portugais in Annalas de la Sociedad Retorumantscha. Cuira: Sociedad Retorumantscha, 2000.

. A construção verbo + advérbio de lugar no romanche: herança latina ou decalque germânico? Tese de doutoramento em Letras (Filologia Românica). São Paulo: USP, 2001.

. Semelhanças entre o português brasileiro e as variedades africanas e asiáticas.

In: SILVA, Luiz A. (org). A língua que falamos - Português: história, variação e discurso. São Paulo: Globo, 2005.

VIDESOTT, Paul. Evolution und Chancen der ladinischen Sprache. Innsbruck: Wagner, 2002.

VITTI, Guilherme. "En contadin de Meano che s'ha fat bon brasiliano" - Centenario dell’imigrazione dei tirolesi del Municipio di Piracicaba - Brasile 1877-1977 (texto apresentado como apêndice na dissertação de Grosselli, 1990). Trento: Provincia Autonoma di Trento, 1990. 
VITTI, Guilherme. Esperança de uma vida nova - 100 anos de Santana 1893 - 1993. Piracicaba: Shekinah, 1993.

WAGEMANN, Ernst. A colonização alemã no Espírito Santo. Rio de Janeiro: IBGH, 1949. WARTBURG, Walther von. Die Ausgliederung der romanischen Sprachräume. Bonn: Klopp, 1928.

. Problemas y métodos de la linguística. Trad. Dámaso Alonso \& Emilio Lorenzo. Madri: CSIC, 1951.

WEBER, Beda, Das Thal Passeier und seine Bewohner. Mit besonderer Rücksicht auf Andreas Hofer und das Jahr 1809. Innsbruck: UI, 1852.

WEINREICH, U. Languages in contact. The Hague: Mouton, 1953.

ZAMBONI, Alberto. In: FROSI, Vitalina \& MIORANZA, Ciro. Dialetos italianos: um perfil lingüistico dos ítalo-brasileiros no Nordeste do Rio Grande do Sul. Caxias do Sul: EDUCS, 1983.

ZORZI, Narciso. Dizionarietto del dialetto fiemmese parlato nel quartiere di Tesero Panchià - Ziano. Panchià/Ziano: PAT, 1977.

\section{Anexos}




\section{ANEXO 1 - DADOS PESSOAIS DOS INFORMANTES}

Para a tabela de dados dos entrevistados, utilizamos os modelos propostos pelo Atlas Linguístico Brasileiro. Na tabela constam as iniciais do nome do informante, idade, sexo, bairro onde reside, escolaridade, profissão, descendência tirolesa (ambos os pais nascidos no Tirol ou descendentes), religião e grau de contato com meios de comunicação de massa.

\begin{tabular}{|c|c|c|c|c|c|c|c|c|}
\hline Iniciais & Idade & Sexo & Bairro & Escolaridade & Profissão & $\begin{array}{c}\text { Ambos } \\
\text { os pais } \\
\text { tiroleses }\end{array}$ & $\begin{array}{c}\text { Religião } \\
\text { Contato com } \\
\text { meios de } \\
\text { comunicação }\end{array}$ \\
\hline G.V.B. & 11 & $\mathrm{~F}$ & $\mathrm{~S}$ & fundamental & estudante & não ${ }^{242}$ & católica & muito \\
\hline F.V.C. & 15 & $\mathrm{M}$ & $\mathrm{S}$ & ensino médio & estudante & sim & católica & muito \\
\hline L.D. & 17 & $\mathrm{M}$ & $\mathrm{SO}$ & ensino médio & estudante & sim & católica & muito \\
\hline
\end{tabular}

${ }^{242}$ A mãe é descendente de tiroleses; o pai de tiroleses e alemães. 


\begin{tabular}{|c|c|c|c|c|c|c|c|c|}
\hline E.S. & 24 & $\mathrm{~F}$ & $\mathrm{SO}$ & superior & fonoaudióloga & sim & católica & muito \\
\hline A.C.B. & 30 & $\mathrm{~F}$ & $\mathrm{~S}$ & superior & $\begin{array}{c}\text { técnica em } \\
\text { segurança }\end{array}$ & não $^{243}$ & católica & médio \\
\hline O.P. & 41 & $\mathrm{~F}$ & $\mathrm{SO}$ & superior & professora & sim & católica & muito \\
\hline E.P. & 47 & $\mathrm{M}$ & $\mathrm{SO}$ & ensino médio & técnico & sim & católica & muito \\
\hline J.E.S. & 50 & $\mathrm{M}$ & $\mathrm{SO}$ & superior & empresário & sim & católica & muito \\
\hline R.C.C. & 58 & $\mathrm{~F}$ & $\mathrm{SO}$ & ensino médio & enfermeira & não & católica & muito \\
\hline J.B. & 59 & $\mathrm{M}$ & $\mathrm{S}$ & ensino médio & comerciante & não & católica & médio \\
\hline M.C.S.C. & 71 & $\mathrm{~F}$ & $\mathrm{SO}$ & fundamental & dona-de-casa & sim & católica & muito \\
\hline A.F.V. & 83 & $\mathrm{~F}$ & $\mathrm{~S}$ & fundamental & dona-de-casa & sim & católica & pouco \\
\hline J.V. & 83 & $\mathrm{M}$ & $\mathrm{S}$ & fundamental & agricultor & sim & católica & pouco \\
\hline J.D. & 87 & $\mathrm{M}$ & $\mathrm{SO}$ & fundamental & agricultor & sim & católica & médio \\
\hline F.C.D. & 98 & $\mathrm{M}$ & $\mathrm{SO}$ & fundamental & agricultor & sim & católica & médio \\
\hline
\end{tabular}

ANEXO 2 - TranSCRIÇÕES

\section{2 - CRITÉRIOS ADOTADOS NA TRANSCRIÇÃo ORTOGRÁFICA DAS ENTREVISTAS}

Para as transcrições, adotamos as orientações das NORMAS DE TRANSCRIÇÃO DO NURC, projeto de estudo da norma linguística urbana culta. Observa-se que:

- As palavras estrangeiras aparecem em transcrição fonética.

- As iniciais maiúsculas foram utilizadas para nomes próprios, siglas, nomes de cidades, estados e países.

- Fáticos: AH, OH, ahn, hum etc.

- Não se indica o ponto de exclamação, apenas o de interrogação.

${ }^{243}$ Pai descendente de alemães e mãe descendente de tiroleses.

${ }^{244}$ Pai descendente de tiroleses e mãe descendente de italianos (acreditam ser vênetos).

${ }^{245}$ J.D. é sobrinho de F.C.D., cuja avó afirmam ser de família francesa, mas era nascida no Tirol e falante do trentino (suíça? Piemontesina?).

${ }^{246}$ A família da mãe era francesa. 
- Não se indicam os sinais de pausa da língua escrita com ponto final, vírgula ou ponto-e-vírgula; a pausa é indicada com o sinal apropriado, conforme tabela abaixo.

- Ocorre combinação de sinais, como no exemplo: é a/ é:: aí [o]:: [o]:::...

- Todas as palavras em dialeto trentino aparecem transcritas foneticamente.

- Toda vez que o -r [r] do infinitivo, em posição de coda, não aparecer, não será indicado. Quando utilizada a retroflexa $[\iota]$, será indicada. A retroflexa também é indicada em todos os casos em que aparece, por se tratar de uma característica pouco frequente na fala da comunidade tirolesa, se comparada aos falares das demais áreas piracicabanas.

- As formas verbais na terceira pessoa do plural, como em [fa'larv] <falaram>, não aparecem indicadas.

- Todo -o e - $\boldsymbol{e}$ postônicos devem ser interpretados como [i] e [u] / [ ], exceto se indicados. Ainda que, no caso da comunidade tirolesa, é comum o uso de [e] e [o] postônicos, todos os casos aparecem indicados.

- A sequência -ou-, como em falou, ocorre sempre monotongada enquanto [o]. A sequência -eiaparece monotongada em [e], sendo indicada, em caso de sequência vogal + semivogal, como [ej].

- O -l-, em posição de coda, quando realizado como [w] não aparece assinalado, mas é indicado quando realizado como $[t]$.

- Nas variações entre [a] e [aj], [e] e [ej], [วs] e [jj] diante de $\boldsymbol{- s}$ e $\boldsymbol{- z}$ finais, a variante do português da comunidade tirolesa apresenta a queda da sílaba final (como em ['nəj] $<$ nós $>$ e $[$ faj] $<$ faz $>$ ). Todos esses casos aparecem indicados nas transcrições.

- Quando não é pronunciado o -s final das primeiras pessoas do plural, usa-se $\varnothing$. O mesmo ocorre quando não é pronunciado algum segmento.

- Quando o $\boldsymbol{b}$ da palavra também não aparece pronunciado, usa-se $\varnothing$.

- As conjunções $\boldsymbol{e}$ e $\boldsymbol{o u}$ devem ser lidas como [e] e [o] e não são indicadas nas trasncrições.

- As formas pra, pras, pro, pros, prum, pruns não são indicadas e aparecem dessa maneira nas transcrições. As formas sincopadas pa, pas, po, pos, ocorrem raramente e aparecem indicadas.

- As sequências com a, com as, com o, com os são indicadas quando ocorrem como [ka], [kas], [ko] e [kos].

\begin{tabular}{|l|l|l|}
\hline Ocorrência & Sinal & Exemplo ortográfico \\
\hline
\end{tabular}




\begin{tabular}{|c|c|c|}
\hline $\begin{array}{c}\text { Superposição ou tomada } \\
\text { de voz }\end{array}$ & \llcorner & $\begin{array}{c}\text { tentou procurar? } \\
\text { LL2 }- \text { nos tentamoØ... }\end{array}$ \\
\hline $\begin{array}{c}\text { Reprodução de fala durante } \\
\text { o discurso }\end{array}$ & “ & $\begin{array}{c}\text { "quem qu[e] é ess[e]? quem qu[e] é } \\
\text { ess[e]?" né? }\end{array}$ \\
\hline $\begin{array}{c}\text { Incompreensão de palavra } \\
\text { ou segmento }\end{array}$ & $(\quad)$ & morava lá em baixo ali e::: ( ) ele falava \\
\hline $\begin{array}{c}\text { Hipótese de palavra ouvida } \\
\text { Comentário descritivo } \\
\text { do transcritor }\end{array}$ & $(($ comentário) $)$ & era ((risos)) mas não era ((risos)) \\
\hline $\begin{array}{c}\text { Prolongamento de vogal } \\
\text { Pausa }\end{array}$ & $:$ & plantou:: d[o] lad[o] d[e] lá \\
\hline Interrogação & $\ldots$ & d[y]as planta... pé d[e] jambeir[o] \\
\hline Truncamento & lá tem bastant[e] qualidad[e] né? \\
\hline Entonação fática & letra maiúscula & ja/ essa::: e/ essas árvore \\
\hline
\end{tabular}

\section{A.S - G.V.B.}

L1 - o menino te atacou pedra na cabeça? que que ele fez?

L2 - n[ũ] é... el[e] tava el[e] foi tacar pedra na galinha ace[^]tou na minha testa

L1 - na sua testa? e aí?

L2 - aí depois começou a sangrar tud[o]

L1 - você chorou?

L2 - tsc tsc

L1 - não chorOU?

L2 - hum... chorei... mas só um pouquinh[o]

L1 - de raiva ou de dor?

L2 - [o]s do[j]

L1 - ((risos)) e a galinha? fugiu?

L2 - n[ũ] sei... eu n[ũ] vi

L1 - que que você fez com o menino depois?

L2 - nAda... eu fui lá na minha vó aí depo[j] a minha mãe levou n[o] médic[o]

L1 - hum

L2 - depo[j] ela deu pont[o]

L1 - hum 
L2 - [e]::.... [e] depo/ [e] ho[ı]a qu[e]... qu[e] eu tinha mentid[o] com a... com a minha v/ com minha tia... eu tinha falado qu[e]:: qu[e] eu tinha caíd[o]... aí depo[j] a ho[^]a qu[e] a minha mãe/ a ho[^]a qu[e] ela cheg/ a ho[^]a qu[e] ela:.... qu[e] no[j] chegamoØ na vÓ:: a... a mãe $d[o]$ menin[o] falou $p[\iota] a$ minha mãe qu[e] el[e] tinha tacad[o] pedra na minha testa

L1 - e aí?

L2 - aí depo[j] ela... depo[j] eu falei/ depo[j] eu falei pa/ depo[j] a minha mãe falou "por qu[e] cê mentiu?" depo[j] eu falei "po[^]quê::." hum... é::... "po[^]quê::: e/ el[e] começou depo[j] el[e] co/ porquê el[e] ficou trist[e] [e] começou a cho[^]ar

L1 - ((risos)) e cadê a cicatriz? tem cicatriz ou não tem?

L2 - tá aqui ó

L1 - deixa eu ver

L2 - n[ũ] dá pa ver ( )

L1 - AH:: não dá pra ver porque ficou aí em cima na sobrancelha... e faz tempo que você tá dançando na dança ou não? dos tirolês?

L2 - tsc... nÃO

L1 - quando que você começou? você lembra?

L2 - não... [o] an[o] passad[o] ach[o] qu[e] foi

L1 - ah... você já apresentou aonde? só aqui em santana?

L2 - é

L1 - nenhum outro lugar?

L2 - tsc tsc

L1 - quantas vezes? você lembra?

L2 - $\operatorname{tr}[\mathrm{ej}] \mathrm{s}$

L1 - três vezes? aonde? na igreja?

L2 - na igreja... na escola e... doming[o]

L1 - domingo agora?

L2 - é

L1 - ah é? e aí? o menino parou de atacar pedra na galinha?

L2 - hum hum

L1 - ah é? é você agora que ataca pedra na galinha? ou não?

L2 - tsc tsc

L1 - não

L2 - não

L1 - como é que é lá na escola? é legal?

L2 - é

L1 - que que você faz lá?

L2 - é:: qu[e] que eu faç[o]? n[ũ] sei

L1 - ah:: tudo bem... quando você brinca... do que que vocês brincam lá?

$\mathrm{L} 2$ - d[e] brincar d[e] pega-pe:ga... bo:la... d[e] um mont[e] d[e]... coisa

L1 - que bola vocês jogam? que tipo de... vôlei... futebol?

L2 - fut[e]bol

L1 - vocês tem time? 
L2 - não... ( ) eles n[ũ] fa[j]

L1 - como é que é?

L2 - tira tim[e]

L1 - como que faz isso... não sei

L2 - tira pa[^] ou ímpa[^]... depo[j] vai escolhend[o] a gent[e]

L1 - e faz quantas pessoas por time?

L2 - quant[o] quiser... pois... se tiver... se tiver d[ej]s sai cinc[o] pa cada tim[e]

L1 - sempre são dez pessoas ou tem mais?

L2 - se tiver ma[j] aí... ( ) fica um ma[j] co/ um p[^o] tim[e] mais f[ı]ac[o]

L1 - hum hum... por que pro time mais fraco?

L2 - po[ı]qu[e] senão aí pe[^]d[e]

L1 - ah é? voc/ você é do time fraco ou do time forte?

$\mathrm{L} 2-\mathrm{d}[\mathrm{o}] \mathrm{fo}[\imath] \mathrm{t}[\mathrm{e}]$

L1 - ah é? quem que/ você sempre que tira o time?

L2 - tsc tsc

L1 - não? eles te escolhem muito?

L2 - não

L1 - você fica no gol ou você joga na linha?

L2 - na linha

L1 - ah é? qual/ como que você gosta de jogar?

$\mathrm{L} 2$ - $\mathrm{n}[\mathrm{o}]$ ataqu[e]

L1 - no ataque?

L2 - é

L1 - faz muito gol é?

L2 - aham

L1 - ah é? você lembra de um gol bem legal que você fez?

L2 - lemb[^]o tem um/ tinha um::: um mulequ[e] que el[e] é/ era ru[j]m... aí chutei aí el[e]/ chutei pelo lad[o] de long[e] [e] el[e] foi... el[e] foi pegar [e] passou por baix[o] da pe[^]na del[e]

L1 - ele era goleiro?

L2 - é

L1 - e fez gol ali?

L2 - hum hum

L1 - você sai pulando quando você faz gol também? que que você faz? dá um berro?

L2 - não

L1 - ((risos)) go::I não berra gol?... só sai rindo só? ((risos))

L2 - é

L1 - é:: grande jogadora né? só esse que você fez gol? essa vez só que você fez gol?

L2 - não um mont[e]

L1 - ah então me conta mais aí... como é que é? não tem uns gols bonitos que você fez? 
L2 - hum hum... enta/ um dia eu jogan[o] $\mathrm{n}[\mathrm{o}] \mathrm{gol}$ qu[e] manda[^o] eu ir aí [o] menin[o] falou $p[\iota]$ a eu toca $p[\iota] a$ el[e] eu falei "deixa eu chutar no gol p[^]a ver o qu[e] acontec[e]" eu chutei foi $d[e]$ cobertura no gol[e^o] e fiz [o] gol

L1 - o:::rra:: que bele::za heim?... e estava no meio do campo ou estava assim a dois pés do gol?

L2 - tava $\mathrm{n}[\mathrm{o}] \mathrm{gol}$

L1 - você... vocÊ?

L2 - é eu tava $\mathrm{n}[\mathrm{o}] \mathrm{gol}$

L1 - ah você estava de goleira?

L2 - é

L1 - e chutou pro outro IAdo?

L2 - fui pr[o] gol [e] fiz gol

L1 - o::.rra... então você fica no gol às vezes?

L2 - é

L1 - muito frangueira ou não?

L2 - hum não

L1 - não?... lembra de algum frango bem legal que você tomou?

L2 - hum hum... quando eu tava esperand[o] [o] ônibus pa ir na escola aí no[j] jogan[o] com uma bolinha pequenininha aí eu fui tentar pegar a bola a/ a bolinha ela passou po[t] baix[o] da minha pe[^]na ((risos))

L1 - ((risos)) riram muito de você?

L2 - não fui eu qu[e] [r]i d[e] mim

L1 - ((risos)) você mesmo?

L2 - hum hum

L1 - ah tá... vocês só jogam bola como é que é? não brincam de esconde-esconde dee pega-pega?

L2 - brinca d[e] polícia [e] ladrão

L1 - como é que brinca de polícia e ladrão? nem lembro mais

L2 - é::: tem... alguma gent[e] fica polícia [e] outra ladrão depo[j] as polícia conta [e] os ladrão vai se esconder depo[j] as policia tem que achar os ladrão

L1 - quantas polícias que fica?

L2 - ah: quanta... quanta/ quanta tiver... quanta/ po[ı] exempl[o]... se tirar/ você pega uma folha... cê pega uma folha assim d[e] árvor[e] depo[j] cê fala "que a folha é ladrão [e] a outra mão liv[^e] é polícia" [e] quem bat[e] na mão liv[^e] é:: polícia [e] quem bat[e] na folha é lad[^]ão

L1 - ah é é assim que joga então?

L2 - hum hum

L1 - e geralmente... tem ter igual ou tem que ter mais polícia... menos polícia... como é que é?

L2 - tem qu[e] ter ma[j] lad[ı]ão e menos polícia 
2A.S - F.V.C.

L1 - você acha que está bom o número de danças?

L2 - ah:: tem qu[e] ter ma[j] né?

L1 - quantas?

L2 - umas duas só

L1 - pra esse mês?... você acha que você está dançando bem?

L2 - mais ou men[o]

L1 - por que?

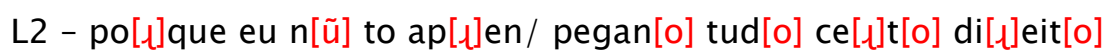

L1 - mas você acha que você não dança bem?

L2 - ah:: sim... ma[j] não tud[o] as música

LL1 - mas é

$\llcorner L 2$ - tem umas qu[e] eu erro

L1 - ah mas eu também erro... não erro?

L2 - ah sim

L1 - então... até aí... mas você acha que você precisa ensaiar?... você não acha que você está bagunçando muito na dança? 
L2 - ((risos)) é

L1 - então... tem que ensalAR... mas você quer fazer dança nova? que tipo de dança? você quer dança que faz ['platler] ${ }^{247}$ ? qual que você quer? aquelas que pula e bate:::

L2 - aquela qu[e] bat[e] palma... aquela qu[e] bat[e]

L1 - então... você quer mais assim? porque cê acha que é melhor?

L2 - porqu[e] é da ho[^]a

L1 - ah é?... e voce acha/ se tivesse coro aqui você cantaria?

L2 - tem... e::.: eu nu/ eu cantava ma[j] ah:: eu tenh[o] comp[^]omiss[o]

L1 - muito compromisso?

L2 - é

L1 - na escola você faz... o que? quant/ quando que você estuda? todo dia?

L2 - lá em cima d[e] segunda a sexta e:: lá na cidad[e] d[e] te[^]ça [e] quinta... depo[j] eu toc[o] violão $\mathrm{d}[\mathrm{e}]$ sexta

L1 - que que você faz na cidade?

L2 - ['haıdwe^] ((Hardware))

L1 - computador?

L2 - técnic[o] d[e] montar

L1 - o que que faz esse curso?

L2 - arruma computado[^]... p[^]a arrumar

L1 - mas é pra::: então não mexe em programação de computador?... só sa/ só mexe pra arrumar computador?

L2 - e: É:: pa arrumar pa instalar... te::ma... tud[o]

L1 - e não tem por exemplo se eu uero fazer um programa no computador... isso daí não? programa de desenho? é só parte de peça?

L2 - é

L1 - você consegue já arrumar um computador?

L2 - é:: eu já to $n[0]$ cinc[o]

L1 - quanto tempo de curso?

L2 - dois anos

L1 - ah é?... você que montou seu computador?

L2 - n[a]o ess[e] eu já co/ eu n[ũ] ap[^]endend[o] ainda quand[o] comp[^]ei el[e]

L1 - hum

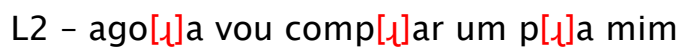

L1 - ah é?

L2 - a ho[^]a qu[e] tiver (computado[^]) ((risos))

L1 - quanto custa?

L2 - um bom dois mil [e] quinhentos po[ı] aí

L1 - ahãm... com o que por exemplo?

L2 - memó[^]ia boa... HD bom... placa d[e] víde[o] bom... tud[o] bom p[^]ocessado[^]

L1 - vídeo? o que que tem que ter?

${ }^{247}$ Plàtler, sapateado típico do folclore tirolês (al. Schuhplattler). 
L2 - placa d[e] víde[o]... pa:: cê jogar jog[o] né? me/ melho[^]

L1 - você joga jogo no computador?

L2 - quand[o] dá vontad[e] eu jog[o]

L1 - o que que é melhor? de computador ou de videogame?

L2 - vid[3]ogame

L1 - por que?

L2 - po[^]que a imagem é melho[ı]

L1 - ah é?

L2 - é dá pa jogar $\mathrm{n}[\mathrm{o}]$ control[e] é me['jə]... po[^]que:: aquel[e] control[e] d[e]:: computador é muit[o] dife[^]ent[e]

L1 - como é que é... como éque é?

L2 - ['dz’ł s'tike] ((joy stick))?... A:: é me[Ø]m[o] estil[o] só qu[e] muda tud[o]::: [Ø]cê você joga $n[\tilde{u}]$ o $X$ acele[^]a lá o:: L1 acele[^]a... é:: difícil pa pegar $\mathrm{d}[\mathrm{e}]$ nov[o]... pa jogar daqui depo[j] i[^] lá:: $n$ [o] computado[^]

L1 - você joga que tipo mais de jogo? Assim

$\mathrm{L} 2-\mathrm{d}[\mathrm{e}]: \ldots . . \mathrm{tud}[\mathrm{o}]$

L1 - por exemplo?

LL2 - um pouc[o] d[e] guerra um pouc[o] $d[e]$ ação um pouc[o] $d[e]$ aventu[^]a um pouc[o] d[e] [gi'taı 'he Ło]... da ho[^]a

L1 - que que é isso?

L2 - [gi'taı 'he^o]... uma guitarra assim aí você vai ape[^]tand[o] os botão atrá[j] [e] el[e] toca o som qu[e] tá pendind[o]

L1 - ah pra inventar música?

L2 - A::: Música já é:: mas só qu[e] vem assim... umas bolinha depo[j] vem um ( ) um (

)... daí a ho[^]a qu[e] chega em cima das bolinha cê tem que ape[^]tar os / a:: L1 L2 aí:: toca música

L1 - ah:::

L2 - música qu[e] tá pedind[o]

L1 - ah entendi... e você está fazendo violão agora?... faz tempo?

L2 - hum... não... semana passada... não/ é... semana passada

L1 - ah começou agora... o que que você já sabe? nada?

L2 - ((risos)) mais ou menos só

L1 - segurar o violão só? ((risos))... mas você quer pra tocar música que tipo de música?

L2 - se[^]tanejo

L1 - qualque[^] tip[o] d[e] música

LL2 - você gosta de sertanejo?

L2 - eu gost[o]

L1 - de quem que você gosta?

L2 - tud[o] canto[^]... Césa[^] [e] Paulinh[o]... Césa[ı] Menotti [e] Fabian[o] é [o] ma[j] qu[e] eu gost[o]

L1 - ahãm... e aqueles... Tchê Garotos? aquelas do sul... você gosta?

L2 - Tchê Garotos?... nunca escutei 
L1 - não?... ah:: tá... aqueles do sul que tocam diferente

L2 - nunca não

L1 - não?... mas e moda caipira? você gosta também?

L2 - mais ou menos

L1 - por que?

L2 - AH muit[o] ( )... eu gost[o] do/ das música ma[j] nova d[e]:: d[e] se[^]tanej[o] sabe? ( ) Vito[^] [e] Lé[o]... esses daí

L1 - hum... e de música tradicional você gosta?... tirolesa?... você ouviu aquele CD que você ganhou?

L2 - ouvi... $\mathrm{n}[\mathrm{o}]$ carr[o] eu ouç[o]... ago[ı]a tirou [o] som d[o] carr[o]

L1 - ah é? por que?

L2 - po[^]que no[j] vai vender

L1 - ah é? vai comprar outro?

L2 - vai

L1 - qual?

L2 - hm... n[ũ] sei... qual pai [Ø]cê vai comp[^]ar? ((risos))

L1 - ((risos)) não sabe ainda?

L2 - tsc tsc

L1 - tá... você sempre/ então cê vai duas vezes por semana pra::: pra cidade?

$\mathrm{L} 2-($ )

L1 - e:: você prefere ir pra lá ou ficar aqui?

L2 - com[o] assim?

L1 - gosta de ficar aqui estudar aqui ou prefere quando vai pra cidade?

L2 - estudar aqui... só po[^]] caus[o] d[o] ônibus

L1 - como assim?

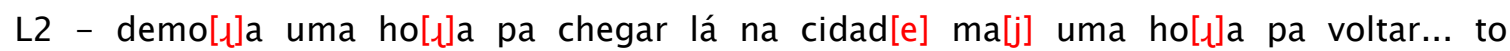
cansad[o] imagina volta uma ho[^] d[e] ônibus... tud[o] mund[o] conve[^]sando

L1 - inclusive você?

L2 - ah não conve[^]s[o] não... to cansad[o] ((risos))

L1 - AH:: ((risos))... mas... porque que demora tanto?... não é tão longe assim... faz muita volta?

$\mathrm{L} 2$ - $\mathrm{fa}[\mathrm{j}]$ muit[o]... entra em muit[o] luga[ı]

L1 - que bairro que é que você estuda?

L2 - bairro?

L1 - lá na cidade?

L2 - estud[o] em Pi[^]aciCAba

L1 - então... que bairro de Piracicaba?

LL2 - e:: é eu só sei a rua:: rua Benjamin

L1 - ah você não sabe? é perto do centro?

L2 - é $\mathrm{n}[\mathrm{o}]$ centr[o] é $\mathrm{n}[\mathrm{o}]$ centr[o] é... ve[^]dad[e]... cent[^૦o] ((risos))

L1 - no centro? ah:: tá... com quantos anos você está?

L2 - [ka]to[^]z[e] 
L1 - ah:: tá

3A.SO - L. D.

L1 - você tá cantando no coralzinho?

L2 - to.

L1 - e que/ quantas pessoas tem no coralzinho?

L2 - ah não sei... umas sessenta mais ou menos

L1 - e o::: vocês apresentaram quando?

L2 - doming[o]

L1 - domingo aonde?

L2 - na missa... depo[j] da missa

L1 - vocês cantaram... ah vocês não cantaram na missa no domingo em santana porque eu não tava...

LL2 - cantamo Ø... na missa

L2 - ah é? que eu não cheguei a tempo... no sábado vocês cantaram na missa ou não?

L1 - n[a]o... só $\mathrm{n}[\mathrm{o}]$ doming[o]... depo[j] te/ cantamoØ duas música

L2 - você dançou?

L1 - n[a]o... eu não t[o] ma[j] na dança

L2 - por quê? 
L1 - porque eu... eu sai $\mathrm{d}[\mathrm{o}] \ldots$ do... d[o]s adolescent[e]... porqu[e] só tem eu [e] [o] gabriel de menin[o] e aí eu fiquei... ah eu não $\mathrm{m}[\mathrm{e}]$ senti bem... só dois menin[o]... daí eu saí... acho que vou po adult[o] agora

L2 - ah é?

LL2 - tô pensand[o]

L1 - você já tem tamanho pra ir pro adulto

$$
\text { LL2 - é }
$$

L1 - aliás ontem... foi o seguinte... nós fizemo::: ensaio lá na::.... na santana

L2 - é

L1 - e o grupo lá jovem tá indo bem aí... podia montar um aqui... não tem menino da tua idade pra fazêr?

L2 - é maØ eles não querem né?... já entraram uma vez já entrou um mo::nt[e] d[e] menin[o]... aí eles saíram tud[o]... saíram tud[o] junt[o]

L1 - é?

L2 - foi saind[o]... saind[o]... saind[o]... ficou só quatr[o] aí agora os outr[o] dois saíram... ficou só mais dois... só um... só dois

L1 - você costuma a viajar muito com o grupo?

L2 - n[a]o... n[a]o muito

L1 - onde mais que apresentava?

L2 - ah... ond[e] fom[o]? em Santa Barbara uma vez... uma v[e]z mont[e] alegr[e] d[o] sul... só acho lugar ma[j] long[e] Mont[e] Alegr[e] d[o] Sul

L1 - e sempre na festa da polenta?

L2 - sempr[e]

L1 - na festa da polenta você chaga a ajudar em outra coisa além da?

L2 - na:: é:: n[a]o na... só $n$ [o] museu... às vezes... às vezes eu ajud[o] um pouc[o] na cozi:nha... só

L1 - já ajudou na cozinha?

L2 - já

L1 - como que... que que cê fez?

L2 - cuscuz

L1 - o que que cê faz lá

L2 - ah... eu faço cuscuz

L1 - faz cuscuz? ((risos))

டL2 - é:: n[a]o n[a]o fa::ç[o]... eu sirv[o] num [pre'tino] né?... ((risos)) que as velha faz ['kos] velho... faz cuzcuz e eu sirvo num pratinh[o] ((risos))

L1 - mas você sabe fazer cuscuz?

L2 - é fácil de fazer

L1 - como é que faz?

L2 - fazer [o] mo:Ih[o] pri:meir[o]... depo[j] tem a farinha... quando falta eles pegam e... jogam [o] molh[o] [e] mistura c[o] a [fe'rina]

L1 - ãh

L2 - só 
L1 - e vai pro forno? ((risos))

L2 - não... esc[ao]a

L1 - endurece?

LL2 - tentando

L1 - é?

L2 - não... é:: ma:: quand[o] [Ø]cê mistura co[o] a farinha el[e] já endurec[e]

L1 - não sei fazer...

டL2 - não? ((risos))

L1 - você sabe fazer [ka'nedeli]248?

L2 - não

L1 - não? vocês comem? gosta de [ka'nedeli]?

L2 - gosto

L1 - ah tá

L2 - eu gosto

L1 - que mais que... que que você gosta de cozinha tirolesa?

L2 - [s'trangola 'prett] ${ }^{249} \ldots$ [ka'nederli $] \ldots$ ['grostoli $]^{250}$

L1 - gosta de ['grostoj]?

L2 - gosto... de ['krawti] ${ }^{251} \mathrm{n}$ [õ] gost[o] muito

L1 - chucrute né?

L2 - é

L1 - ah tá... no caso aí da::.: do coralzinho... você já viajou muito com o coral?

L2 - já... fomoØ uma vez cantar na Red[e] Vida... já... lá em São José d[o] Ri[o] Pret[o] né? que é... na onde qu[e] ma[j]?... só ach[o] (tem) o lugar ma[j] long[e]

L1 - e no ônibus de vocês tem muita bagunça?

$\mathrm{L} 2-\mathrm{fa}[\mathrm{j}]$

L1 - é?

L2 - nossa... canta... da:nça

L1 - você lembra de alguma engraçada que já aconteceu em ônibus?

L2 - ah... não sei

L1 - não?... e na escola? faz muita bagunça essa turma aí da tua geração?

$L 2-\mathrm{fa}[\mathrm{j}] \ldots$ (nossa)

L1 - é?

L2 - a turma da minha geração é a ma[j] que fa[j]

L L1 - é? por que?

\footnotetext{
${ }^{248}$ Espécie de almôndega feita de pão amanhecido, lingüiça, ovos, especiarias e servida numa sopa de frango. Obs. não existe uma receita única, cada região tirolesa possui sua versão do prato.

${ }^{249}$ Literalmente "estrangula padres". Tipo de nhoque de espinafre, servido em uma sopa de lingüiça. Prato típico da região trentina, tornou-se um popular entre os clérigos após o Concílio de Trento (1545 - 1563).

${ }^{250}$ Pasteizinhos doces (trent. gróstoi ou gróstoli).

${ }^{251}$ Chucrute (al. Sauerkraut).
} 
LL2 - da minha clase... eu

não sei... sempre foi a pior class[e] que eles falavam... que era dema[j] bagunceira... sempre

L1 - você também?

L2 - n[a]o... ((risos))

L1 - nunca né? ((risos))

L2 - n[a]o ((risos))

L1 - é verdade que senta separado os do Banco 252 com os de Santana?

LL2 - senta

L1 - como é que é isso aí?

L2 - senta assim... d[e] um/ dess[e] lad[o] aqui/ d[e] um lad[o] sentava só os d[o] Banc[o]... só os d[e] Santana... senta/ porqu[e] tinha menos de Santana né?... menos na nossa class[e]... [e] do/ $\mathrm{n}[\mathrm{o}]$ mei[o] sentavam poc/ e::: ba::nc[o] ma[j] d[o] Banc[o] $\mathrm{n}[\mathrm{o}]$ mei[o] e os... desse lado aqui sentava mais os que vinha $\varnothing$ da cidad[e] [e] alguns $\mathrm{d}[\mathrm{o}]$ Banc[o] tamøém

L1 - tem quem vim da cidade estudar aqui?

L2 - tem

L1 - por que que estuda tão longe?

LL2 - ah... porqu[e] não/ depend[e]... que $\mathrm{n}[\mathrm{o}]$ é:: dos lugar ma[j] pert[o] assim sa[j] que por exemplo/ por exempl[o] do Belém... do/ da reta assim... vem aqui porqu[e]... é ma[j] pert[o]

L1 - ah tá

L2 - tem alguns que vem

L1 - e dava muita briga? dá muita briga quando...

$\llcorner L 2$-da::va

LL1 - que que acontecia?

LL2 - ah

ma[j] só $d[e] \ldots$ de falar assim "ai... a nossa igreja não é bonita porque a nossa parece um... foguet[e] e a sua parec[e] um bol[o]"... "suas/ suas igreja são feia"

$$
\text { LL1 - é? }
$$

discut[e]... discutia

L1 - mas... já chegou a dar briga ou não?

L2 - n[a]o... briga $\mathrm{n}[\mathrm{a}] \mathrm{o} . .$.

L1 - é?

L2 - pel[o] menos eu não... mas sempre... na festa... assim... d[e] vez em quand[o] tem briga entr[e] banc[o] e santana ma[j] não é por caus[o] d[e] que... dos do[j] bairr[o] acho... essa diferença dos... dos do/ do[j] bairr[o]

L1 - que que você acha que é?

L2 - ah não sei... é coisa... não tem nada a ver co/ da... da [rĩ]xa dos dois bai[r]o

${ }^{252}$ Apelido do Bairro Santa Olímpia 
L1 - ah é?... la/ na escola você tá em que série?

L2 - segundo

L1 - segundo colegial... no colegial tem diferença também de/?

L2 - n[a]o né?... agora eu é/ estud[o] na cidad[e] né? segundo colegia[ł]

L1 - a::h tá... aqui não vai até o colegial?

L2 - já tem... e::.... ach[o] qu[e] não... melhor lá acho né? na cidad[e]... então eu vou lá

L1 - ah tá

L2 - porque que/ começou agora né? [o] colegial se/ ess[e] aqui vai ser a primeira turma que vai s[e] formar... $\mathrm{n}[\mathrm{o}]$ colegial aqui

L1 - até agora?

L2 - é?

L1 - e é muita gente que tem nesse colegial agora?

L2 - ah até qu[e] tem bastant[e] viu?... uns trinta

L1 - você fez o primeiro ano também na:: na cidade?

LL2 - tamØém... oitava série eu acabei aqui

L2 - e eles lá na cidade não falam às vezes do sotaque? alguma coisa

L1 - que que eles falam? LL1 - falam...

LL2 - diret[o] ((risos))... imita ((risos))

L1 - é?

L2 - ['dio::] eles falam

L1 - ah é?

L2 - imitand[o] [e] tenta imitar a palavra que fala assim

L1 - às vezes solta alguma coisa que eles não entendem?

L2 - solt/ maØ:: diret[o]

L1 - ah é?... por exemplo?

L2 - [stome'ges]

L1 - ah é?

L2 - é::: eles vão perguntand[o] qu[e] qu[e] é

L1 - ah é? já aconteceu coisa assim de você levar susto e falar alguma coisa e eles darem risada?

LL2 - já

L1 - é? ((risos))

L2 - "que que é iss[o]?" eles perguntam ((risos)) "você é d[e] outr[o] pl[e]neta?

L1 - você lembra de algum caso assim?

L2 - ah esse daí qu[e]... um dia eu falei "ah qu[e] [stome'ges]253" aí ele pergunto[Ø] "que que cê falou aí?" "que el[e] falou?" "[stome'ges]" aí el[e] "[stome'gese]"? tentando imitar sab[e]?

L1 - ãh

L2 - [e] aí... daí é assim... ( )

${ }^{253}$ Pessoa desagradável, coisa desagradável. 
L1 - mas você chegou a dizer o que é ou não?

L2 - explic[o]... d[e] vez em quand[o] eu explic[o] maø $d[e]$ vez em quand[o] eu não explic[o]

L1 - ah é? quando joga bola... não sei alguma coisa aí que... ((risos)) erra o chute não fala alguma coisa aí

L2 - é ((risos))

L1 - não solta?

L2 - é ((risos))

L1 - no caso aí da::: da::: da escola aqui começou agora a ter o::: o colegial?

L2 - é vai fazer três ano... primeira turma agora do/ qu[e] vai se formar n[o] terceir[o] colegial... qu[e] era só até a oitava série

L1 - nossa

L2 - começou agora

L1 - e seus primos mais velhos quando eles queriam faze:r/ todo mundo então ia...

$\mathrm{L} 2$ - todo mund[o] na cidad[e]... alguns $\mathrm{n}[\mathrm{o}]$ angl[o] alguns na industrial alguns $\mathrm{n}[\mathrm{o}] \mathrm{su}[\mathrm{d} \mathrm{I}]$

L1 - e como que faz pra ir pra lá? tem ônibus que vem buscar ou não?

L2 - tem ônibus... d[e] manhã tem ônibus da: da:: viação da Stenic[o]

L1 - ah pra/ mas vocês pagam?

L2 - é paga... é ônibus circular

L1 - ah:: tá bom

L2 - depo[j] e:: tem alguns qu[e] vão d[e] van qu[e] nem eu vou d[e] van... é mais fácil né?

L1 - quem que...

L2 - aí meu prim[o] leva e:: tem a van né? qu[e] el[e] leva (...) (aí mais fácil)

L1 - você acha que Santa Olímpia e Santana também têm potencial turístico?

L2 - tem... ach[o] qu[e] tem

L1 - o que você acha que deveria ser feito pra isso?

L2 - ah... casas daquel[e] estil[o] lá... estil[o] trentin[o]

$\mathrm{Ll}-\mathrm{hm}$

L2 - e:: pousada... pra quem quer dormir... ah não sei

L1 - a rua você acha que tinha que ter asfalto?

டL2 - ah clAro né? asfalt[o] na rua

L1 - hum

L2 - só

L1 - só isso?

L2 - ah n[ũ] sei... que ma[j]?

L1 - não sei... que você acha que tinha que ter? como você pensa uma Santa Olímpia legal? assim

L2 - ah... só co $\varnothing$ iss[o] ach[o] asfalto na [r]ua... e.:.: casas de estil[o] trentin[o]... algum lugar pra vender lembrancinha assim

L1 - hum hum

L2 - [e] um [r]estaurant[e]

L1 - hum... típico? 
L2 - típic[o]

L1 - AH:: tá

L2 - é ((risos))

L1 - você acha... que que você acha quando essa questão de trentino e tirolês? o que que você pensa dessa diferença?

$$
\text { LL2 - tirolês }
$$

L1 - é?

L2 - eu ach[o] qu[e] puxam muit[o] o sac[o] da itália... falar qu[e] é trentin[o]... porqu[e] sab[e]? pra ganha dinheir[o] né? do Cí::rcul[o] né? da... maø ach[o] que é tirolês n[õ] é? [o] cert[o] tirolês

L1 - é? o que que você pensa mais sobre isso... você você chega a discutir sobre isso?

L2 - cheg[o]

L1 - porque aqui isso é uma questão de identidade né?

L2 - é... eu ach[o] qu[e] é tirolês [o] cert[o]... porqu[e] sempr[e] falamo[Ø] desd[e] qu[e]/ desd[e] pequen[o] "Al no[j] som[o] tirolês... tirolÊs... a tirolEsa... dialet[o] tirolês" nunca falou trentin[o]

L1 - quando que começou?

L2 - ah não sei viu? ma[j] $\mathrm{n}[\mathrm{o}] \mathrm{fa}[\mathrm{j}]$ muit[o] temp[o] ach[o] que começou vim a história $\mathrm{d}[\mathrm{e}]$ trentin[o]... d[o] círcul[o] trentin[o]... ma[j] sempr[e] falam [o] tirolês aqui em Santa Olímpia... sempr[e] tirolês

L1 - você não gosta da palavra trentino ou você se sente trentino?

L2 - n[a]o não é que eu não gosto da palavra maØ eu ach[o] qu[e] é tirolês [o] cert[o]... sempre falam[o] tirolês ((risos))

L1 - ((risos)) tá... e no caso sobre a questão lá da da turma de santana... eles eles... eles quase só falam ItÁlia ItÁlia assim

L2 - é::: então... isso qu[e] eu falei... os $\mathrm{d}[\mathrm{e}]$ santana só falam de itÁlia da itÁlia e $\mathrm{n}[\mathrm{o}]$ falam d[e] d[e] trentin[o] d[e] tirolês

L1 - e da Áustria o que você pensa?

L2 - ah não sei viu? não sei muito da Áustria

L1 - não... sobre a questão do Tirol ser austríaco

L2 - AH:..... ach[o] qu[e] é austríac[o] n[o] é?

L1 - metade dele é

L2 - é

L1 - então... e a outra metade que tá na Itália? hoje é Itália... que que voc/

era da Áustria?

L1 - claro

L2 - AH daí então... tem qu[e] ser da Áustria né?

L1 - tem que voltar pra Áustria?

$$
\text { LL2 - é:: ((risos)) }
$$

L1 - ((risos)) e sobre identidade assim... isso tem gerado algumas confusões aí na turma né? 
L2 - é

L1 - sobre Trento Itália Áustria... se te pergunto se você é descendente de austríaco ou italiano o que você diz?

L2 - ah n[ũ] sei viu?

L1 - como é que você diria?

L2 - da/ de austríac[o] ach[o]

L1 - se eu te/

$\llcorner L 2$ - de tirolÊs ((risos))

L1 - se eu te pergunto "você é descendente do quê?"

L2 - tirolês

L1 - de tirolês.. aí eu falo "aonde fica o Tirol?"

L2 - hum... norte da itália

L1 - ah então

$$
\text { LL2 - é::: }
$$

L1 - então vai pegar a Itália

L2 - vai pegar a itália

L1 - então tá bom... ((risos)) só pra saber

L2 - ((risos))

L1 - você vocês têm uva aqui... vocês fazem vinho?

L2 - não... meu avô fa[j]... ma $\varnothing$ aqui em casa não

\section{A.SO - E.S.}

L1 - como é que era quando você começou:....

$$
\text { டL2 - dançar? }
$$

L1 - a dançar?

L2 - na ve[^]dad[e] eu tava $\mathrm{n}[\mathrm{o}]$ coral...

L1 - ah é?

L2 - no coralzinho... da J.... não... era da S primeiro... aí tinha minha turma inteira no coral... e num tinha quase ninguém na dança... e... acho que era duas meninas $\mathrm{d}[\mathrm{o}] \mathrm{da}$ turminha que tava na dança... aí eu:.: eu... daí a $\mathrm{S}$ saiu... entrou a J... aí eu fiquei lá no coral... as meninas da minha turma tud[o] passaram pra dança... e eu cont[[]inuei no coral porque eu queria o coral... aí chegou uma época ficou só eu e mais uma colega... aí essa colega falou "ai acho que vou entrar na dança"... daí eu falei assim "ah eu gosto mais do coral mas eu não sei onde que eu vou ficar" ((risos))... daí não... eles não... assim... naquela Época... eles não queriam que ficasse $\mathrm{n}[\mathrm{o}]: . .$. na dança e $\mathrm{n}[\mathrm{o}]$ coral junto... porqu[e] $\mathrm{s}[\mathrm{e}]$ batesse a/ as apresentações... ia... $\mathrm{n}[\mathrm{o}]$ ia:.... não ia saber qu[e] lado qu[e] ia... daí eles decidiram fazer ou só ficar no coral ou só na dança 
L1 - o que que você prefiria?

L2 - naquela época eu preferia ficar $n[0]$ coral porque eu tinha muita vergonha

L1 - ah é?

L2 - aí eu... eu fiquei no coral porqu[e] era aquela coisa mais dura né?... fica lá cantand[o]... não precisava $\mathrm{s}[\mathrm{e}]$ movimentar muito... daí eu fiquei no coral... daí como que o bruno tinha saído não tinha mais... assim... amizad[e] com quas[e] mais ninguém... aí eu decidi entrar no grupo... aí entrei $\mathrm{n}[\mathrm{o}]$ infantil e a maioria da minha tu[^]ma ela tava $\mathrm{n}[\mathrm{o}]$ $\mathrm{n}[\mathrm{o}]$ juvenil e eu queria passar pro juvenil... qu[e] era minha tu[^]ma qu[e] tava lá...

L1 - é

L2 - aí o Diva falou "ó... quem entra por últim[o] tem qu[e] ir passa:nd[o] né?... então você vai entrar n[o] infantil e depois cê vai passand[o] pros outros"... aí eu entrei... fiquei acho que um dois anos... e passei pra/ pr[o] juvenil

L1 - nossa... quanto tempo heim?

L2 - ahã... acho que mais ou menos... uns dois anos... aí eu fiquei $\mathrm{n}[\mathrm{o}]$ juvenil até [o]s dezoit[o] an[o]s... com dezoit[o] anos eu entrei $\mathrm{n}[\mathrm{o}]$ adult[o]... aí eu fiquei alguns meses $\mathrm{n}$ [o] adult[o] e continuei no juvenil... daí eu falei "os dois não vai dar pra ficar"... "ou escolh[o] [o] adult[o] ou inf/ [o] juvenil"... aí peguei e fui pro... decidi ir pr[o] adulto L1 - mas é::... tinha apresentação... isso é até... tinha apresentação separada? assim... chegava a bater... data? L2 - assim... ah... d[o] juvenil e a...

$\llcorner L 1$ - do adulto

$$
\llcorner\mathrm{L} 2 \text { - do adult[o]? }
$$

L2 - tinha as vez[e]s qu[e] [o]... [o] diva colocava os dois grup[o]s pra dançar $\mathrm{n}[\mathrm{o}] \mathrm{mesm}$ [o] dia... qu[e] nem levava na festa [o]s dois grup[o]s juvenil [e] adult[o]... ou s[e] não qu[e] nem tinha:: a festa d[e] Batatais e Pirassununga... aí... é:.: el[e] decidia... [o] adult[o] ia pra uma...

$$
\text { LL1 - ah é? }
$$

LL2 - e [o] juvenil ia pra outra

$$
\text { LL1 - nossa }
$$

L2 - então geralmente [o]... [o] juvenil ia pra Batatais e [o] adult[o] ia pra Pirassununga... geralment[e] era assim

L1 - por quê?

L2 - porqu[e]::

$$
\text { டL1 - pra não dar briga? }
$$

LL2 - não... porqu[e] [o]:: grup[o] d[o] juvenil gostava mais d[e] Batatais né?... queriam ir porqu[e] era aquel[e] negóci[o] d[e] viag[e]... que era mais longo né? e o juvenil gostava dessas coisas... então o diva colocava eles pra Batatais L1 - a turma bagunçava muito no ônibus?

L2 - muito... muito... levava tambo[ı]... levava $\mathrm{d}[\mathrm{e}] \mathrm{tud}[\mathrm{o}] \ldots$ instrumento... cantava... gritava... abria o vidr[o] gritava na rua... era $\mathrm{m}$ [ó] bagunça ((risos))... era $\mathrm{m}$ [ó] bagunça... era muito gostos[o] 
L1 - você berrava também é?

L2 - clar[o]...

L1 - ah é?

L2 - cê acha que não?

L1 - ah é?

L2 - depois aí... eu num fiquei mais...

L1 - aí já não tinha mais vergonha

L2 - não tinha mais vergonha ((risos))... aí já m[e] soltei...

L1 - ah

L2 - mas... foi assim... d[o] grup[o] d[e] dança

L1 - e quantos anos você tinha?

L2 - eu entrei $n[0]$ grup[o] com onz[e] an[o]s... $n[0]$ grup[o] d[e] dAnça... $n[o]$ coral eu não sei

L1 - bem pequeninha você era

L2 - ah... acho qu[e] eu tinha uns seis anos

L1 - no::ssa

L2 - seis... é acho qu[e] é mais ou menos seis anos

L1 - até os onze você ficou no coral?

L2 - até [o] onze

L1 - quem que comandava?

L2 - primeiro era a S. e depois a J.

L1 - e o...

LL2 - a J. é essa que tá ali né? agora

L1 - hoje é o... é... hoje é o:......

LL2 - hoje não tem mais coral... infantil... tem a... tem [o] coral da igreja qu[e] é da $O$.

L1 - aham

L2 - que se/ não se dizer se é da igreja mas é/ é ela que tá ensaiando um coralzinho infantil

L1 - hum hum

L2 - mas... não tem mais [o] coral da S. não tem mais... te[^]minou

L1 - o que vocês cantavam?

L2 - ah... não vou lembrar

L1 - mas tinha música... tirolesa?

L2 - tinha... é...italiana

L1 - mais italiana?

L2 - é... tinha uma que era $\mathrm{d}[\mathrm{o}]$ macarrão lá... $\mathrm{d}[\mathrm{o}]$ maca[r]one que falava ((risos))... não sei como que era

L1 - como que era a sua pronúncia então? vocês sabiam certinho?

L2 - ah eles ensinava... a Sheila ensinava né? tinha uma pasta pra cada um... c[o] as le:tras e ela ensinava... é:.: pala:vras... né? [e] ia cantand[o] junt[o] com a gente...

L1 - hum hum 
L2 - daí tinha que ir decorand[o] né?

L1 - e na dança... você pegou rápido ou não?

L2 - na dança sim

L1 - é? quem que era seu par?

L2 - no começo não tinha

L1 - não?

L2 - não... aí eu peguei um menin[o] qu[e] estudava comig[o]... [o] R. e el[e] não gostava muito da/ d[e] dançar... mas só que daí el[e] ficou até ach[o] qu[e] até ele... daí... quand[o] eu entrei no juvenil el[e] saiu

L1 - ah tá

L2 - depois eu fiquei sem par $\mathrm{d}[\mathrm{e}]$ nov[o]

L1 - porque aqui é par fixo né?

L2 - é... aí [o]:..... quand[o] eu entrei $n[0]$ juvenil el[e] saiu eu fiquei sem pa[^]... aí entrei c[o] [o] da/ daí [o] da/ [o] Danilo entrou...[o] Danilo Christofoleti... não sei se você conhece

L1 - hum hum

L2 - daí eu fiquei dançando com el[e]... aí ele saiu tamØém... aí eu comecei namorar... aí meu namorado começou a dançar comig[o] porque el[e] já fazia pa[^]t[e] d[o] grup[o] d[e] dança

L1 - ah tá

L2 - e daí eu fiquei até dezoit[o] ano... el[e] saiu d[o] grup[o]... porqu[e] el[e] tinha outros compromissos

L1 - ele era daqui do banco?

L2 - el[e] era... el[e] é daqui

LL1 - daqui né?

L2 - e el[e] saiu porqu[e] ele começou a trabalhar... estudar... e eu já não era mais namorada del[e] tamØém... e daí eu continuei ficando sem pa[^] d[e]nov[o]...

L1 - hum hum

L2 - daí eu entrei no adulto sem pa[^]... na maioria do... dos anos... eu acho qu[e] não tiv[e] par... acho que eu tive só na:: no::: $n[0]$ início $d[o]::$ juvenil até quas[e] [o] final... depois eu fiquei sem pa[^] ((risos))

L1 - por isso você reclamava que você não tinha par? por isso que você saiu do grupo?

L2 - não... não foi por causa disso

L1 - não?

L2 - foi porqu[e] as meninas não... elas não aceitam dividir as danças que nem a $D$. ...essas daí que têm tudo $\mathrm{pa}[\iota]$.... elas queriam só elas dançar. tinha v[e]z qu[e] elas davam assim... uma música ou outra... agora... $\mathrm{n}[\mathrm{u}]$ é... eu não acho ce[^]to... eu vou lá.... ensai[o] [o] mês inteir[o] pra dançar uma música... eu prefiro ficar em casa d[o] qu[e] dançar uma música 


\section{A.S - A.C.B.}

L1 - como era a sua avó?

L2 - fui pegar um cade[^]no... ((risos))

L1 - ah

L2 - um livr[o] d[e] receita italiana... daí abrim[o] assim... tinha prat[o] típico né?... eu e minha prima... [e] minha avó é cheia d[e] falar assim "quem qu[e] é ess[e]? quem qu[e] é ess[e]?" né? quand[o] ela vê retrat[o]... al ela olhou assim a minha prima vend[o] [o]:: cade[^]n[o] d[e] [r]eceita ela olhou as fot[o] e ela falou assim "quem qu[e] é ess[e]?" E: era fot[o] d[e] comida assim... era umas verdura lá uns legum[e] né? "quem qu[e] é ess[e]?" eu [e] minha prima "ah vó cê não tá vend[o] aqui é a senhora aqui"... "mas sou eu essa aí?" eu falei "é é a senhora"... coitada... ((risos)) eu eu minha prima dando risada ((risos)) Al veja quem qu[e] a senhora tá enxergand[o] mais aqui... "será que esse aqui é [o] vô V.?" ((risos)) não era... era ((risos)) mas não era ((risos))

\section{$\llcorner\mathrm{L} 1$ era um legume?}

L2 - eu acho que ela sabia que era legum[e] fruta assim... é qu[e] ela era também era bem assim de tirar sarro dar risada aí todo mundo "vó não é fot[o]... você não tá vendo qu[e] é 
legume?"... "[ma'si ma'si] $254 . .$. eu sei qu[e] é legume... cê pensa que eu sou boba?" ai... não sei não se ela tava enxe[^]gand[o]... ach[o] qu[e] ela não tava enxe[^]gand[o] qu[e] ela tava com [o]s oitenta an[o] dela...

L1 - ela não enxergava bem?

L2 - não

L1 - ela costurava?

L2 - não

L1 - não conseguia mais?

$\llcorner L 2$-assim... que eu lembr[o] não não

L1 - ou não era hábito?

L2 - acho que não era hábit[o] mesm[o]... ach[o] que não era hábit[o] mesmo

L1 - ah é? mas essa é a vó... a vitti?

L2 - é a vó adélia vit[]]i

L1 - ela faleceu?

L2 - faleceu... tem uns quatr[o] an[o] já

L1 - ah tá

L2 - e ela também... ela uma bem teimosa assim...

L1 - é?

L2 - é... ela dormia no sofá e roncava e d[e] repent[e] assistia televisão... "vó vai dormir"... "não não tô com son[o]"... a minha mãe falava qu[e] ela tinha ciúmes d[o] meu pai... qu[e] ela não queria deixar meu pai sozinh[o] e ela...

L1 - mãe do seu pai era?

L2 - é... mãe d[o] meu pai... e ela não queria deixar meu pai sozinh[o]... e ela... até tod[o] mund[o] não ir dormir ela $\mathrm{n}[\mathrm{o}] \mathrm{ia...} \mathrm{[e]} \mathrm{ficava} \mathrm{lá} \mathrm{no} \mathrm{sofá....} \mathrm{[ka]} \mathrm{bocona} \mathrm{abe[„]ta} \mathrm{e}$ [r]oncand[o] ((risos))... é bem teimosa ela

L1 - do terço era ela?

L2 - ela rezava bastant[e]... sempre que batia o te[ı]ço ela pegava e ia no te[ı]ç[o]

L1 - como eles vão lá em cima?

$\mathrm{L} 2$ - isso

L1 - eles tão agora lá né?

L2 - eles tão no/ tão na igreja agora ( )

LL1 - quem mais vai agora são os vét[]io né?

L2 - é mais os velh[o] só que vão... os nov[o] infelizment[e]... pra eles basta ir na missa... mas...

L1 - as vezes você vai no/no terço?

L2 - no terç[o]? ah:: ['dio]... d[e] vez em quand[o]... não é sempr[e] ((risos)) as vezes também eu chego:: quinze pra $\mathrm{sEt}[\mathrm{e}]$ né? $\mathrm{d}[\mathrm{o}]$ trabalh[o] então nem dá tempo também qu[e]... set[e] horas qu[e] eles começam

L1 - eles rezam em português ou em italiano?

L2 - em português

${ }^{254}$ Até parece! (literalmente: mas sim!) 
L1 - ah... mas depois que saem pra falar

L2 - ah... os... [o]s velh[o]? só em dialet[o] eles falam na praça né? pel[o] menos a maioria deles ali

L1 - é... cê/ você não entende né?

$\llcorner$ L2 - não acho que é porqu[e]

$$
\text { L L1 - vô/ se você escutar você/ }
$$

você entende quando tão falando?

L2 - ah... entendo... dá pra entender as vezes assim

L1 - ah tá... o que você você tinha falado da sua avó do terço... que ela rezava

L2 - ah ela gostava d[e] rezar muito... só que: ela ia $\mathrm{n}[\mathrm{o}]$ terç[o] sempr[e] né?... só que aí depois ela começou a ficar mais frAca né?... [e] ela não tem condição de ir... entendeu? a gente falava "vó fica aí não vai no te[^]ç[o]"... e a teimosa ia... aí a gent[e] acompanhava ela às vezes pra levar ela né? só qu[e] depois ela ela também gostava sabe $d[0]$ qu[e]? $d[e]$ ouvir o rádio Nossa Senhora Aparecida... ela gostava de ouvir que t[]]inha aquela bença da água... ela não perdia... era cho qu[e]... uma hora... uma hora e seis hora da tard[e]... ela tinha um radinh[o] vElh[o] antlg[o]... que só aqueles [r]ádi[o] velh[o] antig[o] que pega a estação da Nossa Senhora Aparecida ((risos))

$$
\text { L L1 - nossa... é? cê vê? }
$$

L2 - e ela gostava muit[o]... ela gostava... ela recebia aqueles santinh[o] da Nossa Senhora Aparecida... d[e] sócia

L1 - a/ela... ela era irmã de Maria?... aquelas... era... filha de Maria?

L2 - ela devia... fazer parte acho né? que é da...

L1 - que usa aquela faixa né?

L2 - é... naquela época...

$$
\text { LL1 - é... }
$$

L2 - e ela também contou uma vez... uma história qu[e] ela... que ela... uma vez ela contava né?... tomat[e]... sabe uns tomatinh[o] pequen[o]? que uma vez ela comeu trinta d[e] uma vez só... daí ela não quis nem... não quer nem saber ma[j] d[e] tomat[e]

L1 - nem do grande?

L2 - nem d[o] grand[e]

L1 - nem macarronada ela não comia?

L2 - nÃO... comia mas... mas tomate fruta assim ela ( ) é boa ((risos))

L1 - nem na salada?

L2 - ah não ((risos))

LL1 - se tinha salada com tomate ela não comia?

L2 - não comia... não comia... e... ela gostava também de ficar perguntand[o] "de quem qu[e] ocê é filh[o]? quem é você?" ((risos))

L1 - pra quem era de fora?

L2 - pra quem é de fora

L1 - ah tá... pensei que pros netos ((risos)) 
L2 - não... hum com netos não... netos ach[o] que ela conheceu... a última ach[o] qu[e] foi a G. que era pequeninha depois... ela não conheceu os outros... depois nasceu o G., o M.... não conheceu

L1 - não né? era ela que você falou... quando rezava terço dormia?

L2 - a::.h tá... não eu dormia junto com ela né?... aí ela começava a rezar o te[ı]ç[o]... aí ela começava a dormir... aí eu falava "vó [o] te[^]ç[o]" ela falava assim "mas eu tô [r]ezand[o] [o] te[ı]ç[o]" então... ela se perdia toda... também... tamØém eu tinha bastante u[^]sinho $(($ risos $)) \ldots$ quando ela roncava... ela... ((risos)) voava u[^]sinho ((risos))... ela roncava muit[o] ((risos)) aí ela assustava coitada ((risos))

L1 - é que você dormia com ela né?

L2 - dormia... ((risos)) coitada

L1 - nossa e eram quantos ursinhos por noite aí? ((risos))

L2 - ah... vo/voavam uns três ach[o]... Ømofada ((risos))

L1 - até você pegar no sono?

L2 - até... mas não tinha com[o]... ((risos)) aí ela... ela dava uns pul[o] de susto coitada... eu falava "vó vira d[o] lad[o] qu[e] cê tá roncand[o]"... "eu não to [r]oncand[o]... eu to eu to [r]ezand[o] [o] te[^]ç[o]"... falei "que [r]ezand[o] [o] ter[ı]ç[o] [o] quê... cê tá roncand[o]" ela era bem teimosa ((risos)) mu::ito

L1 - é... a maioria deles aqui são bem...

$$
\text { LL2 - é }
$$

L1 - casca né? um temperamento né?

L2 - fo[^]t][e]

$\mathrm{L} 1-$ é...

L2 - fo[^]t[e]... fo[^]t[e]

L1 - é... eu tava hoje ali com... com uns ali contando que... hoje em dia é tudo fácil... são tudo vagabundos os jovens... que no tempo deles

L2 - é qu[e] ach[o] qu[e] é... antigament[e] era mais difícil... difícil as coisas... hoj[e] tá mais fácil... ach[o] qu[e] é por isso né?

L1 - ela tinha essa mania de fazer tudo... com a mão dela... lavar roupa... e fazer

L2 - ela queria fazer... não queria ficar parada

L1 - não né?

L2 - não queria ficar parada... mesmo de idad[e] já:: fraquinha... ela queria... ela gostava $\mathrm{d}[\mathrm{e}]$ varrer [o] quintal... gostava $\mathrm{d}[\mathrm{e}]$ varrer [o] quintal

L1 - e é grande aqui

L2 - é grand[e]... e tinha o abacateiro... dois pé de abacat[e]... tinha um... um tinha bastante folha... então ela gostava de varrer [o] quintal as folha... até um... um... ir... mesmo fraca agente falava "não vá varrer" e se não deixasse ela varrer ela ficava brava... até teve uma vez ela quase desmaiou... aí que ela parou né? ach[o] que ela viu qu[e] tava...

certa idade

LL1 - já tinha uma

L2 - já tinha uma certa idad[e]... tava com setenta e oit[o] ach[o] já aí ela viu ela desmaiou varrend[o] [o] quintal ela passou mal aí depois daquele sust[o] ela começou a ouvir nós... 
mas até não acontecer isso ela queria va[r]er [o] quintal... ela gostava $\mathrm{d}[\mathrm{e}] \mathrm{va}$ [r]er [o] quintal... ((risos)) em xícara cop[o] se tivesse na pia ela ia também... é... e aí era perigos[o] né? na idade dela setenta e oit[o]... anos... ficar lavand[o] cop[o] escorrega quebra. se co[^]ta. né? aí dá dó né? porque acho qu[e] eles querem se sentir útil né? ach[o] que era essa a vontade dela né? de se sentir útil ma aí ficava preocupada né? d[e] deixar fazer L1 - mas aí no caso... assim.. era só varrer o quintal... não era mais nada assim?

L2 - só va[r]er [o] quintal

L1 - é né? lavar roupa... na mão

L2 - não... minha mãe lavava

L1 - é?

L2 - é

L1 - não deixava ela?

L2 - não?

L1 - mas se deixasse?

L2 - fazia

L1 - fazia?

L2 - [ma'dona $]^{255} \ldots($ (risos))

L1 - deu algum trabalho...

L2 - ah... ela fazia

L1 - nossa... minha avó também era assim viu?... fazia umas coisas dessas assim

L2 - é... ( )

L1 - ela tem os irmãos dela por aqui? irmãs?

L2 - tem

L1 - tias... tios

L2 - G. Vitti... tem [o] C.

L1 - você é parente do Diogo? aqui em baixo?

L2 - d[o] D.?

L1 - não sabe?

L2 - não sei... ma[j] deve ser... po[^]qu[e] um Vitti

L1 - Vitti é

L2 - Vitti é d[o] Bortol[o] lá né?

L1 - o R. é parente deles né?

L2 - hum... é... deve ser... mas tud[o] é... qu[e] nem... meu descendent[e] é [o] Angel[o] Pietr[o] Vitti... que era um dos filh[o]s

L1 - do Vitti

L2 - é

L1 - do Bortolo?

L2 - é

${ }^{255}$ Nossa Senhora! 


\section{B.SO - O.P.}

L1 - você chegou a trabalhar na roça?

L2 - O::pa... até ter meningit[e]... aí quando tev[e]/ tives/ tiv[e] set[e] anos aí tiv[e] meningit[e] aí... qu/ qu[e] parei d[e] ir na [x]oça... fiquei na casa ((risos))

L1 - no que que você trabalhava?

L2 - ah catand[o] a[r]oz e:: ant/ catand[o] a[r]oz catando milh[o]... feijão... ajudand[o] a amarrar cana... fazer feixe d[e] cana

L1 - trabalhou na cana?

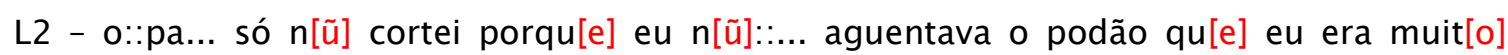
pequena... mas aprendi fazer nó então os mais velhos corta:vam... aquela época não era cana queimada então... eu fazia feixe... né? pra poder pôr n[o] caminhão/ não tinha ca[r]egadeira

L1 - hum hum

L2 - então foi assim qu[e] funcionou

L1 - ah tá 
L2 - ma[j]::s aí e depois... começam[o] trabalhar fora... minhas irmãs saíram pra fazer/ por sinal a minha mãe sempr[e] conta né? com orgulho qu[e] a primeira qu[e] saiu pra não ser freira... pra estudar foi minha irmã

L1 - é?

L2 - da casa né? ela foi fazer enfermagem... aí tod[o] mund[o] [r]esolveu fazer enfermagem

L1 - aham

L2 - aí depois abriu [o] caminh[o]... a gent[e] morou em [r]epública

L1 - é?

L2 - porque não tinha ônibus... eu morei doi/ doz[e] anos em [r]epública

L1 - aonde?

L2 - aí d[o] lad[o] do Teatr[o] Municipal

L1 - aham

L2 - né? na... na na:: avenida/ na [r]ua Santa Cruz na [r]ua José Pint[o]... [e] na [r]ua São Francisc[o]... nós dem[o] volta assim $\mathrm{n}[\mathrm{o}]$ quarteirão inteir[o]... ma::s era sempre (uma) [e] do seu joa/ [e] a gent[e] pagava aluguel pr[o] mesm[o] cara... pr[o] seu joaquim... então a gent[e]... eu morei por doz[e] anos aí::/ eu a G. a R. qu[e] faz/ qu[e] faz part[e] d[o] coral... a / a:: eu a G. a R.... a T. a V. todo mund[o] nós morand[o] num bolo... nós morávamos em vint $[\mathrm{e}][\mathrm{e}]$ seis pessoas

L1 - nossa

L2 - meninas e meninos aí... agent[e] dividia tarefa da casa... sexta-feira todo mundo fazia a faxina aí tod[o] mund[o] saía comer junt[o]... mas era uma delícia... aí depo[j].. quand[o] eu comecei trabalhar né? fiz faculdad[e] d[e] história aí eu falei né? "eu vou voltar e vou trabalhar com a comunidad[e]" qu[e] eu percebi que tava mo[x]end[o] muit[o]

L1 - hum hum

L2 - eu falei "o qu[e] eu mais gost[o] d[e] fazer... n[ũ] gost[o] de ficar escrevend[o] muita coisa... eu gosto d[e] cantar... euntão eu vou fazer/ dançar não é [o] meu fort[e] porqu[e] eu to sempr[e] d[o] lad[o] contrári[o]... né? aí eu comecei a fazer o [x]esgat[e] com as músicas... tant[o] [o] coral infantil já existia mas ele chamava coral infantil da infância missionária aí eu

LL1 - era ligado à igreja?

L2 - era ligado à igreja... só igreja... aí eu cheguei falei pa L. né? que a L. era [r]esponsável pra C. falei "vam[o] fazer [r]esgat[e] cultural?" ela falou "maØ quem que faz?" eu falei "eu faç[o]"

L1 - é

L2 - pode deixar qu[e] eu co[r]o atrás... eu vou atrás das músicas... eu pego do / eu tenh[o] um mont[e] d[e]/ guard[o] tud[o] né?

L1 - hum hum

L2 - eu tenh[o] mania d[e] guardar tud[o] né?

$$
\text { LL1 - é }
$$


L2 - aí eu falei "eu vou e o qu[e] não souber eu co[r]o atrás e vou trazend[o] gíria e vou transitand[o] [o] mund[o]... [e] foi aí que me co/ eu comecei o coralzinh[o] infantil... infanto-juvenil agora porqu[e] eles não querem sair

L1 - é

L2 -qu[e] $n[0]$ começ[o] era infantil porqu[e] tinha até dez anos

L1 - hum hum

L2 - agora... tem até dezeset[e] ((risos))

L1 - ((risos))

$\mathrm{L} 2$ - $\mathrm{d}[\mathrm{e}]$ quatr[o] a dezeset[e]

L1 -vai ter que dividir

LL2 - vai ter qu[e] dividir... tem setenta e cinc[o] crianças

L1 - é?... no começou foi difícil? passar a:: pa/ e:: por exemplo pra eles cantarem em dialeto? ou até aquela geração::

L2 - hum... sabe o qu[e] é dificil? e::: é a maioria não sabia ler... então eu tive qu[e] ensinar que o [ze] [a'ga] ((gh)) era guê:: sabe essas coisas?... e d[e] repent[e] você ensina qu[e] é [t $\mathrm{fi}$ [k]ando s[e] vai/ $\mathrm{n}$ [o] italiano aí quand[o] você vai falar o tirolês é ['se]

L1 - hum hum

L2 - né? [maso'lĩ] né? então eles eles "AH MEU DEUS d[o] céu... soCOrr[o]" [e] [o] dur[o] deles era entonação

L1 - ah tá

L2 - por causa d[o] ['Ere] né? principalmente eles queriam cantar tud[o] com dois ['€xes] e:: tudo qu[e] terminava $\mathrm{t}[\mathrm{e}] \ldots$ né? pra $\mathrm{t}[\mathrm{e}]$ "pra $\mathrm{t}\left[[] \mathrm{i}\right.$ " eles falavam "pra $\mathrm{t}\left[\int\right] \mathrm{i}$ dar" "pra $\mathrm{t}\left[\int\right] \mathrm{i}$ ofertar"... então é:: aí foi complicado

L1 - hum hum

L2 - até::: assim... ma $\varnothing$ depois [k]os mais velhos aprenderam os outros vêm só imitand[o] né?

L1 - e é uma coisa engraçada porque:: esse esse [t $\mathrm{t} i]$ e [ti] quando eles falam naturalmente sai

L2 - sai

L1 - mas quando eles lêem

L2 - e pra cantar

L1 - ah:: e eles faziam isso?

L2 - mas por que? porque:: é uma coisa qu[e] tá fazendo:: o/ sabe?

LL1 - influência da

escola?

L2 - eu ach[o] qu[e] é bastant[e]... porqu[e] o/ por sinal [o] mod[o] negat[]]ivo da escola foi ess[e] né?... na minha geração pod[e] perguntar pra minha mãe... eles chamaram as mães e pediram "por favor pra parar d[e] falar tirolês na/ na:: na cAsa qu[e] a gent[e] escrevia tud[o] um com ['єre] só... tud[o] com final d[e] ['ene] [e] tava atrapalhand[o] [o] aprendizad[o] d[e] português... só qu[e] isso era de/ uma evolução qu[e] a gent[]]i ia descobrir

L1 - claro 
L2 - eles não tinham ess[e] direit[o]

L1 - claro

LL2 - mas [e] ainda mais aqui qu[e] a escola sempr[e] foi sagrada

L1 - hum hum

L2 - tant[o] qu[e] [o] ['bepI] tirou d[o] própri[o] bols[o] pra construir o primeiro prédio... escola né?

L1 - hum hum

L2 - entÃO... é uma coisa que:: eles sempre valorizaram e o que qu[e] [o] professor falava aqui era ordem... então iss[o] infelizment[e] influenciou muit[o] nEGAtivamente aqui pra nós... muit[o] muito muito muito... e aí::: [o] dialet[o] acabou se perdend[o] né? tant[o] que s[e] pode ver o/ um casla aqui o T. com a D. ... entre eles dois eles falam português e:: em tirolês mas os filhos deles não entender uma palavra em t[]]irolês

L1 - é

L2 - porque nunca conversaram com os filhos em tirolês

L1 - vocês ainda mantêm né?

L2 - a gent[e] ainda mantêm... e: eu não fal[o] tant[o]... eu entend[o] mais d[o] qu[e] fal[o]

L1 - e seus pais só falam entre eles

L1 - maØ meu pAi [e] minha mãe eles falam tudo em t[]]irolês... e ainda com a gent[e] eles falam tud[o] em tirolês... meu pai pel[o] menos quando el[e] quer [r]eclamar ele [r]eclama tud[o] em tirolês né?

L1 - hum hum

L2 - s[e] el[e] quer falar alguma coisa pra cê fazer... ma[j]::s a maioria dos pais aqui não conversa em tirolês... meu sobrinh[o] filh[o] dessa minha irmã el[e] briga pra ela [e] fala qu[e] nunca vai perdoar ela $\mathrm{d}[\mathrm{e}]$ ela não ter ensinado el[e] a falar tirolês

L1 - hum hum

L2 - el[e] tá frequentand[o] [o] curs[o] d[e] tirolês agora

L1 - hum hum

$$
\text { L2 - então }
$$

L1 - é que também houve... talvez nas novas gerações porque casaram gnte de fora que também nem entendia né?

L2 - nem entendia mas também não fazia nem o mínimo esforço nenhum pra entender né?

L1 - ah tá

L2 - n[ũ] é? s[e] eu cheg[o] em algu:::m lugar eu tenho qu[e] me adaptar ao::: com/ não impor o/ não é mesmo?

L1 - é

L2 - então eu acho que foi mais é [x]elaxo do povo daqui mesmo

L1 - e dentro da escola qual que está sendo o seu trabalho de resgate? a dialeto entra?

L2 - ah/ ó... na escola a gent[e] eu pel[o] menos nem qu[e] não queira fazer eu eu vo/ as nossas expressões essas coisas a gent[[]i usa esse $\mathrm{d}[3]$ ialeto... mas bastante vez quando eu vou trabalhar a/ [o] [x]esgat[e] dA da própria história da escola eu fal[o] frases tirolesas eu falo essas coisas daí fal[o] "procure [o] qu[e] significa isso" 
L1 - hum hum

L2 - porque é uma forma... também não posso imPOr porque aí temos os alunos qu[e] não são... da origem tirolesa

$$
\begin{aligned}
& \text { LL1 - é } \\
& \qquad \begin{array}{l}
\text { LL2 - então } \\
\quad \text { LL1 - de...d de] qu[e] idad[e] são os seus alunos? }
\end{array}
\end{aligned}
$$

L2 - são d[e] quinta a terceiro colegial

$$
\text { LL1 - é brabo heim? }
$$

L2 - da d[e] dez a:: dezesseis anos

L1 - é uma turma bagunceira heim? ((risos))

L2 - ah uns anjos $(($ risos $)) \ldots$ uns aMOres $(($ risos $)) \ldots$ mas eu não tenh[o] tanta [x]esistência sabe?

L1 - não?

L2 - porque e:: é assim... e:.: mesm[o] qu[e] eles queiram falar qu[e] não []tão nem aí principalment $[\mathrm{e}]$ os $\mathrm{d}[\mathrm{e}]$ terceiro colegiAl segund[o] aquel[e] pessoal rebEld[e] né? que eles quer/ aqueles qu[e] contestam tudo não sabem nem por que mas tão contestando né? mas... é... é uma coisa qu[e] puxa

L1 - hum hum

L2 - então é uma coisa qu[e] acaba puxando então não tem co::m[o] n[ũ] querer fazer

L1 - mas eles se us/ eles usam expressões também

L2 - bastant[e]

L1 - é?

L2 - mais ainda os d[e] Santana

L1 - ah é?

L2 - os d[e] santana usam mais expressão... eu perceb[o] assim... um colegial principalment[e]... segu:nd[o] colegial que:: o pessoal $\mathrm{d}[\mathrm{o}]:: \mathrm{d}[\mathrm{o}]$ banc[o] daqui $\mathrm{d}[\mathrm{e}]$ santa olímpia eles têm muito mais / eles são muito mais é:: esqueceram muito mais as frases as expressões $\mathrm{d}[\mathrm{o}]$ qu[e] [o] pessoal $\mathrm{d}[\mathrm{e}]$ santana... nessa parte

L1 - ah é?

L2 - que o pessoal d[e] santana eles falam aind/ sabe aquelas expressões assim "a::i (maØ que)" n[ũ] sei o qu[e]... sabe essas coisas? e:: os do do:: daqui não os daqui já:: já fazem a expressão em português mesmo

L1 - ah tá

L2 - né? que:: gato escaldado tem medo d[e] água fria... já vai fal/ eles falam provérbio... mais provérbio brasileir[o] mesmo

L1 - e a turma de santana é mais conservadora?

L2 - a turma d[e] santana já é mais conservadora pra:: pro dialeto e aí quando começo a falar essas coisas assim eles "['di::o] ${ }^{256}$ par[e] d[e] falar igual ['nona]257 não sei o quê ((risos))

${ }^{256}$ Deus!
257 Avó. 
2B.SO - E.P.

L1 - como que tá o curso de dialeto? os caras não tão pagando aliás né?

L2 - não... não estão pagand[o] mas eu/ no[j] vamo Ø dar um jeit[o] já... (falando)

L L1 - porque...

quanto vocês receberam aí? quanto tempo?

L1 - até:: dezembr[o]... de setembr[o] a dezembr[o]... [e] [r]einiciou em fevereir[o] ma $\varnothing$ até agora

L1 - nada

L2 - nem um tostão

L1 - e tá indo lá a turminha... tudo?

L2 - tUdo mais... eu vou mesm[o] qu[e] ninguém vai pagar eu vou continuand[o]... [o] important[e] pra mim é qu[e] continu[e] né? (o curso)

L1 - mas eles estavam pagando o seu ou pagando... 
டL2 - pagand[o] assim... é [o] seguinte... tem a coordenadoria né? que coordena o curs[o]... era uma part[e] pra eles uma part[e] pra mim

L1 - pra ajuda né?

L2 - pra ajuda é

L1 -ser usado em material né?

L2 - materiAl... então porque um/ uma pa[^]te eles... eles tão guardando pra fazer a festa final [e] os gastou qu[e] tem também n[o] mei[o] d[o] curs[o] né?

L1 - ah vai ter uma festinha no final?

LL2 - vAi... se Deus quiser

L1 - ah::: tá

LL2 - e inclusive a prefeitura prometeu qu[e] vai fazer [o]s [o]s certificados e ajudar $\mathrm{n}[\mathrm{o}] \mathrm{n}[\mathrm{o}]:$ : dicionári[o]

L1 - hum hum

L2 - e a[r]anjar um espaç[o] pra fazer uma peça qu[e] a gent[e] ia formar... uma peça teatral

L1 - da ['bestja] $258 ?$

L2 - talvez ão seja o o da ['bestja]... hum uma ou outra meno[^] mas qu[e] tivess[e] qu[e]/ qu[e] foss[e] passar lá... na biblioteca municipal

L1 - lá né?

L2 - lá

L1 - aliás o que eu/ eu queria falar contigo... a gente tem que ir na prefeitura pra... formalizar mais esse negócio talvez

L2 - o problema tá send[o] é... é [o] contAt[o] na prefeitura

L1 - hum

L2 - porqu[e] era só a G. né?

L1 -é

L2 - mostrei pra você... ela saiu daí... tr[e]s meses d[e] férias de licença prêmi[o]... então

[e] não deixou ninguém na coordenação

L1 - aí por isso ninguém paga?

L2 - ninguém pAga... não pagou e não veio nem ver se [Ø]ta... s[e] [Ø]tá tendo [o] curs[o]

s[e] não tá... é qu[e] eu to... no[j] vamoØ porquê

L1 - criou vínculo

L2 - tem consciência também né? de/ [e]:: e [o] pov[o] quer né? e::.... as criança[Ø] adora

LL1 - entrou mais criança?

L2 - s[e] deixar entra tud[o] sábad[o]... é qu[e] a gent[e] tem que... que manerar né? aí...

L1 - tá com quanto?

L2 - agora?... entre as dua $\varnothing$ turma deve ter uns sessenta mais ou menos

L1 - olha que beleza

${ }^{258}$ Ser mitológico semelhante ao lobo (al. Krampus). 
L2 - é... mas [o] qu[e] nos queremos fazer e:: eu to tentand[o] conversand[o] né? qu[e] ela vai pagar ess[e]::..... com/ é qu[e] vai pagar essa qu[e] se/ nos já demo $\varnothing$ até agora e vão tentar prolongar [o] curs[o] tamØém

L1 - ah mas não pode ser um curso/

$$
\text { LL2 - é }
$$

L1 - tem que ser um curso contínuo

L2 - então... mas n[o] começ[o] era só nov[e] meses né?

L1 - hum hum

L2 - agora vamo $\varnothing$ tentar... tocar pra frent[e]

L1 - tocar pra frente né?

L2 - qualquer coisa escreve pr[o]... pra província... e vê [o] qu[e] vai fazer

L1 - é... faz alguma coisa

L2 - se virar

L1 - ah isso se vira... não é problema nenhum

\section{LL2 - com certeza}

L1 - aliás nós vamos montar inclusive a/ vamos montar uma apostila né? gramatical... acho que era bom também né?

L2 - mas então... mas é isso qu[e] precisamo $\varnothing$ ver qu[e] vai fazer... igual falei pra você as palavra os velho vão lembrando é::

L1 - hum hum

L2 - com o tempo

L1 - é

L2 - se eles forem falar igual eles com/... forem delclamar pra você uma poesia eles não podem parar... eles têm que vim dela d[e] com[o] eles falavam antigament[e] pra lembrar na memória deles... entendeu? eles não falam pra você... por você em pedaços... eles vão lembrand[o]... se eles lembrarem naquela hora tem qu[e] ir lá... marcar

L1 - por isso que é bom gravar como a gente fez

L2 - iss[o]... po[ı]que senão eles esquec[e]

L1 - ah eles... vai no... no no

L2 - $\mathrm{n}[\mathrm{o}]$ soc[o]... hoj[e] eles já lembraram mais uma... já ligaram pra mim

L1 - ah é?

L2 - é... ma[j] tem qu[e] ser aquela hora s[e] depois eles $\mathrm{s}[\mathrm{e}]$ esquecer eles não lembram mais ((risos))

L1 - os velhos estão fazendo isso então?

L2 - faz... ligam... opa

$\mathrm{L} 1-\mathrm{ah}$

L2 - eles/ ou se não ligam mandam pra alguém... o L. geralment[e] qu[e] escrev[e] né? depo[j] tra[j]

L1 - o L. não te passou aquele caderno á né?

L2 - passou... então... deu pra aproveitar várias coisas né?

L1 - eu usei de dicionário aquilo 
LL2 - então... então... e::: várias criança/ repetida... eu montei cinc[o] grup[o] d[e] criança... essas criança foram pesquisar no bai[r]o... alumas palavras novas...

$$
\text { L1 - surgiram }
$$

L2 - apareceram... algumas né? bastant[e] qu[e] já tava [r]epetida já

L1 - é... bom quando tem dois significados... vem com dois significados parecidos... porque aí pro dicionário né?

L2 - iss[o]... aí sim... quand[o] sai parecid[o] mas... [o] problema é que vei[o] com muita [r]epetida... eu to achand[o] qu[e] precisa mais um tempinh[o]... mas também se não der E. no[j] vamoØ fazer...

L1 - ah um vocabulário

L2 - é.... um vocabulári[o]... paciência

L1 - eu acho que pro dicionário nós temos que ter tempo

L2 - temp[o] é... mas eu já falei pra ela lá "avis[e] lá qu[e] não vai dar naquel[e] temp[o] qu[e] você queria"... qu[e] ela queria em junh[o] já queria [o]:.... lembra que você/ em junh[o] julh[o] cê falei "não vai dar"

L1 - hum

L2 - "não tem mais condição"... pra el[e] e pr[o]/ é::..... projetand[o] $\operatorname{pr[o]~futur[o]\ldots .~iss[o]~}$ daí

L1 - é... porque se vai fazer o negócio tem que ter aqueles... poemas

L2 - tud[o]... É:: tud[o] agora... tud[o] essas coisas principais vai ter iss[o]... principalment[e] [o] qu[e] tá dand[o] $\mathrm{n}[\mathrm{o}]$ curs[o]... as principais entendeu?

L1 - hum hum

L2 - [e] os velhos/ inclusive qu[e] nós fizemos apresentação né?

L1 - hum humm

L2 - falei pra você né?... qu[e] os velhos adoraram né?

L1 - hum hum

L2 - [e] eles queriam qu[e] tivess[e] faland[o] mAls

L1 - ah é?

L2 - eles tão planejand[o] pra fazer uma outra apresentação... assim com mais poesias

L1 - e a peça do teatro?

L2 - então a peça $d[0]$ teatr[o] até hum... né?... eu quer[o] deixar passar essas festa aqui entendeu?

L1 - hum hum

L2 - aí no/ depois d[e] junh[o] aí eu começ[o] já... ensaiar de/aí depo[j] pára na festa da polenta também né? naqueles dias depoi[j] vai embora $\mathrm{d}[\mathrm{e}]$ nov[o]... até sair... ma sair bonita não sair uma coisa mais ou menos... sair uma coisa bonita

L1 - ah ensaiar até depois da festa?

L2 - depo[j] da festa... porqu[e] eles queriam hum/ falar uma coisa pra você não dá pra fazer uma peça int[e]ra em dialet[o]

L1 - hum hum 
L2 - qu[e] não tem sentid[o] tamØém qu[e]... metad[e] do pov[o] não vai entender uma palavra né?

L1 - hum hum

L2 - então... temoØ qu[e] fazer... planejar $\mathrm{d}[\mathrm{e}]$ fazer ela... metad[e] tirolesa mais ou menos

[e] metad[e] em português OU faland[o] ela em... em dialet[o] [e] simultaneament[e] já

L1 - em português

$\llcorner L 2$ - já em português

L1 - ou partes mais engraçadas

LL2 - I:ss[o]... pa poder entender

L1 - em tirolês

L2 - pa poder saber [o] qu[e] cê tá faland[o] lá

L1 - é... aí o que você quer fazer

L2 - [e] aproveitar [o] cu[^]s[o] né? d[o] qu[e] as criança aprenderam um pouc[o]... [o] jeit[o] de falar pel[o] menos... [o] sotaqu[e] qu[e] eles tão pegand[o]... qu[e] precisa adquirir até iss[o] pra falar o tirolês né?... não adianta falar... fechad[o] igual fala $n[0]$ português... é tud[o] o/ mais abert[o] né?

L1 - hum hum

L2 - $\mathrm{n}[\mathrm{o}]$ dialet[o]

L1 - a entonação eles têm né?

L2 - tEm porqu[e] eu fic[o] passand[o] pra eles né?

L1 - hum

L2 - eles já têm [o] sotaqu[e]

L1 - hum

L2 - de criança... mas na hora d[e] falar eles não sabem... s[e] você não ensinar pa abir bem a boca e falar a:: as... vogais bem abertas eles... eles falam fechad[o] ( )

L1 - aqueles que têm contato com os avós... agente vê que são bEm melhores

L2 - com certeza... e muit[o] mais facilidad[e] pra aprender

$$
\text { LL1 - é }
$$

L2 - assim na hora aí... inclusive tem... s[e] ocê for ver na class[e] uns cinc[o] ou seis qu[e] nem precisaria tá lá... tá lá pra acompanhar alguma gramática ma $\varnothing$ assim mas já sabe falAr... entendeu? sabe falar as coisas... sabe falar não sabe escrever... nem no[j] sabem[o]... não tam[o]... tam[o] em projet[o] d[e]

L1 - é... grafia né?

L2 - d[e] conheciment[o] né?

L1 - é

L2 - maØ dá/ dá pra... pra ir tocand[o]

L1 - com verbo você já começou alguma coisa?

L2 - começamos alguma coisa... maø eu dei uma parada pra eles [r]ever [o] qu[e] no[j] falam[o] nas frases 


\section{B.SO - J.E.S.}

L1 - mas ele fazia porque ele gostava das cestas assim... como é que chama essa cesta em::

L2 - é::: jacá... jacá

L1 - é feita em que?

L2 - bambu

L1 - ah bambu

L2 - bambu... AH maØ dá um trabalh[o] el[e] pegava limpava tu:d[o] [e]:: era um trabalh[o] a[^]tesanal pu[^o]... artesanal mesm[o]... aí [o] meu... cunhad[o] lá [o]::: M. el[e]:: [e]::: 
começou a querer saber com[o] fazia [ma'eł] Bepin259 [la la l€ res'ta ma'la en'd€ ke'l€ na'dã 'via... o:: prrca'menta] ${ }^{260} \mathrm{ma}[\varnothing]$ é isso aí... depo[j]

LL1 - mas ele não

comercializava?

L2 - [no no no] era pra:: pra turma:: porqu[e] [o] pessoal tinha... plantaç[õ] d[e] milh[o]

L1 - aham

L2 - [e] el[e] eles precisavam na [x]oça pra jogar [o] milh[o] dentr[o] qu[e] el[e] é:: é:: era bastant[e] é:: [r]esistent[e] [e]:: além d[o] jacá el[e] levava também cesta qu[e] el[e] [o] pessoal coloca/ é:: levava... comida né? marmita de::: pa [x]oça dentr[o] da cesta feita $\mathrm{d}[\mathrm{e}]:: \mathrm{d}[\mathrm{e}]$ bambu

L1 - como é que eles falavam pra essas marmitas mesmo? tinha um nome quando comia né? era

L2 - OH pra mim era marmita meøm[o]

L1 - marmita

LL2 - pra mim já chegou com[o] marmita ((risos)) ma[^]mita ( )

LL1 - merenda

alguma coisa assim

LL2 - não... é:: e:: um pessoalzinho... o almoç[o] né? qu[e] na [r]oça comiam àø nov[e] hora da manhã... [e] a[o] mei[o] dia faziam a::: a:: merenda

L1 - ah

L2 - então aqui era assim ó... d[e] manhã lá pa seis hora Ø era a [kola'siõ]261... polenta... leit[e]... aí eles iam pa [x]oça lá pelas nov[e] [e] meia era um trabalh[o] forçad[o] aí eles queriam comer... mei[o] dia eles é:: to/ faziam a merenda e lá pa uma quatr[o] [e] meia cinc[o] horas vinham embora com uma fom[e] d[o] cão ((risos)) [ma'nava ma'nava] ( ) ]262 ((risos))

L1 - e aí:.... você trabalhou na roça quanto tempo?

L2 - até os dezoit[o] ano

L1 - ah é?

L2 - é

L1 - depois aí você foi estudar como é que foi isso?

L2 - aí fui na:...... traba[j]ei na Phillips... fiscal... produção $\mathrm{d}[\mathrm{e}]: .:$

LL1 - saiu daqui então?

L2 - sai daqui... tive qu[e] SAIR... senão ia passar fom[e] [ma'dəna] ${ }^{263}$

L1 - ah é?

L2 - AH:: passo[Ø] os três/ por causa da:: é:: [male'deta] ${ }^{264}$ monocultura da cana... passou a ser pouca te[r]a pra muita gent[e]

\footnotetext{
${ }^{259}$ Apocorístico de Giuseppe (mas o Bepìn).

${ }^{260}$ Ele começou a ficar doente até que foi embora (= faleceu). Pòrcamenta! - fusão que o falante realiza das expressões trentinas pòrca (misèria, bèstia, pipa etc) e sacraménta.

${ }^{261}$ Café da manhã.

${ }^{262}$ Comiam, comiam. Obs. no dialeto trentino, os verbos da terceira pessoa do plural se realizam exatamente como na terceira pessoa do singular, desse modo: el 'l màgna <ele come>, lóri ei màgna <eles comem>.

${ }^{263}$ Nossa Senhora!
} 
L1 - ah:: não tinha diversidade?

L2 - não não então a::: a:: geração nossa ou ia embora... trabalhar ou ia embora... d[e] outra escolha

L1 - e a geração que vai em mil novecentos e setenta né? quer dizer... mais ou menos

LL2 -

É::: nasce/ nasceram na década $\mathrm{d}[\mathrm{e}]$ sessenta setenta por aí... daí pra frent [e] tev[e] qu[e]:::

L1 - você nasceu quando?

L2 - cinquenta [e] oit[o]

L1 - cinquenta e oito

L2 - a::: a::: a geração $d[0]:: \mathrm{d}[0]$ até a geração qu[e] nasceu $\mathrm{n}[\mathrm{o}]$ sesse/ $\mathrm{d}[\mathrm{o}]$ ante[Ø] $\mathrm{d}[\mathrm{o}]:$ : sessenta eles viviam aqui era um guet[o] meØm[o]... um guet[o]... depo[j] teve qu[e] abrir

L1 - hum hum

L2 - mas era uma era uma/ eu eu eu ma $\varnothing$

L1 - um gueto é uma coisa mais isolada na verdade

LL2 - I::ss[o]

L1 - aqui era mais... era fechado pra eles né? parece

L2 - [e] cem por cent[o] determinad[o] [e] conduzid[o] pel[o]::: e:: fator [r]eligios[o]

L1 - ah é?

$\mathrm{L} 2$ - POH:: cem por cent[o]

L1 - a igreja falava

L2 - ah:: falou tá falad[o]

L1 - e eram padres tiroleses?

L2 - com certeza... ((tosse)) até mil novecent[o] [e] trinta... aliás até mil novecentos [e] trinta quarenta quem quem ficou aqui com a gent[e] foi os frades os frades capuchinhos... tod[o] aquel[e] tradicionalis::mo deles

L1 - tudo tirolês trentino?

L2 - tud[o] tirolês... a:: aliás a minha [biz'nona]265 ela ela conheceu os frades qu[e] vieram pr[o] Brasil ela já conhecia lá em Trent[o]

$\mathrm{L} 1$ - AH::: entendi

L2 - eles qu[e] qu[e]::: pega::vam é é... ajuda::vam po[ı]qu[e]:: quand[o] compraram as te[r]as eles foram engambelad[o] até falar chega... é eles não conheciam a:: a lei aqui entrou agiota $\mathrm{n}[\mathrm{o}] \mathrm{mei}[\mathrm{o}] \mathrm{OH}:$ : [po'reti]266 ((risos))

L1 - ah por isso do banco né?

L2 - é:.: é porqu[e] seria... não de um banco qu[e] a gent[e] conhec[e] hoj[e]... seria ['dela 'banka] $267 . .$. entendeu?... seria $\mathrm{d}[\mathrm{e}] \mathrm{um}$ agiota... entendeu?

$$
\text { LL1 - ah:: }
$$

L2 - qu[e] quand[o] comprar[o] a fazenda já tava hipotecada pel[o] banc[o] qu[e] falavam aqui [la'banka] ${ }^{268}$

\footnotetext{
${ }^{264}$ Maldita, desgraçada.

${ }^{265}$ Bisavó.

${ }^{266}$ Oh coitados!

${ }^{267}$ Do banco.
} 
L1 - aham

L2 - com[o] qu[e] hoj[e] ficou banc[o] ent[õ] falou a fazenda $d[0]$ banc[o]... até hoje

L1 - ah que é o apelido né?

L2 - é:: "cê mora aond[e]?" "eu mor[o] n[o] banc[o]"

L1 - é

L2 - não é porqu[e] é [laj'koni]269 qu[e] sentava n[o] banc[o] não ((risos))... entendeu?

L1 - ((risos))... e aí:: quer dizer depois você sai e vai trabalhar na Philips?

L2 - tiv[e] qu[e] ir lá... Aí eu comecei a fazer [o] segund[o] grau... comecei a fazer cu[„]s[o] unive[^]sitário

L1 - ah:: um dos primeiros heim?

L2 - é:: a a é:: antes d[e] mim tinha os dois t[J]ios meu qu[e] tinha feit[o]... um ou outr[o]

L1 - tios seus já tinham feito?

L2 - tinha

L1 - ah os

L2 - tinham assim... é qu[e] qu[e] [o] meu pai é é [o] mais velh[o] etão eles são praticament[e] [o] meu [o] meu irmão mais velh[o] é mais velh[o] d[o] qu[e] [o] meu ti[o] entendeu?

L1 - sério?

L2 - meu ti[o] já nasceu ti[o]

L1 - ah:: entendi... tem muito isso cruzamento de gerações né?

LL2 - é:: é... [e] ess[e] meu ti[o] foi estudar [o] seminári[o] dos frades capuchinh[o]... lá el[e] viu... a (cidade) tev[e] uma oportunidad[e] estudou mesmo... fez economia um letras outr[o] entendeu?

L1 - ah::: sim

L2 - porqu[e] quem

LL1 - mas eram padres então?

L2 - não... el[e] estudo[Ø] n[o] seminári[o] dos padres maØ depois el[e] el[e] acabou saind[o] [e] continuou [o]:::

L1 - os estudos

L2 - por conta própria... mas a única chanc[e] da turma sair daqui na década d[e] vint[e] $\mathrm{d}[\mathrm{e}]$ trinta era ir pr[o] seminári[o]... só tem uns padres aí muit[o] bons aí hoj[e] maØ foram pr[o] seminári[o] porqu[e] tavam com vontad[e] d[e] comer pão

L1 - sério?

L2 - [e] gostar[o] da vida... gostar[o] d[o]:: da vida finalidad[e] da vida deles [e] aca/ acabaram ficand[o]... aqui $\mathrm{d}[\mathrm{o}]$ nosso bai[ro] já sairam mais $\mathrm{d}[\mathrm{e}]$ trinta padres

L1 - bispo daqui saiu?

L2 - tem um... tinha um né? ['nde a'lont 'via] 270 daí [ke'le] ((risos))

L1 - ((risos)) era o Correr?

L2 - Correr... [o] M. Correr

268 O banco.

269 Preguiçosos.

${ }^{270}$ Ele está longe agora (= faleceu). 
L1 - tem um Vitti que é bispo ainda né?

L2 - el[e] é arcebisp[o]

L1 - arcebispo

LL2 - arcebisp[o]... lá em Curitiba

L1 - ah é Vitti

L2 - uns falam qu[e] el[e] nasce[o] na Santana porqu[e] porqu[e] el[e] era Vitti... [o] meu pai fala qu[e]::: os pai del[e] eram colon[o] da fazenda Negri aqui em baixo... el[e] nasceu na fazenda Negri... inclusiv[e] quand[o] que el[e] era criança a::: ma/ a:.: minha mãe conta qu[e] el[e] tava tud[o] empest[J]ad[o] sabe? porqu[e] era é um uma vida vida muit[o] simples muit[o] carent[e] el[e] el[e] tava empest[[]ad[o]

L1 - como assim? de bicho?

L2 - doent[e]

L1 - ah doent[e]

L2 - doent[e]... pest[J]ado... a a:.: a tia del[e] falou assim "[วkra'menta se se koł se'kwest mate'lot 'ki ef ł'ven eł'ven 'fora 'resta un'vesko] ${ }^{271 "}$ ((risos)) era é:: ela sabia bem [ko'zi]272 então [mate'lıt 'ke I€'ra pi'en da'vermi 'kola 'pansa ( )... sakra'meyta] ${ }^{273}$ ((risos))... ma[j] $\mathrm{d}[\mathrm{e}] \mathrm{d}[\mathrm{e}]$ tanta criança qu[e] eles tinham salvava quem era teimos[o] meØmo ((risos)) porqu[e] eles tinha vint[e] mo[r]ia $d[\epsilon j] \ldots$ agora a:::

LL1 - ah sim... ouvi nossa história de uns aí que

L2 - a minha mãe tev[e] trez[e] mo[r]eu só um... só um foi espert[o] foi embora ((risos))... [ma'dəna] ${ }^{274}$

L1 - mas eu também acho que era também esse... esse negócio de longe de hospital né? L2 - AH sim... aí é::.:

LL1 - eles nem sabiam o que era isso direito eu acho

L2 - porqu[e] as tias d[o] meu pai a maioria delas foram ser fre/ irmãs [r]eligiosas... Campinas em São Paul[o] e elas qu[e] começaram socorrer na part[e] da saúd[e] [o]:: os a geração dos meus avós e d[o] meu pai... elas começaram a poder dar/atender ( ) a levar pra lá aí qu[e] começou melhorar um pouquinh[o] [o] nível $\mathrm{d}[\mathrm{e}]$ vida... conciência $\mathrm{d}[\mathrm{e}]$ no sentid[o] de $d[e]::$ conservar a saúd[e]... porqu[e] foi mais $d[e]$ cinqüenta freira qu[e] tev[e]... tant[o] é qu[e] quand[o] meu avô e os irmãos del[e] os prim[o] del[e] foram casar não tinha nenhuma ['muje] aqui na: na fazenda... é só podiam ser freira aí foram casar com as mulheres tirolesa[Ø] tamØém mas d[e] Santa:na da da d[e] d[e] fazendas vizinhas qu[e] eles conheciam... Pompermayer entendeu?

L1 - ah tinha tiroleses em outras fazendas?

L2 - ti::nha [ma'dəna]... é qu[e] quand[o] chegaram em é:: em Mont[J] Alegr[e]... lá na na em Indaiatuba na fazenda $\mathrm{d}[\mathrm{o}] \mathrm{d}[\mathrm{e}]:$ : $\mathrm{d}[\mathrm{o}]$ viscond[e] lá... depo[j] qu[e] saíram d[e] lá tev[e] é::: ah Stenico por exempl[o] qu[e] é o/ tev[e] Stenico qu[e] veio aqui em Santa Olímpia

\footnotetext{
${ }^{271}$ Sacramenta! Se com/ se este menino aqui (sobreviver e) colocar tudo o que tem na barriga (lombrigas), vai se tornar um bispo (= santo)!

${ }^{272}$ Assim.

${ }^{273}$ Crianças que tinham a barriga cheia de vermes ( )... Sacramenta!

${ }^{274}$ Nossa Senhora!
} 
ma[Ø] tev[e] Stenico qu[e] foi pra Capivari... tev[e] Pompermayer qu[e] vei[o] aqui... tev[e] Pompermayer qu[e] foi pra lá L1 - em Jundiaí também teve

டL2 - Christofoletti entendeu? em em Traviú lá

L1 - é

L2 - [e] quand[o] qu[e] qu[e] [o]:: a geração d[o] meu avô foi casar e:: a minha bisavó não queria qu[e] misturass[e] ['kotra] coisa ela:: Øinda ela falou "vai lá pegar uma tirolesa doutr[o] cant[o]"

L1 - hum hum

L2 - [se vo'leva 'far la'mor kõ'more... po'retr ${ }^{275}$

L1 - nossa né?

L2 - ['ela ma'sava] 276

L1 - era uma coisa um tabu né?

L2 - poh... hoje em dia a a::: já avaca[j]ou tud[o] já ((risos))

L1 - do oito pro oitenta

L2 - ah [i'€ semari'da koj koj koj'məri koj'załdi... sakra'menta... de o'tetet deo'tfõ] ${ }^{277}$ ((risos))

4B.SO - R.C.C.

L1 - porque ela não entendia tirolês?

L2 - minha mãe não entendia nada... ela casou coitada ela morava na casa aqui em frent[e] na casa da minha sogra... ela falou pr[o]/ qu[e] [o] irmão d[o] meu pai [o] caçulinha falava assim pra ela "['dame 'lato]278" leit[e] né? ela n[ũ] sabia

L1 - não?

L2 - depo[j] ela ela sabia depo[j] qu[e] falaram pra ela qu[e] quantas coisa[Ø]... ela não sabia

${ }^{275}$ Se queriam namorar um negras, coitados!

${ }^{276}$ Ela matava.

${ }^{277}$ Se casaram com os negros, com os amarelos... Sacramenta! De olhos pequenos, olhos grandes.

278 Dê-me leite. A forma correta no dialeto trentino seria dàme lat; lato parece uma influência do italiano (vêneto?). 
L1 - mas ela era de família italiana né?

L2 - ela era ma $\varnothing$ só qu[e] ela não entendia qu[e] eles n[ũ]::

LL1 - de outra área né?

L2 - não falava [ĩ]gual os nosso[Ø] aqui... ela sofreu muit[o] ela fal[o] qu[e] ela sofreu bastant[e]... ela ia lavar roupa qu[e] tinha uma bica aí em cima [e] ela falou qu[e] eles falava ela "n[ũ] entendia nAda nAda nada"

L1 - eu lembro que... que quem que falou? a senhora? que uma vez acho que a mentina era pequeninha e ela pedia não sei o que pra M. e a M. não entendeu e foi embora

L2 - é ((risos))... ela foi mesm[o] ela não entendia porque... a::.:

L1 - que história é essa... no:::

L2 - não... porque é assim... ela pediu um/ uma coisa pra mentina fazer a Mentina era pequena mas a Mentina não entendia [ka] Mentina entendia só tirolês... só [o] dial/ [o]:: falavam né? porqu[e] os meus... os meus avós só conversavam em tirolês

$\mathrm{L}$ - hum hum

L2 - então a minha... ela não sabia... aí depois ela foi acostumand[o] mas Øté hoj[e] qu[e] ela vai fazer noventa e quatr[o] ano ela não sab[e] falar em tirolês ela entend[e] mas ela não sab[e]

L1 - ah é?

L2 - ela entend[e] tud[o]

L1 - ela falava italiano?

L2 - a minha mãe não... pronúncia qu[e] nem nós assim... em po[^]tuguês mesmo

L1 - é? vocês... vo/ vocês falavam os filhos italiano em casa?

L2 - é... mas a gent[e] falava bastant[e] porqu[e] meu pai falava né?

L1 - é

L2 - mas aí minha mãe não tem/ ela tem uma dificuldad[e]... ela entend[e] tUdo tudo Everton mas não consegu[e] falar

L1 - eu lembro que a senhora falou que quando ia na cana no corte da cana é que:: que a turma aprendia a falar tirolês aqui né?

L2 - ((risos)) é

L1 - porque ouvia a:: os velhos... como é que era isso?

L2 - assim... qu[e] a gent[e] cortava ca/ [o] qu[e] [k]and[o] a gent[e] saĺa a gent[e] convivia muit[o] [kos] mais idosos né? qu[e] a gent[e] era criança então... a gent[e]/ eles cortava cana a gent[e] qu[e] amarrava a ca::na então a gent[e] convivia junt[o]... chegava na hora $\mathrm{d}[\mathrm{o}]$ almoç[o]... chegava as vasilhas assim

L1 - hum hum

L2 - sab[e]? qu[e] cada um chegava::... era uma vasilha grand[e] [e] cada um tirava pra el[e] L1 - é

L2 - [e] aí conversava... e aí eles falava tinha qu[e] aprender tinha que falar

L1 - hum hum

L2 - qu[e] a gent[e] entendia tud[o] depo[j] qu[e] foi deixand[o] com[o] tem muitas famílias aqui qu[e] os filhos sabem bastant[e] porqu[e] os pais

L1 - fazem questão 
L2 - fazem questão

L1 - é... agora os pequeninhos... os netos da senhora estão

L2 - o mais velho tá fazendo

L1 - dialeto... o curso né?

L2 - el[e] tá fazend[o]

L1 - a senhora conversa com ele também? um pouquinho?

L2 - conve[ı]s[o]... AH eles chegam aqui eu fal[o] por exempl[o]... qu[e] nem ['bon 'dzวrno 'bəna 'sera 'bəna 'note]279" cant[o] bastant[e] música em tirolê::s sabe?

L1 - hum hum

L2 - pra eles aprenderem

L1 - é

L2 - (falo) convers[o] bastant[e]

L1 - a no:: no::: a senhora te/ trabalhou muito tempo fora daqui né? sempre assim voltando todo dia

L2 - ia [e] voltava tod[o] dia

L1 - no que?

L2 - na saúd[e]

L1 - fazendo o que?

L2 - na enfe[^]mage Ø... na part[e] $d[e]$ enfe[^]mage $\varnothing . .$. eu trabalhei nesses PSS... esses programa[Ø] qu[e] tem qu[e] a gent[e] vai visitar as famílias né?

L1 - hum hum

L2 - [e] tinha um médic[o] qu[e] trabalhava comig[o]... é uma pessoa muit[o] bem d[e] vida... el[e] almo/ el[e] trazia almoç[o] junt[o] comig[o] pra mim ensinar el[e] falar tirolês L1 - ah é?... e como é que era isso aí?

L2 - el[e] chama doutor $\mathrm{H}$. até agora el[e] é um médic[o] d[o]/ daí d[o] INSS... sab[e] negóci[o] d[e] Øposentadoria? essas/ essas tamØém qu[e]/ qu[e] el[e] trabalha aí qu[e] el[e] passou num concurs[o]... el[e] chegava qu[e] el[e] falava assim pra mim qu[e] quand[o] ia/ ((risos))... quand[o] chegava alguma moça bonita el[e] ((risos))... niss[o] s[e] el[e] queria falar assim "ai [ke beł]280 essa [ma'tela] ${ }^{281}$ bonita" né? então el[e] falava assim e eu ficava faland[o] pra el[e] "ah ['bєle 'gz̃be]282" né?... "é... ['bele 'gãbe]" né? qu[e] fala

L1 - é

L2 - [e] el[e] ficava cê acredita qu[e] el[e] ficava... el[e] chegava/ ele ficava não sei quantos final d[e] semana aqui sentad[o] ali na lanchonet[e] pa ouvir [o] pessoal faland[o] em tirolês

L1 - ah é?... ((risos)) queria aprender pra falar essas coisas então né?

\footnotetext{
${ }^{279}$ Bom dia, boa tarde, boa noite. As formas corretas do dialeto trentino são: bon di, bòna séra e bòna nòt. Do mesmo, parece haver uma influencia do italiano, muito provavelmente por causa da origem italiana (vêneta) da informante.

${ }^{280}$ Que bonito.

${ }^{281}$ Moça.

${ }^{282}$ Belas pernas. Atentar para a ocorrência de [̃̃] enquanto realizaçãode [a].
} 
L2 - é... [e] ond[e] qu[e] eu trabalho nós trabalhávamos em quatr[o] tirolesas daqui d[e] santa olímpia e quand[o] tinha alguma coisa qu[e] a gent[e] não queria que os outros soubesse ((risos)) a gent[e] falava em tirolês ((risos)) a nossa chef[e] "o qu[e] cês tão aprontand[o]?" ((risos))

L1 - vocês aprontavam só em tiolês lá?

L2 - é:: eles falavam "a né?" eles falavam assim... nÃO mAl mas... por exempl[o] s[e] uma pessoa ela era cha::ta... a gent[e] conversava em tirolês nós quatr[o]...

L1 - é

L2 - [e] eles ficava tud[o] boiand[o]... ((risos)) "PAr[e] d[e] falar" "o qu[e] vocês falaram?" [e] a gent[e] [r]epetia e eles entendia [e] falava explicava "não é mal na::da... é iss[o]"

L1 - hum hum ((risos))... mas assim... quantos anos a senhora já trabalha ou trabalhou? porque agora a senhora parou?

L2 - agora eu tô afastada... eu trabalhei doz[e] anos fora

L1 - doze anos

L2 - é

L1 - como é que era esse trabalho?

L2 - A:i... trabalh[o] é/ trabalhava na enfe[^]magem então aten[d3]ia as pesso::as fazia medicação::: tud[o] com[o] cuidar $\mathrm{d}[\mathrm{e}]$ um doent[e]

L1 - hum hum... mas era com curso... um curso que a senhora dava ou não?

L2 - não... era trabalho mesmo de / da enfe[^]magem

L1 - nas casas?

L2 - é nas casa[Ø] eu ia nas casas... porque ess[e] trabalh[o] é da prefeitu::ra [e] era um trabalh[o] meu mesm[o] qu[e] a gente tinha qu[e] visitar todas as famílias... pra ver as necessida::ades porque qu[e] a pessoa ficava doe::nt[e] qu[e] tinha iss[o] por exempl[o] uma pessoa qu[e] na casa ela tinha muit[o] fumant[e] fumavam sab[e]?

L1 - é

L2 - s[e] a casa era húmida... sab[e]? a gent[e] poder né? passa/ passava $\mathrm{p}[\mathrm{o}]$ médic[o] $\mathrm{p}[\mathrm{o}]$ médic[o] dia[gi]nosticar po[^]que tem pessoas qu[e] não adianta tomar medicament[o] Everton... s[e] você não descobr[e] d[o] qu[e] qu[e] vem

L1 - é né?

L2 - era iss[o] daí qu[e] a gent[e] fazia

L1 - a senhora fez algum curso pra isso?

L2 - e::: fiz eu fiz enfe[^]magem depois eu fiz um cu[^]s[o] pra iss[o] eu fiz em são paulo

L1 - ah é?

L2 - pela prefeitura

L1 - pela prefeitura? morou lá em são paulo?

L2 - não... a gent[e] ia assim duas vez po[^] semana a gent[e] ia a prefeitura pagava a gent [e] ia [e] voltava

L1 e:: esse curso chega a ser de enfermagem ou é de/ uma uma::

L2 - é um curso d[e]:: é assim... um curs[o] d[e] medicina preventiva pra gent[e] prevenir as doenças

L1 - ah tá 
L2 - pra gent[e] ensinar [o] pov[o] a prevenção

L1 - legal

L2 - em tud[o] pra:: em todas as áreas

$\mathrm{L} 1$ - ah

L2 - então a gent[e] tinha conheciment[o] em piracicaba agent[e] passava em todas casas sab[e]? gent[e] rica gent[e] gent[e] pobr[e] baian[o] d[e] tud[o] quant[o] é raça

L1 - é?

L2 - maØ a gent[e] chegava... interessant[e]

L1 - hãm

L2 - era eu [e] outr[a] chegava/ começava a conversar eles falavam assim "NOssa"... quem conhec[e] tirolês falava "você é tirolesa" sem essa/ sem

L1 - é... quando era aqui de piracicaba né?

L2 - é falava "você é tirolês"... [e] tinha gent[e] qu[e] falava "nossa ma[j] com[o] qu[e] que engraçad[o] que vocês falam... d[o] jeit[o] qu[e] você fala" porqu[e] a outra falava direit[o]... aí falava que era tirolês qu[e] era um bairro aqui $\mathrm{d}[\mathrm{e}]$ piracica::ba né? qu[e] nosso pais vie[^]am d[e] lá:: nossos avós né?... ma[j] tod[o] mund[o] conhec[e] [o] sotaqu[e] fiøo não nega ((risos))

L1 - ((risos)) e como é que era no tempo da da sua infância

$$
\text { LL2 - hãn }
$$

L1 - essa essa questão da da:: de falar tirolês... quando a senhora por exemplo ia na casa de alguém... de algum vizinho buscar alguma coisa... ajudar em alguma coisa

L2 - p[e]dia em tirolês

L1 - tinha que ser em tirolês

L2 - falava em tirolês... falava... na esco::la a gent[e] conve[^]sava assim ['kas] professoras tinha dificuldad[e] tamØém qu[e] elas não sabiam né? mas bastant[e] coisa falava gent[e]... falava quas[e] tud[o] em tirolês

L1 - é né?

L2 - sofria com iss[o] porque tinha gent[e] qu[e] não entendia [k]ocê pedia

L1 - era sofrido nesse (tempo)?

L2 - era com[o]/ era ma[j] sofrid[o] porque tem gent[e]... por exempl[o] cê ia na cidad[e]... cê tinha qu[e] aprender a falar em... português po[ı]quê:: eles não entend[e] tem coisas... cê viu/ cê vê os mais velhos com[o] eles faziam coitad[o] eles pediam não sabiam [o] qu[e] eles pediam

L1 - é

L2 - então... mas nós já... foi mais

L1 - mais fácil

L2 - mais fácil

L1 - mas a senhora lembra de algum caso que aconteceu com a senhora que deu algum rolo aí porque::

L2 - não comig[o] não... comig[o] niss[o] não

L1 - porque desd/ na escola a prof/ os professores eram de foar né?

$\mathrm{L} 2$ - os professores eram $\mathrm{d}[\mathrm{e}]$ fora 
L1 - a senhora foi aprender português na escola ou com a mãe já também falava?

டL2 - não [ka] mãe... a mãe... misturou né? s[e] não tivess[e] minha mãe nem eu $n[u ̃]$ saberia... por causa da minha mãe qu[e] a minha mãe então a gent[e] convivia bastant[e] [ka] mãe e:: depo[j] foi pegando uma idad[e] na roça.. com o meu pa::i... [o] meu pai trabalhava sempr[e] com mais pessoas né? então por iss[o] [ka] gent[e] falava... os dois

L1 - hum hum

L2 - tinha mais facilidad[e]... agora minhas irmãs/ [o] meu i[^]mão mais nov[o]... já nunca falou... po[^]qu[e] aí:::

L1 - o caçula?

L2 - [o] caçulinha já falav/ fala igual... só português... el[e] não sab[e] falar nada nada em tirolês

L1 - seus primos e primas então devem falar

L2 - falam... bastant $\left[\int \mathrm{I}\right]$ ainda

L1 - é?

L2 - a minha irmã... eu tenh[o] uma irmã qu[e] moa ali a D. não sei s[e] cê conhece[e]... maØ ela fala bastant[e] ela sab[e] falar bem mesm[o] [o] tirolês ma[j] d[o] qu[e] eu... bem mais

L1 - é? e quando por exemplo a senhora quer conversar com alguém de mais idade... por exemplo vai pegar a dona M. o C. ou até aqueles mais velhos ainda

L2 - Øinda conve[^]s[o]

L1 - conversa né?

LL2 - eu não fal[o] TÃO bem assim... mas dá bem eu conve[^]s[o]

L1 - a senhora procura falar mais em tirolês pra eles entenderem melhor? que eu vejo isso... a turma aqui quando vai se dirigir ao mais velho eles falam em tirolês

LL2 - em

tirolês... eu tamØém... quand[o] eu convers[o] com a F. qu[e] a gent[e] sob[e] na missa junt[o] aí vou conversand[o] em tirolês com ela

L1 - é né?

L2 - é

L1 - parece que aí eles se sentem melhor e é um respeito também né? que a pessoa tem

mesm[o]... é porque eles eles sabem né? pra eles é mais fácil falar falar tirolês

L1 - é né?

L2 - é... cê pod[e] ver... pra eles é mais fácil 
5B.S - J.B.

L1 - o que é que tinha antigamente?

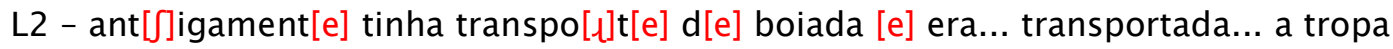

L1 - é

L2 - cento [e] cinqüenta duzentas cabeça... então era transpo[^]tada tud[o] com p[i]ão d[e] boiadeir[o] né? aquelas coisa [e] tal... ia uma mula na f[^]ent[e] com sini::nh[o] os p[i]ão $\mathrm{d}[\mathrm{e}] \operatorname{lad}[\mathrm{o}]$ [o] gad[o] tud[o] acompanhand[o] os/ tud[o] ce[^]tinh[o] né?... passava aqui... eu vi tropa passar aqui... a época ainda... lá atra[j] né? [e]:: aí então uma ocasião eles viajavam com tropa assim lá pos lado $\mathrm{d}[\mathrm{o}]$ estad[o] d[e] goiás... [e] aond[e] lá os gad[o] né? qu[e] vinha e::: eles ficavam assistind[o] na pousada um fazendeir[o] dava pous[o] $\mathrm{p}[\curlywedge] a$ eles né? ent[õ] tev[e] os p[i]ão qu[e] pous/ ia posar na casa d[o] hom[e] e:: d[e] lá d[e] um outr[o] bai[r]o vizinh[o] ia ter bail[e] festa tud[o] né? então eles saír[o] $\mathrm{d}[\mathrm{o}]:$ : da casa $\mathrm{d}[\mathrm{o}]$ 
hom[e] toma[^]am banh[o] trocar[o] d[e] [r]opa [e] for[o] [e] viram a pé[^]gola d[e] lingüiça lá né?... aí for[o] $\mathrm{n}[\mathrm{o}]$ bail[e]... f[o] lá dançar[o] quand[o] vo[ı]tar[o] d[e] d[e] lá pas três hora da madrugada viram a lingüiça lá passar[o] a faca assim... cortar[o] uma dua $\varnothing$ tre[j] $\varnothing$ lingüiça pa eles comerem sem qu[e] o patrão soubess[e] né?... AH:: quand[o] foi $n[0]$ dia seguint[e] né?... ficar[o] lá pa depois seguir viagem né? patrão fe[j] [o] a[ı]moç[o] tud[o]... pegou tud[o] as lingüiça da pé[ı]gola... colocou nos prato[Ø] assim colocou em cima da mesa p[^]a eles comer... é quis/ "coma linguiça aí ago[^]a aí" ((risos)) "co::ma" ((risos))

L1 - ah... e o patrão era daqui?... ou não?

L2 - não... era d[e] goiás

L1 - ah de Goiás

LL2 - conta[^o] esse caus[o]

LL1 - ah tá... mas lá esles também faziam esse...

será que o mesmo jeito do:: pérgola que nem aqui?

L1 - é:: né?

டL2 - é a pé[^]gola qu[e] sempr[e] existia a pé[^]gola

L2 - é

L1 - porque aqui como é que fala lingüiça? eles têm outro nome também

L1 - [lu'ganega]

LL2 - [lu'ganega]

L2 - [lu'ganega] é

L1 - é

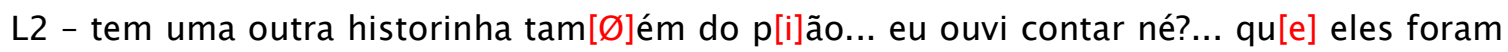
numa festa e coisa [e] tal... acaba[^]am comp[^]and[o] um litro d[e] pinga [e] um perfum[e] caríssim[o] né? sab? pe[^]fum[e] era/ sempre foi ma[j] bem ma[j] car[o]... aí colocar[o] num bo[^]nal assim d[o] lad[o] da sela $\mathrm{d}[\mathrm{o}]$ animal [e] vinham vind[o] "pla pla pla"... aí quand[o] el[e] chegou numa porteira "PÁ::" bateu um litr[o] na na na:: na porTEira aí eles falar[o] "tomara qu[e] seja [o] perfume" ((risos)) a pinga eles não queriam... quebrar ((risos)) nem qu[e] era mais car[o] ((risos))

L1 - mas a pinga tinha que beber? ((risos))

L2 - tinha qu[e]:: su[^]a a pinga ((risos))

L1 - eles tem um outro nome pra pinga aqui que eles falam quando é feito

L2 - ah é cachaça é::: que ma[j]?

L1 - é::: não é grapa não?

L2 - gra:: ['graspa] é:: é um outr[o]

L3 - é outra coisa

L1 - da:: da casca da uva né?

LL3 - ( ) ['graspa]

L2 - da casca da uva né?... ['graspa]...['graspa]

L1 - e tem a [3'napa] né?

$$
\text { LL3 - ['de 'la 'kaska 'da 'yva] }
$$

L2 - bom a [3'napa] é quand[o] fica d[e] fogo

$$
\text { LL3 - é ((risos)) }
$$


L2 - quand[o] bebe dema[j] fica $d[e]$ fog[o]

L1 - fica [3'napa]

L2 - fica [3'napa]

L3 - ['resta 'pu 'mel jo 'de 'ke no'ałtri] ((risos))

L2 - é... aí n[o]:: tamØém uma outra... aconteciment[o] qu[e]:: [o] N./ foi el[e] qu[e] contou pra mim

L3 - é

L2 - el[e] falou qu[e] a senhora com... [ko] a:: B.... eram mocinha[Ø] diz qu[e] foram na santa olímpia lá né?... então tinha as ca[^]tola d[e] vinh[o] qu[e] ficavam... fe[^]vend[o] eles pegavamo um canudinh[o] e chupavam... [o] vinh[o]... e ela foi ela [ko] a B. lá [e] ((gesticula))

LL3 - nossa senhora

L2 - [e] ficar[o] ['una 'znapa] né?

L3 - é::

L2 - aí qu[e] aconteceu? Tinha umas pa[j]a lá na::/ no saguão... as duaØ pegar[o] [e] ficar[o] do[^]mind[o]... quand[o] chegou meia noit[e] meia noit[e] [e] meia on/ uma da manhã... os pai vir[o] qu[e] eles n[ũ] vo[^]tava[Ø]... co[r]eu foi lá:: "ach[o] qu[e] tão na Santa Olímpia lá... for[o] faz/ ah eles [Ø]tão lá na na adega lá" né?

L3 - é

L2 - fo[^o] lá encontro[Ø] as duaØ do[ı]mi::nd[o] na pa[j]a ((risos)) aí diz qu[e] el[e] falou $\mathrm{p}[\mathrm{o}]::$ don[o] lá né?

L3 - ['ma 'Ikra 'bon] viu? ((risos))

L1 - ['IEra 'bon 'anka] né? ((risos))

LL3 - O:.:.:

L2 - falou "ah deixa elas qu[e] tá do[^]mind[o]... deixa elas qu[ع]ta [e] amanhã ced[o] elas vão embora ((risos)) deixou elas do[^]mind[o]... né?... a senho[^]a [ko] a $B$.

L1 - ['le 'me jo 'dərmir per'ke 'dopo 'nõ 'se 'pəde tor'nar 'a 'ka] né?

L2 - elas gostava do:::

L1 - ['de 'la 'znapa 'ke 'lera] ((risos))

L3 - ['no 'ne 'a ma'nar 'a] nada

L1 - é?

L3 - ( ) [noj] ((risos))

L2 - como chamava a mãe da senhora?

L3 - Maria

L2 - é... Maria

L1 - esses tiroleses aqui

L3 - ma ['nent] qu[e] falava porqu[e] os tirole[j] os itali[a]n[o] era Marieta com[o] os qu[e] falava... ela chamava Maria

L2 - é

L3 - ah:::

L1 - que os tiroleses tinham umas aqui... umas histórias aí que... de... como é que era aquela que a mãe do D. foi lá na escola? do ros / do ['rospo] 
L2 - ah::: sim... tinha uma escolinha d[e]:: d[e] adult[o] sab[e]?

L1 - ahn

L2 - vieram dar umas aula d[e] adult[o] [e]:: aí então [o]::: a professora colocou lá um... um sap[o] né? [e] mandou os alun[o] fala com[o] qu[e] era [o] nom[e] daquil[o] lá... aí pe[^]gunto[Ø] pa m[a]e d[o] D. "qu[e] qu[e] é ess[e] animal aí... pa[^]ec[e] ess[e] bicho" né?... ela o[j]ou falou "é um ['rosko]"((risos))

L3 - ((risos)) ma Ø era bem ( ) Lque... [o] ['rosko] é [o] sap[o] né?

L1 -acho que ela nem sabe como dizer sapo

டL2 - ela não sabia na época

L1 - é... era tipo mobral? que que era?

L2 - É:: um mob[^]al uma escolinha... eu tamØém ia lá... eu era ma[j] jovem maØ tamØém [Ø]companhava a tu[^]minha lá os ['veju]... eu gostava $d[e]$ ver d[e]:: ficar tamØém rodeando... aí aí depo[j] tev[e] um dia qu[e]:: [o]::: pØofessor [o]:: tava dand[o] aula [e] [o] S. Vitti [o] S.

L3 - é

L2 - el[e] precisava sair né? aí então o $\mathrm{p}$ [o]fessor pa adiantar um pouc[o] a aula del[e] escreveu umas palavra lá na lousa pa el[e] ler né?... aí chegou tava escrit[o] lá "lápis" né? lápis... aí el[e] chegou e:: "la::.... la::: la:::" aí [o] V. falou "['porko 'bəja]" lá::PIS ['pis] em/ [e] ['pis] quer dizer urinar aqui né?

L1 - é ((risos))

L2 - ((risos)) É:: PIS ((risos)) el[e] consertou ((risos)) [e] foi só [r]isada

L1 - o senhor foi até que série da escola aqui?

$\llcorner L 2$ - ah eu fiz quatr[o] ano $\varnothing$

L1 - quatro anos que tinha aqui?

L2 - é na minha época era[Ø] quatr[o] ano Ø

L1 - agora aqui vai até o que? vai até colegial?

LL3 - vai ma[j] na frent[e]... ma[j] frent[e]

LL2 - é aqui vai até... até

colegial

L1 - é né?

L2 - então depois eu:: qu[e] eu era mais adult[o] fiz um... um estud[o] por co[r]espondência

L1 - ah::: tá

L2 - é... eu estudei eu ap[^]endi alguma coisa viu?

L1 - é né?

L2 - é ((risos))

L1 - mas era técnico também? o que que tinha?... ou era geral geral?

LL2 - é::: vinha as apostila

sab[e]? matemática português e coisa [e] tal... até eu ess[e] dia eu tava vend[o] lá eu vi [o] liv[ıo] daquela época qu[e] eu escrevia... as palavra com[o] deveriam ser co[r]eta né?

L1 - é 
L2 - português

L1 - e:: quando por exemplo tinha dúvia em matemática alguma coisa como que fazia?

L2 - a gent[e]:: dava [r]esposta pel[o] co[r]ei[o]

L1 - vinha rápido isso? a resposta?

LL2 - vinha... vinha o:..... cheva $\mathrm{n}[\mathrm{o}]$ co[r]ei[o] lá... né? cê pagava lá o... e vinha cê ia $\mathrm{n}[\mathrm{o}]$ co[r]ei[o] pegava as apostila

L1 - ah tá

L2 - é deu dó qu[e] eu perdi as apostila velh... maØ tem um caus[o] tamØém é:: um ensinament[o] deles lá né? ((pássaro joão-de-barro canta bem alto ao fundo))

L1 - ahn

L2 - você ter... [ũ]a é/ uma noção d[o] qu[e]:: uma pessoa a outra né? pr[o] [Ø] cê ver uma pessoa [e] analisar... é duas coi/ aconteceu [o] seguint[e]... vamo $\varnothing$ supo[^] qu[e]::: tem uma $\mathrm{p}[\mathrm{J}]$ ça $\mathrm{d}[\mathrm{e}]$ água na [r]ua

L1 - ahn

L2 - [e] um ca[ro] espi[r]a água [ne] um executiv[o]... foi [ne] um uma pessoa mais graduada

L1 - ahã

L2 - aí [o] qu[e] qu[e] ele fa[j]? el[e] pega o[j]a aquel[e] esb[u]rrif[o] d[e] água

L1 - ahn

L2 - bat[e] ['kos] ded[o] na... nas calça assim

L1 - é

L2 - tranqüil[o] [e] segu[e] [e]:: vai embora

L1 - é

L2 - [e] agora ia passand[o] um lav[^]ado[^]... espi[r]ou água nel[e]... a [r]eação del[e] foi "EH:: po[^]c[o] bóia EH:::" não sei [o] qu[e]:: já é uma [r]eação diferent[e]... por que? porque [o] serviç[o] d[e] executiv[o] dessas pessoa mais estudada é um se[^]viç[o] ma[j] calm[o] $\mathrm{ma}[\mathrm{j}] \operatorname{lev}[\mathrm{e}]$

L1 - hum

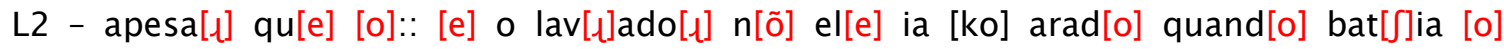
$\operatorname{arad[o]~} n[u ̃]$ toc[o] el[e] já a[r]ancava uma [e] VA:I... então fica um mod[o] mais agressv[o] d[e] ser né?

L1 - é::: 
1C.SO - M.C.S.C.

L1 - quando que você aprendeu a falar português? você é uma das que melhor fala português na segunda geração

L2 - aprendi quando fui pa [x]ibeirão pret[o]... trabalhei um an[o] lá... aprendi lá

L1 - na escola aqui como é que era?

L2 - também aprendi um pouc[o] também e:: a professora nossa ensinava sim ma $\varnothing$ em casa era ma[j] [o] dialet[o] né? qu[e] s[e] falava

L1 - hum hum

L2 - aí já começou a entrar um poc[o] né? aí a gent[e] saiu pra ir pra/ pra ir pa [xe]beirão aí já começou [o] português

L1 - hum hum... porque com seus pais só:: até os 
LL2 - a maioria era dialet[o]... maioria...

e começaram tammØém a falar [o] port[y]guês maØ a maioria era dialet[o]

L1 - ah é?... por exemplo quando você conversa com o tio C. ali

L2 - ah:: aqui ta/ também aqui em casa às vez $\varnothing$ [ko] meu marid[o] é:: a gent[e] fala dialet[o]

L1 - ah só fala em tirolês?

$\llcorner L 2$ - [nว nõ] tud[o] ah... n[õ] tudo... maø bastant[e] coisa a gent[e]

fala... procura manter

L1 - ela fala bem também o dialeto né?

LL2 - fala... fala

L1 - o L. né?

LL2 - fala... fa::la

L1 - com seus irmãos?

L2 - agora... meu sogr[o] com a minha sogra era tud[o] em dialet[o]

L1 - ah é?

L2 - sempr[e] falava dialet[o] meu sogr[o] com minha sogra... meu pai já começo[Ø] falar mais português não sei s[e] porque era a casa mais freqüentada $\mathrm{d}[\mathrm{o}]$ bai[r]o né?

L1 - era?

L2 - [r]ecebia políticos [r]cebia tud[o] [o] pessoal qu[e] vinha d[e] fora

L1 - o prefeito vinha í não vinha?

L2 - vi::nha [o] prefeit[o] [o] senhor bisp[o] autoridades teve um jantar uma vez pra ajudar na construção da igreja daí [o] M. D. esse pessoal sab[e]? tud[o] ess[e] a[e]... a gent[e] tem fot[o] dess[e] dess[e] encontr[o]

L1 - não é seu pai que está cantando numa foto?

LL2 - é... J. el[e] chamava joão mas tod[o] mund[o] conhecia como J. ninguém conhecia com[o] J.

L1 - ah é? ((risos))

L2 - falava J. Stenico ninguém sabia quem era falava J. "ah bom J. eu sei quem é"

L1 - o::S patriarcas... você tem descendência deles a Rosa Pompermayer e do Jacó Correr ou não?

L2 - clar/ a minha avó é... filha deles

L1 - a sua avó é filha deles?

L2 - filha... a Maria Stenico... Maria Correr não a Stenico

L1 - a ['zia] Maria?

L2 - é:: a ['zia] Maria... é filha d[o] Jacó Correr e da Rosa

L1 - ah ela é Stenico por casamento?

L2 - por causa d[o] ['nono] Simão... maø ela é Correr... ela qu[e] vei[o] da/ d[o] qu[e] conta a história... a gent[e] tem dados porqu[e] ela deixou por escrit[o]

L1 - quando vieram do Tirol?

L2 - quando vie::ram porque vie::ram como vieram como chegaram... ela deixou tud[o] aquela história qu[e] a gent[e] tem foi tud[o] ela... co/ a punh[o] ela escreveu

L1 - hum hum... com quem está isso? 
L2 - ninguém sab[e] no[j] $n[u ̃]$ consegu[e] saber... a[ł]guém tá escondend[o] ninguém mostra... no[j] tem ela se [po'na] uma história contar... escrita uma c[o]pia ma $\varnothing$ original de/ dela meØm[o] assim dela no[j] n[ũ] tem não

L1 - sumiu?

L2 - tá com a[ł] guém ninguém quer falar com quem tá

L1 - ah é?

L2 - é... [Ø]tá escondida eu acho

L1 - você já tentou procurar?

LL2 - nos tentamo Ø... hum... po[ı]qu[e]... né?

L1 - é

L2 - ela foi copiada assim... padr[e] A. padr[e] J. copiou ma Ø a original meØm[o] a gent[e] $\mathrm{n}[\tilde{u}]$ tem... eu tenh[o] só original $\mathrm{d}[\mathrm{o}] \ldots \mathrm{d}[\mathrm{o}]$ testament[o] espirtual qu[e] ela escreveu eu tenh[o] a letra dela meØm[o]... aquela a original tá com [o] T. Stenico ele tira cópia pa quem quer... aí el[e] vai tirar cópia não dá pa gent[e] tirar cópia

L1 - ah tudo bem mas ele dá a cópia?

L2 - é:: iss[o] ele deu... um dia eu fui lá el[e] pedir pr[o] sobrinh[o] del[e] "vai lá n[o] grup[o] [e] tira a cópia pra ela e traga agora" eu fiquei lá esperand[o] el[e] chegar com a cópia a original ficou com el[e] [o] T. Stenico

L1 - hum hum

L2 - agora a original da hisTÓria... qu[e] [o] padr[e] A. copiou [o] padr[e] J. também a gent[e] não sab[e] com quem tá

L1 - a cópia você tem?

L2 - a cópia sim maØ original [ka] letra dela meØm[o]... cê pergunta pra um "tá [ka]quele" cê pergunta pra outro "ah comig[o] n[õ] tá dev[e] tá [ka]quele" cê pergunta pra aquel[e] outr[o] n[ũ] tá

L1 - i::: ((risos))

L2 - em a[ł]gum lugar guardad[o] tá... qu[e] quand[o] vó falece/ a ['nona] ${ }^{283}$ mo[r]eu né? a[ł]guém dev[e] ter peg[o] ess[e] negóci[o] aí

L1 - e está escrito em quê? em que língua?

L2 - tá em português... ela escreveu

L1 - em português?

L2 - tá escrit[o] em português aliás... [no no] ${ }^{284}$ [o] padr[e]:: [o] padr[e] A. traduziu s[e] não me engan[o]... [Ø]tá na cópia "traduzida"

$$
\text { LL1 - é:: né? }
$$

L2 - é... ma[Ø]:: porque ela tinha quinz[e] an[o] qu[a]nd[o] ela vei[o] d[e] lá ainda maØ ela escreveu mais tard[e] né? maØ já morava n[o] Brasil era ['nona] ela tinha bastant[e] conheciment[o] $d[e]$ português porque:: quand[o] era pra [r]esolver problema fora da cidad[e] era era a ['zia]285 Maria qu[e] ia

\footnotetext{
283 Avó.

${ }^{284}$ Avô.

285 Tia.
} 
L1 - ela era a [komanda'resa]286 que a turma fala né?

L2 - [komanda'resa] ent[õ]... ent[õ] ela ia pa São Paul[o] levar quando precisava internar criança/ as criança qu[e] tava/ qu[e] $\mathrm{n}$ [ũ] tinha atendiment[o] médic[o] especializad[o] ent[õ] com[o] tinha as três da nossa lá né? na S[a]nta Casa... ela ia levar as criança[Ø] pa internar ela ia [r]esolver problemas

L1 - a família sua/ nessa parte aí sempre foi muito de comandar aqui é:: não comandar

líderes

L1 - líderes né?

L2 - líderes... bastant[e]

L1 - els que iam resolver os problemas

L2 - a a ['zia] Maria foi na época ela::: meØm[o] na fundação da escola ela [ko] doutor Samuel for[õ] os líder pa procurar professores ela orientava a part[e]... recebia as visita tud[o] ela qu[e]:: né?

L1 -que organizava as coisas aí?

L2 - é... maØ... organizava

L1 - é

L2 - Øpois ficou uma parte [ko] bastant[e] quem taØmém é líder qu[e] vê bastant[e] coisa tamØém foi [o] G.... G. meu i[^]mão... el[e] tem um trabalh[o] bom na comunidad[e] participou d[e] várias coisa... el[e] não aparec[e] muit[o] maø el[e] fez um trabalh[o] tud[o] $\mathrm{d}[\mathrm{e}]$ fund[o]

L1 - o G. aqui?

L2 - é... G. é... o::

L1 - é?

L2 - inc[r]usiv[e] el[e] qu[e] começou quand[o] assim... levar as moça pa passear valorizar a mulher... foi el[e]... as primeira aula sobr[e] sex[o] pras mocinha qu[e] naquela época era [o] tabu depo[j] quem quebro[Ø] foi el[e]

L1 - é? como é que era?

L2 - então... é qu[e] não s[e] falava sobr[e] iss[o]... nem [o] pai nem ninguém [e] el[e] começou a ler uns livr[o] aí começo:::

L1 - explicar

L2 - el[e] [r]eunia as menina[Ø]... fala::va fal/ explicou tud[o]

L1 - verdade que o homem não pegava uma criança no colo né?

L2 - não... é verdad[e] iss[o]

L1 - foi com/ através dele também que começou a parar isso?

L2 - não... a:: e::/ el[e] el[e] tev[e] de valorizar a mulher qu[e] quand[o] trabalhava na [r]oça qu[e] eu vinha embora com el[e]... el[e] vinha $\mathrm{m}[\mathrm{e}]$ ajudar a lavar as ga[r]afa d[o] café qu[e] a gent[e] levava ga[r]ava não térmica não tinha né?... qu[e] qu[e] vinha me ajudar a buscar água... então el[e] começou a quebrar ess[e] tabu aí... Øgora d[e] levar as criança passear foi o A.... um dos primeir[o] hom[e] qu[e] começou descer na praça na frent[e] da

${ }^{286}$ Mulher mandona, comandante. 
igreja qu[e] não tinha praça naquela época levand[o] as criança enquant[o] a mulher a[r]umava a cozinha... el[e] foi muit[o] criticad[o] por iss[o] pessoal tirava sa[ro] el[e] falava "ah ela tá fazend[o] [o] serviç[o] dela eu vou ficar um pouc[o] [kas] criança"... aí começou... agora [o] G. sempre foi mais assim... valorizand[o] a mulher... já sempr[e] foi mais

L1 - era um tabu isso heim?

L2 - era um tabu gr[a]nd[e] é:: [o] G. [e] [o] S. tamØém porque [o] S. começou namorar a I. [o] pai d[o] E.... el[e] namorava a I. né? qu[e] era dos Negri

$$
\text { LL1 - dos Negri }
$$

L2 - [e] eles era considerad[o] fazendeir[o] ent[õ] eles falava "só porqu[e] el[e] vai casar [ko] uma fazendeira el[e] ajuda a fazer [o] serviç[o] d[e] casa"

L1 - é porque os Negri eram... eles estavam muito bem de vida né?

L2 - muit[o] muit[o]... ah dá dó $\mathrm{d}[\mathrm{e}$ ] saber quem conheceu [o] qu[e] tinha $\mathrm{n}[\mathrm{o}]$ Negri e pensar qu[e] agora $\mathrm{n}[\tilde{o}]$ tem ma[j] nada... tinha moinh[o] se[r]aria... eu cheguei a conhecer essa part[e]

LL1 - o Negri veio sozinho do Tirol inclusive né?

L2 - eu não sei qu[e] época qu[e] eles vieram

L1 - eu li alguma coisa que ele veio sozinho e que eu sei que

L2 - bom eles tinham meØm[o] na cidad[e]... eles tinham um quarteirão qu[e] era tud[o] deles

L1 - ah é?

L2 - sim... lá pe[^] d[e]::... [o] E. dev[e] saber [o] endereç[o] ce[^]t[o]... um quarteir[õ] qu[e] era só deles... agora aqui eles tinha benefíci[o] d[e] a[x]oz [o] café a se[r]aria... qu[e] era... uma [r]odona qu[e] era... e/ e:: girava a água... eu lembr[o] diss[o] a gent[e] ia lá... eles eram muit[o] ric[o]... aí [o] S. começaram a falr qu[e] el[e] el[e] ajuda/ m[e] ajudava fazer [o] serviç[o] assim d[e] ba[ı]d[e] água essas coisa porque el[e] ia casar com uma fazendeira... ent[õ] começou aí maØ [o] G. sempr[e] foi mas assim d[e] quebrar ess[e] tabu $\mathrm{d}[\mathrm{e}]$ valorizar a mulher $\mathrm{d}[\mathrm{e}] \ldots \mathrm{d}[\mathrm{e}]$ fazer pequenas coisa el[e] sempr[e] foi

L1 - e você? chegou a trabalhar em alguma coisa aí ne/ nessa área? de conscientização ou de

L2 - [no] nós trabalhava na [r]oça qu[e] nem eles

L1 - é?

L2 - trabalhava na [r]oça... [e] co:: po cê ter uma idéia como qu[e] era... $\mathrm{n}$ [o] sábad[o] a gent[e] trabalhava até [o] mei[o] dia... depo[j] a gent[e] vinha embora mei[o] dia [e] tinha qu[e] ajudár lavar [r]oupa da casa... [e] eles né?

L1 - hum hum

L2 - assim... tinha mais... co/ mesm[o] a noit[e]... semp[e] fal[o] pras minhas menina "não $\mathrm{qu}[\mathrm{e}]$ eu $\mathrm{m}[\mathrm{e}] \mathrm{a}[\mathrm{r}]$ ependa... a gent[e] costumava a bor/ as mo/ as noiv/ as moça bordava [o] enxova[ł]

L1 - sim

L2 - é... [e] eu bordei tud[o] meu enxoval... d[e] doming[o] [e] na [r]oça... na hora d[o] descanç[o]... tud[o] meu enxova[ł] foi bordad[o] assim... tud[o] meu enxova[ł]... daí escolhia [o] desenh[o] bordava meu enxovalzinh[o] 
L1 - hum hum

L2 - devagarinh[o] na [r]oça enquant[o] os hom[e] descançava[Ø]... bordava

L1 - era duro heim? porque:: cansa né?

LL2 - então... maØ queria aproveitar né? agent[e] n[õ] tinha outr[o] espaç[o]... porqu[e] à tard[e] a gent[e]... à tard[e] sempr[e] s[e] vinha... tinha qu[e] ajudar... na cozinha qu[e] nem dizia a[r]umar não a[r]umar a cozinha ba[^]dear água essas coisa tinha qu[e] ajudar a mãe

\section{C.S - A.F.V.}

L1 - nem sei quantas crianças tem ali

L3 - quanta? umas oit[o] não é?

L1 - por aí

$$
\text { L L2 - ['pø::ki]287 (tem/ tem cri[a]nça) }
$$

L1 - tem...

L L2 - pouca... [an'kora at'banko] ${ }^{288} \mathrm{tEm}$

L1 - é::

L2 - (tem pouco?)

L1 - é:: tem pouco tem/

L O::: [ma'si 'pøki... 'tanti ge'nc] ${ }^{289}$ ( )

$$
\text { ᄂ L3 ( ) nada [nõ]? }
$$

${ }^{287}$ Poucos.

${ }^{288}$ Ainda no Banco (= SO)

${ }^{289}$ Até parece poucos! Há muitos. 
L1 - é:::

$\llcorner\mathrm{L} 2($ )

L3 - eles não cantaø? não canta... eles dançavam né?

L1 - eles dançam

$\mathrm{L} 3-\mathrm{AH}:$ :

L2 - quanta na igreja [ge'nعj 'tanti]... que d[a]nça

L1 - no que? naquele da dança?

L2 - é... [mate'lıti / o:: en la 't $\int e z a$ kej 'bala]290

L1 - AH sim mas os pequeninho né?

L2 - é

L1 - mas atigamente tinha bastante criança que dançava aqui?

L2 - o:: tinha tinha

L1 - tinha né?

L2 - a V. cantava aqui ( )

L 3 - cantava ( )

L1 - a V. né?

L2 - a G. qu[a]ndo eles cantava $\varnothing \mathrm{t}[\mathrm{y}] \mathrm{d}[\mathrm{o}]$ quant[ع] I[y]gar... [ne'sun noj'fa 'nent] ${ }^{291}$

L1 - ah é?

L2 - [en'sin noj'sa 'nent] ${ }^{292}$

L1 - ah é? no tempo da senhora que que eles dançavam?

L2 - o:: ['kwet 'temp]293 [no] tinha ((risos))

L L3 ((risos))

L1 - não dançava a ['kwatro 'pasi]294?

L2 - ah?

L1 - não dançava a ['kwatro 'pasi]? aquele/

L L2 - [no] só bail[e]... [mi'neva 'søl at'banko a

ba'lar]295 ((risos))

L1 - AH era no banco que tinha os baile naquele tempo?

L2 - naquel[e] temp[o] tinha ba/ tinha ba/ ['gera na 'casa] d[e] our[o] lá... até/ [en'fin]296

$d[e]$ sete $d[e][m a ' t i n a]^{297} n[o j]$ ia lo::nge $t[y] d[o] d[e]$ a pé

L1 - todo dia?

L2 - no::: ( ) n[o] J. Correr

L1 - é

L2 - era sempr[e] lá

L1 - é?

${ }^{290}$ Crianças... oh! Na igreja que eles dançam.

${ }^{291}$ Nenhum não faz nada.

${ }^{292}$ Até que não sabem nada.

${ }^{293}$ Naquele tempo.

294 “Quatro-passos", dança típica trentina.

${ }^{295}$ Eu só ia ao Banco (= SO) dançar.

${ }^{296}$ Até.

${ }^{297}$ Manhã. 
L2 - dançar é... me pegava d[e] noit[e]/ não tinha luz ( ) ((risos))

L L1 - é? ((risos)) ia com lampião? com que que era?

L2 - ah?

L1 - com a lanterna na/

L L 2 - AH [la 'lym]298 ((risos))

L L1 - AH [la 'lym] ((risos))

'kera 'li en 'kwet 'temp]299

L L2 - [la 'lym] ((risos)) [en pøk 'negro

L1 - TA lo[ko]! que ['bujo] que era então

L2 - é:: qu[e] med[o]... [la 'lym] d[e] querosen[e]

L1 -querosene que era né?

L2 - é

L1 - no::ssa era outro tempo né? mas quem que tocava nas bandas antigamente aqui? quem que fazia/

L 2 - NO:: é só sanfona

L1 - AH é só sanfona só?

L L2 - é::

L L1 - quem que tocava?

L2 - quem?

L1 - quem que tocava sanfona naquela/ naquele tempo?

L2 - aqui?

L1 - é

L2 - n[o] tinha dig[o]... ma[j] qu[e] era d[e] Santa Olímpia ( ) no[j] ia lá

L1 - é? opa

L2 - ( ) [d $\varepsilon \dagger^{\prime}$ 'bus] 300

L1 - ah é?

L2 - ((risos)) (n[o] esparramar) ma ( ) ma[j] long[e] qu[e] t[y]d[o] meus parent[e] ou ma[j] long[e] no[j] ia t[y]d[o] d[e] a pé

L1 - ah é?

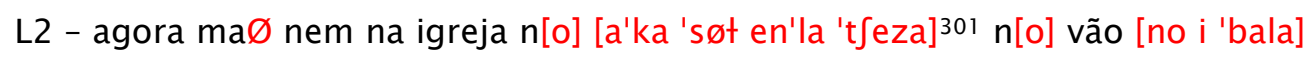

L1 - não vão mais né?

L2 - [a'ka 'søt en'la 't $\left.\int e z a\right]$

L1 - é né?

L2 - é

L1 - vão tudo de carro né? agora... não vão mais a pé né?

L2 - o::: maø vai t[y]d[o] d[e] ca[ro] ah:: ( )

\footnotetext{
${ }^{298}$ O lampião.

${ }^{299}$ Um pouco escuro era ali naquele tempo.

${ }^{300}$ Do buraco, referindo-se ao bairro SO (que se localiza numa faixa de terra mais baixa que $\mathbf{S}$ ).

${ }^{301}$ Aqui somente na igreja.
} 
L1 - é? hoje lá o J. tava falando como que eles pegavam a cana... que pegava os feixe de cana e punha no/ no vagão do trem

L2 - é::: é ['tyt] ${ }^{302}$ em palha/ palha meØmo d[e] c[a]na $n[0]$ era d[e] queimada $n[o] \ldots$ ['tyt] em palha

L1 - tinha perigo de cortar a mão

L2 - ah era

L1 - a senhora chegou a trabalhar nesse também?

LL2 - E::: maø( )

L1 - é mesmo?

L2 - é:: ia/ ia na [r]oça ia carpir... bater [a'roj]... ['tyt... 'tyt 'me ga'fat] ${ }^{303}$

L1 - é:: era

L2 - (bater [a'roj]) [maj'a a'roj] 304 ((risos)) [maj'a a'roj di'zeva]

L1 - é ((risos))

L2 - tinha (os bu[ro]) quand[o] [et] tinha bastant[e] te[r]a

L1 - é

L2 - vai aí ver $\mathrm{t}[\mathrm{y}] \mathrm{d}[\mathrm{o}]$ pra baix[o] $\mathrm{d}[\mathrm{o}] /$ daquel[e] cois[o] $\mathrm{d}[\mathrm{o}] / \mathrm{d}[\mathrm{o}]$ qu[e] sai em Santa Olímpia

L1 - ah

L2 - aquel[e] $\mathrm{n}[\mathrm{o}] \mathrm{qu}[\mathrm{e}]$ fica pra ca

L1 - ah sei

$\mathrm{L} 2$ - era $\mathrm{t}[\mathrm{y}] \mathrm{d}[\mathrm{o}]$ dos meus irm[õ]... $\mathrm{t}[\mathrm{y}] \mathrm{d}[\mathrm{o}] \operatorname{noss}[\mathrm{o}]$

$\mathrm{L} 1$ - AH era deles?

L2 - é... agora vender[o] t[y]d[o]

L1 - AH... o sobrenome da senhora de solteira qual que é?

L L2 - a::

L1 - o seu pai o nome do seu pai qual que é?

L2 - F. Forti

L1 - dos Forti a senhora é... mas então a senhora é parente da M. aqui? dos marido/ da M. aqui m. é:::

L2 - d[e] Santa Olímpia?

L1 - aqui dos Forti da M.

L2 - Ah:: ma Ø aquela é minha c[y]nhada aquela

L1 - AH:: é cunhada ela? mas ela é da primeira geração ela... acho que ela é última né?

L2 - ach[o] qu[e] ela ( )

L1 - ela é mais velha que a senhora ou não?

L2 - quant[o] an[o] qu[e] tem a ['nona] ${ }^{305}$ ?

L1 - quantos anos será que ela tem?

L4 - oitenta [e] nov[e]

\footnotetext{
302 Tudo.

${ }^{303}$ De tudo eu fiz.

${ }^{304}$ Malhar arroz.

${ }^{305}$ Avó.
} 
L1 - oitenta e nove ela vai fazer

L4 - noventa

L1 - noventa noventa ela vai fazer

L2 - noventa?

L1 - é

L2 - eu tenh[o] oitenta [e] cinc[o]

L1 - oitenta e cinco? quando que a senhora nasceu?

L2 - ah?

L1 - quando que a senhora nasceu?

L2 - mi[t] novencento/ no[j] fala mi[t] novescent[o] e vint[i] um

L1 - vinte e um? EH::: ((risos))

L2 - ((risos))

L1 - era tudop mato aqui não era?

L2 - ah:: t[y]d[o] mat[o] t[y]d[o] mat[o]

L1 - como é que era aí tudo naquele tempo?

L2 - U:: ( ) aqui... o:: tinha t[y]d[o] mat[o]

L1 - mato né? tinha muito bicho?

L2 - ((risos)) bich[o] ( )

L1 - cobra

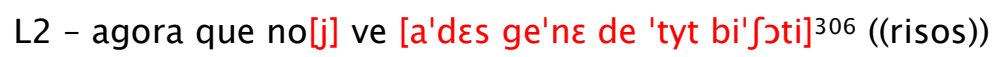

\section{C.S - J.V.}

L1 - quando começou a plantar cana aí?

L2 - aí n[o] n[o] n[o]::: aí era d[e] um temp[o]... ['Iera det ĩ'dzeno t tej'trał] ${ }^{307}$

L1 - ah

L2 - qu[e] era:: qu[e] era d[e] franceses [o] centra[t]

L1 - ah de franceses ali?

LL2 - tinha os/ usina centra[ł]... ma $\varnothing$ tinha máquina trem... te/ máquina meØm[o]... depo[j] a gen/ [po'naro] uma a ['oljo] aí porqu[e] era muit[o] vag[õ] ali

máquina qu[e] levava cana na usina

LL2 - aí:: até as ( ) levava lá n[o] [en'dzeno] centra[ł]

LL3 - levava de

vagão

${ }^{306}$ Agora há todo tipo de bichinhos.
${ }^{307}$ Era do Engenho Central. 
L1 - ah::

L2 - que era... que era dos franceses

L1 - eles vinha então aqui cuidar tudo disso ou não?

L2 - [no] eles tinha fazenda aí... era del[e] aí no caiapiá era del[e]

L1 - ah:::

L2 - d[e] lá pra lá d[e] santa [r]osa lá... aí depo[j]:: Co[J]ta Pint[o] ['eł] e:: be/ n[o] mei[o] da cidad[e] aí [o] Co[S]ta Pint[o] comprou tud[o]

L1 - o senhor foi naquela época trabalhar lá também?

L2 - em cinquenta [e] nov[e] ele deu a quinta pa[r]t[e]... em vez qu[e] no[j] ir pegar [e] ir $\mathrm{n}[\mathrm{o}]::$ atrá[j] d[o] deles aí qu[e] for[o] no Co[J]/ $\mathrm{n}[\mathrm{o}]$ centra[ł] qu[e] ele pegava Øté d[e] se/ $\mathrm{d}[\mathrm{e}]$ setenta an[o]... fomo $\varnothing$ lá... parecia qu[e] no[j] ficava [r]ic[o]... de[r]ubar um [ka'lipio] assim... trazer em casa porque te/ era gr[an]d[e] qu[e] d[e] d[e] vint[I] metro[Ø]... precisava [ko... ko] machad[o] e e limpar e depo[j] passar arad[o] ((L3 comenta algo com alguém))... levar água d[e $\mathrm{d}[\mathrm{e}]$ cartola pos bu[ro]... na mei[o] dia tirava [e] [po'nava] lá

L1 - vocês que faziam? os tiroleses que faziam isso tudo?

L2 - é... [e] depo[j] pa fazer estrada po caminh[õ]... no[j] no[j] pegava... tinha pa[j]a tamØém de/ dess[e] [kali'pja]... pegava cortava... fazia baix[o] assim pra el[e] passar

LL3 - pra

não estourar o pneu d[o] caminhão

L1 -AH:: tá

LL2 - qu[e] era po caminh[õ] po caminh[õ] pa descer pa ca[r]egar n[o] vag[õ]

L1 - vocês estavam abrindo mato então?

L2 - é... ver/ [kali'pja]... era t[y]d[o] [kali'pja]... bre::j[o]... eles plantar[o] [kali'pja] porque era $\mathrm{t}[\mathrm{y}] \mathrm{d}[\mathrm{o}]$ brej[o]

L1 - ah porque ele tira água quando::

LL2 - sim [o] [o]::

டL1 - quando tem tira tudo a água né?

L2 - [o] [ka'lipjo] com[e] a água

L1 - ah:: tá

L2 - é

L1 - mas era duro então o negócio ali?

L2 - eh::: pel[o] amor d[e] ['dio] eh? e depo[j] eles fala esses da cidad[e] porque $n[o] ~ n[o]$ conhec[e] te[r]a... n[o] conhec[e] serviç[o] d[e] [r]oça

L1 - e é pesado né?... meu avô trabalhava ((L3 comenta algo))

L2 - primeir[o] primeir[o] no[j]... Øpera... Øpera primeir[o] no[j] [e] [e] depo[j] os favelad[o]... [o]/ os favelad[o] $\mathrm{t}[\tilde{0}]$ acima um um/ naqueles temp[o]... agora [no]

L1 - como assim? eles invadiram depois?

L2 - n[õ]::: naqueles temp[o] n[ũ] tinha maquiNÁri[o] ( )

L1 - ah:: tá na/ no braço

L2 - t[y]d[o] n[o] braç[o]... com ca[r]oça o/ puxar c[a]::na

L1 - como é que fazia por exemplo quando:::

LL3 - queria plantar cana? como é que era? 
cana? como é que era?

L2 - plantar c[a]na? tinha do[j] bu[ro] d[e] a/ às ve[j] [po'nava] tre[j]... [e] com ( ) assim na $\mathrm{m}$ [on]

L1 - tudo na mão né?

L2 - tu::d[o] na m[op]... [e] [e] pl[an]tava c[a]na [e] tinha qu[e] picar... agora... é... do[j] [r]isc[o] [o] trator fa[j] a cada ve[j]

L1 - é

L2 - [e] [e] p[õ] dentr[o] a c[a]na s[e] é direita [e] quas[e] nem pica... [e] tem a máquina d[e] $\mathrm{d}[\mathrm{e}] \mathrm{d}[\mathrm{e}] \mathrm{sco} / \ldots$ naqueles temp[o] no[j] ia caía do [r]isc[o]... ad[y]bar

L1 - ah tá

L2 - pegava a:: uma latona aqui e/ maø qu[e] nem d[y]as que nme lá n[o] [J]cont[õ] qu[e] nem [r]ua daqui na igreja quas[e]... [e] tinha qu[e] ir lá:: depo[j] voltar b[y]scar n[ũ] sac[o] levar lá:: [e] subir aqui/ agora acabou aquela coisa aí... coBRI... cobri ele... cobria [ko] a enxada

LL1 - é

L2 - agora tem é:: [o] trator

LL1 - trator é::

L2 - é

L1 - passava o dia pra fazer um negócio desses

L2 - pe::I[o] amor d[e] ['dio]... agora plantava quas[e] um a[ł]quer por dia

L1 - com as máquinas né?

L2 - com [o] maquinári[o]

L3 - conta como vocês/ que levavam a cana nos $\mathrm{n}$ [o] $\mathrm{n}$ [o] vagão... [o] vagão ia até [o] engenho centra[ł] com[o] que vocês faziam? levar?

LL2 - ah por exempl[o]

LL1 - vocês

levavam no cordão?

L2 - e:: n[õ]:: ti / tinha ca[r]oça qu[ā]d[o] chovia [e] depo[j] tinha os [o] caminh[õ] tamØém qu[e] levava

L3 - ca[r]egava [o] feix[e] na mão... ca[r]egava o caminhão na mão

LL1 - na mão

carregava?

L2 - [e] [e] [o] caminh[õ] naquela época qu[e] era ma[j] a[ł]t[o] e qu[e] levava quatr[o] mil[I] cinc $[0]$ mi $[\nmid] \ldots$ quil[o]

L1 - nossa

L2 - tonelada... e::

LL1 - tonelada né? é

L2 - cinc[o] tonelada [e] meia... O O.:: tu:: $\mathrm{d}[\mathrm{o}] \mathrm{n}[\mathrm{o}]$ feix[e]... aquelas c[a]na os camarada tud[o] qu[e] queimava depo[j] [e]:: [e] ficava aquel/ aquela coisinha assim [e] d[e] ama[r]ar bastava qu[e] $\mathrm{t}[\mathrm{e}]$ ficass[e] [o] feix[e]... você pegava assim entr[e] puxar [per] ver [la] 
ba[ro]ca no p[ra]ino ond[e] vinha [o] caminh[õ] [e] [e] desama[r]ava depo[j] tinha qu[e] ir lá bla::::m t[y]d[o] c[a]na em cima... n[õ] sei com[o] n[õ] fiquem[o] ceg[o]

L1 - pois é porque a cana corta né?

L2 - O:.:.:

L3 - e cai também né?

L1 - cai aquel/

$$
\text { LL2 - É:: }
$$

LL3 - que ela desama[r]a... cai d[e] ponta

$\llcorner L 2$ - [o] feix[e] desama[r]a nos lugar em cima

L3 - a cana cai d[e] ponta assim

L2 - é

L1 - nossa

LL3 - [o] jeit[o] qu[e] ela é cortada

LL2 - agora $\mathrm{n}[0 \tilde{0}]$... agora a ( ) vai vai dentr[o] d[o]:: ['pẽsjo] assim

[o] caminh[õ] vai dentr[o] d/ ['pẽsjo] [e] a est[e]ra... ond[e] era muit[o] ba[r]anc[o] é:: descida... ficou $\mathrm{p}$ [ra]ina... ond[e] [ko] caminh[õ] [no] ia

L3 - agora vai

L2 - os bu[ro] a ca[r]oça [no] ia... ag[o]ra vai... porque entrou trator arar... el[e] el[e] fica te[r]a te[r]en[o] p[ra]ino

L1 - quando que começou mesmo a plantar cana aqui? que ele/

L2 - mi[t] novecent[o]:: [e]::: quarenta:: [e] um quarenta [e] do[j]

L3 - quarenta [e] nov[e] (era)

L2 - ah? [no]:: em cinquanta [e] nov[e] fom[o] lá/

LL3 - não... quaRENta e Nove

L1 - quarenta e nove mais ou menos?

L2 - eu sei dizer qu[e] em mi[ł] novencent[o] quarenta e se[j]

$\llcorner L 1$ - década de quarenta

L2 - fom[o]Ø fom[o]Ø na na usina... em vez qu[e] ir lá $n$ [õ] tinha ninguém em vez qu[e] ir lá eu [ko] ['zon] Vitti daquel/ daquel[e] d[o] bisp[o] eu [o]::: [t fi'keto] ${ }^{308}$

L3 - pai d[o] bisp[o]

L2 - [o] [o] [dzi'd $3 \epsilon]^{309}[0]$ [dzi'dze] em vez qu[e] entrar lá $\mathrm{n}[\mathrm{o}$ [s]critóri[o] e:: lá na na usina

o:: encostad[o] encostad[o]... eu levei tre[j] peda/ tre[j]:: pe/ [fi'eta] ${ }^{310} \mathrm{~d}[\mathrm{e}]$ polenta ((risos))... cheir[o] qu[e] tava merda... ((risos)) el[e] m[e] falo[Ø] "eu vouØ lá [e] cont[o] pr[o] Met[o]" qu[e] porque [o] Met[o] era um hom[e]

L3 - ((risos)) don[o] da usina

$\mathrm{L} 1$ - ah

L2 - [o] do[o] da [y]sina ['koł ka'peł 'dzo ko'si]311 "eu cont[o] pa [o] [o]::" [e] no[j] lá... lá ve/ vei[o] oit[o] hora n[o]v[e] hor[a] dez hora e:: "viu? [la'ga 'vist 'kwela po'leyta] ${ }^{312 ? " ~ a i ́ ~ q u[e] ~ e u ~}$

\footnotetext{
${ }^{308}$ Cichéto, apocorístico de Francisco.

${ }^{309}$ Gìge, apocorístico de Giovani.

${ }^{310}$ Fatia, pedaço.

${ }^{311}$ Com o chapéu abaixado assim.
} 
diss[e] "eles comeram eles" aí depo[j] vei[o] um lá falou "[o] qu[e] é qu[e] voce[j] tão fazend[o] aqui?" "esper[an]d[o] d[e] ir [r]eceber"

L1 - é

L2 - "FAZ temp[o] vão LÁ qu[e] [r]eceb[e]"

L1 - ah por causa da polenta ficou com medo e não foi?

LL2 - n[õ]::.... n[õ] porque no[j] eles no/ a/

e::

L3 - tinha vergonha

L1 -vergonha

LL2 - d[o] dos... vergonha também

L1 - é

L2 - [e] tinha med[o] d[e] ir lá falar "viu::: com[o] é qu[e] fa[j]?" [o] ['omo] lá... (dinheiro)

L1 - ah::: tá

LL3 - eles não quiseram ( )

LL2 - aí eles dava dava [o] pagament[o] em

dinheir[o] porque era po:::c[o]... d[y]zent[o] [e] trinta... $d[e]$ [a]n[o] tivem[o] primeir[o] [a]n[o] d[y]zent[o] [e] trinta [e] oit[o] tonela:da

L1 - quanto deu de dinheiro?

L2 - é:: dá::: e:: ach[o] qu[e] uns d[€j] doz[e] [r]ea[j]

LL3 - ond[e] vocês [po'nava] [o]

dinheir[o]?

L1 - meu Deus

LL2 - cont[o]

L3 - ond[e] ocê [po'nava] [o] dinheir[o] pra trazer em casa?

L2 - dentr[o] d[e] envel[o]p[e]

L3 - n[ũ] deram um saco pra trazer $n[0]$ saco?

LL2 - pegava um envel[o]p[e]... AH?

L3 - lembra qu[e] tinha g[en]t[e] qu[e] trazia $\mathrm{n}[\mathrm{o}] \mathrm{sac}[\mathrm{o}]$ ?

LL2 - n[o] caminhonet[e] $\mathrm{n}[\mathrm{o}]$ caminhonet[e] e::: d[e] pé no[j] ia... aquel[e] $d[o]$ manguerinha el[e] vinha [ko] sac[o] el[e] ia lá era $t[y] d[o] ~ n[o] t a$ $\mathrm{d}[\mathrm{e}] \operatorname{cinc}[\mathrm{o}] \mathrm{d}[\epsilon \mathrm{j}] \mathrm{d}[\mathrm{e}]:$ : vint[I]

L1 - é

L2 - d[e] cinquenta $n[0 \tilde{]}]$ sei s[e] tinha

L1 - é

L2 - [e] ele vinha [ko] sac[o] po/ pagar a venda aí el[e] [po'nava] [o] sac[o] enqu[an]t[o] el[e] fazia conta o G.... era um hom[e] séri[o]... el[e] fazia conta "é t[an]t[o]" el[e] ia lá ((risos)) qu[e] tirava [o] dinheir[o] um ( )

LL3 - dum saco

LL2 - tud[o] empacotad[o]

L1 - ah é?

${ }^{312}$ Você viu aquela polenta? 
L2 - é... tirava [o] dinheir[o] vinha... no[j] tinha um moinh[o] lá

L1 - ahn

L2 - el[e] vinha pagar el[e] el[e] é "quant[o] é?" "t[an] t[o]" el[e] n[õ] fazia assim

naquela época

LL1 - é

L2 - ['no] era... el[e] pegava tirava um pacotinh[o] assim $t[y] d[o]$ eu ach[o] qu[e] era t[y]d[o]

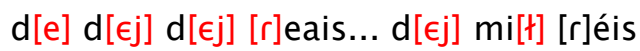

$\llcorner L 3$ - naquela época eles... eles pagava[Ø] por ano

L1 - ah tá

L2 - n[ũ] tinha inflação né?

LL2 - é

L3 - pagava uma vez por ano

L1 - uma vez por ano vocês recebiam?

LL2 - uma vez por [a]n[o]

LL3 - é::

L1 - nossa... trabalhava ano todo ali

$$
\text { LL2 - é }
$$

L3 - só qu[e] vinha [o] pacot[e] tod[o]... assim se guardava

L2 - [e] ag[o]ra ag[o]ra ficou ma[j] fáci[ł] viu? eles d[õ] uma qu[ạ]tia pra empreita [e] um pouc[o] pra pra manter a família

L1 - é

L2 - é... e e:.: depo[j] vei[o] acab[ạ]d[o] a safra... comparaç[õ] qu[e] acaba novembr[o]... eles começa dezembr[o] a dar um pouc[o]... janeir[o] até até esses dia... essa u[ł]tima ve[j] eles der[o] por tonelada

L1 - nossa

L2 - quarenta centav[o] ((L3 tenta falar algo)) Øpera aí... iss[o] é negóci[o] de pi[Ø]otag[e] ((risos))

L1 - é 
4C.S0 - J.D.

L1 - o senhor ia muito pra São Paulo ou não?

L2 - antiga/ quand[o] era moç[o] eu tinha uma::: uma é:: uma tia... irmã E. ela trabalhava na na s[an]ta casa d[e] misericórdia

L1 - hum hum

L2 - ent[õ] eu ia muitas vezes visitar... então eu chegava lá:: e:: conversava passava um $\varnothing$ do[j]Ø três dia lá e depo[j] vo[ł]tava... depois é::: eu eu f[y]i é:: tinha uma tia tamØém lá em taubaté um dia/ porqu[e] qu[an]d[o] ela vinha fazer [o] [r]etir[o] vinha aqui em itú então nós aqui aproveitam[o] pra ir ma[j] per[o] qui d[e] [i'ty] né? então fomos lá pra visitá-la... então eu eu não sei [o] qu[e] ela achou d[e] mim ela me convidou pra ir trabalhar lá na na $\mathrm{n}[\mathrm{o}] \mathrm{n}[\mathrm{o}]$ hospita[ł] ond[e] ela trabalhava ond[e] qu[e] ela trabalhava eu fa/ falei "tá bom eu vo"... aí fui lá... maØ justament[e] no primeir[o] dia ela estava fazendo um c[y]rativ[o] em $\mathrm{d}[\mathrm{y}]$ as moça qu[e] elas trabalhava n[y]ma:: numa fábrica... e o: a polia pegou os cabelos dela e a[r]ancou $t[y] d[o]$ ficou... ficou uma ferida só 
L1 - nossa

L2 - aí e:: ((risos)) não gostei muit[o] d[e] ficar lá né? então aí pert[o] tinha [o]::: [o]:: ginási[o] sant[o] Antoni[o] colégi[o] sant[o] Antoni[o] era:: de a/ de alunos externos [e] ela falou "cê quer ir lá:: é::tomar conta dos al[y]nos?" "ah eu vo"... foi lá qu[e] [o] padr[e] é:: é:: J. C. aquel[e] queria la é:: el[e] me aceitou [e] fiquei lá cinc[o] meses é:: e:: tom[aク]d[o] conta dos al[y]n[o]... depois eu enjoei falei "ah... tsc... vou vo[ł]tar pra casa porque a minha:: a minha minha vocação $n[0 \tilde{]}$ é essa... a minha vocação é trabalhar na [r]oça" [e] $\mathrm{m}[\mathrm{e}]$... eu $\mathrm{m}[\mathrm{e}]$ acost[y]mei/ [e] $\mathrm{m}[\mathrm{e}]$ e[o]:: achei qu[e] tava [r]ealizado trabalh[ay]d[o] na [r]oça

L1 - ah é que::: o senhor sempre trabalhou na roça né?

L2 - sempr[e] trabalhei a:: única cois / a::: [o] qu[e] eu fiz d[e] coisa é qu[e] é:: foi lá... saí saí esses tempos aí e:: e:: depo[j] vo[ł]tei

L1 - o senhor foi do seminário

L2 - eu fui n[o] seminári[o] em [r]i[o] clar[o]... é:: fiquei:: dois anos lá... depo[j] m[e] mandar[o] embora eu tava doent[e]... depo[j] eu $m[e]$ c[y]rei eu peguei/ m[e] $m[e]$ [r]eceberam ma[j] fiquei apenas vint[e] dia... n[õ] quis mais saber $d[e]$ ficar... aí vo[ł]tei $\mathrm{ma}[\mathrm{j}] \mathrm{n}$ [õ] $\mathrm{m}[\mathrm{e}$ ] conformava... eu queria ser padr[e] aí [o]::: zi/ [o] vigári[o] a ['zia] Maria aqui [e] [o] vigári[o] era [o] [o] monsenhor G. G. eles me a[r]umaram n[o] seminário lá em campinas ah... ah... deixa desligar iss[o] aqui qu[e] ((ajusta o aparelho para audição))... $m[e]:: m[e]$ aj[y]daram e eu f[y]i lá... fiquei ma[j] dois an[o] lá... eu falei é:: quand[o] cheguei/ porque tinha feit[o] dois an[o] em [r]i[o] claro[o] [e] depo[j] mais dois... em campinas $\mathrm{n}[\mathrm{o}] . .$. ((ruído)) aí... eu ia passar pr[o]:: qu[e] qu[e] naquel[e] temp[o] vestia a batina

L1 - aham

L2 - eu ia fa/ vestia a batina... [e] daí pra frent[e] eu ia:: começar est[y]dar filosofia

L1 - é?

L2 - eu falei "agora vou me"/ porque entrava saía entrava saía... falei "ago::ra e:: to [r]eso[ł]vid[o] a ir"... [o] diretor espiritua[ł] falou pra mim "você não pod[e] ficar padr[e]"... aí peguei [e] vim embora

L1 - e casou muito depois ou não?

L2 - ah?

L1 - o senhor se casou muito depois desse tempo ou não?

L2 - é::: ach[o] qu[e]... ess[e] é... quand[o] saí eu... AH É quand[o] eu saí eu tinha mais ou men[o] $\varnothing$ vint[i] [e] um an[o]... depois casei com vint[e] [e] set[e]

L3 - vint[e] [e] set[e]

L1 - o senhor casou tarde pelos padrões da época aqui né?

L2 - é

L1 - porque a turma casava muito cedo aqui

L2 - vint[e] [e] set[e] an[o] eu tinha

L1 - é... o senhor nasceu quando?

L2 - ãh?

L1 - quando o senhor nasceu? 
L2 - mi[ł] novescentos [e] vint[I] um

L1 - vinte e um?

L2 - dia set[e] d[e] j[y]lh[o]

L1 - aham

L2 - mi[t] novescentos [e] vint[e] um

L1 - onde o senhor morava?

L2 - ãh? aqui

L1 - nesta casa?

L2 - só qu[e] era uma casa velha né? é:: essa casa aqui essa casa aqui f[y]i eu qu[e] fiz... eu [e] os

LL3 - de[r]ubou a casa velha [e] fez $\mathrm{n}[\mathrm{o}]$ mesm[o] lugar

L1 - ah fez no mesmo lugar?

L2 - eu nasci pra lá d[o] cois[o] d[o] [r]ibeirão aí

L1 - ah do ribeirão? Como é que era a casa?

L2 - uma casa d[e] pau a piqu[e] é:: [r]ebocad[o] com ba[r]ot[e]

L1 - ah::

L2 - ba[r]ote... é uma casa qu[e]::: diziam... qu[e] era era:: dos escravos... morava escrav[o] aí

L1 - ah já tinha ela aqui?

L2 - é:: porque aqui era uma fazenda né?

L1 - é

L2 - e::: qu[an]d[o] eles vieram aqui eles... tinha casa... casa $\mathrm{d}[\mathrm{o}]:: \mathrm{d}[\mathrm{o}] \mathrm{d}[\mathrm{o}]$ fazendeir[o]... tinha a casa das máquinas e:: ((tosse)) ti/ até tinha uma:: um encanament[o] d[e] água qu[e] el[e] vinha/ aquel[e] qu[e] vinha aí na gr[y]ta... só qu[e] el[e] vinha $\mathrm{n}[\mathrm{y}] \mathrm{m}$ can[o]... qu[e] aí n[o] mei[o] d[o] te[r]en[o] tinha uma uma:: uma caixa d'água

L1 - hum hum

L2 - tinha um can[o] virad[o] assim qu[e] qu[e]:: jogava água ( ) da caixa ((tosse))

L3 - tod[o] mund[o] lavava [r]oupa junt[o]

L1 - é? todo mundo lavava roupa junto né?

L2 - u::ff

L3 - tinha:: tinha a bica no[j] falava... bica grand[e] [e] a:: [e] [o] [fõta'nєł] pa [r]epas/ pa [r]e/ pa enxaguár né?... [resen'tar le 'robe] ${ }^{313}$ ((risos))

L1 - e e como é que era::: nauele tempo a vida aqui? só: tinha muito mato? como é que era?

L2 - $\mathrm{n}[\mathrm{o}]$ [o] mat[o] é mais ou men[o]... quase tem ma[j] mat[o] agora d[o] qu[e]:::

L1 - do que antes?

L2 - d[o] qu[e] naquel[e] temp[o]... (o meu)

LL1 - vocês plantaram árvores?

L2 - meu pai... el[e] falou qu[e] quand[o] e eles vieram aqui... daqui até::: lá [o]:: falam [o]:: [o] Borguinha né? falam Borguinha... é:: é t[y]d[o] mat[o]... diz cê podia co[r]er n[o] mei[o]

${ }^{313}$ Enxaguar as roupas. 
$\mathrm{d}[\mathrm{o}]$ mat[o] [ge] era $\mathrm{t}[\mathrm{y}] \mathrm{d}[\mathrm{o}]$ limp[o] bonit[o] $\mathrm{t}[\mathrm{y}] \mathrm{d}[\mathrm{o}]$ ag[o]ra... só qu[e] depo[j] tinha invernada... é é:: aí [o]:: [o]::.... depois de[r]ubar[o] [e] começaram a plantar e::: ficou com[o] qu[e] tá agora

L1 - mas essas árvores que estão por aí muita gente então plantou árvore depois?

L2 - [no] é viu? essa é e/ tud[o] ja/ essa::: e/ essas árvore qu[e] tem aqui é quas[e] t[y]d[o]:: jambeir[o]... meu pai el[e] tinha aí num bar/ num bai[ro] aqui chamad[o] glória L1 - ahn

L2 - ele pegou d[y]as planta... pé $\mathrm{d}[\mathrm{e}]$ jambeir[o] [e] plantou:: $\mathrm{d}[\mathrm{o}]$ lad[o] $\mathrm{d}[\mathrm{e}]$ lá... aí pra lá... [e] dessas d[y]as plant[a] foi s[e] espa[r]amand[o] n[ũ] sei com[o]

L2 - começo[Ø] a nascer aqui a lá LL3 - ( )

L1 - ah:: tá

LL3 - lá pra aqueles lad[o] lá tem bastant[e] qualidad[e] né?

L1 - ah tá

டL2 - a maioria é jambeir[o] [ge] tem aqui

L1 - ah:: tá (depois você que fala)

L3 - [no no] ((risos))

L1 - no::: no caso aqui quando fazia::: é::: por exemplo... as festas aqui onde que era feito? aqui ou mais em Santana?

L2 - [las] festa?

L1 - é

L2 - ah:: ca/ as festa tinha festa $\mathrm{d}[\mathrm{e}] \mathrm{d}[\mathrm{e}]::$ daqui... [e] a festa $\mathrm{d}[\mathrm{e}]$ santana

L1 - porque muita gente de Santana falou "ah eu ia pro Banco nos bailes"

L2 - é::: per/ i[o]:: [o]:: cas[o] é iss[o]/ é qu[e]::: [r]eparam muit[o]... qu[e] quand[o] [o]/ vei[o] vei[o] da/ vem um da cidad[e] passa em santana lá pelas seis horas da tard[e] né?... não tem ninguém

L1 - hum hum

L2 - [e] aqui... até ess/ oit[o] dez hora d[e] noit[e] tá chei[o]:: [o]:::

L1 - a praça

L2 - a praça tá cheia

L1 - é

L2 - d[e] mod[o] qu[e] era:: tem muita diferença... aqueles $d[e]$ lá... d[e] santana... eles tão muit[o]... são muit[o] caseir[o]

L1 - é

L2 - [e] esses aqui... em vez é mais abert[o] ((risos)) 
5C.SO - F.C.D.

L1 - como é que eles perguntaram?

L2 - perg[y]ntaram "['kosa 'ke 'lej 'załd kom'en ko'd’j]] 314 ?"

L1 - ah

L2 - ['ki 'ke 'lej ko'd’j] ${ }^{315 ?}$

L1 - não é a:: fruta o:: marmelo?

L2 - marmel[o]

L1 - "amarelo que nem um marmelo"

${ }^{314} \mathrm{O}$ que significa 'amarelo como um marmelo'?

${ }^{315} \mathrm{O}$ que significa codoign $<$ marmelo $>$ ? Do mesmo modo que na pergunta anterior, o entrevistado pergunta em dialeto trentino o significado de uma palavra do próprio dialeto. Utilizou o dialeto conosco por saber que o dominamos, mas perguntou o que significava codòign para testar nosso conhecimento, por se tratar de uma palavra pouco conhecida entre os tiroleses de Piracicaba. 


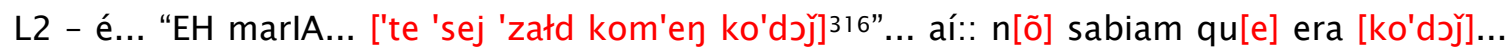
"é muit[o] fáci[t]"... é amarel[o]:: e:: veja bem [k]a diferença... em port[y]guês é marmel[o] né?

L1 - é

L2 - agora... porque::: [i 'parla dia'leto lej]317 "marmel[e]"

L1 - ah eles falavam marmel[e]?

L2 - marmel[e]

L1 - ah:: mas o certo é [ko'd’ǰ]?

L2 - [ko'doj]

L1 - e tem muita gente que não sabe o que é [ko'd’j] aqui

L2 - então

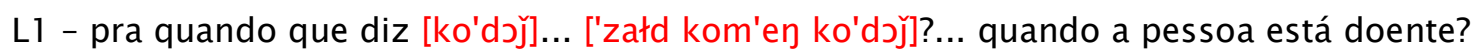

L2 - é porque [o]::: marmel[o] el[e] é a fr[y]ta ama/ amarela meØmo né?... qu[a]nd[o] tá bem mad[y]ra... tinha aqui... meu pai tinha uns tre[j] quatr[o] pé lá em baixo

L1 - ah é?

L2 - morava lá em baixo ali e::: ( ) ele falava "[ø]:: ['ke 'boj ko'dəñ] ${ }^{318 " \ldots}$ é::: aprend[e] $\mathrm{d}[\mathrm{e}]$ criança né?

L1 - é/ onde que o senhor morava?

L2 - ali

L1 - ali pra baixo ali

L2 - n[õ] tem uma casinha Øli em baixo?

L1 - sim

L2 - tem a a:: piscina

L1 - é

L2 - atra[j] tem uma casa maø é ali é uma casa d[e] ba[r]ot[e] ali... anTIga anTIga [an'kora 'dele] qu[a]nd[o] ia comprar fazenda ['ke 'era 'sta 'ka 'de ba'rote e 'me 'pare 'lej ve'sy a 'star 'li] 319

L1 - ah::

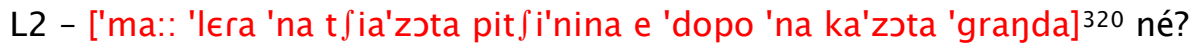

L1 - ahã

L2 - ['ma: 'Iera 'na 'roba 'bela... 'era: sin'kwanta 'metri a'la 'kaza] era uma cachoeira [co'zi 'varda] 321

L1 - ah uma::

L2 - ['no e ge'dis] cachueira [e: ge'dis] 322

\footnotetext{
${ }^{316}$ Nossa Senhora! Você está amarelo (doente) como um marmelo!

${ }^{317}$ (porque) eles falam dialeto é marmele. Trata-se de uma alusão à forma trentinizada marmele, que, segundo o informante, também ocorre entre os falantes do dialeto trentino da comunidade.

${ }^{318} \mathrm{Oh}$, que bonitos marmelos!

${ }^{319}$ Que havia esta casa feita de taipa e meu pai veio morar ali.

${ }^{320}$ Mas era uma casinha pequena e depois (quando ampliada) ficou grande.

${ }^{321}$ Mas era uma coisa bonita, há cinqüenta metros da casa havia uma cachoeira assim, olha (demonstra com gestos a altura da cascata).

322 Não se diz "cachoeira", o correto é...
} 
L1 - [na 'røza $]^{323}$

L2 - é

LL1 - que eles falam

LL2 - [la 'røza 'propi] $]^{324}$

L1 - é

L2 - "['or 'ge 'ven 'zo la 'røza] 325 "

L1 - ah sei... e era de dois andares a casa?

L2 - [no'no... 'ka de ba'rote de/ de: ba'rote ko'zi en'fet de 'baro] ${ }^{326}$

L1 - de pau a pique? pau a pique que fala?

LL2 - ma[j] ou men[o] pau a piqu[e]

L1 - ah::: era grande?

L2 - ['kwando 'me 'pare 'Iej 've'ny a 'star 'li 'lera a'veva 'kwatro kwar'tini ${ }^{327}$

L1 - é

L2 - ['ke 'lera la 'kaza de ka'rero... ka'rero] ${ }^{328}$ da fazenda né?

L1 - ah::

L2 - [de 'prim pa'trõ ke'g€] ${ }^{329}$

L1 - ahã

L2 - era negr[o]... ['Iera 'dent a'li] 330

L1 - dos escravos ali?

L2 - ['temp de 'skravi 'nkora... 'ge 'bøj erã'tõ s'teva 'li 'Eł ka'rego e 'dop] ia comprar la fazenda [e] [i: st $\int i$ 'avi $\epsilon$ 'nadi 'tyt ĩ'bora] ${ }^{331}$ né?

L1 - ahã

L2 - [e 'me 'pare 'mio $\in$ 'sta 'li tyt 'kwatro kwar'tini e: pi'an pia'nin pi'an pia'nin 'le se a:... a 'fat 'trop 'bela] ${ }^{332}$ né?

L1 - ahã... aí foi melhorando?

L2 - é melhorand[o] e::: depo[j]... a coisa que/ melhorOU... aí eu:: Øventei d[e] fazer a casa ma[j] pra cima Øqui né?

L1 - hum hum... faz tempo que o senhor mora aqui ou não?

L2 - ah ja fazem mais ou men[o] cinqüenta/ quarenta e cinc[o] an[o]

L1 - quarenta e cinco anos?... e dos seus nove filhos todos moram por aqui? tem aquele que está de/ de Brasília né?

$$
\text { L2 - tem do[j] em Brasília t[ẽ] um em S[a]o Paulo lá na Moóca }
$$

\footnotetext{
${ }^{323}$ Rösa significa, exatamente, pequena cascata, mas também pode ter o sentido de uma fonte natural d'água.

${ }^{324}$ Exatamente, uma cachoeira.

${ }^{325}$ Veja como desce a água da cachoeira!

${ }^{326}$ Não, não. Casa de barro, feita de barro (taipa).

${ }^{327}$ Quando meu pai se mudou para aquela casa, havia nela quatro quartinhos.

${ }^{328}$ Era a casa dos carreiros (puxadores de carro de boi), carreiros da fazenda, né?

${ }^{329}$ Do primeiro patrão que havia.

${ }^{330}$ Era ali dentro.

${ }^{331}$ Era ainda no tempo dos escravos... Havia bois ali que foram levados e depois ia comprar a fazenda e os escravos foram todos embora.

${ }^{332} \mathrm{E}$ meu pai meu ficou ali com os quatro quartos e devagar, devagarzinho, ia reformando a casa e deixando-a mais bonita.
} 
L1 - ah na Moóca?

L2 - é... e tem um aqui na Santa Teresinha

L1 - hum hum

L2 - o outr[o]... [o] outr[o] mora aqui ó... esquerda da oficina aí

L1 - ah ele que é dono?

L2 - é

L1 - ah tá... dos seus irmãos quantos são vivos hoje? é:: tem o senhor a R.

L2 - do[j]

L1 - depois tem

LL2 - C. [e] [o] F.

L1 - ah:: a C. e o F.... o F. é o caçula?

L2 - caç[y]la

L1 - ah tá... a sua esposa é da segunda geração porque ela é irmã da A. né?

L2 - é... ['ela la $\in$ fi'øla deł] F. [ke] F. ['Iera 'fi'øł deł] F.333

L1 - hum

L2 - ['porki] né? ((risos))

L1 - (risos)) ah dos Forti

LL2 - ['frãsele... 'ej di'zeva 'frãsele 'kweł 'temp] ${ }^{334}$

L1 - ['frãsele] né? é:::

L2 - ['frãsele] é [fran'tfesko] né?

L1 - é:: [fran'tfesko]... e dos Forti aqui né? do núcleo deles aqui em cima né? os Forti que estão aqui em cima... da $M$. né?

L2 - é:: aqui na frent[e] da escola aqui... log[o] depo[j] da escola aí

L1 - ah tá... era diferente aqui tudo antigamente não era?

L2 - IH:: pel[o] amor d[e] Deus

L1 - era muito mato?

L2 - nO:ssa senhora

L1 - ah é?

L2 - ia contar... precisa fazer um livr[o] mas é... saber escrever bem direitinh[o] pa ver qu[e] qu[e]... tÁ: na cabeça tem t[y]d[o] maØ pa tirar é difíc[I] né?

L1 - é

L2 - [per i mate'loti te/ na mata'ria] ${ }^{335}$

L1 - é?

L2 - ['ke 'si 'soł 'mi... sĩ'kwanta kª'a'ranta 'sĩki pe de ka'fe 'ke 'єra... 'kwando i'a: kom'prati... e 'sĩk'e 'kaze de ba'rote] ${ }^{336} \ldots$ só iss[o] aí

L1 - só isso que tinha?

\footnotetext{
${ }^{333}$ Ela é filha de F. que era filho de F.

${ }^{334}$ Franzele, eles diziam assim naquele tempo.

${ }^{335}$ Para as crianças / criançada.

${ }^{336}$ Que se sei bem eram cinqüenta, quarenta e cinco pés de café que havia quando eles (os tiroleses) compraram (a fazenda Santa Olímpia) e cinco casas de barrote (taipa).
} 
L2 - só iss[o]... ['ma 'de ba'rote 'nõ 'de: de ti'zoj no... de ba'rıta de:... faz si 'kole:: 'kəza si 'kole ko ( ) 'baro] ${ }^{337}$ dá uma [r]ebocada mais ou men[o] né?

L1 - hã

L2 - [e] d[e] ( ) né?

L1 - ah quando vocês chegaram que comprou aqui

L2 - quando meu pai chegou

L1 - ah é? o senhor nasceu aqui né?

L2 -eu nasci aqui

L1 - eles ficaram primeiro lá na na/ em campinas né?

L2 - tinha [o]:: [o] meu pai não... agora [o] [o]::: pai da minha mãe sim... [o] Correr

L1 - hum hum

L2 - [Ø]cê viu ach[o] [o] cois[o] Correr

L1 - ele era o Jacob? o Jacó Correr?

L2 - Jacó

L1 - a mãe dela então era a Pompermayer a Rosa a::

LL2 - Pompermayer é

L1 - ah::: tá

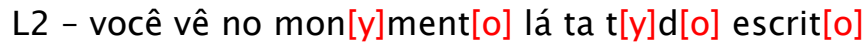

L1 - sim os patriarcas... os Degasperi que vieram depois né? porque como é que é? ele passou/ primeiro ele foi pra Argentina?

L1 - mas ele foi direto do Tirol pra Argentina?

L2 - pra argentina diret[o]... eu ach[o] qu[e] vieram assim... vinha/ às vez sem destin[o]... tem vontad[e] d[e]... porque [eł 'pare me keł vo'leva de ve'nir soł]338

L1 - é::

L2 - [€ 'na sto'ria da kun'tar 'anka 'li ( ) ]339... qu[e] [o] meu pai el[e] tinha dezesset[e] anoØ... agora é/o::: [o] irm[õ] del[e] o:: segund[o] irm[õ] del[e] el[e] el/ é:: [o]:: T. qu[e] era pequeninh[o] baixinh[o] ['k ${ }^{\mathrm{w}} \mathrm{e} \mathrm{H}^{\prime}$ noł se ' $\epsilon$ mari'da ' $\left.\epsilon \nmid\right]{ }^{340}$ [e] outr[o] é um grand[õ] ((risos)) n[õ] [grant] um diØ el[e] contava sempre né? ['me 'pare 'Iera 'na sta'tyra majzo'men] d[e] um metr[o] [se'tanta 'sĩk'e ma 'kweł eł ga'veva en 'metro e no'vanta 'sĩk ${ }^{w}$ e] ${ }^{341}$

L1 - nossa

L2 - ['era 'ałt] TE:ria a servir [o] govern[o]

L1 - ah::

L2 - ['sta 'tre 'ani 'deyt ko/ kõ dzan'dar ge di'zeva] ${ }^{342}$ né?

L1 - do império né?

\footnotetext{
${ }^{337}$ Mas de barro, não de tijolo (trent. matón) não. Feita de barro. Faz assim com o barro e dá-se uma rebocada mais ou menos, né?

${ }^{338} \mathrm{O}$ meu pai que quis vir (emigrar) sozinho.

339 É uma história para se contar também ali ( ).

${ }^{340}$ Ele não se casou.

${ }^{341}$ Meu pai era de uma estatura mais ou menos de um metro e setenta e cinco, mas aquele ele tinha um metro e noventa e cinco.

${ }^{342}$ Estava havia três anos ali, servindo o exército (austríaco).
} 
L2 - é... ficou três anoØ lá ma[j] quand[o] el[e] voltou el[e] não era mais aquel[e] qu[e]:: qu[e] saiu né? e [o] meu avô era um/ [o] meu pai contava era homem [r]eligios[o] católic[o] [nõ (vo'leva sa'ver) de 'tante ma'terie] ${ }^{343}$ não e:: [ve'veva ke 'kw ela 'kweł 'zenio.. 'brut ( ) kel'єł por'tava dał 'koro... b baste'mava... tyt 'kwele 'robe li] né? [la'a mpa'ra tyt tyt... per'ke $\epsilon$ 'na 'roba ke ne'anka oko'reva 'me 'digo] ${ }^{344}$ L1 - hum hum

\section{AneXo 3. CONTEXTo Linguístico ALPINO}

\subsection{INTRODUÇ̃̃o}

Para compreendermos a realidade linguística na qual o dialeto trentino está inserido, é preciso tratarmos inicialmente dos principais idiomas e grupos dialetais que ocorrem na região do Tirol Histórico. Por se localizar numa área alpina, o fator geográfico é também

\footnotetext{
${ }^{343}$ Não queria saber de brincadeiras não.

${ }^{344}$ Vivia com aquela amargura no coração e com aquele gênio ruim; blasfemava e dizia todas aquelas coisas (ruins) né? Aprendeu tudo ali (servindo o exército), porque é uma coisa que, acho eu, nem havia (na família).
} 
relevante e, muitas vezes, decisivo para determinar os confins linguísticos entre os diferentes idiomas e dialetos.

Para ilustração, apresentamos um trecho da estória da raposa e do corvo (Esopo), traduzidos para alguns idiomas alpinos e dialetos aqui tratados. $\mathrm{O}$ mesmo trecho foi utilizado por GROSS et alii (1996) e por VIARO (2001). Iniciamos com a versão latina, utilizada por VIDESSOT (2002) $)^{345}$ :

Vulpes ex more suo fame vexata corvum frustrum casei in rostro tenentem videt. "Id mihi bene saperet!" secum cogitavit et corvum vocavit: "Quam pulcher es! Si cantus tuus tam pulcher est quam adspectus tuus, non dubium est te pulcherrimum omnium esse”.

TRADUÇÃO ${ }^{346}$ : A raposa estava novamente com fome. Eis que ela viu num pinheiro um corvo que tinha um pedaço de queijo em seu bico. 'Isso me saberia bom', pensou ela, e clamou ao corvo: 'Que belo pássaro que és! Se teu canto fosse tão belo quanto tua aparência, serias o mais belo de todos'.

\footnotetext{
${ }^{345}$ Tradução latina de Dr. Wolfgang Kofler (Universität Innsbruck).

346 Tradução utilizada em VIARO (2001).
} 


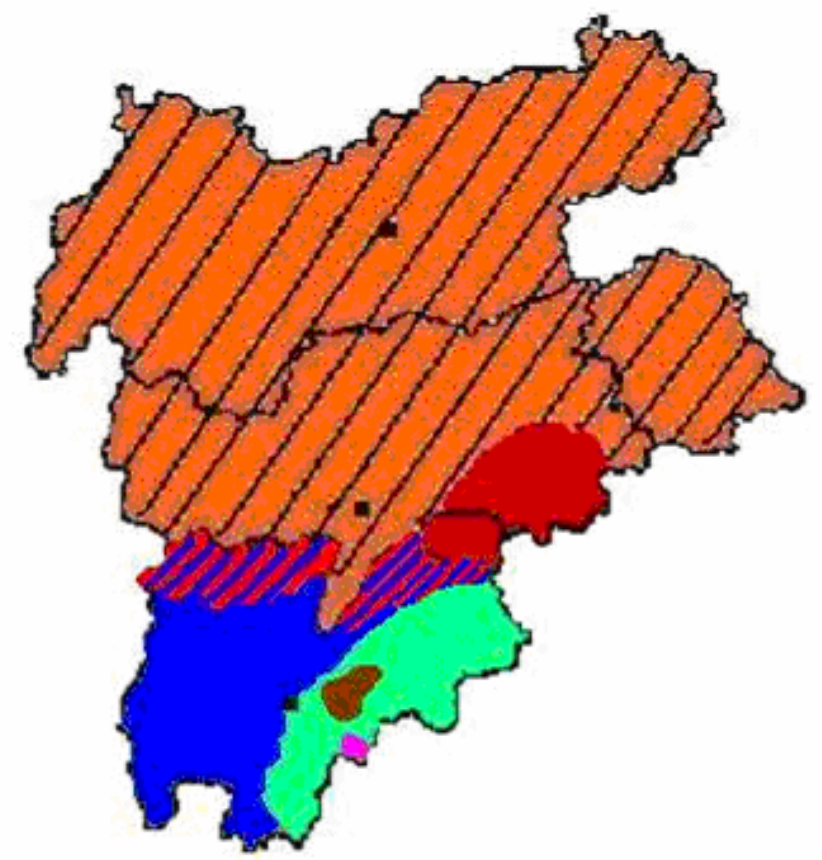

GRUPO ALEMÄO

ALTO ALEMÄO (HOCHDEUTSCH) GRUPO BÁVARO (SÜDBAIRISCH)

Z/Z TIROLERISCH (TIROLÊS)

BERSNTOLERISCH (MÒCHENO)

ZIMBARN (ZIMBERISCH / CIMBRO)
GRUPO ITALIANO

GALO-ITÁLICO LOMBARDO ORIENTAL

TRENTINO OCIDENTAL

VÊNETO

TRENTINO ORIENTAL
GRUPO LADINO

LADINO (LADIN)

ÁREAS DE TRANSIÇÄO (ANFIZONE)

LADINO TRENTINIZADO

Mapa 12: Os grupos linguísticos na região do Tirol histórico ${ }^{347}$.

\subsection{LÍNGUAS E DIALETOS ROMÂNICOS DA REGIÃO TRENTINA}

As semelhanças entre os dialetos setentrionais italianos e entre estes e os falares retorromânicos não são suficientes para uma afirmação de que no passado houvesse alguma unidade linguística que abrangesse toda a região alpina desde a França através da região sul da Suíça até a Ístria.

\footnotetext{
${ }^{347}$ MAPA: nosso.
} 
Analisando, por exemplo, os falares retorromânicos, percebe-se que são semelhantes em alguns aspectos e diferentes em outros, e mesmo as semelhanças existentes não são suficientes para uma afirmação de que houvesse no passado uma unidade linguística desse grupo (se é que se trata de um único grupo). Quando comparados com os dialetos setentrionais italianos, os falares retorromânicos apresentam várias características comuns, de forma que muitos fatores fonéticos, lexicais e morfossintáticos não são exclusivos do grupo, como o plural sigmático, que também aparecia no lombardo antigo e, por consequência, no trentino antigo.

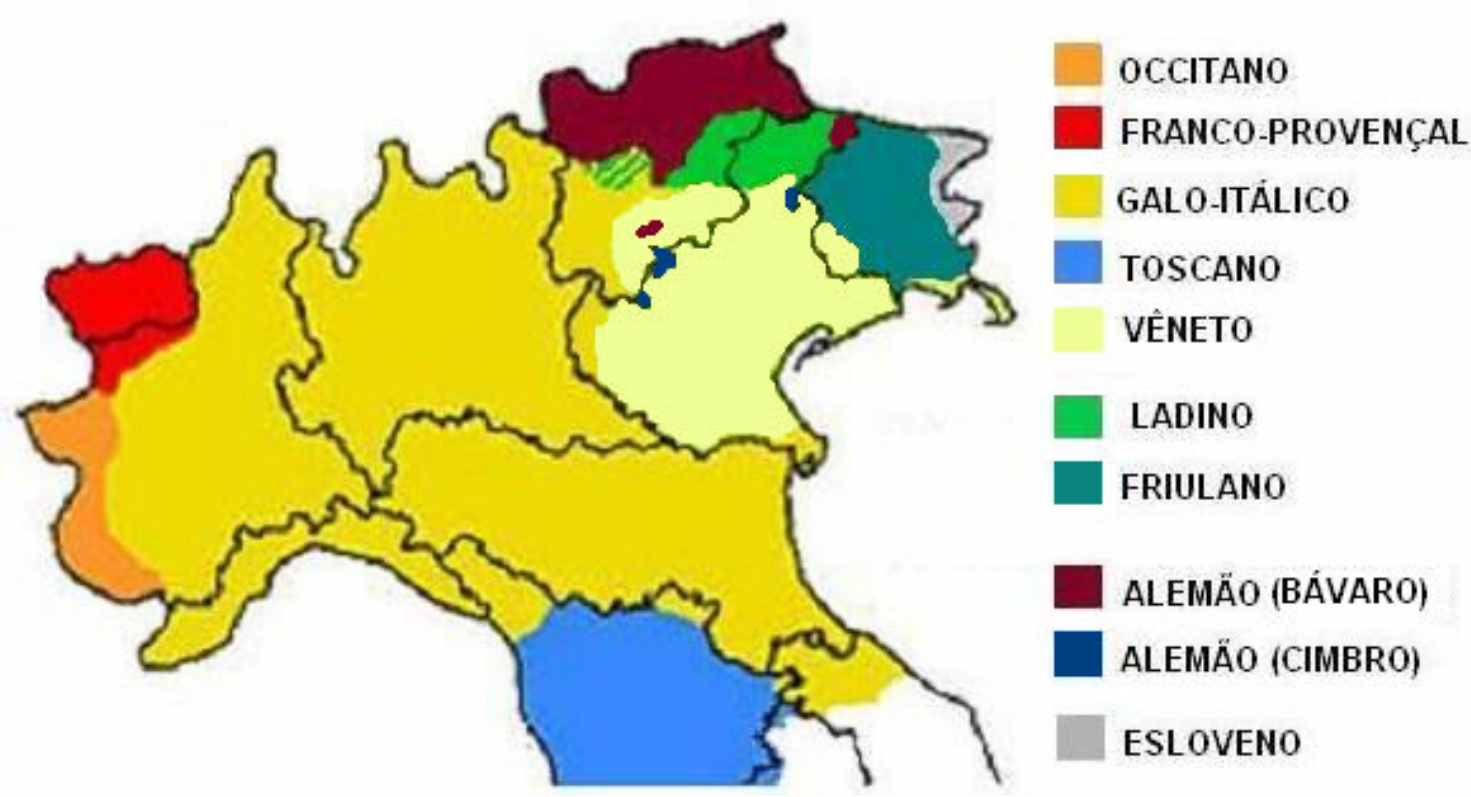

Mapa 13: Os grupos linguísticos e dialetais no norte da Itália ${ }^{348}$.

Um defensor da identidade linguística das "minorias" alpinas foi o renomado lingüista goriziano Graziadio Isaia ASCOLI (1829 - 1907), representada, sobretudo, em seus Saggi Ladini (“Ensaios ladinos”) publicados em $1873^{349}$.

\footnotetext{
${ }^{348}$ MAPA: www.grupotirol.com/dialetti

349 Ascoli foi o principal responsável pela idéia de uma "unidade linguística" do ladino, do romanche e do friulano; apesar de não provar lingüisticamente essa unidade (por conta dos diferentes substratos e superstratos linguísticos), foi importante para diferenciar esses grupos dos dialetos italianos. No caso europeu, com sua facetada história e as realidades de comunidades isoladas formadas, sobretudo, do sistema feudatário medieval, a classificação dos dialetos é muitas vezes complicada por conta dos nacionalismos e aspectos históricos.
} 
Segundo Viaro (2001), o mais razoável, do ponto de vista científico, é que se trata de grupos linguísticos independentes e que representam três sobrevivências isoladas. Ainda que o grupo ladino fora outrora muito maior do que é hoje, não é possível afirmar categoricamente a existência da unidade que ASCOLI defendia em seus ensaios. VIARO (2001, 60 - 62) apresenta algumas hipóteses sobre as origens dessa realidade dialetal tão diversa na região alpina:

a) A hipótese monogenética de oposição binária, ou seja, aquela que opõe dois blocos homogêneos (grupo retorromânico e italiano setentrional). Desse modo, a área da língua que VIARO chamou de "proto-retorromânico" era contínua e convivia com os falares italianos setentrionais que, por semelhança, reuniam-se num "proto-galo-itálico" que não se confundia com o "proto-retorromânico".

b) A área do "proto-retorromânico" fora contínua e convivia com a área dos dialetos setentrionais, que jamais formaram um grupo uniforme, e aquele não se confundia com estes. Assim, o "proto-retorromânico" não estava ao lado do "proto-galo-itálico", mas do "proto-lombardo" ou do "proto-vêneto" etc, evoluções naturais que surgiram na área alpina. Trata-se da hipótese monogenética de oposição múltipla defendida por ASCOLI (1873) e principalmente por GARTNER (1883).

c) Jamais existiu um "proto-retorromânico", mas três grupos de falares retorromânicos distintos, ou seja, um "proto-romanche", um "proto-ladino" e um "proto-friulano", que se opunham a um único "proto-galo-italiano". Trata-se da hipótese poligenética de oposição negativa defendida por WARTBURG (1928).

d) Nunca houve um "proto-retorromânico" nem mesmo um "proto-galo-itálico": os grupos ladino, romanche e friulano sempre existiram e nunca formaram uma unidade. Cada grupo subordina-se, desse modo, a um grupo maior que inclui alguns dialetos italianos (como o trentino). Trata-se da hipótese poligenética incorporada defendida por BAtTisti (1931) e PELLEGRINI (1972). Ainda outra versão, a hipótese poligenética de oposição múltipla e negativa, afirma que os grupos retorromânicos, ainda que não formem uma unidade, distinguem-se dos grupos dialetais italianos que os circundam, posição defendida por TAGLIAVINI (1972).

e) A hipótese monogenética incorporadora, que afirma jamais ter existido um "protoretorromânico" nem um "proto-galo-itálico", pois ambos são derivações ou do italoromânico (SALVIONI, 1917) ou do galorromânico (BEC, 1971). 
Segundo Viaro (2001: 79), torna-se difícil estabelecer, nos estágios mais antigos, as características que sejam próprias do "proto-retorromânico", por conta da fragmentação anterior a qualquer unidade nacional na região.

EICHENHOFER (1989) admite que os fonemas /c/ e /ł/ são uma regra para o território galorromânico e para os dialetos setentrionais italianos, incluindo o "proto-retorromânico" por causa do "substrato celta". As manifestações de /k/ e /g/ são, portanto, posteriores. Deste modo, existem semelhanças do vocalismo do ladino com o romanche e com o friulano, mas também com dialetos setentrionais italianos como o lombardo e o vêneto ou mesmo com línguas latinas fora da área geográfica desses falares (apesar da datação desses paralelos ser diferente). REDFERN (1971) procurou encontrar uma unidade reto-românica baseando-se no léxico, um estudo que se mostra extremamente dificultoso, pois não há um vocabulário comum retorromânico; as palavras comuns existentes não permitem um estudo que permita remontá-las a um passado tão distante, nos tempos da fragmentação. Fica difícil estabelecer criteriosamente os casos de concidências vocabulares e coincidências fonéticas.

O romanche possui a palavra crap ("rocha"), que ocorre no friulano clap, de etimologia obscura. O italiano tem muitas palavras comuns ao francês e que não ocorrem nos falares retorromânicos. Não parece possível, desse modo, afiliar o léxico retorromânico a um grupo homogêneo.

Tendo havido uma unidade linguística, é diacronicamente inegável que os superstratos italiano e alemão interferiram de forma significativa na continuidade do grupo retorromânico (VIARO, 2001), diferenciando cada vez mais entre si o ladino, o romanche e o friulano, que se aproximaram em alguns aspectos - pelo contato existente - das línguas de superstrato. São as regiões das anfizone (áreas de línguas mistas; áreas de transição linguística), termo utilizado por AsCOLI (1873) para designar as mesclas de línguas ou dialetos, como o vêneto e o ladino que formaram falares ladino-vênetos e vêneto-ladinos ${ }^{350}$.

\footnotetext{
${ }^{350}$ As questões políticas são também bastante relevantes no contexto retorromânico, como, por exemplo, entre os falantes de ladino, romanche e friulano, que jamais aceitariam afirmar que falam um dialeto italiano. Por outro lado, PELLEGRINI (1971) mostrou como há o incentivo de se propagar o ladino nas regiões de Val Gherdëina e Val Badia, no Südtirol, pois é desejável que se promova um idioma neolatino a permitir o uso do alemão naquela região outrora austríaca; na região ladina de Val di Fassa, no Trentino, não há grandes incentivos nas escolas para a promoção da língua ladina, pois entre o ladino e o italiano, este acaba sendo mais usado em prol da unidade linguística regional (no caso trentino, o idioma italiano).
} 
Na região trentina, os falares de Val di Non, Val di Sole e Val di Fiemme são considerados como de anfizone, pelo fato de trazerem em si características linguísticas existentes no grupo ladino (e no caso de Val di Sole, também de um lombardo antigo). Por sua posição geográfica situada ao norte do Trentino, entre as áreas limítrofes que separam o dialeto trentino do alemão, falado nos vales ao norte de Val di Sole, muitos dialetólogos (Ascoli, 1873; BARTOLI, 1900; Fox 1997) afirmam que esses dialetos são de áreas originalmente ladinas que receberam posterior superstrato italiano (trentino e lombardo no caso solandro) e alemão (bávaro). Nas áreas onde ocorreu contato com o italiano (trentino), houve conservação de aspectos fonéticos, lexicais e morfossintáticos originários do substrato ladino.

\subsubsection{O GRUPO GALO-ITÁLICO}

O galo-itálico é um grupo linguístico românico, que compreende principalmente as regiões das áreas alpinas central e ocidental, seguindo para o sul em direção da região toscana, banhada pelo Mar mediterrâneo. Sua difusão ocorreu por principalmente na área alpina ocidental, mas outrora também se estendeu até os confins com o Vêneto, recuando exatamente até a margem esquerda do Rio Adige que corta o território trentino, influenciando principalmente os falares trentinos da região próxima ao lago de Garda (= Gartensee / Gardasee).

A pressão vêneta não permitiu o avanço do galo-itálico até a região friulana, mas o contato entre os dois grupos linguísticos teria permitido a formação de uma koiné lombardo-vêneta, variante de prestígio literário anterior ao toscano e difundida entre os séculos XIII e XIV, tendo sido também chamada koiné alto-italiana.

Foi o filólogo e medievalista Adolf Mussafia quem tratou de evidenciar a possível existência dessa koiné no seu trabalho Monumenti antichi di dialetti italiani (1864). Os filólogos Ascoli e Contini rejeitavam a existência dessa koiné medieval; outros estudiosos, como TAgLiavini (1972), costataram a existência de uma koiné literária, utilizada por 
autores medievais como Bonvesin de la Riva, Giacomo da Verona, Girardo Pattechio, entre outros.

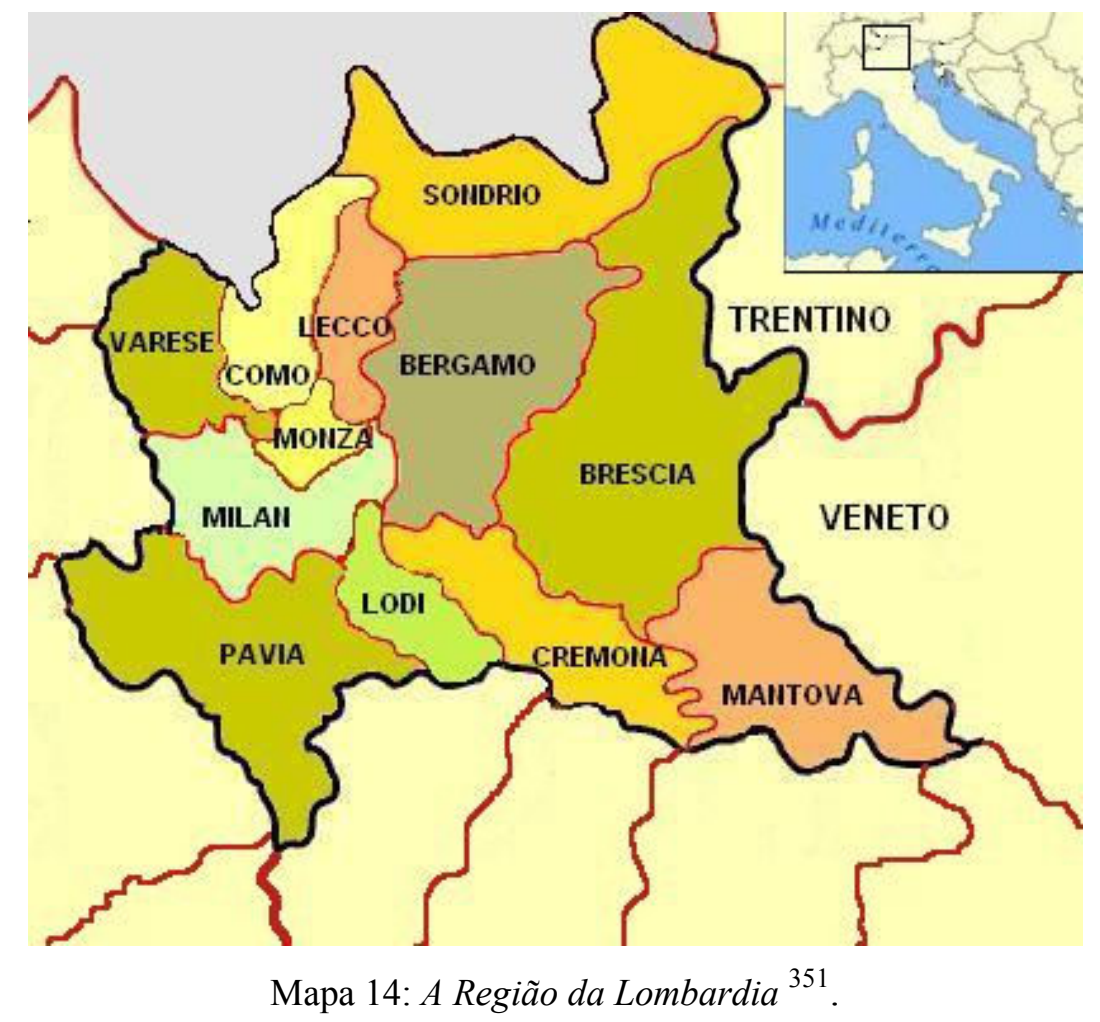

A partir do século $\mathrm{XV}$, o florentino teria ocupado o lugar de prestígio da koiné lombardo-vêneta, com os grandes toscanos Dante, Petrarca e Boccaccio, com o prestígio que a região de Florença alcançava.

As características linguísticas da Galorromânia presentes nos dialetos galo-itálicos são: o enfraquecimento das sílabas átonas; a sonorização das consoantes oclusivas intervocálicas e a redução das consoantes geminadas na mesma posição (caracterítica própria dos dialetos setentrionais italianos); a falta de epíteses (paragoges) típicas do italiano (amant > it. amano; lomb. aman <eles amam>) e queda, em muitos casos, das consoantes finais ou, no caso trentino, da última sílaba (principalmente nos verbos de primeira, segunda e terceira pessoas do singular, e de terceira pessoa do plural no pretértito perfeito do indicativo: è malà <adoentou-se>; ga parlà <falou>). Demais características

\footnotetext{
${ }^{351}$ MAPA: http://www.ens.it/risorse/geografia/italia_lombardia.gif
} 
comuns aos dialetos galo-itálicos são: a assibilação de $\boldsymbol{c}$ - e $\boldsymbol{g}$ - antes de $\boldsymbol{- \boldsymbol { e }}$ e $\boldsymbol{- \boldsymbol { i }}$; a sonorização das oclusivas surdas intervocálicas [p], $[\mathrm{t}] \mathrm{e}$ [k] em posição intervocálica numa evolução $p$ $>b b>v ; t>d>r ; c+a, o, u>g>\emptyset$.

Característica arcaica do galo-itálico era a palatalização de $\boldsymbol{c a}$ - e $\boldsymbol{g a}$ - (como ocorre no ladino, no friulano, no romanche e no dialeto trentino de Val di Non) que rapidamente retrocedeu durante a Alta Idade Média (RoHLFS, 1954). Também a palatalização de $\boldsymbol{c l}$ - e $\boldsymbol{g l}$ latinas, ainda que se mantenha conservação dessas formas em um pequeno número de vocábulos (clav / claf < chave>), comuns ao ladino.

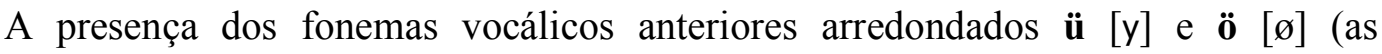
antigamente chamadas vocale turbate pelos dialetólogos italianos) gera controvérsias sobre ser ou não um resquício do antigo substrato céltico da área da Galorromânia, ou apenas uma evolução independente ocorrida nos idiomas daquela área setentrional da península itálica.

Alguns dialetos galo-itálicos preservam alguns resquícios da antiga desinência plural com o morfema $\mathbf{s}$ (que sobrevive no ladino, no romanche e no friulano), que outrora se estendia por boa parte da área alpina ocidental.

Os dialetos (ou idiomas ${ }^{352}$ ) galo-itálicos se dividem da seguinte forma:

1. Piemontês - falado, sobretudo, no Piemonte e Val d'Aosta.

2. Lombardo - subdividido em:

- Lombardo ocidental ou Insubre - falado nas regiões de Milão, Como, Lecco, Varese, Lodi, Novara, Verbania, em Brianza, em Valtellina, no Cantão Ticino da Suíça e em alguns vales suíços dos Grisões.

- Lombardo oriental ou Orobico - falado nas províncias de Bergamo, Brescia, em Crema e parte do Trentino (Val di Sole e áreas limítrofes com a Lombardia).

\footnotetext{
352 Não pretendemos aqui discutir sobre o status de língua ou dialeto, uma vez que até entre os maiores especialistas sobre o assunto isso não é um consenso. Acreditamos que paralelamente aos conceitos linguísticos e à classificação dos idiomas românicos, caminham também os interesses políticos e os nacionalismos que podem concordar ou não com a classificação científica.
} 
3. Ligúrio - falado na Liguria, Basso Piemonte, no Principado de Mônaco, como variante em algumas áreas da França (Mentone, Roquebrune-Cap-Martin e Boniface) e nas comunidades de Carloforte na Ilha de São Pedro e de Calasetta na Ilha de São Antíoco, na Sardenha.

4. Emiliano-romanholo - subdividido em:

- Emiliano - falado na Emília, Lombardia e parte da província de Mântua, Pavia, Lunigiana.

- Carrarese - falado na região de Carrara

- Romagnolo - falado na Romagna, na parte norte de Marche e na República de San Marino.

5. Galo-itálico da Sicília - falado pelas minorias das províncias de Enna e Messina.

Ilustram-se os falares lombardos com o exemplo da estória da raposa e do corvo, através das traduções apresentadas por VIARO (2001):

\section{Piemontês:}

La volp l'avia ancor na vòlta fam e varda lì ch'a l'ha vëddù un crov ans un pin ch'a tnìa un tòch ëd formag ant ël bèch. "Sto-sì a'm piasrìa tant", a l'ha pensà e l'ha crijaje al crov: "Che bel ch 'it ses! Se tò cant a l'è tant bel coma toa aparensa, alora it ses ël pì bel osel ëd tuti'”.

\section{Lombardo (milanês):}

La vòlp, anmò ona vòlta, la gh'aveva fàm, quand lee l'ha vist un scorbàt sora 'n pin, ch'el tegniva um tòch de formag in del bèch. "Quel lì el me piasaria debon", l'ha vosaa al scorbàt: "Me te see bèl" Se il to cantà l'è insci bèl come el to aspett, alora ti te seet el pusee bèl de tuti i osèj".

\section{Ligúrio:}

A vorpe a gh'aveiva ancon 'na vòta fame e te ô li ch'a l'ha visto un cròvo in sce 'n pin ch'o gh'aveiva un tòco de formagio into beco. "Sto chì o me piaxieiva tanto" a l'ha pensòu e a gh'a criòu a-o cròvo: "che belo che t'ê! Se o teu canto o l'è coscì belo come a teu aparensa, alöa t'ê o cì bel'öxelo de tuti".

\section{Emiliano:}

La vòlpa la ghiva ancòra 'na vòlta fam ed ech che in tàl védèr un corv sdu sovra un pin con un pès èd furmaj in tal bèch: "Còos ché'am gustarès béin", l'ha pinsèe ed ha gridè al corv: "Che bèl ca t'ee! Se al to cant l'è bèl quant la tò parejnsa, alòra te t'ee al piò bèl ed tòt jozvèe”. 


\section{Emiliano-romanholo (Ferrara):}

La vólp l'aveva ancóra fam e èco ch'la véd un corv su un pin ch'la avéva un pèz ad furmai int al bèch. "L'am pasrév pròpia anch a mi!" l'à pensà l'à unclà al còrv: "Cum at ié bèl! Se al tò cantàr l'è tanta bèl com la to simbianza, ti at saressi al più bèl ad tuti j'usié’”.

\section{Emiliano-romanholo (Bolonha):}

La våulp l'avêva fâm un'ètra vôlta, e in cal mumänt la vdé un côrv in vatta a un pên con un pèz ed furmài int al bèc. "Pròpi qual ch'am vlêva”, la pinsé, e la gé al côrv: "Cum t î bèl! Se al tô cant lè bèl come té, alåura t î té al pió bèl ed tót i usî̀".

\subsubsection{O VÊNETO}

O vêneto é um idioma românico que se caracteriza pela conservação de características históricas, presentes nos subdialetos e comprovadas nos diversos documentos históricos escritos em vèneto e que remetem, sobretudo, ao período da Sereníssima República de Veneza, que dominou o comércio marítimo do Adriático e do Mediterrâneo até a região da Istria (parte da atual Eslovênia e Croácia) entre os séculos IX e XVIII. Nos séculos seguintes houve por parte da República de Veneza uma intenção de dominar a porção italiana do Tirol, e a influência cultural e linguística vêneta permanece no atual Trentino. Sobre a influência vêneta no falar trentino, é importante destacar que por volta do ano 1000 as relações comerciais vênetas se estendiam por terra até região da atual Província Autônoma de Trento, mas quase não avançava nos vales germanófonos do Südtirol.

$\mathrm{O}$ vêneto se caracteriza pela manutenção de sua pronúncia histórica ${ }^{353}$, ainda que houvesse um vêneto antigo muito mais próximo dos falares retorromânicos (RIzzoLATTI, 1984), e que evoluiu para o seu atual estado. Suas variantes dialetais são faladas nas províncias de Belluno, Venezia-Giulia, em algumas áreas do Friuli, nos vales orientais do

\footnotetext{
353 "[Venetus est] pulcherrimus et doctissimus omnium sermo, in quo redolet nota linguae Grecae maiestas" Pontico Virunio (humanista belunês nascido em 1467) in GIUSTINIANI, B. (1969).
} 
Trentino (Valsugana sobretudo), em áreas limítrofes da Eslovênia, em algumas localidades da costa da Istria, no golfo de Quarnero (Croácia) e no golfo de Cattaro (Montenegro).

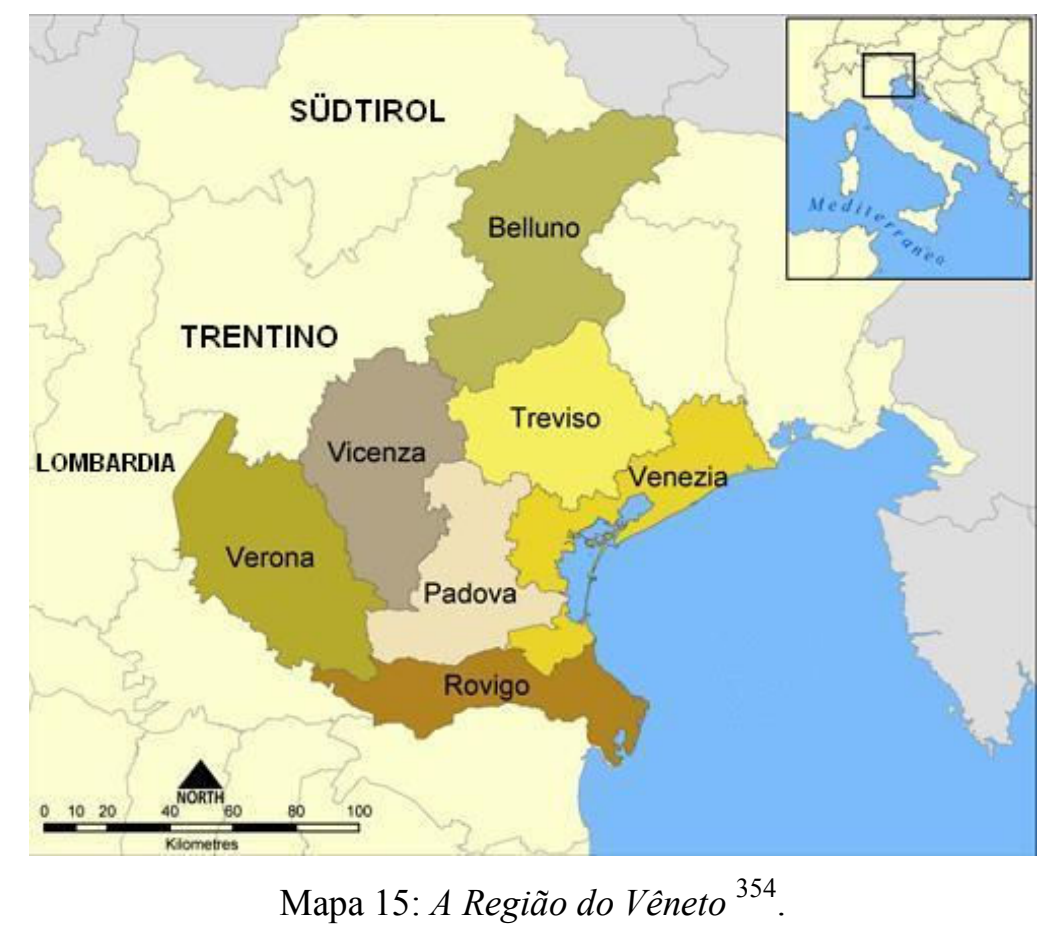

Os dialetos do grupo vêneto são divididos da seguinte maneira:

1. Vêneto Central: padovano, vicentino e polesano.

2. Vêneto lagunare: na região de Laguna Veneta.

3. Vêneto ocidental ou veronês: próximo ao dialeto trentino.

4. Vêneto centro-setentrional ou trevigiano: trevigiano, coneglianese, sandonatese e parte limítrofe da Província de Pordenone.

5. Vêneto setentrional: belunese (também chamado belumàt) e feltrino.

Além dos dialetos do grupo vêneto, nas comunidades belunesas de Cadore, Cortina d'Ampezzo, Livinallongo e Colle Santa Lucia é mantido o idioma ladino em dois dialetos (ampezano e fodom). Essa região pertenceu até 1926 à Província de Bolzano, sendo

${ }^{354}$ MAPA: http://it.wikipedia.org/wiki/Immagine:Provinces_of_Veneto_map.png 
incorporada durante o regime fascista à província de Belluno. $\mathrm{Na}$ região belunesa de Sappada é mantido o alemão bávaro (bairisch).

$\mathrm{O}$ vêneto possui estruturas morfossintáticas muito próprias, como o pronome clítico obrigatório antes do verbo na segunda pessoa singular e na terceira pessoa singular e plural (ti te/tu pàrli <tu falas >; el 'l pàrla / lu 'l pàrla <ele fala>; lóri i pàrla <eles falam>; $i$ vèci $i$ pàrla $<$ os velhos falam>). Em alguns dialetos galo-itálicos como o piemontês ou em alguns dialetos do lombardo ocidental (milanês sobretudo), o sentido da frase depende da desinência plural (piemontês: a canto <ele canta $>$ a canta $<$ eles cantam>; milanês: el canta $<$ ele canta $>i$ canten $<$ eles cantam $>$ ). O pronome clítico possui caráter distintivo no vêneto (principalmente na oposição entre a terceira pessoa no singular e no plural), de forma que determina o sentido da frase, uma vez que as diferenças não se encontram nas desinências finais dos verbos, como no italiano ou em alguns dialetos galo-itálicos. Isso permite, em alguns casos, a queda das vogais finais em alguns verbos (el sent $<$ ele ouve $>$ ei sent $<$ eles escutam>). Outra característica vêneta é a fusão enclítica dos pronomes com os verbos na forma interrogativa na segunda pessoa singular ( $\mathbf{s} t u$ ndà? <tu foste?>), na terceira pessoa singular (pàrlelo? <fala ele?>, pàrlela $<$ fala ela?>, pàrleli? $<$ falam eles? $>$, pàrlele $<$ falam elas?>) e na segunda pessoa plural (parlèo? parlèu? $<$ falais vós?>), característica cada vez mais em desuso no falar das áreas urbanas vênetas.

Apresentamos aqui o exemplo da estória da raposa e do corvo, no dialeto vêneto, apresentado por VIARO (2001: 58):

\section{Vêneto (central):}

La volpe la gaveva ancora na vòlta fame e èco che la gà visto un còrvo su un pin che gaveva un tòco de formagio int'el bèco. "Sto qua mi piaxarìa tanto" la ga pensà e la ghe ga crià al còrvo: "Che bèo che ti xe! Se el tu canto se cuxì beo cofà la to aparensa, alora ti xe el più bèl'oxèo de tuti".

A duplicação do sujeito é, como visto, um fenômeno que se observa nos dialetos lombardos e vênetos e, de modo geral, nos falares setentrionais italianos. VIARO (2001: 59) aponta as semelhanças entre o retorromânico e os falares setentrionais italianos e afirma que essa realidade fragmentada de dialetos não pressupõe a existência de uma unidade 
linguística nem para os falares retorromânicos, nem para os dialetos setentrionais italianos $^{355}$.

\section{Vêneto brasileiro (Talian) ${ }^{356}$ :}

La vólpe la gavéva ancóra na vòlta fàme e èco che la gà visto un còrvo sóra un pìno e lu 'l gavéva un tòco de formài int'el bèco. "Sto qua mi sarìa pròpio bèlo" la ga pensà e la ga dit al còrvo: "Che bèlo che te sei! Se el to cànto l'èi cosita bèlo cossita come la to aparénsa, lóra te sei el più (pù) bèl'osèl (ocèl) de tuti".

\subsubsection{O GRUPO LADINO (DOLOMÍTICO)}

O ladino (também chamado ladino dolomítico ou ladino central) é um grupo de variantes faladas por cerca de trinta mil pessoas (VIARO, 2001) na região montanhosa do Maciço do Sella, entre as províncias italianas do Trentino, Südtirol e Belluno (Vêneto), circundado pelo alemão tirolês (bairisch) e pelos dialetos italianos trentino e vêneto (belunês). O substrato linguístico do ladino remontaria a antigas populações réticas e celtas latinizadas pelos romanos na época de Augusto (meados de 25 a.C.).

Segundo AsCOLI (1873) e BARTOLI (1900) os idiomas ladinos (romanche, ladino dolomítico e friulano) seriam o resquício de um idioma comum ("ladino antigo") que existia em toda a área montanhosa entre a Suíça e a Eslovênia, inclusive na região de Osttirol < Tirol oriental $>$, hoje de língua alemã. Também RoHLFs (1972) considera o ladino como pertencente a um grupo linguístico diferenciado. Alguns dos mais antigos topônimos

\footnotetext{
355 Apresenta, a partir dessa afirmação, algumas hipóteses para o problema da pseudo-unidade do retorromânico e para a fragmentação das variantes dialetais na área alpina.

${ }^{356}$ Idioma da imigração, ainda corrente em áreas coloniais venetas do Sul do Brasil, sobretudo no RS e SC. Em algumas áreas o Taliàn é uma verdadeira koiné dos falares vênetos, lombardos e trentinos. Mantém-se, sobretudo, com substrato vêneto em todas as áreas onde é falado. Nas áreas coloniais trentinas de SC, o dialeto trentino (sem qualquer inflência veneta) é também chamado taliàn. Tradução nossa a partir do dicionário de LUZZATO (2000).
} 
tiroleses têm origem ladina e o próprio nome Tirol (Tyrol) ${ }^{357}$ teria sua origem numa antiga palavra ladina, de significado desconhecido ${ }^{358}$.

Com as pressões linguísticas do galo-itálico, do vêneto, do alemão e do esloveno, o antigo ladino se teria confinado em alguns vales alpinos ${ }^{359}$. Os "fenômenos ladinos" foram estudados por AsCOLI (1873) em seus Saggi Ladini, quando procurou identificar a área linguística original do antigo ladino. Suas pesquisas se basearam na busca de resquícios linguísticos de origem ladina nos dialetos da região alpina e no estudo dos topônimos ladinos em áreas onde o idioma não mais existe. GARTNER (1883), em seus estudos sobre o romanche $\mathrm{e}^{360}$, também procurou identificar a área ladina por meio de topônimos históricos ${ }^{361}$.

O ladino dolomítico se subdivide em dialetos distintos, que apresentamos aqui de modo semelhante à divisão classificatória dos dialetos organizada por VIARO (2001):

a) Grupo sul-tirolês do Sella, onde o ladino é falado ao lado do alemão tirolês e, em alguns lugares, das variantes dialetais trentinas de Branzoll (Bronzollo), Pfaten (Vadena) e Salurn (Salorno). O grupo é composto pelos dialetos:

- badioto (lad. badiot; it. badioto; al. gadertalisch ou gadertalerisch), falado em Val Badia (= Gadertal / Val Badia). Em Rina (= Welschellen / Rina) é falado o marebano (lad. mareo; it. marebano; al. Ennebergisch), uma variante próxima do badioto.

\footnotetext{
${ }^{357}$ A origem do nome é tão incerta como seu significado. Ocorre inicialmente em alemão como Tyrol, depois Tirol (em algumas peças teatrais e músicas populares aparece também Türol) e em Dante Tirallis (SULZER, 1855), no sentido de "torre alta". Desde 1271 os condes do Castelo Tirol se denominavam senhores do Tirol. Alguns topônimos tiroleses são ainda mais antigos, com origens no idioma paleovêneto, como a região de Vintschgau (=Val Venosta), no Südtirol.

${ }^{358}$ Alguns topônimos tiroleses são ainda mais antigos, com origens no idioma paleovêneto, como a região de Vintschgau (=Val Venosta), no Südtirol.

${ }^{359}$ BATTISTI (1970) e FoX (1997) consideram as variantes trentinizadas de Val di Non e Val di Sole como resquícios de um trentino arcaico, que manteve traços fonéticos de um antigo ladino que na Alta Idade Média se estendia por toda aquela área alpina.

${ }^{360}$ Gärtner utilizou pela primeira vez o termo Räto-romanisch ("retorromânico") como sinônimo do ladino ascoliano, o que gerou uma confusão de nomenclatura na identificação do romanche. Retorromânico seria, dessa forma, um grupo linguístico de comum origem, do qual fazem parte o ladino dolomítico, o romanche suíço e o friulano. Antes dele, Sulzer (1855), padre da diocese de Trento, em seus estudos sobre as línguas românicas da região tirolesa, já considerava o ladino dolomítico e o romanche como variantes de uma mesma língua de origem rética. Atualmente, considera-se que esses idiomas (com seus respectivos dialetos) não possuam uma única origem comum e que, na verdade, trata-se de três grupos linguísticos diferenciados (VIARO, 2001).

${ }^{361}$ São raros os textos em ladino arcaico e o mais antigo é de 1631. Destacam-se os trabalhos de BARTOLOMEI (1763) e MiCURÀ DE RÜ (1833).
} 
- gardenês (lad. gherdëina; it. gardenese; al. grödnerisch), falado em Val Gherdëina (= Grödnertal / Val Gardena). Até o século XVII o ladino novês (lad. noves; it. novese; al. Eggentalerisch), variante próxima do gardenês, se difundia desde a montanha de Siusi (Seiseralm / Alpe di Siusi) até Welschnofen (= Nova Levante).

b) Grupo trentino do Sella, de original língua ladina, mas desde o século XII bastante marcado pelas influências do dialeto trentino:

- fassano (lad. fascian; it. fassano; al. fassanisch), falado em Val de Fascia (=Val di Fassa

/Fassatal; Fassertal; Faßtal), que convive apenas com o italiano e com o trentino.

c) Grupo agordino do Sella, na província vêneta de Belluno, numa região ligada historicamente ao condado tirolês e desmembrada da província de Bolzano (Südtirol) em 1926, durante o regime fascista. Desde o século XI com marcada influência belunesa, e influência vêneta posterior.

- fodom (lad. fodom; it. livinallese; al. buchensteinisch), falado em Fodom (= Livinallongo /Buchenstein).

d) Grupo ampezzano, na província de Belluno, de substrato cadorino e superstrato belunês e vêneto:

- ampezzano (lad. ampezan; it. ampezzano; al. ampezzanisch), falado em Val Ampëz ou Val Ampezo (= Val Ampezzo /Petsch-Hayden).

e) Grupo cadorino, da região do Alto Piave, na província de Belluno, considerado intermediário entre o ladino e o friulano cárnico, com superstrato vêneto que data desde o século XV:

- comélico (lad. comelego; it. comelicano). Na área friulana de Vaiónt existe uma forma intermediária entre o ladino, o friulano e o vêneto-belunês.

f) Grupos trentinos nonês e solandro, no noroeste da província de Trento, distantes da região do Maciço do Sella. São geralmente considerados um grupo ladino trentinizado ou, ainda, resquícios de um trentino arcaico (FoX, 1997). Trazem características típicas do ladino, como a palatalização de $\boldsymbol{c} \boldsymbol{a}$ e $\boldsymbol{g} \boldsymbol{a}$ que ASCOLI (1873) indica como conservação de arcaísmos.

- solandro (lad. solànder; it. solandro; al. sulzbergisch), falado em Val di Sole (= Sulzberg /Sulztal) e em Val di Rabbi.

- nonês (lad. nónes ou anàune; it. nonese; al. anaunisch), falado em Val di Non (= Nonsberg / Nonstal). 
Em Val di Fiemme (= Fleimstal) e partes de Val di Cembra (= Zimmertal), ao sul de Val di Fassa, as variantes trentinas apresentam características ladinas, consideradas como resquícios de um ladino que recebeu, desde a Idade Média, um superstrato trentino (RizzolatTI, 1984). O dialeto de Val di Fiemme é chamado fiamazzo (lad. fiamaz; it. fiammazzo; al. fleimstalerisch).

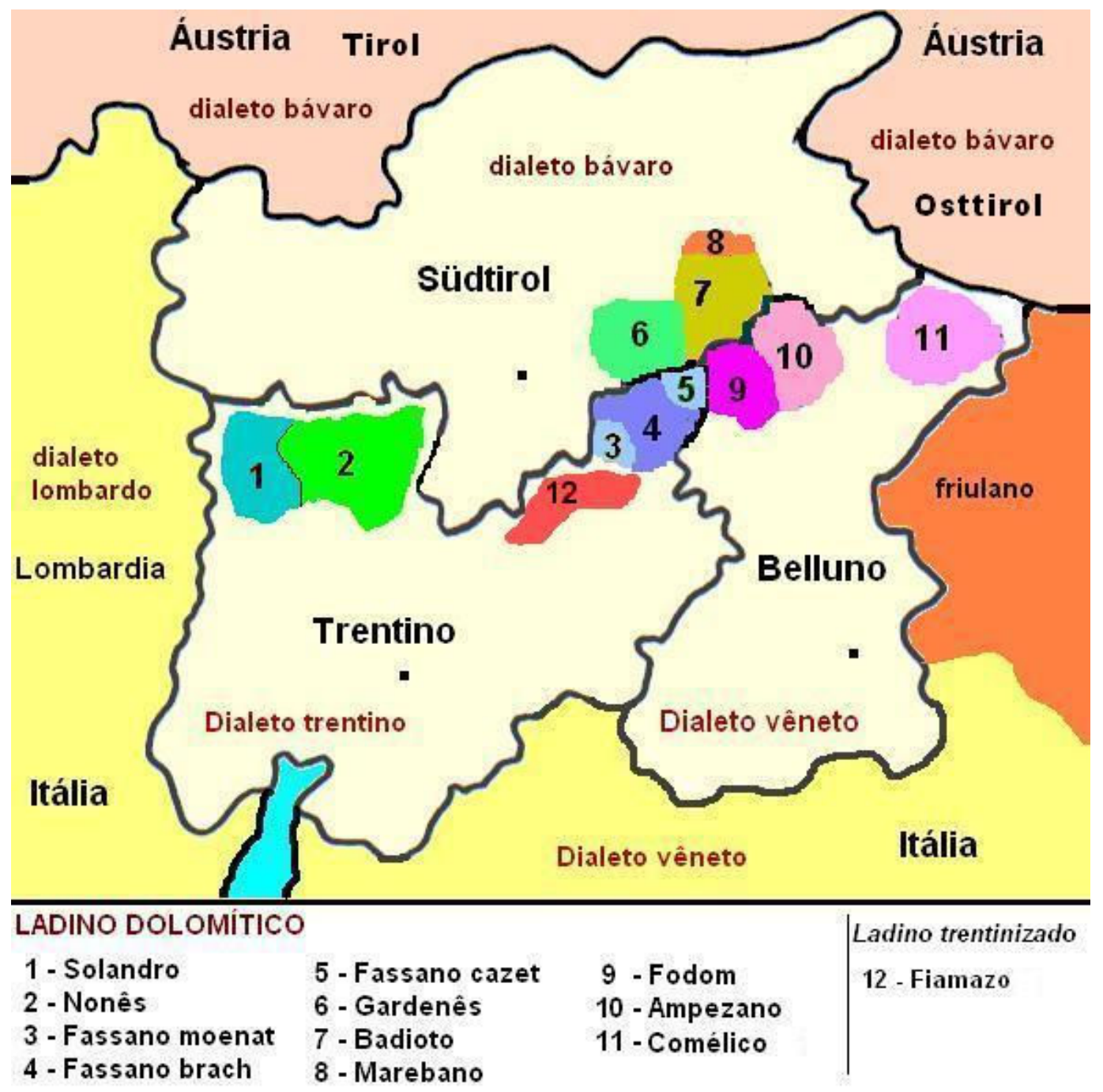

Mapa 16: As regiões ladinas nas províncias italianas de Trento, Bolzano e Belluno ${ }^{362}$

São características ladinas a palatalização de $\boldsymbol{- c} \boldsymbol{a}$ e $\boldsymbol{- g} \boldsymbol{a}$ principalmente em posição inicial (ainda que ocorra em qualquer posição): ciar $<$ caro $>$; ciarità $<$ caridade $>$; ciaura $<$ cabra $>$; ciasa $<$ casa $>$; ciaval $<$ cavalo $>$; gial $<$ galo $>$; gialina $<$ galinha $>$; giat $<$ gato $>$. Outra

${ }^{362}$ MAPA: VIARO (2001). 
característica ladina é a manutenção da antiga desinência plural em $\boldsymbol{- s}$ que, segundo alguns autores (RIZzOLATTI, 1984), outrora se estendia por toda a região alpina. A pressão linguística exercida pelo vêneto e pelo lombardo (que não possuem plurais sigmáticos) influenciou o falar trentino de forma a praticamente eliminar a antiga desinência plural que se manteve no ladino, no romanche e no friulano ${ }^{363}$. Com a finalidade de ilustrar as diferenças entre os falares ladinos, seguimos com a mesma estória da raposa e do corvo nas versões dialetais ladinas apresentadas por VIARO (2001: 51) e VIDESSOT (2002: 10) ${ }^{364}$ :

\section{Badioto:}

La olp ê indô $n$ iade afamada. Te chël vëighera $n$ corf che tignî $n$ tòch de ćiajó te so bech. "Chël me savess bun", s'àra ponsè, y à cherdè le corf: "Tan bel che t'es! Sce to ćiantè é tan bel co to ćiarè fora, spo este dessigü tö le plü bel vicel de düć".

\section{Marebano:}

La olp â endô n iade fam. Te chëra ára odü en corf sön en aidin, co se tegnia en toch de ćiajó tal bech. "Chël mo sess bun", se ponsâl, y ti scraia al corf: "Tan bel che t'es! Sce to ćianté é tan bel co che te ćiares fòra, spo éste le plü bel de düći vicí”.

\section{Gardenês:}

La bolp fova inò $n$ iede arfameda. Te chëla vëijela $n$ corf che tën $n$ tòch de ciajuel te si bech. "Chël me savëssa bon", se ala mpensà y à cherdà l corf: "Ce bel che te ies! Sce te ciantes tan bel coche te cëles ora, pona ies dessegur tu l plu bel ucel de duc".

\section{Fassano:}

La bolp era endò famèda. Te chela la veit $n$ corf con $n$ toch de formai tel bech. "Chel, vé, me saessa bon", la se peissa e la ge disc al corf: "Che bel che t'es! Se tie ciantèr l'é scì bel che tia parbuda dapò t'es de segur tu l più bel anter duc i ucìe".

\section{Fodom:}

La volp leva ndavò afamada. Nte chëla la veiga n còrf che l se tegniva $n$ tòch de formai ntel bech. "Chël l me savëssa ben bon”, la s'à pensé ntra de dëla, e l'à clamé l còrf: "Cotánt bel che t'es! Se tuo cianté lé bel coche ti te ciale fòra, nlouta t'es segur ti l plu bel de duc cánc $i$ uciei!".

\footnotetext{
${ }^{363}$ Trata-se de um dos poucos pontos sobre os quais se sustenta a unidade linguística dos três grupos, além da palatalização de $\boldsymbol{c}[\mathrm{t}] \mathrm{e} \boldsymbol{g}[\mathrm{d} 3]$.

${ }^{364}$ Os exemplos apresentados em VIARO (2001) foram enviados por VIDESSOT.
} 


\section{Ampezzano:}

$R a$ volpe (olpe) r'èa danoo infamentada. Cenoné ra vede un cròo, che 'l aéa inze 'l bèco un tòco de forméi. "Chel sì che el me piajaràe”, ra s'à pensà ra volpe (olpe), e r'à ciamà el croo: "Cé un bel che te sos! Se te ciantes polito cemodo che te se vede, de seguro te sos el pi bel de dute $i$ uziéi!’”.

\subsubsection{EXEMPLOS EM DIALETO TRENTINO}

Para ilustração das variedades regionais do dialeto trentino (ora com maior influência lombarda, ora com maior influência vêneta, além dos casos de dialetos cujo substrato ladino é bastante notório), apresentamos um trecho da estória da raposa e do corvo (Esopo), traduzidos em alguns exemplos ${ }^{365}$ :

\section{Trentino central (cidade de Trento):}

La bòlp l'èra ancòr famàda e l'ha vist un còrvo sóra un pin, che 'l avéva un tòch de formài nel bèch (bèco). "Quel li me par bon!" l'ha pensà e l'hà ciamà al còrvo: "Cóme te sei bèl! Se el to cànto l'èi cossì bèl cóme la to aparénsa, te sei el pù bèl de tùti i osèi (usèi)".

\section{Trentino rural (arredores de Trento / Altopiano di Pinè) ${ }^{366}$ :}

La bolp l'èra ancór sfamàda e la ga (l'ha) vist en corf sóra en pin, che 'l gavéva (avéva) en tòch de formài ntel bèch. "Chel li me par bon!" la ga (l'ha) pensà e la ga (l'hà) ciamà al corf: "Com te sei bèl! Se el to cànto l'èi cossì bèl com la to aparénsa, pròpi che te sei el pù bèl de tüt ei osèi".

\section{Valsuganotto:}

La bolp l'èra ancóra sfamàda e la ga visto un còrvo sóra un pin, che 'l gavéva un tòch de formài ntel bèch (bèco). "Chel li me pàre (par) bon!" la ga (l'ha) pensà e la ga (l'ha) ciamà al còrvo: "Cóme te sei bèl! Se el to cànto l'è cossì bèl cóme la to aparénsa, pròpio te sei el pù bèl de tuti i osèi".

\footnotetext{
365 Traduções nossas a partir dos dicionários de Trento e Pinè (VitTORE, 1904; GrofF, 1955); Vallagarina (AzZOlini, 1974); Cembra (ANegGi, 1984); Valsugana (PRATI, 1960); Val di Non e Val di Sole (QuARESIMA, 1964); Val di Fiemme (ZORZI, 1977; BONISEGNA, 1980); Val Rendena e Giudicarie (FrANCHINI, 1984; GuAdagnini, 1985); Primiero (TISSOT, 1996). Na maioria dos casos, as diferenças encontram-se no plano fonético e lexical, não havendo grandes diferenças no plano sintático. A grafia utilizada respeitou aquela apresentada nos respectivos dicionários.

${ }^{366}$ A partir do exemplo retirado em http://it.wikipedia.org/wiki/Dialetto trentino, que serviu para o exemplo da cidade de Trento, cujas diferenças se encontram principalmente no plano fonético.
} 


\section{Vallagarino:}

La bolp l'èra ancór famàda e la ga vìsto en corv sóra en pin, che 'l gavéva en tòch de formài nel bèch. "Chel li me par bon!” la ga pensà e la ga ciamà al corv: "Com te sei bèl! Se el to cànto l'èi cossì bèl com la to aparénsa, te sei el pù bèl de tùti i usèi”."

Primieroto $^{367}$ :

La bolp l'èra ancóra famàda e l'à vìsto en crò (cròch) sóra en pin, che l'avéva en tòch de formài tél bèch. "Chel li me pàre bon!" l'à pensà e l'à ciamà al crò (cròch): "Com te sei bèl! Se el to cànto l'èi cossì bèl com la to aparénsa, te sei 'l pì bèl de tùti i ausèi”.

\section{Ledro-giudicario:}

La bolp l'èra ancór sfamàda e la ga vist en corf sóra ' $n$ pin, che 'l gavéva 'n tòch de formài nel bèch. "Chel li me par bon!” la ga pensà e la ga ciamà al corf: "Com te sei bèl! Se 'l to cànt l'èi cossì bèl com la to aparénsa, te sei el pù bèl de tùti i usèi”.

\section{Rendenese (Giudicarie):}

La bolp l'era ancör famàda e l'à vist ün crof sóra en pin, al cu ün tòc de formai 'n bèch. "Chel li me par bon!" l'à pensà e l'à ciamà al crof: "Com te ses bèl! S'al to cantar l'è tan bèl com la to aparénsa, segür te ses al pü bèl de tüt i usèi”.

\section{Fiamazzo:}

La bolp l'èra de nöf sfamàda e l'ha vìst en corf sóra ' $n$ pin, che 'l avéva ' $n$ tòch de formàe tel bèch. "Chel li me par bon!" l'ha pensà e l'ha ciamà al corf: "Com te ses bèl! Se 'l to cant l'è cossì bèl com la to aparénsa, te ses el pü bèl de tüt i osèi”.

\section{Solandro:}

La bolp l'èra de nuèu famàda. Nte chèla la vet en crol con en toc de furmài en tel bèch. "Chel 'l me par bon", l'ha mpensà, e la dis al crol: „, Che bel che es! Se 'l to ciantàr l'è enzì bel com te es, de segùr es el pü bel di tüt i aucièi!"

Nones (anaune) ${ }^{368}$ :

La bolp l'era de nuèu famada. Nte chela la vet en grol con en toć de ciajolet tel beć (bèch). "Chel, vè, el me saverues bon", la mpensa ntrà de ela, e la ge dis al grol: „Che bel che es! Si l to ciantar l'è nzì bel come che vardes fuera, de segur es el pu bel di tut i aucièi!"

${ }^{367}$ Dialeto que conhecemos, por ser aquele da região de nossa família.

${ }^{368}$ Exemplo retirado em http://it.wikipedia.org/wiki/Dialetto trentino 


\subsubsection{MAPA DIALETAL TRENTINO ${ }^{369}$}

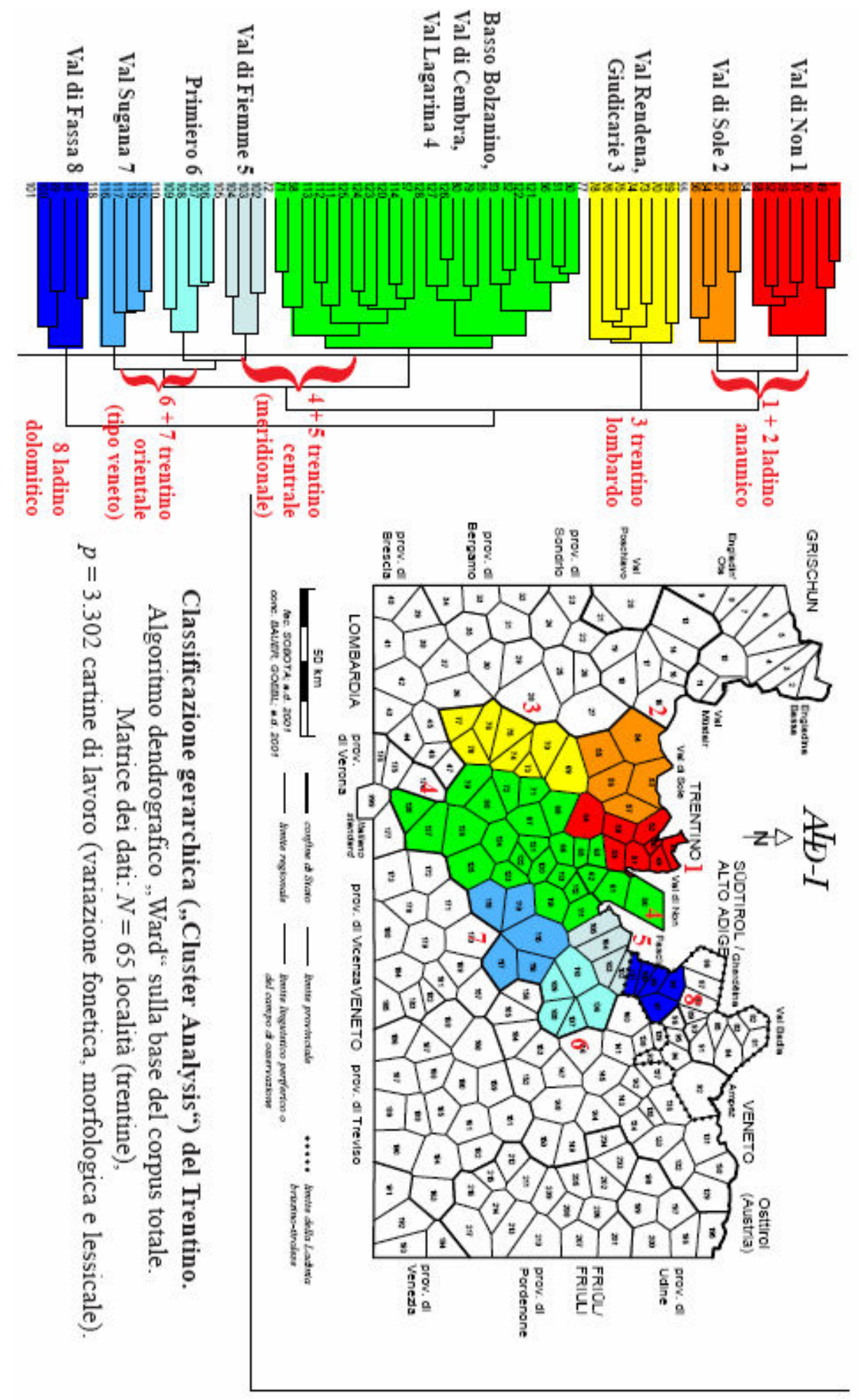

${ }^{369}$ Fonte: $\underline{\text { http://it.wikipedia.org/wiki/File:Dialetti trentino.png }}$ 


\subsection{O GRUPO GERMÂNICO}

A povoação germânica na área alpina tirolesa está ligada às incursões germânicas no Império Romano, ocorridas desde o final do século IV. Faltam documentos históricos que comprovem o exato período histórico da influência alemã nas línguas românicas da área alpina, mas os termos mais antigos são provavelmente aqueles do período das invasões germânicas no Império Romano, sobretudo dos longobardos ${ }^{370}$, alamanos e baiuvares.

Os alamanos (Alemannen; Alamannen) se estabeleceram principalmente na região da atual Suíça, ocupando uma área relativamente extensa: região de Alsácia, na França, parte sudoeste da Alemanha (Baden-Würtenberg, parte da Floresta Negra até os confins com a Suábia), boa parte da Suíça, Liechtenstein e uma pequena porção da Áustria (Vorarlberg e a região tirolesa de Lechtal).

Os longobardos se estabeleceram na região que corresponde atualmente aos territórios da Lombardia, Piemonte, Val d'Aosta até o atual Vêneto, e seguiram para o sul em direção da região da atual Toscana. Adotaram o latim como seu idioma, de modo que atualmente não existem minorias falantes de longobardo na região setentrional italiana, mas as influências linguísticas estão presentes nos dialetos e em vários topônimos. Os baiuvares (Bajuwaren; Baiuwaren) se estabeleceram no território que atualmente corresponde à Baviera alemã, praticamente toda a Áustria (com esxcessão das áreas de falares alamânicos de Vorarlberg e Lechtal), parte do Tirol meridional e em pequenas comunidades italianas no Vêneto (Belluno e Sete Comuni) e Friulia.

Os dialetos que influenciaram os falares da região tirolesa são pertencentes ao altoalemão, sendo eles o bávaro (Bairisch), falado no Tirol meridional, Osttirol, Südtirol e entre as minorias germanófonas trentinas, e o alamano (Alemannisch), falado na região de Lechtal, no Tirol meridional, fronteiriça com o estado austríaco de Vorarlberg.

\footnotetext{
${ }^{370}$ Influências longobardas existem no léxico dialetal de boa parte da área setentrional italiana.
} 


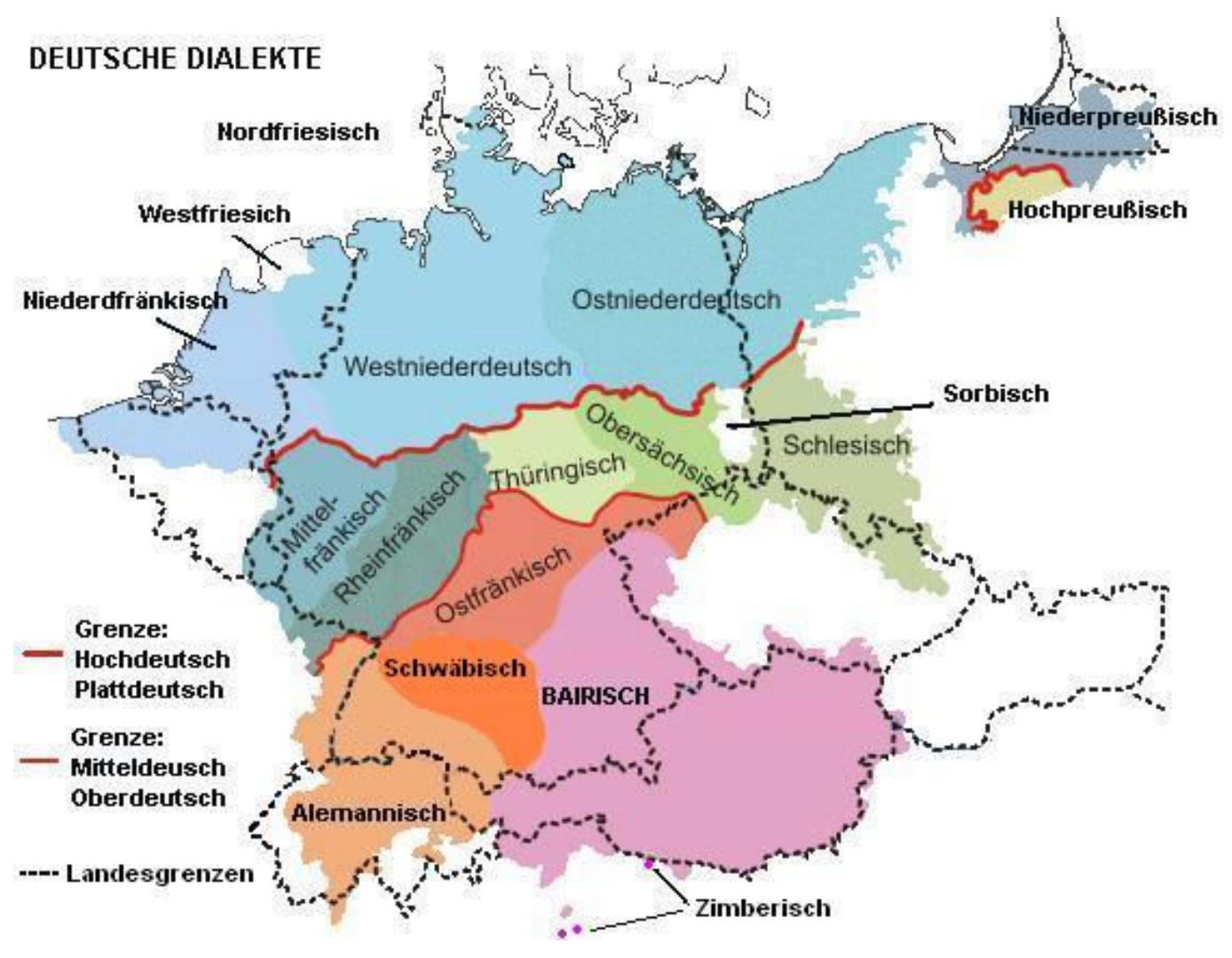

Mapa 17: Os dialetos alemães ${ }^{371}$.

\subsubsection{O ALEMÃo BÁVARO}

O alemão bávaro (al. Bairisch; bav. Boarisch) pertence ao grupo alto-alemão (Hochdeutsch) e preserva em si antigas formas fonéticas, morfológicas e sintáticas outrora comuns também ao médio alto alemão (Mittelhochdeutsch). O bávaro se divide em três subdialetos:

a) Bávaro setentrional (Nordbairisch), falado na área norte da Baviera, onde se mescla com algumas variantes do franco oriental (Ostfränkisch) e áreas limítrofes da República Tcheca (antiga Boêmia).

\footnotetext{
${ }^{371}$ MAPA: http://home.arcor.de/owbbayreuth/images/karte dialekte.gif
} 
b) Bávaro central (Mittelbairisch), também chamado Donaubairisch, falado em boa parte da Baviera, centro-norte da Áustria (Oberösterreich, Niederösterreich, Viena, parte de Salzburg, parte de Steiermark e parte de Burgenland) e áreas limítrofes da Hungria ${ }^{372}$. Era falado até o século XIV na região de Samnaun nos Grisões (Suíça), sendo gradativamente substituído pelo alamânico (Alemannisch).

c) Bávaro meridional (Südbairisch), falado no sul da Baviera, Áustria (Steiermark ${ }^{373}$, Salzburg, Burgenland, Kärnten e Tirol/Osttirol). Na Itália: Südtirol, Trentino (Fersental / Val Fersina e Lusern / Luserna), em Belluno (Sappada / Plodn e Cansiglio), em Vicenza (sieben Gemeinde / Sette Comuni), Verona (Lessinia) e em Udine (Tischlwang / Timau e Zahre / Sauris).

\subsubsection{O ALEMÃO TIROLÊS}

O alemão tirolês (Tirolerisch) pertence ao subdialeto Südbairisch e possui muitas variantes, próprias a cada vale. As palavras de origem bávara existentes no dialeto trentino são geralmente comuns ao alemão tirolês (tirolerisch), ainda que sejam adaptadas à

\footnotetext{
${ }^{372}$ Cuja presença alemã remete ao ano 1000, quando a condessa Gisela da Baviera (985 - 1060), esposa do primeiro rei da Hungria S. Estevão I (969 - 1038), instalou colonos bávaros na região do Danúbio. No século XVIII, transferiram-se colonos oriundos da Suábia (Schwaben), denominados Donauschwaben <suábios do Danúbio>. Além deles, entre os séculos XVIII e XIX, os Banater Schwaben <suábios do Banat> ocuparam partes das atuais Romênia, Sérvia e Hungria (então pertencentes à coroa austríaca); sabe-se que eram oriundos também da Baviera, Áustria (Niederösterreich e Burgenland), Alsácia-Lorena, Rheinpfalz e Luxemburgo. Na antiga Bucovina (al. Bukowina), região entre a Romênia, Ucrânia e parte da Moldávia, o alemão bávaro (do tipo central) era mantido de forma muito conservadora até meados do século XIX. Saídos no século XVIII da Suábia bávara e instalados primeiramente na Boêmia, seus descendentes seguiram para a Bucovina entre 1838 e 1840, onde permaneceram até o final do Império Austro-húngaro, quando a grande maioria emigrou para a Alemanha, Áustria e América. No Brasil, a colônia mais expressiva é das cidades de Rio Negro (Paraná) e Mafra (Santa Catarina). Destaca-se, nesse contexto, o idioma íidiche, mantido durante séculos em várias localidades da Europa Oriental, que possui várias características comuns ao bávaro.

${ }^{373} \mathrm{Na}$ antiga província do Krain (atual Eslovênia), região que formava a Baixa Estíria (Untersteiermark), a presença alemã é tão antiga quanto na Hungria.
} 
fonologia trentina. Originaram-se do contato entre o dialeto trentino com o alemão das áreas tirolesas do norte do vale do Adige, assim como dos vales trentinos colonizados por tiroleses de língua alemã.

Durante a Idade Média, com a administração dos feudatários dos condes do Tirol e do bispo de Trento, foram instalados colonos de língua alemã em várias áreas trentinas. Essa migração originou ilhas étnicas alemãs (ou germanófonas) que se mantêm até hoje, como Val Fersina (= Fersental / Val dei Mòcheni), Lavarone (= Lafraun), Luserna (= Lusern) e Alta Val di Non (= Nonsberg). Há, além disso, um considerável número de sobrenomes de origem alemã em demais áreas trentinas (Primiero, Valsugana, Giudicarie, Val di Fiemme), originários não somente do período medieval, mas que entraram nos vales trentinos a partir do século XVII após a peste que assolou a população tirolesa italianófona da área meridional. A peste possibilitou, assim, a substituição, em algumas áreas, da população italianófona por aquela germanófona. Contudo, como afirma RICCADONNA (2009: 45), ocorreu gradativamente a perda da língua alemã em diversas dessas localidades e muitos sobrenomes foram trentinizados.

Entre os séculos XIV e XVI, algumas levas de trabalhadores saídos dos vales alemães do Tirol Meridional (sobretudo da região de Schwaz - Unterinntal) se estabeleceram nas regiões trentinas de Primiero e Valsugana como trabalhadores, sobretudo mineiros (Knappen). Essa classe de trabalhadores se estabeleceu definitivamente na região (sendo identificados como canòpi) e seus sobrenomes ainda são comuns em várias áreas trentinas. Alguns vocábulos são referentes às profissões e são ainda encontrados em alguns dialetos trentinos (sùster $<$ Schuster $<$ sapateiro $>$; tìsler $<$ Tischler $<$ carpinteiro $>$; slózer $>$ Schlosser $<$ chaveiro $>)^{374}$. Também a esse período remetem alguns dos termos de origem administrativa. No que se refere à culinária, existe um grande número de palavras vindas do alemão tirolês (tirolerisch), utilizadas em praticamente todo o

\footnotetext{
${ }^{374}$ Em algumas áreas vinícolas trentinas e sobretudo nos vinhedos do Südtirol (principalmente na região de Meran) sobreviveu até meados do século XX o antiquíssimo ofício do Saltner (em trentino saltàro), ou protetor de vinhedos. Tratava-se de um ofício permanente de guarda das áreas vinícolas que trazia em si não somente o caráter profissional mas também o caráter religioso de um ofício que se mantinha pela crença popular, uma vez que a função do protetor e guarda era a de afugentar os maus espíritos e pragas dos vinhedos. O saltàro utilizava uma roupa toda cheia de apetrechos em penas e peles, que remete às antigas tradições de origem provavelmente celta, ainda vistas nos carnavais tradicionais tiroleses (Tresterer, Perchten). Sua profissão não era assalariada, cabendo à comunidade o dever de alimentar e suprir suas necessidades, e seu ofício era geralmente passado de pai para filho.
} 
Trentino: canéderle (ou canéderle) < Knödel (tir. Knedl e, ainda, Knederl <literalmente: "pequeno Knödel">); cròfen > Krapfen (tir. Kropfn); smòrun < Schmarren (tir. Schmorn).

Vale lembrar que no século XIX e início do século XX ocorreu nas regiões ladinas e italianas (trentinas) do Tirol um processo de germanização, levado a cabo principalmente pelo Tiroler Volksbund $<$ Federação popular tirolesa $>$, que abria escolas de língua alemã e incentivava o aprendizado do alemão em vários vales de falares italianos. Essa postura contribuiu não somente para a difusão do idioma alemão, como para reforçar o status linguístico alemão no Tirol.

As palavras de significado administrativo e principalmente militar remetem ao período do Império Austro-húngaro e provavelmente ao período da revolta tirolesa de 1809, quando tropas de tiroleses italianos atuavam juntamente com tropas de tiroleses alemães. Também existem vocábulos que parecem remeter aos anos que antecederam a Primeira Guerra Mundial, com o alistamento dos jovens entre os caçadores (Tiroler Kaiserjäger).

Ainda que houvesse em séculos passados uma razoável população de língua alemã na cidade de Trento, que lhe garantiu o nome histórico Trient (assim como Rovereto era também chamada Rofreit ou Rovereit), a parte sul do vale atesino fora desde sempre uma área italianófona, terra de transição que suavizava a fronteira linguística italo-germânica principalmente pelo fator cultural de sua população, intrinssecamente ligada aos tiroleses de língua alemã. Se essa ligação garantiu um considerável número de vocábulos de origem germânica no dialeto trentino, também garantiu a identidade linguística italiana do Trentino.

\subsubsection{O MOQUENO}

São pouco mais de duas mil pessoas pertencentes à essa minoria germanófona trentina de Val Fersina (al. Fersental; moq. Bersntol), falantes do idioma moqueno (moq. 
bersntolerisch; al. fersentalerisch; it. mòcheno) e descendentes de trabalhadores ${ }^{375}$ saídos em meados do século XII de vales do Tirol Meridional (Inntal) e da Baviera (Oberbayern), tendo se estabelecido na região trentina de Valsugana, no vale que os identifica (Val dei Mòcheni, mas também Fersental ou Val Fersina), formado por quatro distritos: Vlarotz (= Florutz / Fierozzo), Garait (= Gereut; Frassilongo), Palae en Bersntol (= Palai im Fersental / Palù del Fersina) e Oachlait (=Eichleit / Roveda).

Ligado ao grupo bávaro (Südbairisch), o moqueno mantém diversos arcaísmos e traz as características de um antigo alemão tirolês. Mantém traços arcaicos do antigo altoalemão (Althochdeutsch), além de possuir características muito próprias, como a realização da oclusiva bilabial sonora [b] em casos que no alemão bávaro ocorrem com a fricativa labiodental surda [f]: bòsser <água $>$ (al. Wasser); bòlt $<$ floresta $>$ (al. Wald); bèlsn $<$ rocha $>$ (al. Felsen); bàibar <mulheres $>$ (al. Weiber). Ainda é mantida uma antiga variante dialetal trentina (cada vez menos usada), outrora utilizada pelos comerciantes locais (Krùmern) que outrora viajavam por todo Tirol. Trata-se de uma variante que preserva um considerável número de palavras arcaicas e a antiga forma verbal do passato bicomposto (mi go abù fat), que outrora era comum nos dialetos da área alpina central (RoHLFS, 1954) e no trentino arcaico, embora atualmente nenhum dialeto trentino a realize mais. Seu uso ocorre no mexmo contexto do francês moderno, que conhece o passado bicomposto.

\subsubsection{O CIMBRO}

As origens do grupo linguístico cimbro (cimb. zimbarn; al. zimberisch; it. cimbro) são ainda incertas. São cerca de três mil pessoas pertencentes a essa minoria germanófona italiana existente na região trentina e vêneta.

Os cimbros habitam regiões que atualmente estão isoladas do ponto de vista lingüistico. Concentram-se principalmente no Vêneto, nas províncias de Vicenza (Altopiano

\footnotetext{
${ }^{375} \mathrm{O}$ termo mòcheni, segundo alguns, poderia derivar do verbo alemão machen $<$ fazer $>$, realizado no bávaro como mochen, ou ainda especificamente da frase dialetal local mochen $i<$ faço eu $>$. Trata-se de uma etimologia incerta, muito improvável, e que faz parte da cultura trentina; limitamo-nos aqui a registrá-la.
} 
di Asiago / Schlege, também chamado Federazione dei sette comuni cimbre - 7 distritos), Verona (Lessinia - 13 distritos) e no planalto de Cansiglio, entre as províncias de Belluno e Treviso. No Trentino, a comunidade de Luserna (= Lusern) próxima da região de Valsugana ${ }^{376}$. A comunidade mais antiga é aquela formada pelos sete distritos (Sette Comuni), na fronteira entre o Vêneto e o Trentino, que formava outrora a mais antiga federação independente da história européia, a Spetaculare Reggenza delle sette Comuni $<$ Espetacular Regência dos sete Distritos>, caída no período da dominação napoleônica. A comunidade de Cansiglio se formou com uma emigração da população cimbra para Belluno, ocorrida no século XVIII. Os cimbros no Trentino também são originários de uma onda migratória que adentrou o planalto de Folgaria, seguiu por Lavarone e formou a comunidade de Luserna .

Entre os séculos XV e XVII, a comunidade cimbra era de cerca de duzentas mil pessoas, com todas suas paróquias em língua alemã, e seu crescimento se extendia a várias áreas trentinas, que foram posteriormente italianizadas (SULZER, 1855). Várias áreas trentinas de presença cimbra histórica possuem topônimos alemães: Folgaria (= Vielgereut), Lavarone (= Lafraun), Luserna (= Lusern), Terragnolo (= Leimtal), Trambileno (= Trumelays), Vallarsa (= Brandtal), Centa San Nicolò (= Tschint) e parte de Ala $(=A h l)$ em Val di Ronchi (= Reuttal). SULZER (1855) afirma que era comum até metade do século XIX o uso do alemão do tipo bávaro na região de Rovereto (= Rofreit) e registra a variante alemã - muito trentinizada - de Terragnolo. STEUB (1834) afirma que a presença alemã em Folgaria (= Vielgereuth) se origina com um pedido de Federico Vanga (Friederich von Wanga), bispo de Trento entre 1205 e 1218, ao conde Udalrich de Bolzano. O bispo solicitou em 1216 alguns colonos da área alemã do Tirol para povoarem a região de Costa Cartura, nos arredores de Folgaria, tendo sido enviadas pelo conde vinte e nove famílias de bons camponeses, que construíram ali vinte e nove casas familiares (Hof / Maso). Por ser um idioma próprio das áreas rurais, existem variantes dialetais próprias a cada localidade.

\footnotetext{
${ }^{376}$ No princípio do século XVII os cimbros da Valsugana habitavam até os limites da margem esquerda do Rio Brenta, em direção a Grigno (SULZER, 1855).
} 